\title{
The International Response to Disease Outbreaks: The Relevance of Epistemic Communities in International Cooperation
}

\author{
by \\ María Esther Coronado Martínez
}

A thesis submitted to the

Faculty of Graduate and Postdoctoral Affairs in partial fulfillment of the requirements for the degree of

Doctor of Philosophy

in

International Affairs

Norman Paterson School of International Affairs

Carleton University

Ottawa, Ontario

(C) 2019, María Esther Coronado Martínez 


\section{Abstract}

This research explores the question why does the level of international cooperation vary in the international response to pandemics? The research presents an analytical model to analyse the differences among the levels of international cooperation in four disease outbreaks: Influenza H1N1 in 2009, MERS-CoV in 2012, Ebola in 2013-2016, and Zika in 2013-2016. The model introduces sixteen indicators categorized in four main areas: i) international participation; ii) international assistance; iii) scientific response, and; iv) policy convergence. These indicators facilitate comparison across cases and show that Influenza H1N1 had a high level of cooperation, MERS-CoV a low-medium level, Ebola a lowmedium level, and Zika a high level.

This study applies the theory of epistemic communities developed by Peter Haas to explain variation in the level of cooperation in global health. The research identifies an epistemic community for each case and examines three general characteristics underlined in Haas' theory: a) the creation of consensual knowledge; b) the dissemination of knowledge to the policymakers and; c) the institutionalization of bureaucratic power. This research shows that although all epistemic communities possess these characteristics, these do not equally depict the same values across epistemic communities. This variation affects the way epistemic communities actors influence cooperation. While some epistemic communities created consensual knowledge and a clear policy goal, they were unable to disseminate their knowledge to relevant policymakers, and thus had limited bureaucratic power. Other epistemic communities established consensual knowledge, disseminated it to key policymakers and therefore exhibited enough bureaucratic power to influence the policymaking process. The proposed framework presents a comprehensive and simplified model 
that measures these characteristics.

The research finds that in the Influenza H1N1 outbreak, an epistemic community created consensual knowledge, disseminated it to key policymakers, and influenced the decision-making process during the outbreak. This epistemic community institutionalized and consolidated its bureaucratic position participating directly into the policy process and contributed to the level of cooperation seen during the international response at different levels. In the case of the MERS-CoV outbreak, the epistemic community had disagreements, and it was unable to build a strong consensus, affecting its capacity to disseminate relevant knowledge for policymaking. Therefore, its influence in the policy process was less evident, and it did not institutionalize its bureaucratic power, resulting in a lower capacity to increase cooperation. The Ebola outbreak in West Africa showed an epistemic community that confronted circumstances that challenged its previous knowledge of Ebola outbreaks. This created conflict within the community that debilitated its position and influence, affecting its capacity to improve international cooperation. Finally, in the Zika outbreak, an epistemic community built a fast consensus regarding the situation and was able to formulate strong recommendations to the international community. Policymakers accepted the epistemic community's advice leading to a quick response and high level of international cooperation even when there was much uncertainty.

The findings show that in the absence of a clear consensus regarding the nature of the problem and possible solutions among members of the epistemic community; the inability to disseminate this consensual knowledge to policymakers; and the building of bureaucratic power through their participation in crucial parts of the process; the ability to influence global health governance towards cooperative outcomes is diminished. 


\section{Acknowledgments}

Throughout the writing of this dissertation, I received a lot of support and assistance. Foremost, I would like to express my deepest gratitude to my supervisor Dr. Valerie Percival for her patience, motivation, and support during the whole process. Her knowledge and expertise provided invaluable guidance for the successful conclusion of this research. Her dedication, keen interest, but above all, her compassion and understanding gave me the inspiration and encouragement to finish this project. I would also like to thank the members of my committee, Dr. David Long and Dr. Inger Weibust, for their valuable insights and experience were invaluable to improve my research; and Dr. Lisa Mills and Dr. Jeremy Youde for accepting to take part in my thesis examination.

Thank you to the NPSIA faculty and those people who facilitated my admission into the program. I want to thank NPSIA for the financial support provided to finish the program. I am greatly honoured to have been a recipient of the Ontario Trillium Scholarship, which enabled me to pay my fees, carry out interviews, attend conferences and to work on my research. Thank you also to CONACYT Mexico for the scholarship that allowed me to conclude the program and finish my research.

I want to give special thanks to Patricia Lacroix for her kindness, guidance, and support since I arrived at Carleton as an international student. I also would like to express my gratitude to NPSIA staff, Tabbatha, Karen, Coleen, Norean, for all their help in different moments and circumstances.

To my NPSIA classmates, thank you for your patience. I learned a lot from each one of you. I am especially thankful to Rachel, Babita, and Israr for their friendship and 
encouragement. To my friends from Mexico and other parts of the world, thank you for your words and support always.

I am extremely grateful to my parents for their love, caring and sacrifices for educating and preparing me to the future. Gracias mamá, papá, Diana e Inci por su amor incondicional y sacrificios, por siempre impulsarme a seguir mis sueños y creer en mí. Su ejemplo y amor lo llevo siempre conmigo. Abuelos, donde quiera que estén, gracias por las enseñanzas y valores que me inculcaron.

Thank you to my dear husband, Jean-Paul Noël. I wouldn't have been able to reach the end of this project without your endless love, support, and encouragement. You gave me the confidence to continue even in the hardest moments.

Finally, I want to dedicate this thesis to my daughter Sophie. My sweet little girl, you have completely changed my world. Despite being a new mom and caregiver, I embraced my new life while continuing with the Ph.D. and the research. I know it has been hard for both of us, but I wanted to show you that even in the most difficult circumstances, it is always possible to make your dreams come true. I want you to know that although life is full of challenges, you should never give up. Don't forget that I will be there to give you the strength and my unconditional love to get you through whenever you might need support. 


\section{Table of Contents}

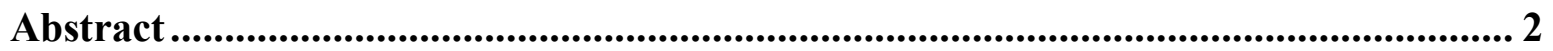

Acknowledgments .............................................................................................................................. 4

Table of Contents ..................................................................................................................... 6

Acronyms and abbreviations................................................................................................. 11

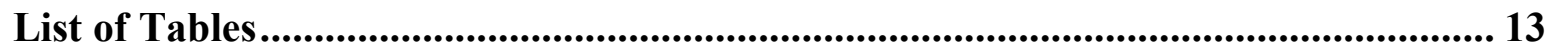

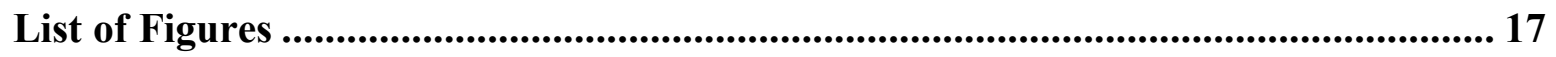

List of Appendices................................................................................................................. 19

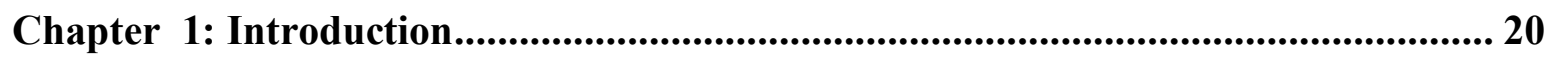

1.1 The relevance of epistemic communities in the international response to infectious

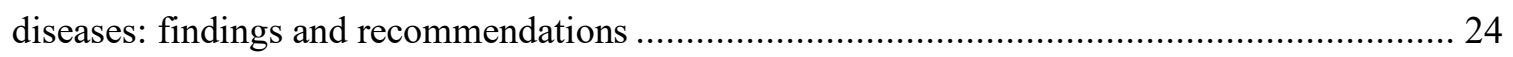

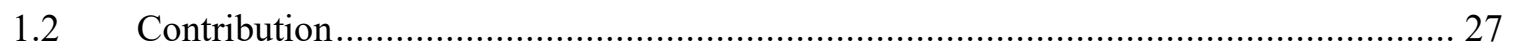

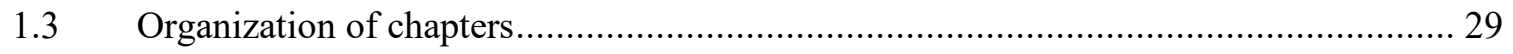

Chapter 2: Research methodology ............................................................... 31

$2.1 \quad$ Identifying epistemic communities (independent variable) .................................... 31

2.2 Determining the level of international cooperation (dependent variable) ............................ 34

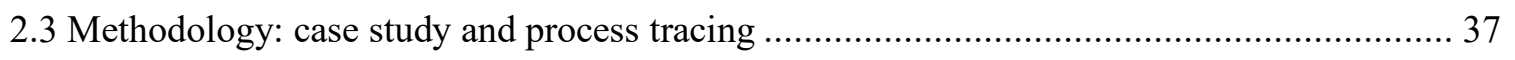

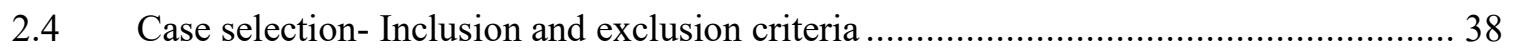

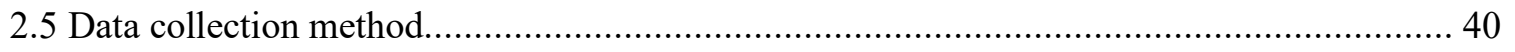

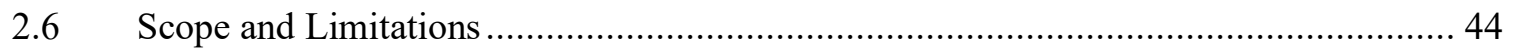

Chapter 3: International cooperation .............................................................. 49

3.1 Introducing the problem of international cooperation ........................................ 49

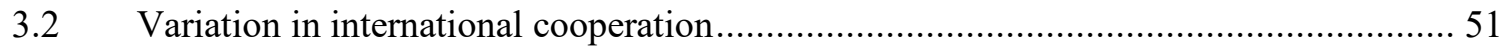

3.2.1 An analytical framework to analyze variation in global health cooperation ............. 55

3.2.2 Levels of cooperation in the international response to infectious diseases ............... 59 


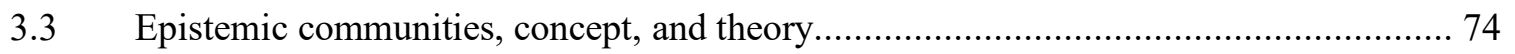

3.3.1 Towards a theoretical framework to explain international cooperation .................... 77

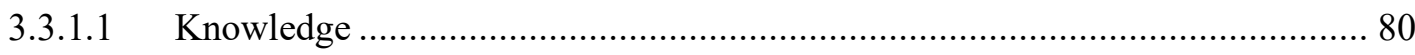

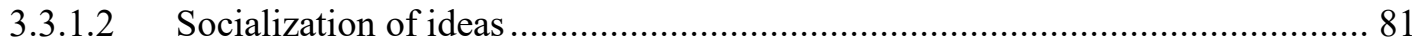

3.3.1.3 Institutionalization of an epistemic community's bureaucratic power .............. 83

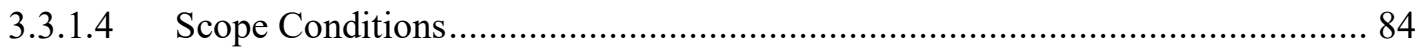

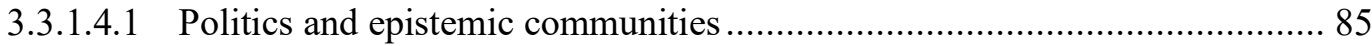

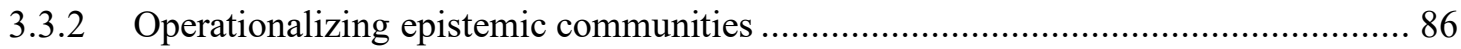

3.4 Testing the theoretical framework in global health............................................. 93

3.4.1 Tobacco control and the Framework Convention................................................. 93

\section{Chapter 4: International cooperation and the international response to infectious}

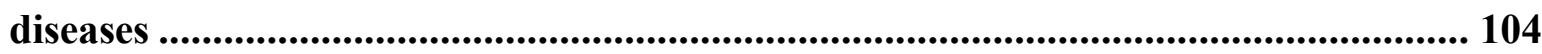

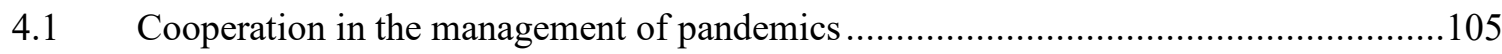

4.1.1. The international system for the management of disease outbreaks and its relevance to

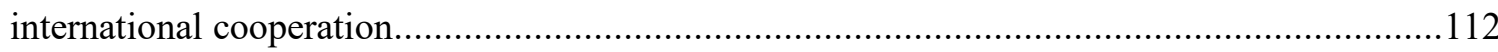

4.1.1.1 The SARS' outbreak and the reform of the IHRs........................................113

4.1.1.2 The updated IHR 2005 and the new governance for pandemics .....................115

4.2 Epistemic communities in the international response to a disease outbreak ................118

4.2.1 Epistemic communities and the International Health Regulations .........................118

4.2.2 Epistemic communities' capabilities to influence international cooperation in the response to infectious diseases.

Chapter 5: The A(H1N1) Influenza outbreak 2009 ......................................... 124

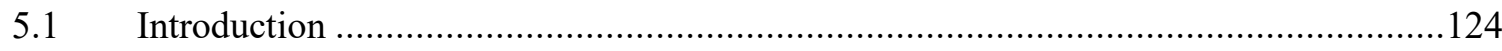

5.2 Influenza pandemic cooperation and the evolution of an epistemic community ...........129

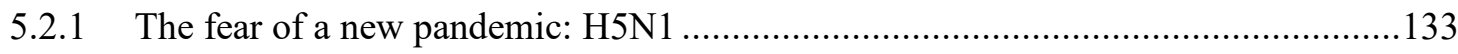

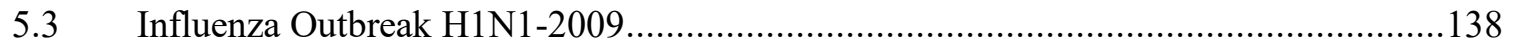




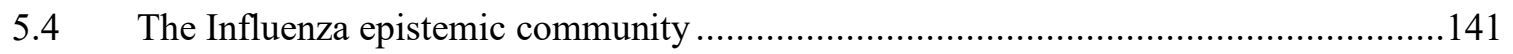

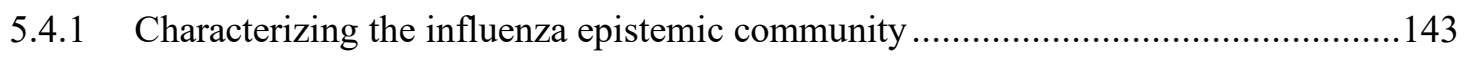

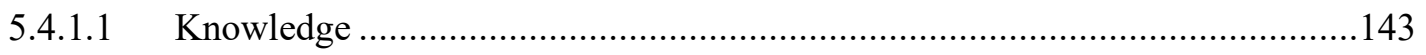

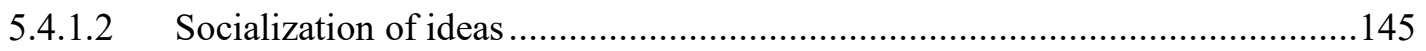

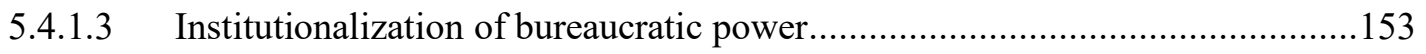

5.5 The international response and the influenza epistemic community............................160

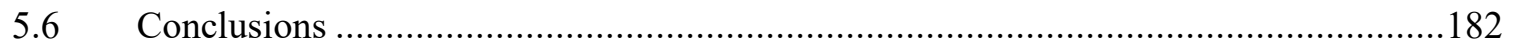

Chapter 6: Middle East Respiratory Syndrome MERS-CoV ................................... 185

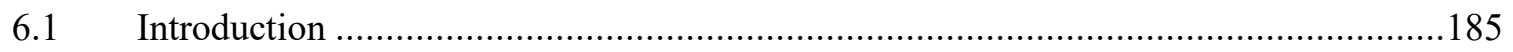

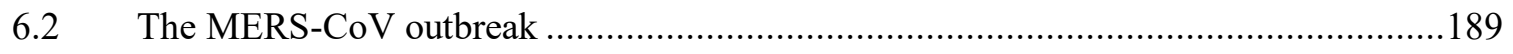

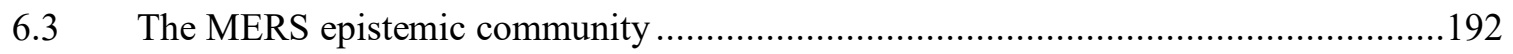

6.3.1 Origins of the MERS epistemic community: the Coronavirus epistemic community. 192

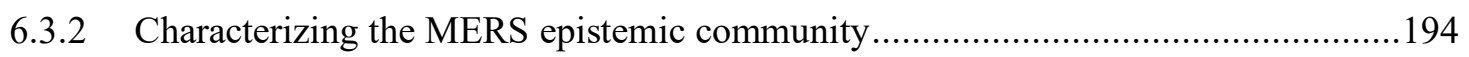

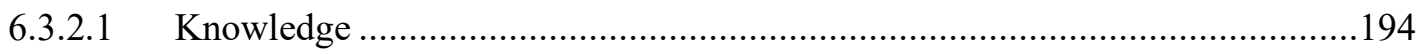

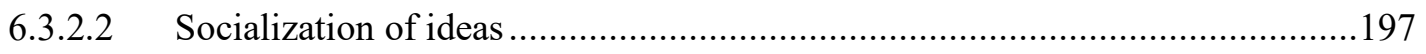

6.3.2.3 Institutionalization of bureaucratic power..............................................204

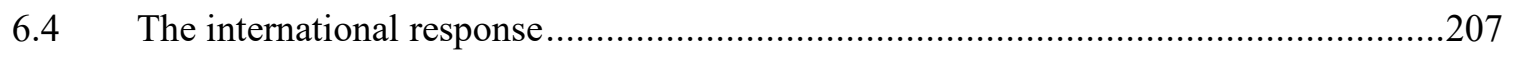

6.5 Influence of the epistemic community in the level of cooperation. ............................218

Chapter 7: Ebola Outbreak 2013-2016 .................................................................. 221

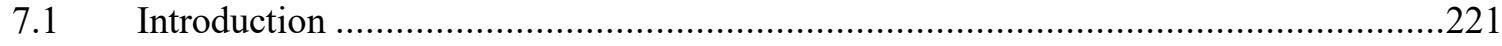

7.2 Ebola outbreak in West Africa 2013-2016 ........................................................227

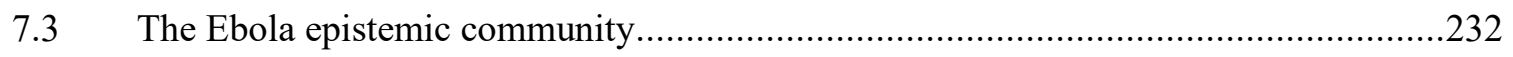

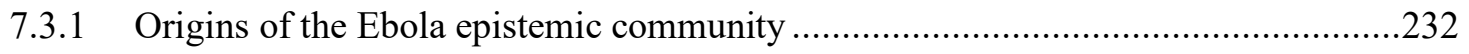

7.3.2 Characterizing the Ebola epistemic community …........................................236

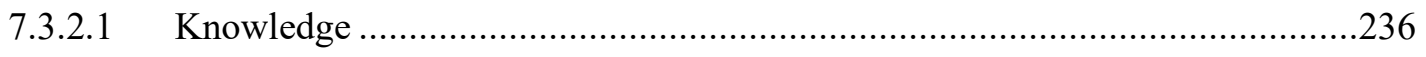




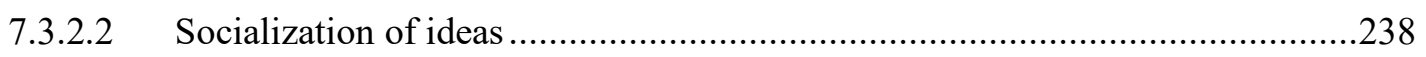

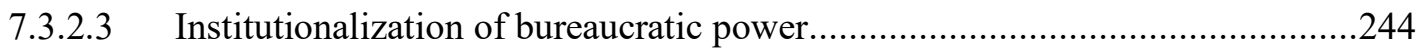

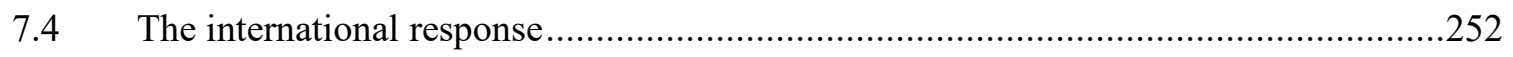

7.5 Influence of an epistemic community in the level of cooperation. ............................265

Chapter 8: Zika Virus 2013-2016 ................................................................................... 268

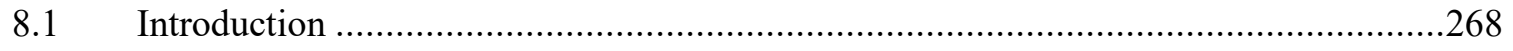

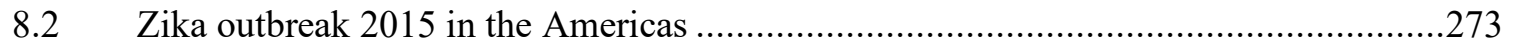

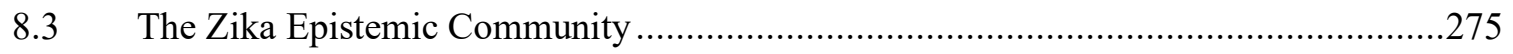

8.3.1 History: Vector-control and the Zika epistemic community. ...............................275

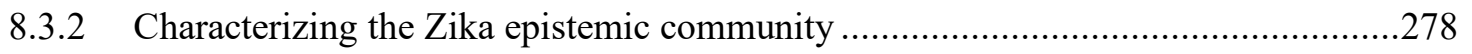

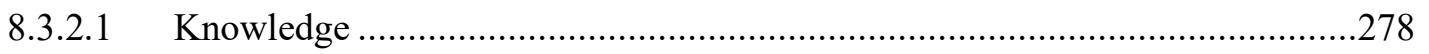

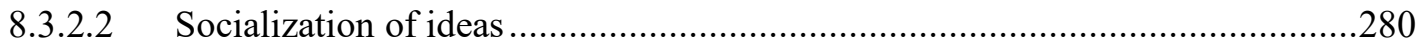

8.3.2.3 Institutionalization of bureaucratic power...............................................290

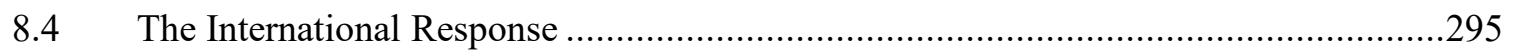

8.5 Influence of an epistemic community in the level of cooperation. .................................

Chapter 9: Conclusions..................................................................................... 311

9.1 Comparison of the international response among the four cases ................................311

9.2 Epistemic communities' characteristics and their effects in variation in international

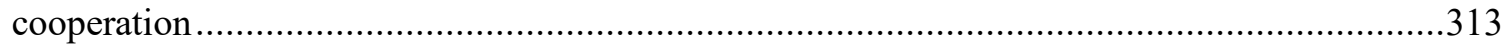

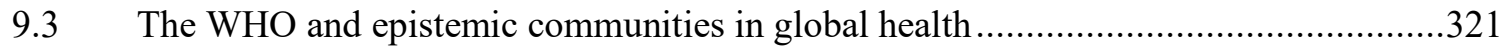

9.3.1 The system of pandemic governance and politics..............................................323

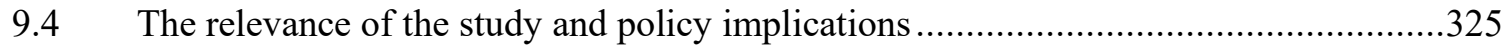

Appendices ........................................................................................................... 329

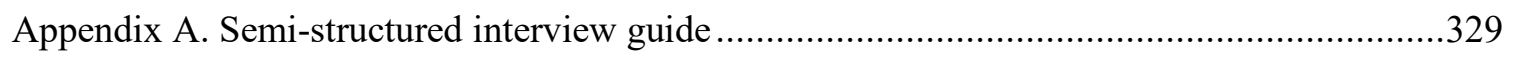

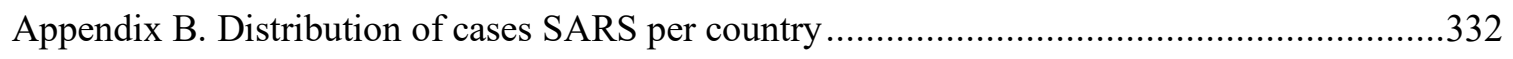

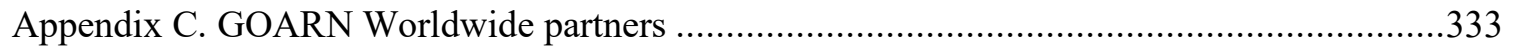




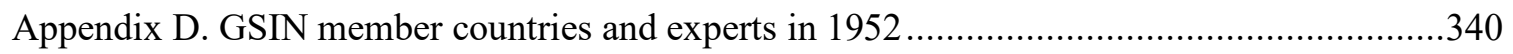

Appendix E. International Pledging Conferences on Avian and Human Influenza ...................342

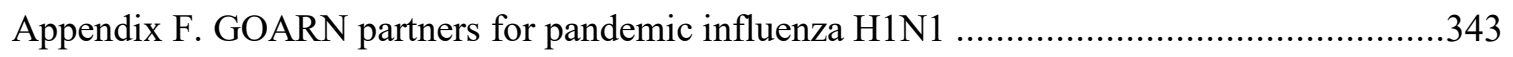

Appendix G. Participants meeting H1N1 influenza Cancun 2009 .........................................345

Appendix H. Pandemic Influenza Epistemic Community Members .......................................346

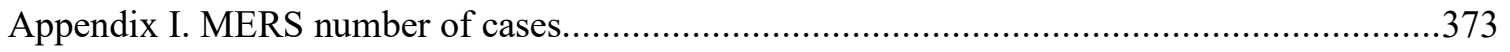

Appendix J. MERS CoV Epistemic Community ................................................................374

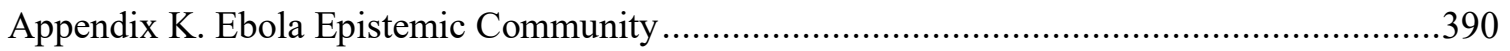

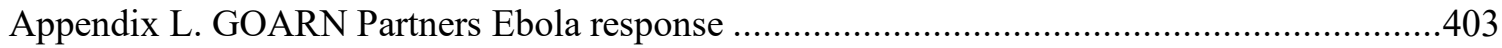

Appendix M. Distribution of Zika cases in the Americas as of January 2018 ........................407

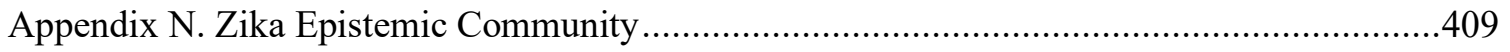

N.1. Zika participating institutions in the Epistemic Community...................................412

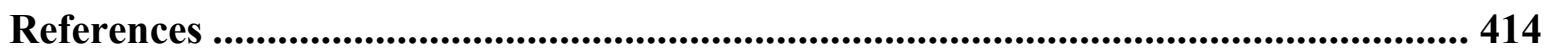




\section{Acronyms and abbreviations}

\begin{tabular}{|c|c|}
\hline AFRO & WHO Regional Office for Africa \\
\hline AIDS & Acquired Immunodeficiency Syndrome \\
\hline AMRO & WHO Regional Office for the Americas (PAHO) \\
\hline APEC-HGW & Asia-Pacific Economic Cooperation Health Working Group \\
\hline ASEAN & Association of Southeast Asian Nations \\
\hline BMJ & British Medical Journal \\
\hline $\mathrm{CDC}$ & Centers for Disease Control and Prevention \\
\hline COP & Conference of the Parties \\
\hline CSG & Coronavirus Study Group \\
\hline DG & Director-General \\
\hline DHHS & Department of Human Health and Services (US) \\
\hline DRC & Democratic Republic of Congo \\
\hline EB & Executive Board \\
\hline $\mathrm{EC}$ & Emergency Committee \\
\hline EDPLN & Emerging and Dangerous Pathogens Laboratory Network \\
\hline EID & Emerging Infectious Disease \\
\hline EMRO & WHO Regional Office for Eastern Mediterranean \\
\hline EURO & WHO Regional Office for Europe \\
\hline FAO & Food and Agriculture Organization \\
\hline FCTC & Framework Convention on Tobacco Control \\
\hline GAP & Global Programme on AIDS \\
\hline GBS & Guillain-Barré syndrome \\
\hline GHSI & Global Health Security Initiative \\
\hline GISAID & Global Initiative on Sharing All Influenza Data \\
\hline GISN & Global Influenza Surveillance Network \\
\hline GISRS & Global Influenza Surveillance and Response System \\
\hline GOARN & Global Outbreak and Response Network \\
\hline HIV & Human Immunodeficiency Virus \\
\hline HQ & Headquarters \\
\hline IHR & International Health Regulations \\
\hline IMF & International Monetary Fund \\
\hline IPAPI & International Partnership on Avian and Pandemic Influenza \\
\hline ISR & International Sanitary Regulations \\
\hline IVM & Integrated Vector Management \\
\hline LSHTM & London School of Hygiene and Tropical Medicine \\
\hline MDG & Millennium Development Goals \\
\hline MERS-CoV & Middle East Respiratory Syndrome \\
\hline MPTF & Multi-Partner Trust Fund \\
\hline MSF & Médecins Sans Frontières \\
\hline
\end{tabular}


NAPAPI North American Plan for Avian and Pandemic Influenza

$\mathrm{NHI}$

National Health Institutes (US)

NIC

National Influenza Centre

OAS

Organization of American States

OIE

World Organization for Animal Health

OIHP

Office International d'Hygiene Publique

PAHO

Pan-American Health Organization

PHAC

Public Health Agency of Canada

PHEIC

Public Health Emergency of International Concern

PIP

Pandemic Influenza Preparedness

ProMED

Program for Monitoring Emerging Diseases

REID

Re-Emerging Infectious Disease

SARS

Severe Acute Respiratory Syndrome

SDG

Sustainable Development Goals

SEARO

WHO Regional Office for South-East Asia

STI

TRIPS

Sexually transmitted infection

UK

Agreement on Trade-Related Aspects of Intellectual Property Rights

UN United Nations

UNAIDS Joint United Nations Programme on HIV/AIDS

UNEP United Nations Environment Program

UNGASS United Nations General Assembly

UNMEER United Nations Mission for Ebola Emergency Response

USA United States of America

USAID United States Agency for International Development

VCAG Vector Control Advisory Group

WB World Bank

WCTH World Conference on Tobacco or Health

WHA World Health Assembly

WHO World Health Organization

WHOPES WHO Pesticide Evaluation Scheme

WIC World Influenza Centre

WPRO WHO Regional Office for Western Pacific

WTO World Trade Organization 


\section{List of Tables}

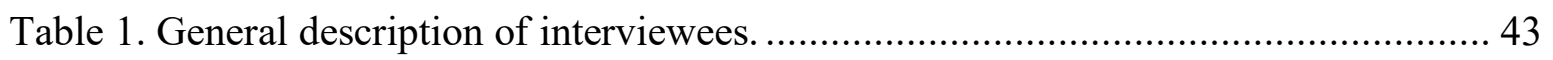

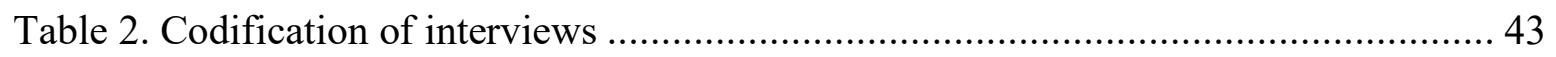

Table 3. International cooperation dimensions in the international response to infectious

diseases.

Table 4. Activities in the international response to infectious diseases.............................. 63

Table 5. Activities in the international response and indicators........................................... 66

Table 6. Activities and indicators for each level of international cooperation in the

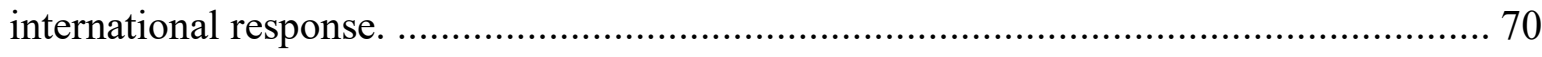

Table 7. Main characteristics of epistemic communities, a literature review..................... 78

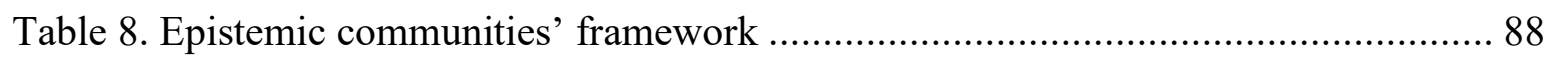

Table 9. Indicators for measuring epistemic communities' characteristics......................... 91

Table 10. The epistemic community in tobacco control. Based on multiple sources.......... 96

Table 11. Analysis of the tobacco control epistemic community's strength. ..................... 97

Table 12. The causes of the EIDs. Adapted from Foladori $(2005: 147)$ and $(210,121) \ldots . .104$

Table 13. Case fatality rate and the reproductive ratio of selected diseases. Multiple

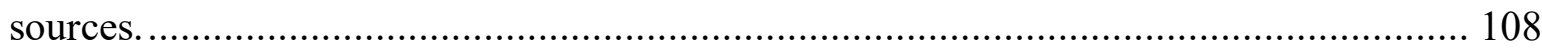

Table 14. Main characteristics of the SARS outbreak. Various sources. .......................... 114

Table 15. Epistemic communities' characteristics and indicators for the analysis of their

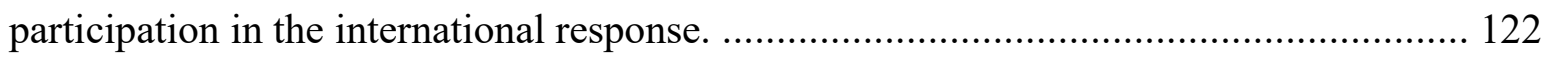

Table 16. Recent meetings GISRS. …………………………………………….... 133

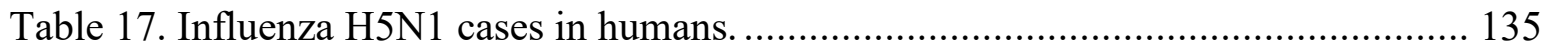

Table 18. Main characteristics H5N1 outbreak......................................................... 135 
Table 19. Characteristics influenza 2009 A(H1N1) outbreak.

Table 20. Distribution of deaths by region 2009 A(H1N1) influenza outbreak. Source.

WHO, GOARN

Table 21. The influenza pandemic epistemic community. 142

Table 22. Influenza networks.

Table 23. WHO Regional Offices. 151

Table 24. List Emergency Committee members and overlapping with other groups. ...... 155

Table 25. Meetings Influenza A(H1N1) 2009.................................................. 159

Table 26. Characteristics influenza epistemic community ................................... 160

Table 27. Statements WHO Director-General during A(H1N1) pandemic. Based on

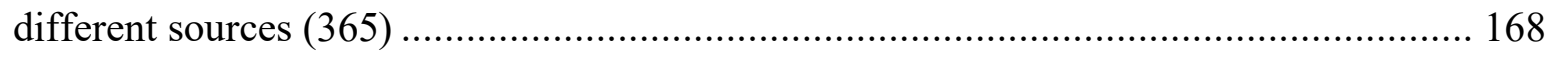

Table 28. Recommendations Influenza Emergency Committee. 169

Table 29. Sample of organizations publishing scientific references during the 2009 A(H1N1) outbreak. 170

Table 30. Number of publications during the influenza outbreak selected experts. Source:

Google Scholar 170

Table 31. Levels of cooperation Influenza outbreak 179

Table 32. Characteristics of the MERS-CoV outbreak. 191

Table 33. Institutions with experts participating in the core groups of the epistemic community. 194

Table 34. Members interconnecting the core epistemic community's groups. 199 Table 35. Global partners in the WHO's response to MERS-CoV between September 2012 and May 2014. 202 
Table 36. Global partners in the MERS-CoV response and their connections to the

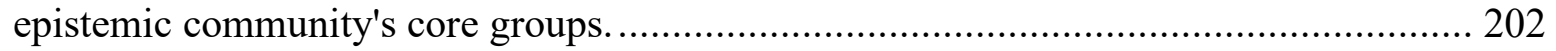

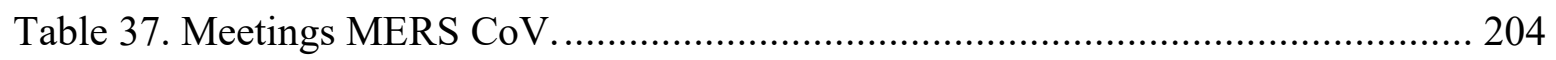

Table 38. Characteristics MERS CoV epistemic community. .................................. 207

Table 39. MERS-CoV meetings and expert groups. Source: WHO/EMRO and various

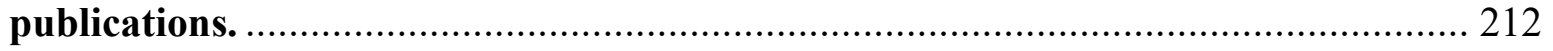

Table 40. Analysis levels of cooperation in the MERS-CoV response ......................... 215

Table 41. Characteristics Ebola outbreak West Africa 2013-2016. .............................. 227

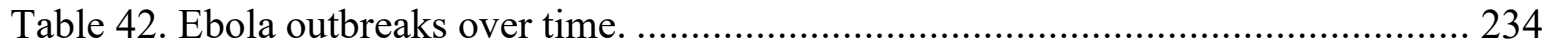

Table 43. Conferences related to Ebola and other Filoviruses (526)........................... 235

Table 44. Characteristics Ebola epistemic community......................................... 236

Table 45. Emergency Committee summary recommendations Ebola outbreak. ...... 242

Table 46. Overlapping of members in the epistemic community's core groups with the

Ebola Emergency Committee (EC). ........................................................... 246

Table 47. Overlapping institutions with multiple representations in the epistemic

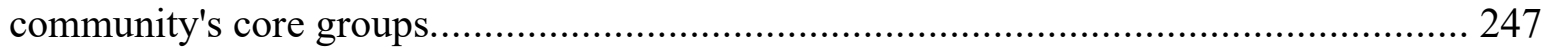

Table 48. Participants WHO Ebola Interim Assessment Panel (499). .......................... 250

Table 49. Characteristics Ebola epistemic community....................................... 252

Table 50. Analysis levels of cooperation in the international response to the Ebola outbreak in West Africa............................................................................................. 262

Table 51. Vectors and the diseases they transmit............................................ 276

Table 52. Main institutions and participants in the Zika epistemic community.............. 281 
Table 53. Central institutions participating in the response to the Zika outbreak and the epistemic community. The table presents all the meetings or groups where these institutions had participants and the number of people representing them.................................. 283 Table 54. Central institutions participating in the response to the Zika outbreak and the epistemic community. The table presents all the meetings or groups where these institutions had participants and the number of people representing them............................... 284 Table 55. Members of the Vector Control epistemic community directly participating in the Zika epistemic community. ....................................................................... 287

Table 56. Meetings Zika outbreak............................................................. 290

Table 57. Meetings expert groups Zika.............................................................. 291

Table 58. Characteristics Zika epistemic community.......................................... 294

Table 59. Summary recommendations Emergency Committee on Zika (645)............... 298

Table 60. Levels of cooperation in the international response to Zika outbreak.............. 305

Table 61. Comparison levels of cooperation in the international response to four disease

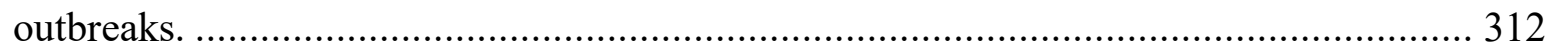

Table 62. The aggregate level of international cooperation in the response to four disease

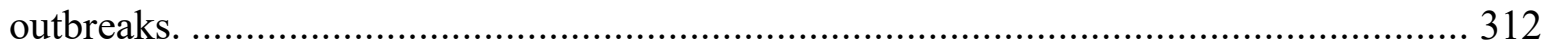

Table 63. Characteristics epistemic communities across cases. .................................. 313 


\section{List of Figures}

Figure 1. Identification of an epistemic community. Based on Davis Cross 2011 and

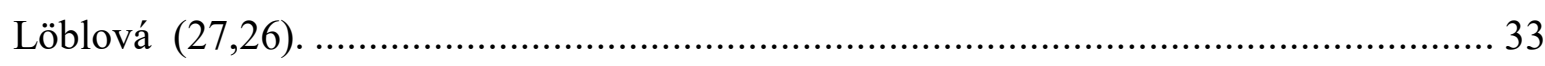

Figure 2. The proposed spectrum of cooperation in global health. ............................. 35

Figure 3. A theoretical framework for analyzing the role of epistemic communities in the international response to infectious disease outbreaks ........................................... 36

Figure 4. Map of the outbreaks assessed under the IHRs 2005 between 2005 and 2015... 39

Figure 5. Distributional conflicts outside the Pareto Frontier. Based on Sebenius 1992 (23).

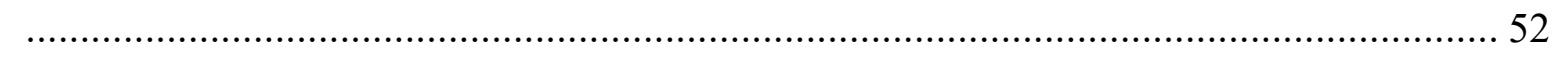

Figure 6. A proposed spectrum of international cooperation in global health................. 56

Figure 7. A proposed spectrum of global health cooperation. Based on the Pareto Frontier

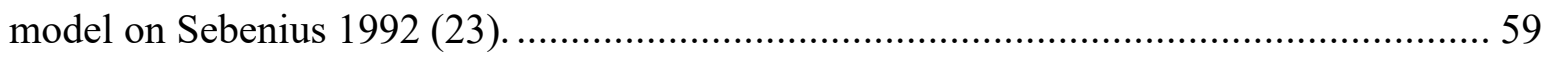

Figure 8. Proposed framework for the analysis of an epistemic community's strength ...... 89

Figure 9. Levels of Cooperation Tobacco Control ................................................ 102

Figure 10. Factors influencing international cooperation to manage infectious diseases.. 106

Figure 11. Relationship between a strong epistemic community and the level of cooperation

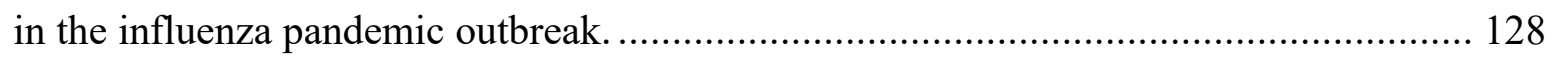

Figure 12. WHO Global Influenza Surveillance and Response System. Source: WHO (301)

Figure 13. Timeline of events firsts weeks H1N1 outbreak. Sources: CDC Europe; Nature 2009; WHO 2011. 139

Figure 14. GISRS geographical distribution Influenza A(H1N1) outbreak. Source: WHO, 2010, (337). 148 
Figure 15. Geographical distribution of influenza networks' members

Figure 16. Structure, connections, and interactions of the influenza epistemic community.

Figure 17. Participation of the influenza epistemic community in the international response.

Figure 18. MERS epistemic community and its connection to the international response. 188

Figure 19. Geographical distribution of MERS CoV epistemic community main members.

Figure 20. Process for the international response to MERS-CoV

Figure 21. Ebola epistemic community and its participation in the international response

Figure 22. Chronology Ebola outbreak in West Africa 2013-2014............................... 230

Figure 23. Geographical distribution of Ebola cases, October 2014......................... 231

Figure 24. Geographical distribution epistemic community members Ebola................. 240

Figure 25. The process of the international response to the Ebola outbreak and the

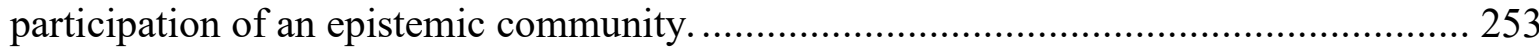

Figure 26. Zika epistemic community and its influence in the international response..... 272

Figure 27. Connection between the Vector Control and Zika epistemic communities. .... 286

Figure 28. Process of the international response to the Zika outbreak and the epistemic community 303

Figure 29. Relationship epistemic communities and the level of international cooperation for each case. 320 


\section{List of Appendices}

Appendix A. Semi-structured interview guide................................. 329

Appendix B. Distribution of cases SARS outbreak............................. 332

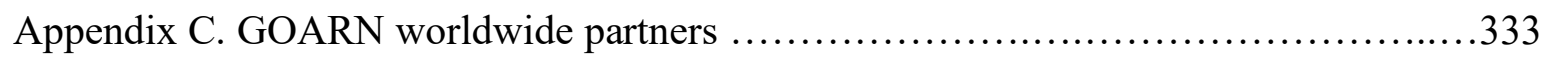

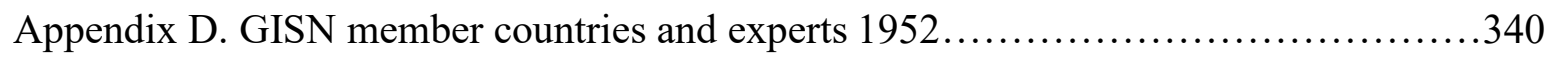

Appendix E. International Pledging Conferences on Avian and Human Influenza .........342

Appendix F. GOARN partners for pandemic influenza A (H1N1) outbreak..............343

Appendix G. Participants Influenza A(H1N1) meeting Cancun 2009..................345

Appendix H. Pandemic Influenza epistemic community members.....................346

Appendix I. Distribution of cases MERS-CoV outbreak............................ 373

Appendix J. MERS-CoV epistemic community members.......................... 374

Appendix K. Ebola epistemic community members...............................390

Appendix L. GOARN partners for Ebola response $\ldots \ldots \ldots \ldots \ldots \ldots \ldots \ldots \ldots \ldots \ldots \ldots \ldots . \ldots \ldots 3$

Appendix M. Distribution of cases Zika in the Americas...........................407

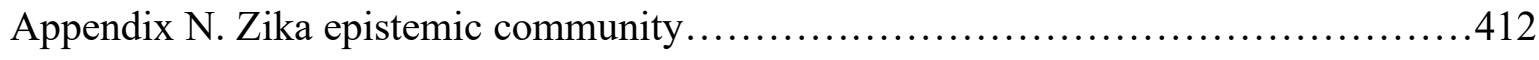

N.1 Institutions participating in the Zika epistemic community...................414 


\section{Chapter 1: Introduction}

This research examines the question, why does the level of international cooperation vary in response to disease outbreaks with similar pandemic potential? This study presents evidence that the participation of epistemic communities in the international response contributes to the variance observed in the level of international cooperation.

The international response to infectious diseases is a set of activities to fight and control outbreaks. It consists of "detection systems, skilled and properly equipped personnel, authorities, methods and tools to coordinate different governing bodies, which possess varying levels of preparedness, capacity, and resources in a timely manner to prevent additional events (1)". International cooperation plays a central role in the global system to manage and control pandemic outbreaks, which occur when infectious diseases that are easily transmissible affect a large population and spread over a wide geographical area in a short period (2).

The transnational nature and pandemic potential of many emerging and re-emerging diseases represent a global threat. Globalization facilitates the transmission of these diseases and increases all countries' vulnerability, making them less capable of securing the health of their citizens through unilateral action $(3,4,5,6,7,8)$. Therefore, international cooperation is more important than ever to complement and strengthen national efforts, to minimize the spread of the disease and mitigate its impact on the population $(9,10,11)$.

The analysis of variation in international cooperation is relevant for the global response to pandemic diseases. There is always a degree of cooperation in the international response to disease outbreak (there is no defection), but full cooperation is only achieved when all the international community contributes to the prompt management and control of 
an outbreak, and all states comply with relevant international norms and agreements. Therefore, this research examines cooperation as a spectrum that "measures positive statements, agreements, and assistance (12)". International cooperation in global health manifests itself as adherence to the process of outbreak notification, pathogen identification, consensus on the nature of the event, identification of actions to mitigate the outbreak, implementation of measures, and the provision of financial, material and human resources to support the response. The failure to reach full cooperation means the difference between an outbreak being successfully managed and controlled, to one spinning out of control, infecting and killing more people, along with other severe economic and social consequences.

States have created international norms and institutions to guide both the domestic and international responses to infectious disease outbreaks, as well as to improve and increase their potential for the control and eradication of pandemic diseases. The constant evolution of factors generating and facilitating the spread of disease outbreaks has required a periodic assessment and adaptation of these norms and institutions to address new challenges. To this aim, in 2005, the World Health Assembly (WHA) approved the International Health Regulations (IHRs 2005), providing an updated framework to prevent and manage pandemics. These guidelines aimed to reduce the burden caused by infectious disease outbreaks with pandemic potential, to coordinate international action, and to increase cooperation. Despite providing procedures for a uniform response to outbreaks with similar pandemic potential, international cooperation - even under the IHRs 2005 - varied in recent cases. For some outbreaks, such as pandemic influenza $\mathrm{H} 1 \mathrm{~N} 1$ and Zika virus, the international community cooperated, responding rapidly and controlling the spread of the disease. Whereas in the Ebola outbreak in West Africa, international actors responded slowly and inadequately, facilitating the spread of the disease beyond national borders in a short 
period. The Ebola outbreak is now considered as "the most intense and prolonged epidemic of the disease ever recorded (13)". This lack of initial response caused more deaths and high economic costs for affected countries (14). Finally, despite acknowledging the potential global threat of the Middle East Respiratory Syndrome (MERS-CoV), scientific and policy engagement with affected countries was limited (15).

The existence of variation in cooperation across these cases presents a puzzle. All four disease outbreaks needed international collaboration; they were diseases with the potential to rapidly spread, and it was in the interest of all states to manage the outbreaks. Yet, the four cases elicited very different responses. All four pandemics occurred under the same set of international norms and institutions that were created "to prevent, protect against, control and provide a public health response to the international spread of disease (16)".

Traditional theories of international relations have not sufficiently examined variation in cooperation. International diplomacy, however, entails different degrees of cooperation -from treaties that are signed and approved for most countries, but partially implemented, or states negotiating norms in the United Nations General Assembly (UNGASS) without reaching an agreement, to the financing of development projects for only a few countries. Social constructivist theories provide a promising avenue of exploration due to their explanation that differences in processes influence the various policy approaches adopted by governments $(17,18)$. Constructivism centres its attention on actors in the international system, including epistemic communities $(19,20,21,22)$.

The role of epistemic communities in global health cooperation is related to the importance of scientific evidence in global health and the need for experts to both provide and translate this evidence to guide the policy process. Members of epistemic communities actively participate (through direct and indirect channels) in the formulation of policies in 
governments, multilateral institutions, and non-governmental organizations (NGOs). The dual role of some members of the epistemic community as both providers of evidence and as decisionmakers places them in a unique position to influence international cooperation.

Previous studies on epistemic communities provided evidence that these non-state actors improved international cooperation, moving it towards optimal levels $(20,23,24)$. Researchers have systematically reviewed these groups' characteristics and how they influence the policy process. In his seminal work, Peter Haas characterized an epistemic community as a group of experts that share normative beliefs, causal beliefs, notions of validity, and a policy goal $(25,24,26)$. His theory suggested that when epistemic communities develop a consensual knowledge and clear policy goal, disseminate this knowledge and institutionalize its bureaucratic power (consolidating its influence), they can improve cooperation. This research further explores Haas' theory and the hypothesis that these characteristics vary, and they are not homogenous across epistemic communities. The ability of an epistemic community to exercise influence on international cooperation will depend on the extent of its members' agreement on the problem and solutions; the availability of the epistemic community to disseminate its knowledge to policymakers; and the amount of bureaucratic power accumulated by the epistemic community's members within the policy process.

Other approaches have attempted to explain international cooperation during pandemics. One line of research considers diseases as security threats $(27,28,29,30,31,32,33,34,35,36)$. Health security scholars expect that pandemic outbreaks will mobilize international cooperation due to security concerns (37), under the belief that "collective health security against infectious diseases (38)" is the best policy response. Yet this research does not examine or explore variation in international cooperation and does not 
explain why some 'pandemic' diseases are more relevant for security reasons than others.

Another set of arguments centres its explanations on the dynamics of globalization and international trade. This scholarship assesses the link between global health and trade, taking into consideration that for decades, countries have tried to remove public health measures that could limit trade disruptions during pandemic outbreaks (39). International norms, such as the IHRs, included this idea. The study of health and trade, however, does not clearly explain why some pandemics garner more cooperation and limit restrictions on the movement of people and goods, while the response to other disease outbreaks leads to establish trade and travel barriers.

Scholars working in the field of global health governance $(40,41,42)$ state that suboptimal global health cooperation results from the complexity of health problems, political interest, and inadequate mechanisms available for collective action $(41,43)$. While these multiple factors affect cooperation during pandemics, the approach lacks specificity. Global governance can be identified as regimes (7) or institutions, and "it appears to be virtually anything (44).”

These theoretical approaches offer some explanation for sub-optimal cooperation. Yet, as outlined below, the examination of the role of epistemic communities in facilitating

global health cooperation provides an important and overlooked explanation. Emphasizing the agency of epistemic communities recognizes actors that have an active role in the global system of governance.

\subsection{The relevance of epistemic communities in the international response to infectious diseases: findings and recommendations}

Global health problems are becoming more complex, with the participation of multiple actors at multiple levels and health intertwined with economic and security issues. 
Policymakers rely upon several actors to get information, advice, and political support to advance their interests. There is especially an influx of global health networks providing resources, knowledge, advocacy, policy ideas, and defining programs that can effectively influence policy outcomes (45). Global health policy highly depends on the advice and evidence-based knowledge provided by experts and professionals with experience in highly technical and specialized areas. Although experts in global health ${ }^{\mathrm{i}}$ have a primary role in the definition of global health institutions, policies, and norms, their influence does not always translate into improved cooperation.

In the international response to any infectious disease, epistemic communities act as providers of knowledge and policy advisors. They produce the information to understand the context, the pathogen/disease, and the knowledge to develop interventions to manage and control the outbreak. Even though these actors are involved in the response to pandemic outbreaks, it is not clear how much they can "change the game" and move cooperation outcomes closer to the Pareto frontier (Chapter 3). The analysis of the international response to four pandemics, A(H1N1) Influenza, Zika, Ebola, and MERS-CoV, offers evidence to improve our understanding of these networks. Each one of these responses was unique, with a different level of cooperation. With the framework proposed in chapter 3 , table 6 , the study determined that the response to the $\mathrm{A}(\mathrm{H} 1 \mathrm{~N} 1)$ Influenza outbreak had the highest level of cooperation with 5.43 out of 6 , followed by Zika with 4.62 out of 6, then Ebola with 2.62 out of 6 and with the lowest level MERS-CoV with 2.37 out of 6.

In all these cases, it is possible to identify an epistemic community and the

\footnotetext{
${ }^{\mathrm{i}}$ These experts are identified as all those people with the knowledge (technical, scientific, managerial, diplomatic, etc.) to design and participate in the definition of global health policy.
} 
characteristics attributed to it. With this information, and following the analytical framework proposed in chapter 4, the research assesses the differences in the epistemic communities' characteristics across cases and estimates how these differences contribute to determining each epistemic community's capabilities to influence international cooperation. These results show that the epistemic communities' characteristics vary across cases, and this variance influences the level of international cooperation in each case.

During the A (H1N1) influenza outbreak, the influenza epidemic community developed explicit consensual knowledge, increased its bureaucratic power, and broadly socialized its ideas, improving the level of cooperation. The Ebola epistemic community did not consolidate itself as an important actor in the global policymaking system during the outbreak in West Africa, having problems to create consensual knowledge, with internal divisions, limiting the socialization of its ideas and reducing its bureaucratic power. The Influenza epistemic community was vital in the level of international cooperation depicted in the response to the influenza $\mathrm{A}(\mathrm{H} 1 \mathrm{~N} 1)$ outbreak. The Ebola epistemic community had marginal participation and influence in the level of cooperation during the outbreak in West Africa.

In the cases of MERS-CoV and Zika, the epistemic communities participating in these outbreaks formed under comparable circumstances but with different results and impact. They originated in epistemic communities that had previously worked on diseases with characteristics similar to the ones producing the outbreaks. Nonetheless, the MERS$\mathrm{CoV}$ epistemic community was unable to generate explicit consensual knowledge to convince policymakers that global action was needed to control the epidemic. The lack of information slowed down the production of knowledge and dissemination of the epistemic community ideas. Instead, the Zika epistemic community used the uncertainty surrounding 
the virus to build an internal consensus about the risk of the disease and convince policymakers to implement worldwide control activities. The Zika epistemic community institutionalized its bureaucratic power in a short period, being able to disseminate its ideas fast, and reaching key actors in the process. Therefore, the MERS-CoV epistemic community had less influence and less ability to increase international cooperation, while the Zika epistemic community was a relevant actor in the implementation of international measures to control and manage the outbreak.

Even though there is evidence that epistemic communities can improve the level of cooperation, their influence has limitations. These networks are embedded in a system of global governance where the main actors are nation-states and international organizations. The dynamics in the system and its structure circumscribe epistemic communities' participation in the global policy-making process.

In global health, the importance of epistemic communities is increasing. The implications of their influence, or their failure to do it, are very relevant in a moment when evidence-based, and science-based policymaking is rejected by many. Hence, this research is an exploratory analysis since each of the cases studied here is rich in information and with multiple elements that could be analyzed with more detail. The next step would require doing a within-case empirical analysis for each outbreak, and with that to obtain other insights on the role of epistemic communities.

\subsection{Contribution}

This examination of the international response to disease outbreaks makes two main contributions. First, the system of global health governance built to face disease outbreaks requires high levels of international cooperation. Yet, there is little recognition that this cooperation is frequently suboptimal. The research shows that each outbreak case resulted in 
a different level of cooperation. This study presents an analytical tool to understand the different ways that the international community cooperates in global health, and it analyses the variance and patterns of cooperation in response to infectious disease outbreaks of international concern. This tool provides a method to operationalize the complex issue of how cooperation varies.

Second, the theoretical framework measuring the characteristics of epistemic communities, as well as the degree of international cooperation confirms that these actors can influence cooperation. The proposed model of epistemic communities examined the attributes of epistemic communities, including how they connect to the system of global institutions and governance, and how their participation impacts the outcome. Some epistemic communities can develop strong consensual knowledge and present a policy goal, disseminate their knowledge through their structure, and their multiple connections outside the network. They disseminate their widespread agreement on the problem definitions, the methods required to solve the 'problem,' and identification of possible solutions through publications and conferences. This activity will support an epistemic community's authoritative knowledge claim. Some epistemic communities will also influence the policymaking process to the extent they can participate and institutionalize their bureaucratic power in the policy-making process, with the possibility of having direct involvement in the formulation and implementation of policies. As outlined below, in the Influenza H1N1 case, with a high level of cooperation, the epistemic community developed consensual knowledge, a policy goal, and established a network connecting its members inside and outside. Members of the Influenza epistemic community disseminated their knowledge, published, and participated in conferences continuously transmitting and distributing their research. They also participated in critical expert groups and committees, which institutionalized and 
consolidated its bureaucratic power. Whereas in the case of MERS, where the level of cooperation was low, the epistemic community reached a partial consensus about the problem and solution, its structure was small, and its knowledge dissemination centered at the regional level, with limited bureaucratic power.

Epistemic communities are not the only factor that influences international cooperation. Yet, these findings confirm that epistemic communities facilitate the functioning of the system of global health governance, i.e., the implementation of norms, the creation of sound policy, and effective collaboration across the international system. Epistemic communities have a more substantial influence on international cooperation when they act together and produce consensual knowledge that is transmitted to policymakers, in a well-organized structure, with multiple connections among them and that have institutionalized their bureaucratic power in the global policymaking process.

\subsection{Organization of chapters}

This document consists of nine chapters, including the introduction. Chapter 2 explains the research methods used in this study. It outlines the roadmap guiding the analysis, and the methodological framework developed for the research. Chapter 3 discusses the dependent and independent variables, beginning with a literature review of international cooperation (dependent variable), introducing a model to analyze international cooperation in global health. The second part of the chapter focuses on analyzing epistemic communities to explain variation in international cooperation. It presents a proposal to measure epistemic communities' characteristics and their influence on the level of international cooperation. Chapter 4 discusses the problem of cooperation in the international response to infectious diseases. It briefly explains this process and its most essential aspects. The chapter also introduces the study cases and explains the role of epistemic communities in the international 
response to pandemics. Chapter 5 examines the $\mathrm{A}(\mathrm{H} 1 \mathrm{~N} 1)$ influenza pandemic of 2009 , explaining the origins of the influenza epistemic community, its evolution, and the factors that have made this community stronger than others. Based on this analysis, the chapter analyzes if and how the epistemic community facilitated international cooperation during the pandemic outbreak. Chapter 6 reviews the MERS-CoV outbreak. It provides a general background about the disease and the origins of the epistemic community. The case examines the problems during the outbreak and the limited influence of the epistemic community. Chapter 7 presents the case of Ebola. It explains the complexity of the Ebola outbreak and the multiple factors that affected the level of cooperation. This chapter positions the participation of an epistemic community within this context and explains the epistemic community's influence in the process. Chapter 8 examines the Zika outbreak and the epistemic community that adapted itself to deal with the re-emergence of a virus that severely affects women and newborns. It explains the relevance of the epistemic community to achieve higher levels of cooperation. Chapter 9 summarizes the conclusions from all the cases, comparing the levels of cooperation and the influence of different epistemic communities. It gives a final analysis based on the evidence presented with some policy recommendations and provides options for future research. 


\section{Chapter 2: Research methodology}

The research asks the question - why does international cooperation vary in the response to international infectious disease outbreaks of similar pandemic potential? To explore this research question, I undertake literature reviews of global health governance, international cooperation, and the response to infectious disease outbreaks, presented in Chapters 3 and 4. Through analyses of global health governance, the role of epistemic communities emerged as critically important to facilitate global health governance. After a thorough review of the literature on epistemic communities, this paper hypothesizes that epistemic communities affect variation in international cooperation due to differences in epistemic communities' characteristics (degree of consensual knowledge, capabilities to disseminate it, the extent of institutionalization of their bureaucratic power). The research then operationalizes the concept of epistemic communities (independent variable) and identifies how international cooperation varies in global health (dependent variable). It builds a theoretical framework showing the pathways between epistemic communities and international cooperation and applies this framework to the relationship between epistemic communities and cooperation in four case studies.

\subsection{Identifying epistemic communities (independent variable)}

The literature on epistemic communities provides a general definition of what an epistemic community is, and which actors are part of it. Most studies based their description of an epistemic community on the characteristics defined by Peter Hass (normative beliefs; casual beliefs; epistemological criteria; and a joint policy enterprise) (19). Scholars, however, do not usually identify who these actors are. There is an underlining assumption that a group of experts showing Haas' characteristics represents an epistemic community. Therefore, 
establishing the boundaries of any epistemic community is challenging. A critical element in the identification of these knowledge networks is their expertise in a field of knowledge $(25,51,52,53)$. As a result, when describing epistemic communities' membership usually includes experts working for universities, research institutions, NGOs, and professionals working in government-financed agencies. Epistemic communities also have a direct connection to the policymaking process $(24,51,54)$. Therefore, members of epistemic communities usually include bureaucrats (at the national and international level), policymakers and diplomats.

To operationalize the concept of epistemic community and determine why some succeed in influencing cooperation, and others do not, this research first identifies the epistemic communities of interest and their members $(26,27,28)$. It tracks the creation and foundations of each one these networks, their membership, their members' interactions among themselves and within the policy process, the evolution of the communities over time, and their influence on cooperative outcomes $(26,29)$. To conduct a thorough identification, the researcher used the criteria described in figure 1. 


\section{WHO}

are they?

- experts with knowledge in the field (epidemiologists, physicians, biologists, veterinarians, laboratory scientists, clinicians, academics, social workers, administrators, among others)

-they can be members of governments(diplomats, bureaucrats, decision makers); international

organizations (mostly WHO), or other relevant policy actors

-they share a common interest in the topic

-they have a policy goal

\section{HOW do they interact?}

-international organizations' meetings (governance bodies)

-international committees or other technical groups

-experts meetings

- academic conferences

•internet

\section{WHAT}

kind of resources do they have available to influence the policy process? What do they do?

-institutionalized expert's advice

-access to privileged information

- scientific publications

-holders of information

-access to the policy process

-personal relationships

Figure 1. Identification of an epistemic community. Based on Davis Cross 2011 and Löblová (27,26).

With these criteria, this research considers that epistemic communities in global health include WHO officials and other UN bureaucrats with expertise in fields related to health and international development; scientists and experts working in universities, research institutions, NGOs and non profit organizations from disciplines relevant to public health (epidemiologists, biologist, clinical laboratory scientist, public health experts among others); domestic bureaucrats (from health agencies and others agencies); and health attachés (diplomats specialized on global health). Identifying the members of a given epistemic community in global health, therefore, requires cross-checked lists of international meetings (28) such as the WHO governance bodies meetings, expert group consultations, and committees; recurrent names are usually members of these communities. 


\subsection{Determining the level of international cooperation (dependent variable)}

To determine how international cooperation varies, Chapter 3 reviews the literature on global health and international cooperation. The literature is the foundation for operationalizing variation in global health cooperation, as outlined in Figure 2. Chapter 3 then describes the link between epistemic communities and international cooperation, namely through the structure of global health governance. Figure 3 lays out this link, and Chapter 3 articulates this framework in detail. 

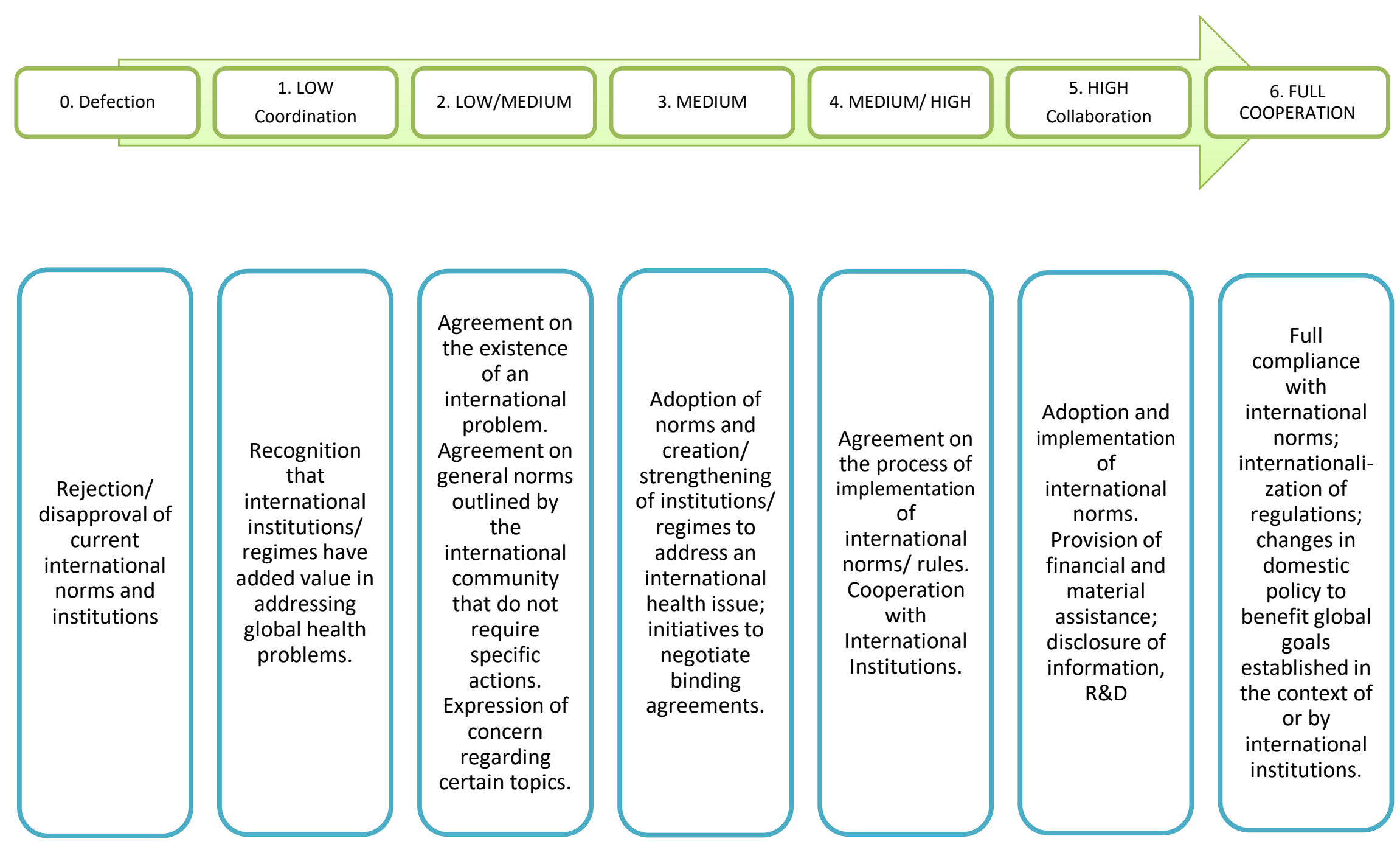

Figure 2. The proposed spectrum of cooperation in global health. 


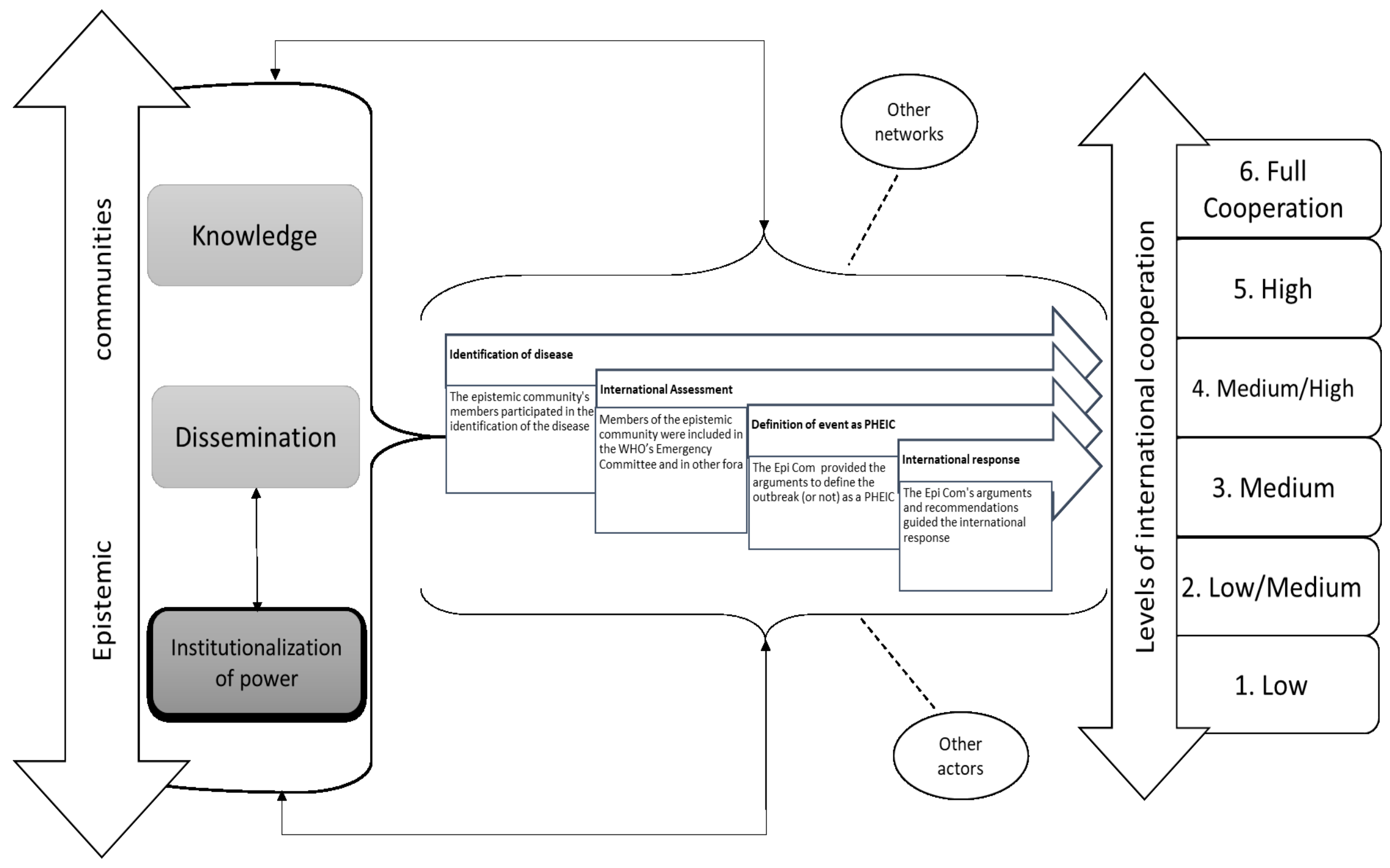

Figure 3. A theoretical framework for analyzing the role of epistemic communities in the international response to infectious disease outbreaks 
To operationalize the framework, the research examines the epistemic communities' individual characteristics to determine how they contributed to the observed level of cooperation. The present study, however, is exploratory since it will likely generate other hypotheses related to epistemic communities and variation in international cooperation providing new insights into the problem (50).

\subsection{Methodology: case study and process tracing}

Case studies are a valuable tool for testing different hypotheses - particularly in the exploratory stages of research. Case studies enable researchers to test explanations that define how the independent variable affects the dependent $(51,52)$. In some instances, particularly for exploratory analysis, case studies are considered more suitable than other approaches for testing theories. This methodology is also convenient to identify and measure indicators that represent the theoretical concepts the researcher intends to measure (51). Case studies are instrumental in analyzing policy transfer mechanisms such as epistemic communities since they permit the identification of complex relationships, interaction effects, and path dependency $(51,49,53)$.

The study also applies the process-tracing method to understand how various factors are relevant to the outcome (54). Process-tracing is valuable for theory building and theory testing. Process-tracing enables researchers to explore the chain of events by which initial case conditions translate into outcomes $(51,55)$. Process tracing supports theory testing as it allows the exploration of a hypothesized causal mechanism against evidence to determine if and how variables contribute to the observed outcome. For theory building, it works to uncover mechanisms that are not clear, and that can affect the outcome (56). It requires using empirical evidence to understand the results (56). Process tracing makes it possible to identify the relationship between independent and dependent variables (51). It facilitates the 
exploration of the hypothesis (51). Comparative case studies using process-tracing are standard and effective methods to understand the causal mechanism through which an epistemic community influences a policy process (48).

For each case, the study applies the proposed framework, characterizing each one of the epistemic communities, determining:

1. if and how members of an epistemic community demonstrated a robust and shared understanding of the problem, if they formulated a policy goal and shared it, or if areas of disagreement or contention existed;

2. if the structure of the epistemic community facilitated connections among its members i.e., who the participants in the network were, how they connected among themselves, how extensive their network was, and how they disseminated information through this structure;

3. how directly the epistemic community participated in decision making during the time frame of the case, and to what extent it institutionalized its bureaucratic power; and,

4. if the epistemic community institutionalized its bureaucratic power, to what extent policymakers applied the information that the epistemic community provided during the during the international response.

\subsection{Case selection- Inclusion and exclusion criteria}

The present research studies the universe of pandemic diseases that were assessed by an Emergency Committee under the International Health Regulations 2005 (IHR 2005) between 2005 and 2015: Influenza A(H1N1) in 2009, MERS in 2012, Ebola 2013-2016, Poliovirus in 2013, and Zika virus 2015-2016. An emergency committee determined if each 


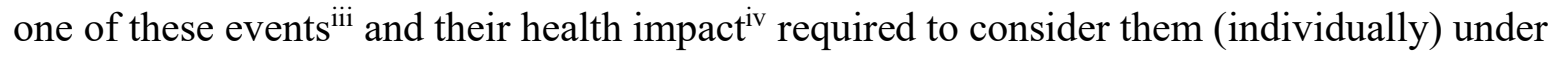
the category of Public Health Emergency of International Concern (PHEIC). Figure 4 presents a map of recent outbreaks assessed under the IHRs 2005.

\section{Outbreaks assessed under IHRs 2005-2015}

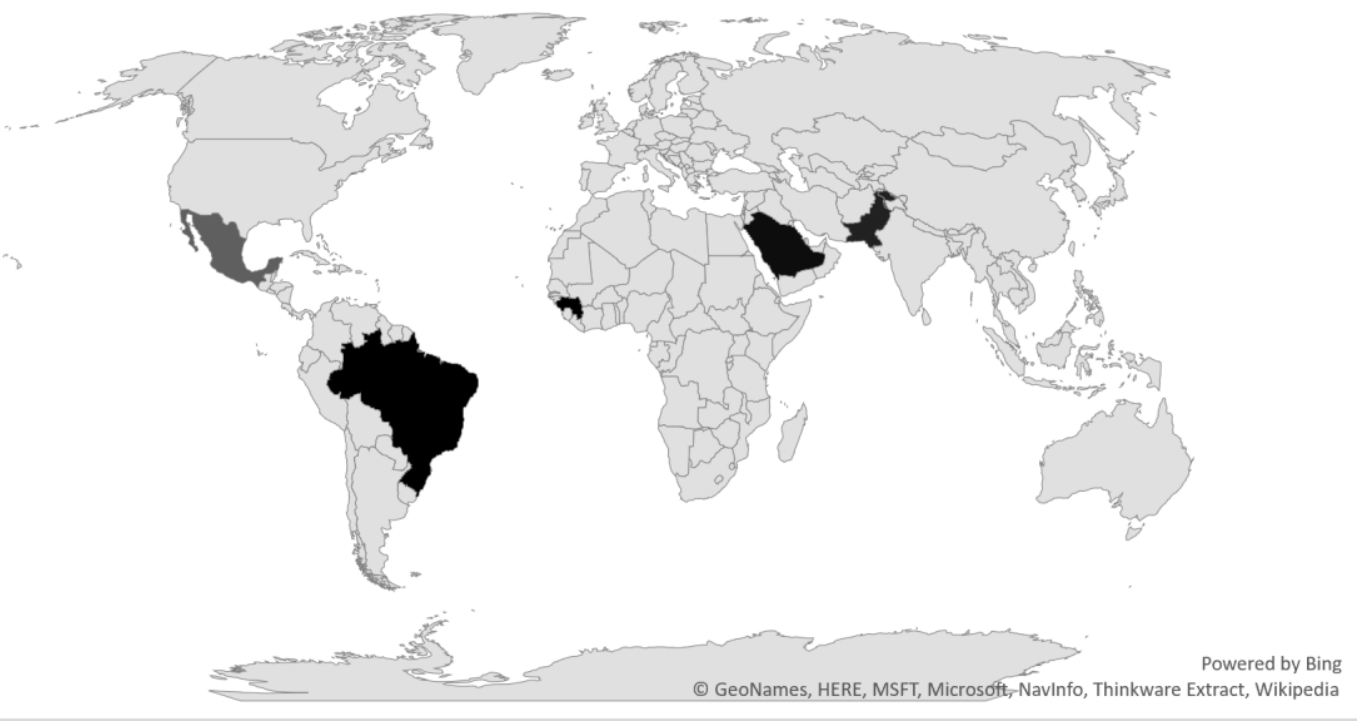

Figure 4. Map of the outbreaks assessed under the IHRs 2005 between 2005 and 2015.

The selection of cases comprises influenza A(H1N1), MERS, Ebola, and Zika virus outbreaks. This study captures variation in the dependent variable by having one case where the level of international cooperation in the response was closer to full cooperation (Influenza $\mathrm{H} 1 \mathrm{~N} 1$ ), one case where international cooperation was high (Zika), one medium-low (Ebola) and one case where there has not been an official international response and cooperation has been medium-low (MERS CoV).

The first case, an influenza pandemic, is a well-known virus. Influenza pandemic

\footnotetext{
iii Defined as "a manifestation of a disease or circumstance that may create a disease" (16)

iv These include the diseases listed in Annex 2, IHR 2005 that are subject of notification according to the decision instrument previously described in this prospectus.
} 
outbreaks occur periodically in the world, and research is highly advanced in the area (57). The second case, MERS-CoV, a coronavirus (a type of virus from the same family that caused the SARS epidemic), is a less-known emerging disease and thus lacks a foundation of scientific research. An emergency committee analyzed and reviewed the MERS-CoV outbreak, but it did not declare it as PHEIC even though it has pandemic potential. The third case, Ebola, was first identified in the 1970s and has shown high mortality levels. The 2014 outbreak was initially not considered a PHEIC even when the case mortality rate was high. The last case, Zika, is the only disease transmitted through a vector (a mosquito). It was declared a PHEIC even though the link between the disease and encephalitis in newborns was not clear by the time the WHO made the declaration.

The research excludes the poliovirus outbreak of 2014 (categorized as a PHEIC). The outbreak was small and took place amid a largely successful disease eradication effort with high levels of cooperation. Since 1988, when the WHO launched the Global Polio Eradication Initiative, the polio cases have decreased by $99 \%$ (58). On May $5^{\text {th, }} 2014$, the WHO Director-General announced that an Emergency Committee assessed an outbreak of wild poliovirus in Afghanistan, Cameroon, Equatorial Guinea, Ethiopia, Israel, Nigeria, Pakistan, Somalia, and the Syrian Arab Republic. An emergency committee decided that the outbreak met the criteria to consider it a Public Health Emergency of International Concern (PHEIC). Yet little new action took place, and polio eradication efforts continued. Therefore, this study does not include the polio PHEIC.

\subsection{Data collection method}

As noted above, process-tracing involves the examination of histories, archival 
documents, interview transcripts, meeting records, public commentary by researchers, and other sources to collect information on relevant variables (51). Collecting data from multiple sources allows triangulation, which provides a more rigorous process of analysis that increases confidence in the validation of findings $(59,60)$. Therefore, this research included information from different sources. The first group of data came from official reports and primary documents from international organizations. It comprised resolutions, historical records, archival documents, individual reports collected and published by the WHO and other organizations. As well, it included previously published interviews with experts and other stakeholders. The consulted documents were obtained through the WHO and its regional offices' websites, WHO headquarters archives, other international organizations' websites, and official governments' websites. Although official documents and archival sources are subject to selective deposit and selective survival (61), in this case, it was best to analyze official sources. The primary source of information was the WHO since each country must report any disease outbreak under the IHRs.

Academic publications were the second group of data sources, including books, peerreviewed and other published articles written by members of epistemic communities in recognized journals of public management, public policy, international affairs, medical sciences, microbiology, virology, global health and health policy (such as The Lancet or The $B M J$ ), among others. The academic literature provided the basis for the theoretical and analytical framework, guiding the research and the tools for analyzing the information and the cases. Scholarly articles were also critical to complete the case studies, providing information that was not clear from other sources but also offering the experts' perspective. 
Finally, to complement the information, I conducted 12 confidential interviews with members of epistemic communities who had participated in one or more of the responses to diseases outbreaks included in this research. I identified those actors through publications, documents from international organizations, and reports from governments. Some of the interviewees also provided names of possible candidates and, in some cases, contacted me to arrange an interview. The interviews were conducted in person, by telephone or skype, and they had a duration of between 30 minutes to 60 minutes. The interviews were semistructured based on the interviewed guide approved by Carleton University's Research Ethics Board (See Appendix A). The guide included questions that helped give a better understanding of the epistemic communities' role in the international response to pandemics.

Even though these questions guided the interviews, participants did not answer all of them. In most cases, interviewees provided answers that combined elements referred to in other questions. Therefore I considered it redundant to ask about something already discussed. During some of the interviews, I introduced some items not included in the guide to make clarifications or to elaborate issues that were relevant for the study.

The number of people included in my sample was small; however, all of them came from different backgrounds, nationalities/regions, and with different positions within organizations and governments. All of them constituted a sample of the type of members in an epistemic community network, with different backgrounds, and roles. Table 1 presents a general description of the interviewees ${ }^{\mathrm{v}}$.

$\mathrm{v}$ To keep the anonymity of the interviewees, this table does not disclose any specific information that can be attributed to a specific
person. 


\begin{tabular}{|l|l|l|}
\hline No. of Interview & Position & Type of organization \\
\hline Interview 1 & Deputy Minister & Government \\
\hline Interview 2 & Director-General & Government \\
\hline Interview 3 & Director Research Centre & Research Institution \\
\hline Interview 4 & Director-General & Government \\
\hline Interview 5 & High-Level Advisor & Private consulting \\
\hline Interview 6 & Senior Consulting Fellow & NGO \\
\hline Interview 7 & Programme Officer & International Organization \\
\hline Interview 8 & Bio Risk Manager & Regional Organization \\
\hline Interview 9 & General Manager & Government \\
\hline Interview 10 & Head of Division & Regional Organization \\
\hline Interview 11 & Director of a Research Centre & University \\
\hline Interview 12 & $\begin{array}{l}\text { Consultant/ Former Deputy } \\
\text { Minister }\end{array}$ & Government \\
\hline
\end{tabular}

Table 1. General description of interviewees.

In the analysis/coding of the data from the interviews, I applied both deductive and inductive analysis. For the deductive analysis, I identified categories a priori based on the theoretical framework $(62,63)$, and based on that, I developed a coding system. The inductive analysis identified common themes that emerged through the interviews. Then, I classified the codes per category, as presented in table 2 .

\begin{tabular}{|l|l|}
\hline Category & Codes \\
\hline $\begin{array}{l}\text { 1. Collaboration and development of } \\
\text { consensual knowledge }\end{array}$ & $\begin{array}{l}\text { Epistemic community collaboration } \\
\text { Agreed definition } \\
\text { History of collaboration }\end{array}$ \\
\hline 2. Structure & $\begin{array}{l}\text { Informal/formal communication } \\
\text { Interactions with other community members } \\
\text { WHO's participation in the epistemic community }\end{array}$ \\
\hline 3. Institutionalization of bureaucratic \\
power & $\begin{array}{l}\text { Bureaucratic power } \\
\text { Influence of institutions/norms } \\
\text { Expert advisors }\end{array}$ \\
& $\begin{array}{l}\text { Evidence-based policymaking } \\
\text { Legitimacy } \\
\text { Participation in international organizations }\end{array}$ \\
& Direct involvement in national governments \\
& Participation in international meetings \\
& Members in a key decision-making position \\
& Leaders-champions-policy entrepreneurs \\
\hline 4. International response & Characteristics of the Influenza outbreak \\
& Characteristics of the Ebola outbreak \\
& Characteristics of the Zika outbreak \\
& Characteristics of the MERS outbreak \\
& Participation of experts in the influenza response \\
&
\end{tabular}

Table 2. Codification of interviews 
This information facilitated assessing the strength of the epistemic communities included in this research, specifically by identifying how relevant epistemic networks engaged in the policy-making process. The information provided by the interviews complemented the data obtained from other sources.

\subsection{Scope and Limitations}

This research was broad and complex, given the type of cases it analyzed, the theoretical framework applied to them, the amount of information that each case comprises, and the research method.

First, an analysis of epistemic communities participating in international cooperation on disease outbreaks offers an opportunity to improve our understanding of the role of professionals working on global health issues. As such, it recognizes them as actors with agency, embedded in an international system of governance managed by sovereign states and international organizations. Research on epistemic communities tends to centre its study on the "power of knowledge" and the assumption that their expertise is their most essential feature. The research, however, acknowledges other characteristics of epistemic communities that make these actors relevant for policymaking. For instance, these groups are social structures that forge relationships necessary to connect their knowledge to the policy process and to make it relevant for decision making. These characteristics are necessary to advance their knowledge into the policy process.

Second, complex webs of professional networks always exist. For individuals engaged in global health, those networks can be quite extensive - including academics, advocates, and policymakers - and span countries. It can be challenging to differentiate 
between establishing the existence of expert networks to identifying the epistemic community's precise influence on cooperative outcomes.

Third, the research required identifying the epistemic community for each one of the study cases. Mapping the entire network in each case study, however, was extremely complex and outside of the scope of this study given their multisectoral and multi-level components. I solved this limitation by identifying a core group or groups that represent an epistemic community. For all cases, this core group included members of the Emergency Committee (EC) and other experts. According to the IHR 2005, the EC is the principal technical advisor to the WHO for the assessment of a disease outbreak, and its decisions can trigger an official international response. Historically, professionals with expertise in different fields of global health have collaborated with the WHO sometimes as members of governments, other international organizations, research centres, universities, professional associations, or as independent experts. Through the EC and other forums, they connect with the WHO and its regional offices. Not all professionals with expertise in a specific area or their institutions of origin are part of a given epistemic community. As the cases will show, an epistemic community can be a small and closed group, and it does not automatically include all professionals with relevant expertise in the field.

Fourth, the analysis of the influence of the epistemic community in international cooperation needs to connect the members of the epistemic community to the policy process and policy decisions. In some of the cases in this research, making this connection was challenging due to the lack of available information. Given that many members of the epistemic communities hold policymaking positions, many of them did not want to be 
recognized or could not share some information. Moreover, the WHO produces and keeps most of the records of meetings and information about disease outbreaks and the unfolding events for an international response. Nevertheless, many of these records are not fully available, and the WHO usually only provides summaries of meetings, such as in the case of the EC meetings. The WHO's access to information policy indicates that the organization has the right to reserve any document for 20 years ${ }^{\mathrm{vi}}$.

Fifth, the research addresses some of the most common problems found in the literature of epistemic communities, such as the analysis of a single case study or that the cases usually present positive outcomes (high cooperation). The study comprised four study cases, all with a different outcome. Having variation in the cases improved the analysis of how and to what extent epistemic communities contributed to this variation. The inclusion of four cases as extensive as the ones chosen in this research, however, creates a problem of limited time and resources for an in-depth and detailed analysis of each one of them. Nonetheless, this study provides a starting point to continue exploring them.

Sixth, the information included sources from different fields such as epidemiology, the biology of infectious diseases, surveillance, laboratory, genetics, vaccine, and drug development, among others. It also required the review of country-specific health reports, international health guidelines, and expert reports on global health produced by international organizations. Since I am not a biologist or health sciences expert, some explanations about the mechanics of diseases and the medical interventions are general and may lack precision.

\footnotetext{
${ }^{v i}$ Email received on May $3^{\text {rd }}, 2017$ from Renee Steelant, WHO Records and Archives, referring to WHO Archives access policy which states "WHO archives are accessible to researchers once the records are at least 20 years old".
} 
For that reason, I tried to include as many sources as possible.

Seventh, the theoretical framework outlining the relationship between epistemic communities and global health cooperation is exploratory and complex. However, while recognizing the challenges of establishing the causal role of the epistemic communities in global health cooperation, we should question what would have happened in the absence of epistemic communities in the cases analyzed in this research.

Eight, despite the broad interest in the study of pandemics, the public health perspective dominates the study of pandemics and global health, even though this field offers multiple cases of interest to advance our knowledge in international relations. This research aims to close that gap by presenting a study from a perspective of international affairs, referring specifically to the problem of international cooperation.

Ninth, the research applied a framework based on theories of epistemic communities to examine international cooperation. This approach is not new in the study of international affairs; however, scholars have considered epistemic communities mostly in the context of the environment and social policy. Few studies examine the concept of epistemic communities to explain international cooperation (64) or global health outcomes $(65,66,67,49,68,69)$. In the field of global health, epistemic communities regularly participate in everyday policymaking. Thus, there are many cases to study the relevance of these actors and their influence on policy outcomes. To my knowledge, this is the first study that comprises four cases at once with variation in the level of cooperation. An extended analysis of four cases with different outcomes provides details of how epistemic communities can modify international cooperation, and what characteristics matter the most to shape their 
impact.

Finally, some studies have already addressed the importance of internal characteristics in the level of influence of an epistemic community (70); as well as the importance of external factors such as the demand of experts (47). Instead of separating the epistemic communities` characteristics from their context, the proposed framework includes both components in a comprehensive model. 


\section{Chapter 3: International cooperation}

This chapter will explore the concept of international cooperation and examine how international cooperation varies. To this aim, the study introduces indicators for measuring variance in international cooperation in global health. Then, the chapter will turn to a discussion of epistemic communities and how and why their relevance for advancing international cooperation in global health. It will then explain and outline the framework that guides the analysis of the case studies.

\subsection{Introducing the problem of international cooperation}

International cooperation materializes when actors adjust their behaviour to the actual or anticipated preferences of others, through a process of policy development, implementation, and coordination (71). Cooperation in the international arena, however, is often difficult to achieve. Traditional theories of international relations have focused their attention on providing different explanations to the central question: when and why do countries cooperate?

Realist scholars argue that cooperation is possible when it increases the net benefits to the state (72). International norms and institutions, therefore, reflect and reinforce national interests and national security calculations. As such, countries cooperate when they are better off than without cooperation. Although these theories draw attention to a fundamental problem in international affairs (national interest over collective wellbeing), they fail to recognize that international cooperation in global health always materializes to some degree and that, sometimes, non-cooperative behaviour is inconsistent with the national interest.

Neoliberal institutionalism focuses on institutions as critical mechanisms for 
cooperation - they establish predictable rules of the game (73) and systems (74) to promote it $(75,76,77)$. In this conception, international institutions work "establishing the ways in which states should cooperate with each other (78)." Institutions guide, enable and constrain the actions of individual actors, such as states (79), by providing information; increasing transparency; reducing incentives to defect either by giving sanctions to violators or by lengthening the "shadow of the future"; reducing uncertainty; and decreasing transaction costs (76). Institutions can increase interdependence, and enable the coordination of policies among states, leading to higher levels of cooperation $(76,80,81,82,83,84)$.

Regardless of a governing framework of international institutions and norms, different levels of international cooperation occur for similar outbreaks. Institutions can modify states' behaviour by enforcing rules $(75,85)$. Variation in international cooperation, therefore, could be a problem of enforcement and implementation. However, most international institutions do not have enforcement mechanisms (organizations on international trade and human rights are the exceptions). In the case of global health, there are no instruments to enforce rules. In the end, national states choose to adhere themselves to certain norms, implement them fully or partially, and whether to adopt them or not at the national level.

Institutional theorists also predict that norms and institutions would induce optimal levels of cooperation by modifying states' behaviour. In global health, the WHO - understood as the organization itself and the collective decision making of its member states - has increased its influence in the development of global health policies, making possible the creation of relevant norms and institutions in different areas (tobacco control, HIV-AIDS, 
communicable diseases, infectious diseases, among others). In infectious diseases, the WHO guided the development, negotiation, and implementation of the current system for prevention, management, and response to disease outbreaks under the IHRs.

Finally, theories of social learning, policy diffusion, and policy transfer go beyond the existence of institutions to argue that cooperation depends on how each country internalizes norms and shares information, knowledge, and ideas (20). Social constructivism theorists focused on explaining other aspects of international cooperation, such as the nature of agents or subjects, problematizing them, and studying them as variables (86). The study of agents allows moving from the study of norms and institutions as stable social structures to "how actors must operationalize their normative context to take specific actions (87)" since norms should be transformed into specific activities. Therefore, it studies the role of nonstate actors such as epistemic communities in shaping cooperative outcomes and increasing levels of cooperation ${ }^{\text {vii }}(20,25,21,22)$.

\subsection{Variation in international cooperation}

International cooperation, particularly in global health, is best understood as a phenomenon of multiple levels $(88,75,89,81)$. While the international community usually cooperates to some degree, the intensity of cooperation varies because states cannot always agree on the terms of cooperation, particularly if cooperation has distributional consequences. The highest level of cooperation is difficult to reach since countries must implement specific actions to benefit others, while the advantages of these actions are not

\footnotetext{
vii Traditional theories of international relations largely assume cooperation is a dichotomy, states either "defect" or "coopera te" (666). The constructivist approach challenges this interpretation, and some authors propose the idea that cooperation has multiple degrees (23,666,93).
} 
reflected directly into their well-being.

Figure 5 shows international cooperation by utilizing the concept of the Pareto frontier. The space between the Pareto frontier and the point of origin are all possible options to reach a cooperative agreement, with the most optimal solutions for each party found on the Pareto Frontier (23). Parties must work together to identify the point on the Pareto frontier of maximum mutual benefit or common interest. Parties do not know the location of the Pareto Frontier, and they do not know what it is "jointly possible" as countries' preferences are unknown, and they do not openly share the range of probable outcomes $(23,90,48)$. Therefore, inferior results, asymmetric outcomes, and impasses are typical (23).

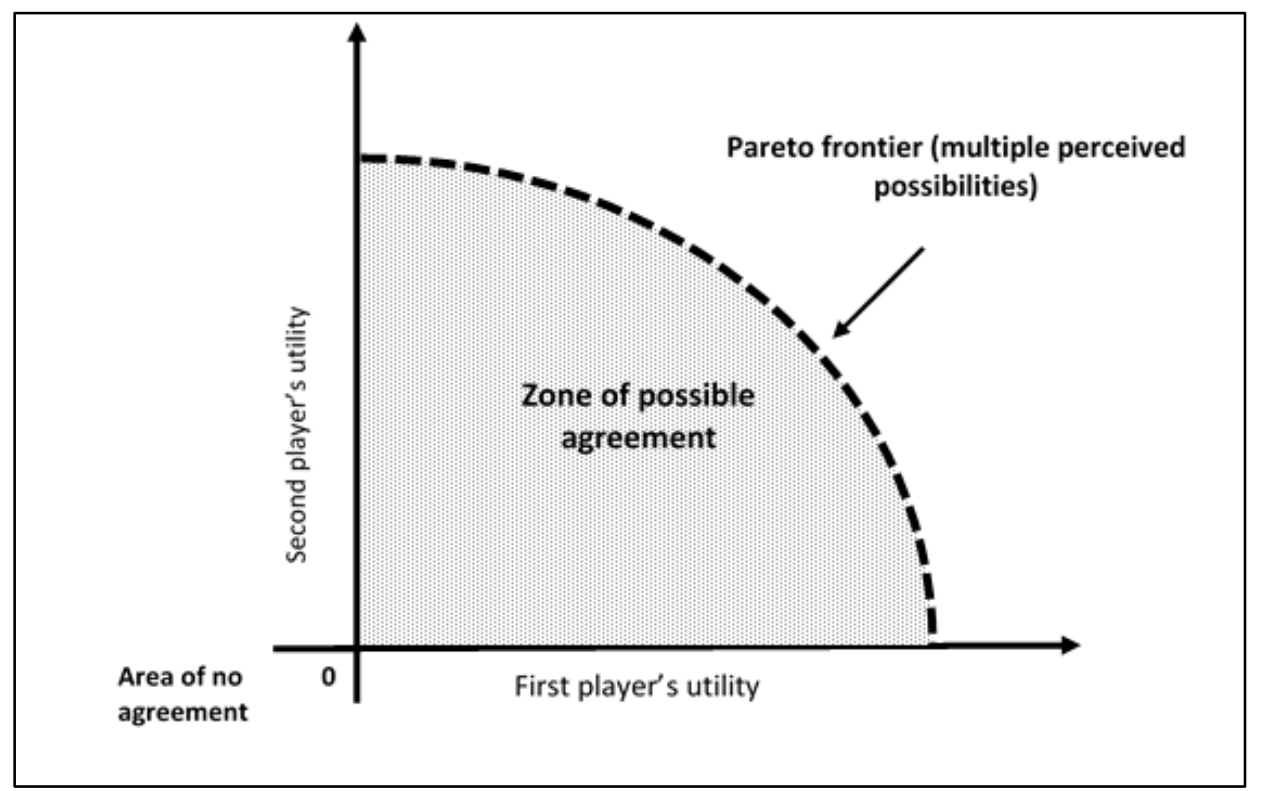

Figure 5. Distributional conflicts outside the Pareto Frontier. Based on Sebenius 1992 (23).

For the analysis of global health, an essential aspect of this model is the existence of suboptimal cooperation. Suboptimal cooperation with distributional conflict is usual in areaissues with a high degree of technical/ scientific or strategic uncertainty $(25,90,23,91,92)$. Technical uncertainty makes it more challenging to understand the existence and nature of a 
problem, as well as to formulate appropriate solutions to solve it (93). Given the role of global health institutions in facilitating discussion and dialogue, they facilitate repeated interactions. Actors enter a process where they learn from each other over the iterative processes of negotiation and discussion. Knowledge about the other actors and the issues under discussion improves during this constant interaction $(23,90)$, and cooperation, therefore, can evolve over time or emerging distrust can undermine future cooperation.

The Pandemic Influenza Preparedness Framework (PIP) negotiations exemplify the distributional consequences of some global health agreements, the importance of iterative interactions, and the difficulty of reaching full cooperation in global health. From 2006 onwards, the global health community watched with concern as a novel H5N1 influenza virus spread among the bird population in Southeast Asia. Many scientific experts feared that H5N1 could spread quickly and devastate global health like the Spanish Influenza outbreak of 1918 .

In 2011, the WHO`s members approved the PIP framework after a controversial negotiation to address how countries could share influenza viruses for research and development (R\&D) purposes, including vaccine development technologies and access to vaccines. The negotiation began after Indonesia claimed that developed countries (and their pharmaceutical industries) were taking advantage of the WHO's system. Countries routinely took viral samples from disease outbreaks, specifically influenza, and gave these samples to companies to develop and manufacture vaccines for their citizens and markets. In the case of an outbreak of pandemic influenza, this would provide countries with the possibility of protecting their citizens $(94,95)$. Indonesia argued that countries and industries collecting 
influenza virus samples to manufacture vaccines for profit should provide benefits to the countries where those viruses originated $(96,97,98)$. Citizens of the originating countries would be first affected by any pandemic outbreak yet would not benefit from vaccines as pharmaceutical companies commercialize them for high-income country markets $(94,95)$.

The distributional conflicts in the negotiation of this agreement included determining who benefits from the acquisition of viral samples; how the pharmaceutical companies access viral samples; how to persuade pharmaceutical companies to share benefits with those affected countries; and, the delimitation of benefits (access to medicines, vaccines, research). In the end, countries found a compromise whereby the originating countries will provide influenza virus samples and receive $R \& D$ benefits in return.

The agreement, however, was less than optimal. The final version did not include all the demands made by either developed or developing countries. Further, private actors undertake many R\&D activities, yet there are no enforcement mechanisms to make them comply with this framework (99). Nevertheless, reaching an agreement was better than no agreement - not having access to virus samples makes it more difficult to control an outbreak. Although this was not an optimal outcome, it represented a joint gain. It was a move towards more cooperation in a critical area where the exchange of viral samples and biological materials is crucial for controlling disease outbreaks.

The PIP, however, does not represent a situation of full cooperation because it only provided a partial solution to the problem - for instance, it created a framework for the pharmaceutical companies that is not enforceable, and that it depends on the goodwill of all actors involved in the system (100). The agreement also only covered influenza viruses, and 
there were no discussions about including other pathogens under the same framework (even though the issue of sample sharing goes beyond influenza).

In the PIP negotiation, the outcome, therefore, was cooperative, although it was still far from the Pareto frontier. Indeed, countries found it difficult to reach an ideal outcome because it required a high level of commitment from all the parties involved in the process. The process did not allow direct participation of non-state actors, including scientific experts, as well as representatives from the pharmaceutical sector. In this case, non-state actors participated through national governments and the WHO. The PIP illustrates that international cooperation in global health can vary dramatically and that even a 'cooperative agreement' can be less than what is needed to fully address a pandemic outbreak.

\subsubsection{An analytical framework to analyze variation in global health cooperation}

The Pareto frontier is a useful conceptual tool that illustrates the existence of "perfect" or full cooperation, and the fact that many international agreements fall below this ideal. The PIP negotiation demonstrates the challenge of reaching that "ideal" cooperative outcome in practice - for a global health issue of high priority. However, what does the spectrum of cooperation look like in practice? How can researchers understand, identify, and operationalize the variation in international cooperation in global health? The present research proposes stages in global health cooperation $(101,102,93,103,88,12,104,105)$. This model presented in figure 6 defines six varying degrees of cooperation, providing concepts, indicators, and an approach to measure this cooperation. 

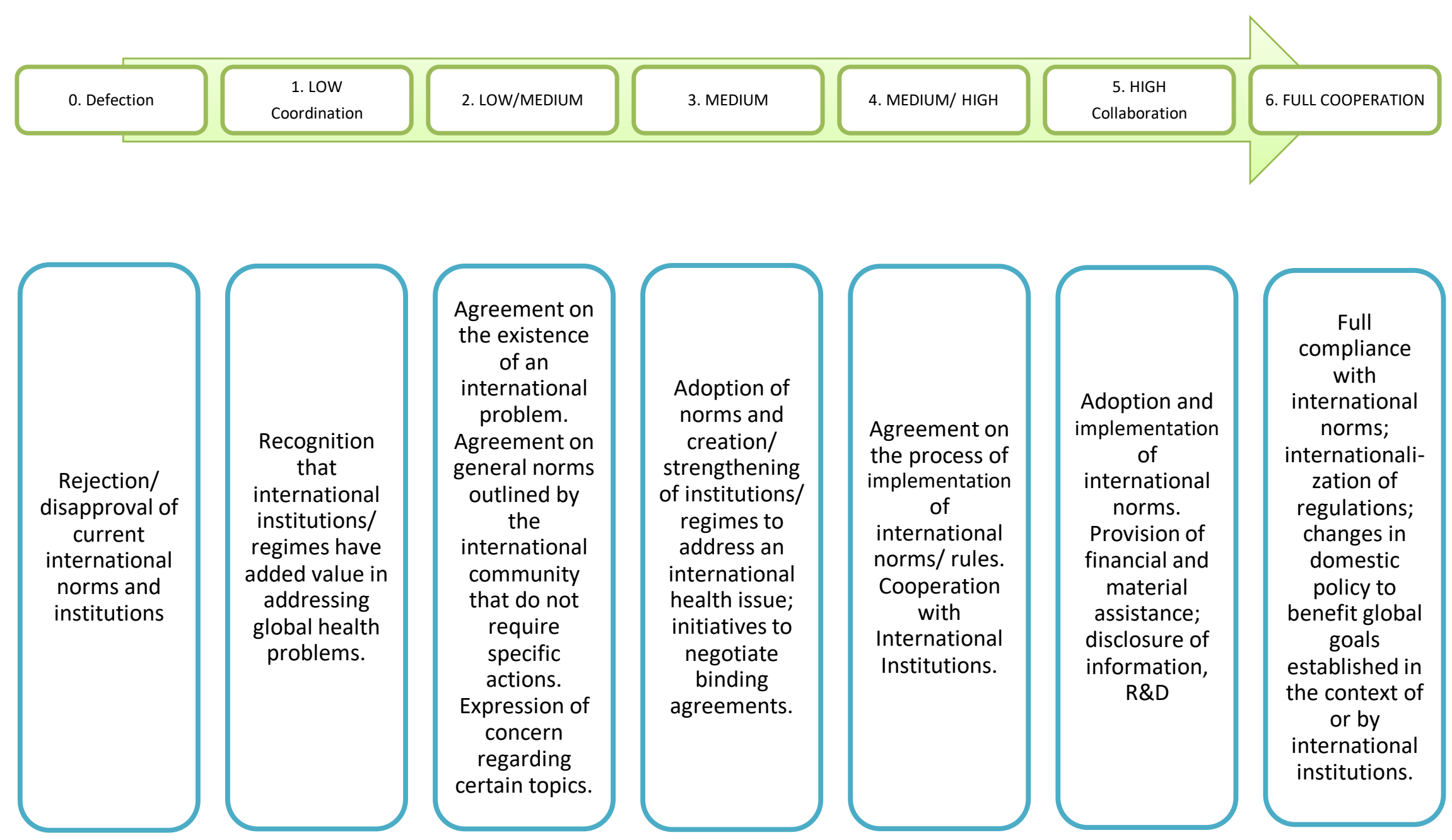

Figure 6. A proposed spectrum of international cooperation in global health. 
In general, cooperation in global health is mostly at levels 1 and 2: coordination. Countries created the WHO and other multilateral agencies to solve coordination problems $(105,81,88,101,106)$, facilitating agreements, and mobilizing resources (102). Although international organizations function as a space to meet, set policies, and approve international programs, these are necessary but not sufficient to ensure cooperation $(105,107)$. As they discuss global health issues, states define the problem, identify its relevance, and set the global health agenda (Level One). Members of the WHO, either at the World Health Assembly (WHA) $)^{\text {viii }}$ or the Executive Board (EB) $)^{\text {ix }}$ meetings, draft and propose resolutions (non-binding) to articulate and problematize global health issues and how to address them. In addition to the development of soft law (non-binding agreements), the establishment of institutions and the broad coordination of policy (Level 2) are also consistent characteristics in global health cooperation (108). Governments participate every year at the WHA to determine the policies of the organization, adopt conventions and agreements regarding any issue within the competence of the WHO (109). It was not until 2003 that countries agreed to exercise Article 19 of the World Health Organization's Constitution and approved the

\footnotetext{
viii The World Health Assembly is the most important body of governance at the World Health Organization where every year on May all its member states gather to discuss topics of international public health. According with the WHO Constitution Article 21 "The Health Assembly shall have authority to adopt regulations concerning: (a) sanitary and quarantine requirements and other procedures designed to prevent the international spread of disease; (b) nomenclatures with respect to diseases, causes of death and public health practices; (c) standards with respect to diagnostic procedures for international use; (d) standards with respect to the safety, purity and potency of biological, pharmaceutical and similar products moving in international commerce; (e) advertising and labelling of biological, pharmaceutical and similar products moving in international commerce."

ix The Executive Board is a governance body at the World Health Organization. Thirty-two member states are elected every three years to be members of the EB. The WHO Constitution in its Article 28 determines that "The functions of the Board shall be: (a) to give effect to the decisions and policies of the Health Assembly; (b) to act as the executive organ of the Health Assembly; (c) to perform any other functions entrusted to it by the Health Assembly; (d) to advise the Health Assembly on questions referred to it by that body and on matters assigned to the Organization by conventions, agreements and regulations; (e) to submit advice or proposals to the Health Assembly on its own initiative; (f) to prepare the agenda of meetings of the Health Assembly; (g) to submit to the Health Assembly for consideration and approval a general programme of work covering a specific period; (h) to study all questions within its competence; (i) to take emergency measures within the functions and financial resources of the Organization to deal with events requiring immediate action. In particular it may authorize the Director-General to take the necessary steps to combat epidemics, to participate in the organization of health relief to victims of a calamity and to undertake studies and research the urgency of which has been drawn to the attention of the Board by any Member or by the Director-General.
} 
Framework Convention on Tobacco Control, a binding agreement $(108,66)$ - cooperation at Level 3. Implementation of these agreements requires establishing specific processes and mechanisms, which is cooperation at Level 4.

Provision of financial and technical assistance - particularly direct support to Ministries of Health that necessitate adhering to goals and benchmarks - requires higher levels of commitment and cooperation that will lead to Level 5. In contrast, full cooperation required to reach Level 6 , is not easy to attain. It requires adjustments that many actors are unable to reach due to the lack of resources and their inability or unwillingness to reform domestic institutions and norms. To fully comply with international norms, all countries must adopt the same policies to achieve a common goal - such as the full implementation of the IHRs. This degree of policy convergence demands prioritization of international cooperation over national interests.

The different levels create a spectrum of cooperation. Figure 7 illustrates this as an incremental process that materializes over time. The international community can move up from low cooperation (Level 1) to low/medium (Level 2) and continue until reaching full cooperation (Level 6), the desired outcome. 


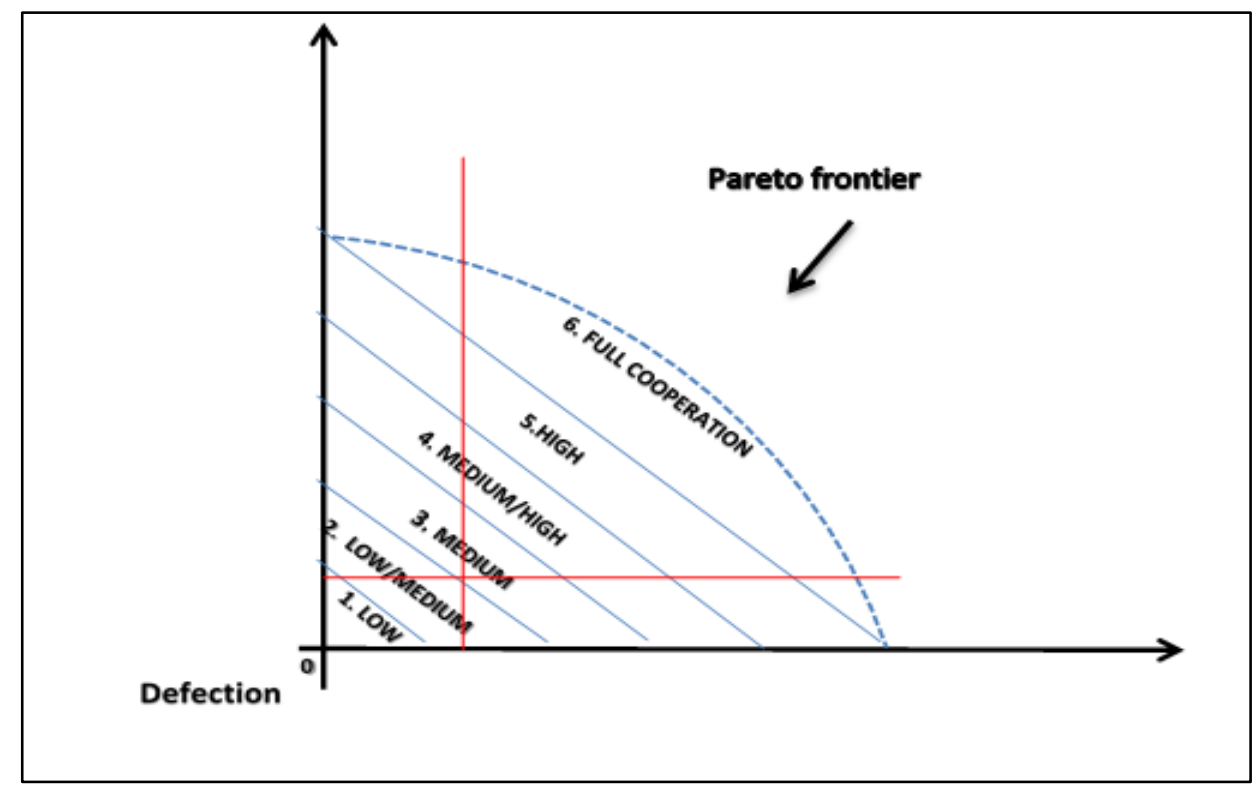

Figure 7. A proposed spectrum of global health cooperation. Based on the Pareto Frontier model on Sebenius 1992 (23).

Under this model, the most common feature of international cooperation is coordination, while collaboration among actors is less common. Full cooperation in global health requires that the international community reacts and responds quickly to health emergencies, and all its members must act together to address endemic health problems. The WHO and non-affected countries must provide financial, material, and human resources to manage the situation, even when this might not directly affect their well-being. That entails the ultimate form of cooperation: nation-states changing their national and local regulations and behaviour to benefit global action (105).

\subsubsection{Levels of cooperation in the international response to infectious diseases}

This analytical framework for international cooperation characterizes the dynamic nature of global health cooperation. To demonstrate the utility of this framework, I identify these different levels and forms of cooperation in the international response to infectious 
diseases. International cooperation to control and manage disease outbreaks presents different outcomes with distributional consequences ${ }^{\mathrm{x}}$ and uneven benefits for all states.

The international response to infectious diseases is a set of activities to manage, control, contain, and eradicate outbreaks. Through the 2005 IHRs and other instruments, the international community has agreed on the basic terms of an international response to an infectious disease outbreak. However, the response is not consistent, with different levels of cooperation. Coordination is the most typical feature, while collaboration among actors is less common.

The coordinated effort requires "the same core competencies and planning on the national level, with the addition of coordination and cooperation of the incident-case country with its immediate neighbors and the global community (1)". Member States will contribute and participate in meetings and committees to discuss the situation and find the best possible solutions. States will follow experts' recommendations issued to manage the disease. These recommendations will require continued surveillance and provision of information to the WHO - such as notification of new cases and other events related to the outbreak. States will also have to adopt other measures, establishing specific national policies that will contribute to reducing the outbreak's impact (16). These include:

- Avoid issuing any policy that could harm other countries unless these measures are specifically recommended and supported by scientific evidence, such as travel alerts, quarantine, or limiting trade;

\footnotetext{
${ }^{x}$ Some of these consequences can take the form of differentiated fees paid by various states in order to implement an agreement. This happens as well when investment in certain health capacities favors a group of countries; or in a limited access to certain supplies (medicines, vaccines) for certain countries during emergencies.
} 
- Enforce specific measures at airports, seaports, and other entry points;

- Facilitate and expedite measures for importing-exporting, transporting and handling of viral samples and other biological materials;

- Implement specific medical and non-medical interventions;

- Provide financial, material, and human resources to manage and contain the outbreak even when the epidemic might not directly affect all Member States' well-being.

The affected countries should be transparent and provide timely information about the state of the epidemic, the number of cases, and their severity $(110,111)$. Transparency and clear communication with the international community enables a more valid assessment of the situation and its consequences, "allowing for a harmonized approach by affected governments, organizations, and communities on disease control and other mitigation strategies (1)". States should be able to openly provide information without fearing any negative impact on trade, travel, and the economy or any other measure that could harm the well-being of the population $(98,110,111,112)$.

Analyzing the different levels of cooperation in the international response to infectious diseases is critical for understanding the factors that can make this international activity consistent. Thus, to establish how this variation in the level of cooperation takes place, the study measures four general dimensions or components of cooperation in the international response. Table 3 explains each one of these dimensions. 


\begin{tabular}{|l|l|}
\hline Dimensions & Description \\
\hline $\begin{array}{l}\text { I. International } \\
\text { Participation }\end{array}$ & $\begin{array}{l}\text { The type of participation that countries have in international } \\
\text { fora. }\end{array}$ \\
\hline $\begin{array}{l}\text { II. International } \\
\text { Assistance }\end{array}$ & $\begin{array}{l}\text { All types of activities attributed to international assistance, } \\
\text { including ODA. }\end{array}$ \\
\hline $\begin{array}{l}\text { III. Scientific } \\
\text { Response }\end{array}$ & $\begin{array}{l}\text { The actions related to R\&D, the disclosure of information, and } \\
\text { the participation of experts. }\end{array}$ \\
\hline $\begin{array}{l}\text { IV. Policy } \\
\text { Convergence }\end{array}$ & $\begin{array}{l}\text { The alignment of domestic policy with international agreements } \\
\text { and law, as well as the implementation of those policies, agreed } \\
\text { at the international level. Member States should ensure that } \\
\text { their administrative and legal frameworks allow cooperation } \\
\text { (113) }\end{array}$ \\
\hline
\end{tabular}

Table 3. International cooperation dimensions in the international response to infectious diseases.

These dimensions connect to specific activities based on the literature of international cooperation and, specifically, documents related to the international response to infectious diseases. Assigning specific actions to those dimensions provides a starting point for measuring the level of cooperation, which facilitates the comparison of cooperation across cases. Table 4 summarized the dimensions and activities with definitions based on the development of recent outbreaks. 


\begin{tabular}{|c|c|c|}
\hline $\begin{array}{l}\text { INTERVENING } \\
\text { DIMENSIONS }\end{array}$ & ACTIVITY & DEFINITION \\
\hline \multirow[t]{3}{*}{$\begin{array}{l}\text { I. International } \\
\text { Participation }\end{array}$} & $\begin{array}{l}\text { Timely } \\
\text { agreement on } \\
\text { the existence of } \\
\text { a problem at } \\
\text { WHO } \\
\text { [PROBLEM] }\end{array}$ & $\begin{array}{l}\text { The identification of an outbreak at the local, national, } \\
\text { and international levels is fundamental to control } \\
\text { infectious diseases and implement rapid measures to } \\
\text { control it }(114,115) \text {. } \\
\text { The international community analyzes the outbreak. } \\
\text { International institutions are primary locations for } \\
\text { decision making }(102,116) \text {. Each forum will lead to a } \\
\text { specific outcome, which will affect the level of } \\
\text { cooperation (103). The Member States and the WHO } \\
\text { participate in meetings to discuss and agree on the } \\
\text { existence of a problem, such as the identification of a } \\
\text { public health emergency of international concern. The } \\
\text { identification of the problem must be early enough to } \\
\text { establish timely measures. }\end{array}$ \\
\hline & $\begin{array}{l}\text { International } \\
\text { response after } \\
\text { notification } \\
\text { [RESPONSE] }\end{array}$ & $\begin{array}{l}\text { A timely and efficient international response reduces the } \\
\text { outbreak's impact on populations (117). Therefore, quick } \\
\text { response after notification of an outbreak implies that } \\
\text { actions are implemented on-time to limit negative } \\
\text { consequences. }\end{array}$ \\
\hline & $\begin{array}{l}\text { Countries } \\
\text { participating in } \\
\text { the response } \\
\text { [NO. } \\
\text { COUNTRIES] }\end{array}$ & $\begin{array}{l}\text { The participation of all countries in health emergencies is } \\
\text { required to address the event adequately (118). Affected } \\
\text { and non-affected countries require not only to provide } \\
\text { assistance but to follow international norms and keep } \\
\text { track of the situation. An effective response will include } \\
\text { all the international community acting together. }\end{array}$ \\
\hline \multirow[b]{2}{*}{$\begin{array}{l}\text { II. International } \\
\text { assistance }\end{array}$} & $\begin{array}{c}\text { Technical } \\
\text { assistance } \\
\text { [TECHNICAL } \\
\text { A.] }\end{array}$ & $\begin{array}{l}\text { Technical assistance provides the human resources } \\
\text { necessary to identify and attack the problem (105). Many } \\
\text { countries experiencing an outbreak do not have enough } \\
\text { technical expertise to confront it. They require experts } \\
\text { that will provide knowledge to assess an outbreak and the } \\
\text { response. Many of the experts come from specific regions } \\
\text { and countries }(116,119) \text {. }\end{array}$ \\
\hline & $\begin{array}{c}\text { Financial } \\
\text { assistance } \\
{[\mathrm{F} .} \\
\text { ASSISTANCE] }\end{array}$ & $\begin{array}{l}\text { Financial resources are always necessary to advance } \\
\text { international cooperation (49). Most countries have } \\
\text { limited resources to manage health emergencies (118). } \\
\text { Then, financial assistance is critical to managing the } \\
\text { situation (from buying medicines and equipment, to } \\
\text { establishing alternative facilities to isolate critical } \\
\text { patients) (120). Including resources for capacity building } \\
\text { since "an international response relies on national and } \\
\text { sub-national capacities; capacities that require sustained } \\
\text { commitments, in the form of budget and policy, from } \\
\text { international organizations, national leaders and from } \\
\text { within the health sector (55)". }\end{array}$ \\
\hline
\end{tabular}

Table 4. Activities in the international response to infectious diseases. 


\begin{tabular}{|c|c|c|}
\hline $\begin{array}{l}\text { INTERVENING } \\
\text { DIMENSIONS }\end{array}$ & ACTIVITY & DEFINITION \\
\hline \multirow[t]{2}{*}{$\begin{array}{l}\text { II. International } \\
\text { assistance }\end{array}$} & $\begin{array}{c}\text { Sharing of } \\
\text { treatments } \\
\text { [TREATMENTS] }\end{array}$ & $\begin{array}{l}\text { Medicines and vaccines constitute the main treatments. } \\
\text { Vaccines are one of the most critical medical interventions to } \\
\text { prevent the spread of the disease and mitigate the impact of a } \\
\text { pandemic (121,122,94). However, pharmaceutical } \\
\text { companies have limited production capacity, and just a few } \\
\text { countries have access to this production (122,123,124). } \\
\text { Countries and IOs provide essential medicines, such as } \\
\text { antiviral during an influenza outbreak (122), and medical } \\
\text { equipment necessary to face the outbreak. Therefore, sharing } \\
\text { available medicines and vaccines (when available) becomes } \\
\text { an essential part of international cooperation during a } \\
\text { pandemic since it will allow affected populations to be } \\
\text { protected. }\end{array}$ \\
\hline & $\begin{array}{l}\text { Provision of } \\
\text { essential health } \\
\text { services and } \\
\text { supplies } \\
\text { [PROVISION] }\end{array}$ & $\begin{array}{l}\text { Medical assistance is essential during emergencies to provide } \\
\text { relief (120), especially in those countries with limited } \\
\text { capacity, including inadequate health facilities and a limited } \\
\text { number of health workers. These resources are essential to } \\
\text { cope with a pandemic, and an emergency can deplete them } \\
\text { quickly (125). }\end{array}$ \\
\hline \multirow[b]{2}{*}{$\begin{array}{l}\text { III. Scientific } \\
\text { response }\end{array}$} & $\begin{array}{c}\text { Sharing of virus } \\
\text { samples } \\
\text { [SAMPLES] }\end{array}$ & $\begin{array}{l}\text { The provision of viral samples is critical to containing a } \\
\text { pandemic and international cooperation }(63,64) \text {. It is the } \\
\text { starting point for the development of vaccines and other } \\
\text { medical interventions. However, a legal framework to } \\
\text { equitably share these samples is still limited and controversial } \\
\text { (126). Sharing a virus will increase the level of cooperation. }\end{array}$ \\
\hline & $\begin{array}{l}\text { Sharing of } \\
\text { epidemiological } \\
\text { information and } \\
\text { specimens, } \\
\text { research capacity } \\
\text { building, and } \\
\text { dissemination of } \\
\text { research [R\&D] }\end{array}$ & $\begin{array}{l}\text { Experts and scientists working in the field must share the data } \\
\text { collected from the outbreak. Sharing information provides the } \\
\text { input to understand an outbreak and formulate a response } \\
\text { (127,114). } \\
\text { Building capacities for health research, research } \\
\text { development, and its dissemination are necessary to improve } \\
\text { health interventions and beneficial to manage disease } \\
\text { outbreaks }(128,129) \text {. The development of vaccines for } \\
\text { pandemic diseases is part of an effective response (130). The } \\
\text { spread of the disease can be slowed down with vaccines } \\
\text { (131)As well, the provision of resources to analyse the virus } \\
\text { and the situation to establish control and preventive } \\
\text { measures. Research findings should be widely disseminated } \\
\text { to be useful (132,133). Finally, research must be coordinated } \\
\text { and aligned with health systems requirements to be useful for } \\
\text { crafting national and international strategies to manage } \\
\text { infectious diseases (128). }\end{array}$ \\
\hline
\end{tabular}

Table 4. Activities international response to infectious diseases (cont.) 


\begin{tabular}{|c|c|c|}
\hline $\begin{array}{l}\text { INTERVENING } \\
\text { DIMENSIONS }\end{array}$ & ACTIVITY & DEFINITION \\
\hline \multirow{3}{*}{$\begin{array}{l}\text { IV. Policy } \\
\text { adoption }\end{array}$} & $\begin{array}{c}\text { Surveillance } \\
\text { systems } \\
\text { [SURVEILLANCE] }\end{array}$ & $\begin{array}{l}\text { The International Health Regulations } 2005 \text { defined } \\
\text { surveillance as "the systematic, ongoing collection, } \\
\text { collation, and analysis of data for public health } \\
\text { purposes and the timely dissemination of public health } \\
\text { information for assessment and public health response } \\
\text { as necessary (WHO 2008: 10)." The existence of } \\
\text { surveillance systems is necessary to generate the data } \\
\text { to respond to the outbreak (134,135,31,136,137) (138). } \\
\text { The data collected during surveillance is subject to } \\
\text { interpretation "for use in planning, implementing and } \\
\text { evaluating public health policies and practices }(123) . "\end{array}$ \\
\hline & $\begin{array}{c}\text { Notification } \\
\text { [NOTIFICATION] }\end{array}$ & $\begin{array}{l}\text { Notification is an essential component of the } \\
\text { international response to infectious diseases. } \\
\text { Notification requires national states to inform the } \\
\text { WHO about infectious diseases in their territory, as } \\
\text { well as provide all relevant information about the } \\
\text { evolution of the outbreak }(111,16) \text {. } \\
\text { The IHRs } 2005 \text { specifies that countries should notify } \\
\text { "within } 24 \text { hours of assessment of public health } \\
\text { information (Art. } 6 \text { Notification (16))". }\end{array}$ \\
\hline & $\begin{array}{c}\text { Alignment of } \\
\text { domestic policies } \\
\text { with international } \\
\text { norms } \\
\text { [POLICY } \\
\text { CONVERGENCE] }\end{array}$ & $\begin{array}{l}\text { International cooperation should translate into changes } \\
\text { in national norms and regulations }(105,113) \text {. } \\
\text { Policy convergence can include the convergence of } \\
\text { policy goals - to deal with everyday problems; of } \\
\text { policy content - such as government policy; of policy } \\
\text { instruments - administrative, judicial, among others.; } \\
\text { on policy outcomes; of policy style - such as the way } \\
\text { policy responses are formulated (139). } \\
\text { Policy convergence presumes national states will adopt } \\
\text { and change domestic policies to pursue an international } \\
\text { goal. In the case of pandemic events, countries are } \\
\text { expected to follow those measures and policies dictated } \\
\text { by the WHO to assist in containing and controlling the } \\
\text { outbreak. }\end{array}$ \\
\hline
\end{tabular}

Table 4. Activities international response to infectious diseases (cont.)

Based on these activities, essential during an international response, the research proposes a model for analyzing how cooperation materializes during the international response to pandemics. It defines each level, providing concepts, indicators, and an approach to measure cooperation, which will facilitate recognition of the degrees of cooperation that take place and the numerous instruments created for delivering such cooperation. The model 
provides parameters to operationalize cooperation during the response to any disease

outbreak. Therefore, in table 5, I identified indicators, measures, and sources of information

for each indicator.

\begin{tabular}{|c|c|c|c|c|}
\hline $\begin{array}{l}\text { INTERVENING } \\
\text { DIMENSIONS }\end{array}$ & ACTIVITY & $\begin{array}{c}\text { INDICATOR } \\
\text { DESCRIPTION }\end{array}$ & MEASURE & SOURCE \\
\hline \multirow{4}{*}{$\begin{array}{l}\text { I. International } \\
\text { Participation }\end{array}$} & $\begin{array}{l}\text { Timely agreement } \\
\text { on the existence } \\
\text { of a problem at } \\
\text { WHO } \\
\text { [PROBLEM] }\end{array}$ & $\begin{array}{l}\text { The type of meetings is } \\
\text { relevant since it will } \\
\text { condition the result and } \\
\text { how it will affect the } \\
\text { international } \\
\text { community }(103,140) \text {. } \\
\text { The time in which the } \\
\text { meeting occurs will } \\
\text { also impact the } \\
\text { response. }\end{array}$ & $\begin{array}{l}\text { Type of meetings } \\
\text { celebrated at WHO } \\
\text { and other settings: } \\
\text { high level, } \\
\text { technical, expert } \\
\text { groups, summits, } \\
\text { conferences, and if } \\
\text { they are celebrated } \\
\text { timely. }\end{array}$ & $\begin{array}{l}\text { WHO and } \\
\text { other } \\
\text { international } \\
\text { organizations. }\end{array}$ \\
\hline & $\begin{array}{l}\text { Timely agreement } \\
\text { on the existence } \\
\text { of a problem at } \\
\text { WHO } \\
\text { [PROBLEM] }\end{array}$ & $\begin{array}{l}\text { The outcome of } \\
\text { international meetings } \\
\text { is important to define } \\
\text { actions. An } \\
\text { international meeting } \\
\text { can generate different } \\
\text { outcomes, from general } \\
\text { rules and principles } \\
\text { (non-binding) to } \\
\text { specific policies, } \\
\text { guidelines, or treaties } \\
\text { (binding) (105). }\end{array}$ & $\begin{array}{l}\text { If there were } \\
\text { actions } \\
\text { implemented as a } \\
\text { result of those } \\
\text { meetings }\end{array}$ & $\begin{array}{l}\text { WHO } \\
\text { resolutions, } \\
\text { reports, and } \\
\text { assessments. }\end{array}$ \\
\hline & $\begin{array}{l}\text { International } \\
\text { response after } \\
\text { notification or/and } \\
\text { assessment } \\
\text { [RESPONSE] }\end{array}$ & $\begin{array}{l}\text { Speed during a health } \\
\text { emergency is crucial } \\
\text { for fast and effective } \\
\text { control of the situation } \\
\text { and for saving lives } \\
\text { (120). }\end{array}$ & $\begin{array}{l}\text { Timeframe after } \\
\text { notification: } \\
\text { (immediate, } \\
\text { moderate, slow, } \\
\text { lack of) the number } \\
\text { of days between the } \\
\text { notification and the } \\
\text { beginning of } \\
\text { international } \\
\text { activities } \\
\text { (response). }\end{array}$ & $\begin{array}{l}\text { WHO reports, } \\
\text { Journals, } \\
\text { documents } \\
\text { from other } \\
\text { international } \\
\text { agencies. }\end{array}$ \\
\hline & $\begin{array}{c}\text { Countries } \\
\text { participating in } \\
\text { the response [NO. } \\
\text { COUNTRIES] }\end{array}$ & $\begin{array}{l}\text { Level of participation } \\
\text { in the international } \\
\text { response }\end{array}$ & $\begin{array}{l}\text { The number of } \\
\text { participants: the } \\
\text { number of countries } \\
\text { participating in the } \\
\text { international } \\
\text { response. High- } \\
\text { Moderate-Limited }\end{array}$ & $\begin{array}{l}\text { WHO reports, } \\
\text { Country } \\
\text { Reports }\end{array}$ \\
\hline
\end{tabular}

Table 5. Activities in the international response and indicators 


\begin{tabular}{|c|c|c|c|c|}
\hline $\begin{array}{l}\text { INTERVENING } \\
\text { DIMENSIONS }\end{array}$ & ACTIVITY & $\begin{array}{c}\text { INDICATOR } \\
\text { DESCRIPTION } \\
\end{array}$ & MEASURE & SOURCE \\
\hline \multirow{5}{*}{$\begin{array}{l}\text { II. International } \\
\text { Assistance }\end{array}$} & $\begin{array}{c}\text { Technical } \\
\text { assistance } \\
\text { [TECHNICAL } \\
\text { A.] }\end{array}$ & $\begin{array}{l}\text { Scientific and expert } \\
\text { collaboration in } \\
\text { international cooperation. } \\
\text { They participate in diverse } \\
\text { activities, doing research, } \\
\text { monitoring, or assessing } \\
\text { the situation (105), and } \\
\text { they complement and } \\
\text { provide human capacities } \\
\text { that countries do not have. }\end{array}$ & $\begin{array}{l}\text { Type of } \\
\text { participation in } \\
\text { international } \\
\text { missions (as an } \\
\text { expert from an } \\
\text { IO, from a } \\
\text { country; assessing } \\
\text { the situation or } \\
\text { assisting affected } \\
\text { countries). }\end{array}$ & WHO reports \\
\hline & $\begin{array}{c}\text { Financial } \\
\text { assistance [F. } \\
\text { ASSISTANCE] }\end{array}$ & $\begin{array}{l}\text { Countries in need should } \\
\text { receive financial assistance } \\
\text { to cope with the problem } \\
\text { they are facing, and this is } \\
\text { an essential component of } \\
\text { cooperation (105). }\end{array}$ & $\begin{array}{l}\text { Financial } \\
\text { resources are } \\
\text { provided and } \\
\text { made available to } \\
\text { affected countries } \\
\text { and the WHO }\end{array}$ & $\begin{array}{l}\text { World Health } \\
\text { Organization, } \\
\text { OECD, World } \\
\text { Bank }\end{array}$ \\
\hline & $\begin{array}{c}\text { Sharing of } \\
\text { treatments } \\
\text { [TREATMENTS] }\end{array}$ & $\begin{array}{l}\text { The medical and } \\
\text { pharmaceutical responses } \\
\text { need to be timely. Since the } \\
\text { development of vaccines } \\
\text { takes time, governments } \\
\text { need to have supplies of } \\
\text { essential medicines to } \\
\text { attend the population } \\
\text { already sick }(94,117) \text {. The } \\
\text { global supply of vaccines } \\
\text { and medicines is limited } \\
\text { during the emergency, and } \\
\text { not all vulnerable } \\
\text { populations have access to } \\
\text { them }(117,94) \text {. }\end{array}$ & $\begin{array}{l}\text { Type of } \\
\text { population getting } \\
\text { the vaccines and } \\
\text { medicines } \\
\text { (vulnerable or } \\
\text { non-vulnerable) }\end{array}$ & Reports \\
\hline & \multirow{2}{*}{$\begin{array}{l}\text { Provision of } \\
\text { essential health } \\
\text { services and } \\
\text { supplies } \\
\text { [PROVISION] }\end{array}$} & $\begin{array}{l}\text { Health experts and } \\
\text { personnel may be required } \\
\text { to assist national actors and } \\
\text { mitigate the outbreak. }\end{array}$ & $\begin{array}{l}\text { How fast was the } \\
\text { deployment of } \\
\text { assistance once } \\
\text { the outbreak } \\
\text { started }\end{array}$ & $\begin{array}{l}\text { WHO reports, } \\
\text { Journals }\end{array}$ \\
\hline & & $\begin{array}{l}\text { During an emergency, } \\
\text { international assistance } \\
\text { provides those resources } \\
\text { that countries need to } \\
\text { respond, from essential } \\
\text { items, such as medical } \\
\text { supplies, to experts in } \\
\text { specific areas. }\end{array}$ & $\begin{array}{l}\text { Type of assistance } \\
\text { (doctors, experts, } \\
\text { technicians; } \\
\text { materials, } \\
\text { equipment; } \\
\text { medicines) }\end{array}$ & $\begin{array}{l}\text { Newspapers, } \\
\text { Grey literature }\end{array}$ \\
\hline $\begin{array}{l}\text { III. Scientific } \\
\text { response }\end{array}$ & $\begin{array}{c}\text { Sharing of virus } \\
\text { samples } \\
\text { [SAMPLES] }\end{array}$ & Sharing virus samples & $\begin{array}{l}\text { If countries have } \\
\text { shared virus } \\
\text { samples }\end{array}$ & WHO \\
\hline
\end{tabular}

Table 5. Activities in the international response and their indicators (cont.) 


\begin{tabular}{|c|c|c|c|c|}
\hline $\begin{array}{l}\text { INTERVENING } \\
\text { DIMENSIONS }\end{array}$ & ACTIVITY & $\begin{array}{l}\text { INDICATOR } \\
\text { DESCRIPTION } \\
\end{array}$ & MEASURE & SOURCE \\
\hline \multirow{2}{*}{$\begin{array}{l}\text { III. Scientific } \\
\text { response }\end{array}$} & \multirow{2}{*}{$\begin{array}{l}\text { Development of } \\
\text { research and } \\
\text { dissemination of } \\
\text { information [R\&D] }\end{array}$} & $\begin{array}{l}\text { Research, in general, } \\
\text { constitute the basis for } \\
\text { developing adequate } \\
\text { interventions and } \\
\text { controlling the disease. } \\
\text { The faster scientist can } \\
\text { understand the disease's } \\
\text { mechanics, the better the } \\
\text { results (141). }\end{array}$ & $\begin{array}{l}\text { If research is } \\
\text { disseminated on } \\
\text { time }\end{array}$ & Journals \\
\hline & & $\begin{array}{l}\text { The more advanced the } \\
\text { stage of the research is } \\
\text { during the outbreak, the } \\
\text { higher the possibilities of } \\
\text { having a vaccine } \\
\text { available on time to } \\
\text { contain the outbreak } \\
\text { (117). }\end{array}$ & $\begin{array}{l}\text { Phases of the } \\
\text { research during the } \\
\text { outbreak (never } \\
\text { started, started, } \\
\text { proves are made, a } \\
\text { vaccine is made } \\
\text { available) }\end{array}$ & $\begin{array}{l}\text { Academic } \\
\text { Journals }\end{array}$ \\
\hline \multirow{4}{*}{$\begin{array}{l}\text { IV. Policy } \\
\text { adoption }\end{array}$} & $\begin{array}{c}\text { Surveillance } \\
\text { Systems } \\
\text { [SURVEILLANCE] }\end{array}$ & $\begin{array}{l}\text { International agreements } \\
\text { require countries to carry } \\
\text { out continue surveillance } \\
\text { during an outbreak, new } \\
\text { cases, and progress. }\end{array}$ & $\begin{array}{l}\text { If all countries } \\
\text { implemented } \\
\text { systems to allowed } \\
\text { constant } \\
\text { notification of cases }\end{array}$ & $\begin{array}{l}\text { WHO } \\
\text { reports, } \\
\text { Country } \\
\text { Reports }\end{array}$ \\
\hline & $\begin{array}{c}\text { Notification } \\
{[\text { NOTIFICATION] }}\end{array}$ & $\begin{array}{l}\text { Countries have agreed to } \\
\text { inform the WHO on time } \\
\text { the emergence of a new } \\
\text { or non-identified disease } \\
\text { that could pose an } \\
\text { international risk. }\end{array}$ & $\begin{array}{l}\text { How long did } \\
\text { countries wait to } \\
\text { notify the WHO } \\
\text { after identifying the } \\
\text { cases? }\end{array}$ & $\begin{array}{l}\text { WHO, } \\
\text { Journals, } \\
\text { gray } \\
\text { literature }\end{array}$ \\
\hline & \multirow[b]{2}{*}{$\begin{array}{c}\text { Alignment of } \\
\text { domestic policies } \\
\text { with international } \\
\text { norms and } \\
\text { agreements } \\
\text { [POLICY } \\
\text { CONVERGENCE] }\end{array}$} & $\begin{array}{l}\text { Adoption of } \\
\text { international agreements, } \\
\text { policies, and } \\
\text { recommendations by all } \\
\text { national governments is } \\
\text { the goal of international } \\
\text { cooperation (105) }\end{array}$ & $\begin{array}{l}\text { How broad were } \\
\text { the } \\
\text { recommendations } \\
\text { adopted and } \\
\text { implemented? }\end{array}$ & WHO \\
\hline & & $\begin{array}{l}\text { It refers to the degree of } \\
\text { adoption of international } \\
\text { policies. Considering } \\
\text { that not all policies } \\
\text { recommended or agreed } \\
\text { at the international level } \\
\text { are adopted equally at } \\
\text { the national level, the } \\
\text { degree of adoption will } \\
\text { have an impact on } \\
\text { international cooperation } \\
\text { (105). The ultimate } \\
\text { degree is when policy } \\
\text { convergence occurs. }\end{array}$ & $\begin{array}{l}\text { The degree of } \\
\text { adoption: from the } \\
\text { general acceptance } \\
\text { of an agreement to } \\
\text { policy convergence. }\end{array}$ & $\begin{array}{l}\text { Country } \\
\text { reports, } \\
\text { WHO, } \\
\text { newspapers, } \\
\text { peer- } \\
\text { reviewed } \\
\text { journals }\end{array}$ \\
\hline
\end{tabular}

Table 5. Activities in the international response and their indicators (cont.) 
The framework presented above makes it possible to measure levels of cooperation and variation. There have been other attempts to explain and measure the existence of levels or degrees of international cooperation. Some authors classified the different types of international organizations and explained their different characteristics and potential to promote cooperation (103), and studied the different types of coordination mechanisms (meetings), proposing that each one of them leads to a different cooperative outcome - policy coordination (102). Others explicitly examined the diverse forms of international cooperation, acknowledging that each of them represents a certain level of cooperation (105). Some researchers offered an international law perspective, referring to the degree of commitment assumed in international agreements (93). Others have designed empirical models with measures and indicators based on those mechanisms that modify cooperation, building models to examine countries' levels of cooperation outside and inside international organizations (101), developing typologies for explaining successful and unsuccessful multilateral sanctions efforts (88) and presenting an empirical model with "aggregate indices of cooperation (12)."

Taking into consideration these studies, this research acknowledges the importance of distinguishing levels of international cooperation and the relevance of them for theory and policymaking. The information shown below in table 6 presents the proposed model of levels of cooperation for the international response to pandemics, presenting the indicators/measurements associated with the different activities. 


\begin{tabular}{|c|c|c|c|c|c|c|c|c|}
\hline ACTIVITY & MEASURE & \multicolumn{7}{|c|}{ LEVELS OF COOPERATION } \\
\hline \multicolumn{2}{|c|}{ I. International Participation } & 0 & 1 & 2 & 3 & 4 & 5 & 6 \\
\hline \multirow[t]{2}{*}{$\begin{array}{l}\text { Agreement on } \\
\text { the existence of } \\
\text { a problem at } \\
\text { WHO } \\
\text { [PROBLEM] }\end{array}$} & $\begin{array}{l}\text { Type of } \\
\text { meetings to } \\
\text { assess the } \\
\text { situation and } \\
\text { when they are } \\
\text { celebrated }\end{array}$ & $\begin{array}{l}\text { No meetings } \\
\text { on the issue }\end{array}$ & $\begin{array}{l}\text { Informative } \\
\text { session once the } \\
\text { outbreak has } \\
\text { expanded }\end{array}$ & $\begin{array}{c}\text { Technical } \\
\text { meetings at the } \\
\text { beginning of the } \\
\text { event }\end{array}$ & $\begin{array}{l}\text { Expert group } \\
\text { when the } \\
\text { outbreak has not } \\
\text { been controlled }\end{array}$ & $\begin{array}{l}\text { Special meeting } \\
\text { to asses the } \\
\text { situation once the } \\
\text { outbreak has } \\
\text { expanded }\end{array}$ & $\begin{array}{c}\text { High-level } \\
\text { meeting } \\
\text { after the event is } \\
\text { detected }\end{array}$ & $\begin{array}{l}\text { Emergency } \\
\text { committee after } \\
\text { the event is } \\
\text { detected }\end{array}$ \\
\hline & $\begin{array}{l}\text { Meeting's } \\
\text { outcome }\end{array}$ & No outcome & $\begin{array}{l}\text { A PHEIC is not } \\
\text { called after some } \\
\text { meetings even } \\
\text { though the } \\
\text { outbreak } \\
\text { continues }\end{array}$ & $\begin{array}{l}\text { A PHEIC is } \\
\text { called after the } \\
\text { number of deaths } \\
\text { has escalated in } \\
\text { different } \\
\text { countries }\end{array}$ & $\begin{array}{l}\text { A PHEIC is } \\
\text { called after the } \\
\text { number of deaths } \\
\text { increase in more } \\
\text { than one } \\
\text { countries, and } \\
\text { there is clear } \\
\text { evidence of } \\
\text { transmission }\end{array}$ & $\begin{array}{l}\text { A PHEIC is } \\
\text { called after the } \\
\text { number of deaths } \\
\text { has increased in } \\
\text { at least one } \\
\text { country }\end{array}$ & $\begin{array}{c}\text { A PHEIC is } \\
\text { called after } \\
\text { evaluating the } \\
\text { number of deaths } \\
\text { and mortality rate } \\
\text { trends }\end{array}$ & $\begin{array}{l}\text { A PHEIC is } \\
\text { called as result of } \\
\text { the first meeting, } \\
\text { with or without } \\
\text { clear evidence of } \\
\text { transmission }\end{array}$ \\
\hline $\begin{array}{c}\text { International } \\
\text { response after } \\
\text { notification } \\
\text { or/and } \\
\text { assessment } \\
\text { [RESPONSE] }\end{array}$ & $\begin{array}{c}\text { Timely } \\
\text { response after } \\
\text { the outbreak }\end{array}$ & $\begin{array}{l}\text { Indifference } \\
\text { towards the } \\
\text { situation }\end{array}$ & $\begin{array}{l}\text { An international } \\
\text { response is } \\
\text { initially not } \\
\text { required even } \\
\text { though there is } \\
\text { evidence that the } \\
\text { outbreak is } \\
\text { spreading quickly } \\
\text { in several } \\
\text { countries }\end{array}$ & $\begin{array}{l}\text { An international } \\
\text { response only } \\
\text { after several } \\
\text { months of } \\
\text { showing the } \\
\text { disease has } \\
\text { spread worldwide }\end{array}$ & $\begin{array}{l}\text { An international } \\
\text { response after the } \\
\text { spread of the } \\
\text { disease is caused } \\
\text { by imported } \\
\text { cases. }\end{array}$ & $\begin{array}{l}\text { An international } \\
\text { response after } \\
\text { more than two } \\
\text { countries in } \\
\text { different regions } \\
\text { notify outbreaks }\end{array}$ & $\begin{array}{l}\text { An international } \\
\text { response after } \\
\text { more than two } \\
\text { countries in the } \\
\text { same region } \\
\text { notify the } \\
\text { presence of the } \\
\text { virus }\end{array}$ & $\begin{array}{l}\text { An international } \\
\text { response } \\
\text { immediately after } \\
\text { the first affected } \\
\text { country notifies } \\
\text { the outbreak }\end{array}$ \\
\hline $\begin{array}{c}\text { Countries } \\
\text { participating in } \\
\text { the response } \\
\text { [NO. } \\
\text { COUNTRIES] }\end{array}$ & $\begin{array}{c}\text { Level of } \\
\text { participation }\end{array}$ & $\begin{array}{l}\text { The } \\
\text { international } \\
\text { community } \\
\text { does not } \\
\text { participate }\end{array}$ & $\begin{array}{c}\text { Affected } \\
\text { countries and the } \\
\text { WHO }\end{array}$ & $\begin{array}{c}\text { Affected } \\
\text { countries and } \\
\text { countries with } \\
\text { expertise and the } \\
\text { WHO }\end{array}$ & $\begin{array}{c}\text { Affected } \\
\text { countries and } \\
\text { other countries in } \\
\text { different regions } \\
\text { and the WHO }\end{array}$ & $\begin{array}{c}\text { Affected } \\
\text { countries and } \\
\text { other countries in } \\
\text { different regions } \\
\text { and the WHO }\end{array}$ & $\begin{array}{l}\text { Countries from } \\
\text { all regions } \\
\text { (worldwide } \\
\text { representation) } \\
\text { and the WHO }\end{array}$ & $\begin{array}{l}\text { All or majority of } \\
\text { states participate }\end{array}$ \\
\hline
\end{tabular}

Table 6. Activities and indicators for each level of international cooperation in the international response. 


\begin{tabular}{|c|c|c|c|c|c|c|c|c|}
\hline ACTIVITY & MEASURE & \multicolumn{7}{|c|}{ LEVELS OF COOPERATION } \\
\hline \multicolumn{2}{|c|}{ II. International Assistance } & 0 & 1 & 2 & 3 & 4 & 5 & 6 \\
\hline $\begin{array}{c}\text { Technical } \\
\text { assistance } \\
\text { [TECHNICAL A.] }\end{array}$ & $\begin{array}{c}\text { Type of } \\
\text { participation } \\
\text { in } \\
\text { international } \\
\text { missions }\end{array}$ & $\begin{array}{c}\text { No } \\
\text { participation } \\
\text { of experts }\end{array}$ & $\begin{array}{l}\text { WHO sends its } \\
\text { experts to assess } \\
\text { the situation }\end{array}$ & $\begin{array}{c}\text { Other } \\
\text { international } \\
\text { experts are } \\
\text { summoned to } \\
\text { WHOs endeavor }\end{array}$ & $\begin{array}{l}\text { WHO sends } \\
\text { experts to assist } \\
\text { affected countries }\end{array}$ & $\begin{array}{c}\text { Individual } \\
\text { countries offer } \\
\text { expertise }\end{array}$ & $\begin{array}{l}\text { An international } \\
\text { coalition of } \\
\text { experts is } \\
\text { organized to } \\
\text { assist affected } \\
\text { countries }\end{array}$ & $\begin{array}{l}\text { Experts from } \\
\text { multiple countries } \\
\text { cooperate with } \\
\text { affected countries } \\
\text { to develop } \\
\text { capacities }\end{array}$ \\
\hline $\begin{array}{c}\text { Financial } \\
\text { assistance } \\
\text { [F. ASSISTANCE] }\end{array}$ & $\begin{array}{l}\text { The receiving } \\
\text { countries of } \\
\text { financial } \\
\text { assistance }\end{array}$ & $\begin{array}{l}\text { No } \\
\text { countries } \\
\text { offer } \\
\text { financial } \\
\text { assistance }\end{array}$ & $\begin{array}{l}\text { Financial } \\
\text { assistance is not } \\
\text { required }\end{array}$ & $\begin{array}{l}\text { WHO regional } \\
\text { office would } \\
\text { provide financial } \\
\text { assistance if } \\
\text { resources were } \\
\text { available }\end{array}$ & $\begin{array}{l}\text { WHO provides } \\
\text { financial } \\
\text { assistance }\end{array}$ & $\begin{array}{l}\text { WHO and some } \\
\text { countries offer } \\
\text { financial } \\
\text { assistance to the } \\
\text { most affected } \\
\text { countries }\end{array}$ & $\begin{array}{l}\text { A few donor } \\
\text { countries provide } \\
\text { financial } \\
\text { assistance }\end{array}$ & $\begin{array}{c}\text { International } \\
\text { disbursements to } \\
\text { fight the disease }\end{array}$ \\
\hline $\begin{array}{c}\text { Sharing of } \\
\text { treatments } \\
\text { [TREATMENTS] }\end{array}$ & $\begin{array}{l}\text { Type of } \\
\text { population } \\
\text { getting } \\
\text { treatments } \\
\quad \text { first }\end{array}$ & $\begin{array}{c}\text { Developer } \\
\text { withholds } \\
\text { treatments/ } \\
\text { No vaccines } \\
\text { have been } \\
\text { developed } \\
\text { yet }\end{array}$ & $\begin{array}{l}\text { Treatments are } \\
\text { provided to } \\
\text { people if their } \\
\text { governments have } \\
\text { access to them } \\
\text { regardless of their } \\
\text { vulnerability }\end{array}$ & $\begin{array}{l}\text { Treatments are } \\
\text { provided only if } \\
\text { the WHO } \\
\text { acquires them or } \\
\text { if the } \\
\text { organization has } \\
\text { them in its } \\
\text { stockpile }\end{array}$ & $\begin{array}{l}\text { Treatments are } \\
\text { provided to } \\
\text { affected } \\
\text { populations if } \\
\text { their governments } \\
\text { have agreements } \\
\text { to supply them }\end{array}$ & $\begin{array}{l}\text { Treatments are } \\
\text { provided to } \\
\text { populations of } \\
\text { those countries } \\
\text { that have a } \\
\text { stockpile, and that } \\
\text { share it with other } \\
\text { countries. }\end{array}$ & $\begin{array}{l}\text { Treatments are } \\
\text { provided to some } \\
\text { affected } \\
\text { populations once } \\
\text { their governments } \\
\text { request them }\end{array}$ & $\begin{array}{l}\text { Treatments are } \\
\text { provided to most } \\
\text { affected } \\
\text { populations } \\
\text { immediately }\end{array}$ \\
\hline $\begin{array}{c}\text { Provision of } \\
\text { essential health } \\
\text { services and } \\
\text { supplies } \\
\text { [PROVISION] }\end{array}$ & $\begin{array}{l}\text { How fast was } \\
\text { the } \\
\text { deployment of } \\
\text { assistance } \\
\text { once the } \\
\text { outbreak } \\
\text { started }\end{array}$ & $\begin{array}{l}\text { Assistance } \\
\text { is not } \\
\text { provided at } \\
\text { all during } \\
\text { the outbreak }\end{array}$ & $\begin{array}{l}\text { Assistance is } \\
\text { deployed late, } \\
\text { once the medical } \\
\text { capacities of the } \\
\text { affected countries } \\
\text { are exhausted }\end{array}$ & $\begin{array}{l}\text { Assistance is } \\
\text { deployed when } \\
\text { the affected } \\
\text { countries } \\
\text { requested }\end{array}$ & $\begin{array}{l}\text { Assistance is } \\
\text { deployed weeks } \\
\text { after a PHEIC is } \\
\text { declared to some } \\
\text { countries }\end{array}$ & $\begin{array}{l}\text { Assistance is } \\
\text { deployed after } \\
\text { days after a } \\
\text { PHEIC is } \\
\text { declared to most } \\
\text { affected countries }\end{array}$ & $\begin{array}{c}\text { Assistance is } \\
\text { deployed } \\
\text { immediately after } \\
\text { a PHEIC is } \\
\text { declared }\end{array}$ & $\begin{array}{c}\text { Assistance is } \\
\text { deployed } \\
\text { immediately to } \\
\text { affected countries } \\
\text { since the } \\
\text { beginning of the } \\
\text { outbreak }\end{array}$ \\
\hline $\begin{array}{c}\text { Provision of } \\
\text { essential health } \\
\text { services and } \\
\text { supplies } \\
\text { [PROVISION] }\end{array}$ & $\begin{array}{c}\text { Type of } \\
\text { assistance }\end{array}$ & $\begin{array}{l}\text { Denial of } \\
\text { material } \\
\text { assistance }\end{array}$ & $\begin{array}{l}\text { WHO provides } \\
\text { personal/ } \\
\text { resources to assist } \\
\text { those countries in } \\
\text { need }\end{array}$ & $\begin{array}{l}\text { Provision of } \\
\text { material } \\
\text { assistance once } \\
\text { the emergency } \\
\text { escalates }\end{array}$ & $\begin{array}{l}\text { Some countries } \\
\text { provide medical } \\
\text { equipment and } \\
\text { personnel during } \\
\text { the outbreak }\end{array}$ & $\begin{array}{l}\text { Some countries } \\
\text { provide medical } \\
\text { equipment and } \\
\text { personal before } \\
\text { the emergency } \\
\text { escalates }\end{array}$ & $\begin{array}{l}\text { An international } \\
\text { coalition assists } \\
\text { before the } \\
\text { emergency } \\
\text { escalates }\end{array}$ & $\begin{array}{l}\text { International } \\
\text { assistance is } \\
\text { mobilized } \\
\text { immediately the } \\
\text { outbreak is } \\
\text { notified }\end{array}$ \\
\hline
\end{tabular}

Table 6. Activities and indicators for each level of international cooperation in the international response (cont.) 


\begin{tabular}{|c|c|c|c|c|c|c|c|c|}
\hline ACTIVITY & MEASURE & \multicolumn{7}{|c|}{ LEVELS OF COOPERATION } \\
\hline \multicolumn{2}{|c|}{ III. Scientific response } & 0 & 1 & 2 & 3 & 4 & 5 & 6 \\
\hline $\begin{array}{c}\text { Sharing of } \\
\text { virus samples } \\
\text { [SAMPLES] }\end{array}$ & $\begin{array}{l}\text { If countries have } \\
\text { shared virus } \\
\text { samples }\end{array}$ & $\begin{array}{l}\text { Affected } \\
\text { country/cou } \\
\text { ntries } \\
\text { refuse(s) to } \\
\text { provide } \\
\text { samples }\end{array}$ & $\begin{array}{c}\text { Affected } \\
\text { countries share } \\
\text { samples with } \\
\text { their } \\
\text { pharmaceutical } \\
\text { companies }\end{array}$ & $\begin{array}{c}\text { Affected } \\
\text { countries share } \\
\text { samples with } \\
\text { other countries }\end{array}$ & $\begin{array}{c}\text { Affected } \\
\text { countries share } \\
\text { samples once the } \\
\text { WHO provides } \\
\text { certain benefits }\end{array}$ & $\begin{array}{c}\text { Affected } \\
\text { countries provide } \\
\text { samples after the } \\
\text { WHO requires it }\end{array}$ & $\begin{array}{l}\text { At least one of } \\
\text { the affected } \\
\text { countries } \\
\text { voluntarily share } \\
\text { samples with the } \\
\text { WHO }\end{array}$ & $\begin{array}{l}\text { All affected } \\
\text { countries } \\
\text { voluntarily share } \\
\text { samples with the } \\
\text { WHO }\end{array}$ \\
\hline \multirow[t]{2}{*}{$\begin{array}{c}\text { Development } \\
\text { of research } \\
\text { and } \\
\text { dissemination } \\
\text { of } \\
\text { information } \\
\text { [R\&D] }\end{array}$} & $\begin{array}{c}\text { If data about the } \\
\text { disease and cases } \\
\text { are disseminated } \\
\text { on time }\end{array}$ & $\begin{array}{l}\text { Information } \\
\text { is withheld }\end{array}$ & $\begin{array}{l}\text { Information is } \\
\text { shared only with } \\
\text { certain actors or } \\
\text { partners }\end{array}$ & $\begin{array}{l}\text { Information is } \\
\text { shared with a } \\
\text { limited number of } \\
\text { experts or } \\
\text { countries }\end{array}$ & $\begin{array}{l}\text { Information is } \\
\text { shared with WHO } \\
\text { and a limited } \\
\text { number of experts }\end{array}$ & $\begin{array}{l}\text { Information is } \\
\text { disseminated and } \\
\text { shared with WHO } \\
\text { and research } \\
\text { institutions in } \\
\text { developed } \\
\text { countries }\end{array}$ & $\begin{array}{l}\text { Information is } \\
\text { disseminated and } \\
\text { shared with WHO } \\
\text { and experts from } \\
\text { developed and } \\
\text { developing } \\
\text { countries }\end{array}$ & $\begin{array}{l}\text { Information is } \\
\text { fully } \\
\text { disseminated } \\
\text { since the first } \\
\text { cases are } \\
\text { detected, and it is } \\
\text { made available } \\
\text { for everybody }\end{array}$ \\
\hline & $\begin{array}{l}\text { If research to } \\
\text { understand the } \\
\text { outbreak is } \\
\text { available (never } \\
\text { started, started, } \\
\text { proves are made, } \\
\text { the vaccine is } \\
\text { made available) }\end{array}$ & $\begin{array}{c}\text { Research } \\
\text { has not been } \\
\text { done }\end{array}$ & $\begin{array}{l}\text { Scarce research } \\
\text { has been done }\end{array}$ & $\begin{array}{l}\text { Research is done } \\
\text { by developed in } \\
\text { developed } \\
\text { countries }\end{array}$ & $\begin{array}{l}\text { Countries with } \\
\text { research } \\
\text { institutions do } \\
\text { research }\end{array}$ & $\begin{array}{l}\text { Some research is } \\
\text { done in all } \\
\text { regions }\end{array}$ & $\begin{array}{l}\text { Research is done } \\
\text { in developing and } \\
\text { developed } \\
\text { countries }\end{array}$ & $\begin{array}{l}\text { Research is done } \\
\text { internationally } \\
\text { and published in } \\
\text { journals }\end{array}$ \\
\hline
\end{tabular}

Table 6. Activities and indicators for each level of international cooperation in the international response (cont.). 


\begin{tabular}{|c|c|c|c|c|c|c|c|c|}
\hline ACTIVITY & MEASURE & \multicolumn{7}{|c|}{ LEVELS OF COOPERATION } \\
\hline \multicolumn{2}{|c|}{ IV. Policy Adoption } & 0 & 1 & 2 & 3 & 4 & 5 & 6 \\
\hline $\begin{array}{c}\text { Surveillance } \\
\text { [SURVEILLANCE] }\end{array}$ & $\begin{array}{l}\text { If countries } \\
\text { implemented } \\
\text { systems to } \\
\text { allowed } \\
\text { constant } \\
\text { notification of } \\
\text { possible cases }\end{array}$ & $\begin{array}{c}\text { No } \\
\text { country } \\
\text { impleme } \\
\text { nts } \\
\text { surveillan } \\
\text { ce }\end{array}$ & $\begin{array}{l}\text { The affected } \\
\text { country does not } \\
\text { implement } \\
\text { systems of } \\
\text { surveillance }\end{array}$ & $\begin{array}{l}\text { The WHO relies } \\
\text { on other sources } \\
\text { to gather } \\
\text { information about } \\
\text { the outbreak }\end{array}$ & $\begin{array}{l}\text { Affected } \\
\text { countries } \\
\text { implement } \\
\text { continuing } \\
\text { surveillance }\end{array}$ & $\begin{array}{l}\text { Other countries } \\
\text { implement } \\
\text { surveillance }\end{array}$ & $\begin{array}{l}\text { Countries from } \\
\text { all regions } \\
\text { implement } \\
\text { surveillance }\end{array}$ & $\begin{array}{l}\text { Affected and non- } \\
\text { affected countries } \\
\text { implement } \\
\text { continuing } \\
\text { surveillance }\end{array}$ \\
\hline $\begin{array}{c}\text { Notification } \\
\text { [NOTIFICATION] }\end{array}$ & $\begin{array}{l}\text { How long did } \\
\text { countries wait } \\
\text { to notify the } \\
\text { WHO after } \\
\text { identifying the } \\
\text { cases? }\end{array}$ & $\begin{array}{c}\text { Informati } \\
\text { on about } \\
\text { the } \\
\text { outbreak } \\
\text { is } \\
\text { withheld }\end{array}$ & $\begin{array}{c}\text { WHO's } \\
\text { involvement } \\
\text { prompts } \\
\text { notification (the } \\
\text { disease might } \\
\text { have spread out } \\
\text { worldwide at this } \\
\text { point) }\end{array}$ & $\begin{array}{l}\text { Notification due } \\
\text { to the } \\
\text { intervention of } \\
\text { other actors } \\
\text { (NGOs, experts, } \\
\text { etc.) }\end{array}$ & $\begin{array}{l}\text { Notification by } \\
\text { affected countries } \\
\text { once the disease } \\
\text { has spread out in } \\
\text { the region }\end{array}$ & $\begin{array}{l}\text { Notification by } \\
\text { the first affected } \\
\text { country once the } \\
\text { disease has } \\
\text { spread to another } \\
\text { country }\end{array}$ & $\begin{array}{l}\text { Notification after } \\
48 \text { hrs that the } \\
\text { disease has } \\
\text { spread around the } \\
\text { country (multiple } \\
\text { cases) }\end{array}$ & $\begin{array}{l}\text { Notification with } \\
24 \text { hours of } \\
\text { assessment by the } \\
\text { affected country } \\
\text { (IHR 2005) }\end{array}$ \\
\hline \multirow[t]{2}{*}{$\begin{array}{c}\text { Alignment of } \\
\text { domestic policies } \\
\text { with international } \\
\text { norms and } \\
\text { agreements } \\
\text { [POLICY } \\
\text { CONVERGENCE] }\end{array}$} & $\begin{array}{l}\text { How broad } \\
\text { were the } \\
\text { recommendatio } \\
\text { ns adopted and } \\
\text { implemented by } \\
\text { the } \\
\text { international } \\
\text { community? }\end{array}$ & $\begin{array}{l}\text { All the } \\
\text { internatio } \\
\text { nal } \\
\text { communi } \\
\text { ty ignores } \\
\text { recomme } \\
\text { ndations }\end{array}$ & $\begin{array}{l}\text { Most members of } \\
\text { the international } \\
\text { community } \\
\text { ignore the } \\
\text { recommendation } \\
\text { and implement } \\
\text { actions non- } \\
\text { recommended or } \\
\text { supported by } \\
\text { evidence }\end{array}$ & $\begin{array}{l}\text { Some affected } \\
\text { countries accept } \\
\text { some measures } \\
\text { and implement } \\
\text { others without } \\
\text { supporting } \\
\text { evidence }\end{array}$ & $\begin{array}{l}\text { The international } \\
\text { community has } \\
\text { partially adopted } \\
\text { suggested } \\
\text { measures }\end{array}$ & $\begin{array}{l}\text { Some members of } \\
\text { the international } \\
\text { community } \\
\text { accept all } \\
\text { measures, and } \\
\text { others are ignored } \\
\text { based on } \\
\text { scientific } \\
\text { evidence }\end{array}$ & $\begin{array}{l}\text { The international } \\
\text { community has } \\
\text { adopted most of } \\
\text { the suggested } \\
\text { measures }\end{array}$ & $\begin{array}{l}\text { The international } \\
\text { community } \\
\text { follows all } \\
\text { recommendations } \\
\text { dictated by the } \\
\text { WHO and other } \\
\text { international } \\
\text { agencies }\end{array}$ \\
\hline & $\begin{array}{l}\text { The degree of } \\
\text { adoption of } \\
\text { international } \\
\text { norms: from the } \\
\text { general } \\
\text { acceptance of } \\
\text { an agreement to } \\
\text { policy } \\
\text { convergence. }\end{array}$ & $\begin{array}{c}\text { No } \\
\text { country } \\
\text { accepts } \\
\text { measures } \\
\text { establishe } \\
\text { d by } \\
\text { WHO }\end{array}$ & $\begin{array}{l}\text { A few countries } \\
\text { have made partial } \\
\text { changes in } \\
\text { domestic policies } \\
\text { to implement } \\
\text { international } \\
\text { norms }\end{array}$ & $\begin{array}{l}\text { Some countries } \\
\text { have made partial } \\
\text { changes in } \\
\text { domestic policies } \\
\text { to implement } \\
\text { international } \\
\text { norms }\end{array}$ & $\begin{array}{l}\text { Some countries } \\
\text { have made } \\
\text { domestic changes } \\
\text { for full } \\
\text { implementation; } \\
\text { some other just } \\
\text { partial changes, } \\
\text { and other no } \\
\text { change at all. }\end{array}$ & $\begin{array}{l}\text { A few countries } \\
\text { have made } \\
\text { domestic changes } \\
\text { to implement } \\
\text { international } \\
\text { norms fully }\end{array}$ & $\begin{array}{l}\text { Some countries in } \\
\text { all regions have } \\
\text { made domestic } \\
\text { changes to } \\
\text { implement } \\
\text { international } \\
\text { norms fully }\end{array}$ & $\begin{array}{c}\text { All countries have } \\
\text { changed domestic } \\
\text { policies to } \\
\text { implement } \\
\text { international } \\
\text { norms. }\end{array}$ \\
\hline
\end{tabular}

Table 6. Activities and indicators for each level of international cooperation in the international response (cont.) 
As noted above, the existence of institutions and norms is insufficient to explain variation in cooperation entirely. The research will examine epistemic communities as complementary explanations for this variation.

\subsection{Epistemic communities, concept, and theory}

Scholars have used the definition of epistemic communities to conceptualize networks of scientists and experts and how they can influence the policy process. The concept has evolved and adjusted to include elements that can distinguish these actors from other networks. For instance, Ruggie (1975) explained that epistemic communities could arise from bureaucratic positions, technocratic training, and similarities in scientific outlook and shared disciplinary paradigms (142). These communities share intentions, expectations, symbols, behavioural rules, and points of reference (142).

Peter Haas crafted a more specific definition, referring to an epistemic community as "a network of professionals with expertise and competence in a particular domain and an authoritative claim to policy-relevant knowledge within that domain (25)." In his conception, an epistemic community's unique feature is their members sharing of an epistemological worldview, including notions of validity (25). They apply or agree with the scientific methodology used to make causal inferences in their area of expertise and provide information about the underlying causes of a problem (19). Sharing norms and principles, as well as common beliefs, facilitates the articulation of common goals. The definition of those goals helps to promote cooperation. Epistemic community networks' members take this shared common understanding of a problem-issue and seek to translate their beliefs into a dominant social discourse and social practice (143). Epistemic communities, therefore, can become "networks of experts who persuade others of their shared causal beliefs and policy 
goals by virtue of their professional knowledge (91)". They have the mechanisms to frame the policy debate on some issues, providing justifications for alternatives, and catalyze national or international coalitions to support chosen policies and advocate change $(144,145,47)$.

Epistemic communities differ from other networks of professionals due to their level of expertise over a policy issue (147). For instance, advocacy networks include many other actors whose primary goal is to advance a policy topic by pressuring and persuading political actors through various techniques, including mobilization. Epistemic communities will advocate for a specific issue with the use of scientific and technical arguments. Members of advocacy groups can also be members of an epistemic community, and they will exchange technical knowledge and contribute to technical debates. Epistemic communities are also different from policy networks (147). Policy networks include actors interested in advancing specific issues in the international agenda by creating strategic relations with other individuals with the same interest. However, they do not necessarily share values or epistemology. Epistemic communities will connect with these other networks to reinforce their position and create stronger arguments that can help them to appeal to a broader community.

Some scholars contend that in global health, all these networks should be studied as part of unified global health networks (45), given that all of them participate in the policy process. However, this research considers that in global health, epistemic communities are distinct from other networks because of the inherent demand for evidence-based policies. These experts are the primary providers of information that support global health policies, and, at the same time, their level of expertise makes them suitable to become decision-makers 
in different organizations (health agencies, international organizations, etc.). Epistemic communities can facilitate diffusion of international cooperation ideas, and, consequently, improve global health outcomes, providing their scientific and expert knowledge and evidence.

Scholars have used the concept of epistemic communities to explain how networks of experts influence international relations and the policymaking process. Contributions using epistemic communities as analytical framework have been in the context of the environment (90,48); security $(146,25,143,53,147)$; development (64); global information policy $(148,116)$ and social policy $(149)$. In the case of global health, some studies examine epistemic communities to explain global health outcomes at the national and international levels, given the demand for evidence-based policies and expert advice, as well as the fact that most national and international health agencies depend on the expertise and scientific knowledge $(65,47,66,49,150,69,68,119,151)$. For instance, the WHO is constantly establishing commissions or expert groups to analyze and explore specific global health problems. These structures are essential for this organization and its role in global health governance since they provide fundamental knowledge for the creation of evidence-based policies found in guidelines and proposals presented by the WHO to its member states. As well, many of the experts collaborating with the WHO also work with their governments in national research institutes, agencies, advisory committees, among others. Their expertise and relations with other professionals and policy actors make it easier for them to establish networks and cut across the rigidity of structures found within international organizations and national governments. They share a common policy goal grounded on scientific knowledge, which provides them with arguments to engage in policymaking $(25,47)$. These 
characteristics make them powerful agents with access to the decision-making process to influence outcomes.

\subsubsection{Towards a theoretical framework to explain international cooperation}

The literature on epistemic communities proposes hypotheses to analyze the connection between knowledge, power, and policy-making, treating these actors as independent variables to explain patterns of cooperation and policy change in international politics $(25,143,53,23)$. The theory analyses the role of experts in the international arena and the vital role that these actors have for the formulation of international policies $(48,151,145)$; as well as how they provide expertise and knowledge that will shape policy outcomes.

Epistemic communities' expert knowledge and ability to position themselves within the policymaking process makes these networks different from others. As evidence shows, epistemic communities use their knowledge and expertise over a domain to define problems and present policy options and influence and modify states' behaviour. Research on epistemic communities has also stressed different characteristics that enable them to influence decision-making processes and modify other actors' behaviour, along with conditions that facilitate this influence. Table 7 provides a summary of the central epistemic community's characteristics found in the literature.

These scholars argue that epistemic communities help define the global health issue $(143,152,53)$. The complex and transnational nature of current issues requires specific technical knowledge, thus requiring the engagement of 'experts' who may be members of epistemic communities. As well, more interconnectivity has facilitated their influence and interaction within their networks and with other actors. Therefore, epistemic communities can 'change the game' on the configuration of a set of possible solutions (23). 


\begin{tabular}{|c|c|c|}
\hline Characteristics & Definition & Reference \\
\hline $\begin{array}{l}\text { Decision Making } \\
\text { under } \\
\text { Uncertainty } \\
\text { (Scope condition) }\end{array}$ & $\begin{array}{l}\text { Scholars of epistemic communities consider } \\
\text { uncertainty as an underlying or scope } \\
\text { condition. It occurs when policymakers do } \\
\text { not know what to do to solve a problem, } \\
\text { given its urgency or technical difficulty. }\end{array}$ & $\begin{array}{l}\text { Haas 1992, 2004; Morin } \\
\text { 1992; Morin 2014; Davis } \\
\text { Cross 2012; Karlsson 2004; } \\
\text { Loblova 2018; Adler 2002; } \\
\text { Checkel 1998; Christiansen } \\
\text { et al. 1999; Guzzini 2000; } \\
\text { Hopf 1998; Ruggie 1998; } \\
\text { Sebenius 1992 }\end{array}$ \\
\hline $\begin{array}{l}\text { Access to the } \\
\text { policy process }\end{array}$ & $\begin{array}{l}\text { Epistemic communities can have better } \\
\text { access to the policy process than other actors. } \\
\text { These groups of professionals and experts } \\
\text { are usually advisors and providers of } \\
\text { evidence for policymaking. However, there } \\
\text { are many instances in which governments are } \\
\text { not open to this, having complete control } \\
\text { over information and limiting their role. }\end{array}$ & $\begin{array}{l}\text { Haas 2004; Morin } 2014 \\
(26,148)\end{array}$ \\
\hline $\begin{array}{l}\text { Position in the } \\
\text { policymaking } \\
\text { process }\end{array}$ & $\begin{array}{l}\text { Epistemic communities' members are either } \\
\text { part of the policy process or have direct } \\
\text { access to it through different institutional } \\
\text { mechanisms, such as expert groups, advisory } \\
\text { groups, international conferences, etc. }\end{array}$ & $\begin{array}{l}\text { Haas 2004; Antoniades 2003; } \\
\text { Davis Cross 2013; Cogburn } \\
\text { 2005; Karlsson } 2004\end{array}$ \\
\hline $\begin{array}{l}\text { Political Context } \\
\text { (Scope condition) }\end{array}$ & $\begin{array}{l}\text { The knowledge and expertise that epistemic } \\
\text { communities have are more relevant if they } \\
\text { can influence politics. Even though this is } \\
\text { more difficult to achieve, scholars agree on } \\
\text { these groups potential to persuade } \\
\text { politicians. Their potential is more likely } \\
\text { when their knowledge helps to justify } \\
\text { specific political programs, and it can be } \\
\text { translated into the dominant social discourse } \\
\text { (Antoniades 2003) since Science can also be } \\
\text { political by itself(Haas 2004) }\end{array}$ & $\begin{array}{l}\text { Haas 2004; Miles 1998; } \\
\text { Nelkin 1979; Antoniades } \\
\text { 2003; Jasanoff et al. 1995; } \\
\text { Miller and Edwards 2001; } \\
\text { Adler } 1992\end{array}$ \\
\hline Knowledge claims & $\begin{array}{l}\text { Authoritative claim to knowledge was one of } \\
\text { the central characteristics in Hass (1992) } \\
\text { definition of an epistemic community. Most } \\
\text { scholars consider an epistemic community- } \\
\text { relevant because of its expert knowledge. }\end{array}$ & $\begin{array}{l}\text { Haas 1992; Antoniades 2003; } \\
\text { Adler 1992; Sebenious 1992; } \\
\text { Clark and Majone 1985; } \\
\text { Davis Cross 2012; Stone } \\
\text { 2002; 2008; Cogburn } 2005\end{array}$ \\
\hline $\begin{array}{l}\text { Interconnections } \\
\text { with other groups }\end{array}$ & $\begin{array}{l}\text { Other groups or networks have an interest in } \\
\text { influencing the policy process (NGOs, policy } \\
\text { networks, advocacy networks). Epistemic } \\
\text { communities can work with them to increase } \\
\text { each other's influence. }\end{array}$ & $\begin{array}{l}\text { Haas 2004; Davis Cross } \\
\text { 2013; Stone } 2008 \\
(91,26,149)\end{array}$ \\
\hline
\end{tabular}

Table 7. Main characteristics of epistemic communities, a literature review. 


\begin{tabular}{|c|c|c|}
\hline Characteristics & Definition & Reference \\
\hline $\begin{array}{l}\text { Connectivity - } \\
\text { transmission of } \\
\text { knowledge }\end{array}$ & $\begin{array}{l}\text { Epistemic communities are considered } \\
\text { knowledge networks (Haas, 2004; Antoniades, } \\
\text { 2003). As such, they can have multiple } \\
\text { connections in a loose structure that facilitates } \\
\text { the transmission of information among its } \\
\text { members, exchange points of view, and diffuse } \\
\text { ideas. However, there are different types of } \\
\text { networks, organized in different forms that } \\
\text { affect their ability to transmit their knowledge } \\
\text { within the network and to the outside. }\end{array}$ & $\begin{array}{l}\text { Morin 2014; Haas 2004; } \\
\text { Antoniades 2003; Adler } \\
\text { and Haas 1992; Zollman } \\
\text { 2007; Cogburn 2005; } \\
\text { Sebenius 1992; Adler 1992; } \\
\text { Zollman 2013; Petersen } \\
2016\end{array}$ \\
\hline Membership & $\begin{array}{l}\text { Experts in the same field are usually members } \\
\text { of the same community. However, other } \\
\text { professionals with different backgrounds and in } \\
\text { different positions can be part of the same } \\
\text { community as well. Therefore, national and } \\
\text { international civil servants, scientists, } \\
\text { diplomats, scholars, can be members of an } \\
\text { epistemic community. They can work at } \\
\text { universities, research institutions, or the private } \\
\text { sector. They also come from different } \\
\text { nationalities. Epistemic communities that are } \\
\text { genuinely global can have better results due to } \\
\text { the number of connections. }\end{array}$ & $\begin{array}{l}\text { Ruggie 1975; Davis Cross } \\
\text { 2013; Morin 2014; } \\
\text { Antoniades 2003; Adler } \\
1992\end{array}$ \\
\hline Cohesiveness & $\begin{array}{l}\text { The epistemic community's cohesiveness } \\
\text { means that all its members shared professional } \\
\text { norms, knowledge, and have a common } \\
\text { understanding of problems and possible } \\
\text { solutions. They agree with a policy goal and } \\
\text { frequently socialize their knowledge. The more } \\
\text { internally cohesive an epistemic community is, } \\
\text { the more able to influence policymaking as a } \\
\text { unit (Davis Cross 2013) }\end{array}$ & $\begin{array}{l}\text { Davis Cross 2013; Morin } \\
\text { 2014; Loblova 2018; } \\
\text { Karlsson 2004; Sebenius } \\
\text { 1992; Adler 1992; Petersen } \\
2016\end{array}$ \\
\hline Legitimacy & $\begin{array}{l}\text { The legitimacy of epistemic communities is } \\
\text { important for influencing the policy-making } \\
\text { process. Even though science can have a } \\
\text { political motivation, evidence-based knowledge } \\
\text { is considered accurate and legitimate. } \\
\text { Legitimacy makes others accept the epistemic } \\
\text { community's knowledge. }\end{array}$ & $\begin{array}{l}\text { Haas 2004; Botcheva 2001; } \\
\text { Andresen et al. 2000; Clark } \\
\text { and Majone 1985; Adler } \\
\text { 1992; Miller and Fox } 2001\end{array}$ \\
\hline $\begin{array}{l}\text { Coherence with } \\
\text { existing norms }\end{array}$ & $\begin{array}{l}\text { An epistemic community shares a clear and } \\
\text { shared understanding of the laws and } \\
\text { institutions regulating the issue of interest. }\end{array}$ & $\begin{array}{l}\text { Morin 2014: Adler 1992; } \\
\text { Jordan and Greenway } 1998\end{array}$ \\
\hline Path dependency & $\begin{array}{l}\text { The continued involvement in policy debates on } \\
\text { the same topic can create path dependency that } \\
\text { will favor their future participation. }\end{array}$ & Morin 2014 \\
\hline
\end{tabular}

Table 7. Main characteristics of epistemic communities, a literature review (cont.).

Peter Haas' concept and contributions are the primary references in these studies of 
epistemic communities. The number of scholars, however, applying and testing his original approach has been relatively small ${ }^{x i}$. Therefore, this research centres its analysis using Haas' original framework. From Haas' work, two central elements emerge as the most important: first, the scope conditions of uncertainty and subsequent need for expert knowledge which favors the participation and influence of epistemic communities; and second, the epistemic community's characteristics that can modify the level of cooperation. The first characteristic is epistemic communities' capability to set up a policy goal and to produce consensual knowledge and information required by policymakers. The second is their ability to disseminate their information and knowledge for reaching policymakers. The third is the epistemic community's access to the policymaking process and its capability to institutionalize and consolidate its bureaucratic power at the national and international levels and shape the policy preferences of policymakers (institutionalizing the epistemic community's influence) $(25,47,153,154,155)$. These characteristics are the basis for establishing a framework to analyze global health and the international response to disease outbreaks.

\subsubsection{Knowledge}

The authoritative claim on knowledge makes epistemic communities influential in policy-making $(143,90,23)$. However, not all knowledge is relevant. Scientific claims perceived by the policymakers as legitimate, objective, and isolated from the political space are more likely to be adopted $(90,94,156,157)$.

An epistemic community needs to produce "usable knowledge" to be able to

\footnotetext{
${ }^{x i}$ Anthony R. Zito (2018) examined the studies of epistemic communities published in peer-reviewed journals and found that out of 212 documents only 11 of them followed Haas original conceptualization (154).
} 
influence the policy process (90). To identify “usable knowledge," Clark and Majone (1985) present four criteria to differentiate it from other knowledge: adequacy, value, legitimacy, and effectiveness. Adequate knowledge includes all the relevant "facts." Value refers to the contribution to further understanding of the scientific/health problem. Legitimacy relates to the acceptance by others of the epistemic community's policy advice. Effectiveness refers to the ability of the community to shape the agenda or influence the debate (158). Thus, epistemic communities influence policy processes when they can develop "usable knowledge," and the decision-makers feel compelled to apply it $(90,140)$.

Epistemic communities are also "de facto natural coalitions" (23). Knowledge developed by epistemic communities helps policymakers to understand and expand the range of possible outcomes, making it possible to expand the area of possible agreement. Epistemic communities also alter the process of learning since the members of a coalition would share a common policy project. They can reduce the conflict of interest regarding this area, making cooperation achievable and more likely to persist in the long term (23). Treaties based on scientific knowledge and that involved the participation of epistemic communities tend to be adopted and ratified faster and last longer $(66,48)$.

\subsubsection{Socialization of ideas}

Epistemic communities produce ideas and knowledge that they must share among the members of the community and outside the community. The diffusion of these ideas can occur through publications in academic, peer-reviewed journals, participation in conferences, research collaboration, and other forms of communication $(159,25)$.

According to Haas, epistemic communities are "channels through which new ideas circulate from societies to governments as well as from country to country (25)." Members 
of an epistemic community transmit their shared understanding of a problem through accessing the policy process and persuading decisionmakers to adopt their expert ideas. Epistemic communities, therefore, are a specific type of knowledge networks $(53,25)$. A network is a "set of actors (nodes) that are linked by various relationships (ties) (160)". Actors in a network are individuals, organizations, or units within organizations. Relationships can be personal, functional between units within an organization or strategic relationships between organizations $(64,161,162,163,160,164,165)$.

The concept of network is useful to understand how epistemic communities communicate, exchange information, and connect with other actors. Network structures facilitate the transmission of information and knowledge through interpersonal ties $(166,167)$. They create communication linkages that forge a new communications structure that connects different people and groups in the organization regardless of their formal position or roles (163).

Epistemic communities connect policy actors and institutions and transmit information for policymaking $(49,48,168)$. As knowledge networks, they are mechanisms through which organizations share and transfer both explicit and implicit knowledge (163). Network structures facilitate the diffusion of knowledge within the network and outside the network, through publications, conferences, the internet. The network structure facilitates the transmission and dissemination of information among the epistemic community's members, influencing how it transmits knowledge and how it associates with relevant policy actors. It enables multiple connections, making it more feasible to associate with different epistemic communities and other groups interested in the same topic. They connect with NGOs, governments, international organizations, and their secretariats. These actors have an impact 
on how epistemic communities influence the policy process since they provide access to policymakers (49). The structure also enables the epistemic community to develop more ties, increases socialization as well as interactions among them that will help the group to cooperate and influence effective cooperative outcomes $(152,64)$. Therefore, they can reach actors directly involved in the policymaking process and become part of it as well.

Epistemic communities are networks with a wide variety of members that connect policy entrepreneurs, experts, and professionals in other areas but with common knowledge over the topic of interest. Policy entrepreneurs may be international bureaucrats, national officials, civil servants, recognized people in business, scholars, or policy activists $(169,170,171)$. Due to their position and resources, they can influence policymaking, facilitating the diffusion of individual policies and the adoption of innovative solutions (172). In global health, policy entrepreneurs have played a crucial role in influencing international cooperation, framing agendas, and persuading policymakers to adopt specific policies (171). They differ from other members due to their strong leadership and their capacity to insert themselves into the policy-making process.

\subsubsection{Institutionalization of an epistemic community's bureaucratic power}

Epistemic communities are relevant to the policy-making process, given that the complexity and variety of issues in international affairs have increased. As a result, governments, delegations, and international secretariats incorporate more experts (48). Thus, epistemic communities have privileged access to the process and, commonly, their members are already part of those structures, "shaping their preferences from within (47)", with a capacity to influence the process as national or international bureaucrats, diplomats or policymakers $(143,23,91,48,49)$. The epistemic community's network structure also facilitates 
access to the policy process. This is a common feature in global health since experts and scientists are part of epistemic communities working at the national and international levels. Since the transfer of ideas occurs through international task forces, committees, or expert groups (173), an epistemic community's influence increases just by belonging to any of these mechanisms (49).

As actors get immersed in the process, epistemic communities can consolidate bureaucratic power and institutionalize their influence $(143,25)$, convincing decisionmakers that their ideas offer the best course of action to follow and providing coherence to the process. Regular participation in these policy networks helps to strengthen epistemic community members' ties $(152,46)$. In global health, the World Health Organization (WHO) has provided a policy space for these actors, by integrating hundreds of professionals with specialized knowledge in its different areas, such as expert committees, task forces, specialized consultations, or as advisors.

\subsubsection{Scope Conditions}

The literature identifies uncertainty as an essential factor impacting on the ability of epistemic communities to influence a policy process. Different types of uncertainty influence how policymakers respond to a situation, and the kind of expertise required to understand a specific problem and solve it $(19,174)$.

With the emergence and re-emergence of infectious diseases, crises become common and usually with high levels of uncertainty (175). Information regarding the situation is scarce, as well as data to formulate the appropriate policy choices for containing an outbreak. Current norms and institutions may be insufficient to galvanize international cooperation. Such emergencies affect political leaders' capacity to formulate policies since they do not 
know the immediate and long-term consequences of the events. Information to estimate risk and calculate costs are scarce, increasing the demand for technical expertise and specialized knowledge $(143,25,90,145,49,176,91)$.

Under uncertainty, therefore, epistemic communities act as sources of information or consultants to define the scope of the problem and possible solutions. In these positions, members of the epistemic community can influence the policy process and actors' interests; they can mobilize support for ideas and influence agenda-setting (143,177). Although uncertainty creates a space for epistemic community activity, the degree of uncertainty does not necessarily correlate with an epistemic community's capacity to influence the process (91).

\subsection{Politics and epistemic communities}

More governments, delegations, and international secretariats have incorporated more experts in their decision-making processes (28). Some countries have also moved towards the professionalization of their civil services, increasing the number of expert scientists and technicians working for their governments. Science and technical knowledge, however, are not necessary apolitical, and sometimes they reflect political priorities and biases $(55,98,181)$. Politics often use scientific knowledge to justify political programs and choices $(55,181)$. The more the interaction between experts and politicians to address current problems requiring a high level of technical knowledge, the higher the probability that politics and partisan issues will affect the epistemic communities' participation and influence. Because members of epistemic communities participate in the policymaking process, it is difficult to isolate these networks from political interests since "there are seldom 
purely technical or purely political issues (180)". Hence, the distributional consequences of science-based advice are themselves political $(95,182,183)$.

Additionally, there are constant disagreements among experts about knowledge claims, and knowledge is continuously contested. Disagreements create and sustain rivalry among epistemic communities $(48,50,26,182)$. Science embodies implicit values of control; therefore, decisions made with scientific support may reflect some hidden values (26).

\subsubsection{Operationalizing epistemic communities}

Skeptics of the role and influence of epistemic communities and knowledge networks argue that there is little research that shows their causal role (47). To deal with this problem, epistemic communities scholars have proposed other approaches such as a clear distinction between external and internal characteristics of epistemic communities (70); defining a causal mechanism (47), and applying concepts of social network theory to explain specific attributes of these actors (64). In addition to the problems with the methodology, a considerable number of researchers apply this approach only to single cases or successful ones $(47,178,53)$, and the definition of an epistemic community is interpreted narrowly, referring most of the time only to scientists and technicians $(91,148)$.

To address these problems, first, this research adopts a broader definition of the “epistemic community network." In global health, an epistemic community network includes one or more groups of professionals embedded in the system of global health governance (dominated by the World Health Organization and nation-states), which members connect and interrelate throughout their common interest and understanding of a particular problem, sharing epistemological beliefs and principles. Epistemic communities in global health include WHO officials and other UN bureaucrats that are experts in their field; scientists and 
experts working in universities and research institutions, from disciplines relevant to public health (epidemiologists, biologist, clinical laboratory scientist, public health experts among others); domestic bureaucrats (from health agencies and others agencies); and health attaches (diplomats specialized on global health). The concept adopted in this research, therefore, emphasizes three aspects:

1. An epistemic community network is not always one single group; it can be multiple groups that share a common interest, epistemological and scientific notions, beliefs, and principles, a common policy goal. The issue-problem is their unifier.

2. Members of an epistemic community network are not only scientists or technicians; they are experts in different areas that contribute in various ways to solve the issueproblem.

3. An epistemic community network is embedded in a system of governance organizations, norms, institutions, states. Even if the epistemic community's members are not part of the system itself, they act through it.

Second, the research introduces a measurement of epistemic communities to test the assumptions made by Peter Haas's original theory about the conditions of knowledge, dissemination, and institutionalization of bureaucratic power, as outlined in table 8 (25). 


\begin{tabular}{|c|l|}
\hline Condition & Definition \\
\hline Knowledge & $\begin{array}{l}\text { To influence any policy process, an epistemic community works together } \\
\text { as a unit and develops clear policy goals, beliefs, and understanding of an } \\
\text { issue. Members of the epistemic community have a shared understanding } \\
\text { and agreement on problems and solutions. This condition answers the } \\
\text { questions: has the epistemic community developed coherent, consensual, } \\
\text { and useful knowledge to guide the policy process? Based on this, does it } \\
\text { have a policy goal? }\end{array}$ \\
\hline Socialization of \\
ideas & $\begin{array}{l}\text { The epistemic community disseminates its knowledge and ideas to reach } \\
\text { policymakers. The community exchanges information and gets to know } \\
\text { each other's position. As a network, the epistemic community transmits the } \\
\text { information within its members. This structure creates channels to } \\
\text { communicate its knowledge and information to other actors, through their } \\
\text { connections and using other mechanisms such as publications and } \\
\text { conferences. This condition answers the question; Has the epistemic } \\
\text { community socialized its knowledge and made it accessible to } \\
\text { policymakers? }\end{array}$ \\
\hline $\begin{array}{c}\text { Epistemic communities institutionalize bureaucratic power by either } \\
\text { influencing policymakers with their ideas or directly accessing the policy } \\
\text { process, getting immersed in it as part of governments, delegations, and } \\
\text { international secretariats (48). The influence of ideas occurs when these } \\
\text { experts are called into international task forces, committees, or expert } \\
\text { groups (173), an epistemic community's influence increases just by } \\
\text { belonging to any of these mechanisms (49). Direct capacity to influence the } \\
\text { process occurs when they are included as national or international } \\
\text { bureaucrats, diplomats, or policymakers (23,143,53,49,48). } \\
\text { This condition answers to the questions: does the epistemic community } \\
\text { pave access to the policy process? How much are they immersed in the } \\
\text { process? }\end{array}$ \\
\hline
\end{tabular}

Table 8. Epistemic communities' framework

Uncertainty is not measured in this framework since it is a contextual characteristic

found equally in all cases studied in this research. The proposal measures the conditions that make an epistemic community capable of modifying cooperative outcomes. These elements are interconnected among themselves, and the output of their interconnections translates into an epistemic community's capacity to influence the policy process. These conditions, however, are not identical in all epistemic communities. Besides, given that epistemic communities are neither isolated nor independent actors, any changes in the system they are embedded in will also influence them, causing possible modifications in these characteristics.

Figure 8 shows these characteristics link to global health cooperation. 


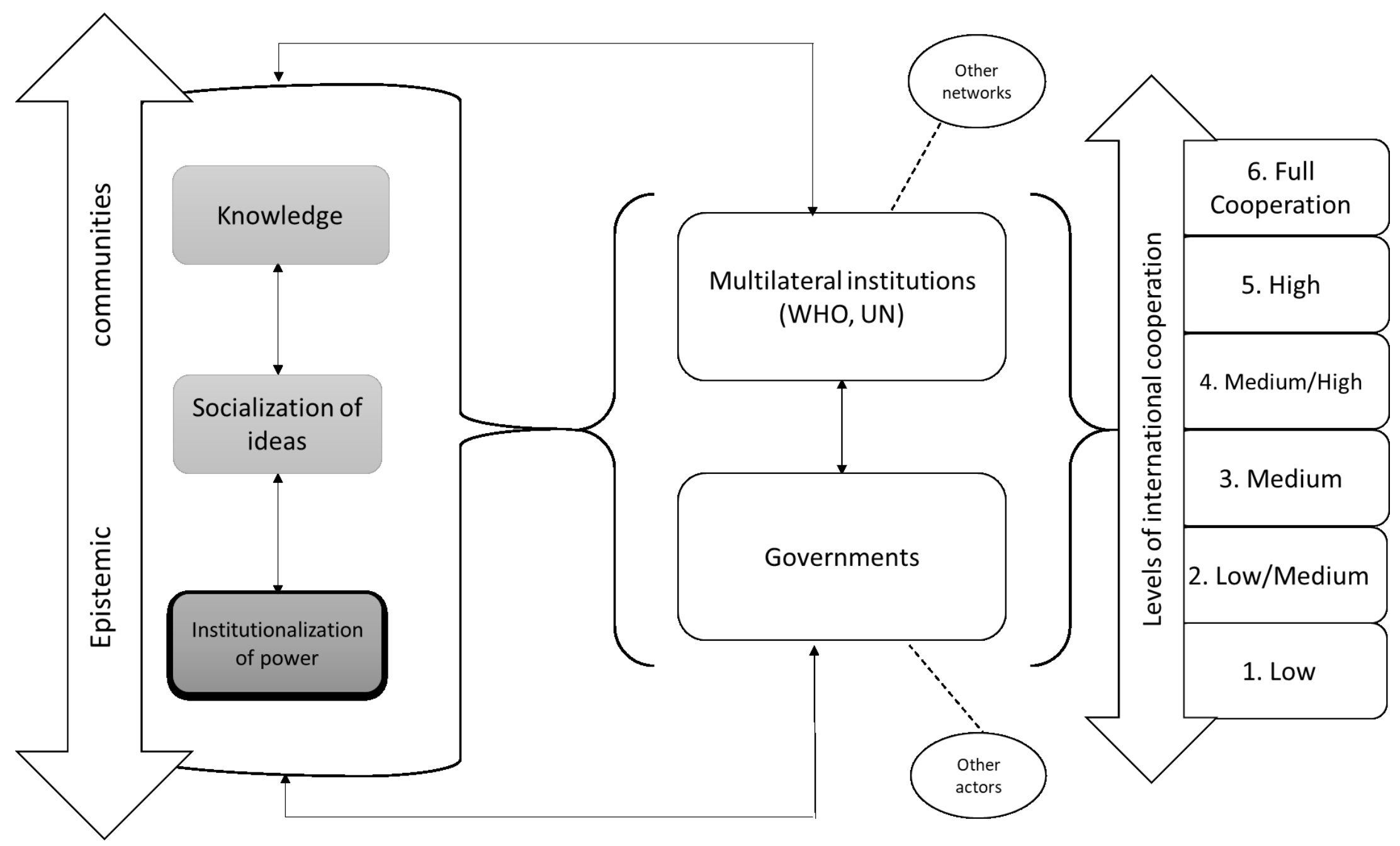

Figure 8. Proposed framework for the analysis of an epistemic community's strength 
Epistemic communities are embedded in an international system where international organizations and national governments are the main actors. The combination and interaction of these characteristics will translate into the epistemic community's ability to influence the level of international cooperation (outcome). This research, therefore, hypothesizes that variance in these conditions affects the epistemic community's ability to influence cooperation.

The framework simplifies factors presented in the literature of epistemic communities and categorizes those initially identified by Haas. The analysis does not ignore other characteristics found in the epistemic community's extensive literature, but it argues that Haas' framework is the most parsimonious and therefore easiest to operationalize. It recognizes that Haas' theory does not explicitly refer to the variation in epistemic communities' characteristics. Epistemic communities, however, are not equal. Some of them have built more policy-oriented knowledge than others. They are better established with clear policy goals and have institutionalized their bureaucratic power. The framework will guide the research under the general argument that the presence of multiple epistemic communities bestowed with differences in their characteristics cause various levels of international cooperation when they participate in phenomena with similar characteristics.

With the definition of epistemic communities' characteristics that influence policymaking, I have identified indicators for measuring these conditions. Table 9 presents those indicators. 


\begin{tabular}{|c|c|c|}
\hline Condition & Indicator & Description \\
\hline \multirow[t]{2}{*}{ 1. Knowledge } & $\begin{array}{l}\text { Agreement on a } \\
\text { common definition of } \\
\text { the problem and } \\
\text { feasible solutions } \\
\text { (consensual } \\
\text { knowledge) }\end{array}$ & $\begin{array}{l}\text { The literature on epistemic communities emphasizes the } \\
\text { importance of "consensual knowledge" and a common } \\
\text { understanding of the problem, to influence policy- } \\
\text { making }(143,26,179) \text {. Therefore, an explicit agreement } \\
\text { on problems and solutions makes a more cohesive } \\
\text { community. This information and knowledge should be } \\
\text { useful and clear for policymaking. }\end{array}$ \\
\hline & $\begin{array}{l}\text { Clear identification of } \\
\text { a common policy goal }\end{array}$ & $\begin{array}{l}\text { All the members agree with a common policy goal. If } \\
\text { there is no such agreement, it is harder to influence the } \\
\text { policy process (143). Sometimes knowledge remains } \\
\text { contested and creates disagreements that can weaken the } \\
\text { epistemic community's position }(180,148) \text {. }\end{array}$ \\
\hline \multirow[t]{2}{*}{$\begin{array}{l}\text { 2. Socialization of } \\
\text { ideas }\end{array}$} & Structure & $\begin{array}{l}\text { The way their members communicate with each other } \\
\text { and with policymakers can affect the network's ability } \\
\text { to influence the policymaking process. Therefore, it is } \\
\text { necessary to identify who interacts with whom, how } \\
\text { extensive is the network, who are the networks' more } \\
\text { important actors (policy entrepreneurs or champions) } \\
\text { (64). The looser the network structure, the more capable } \\
\text { its members, are of reaching and communicating with } \\
\text { each other and with other actors. } \\
\text { Multiple connections (nodes) inside the network } \\
\text { influence cooperation. The broader the network } \\
\text { (international and at different levels), the more capable } \\
\text { it would be to have global influence. The more } \\
\text { connections, the better the network will be transmitting } \\
\text { its information (64). The more frequent members of the } \\
\text { epistemic community interact, the stronger their ties } \\
\text { (64). These interactions are usually through meetings, } \\
\text { sharing information, collaborating. }\end{array}$ \\
\hline & $\begin{array}{l}\text { Dissemination } \\
\text { mechanisms }\end{array}$ & $\begin{array}{l}\text { The epistemic community must disseminate its } \\
\text { knowledge and ideas to reach policymakers and compel } \\
\text { them to adopt their views. To do this, } \\
\text { members of the epistemic community usually publish in } \\
\text { most important and influential academic and policy } \\
\text { journals. When members of an epistemic community } \\
\text { make available their ideas, it is easier for policymakers } \\
\text { and key actors to access them and adopt them. } \\
\text { Sometimes members of the network prefer not to share } \\
\text { their information and ideas when they are needed the } \\
\text { most. When experts withhold information, the epistemic } \\
\text { community's position debilitates, damaging the } \\
\text { prospects of cooperation. }\end{array}$ \\
\hline
\end{tabular}

Table 9. Indicators for measuring epistemic communities' characteristics. 


\begin{tabular}{|c|c|c|}
\hline Condition & Indicator & Description \\
\hline 2. Dissemination & $\begin{array}{l}\text { Participation in } \\
\text { international } \\
\text { meetings }\end{array}$ & $\begin{array}{l}\text { The international community gets together and analyzes } \\
\text { the situation. These settings are, then, primary locations } \\
\text { for decision making }(102,116) \text {. They are also "places" } \\
\text { where people connect and participate. Each type of } \\
\text { forum will lead to a specific outcome that will affect the } \\
\text { level of cooperation (103). Participation in multiple } \\
\text { international conferences organized to discuss the topic } \\
\text { with the involvement of decision-makers and experts } \\
\text { improves these interconnections. }\end{array}$ \\
\hline \multirow[b]{2}{*}{$\begin{array}{l}\text { 3.Institutionalization } \\
\text { of bureaucratic } \\
\text { power }\end{array}$} & $\begin{array}{l}\text { Participation in the } \\
\text { policy process }\end{array}$ & $\begin{array}{l}\text { In global health, international organizations and } \\
\text { governments usually organize experts' groups to } \\
\text { provide advice and recommendations that can be } \\
\text { adopted and implemented in norms and implemented in } \\
\text { specific policies; these are spaces for members of } \\
\text { epistemic communities' networks to understand better } \\
\text { the problems faced at the global level and connect their } \\
\text { knowledge with the policy process }\end{array}$ \\
\hline & $\begin{array}{c}\text { Members of the } \\
\text { epistemic community } \\
\text { in decision-making } \\
\text { positions }\end{array}$ & $\begin{array}{l}\text { Since global health policy requires expert and technical } \\
\text { knowledge, it is common that members of the epistemic } \\
\text { community will be in policymaking and decision- } \\
\text { making positions. When most members of the epistemic } \\
\text { community have direct access to the policy process as } \\
\text { part of a government or an international organization, } \\
\text { the position of the network strengthens. } \\
\text { When an epistemic community has members in } \\
\text { prominent positions or as policy entrepreneurs, they can } \\
\text { help to advance the ideas of community and increased } \\
\text { the possibility that the epistemic community's ideas will } \\
\text { be accepted. }\end{array}$ \\
\hline
\end{tabular}

Table 9. Indicators for measuring epistemic communities' characteristics (cont.)

With these indicators, it is possible to examine the epistemic community's characteristics and analyze its level of influence in international cooperation. An epistemic community is more likely to influence higher levels of international cooperation when it has developed consensual knowledge that clarifies the problem, proposes feasible policy solutions, and agrees international cooperation is necessary to address the situation (25). Its influence also increases when it has a structure that connects its members inside and outside the community and disseminates to policymakers a resonant, evidence-based scientific advice, and reaches a highly institutionalized bureaucratic power with clear connections with 
the policy process.

\subsection{Testing the theoretical framework in global health}

To explore the hypothesis that epistemic communities influence international cooperation and induce variation, I will briefly introduce the case of tobacco control as a plausibility probe of my proposed framework.

This case presents a policy issue considered a success story in global health cooperation, which also underlines the importance of evidence-based information to persuade policymakers.

\subsubsection{Tobacco control and the Framework Convention}

Scholars often mention tobacco control as a model of global health cooperation $(66,181,182,183)$, due to more governments issuing tobacco control policies around the world since 1976, in compliance with international norms (182). Furthermore, after the adoption in 2005 of the "Framework Convention on Tobacco Control (FCTC)," more countries have implemented international regulations and changed national legislation and policies to comply with the agreement (184).

The successful creation of an international legal framework that has effectively influenced stronger national norms to control the industry was the consequence of clear scientific evidence on the effects of tobacco on health. Researchers provided clear evidence of a link between smoking and cancer, as well as other diseases that, in the long term, can create high costs for health systems. The evidence permitted advancing a research agenda that became the foundation of an epistemic community concerned with the consequences of tobacco. The network of professionals applied their knowledge to convince relevant institutions and national governments that coordinated and cooperative international action 
could reduce tobacco consumption $(66,181,185,182,107)$.

Despite the scientific evidence, these experts had to evolve as a unified and cohesive group, able to provide stronger arguments and to gain political spaces to promote its policy goal. In 1964, the epistemic community gathered for the first time in the World Conference on Tobacco or Health (WCTH). Afterward, the US General Surgeon published the first official report on the health consequences of smoking (186). In 1970, the WHO introduced the report Limitation of smoking to the $45^{\text {th }}$ meeting of the Executive Board. A group of experts prepared the document ${ }^{\mathrm{xii}}$, and all of them were active members of the epistemic community. After this meeting, the $23^{\text {rd }}$ WHA issued the resolution WHA23.32 Health Consequences of Smoking (based on the report), calling member states to issue policies for limiting smoking (187).

The epistemic community's pivotal moment was the approval of the Framework Convention on Tobacco Control (FCTC). The FCTC is the first binding agreement in the field of global health. The creation of the treaty was based mainly on scientific evidence about the effects of tobacco in both smokers and non-smokers $(188,181,189)$. The designers of this proposal were two experts from the global epistemic community: Ruth Roemer and Allyn L. Taylor (185). They introduced their conceptualization of a legal document to promote tobacco control at the $1^{\text {st }}$ All-Africa Conference on Tobacco or Health in 1993. There, they presented compelling evidence on the harmful effects of tobacco on health, as well as the options for cost-effective interventions to control the problem (181). The idea of

\footnotetext{
${ }^{x i i}$ Dr. Charles Fletcher from the Royal Postgraduate Medical School; Dr. Daniel Horn, Director National Clearinghouse for Smoking and Health; Dr. Berit As., Institute of Psychology, University of Olso; and Dr. Ramstrom, National Smoking and Health Association, Sweden (187)
} 
creating an international instrument to control tobacco became a resolution adopted at the $9^{\text {th }}$ World Conference on Tobacco or Health (WCTH) in 1994 (185).

The network strengthened its links with government officials and international organizations. Their members convinced these officials of the advantages of coordinated global action to reduce the burden of disease, and the feasibility of implementing specific health interventions $(190,181,191,190,188)$. They persuaded Jean Lariviere, a senior medical adviser at Health Canada, and a delegate to the WHO in 1995 (185) to support global action. He drafted the resolution presented at the $95^{\text {th }}$ WHO Executive Board meeting, which was also co-sponsored by the representatives of Finland, Mexico, and Tanzania. Participants in those delegations would later become active participants in the community and would help to mobilize support at the WHO (185). By 1995, the World Health Assembly approved the resolution WHA48.1, which started the international discussion to create an international instrument (185). This process facilitated the epistemic community's involvement with policymakers. Members of the epistemic community institutionalized their expert advice, working as part of expert committees ${ }^{\text {xiii }}$, and providing background information to the WHO (181). The Framework Convention's negotiation began in 1996 (resolution WHA49.17), and countries adopted the FCTC in May 2003, with 168 state parties.

The epistemic community was also crucial to ratify and implement the FCTC. States participating in international tobacco control networks were the first to ratify the FCTC, making this treaty "among the most widely ratified in existence (66)". According to the Secretariat of the FCTC, by July 2017, 181 states had ratified this agreement (184).

\footnotetext{
xiii This was the case with the Committee of Experts on Tobacco Industry Documents and the Scientific Advisory Committee on Tobacco Product Regulation.
} 
To understand why the epistemic community was able to influence higher levels of cooperation in tobacco control, it is necessary to analyze the epistemic community's characteristics. Table 10 identifies the epistemic community shared policy goal, normative beliefs, causal beliefs, epistemological criteria, and notions of validity.

\begin{tabular}{|l|l|}
\hline Policy goal & Tobacco Epistemic Community \\
\hline Epistemological beliefs & $\begin{array}{l}\text { They agreed that it was necessary to establish an international } \\
\text { mechanism to reduce tobacco consumption based on scientific } \\
\text { evidence }\end{array}$ \\
\hline $\begin{array}{l}\text { Normative-principled } \\
\text { beliefs }\end{array}$ & $\begin{array}{l}\text { They agreed that tobacco consumption was the cause of other } \\
\text { conditions }(187,192)\end{array}$ \\
\hline Causal beliefs & $\begin{array}{l}\text { They had as their normative belief to reduce the number of deaths } \\
\text { due to chronic disease caused by tobacco consumption } \\
\text { consumption would lead to a decrease in other diseases. }\end{array}$ \\
\hline Notions of validity & $\begin{array}{l}\text { They established norms, standards, and practices for research on } \\
\text { tobacco and its effects on health }\end{array}$ \\
\hline
\end{tabular}

Table 10. The epistemic community in tobacco control. Based on multiple sources.

The epistemic community had the knowledge and information to provide strong evidence in favour of a global instrument. The epistemic community convinced governments and international policymakers that this issue required high levels of international cooperation for effective intervention. The network succeeded in advocating for a global framework treaty, and it has continued working to reach full implementation.

This epistemic community was able to influence cooperation due to a clear definition and identification of the problem, as well as its members' consensual agreement on these. Its structure was well-integrated inside and outside the network, creating coherence and reliable interconnections with the decision-making process. The epistemic community members were able to institutionalize their bureaucratic power and influence the policy process. Table 11 describes these features. 


\begin{tabular}{|c|c|c|}
\hline Characteristic & & Evidence \\
\hline \multirow[t]{2}{*}{ Knowledge } & $\begin{array}{l}\text { Agreement } \\
\text { on a common } \\
\text { definition of } \\
\text { a problem } \\
\text { and solutions } \\
\text { (consensual } \\
\text { knowledge) }\end{array}$ & $\begin{array}{l}\text { The research identifies an epistemic community since 1964, at } \\
\text { the first World Conference on Tobacco or Health (WCTH). } \\
\text { There was an agreement that tobacco consumption has severe } \\
\text { effects on health. Since the 1960s, scholars have cumulated } \\
\text { evidence of the impact of smoking on health. The document, } \\
\text { Smoking, and Health: Report of the Advisory Committee of the } \\
\text { Surgeon General of the Public Health Service (1964) presented } \\
\text { by Luther L. Terry, M.D., Surgeon General of the United States. } \\
\text { The report declares that after reviewing more than "7,000 } \\
\text { articles in the biomedical literature relating to smoking and dis- } \\
\text { ease that were available at the time, the Advisory Committee } \\
\text { concluded that cigarette smoking is: } \\
\text { - Associated with } 70 \% \text { higher all-cause mortality } \\
\text { rates among men } \\
\text { - A cause of lung cancer and laryngeal cancer in } \\
\text { men A probable cause of lung cancer in women (193)". } \\
\text { After this, in the } 1970 \text { s, other reports produced by the Office } \\
\text { of the Surgeon General in the US provided more evidence of } \\
\text { the consequences of smoking (194). These documents were } \\
\text { the basis for building consensual knowledge in the epistemic } \\
\text { community. } \\
\text { The need for global action was for the first time included in } \\
\text { 1970, in the document WHA23.32 Health Consequences of } \\
\text { Smoking prepared for the } 23 \text { rd World Health Assembly (195). }\end{array}$ \\
\hline & $\begin{array}{l}\text { Common } \\
\text { policy goal }\end{array}$ & $\begin{array}{l}\text { They agreed on a policy goal: to create an effective } \\
\text { international instrument to curb the global epidemic of } \\
\text { tobacco consumption. The epistemic community adopted the } \\
\text { proposal presented at the } 1 \text { st All-Africa Conference on } \\
\text { Tobacco or Health at the 9th WCTH in } 1994 \text { (185). }\end{array}$ \\
\hline $\begin{array}{l}\text { Socialization of } \\
\text { ideas }\end{array}$ & Structure & $\begin{array}{l}\text { The network has international representation, and } \\
\text { professionals from different areas are part of it. For instance, } \\
\text { the first World Conference on Smoking and Health was held } \\
\text { in } 1967 \text { with } 500 \text { participants from all over the world (196). } \\
\text { Since then, the participants have increased. The group has its } \\
\text { most prominent interaction every three years at the World } \\
\text { Conference on Tobacco or Health; their last meeting was in } \\
\text { March } 2018 \text { in South Africa (197). The epistemic community } \\
\text { has constant interactions and through different events, such as } \\
\text { the WHO Conference of the Parties of the FCTC in which } \\
\text { many of these experts participate as delegates every two years. }\end{array}$ \\
\hline
\end{tabular}

Table 11. Analysis of the tobacco control epistemic community's strength. 


\begin{tabular}{|c|c|c|}
\hline Characteristic & & Evidence \\
\hline \multirow[t]{2}{*}{$\begin{array}{c}\text { Socialization } \\
\text { of ideas }\end{array}$} & $\begin{array}{c}\text { Diffusion } \\
\text { mechanisms }\end{array}$ & $\begin{array}{l}\text { The epistemic community started an international movement for } \\
\text { the creation of an international instrument to control tobacco } \\
\text { consumption worldwide, with publications and proposals in } \\
\text { international conferences that would later influence the starting } \\
\text { of an international process (a compilation of this literature can be } \\
\text { found in The Health Consequences of Smoking - 50 years of } \\
\text { Progress. A report of the Surgeon General (186)). Some relevant } \\
\text { publications are: } \\
\text { Mihajlov VS. 1989. International health law: current status and } \\
\text { prospects. Round table: future of international law. International } \\
\text { Digest of Health Legislation, 1989, 40:9-16, where he discusses } \\
\text { the feasibility of a framework convention on tobacco control. } \\
\text { Ruth Roemer and Allyn L. Taylor introduced their } \\
\text { conceptualization of a legal document to promote tobacco control } \\
\text { at the 1st All-Africa Conference on Tobacco or Health in 1993 } \\
\text { (Roemer et al. 2005). The report would later become the basis for } \\
\text { the background document for the WHO negotiation, introducing } \\
\text { the idea of an international treaty (192). } \\
\text { The World Bank would later publish the study, Jha. P. ed. 1999. } \\
\text { "Curbing the epidemic: the economics of tobacco control," a } \\
\text { document that brought together experts 'analysis of the economic } \\
\text { consequences of smoking and which provided stronger economic } \\
\text { arguments (192). After the FCTC was adopted, there has also an } \\
\text { increase of technical publications at the global and regional } \\
\text { levels produced by the FCTC Secretariat and WHO (198). }\end{array}$ \\
\hline & $\begin{array}{l}\text { Participation } \\
\text { in } \\
\text { international } \\
\text { meetings }\end{array}$ & $\begin{array}{l}\text { During the process of negotiation of the FCTC, it opened public } \\
\text { hearings, with the participation of over } 500 \text { stakeholders, which } \\
\text { included associations of health professionals all over the world } \\
\text { (199). Experts also participated in the process of providing } \\
\text { knowledge during the policymaking process, for instance: } \\
\text { First meeting Working Group on the WHO FCTC (1999): as } \\
\text { providers of technical information (A/FCTC/WG1/7), it } \\
\text { included technical briefings from experts in international law, } \\
\text { public health, and health economics. } \\
\text { Second meeting, Working Group on the WHO FCTC (2000): } \\
\text { review recommendations made in: } \\
\text { WHO International Conference on Tobacco and Health, } \\
\text { "Making a difference in tobacco and health - avoiding the } \\
\text { tobacco epidemic in women and youth," Kobe, Japan, 14-18 } \\
\text { November } 1999 \text {. } \\
\text { WHO International Conference on Global Tobacco Control } \\
\text { Law, "Towards a WHO framework convention on tobacco } \\
\text { control," New Delhi, India, 7-9 January 2000. "Advancing } \\
\text { knowledge on regulating tobacco products," Oslo, Norway, 9- } \\
11 \text { February } 2000\end{array}$ \\
\hline
\end{tabular}

Table 11. Analysis of the tobacco control epistemic community (cont.) 


\begin{tabular}{|c|c|c|}
\hline Characteristic & & Evidence \\
\hline \multirow[t]{2}{*}{$\begin{array}{c}\text { Institutionalization } \\
\text { of bureaucratic } \\
\text { power }\end{array}$} & $\begin{array}{l}\text { Participation } \\
\text { in the policy } \\
\text { process }\end{array}$ & $\begin{array}{l}\text { According to the WHO, the FCTC "is an evidence-based treaty," } \\
\text { and the epistemic community proposals were the base for the } \\
\text { discussion of the FCTC, such as document WHA23.32 Health } \\
\text { Consequences of Smoking prepared for the } 23 \text { the World Assembly. } \\
\text { Resolution WHA } 48.1 \text {, which started the international debate for a } \\
\text { future instrument on tobacco control, proposed at the } 9^{\text {th }} \text { World } \\
\text { Conference on Tobacco or Health } 1999 \text { (192). The WHO created a } \\
\text { working group to assess the available evidence and to elaborate a } \\
\text { proposal for a treaty (Document WHA52.18). After the FCTC was } \\
\text { adopted and entered into force, it created the Conference of the } \\
\text { Parties of the FCTC to assess scientific and evidence-based } \\
\text { proposals for changes in international norms. Experts have been } \\
\text { part of different groups, including: } \\
\text { WHO Expert Committee on Smoking Control (1979), chaired by } \\
\text { Sir George Godber, UK } \\
\text { Committee of Experts on Tobacco Industry (1999), chaired by } \\
\text { Thomas Zelther, Director of the Swiss Federal Office of Public } \\
\text { Health } \\
\text { Scientific Advisory Committee on Tobacco Product Regulation } \\
\text { Expert Group on reporting arrangements (2015) Global Progress } \\
\text { Report } \\
\text { Independent Expert Group to conduct an impact assessment of the } \\
\text { WHO FCTC (2016), which the University of Waterloo published } \\
\text { (200) } \\
\text { Expert Group on Tobacco Advertising, Promotion and } \\
\text { Sponsorship: Depiction of Tobacco in Entertainment Media (2016) }\end{array}$ \\
\hline & $\begin{array}{l}\text { Experts or } \\
\text { professionals } \\
\text { from the } \\
\text { epistemic } \\
\text { community } \\
\text { in decision- } \\
\text { making } \\
\text { positions }\end{array}$ & $\begin{array}{l}\text { Some of the most famous names are (201): } \\
\text { Dr. Ruth Romer and Dr. Ally Taylor (drafted the background } \\
\text { paper for the negotiations of the FCTC). } \\
\text { Mr. Neil Collishaw (was Chief of the Tobacco Unit at the WHO, } \\
\text { worked at Health Canada and helped to promote the idea of an } \\
\text { FCTC, inviting Taylor to join the WHO) } \\
\text { Dr. Judith Mackay (Director of the Asian Consultancy for } \\
\text { Tobacco Control and WHO consultant). She drafted along with } \\
\text { Romer the resolution presented at the } 9^{\text {th }} \text { Conference on Tobacco } \\
\text { and Health in } 1994 \text { calling to governments for international } \\
\text { action). } \\
\text { Dr. Dereck Yach (Chairperson of the } 1993 \text { All Africa Tobacco } \\
\text { Control Conference, later appointed as leader of the Tobacco Free } \\
\text { Initiative established by Dr. Brundtland) (107). } \\
\text { Dr. Jean Lariviere, Senior Medical Advisor at Health Canada, } \\
\text { who supported Roemer and Collishaw to introduce the at WHO a } \\
\text { proposal to develop the FCTC. } \\
\text { Dr. Gro Harlem Brundtland, DG-WHO, she established tobacco } \\
\text { control as a priority for the WHO }\end{array}$ \\
\hline
\end{tabular}

Table 11. Analysis of the tobacco control epistemic community (cont.).

The participation of experts, members of an epistemic community, and the research 
on the health effects of tobacco consumption contributed to the creation and implementation of norms to regulate it. Members of the epistemic community shared common values such as the prevention of tobacco-induced morbidity and mortality, industry accountability, social justice, commitment to scientific truth, altruism, or duty (182). They also had a common understanding of the problem, which facilitated the creation of consensual knowledge. They agreed on the negative consequences of tobacco on smokers and second-hand smoke (182). They shared a comprehensive public health view rather than only a medical view (182); which was reinforced by economic analyses on the consequences of smoking to health systems $^{\mathrm{xiv}}$. These created strong and compelling arguments that convinced decision-makers of the importance of tobacco control.

The group of experts provided scientific evidence that legitimized decisions and including the creation of stronger regulations (such as the FCTC). The network of professionals, scientists, researchers, advocates, expert government officials, and international bureaucrats proved the problem was broader than medical and epidemiological. Having access to policymakers and bureaucrats increased the community's access to the central bodies of international and domestic decision-making. Direct contact with the policy process led to the institutionalization of their scientific advice, which opened spaces for shaping states' interests (25). Members of the epistemic community were part of the committees and expert groups created to provide advice on specific aspects, mostly at the WHO. The WHO expert's committees and advisory groups' recommendations were the backgrounds in the adoption of the World Health Assembly resolutions on tobacco control

xiv In 1999 the World Bank presented the report 'Curbing the Epidemic', providing the economic justification for FCTC (182). 
(182). They have been vital in influencing compliance among states and increasing cooperation since many state parties kept observing international norms $(185)^{\mathrm{xv}}$.

The evolution in tobacco control norms and their implementation demonstrate changes in levels of international cooperation, as well as the critical role played by scientific knowledge and epistemic communities. The Tobacco Control Epistemic community's members provided the necessary information for decision-making through several channels. Figure 9 presents the levels of cooperation in tobacco control and the transition from one level to another.

\footnotetext{
${ }^{x v}$ According to the WHO, around 79\% have strengthened their legislation and national programs (713). An example of this level of success has been the banning of smoking in public places, which is now a global policy. In addition, between 2006 and 2013 around 170 countries have been constantly paying voluntary assessed contributions to support the FCTC (712). The Global Progress Report on the Framework Convention also indicates that the average rate of implementation of treaty provisions across all substantive articles incremented from 52\% by 2010 to $56 \%$ in 2012 (713). Finally, it points out that 159 state parties have submitted at least one implementation report since 2005 (713).
} 


\begin{tabular}{|c|c|c|c|c|c|}
\hline $\begin{array}{l}\text { 1. LOW } \\
\text { Coordination }\end{array}$ & 2. LOW/MEDIUM & 3. MEDIUM & 4. MEDIUM/ HIGH & $\begin{array}{l}\text { 5. HIGH } \\
\text { Collaboration }\end{array}$ & 6. FULL COOPERATION \\
\hline $\begin{array}{l}\text { Agreement on the } \\
\text { need for international } \\
\text { action to control } \\
\text { tobacco's } \\
\text { consumption by the } \\
\text { members of WHO. } \\
\text { Resolution } \\
\text { WHA23.32 }\end{array}$ & $\begin{array}{l}\text { The WHO } \\
\text { Executive Board } \\
\text { adopts Resolution } \\
\text { WHA48.1 starting } \\
\text { the international } \\
\text { discussion for a } \\
\text { future instrument on } \\
\text { tobacco control. } \\
\text { Approval of } \\
\text { resolutions at the } \\
\text { WHO for the } \\
\text { negotiation of a } \\
\text { binding agreement on } \\
\text { Tobacco Control } \\
\text { (Resolution } \\
\text { WHA49.1) }\end{array}$ & $\begin{array}{l}\text { Framework } \\
\text { Convention } \\
\text { creation/ } \\
\text { strengthening of } \\
\text { institutions. } \\
\text { Countries agree on } \\
\text { a mechanism for } \\
\text { financing the future } \\
\text { implementation of } \\
\text { the Framework } \\
\text { Convention }\end{array}$ & $\begin{array}{l}\text { Participation of the } \\
\text { Conference of the } \\
\text { Parties of the } \\
\text { Framework } \\
\text { Convention. } \\
\text { Presentation of } \\
\text { annual reports on the } \\
\text { implementation of } \\
\text { the Framework } \\
\text { Convention. } \\
\text { Adoption of the } \\
\text { Framework } \\
\text { Convention on } \\
\text { Tobacco Control }\end{array}$ & $\begin{array}{l}\text { Conference of the } \\
\text { Parties of the } \\
\text { Framework } \\
\text { Convention is set to be } \\
\text { held every two years. } \\
\text { Countries pay } \\
\text { voluntary contributions } \\
\text { to support the } \\
\text { Framework } \\
\text { Convention. } \\
\text { Adoption of the } \\
\text { Protocol to Eliminate } \\
\text { Illicit Trade on } \\
\text { Tobacco Products } \\
\text { (secondary norm) }\end{array}$ & $\begin{array}{l}\text { Articles } 23 \text { and } 25 \text { of } \\
\text { the FCTC include a } \\
\text { multisectoral } \\
\text { approach which } \\
\text { requires international } \\
\text { cooperation. Based on } \\
\text { these articles the } 7 \text { th } \\
\text { Conference of the } \\
\text { Parties adopted } \\
\text { decision } \\
\text { FCTC/COP7(26) } \\
\text { about the } \\
\text { implementation of } \\
\text { those articles. } \\
\text { Countries continue } \\
\text { working on the } \\
\text { implementation of the } \\
\text { FCTC. By 2016, } 144 \\
\text { had reported to the } \\
\text { WHO the adoption of } \\
\text { new legislation related } \\
\text { to tobacco control and } \\
\text { the strengthening of } \\
\text { other norms } \\
\text { (FCTC/COP7/4) }\end{array}$ \\
\hline
\end{tabular}

Figure 9. Levels of Cooperation Tobacco Control 
Since its inception, the tobacco control epistemic community was dense and cohesive, benefiting from its members' regular interactions. The WCTH has been a crucial setting in the creation of linkages. Moreover, the participation of these experts in other international meetings (in the context of the WHO and other organizations) allowed more interactions.

These elements indicate that the epistemic community influenced international cooperation, increasing it to a level closer to full cooperation. If there had not been a robust epistemic community network, the FCTC would not have been successfully negotiated, given the tobacco industry's pressure and the opposition of some countries with high revenues from tobacco trade. 


\section{Chapter 4: International cooperation and the international response to}

\section{infectious diseases}

Emerging infectious diseases (EIDs) and re-emerging infectious diseases (REIDs) cause most pandemic outbreaks, which quickly spread over a wide geographic area and severely affect population health in a short period $(202,203)$. These diseases are caused by known or unknown pathogens or by microorganisms usually found in animals. There are also common diseases that have increased in incidence ${ }^{\mathrm{xvi}}(204,202,205,206,27,7,4,6)$, or the vector or host range has geographically expanded ${ }^{\text {xvii }}$ (207). Transmission of many EIDs and REIDs is usually from animals to humans, or they are common to both (known as zoonotic diseases) $(208,209,204)$.

Different factors contribute to the spread of EIDs such as technological and communication processes triggered

by globalization

$(210,121,206,211,212,213,214,204,108,215)$. Table 12 presents a summary of these factors.

\begin{tabular}{|c|c|}
\hline Cause & Explanation \\
\hline New technologies & Changes in food chains \\
\hline Changes in ecosystems and land use & $\begin{array}{l}\text { Agricultural practices, small farms, and increased closeness between } \\
\text { humans and animals. Deforestation }\end{array}$ \\
\hline $\begin{array}{l}\text { Globalization: Travel and international } \\
\text { commerce }\end{array}$ & Increasing flows of people and merchandise worldwide \\
\hline Climate change & $\begin{array}{l}\text { Expansion of the ecosystems of some vectors (such as the case of } \\
\text { Malaria, dengue, and yellow fever) }\end{array}$ \\
\hline Wars, terrorism, and massive migration & $\begin{array}{l}\text { Sanitation problems, hunger, famine; limited or lack of access to } \\
\text { health facilities, health personnel, and materials }\end{array}$ \\
\hline Demographic and population changes & Urban concentration, migration from rural areas to cities \\
\hline Socio-cultural changes & Sexual practices and use of drugs \\
\hline Weakened human immune system & Antibiotic resistance due to overconsumption \\
\hline Microbial adaptation & $\begin{array}{l}\text { Adaptation to antibiotics and other products developed to control } \\
\text { diseases (insecticides) }\end{array}$ \\
\hline
\end{tabular}

Table 12. The causes of the EIDs. Adapted from Foladori (2005:147) and (210,121)

xvi Lashley (2003) mentions the cases of diphtheria and pertussis and includes as references to support this claim Lashley and Durham2002; Lederberg and others 1992 (206).

xvii Zika Virus outbreak in the Americas is an example. 
In particular, current patterns of international trade and travel have increased the transmission of diseases across countries $(216,213,217,218,219)$. Due to new means of transportation, the growing number of urban areas increase contact among people and to animal reservoirs and vectors (220). These contextual factors operate in all cases.

Globalization has not only affected the transmission of diseases, but it has also modified their management (221), producing changes in health systems and the way national states craft and implement health policies $(107,222,223)$. States cannot depend exclusively on domestic policies to address infectious diseases, and during pandemics, other governments need to execute complementary actions to get effective results. Medical and non-medical interventions enforced by only one or two countries cannot effectively control an outbreak. Instead, individual responses will likely increase the risk $(33,27,4,6,7,8)$. Furthermore, the complexity and inter-sectoral characteristics of the intervening variables during outbreaks make it necessary to work with other sectors such as animal health, education, economy, tourism, or trade. Health policy has become global (213), and governments have adjusted themselves to the requirements of globalization (222), making international cooperation a necessary and critical instrument to control and manage these outbreaks. Yet, as outlined above, cooperation is not always optimal.

\subsection{Cooperation in the management of pandemics}

Different factors can influence international cooperation in the response to pandemic outbreaks. These include a large number of issues and actors that have the potential to affect the level of international cooperation in global health $(224,225)$. Figure 10 represents these factors and their connection to the process of international cooperation, showing its multidimensional nature. Therefore, to understand this cooperation, it is necessary, first, to know 
the characteristics of the diseases (scientific knowledge) as well as the factors that make some geographic areas more vulnerable than others (globalization of diseases) as well as characteristics that increase vulnerability (social inequalities). For implementing collective action, it is necessary to recognise the resources governments and population have access to (financial resources), and how national institutions work and their characteristics (health systems, domestic politics). Finally, globalization and multiple international factors (globalization of diseases, international traveling, trade, and production, security) will inevitably shape cooperation.

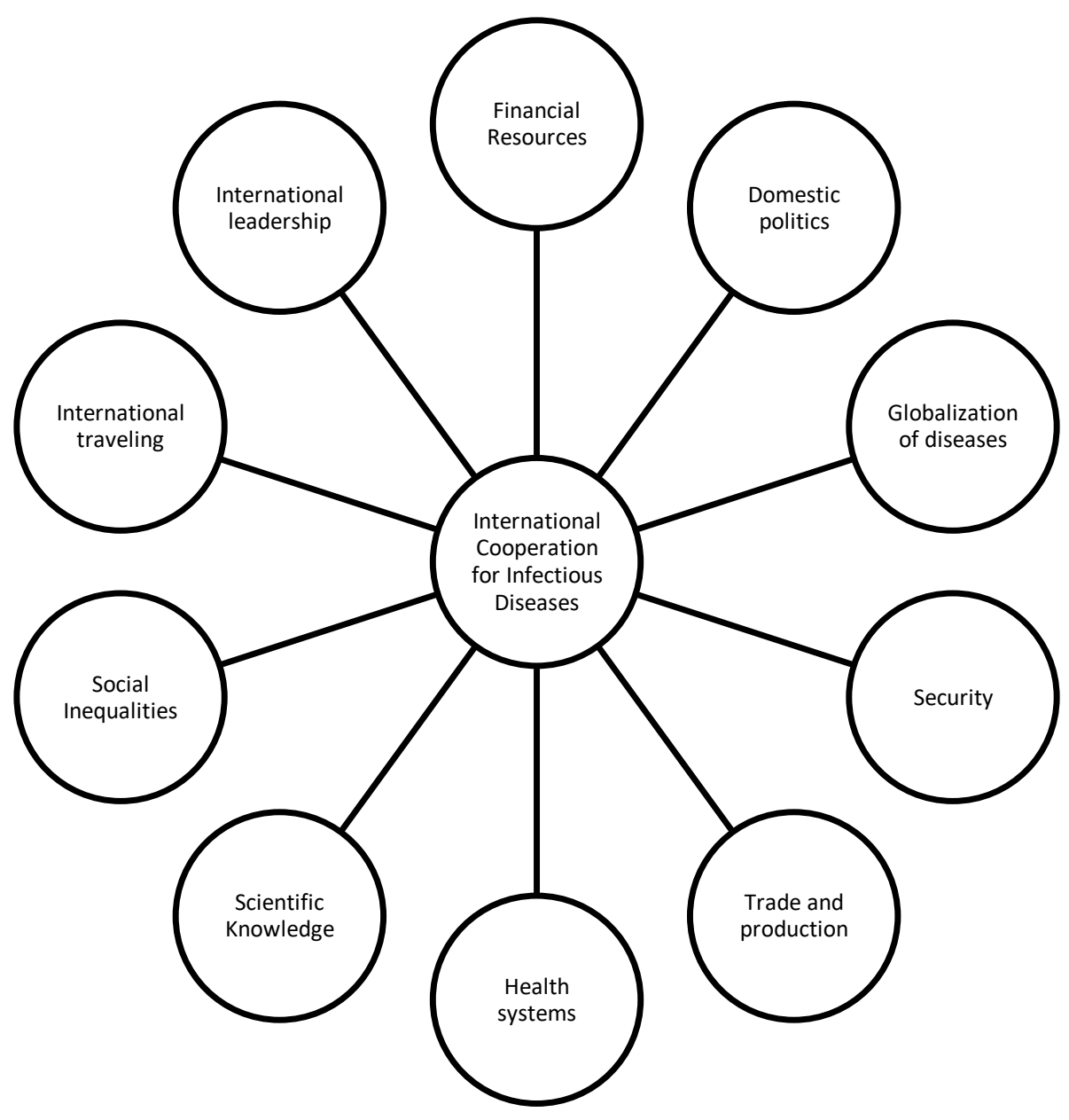

Figure 10. Factors influencing international cooperation to manage infectious diseases.

In general, international cooperation to control and manage infectious diseases begins 
with the analysis of the viruses and germs producing an outbreak $(209,202,121,226,227,228,229,230)$. The level of deaths produced by the disease in a specific period and a geographical area (mortality), as well as the prevalence of the disease in the population (morbidity), will give a first indication of the status of an epidemic. As a result, any health intervention requiring international collaboration could be the consequence of assessing case fatality ratios and reproductive ratios. The case fatality rate or ratio is the estimated percentage of the population that can die from a disease (231). The reproductive ratio or reproduction number is commonly used to measure the pandemic potential of a disease. It "measures the speed at which a disease is capable of spreading in the population (232) ".The value of $R_{0}>1$ usually indicates pandemic potential $(233,234)^{x v i i i}$. Would this be enough to make countries cooperate?

Historically, only smallpox, a disease with high reproductive and fatality ratios, was eradicated through an international vaccination campaign with a high level of international collaboration managed by the Global Smallpox Eradication Program (235). Nonetheless, these indicators did not seem to drive the response of disease outbreaks recently assessed by the WHO Emergency Committee. Ebola and MERS have the highest case fatality rates, as table 13 shows, and their international responses have been either late (Ebola) or limited (MERS).

\footnotetext{
xviii Diseases with a $\mathrm{R}_{0}>1$ do not necessarily become pandemic. The reproductive ration indicates their capability to spread fast and cause pandemics. It is expected that, in the presence of a disease with pandemic potential, there would be a risk assessment of the global situation based on complementary data (epidemiological, biological, among others) (440).
} 


\begin{tabular}{|l|c|c|}
\hline \multicolumn{1}{|c|}{ Disease } & Case fatality rate & Reproductive ratio \\
\hline Ebola & $50-90 \%$ & $1.3-3.65$ \\
\hline SARS & $10 \%$ & $2-4$ \\
\hline MERS & $45 \%$ & $0.3-1.5$ \\
\hline H1N1 (2009) & $0.5 \%$ & $1.3-2.9$ \\
\hline Zika & $8.3 \%$ & $1-4.3$ \\
\hline
\end{tabular}

Table 13. Case fatality rate and the reproductive ratio of selected diseases. Multiple sources.

The nature of the disease is central to determine further action to control and manage an outbreak. However, this aspect by itself cannot influence cooperation as diseases with high fatality rates and reproductive ratios do not necessarily prompt more cooperation- as is evident by the West Africa Ebola Outbreak. The complexity of a disease outbreak response requires analyzing multiple factors that go beyond the disease itself.

The analysis of international cooperation also requires understanding the role of domestic politics $(236,237)$. Some scholars have tried to incorporate the different actors and dynamics that comprise the nation-state into the analysis of international cooperation. For instance, Putnam proposed the "two-level game" approach in which he studied the influence of national politics in negotiation processes (236), and how they affect the adoption and implementation of any international treaty. In global health, this has been a central issue for the functioning of the IHRs 2005. Domestic politics has caused delays in the implementation of the IHRs 2005. The agreement recognized gaps in capabilities among developed and developing countries. It also underscores the importance of building capacities for surveillance and notification, as well as to strengthen health systems for the response in developing countries. Financial and human resources in these countries, however, are indispensable to close the gaps, but the IHRs did not detail mechanisms to increase investment or funding. 
Many developing countries have not improved their health systems nor build capacities to improve the response to pandemics, and they are still highly dependent on international cooperation. Problems include the lack of political will, and commitment to global public health by national governments, barriers to sharing public health information among countries, and constraints imposed by donor agencies on funded projects (238). Lastly, developing countries may face other problems, such as war, famine, and ecological destruction (239). In the case of the Ebola outbreak of 2014, the outbreak originated in countries with weak health systems and a lack of capacity to respond (240). The international community did not mobilize immediately to help these countries, even though NGOs were requesting this assistance (241). Therefore, the assumption that those in need would be the recipients of international cooperation in a prompt manner does not necessarily happen in reality, given their lack of domestic capacity.

Others assume that the inclusion of some EIDS and REIDS in the agendas of trade and security can increase international cooperation. For instance, the field of Global Health Security centres around the principle that infectious diseases are a security imperative, conceptualizing diseases as transnational security threats ${ }^{\mathrm{xix}}(27,28,29,30,31,32,33,34,35,36)$. Under this notion, diseases are common threats to international and national security ${ }^{\mathrm{xxi}}$, affecting not only individuals but health systems, infrastructure, as well as the economy ${ }^{\mathrm{xxii}}$ through their impact on international trade, financial systems, travel, and commerce

\footnotetext{
xix The conceptualization of diseases as threats was reinforced by fears for future bioterrorist attacks $(33,28,36,35,27,34)$.

xxi Ulman 1983 defines it as: "A threat to national security is an action or sequence of events that 1) threatens drastically and over a relatively brief span of time to degrade the quality of life for the inhabitants of a state, or (2) threatens significantly to narrow the range of policy choices available to the government of a state or to private, non-governmental entities (persons, groups, corporations) within the state (710).

${ }^{\text {xxii }}$ As an example, the economic cost of the H1N1 outbreak in Mexico was estimated at $0.33 \%$ of the annual GDP (57)
} 
$(30,8,205,242,243,122,31,244)$. Some scholars argue that infectious diseases can undermine a state's capacity (239). Others focus on biological agents that cause diseases that are categorized as biological weapons, given their potential to create damage to a large population (28).

At the policy level, the term "Global Health Security" has been more frequently referenced since the WHO embraced it in 2007. More recently, in 2014, over 50 partners, including countries and international organizations, launched the Global Health Security Agenda, making a stronger commitment to address health threats $(245,246)$. Global health security emphasizes the importance of collaboration to manage health events such as global outbreaks of infectious diseases. It is difficult, however, to establish whether states are more likely to agree to international mobilizations and coordination because infectious diseases represent public health threats $(30,8)$, or if their cooperative behaviour is driven by a convergence of national and international interest to combat a disease outbreak (30). It is unclear how countries agree on which diseases represent a threat for international and national security, or if there is an accepted definition of health security $(247,32)$. Thus, the idea of naming diseases "threats" is controversial, and in some cases, national security prerogatives are still more important than international security.

In the case of commercial interests, disease outbreaks have affected trade for a long time (40), and countries have tried to reduce health measures that create trade disruptions (222). Hence, improving international cooperation is the best option for everyone. After all, reducing the impact of disease outbreaks in international trade is one of the main functions 
of global health governance for infectious diseases $(175)^{\mathrm{xxiii}}$. Nonetheless, restrictions on trade and travel are common policy responses during outbreaks. For instance, in the SARS outbreak, China denounced at the World Trade Organization the imposition of trade restrictions on Chinese agricultural products, even though there was no evidence of SARS transmission through food (248). Thus, even though there is an international interest in continuing normal trade relations, this interest frequently does not overcome the fear of the disease spreading to other populations through the importation of goods.

In addition to these factors, the WHO's capabilities influence international cooperation. Issues such as the availability of human and financial resources, leadership, and the WHO`s organizational structure, as well as its relations with its Member States, can affect the level of cooperation during the international response (224). National governments provide the money to establish the WHO's budget through assessed contributions, and additional donations from countries and other voluntary contributions (249). The funding of the agency, however, has been affected by budgetary cuts and financial pressures since the financial crisis of 2008 (250). Insufficient resources affect the WHO's investment in programs, the personnel necessary to implement them, as well as its international operations (249). Thus, not having enough human and financial resources can condition the WHO's effective response to disease outbreaks.

Other constraints are due to the WHO's structure. The WHO's headquarters (in Geneva) formulates policy, sets the budget, and defines policy direction. Six Regional

\footnotetext{
xxiii The IHRs in their Second Article state that their main purpose and scope is "to prevent, protect against, control and provide a public health response to the international spread of disease in ways that are commensurate [...] which avoid unnecessary interference with international traffic and trade (16)"
} 
Offices support program implementation, coordination and can also contribute to policy formulation. The State Members elect the WHO Director-General and Regional Directors, appointments that have become more political rather than based on public health imperatives (249). The organization also has some country representatives in developing countries. These country directors support the WHO's activities providing technical advice and acting as consultants in some cases. Regional offices appoint the people in these positions, who usually have little authority and scarce resources (249). This structure is "hierarchical at the top and resource-constrained at the bottom (249)", which can affect the WHO's operations. The leadership of the WHO in technical issues is usually affected by its interactions with its Member States, its dependence on assessed contributions, and political interference. These factors combine and create conditions that affect the international response.

\subsubsection{The international system for the management of disease outbreaks and its relevance to international cooperation}

The creation of institutions such as WHO and other international organizations, have increased the level of trust and interactions among countries, as well as the design of a payoff structure that has potentially benefited international cooperation. For instance, the WHO has created incentives for improving international cooperation during pandemic outbreaks by improving reciprocity and promoting the creation of mechanisms such as the IHRs 2005 and the Pandemic Influenza Preparedness Framework (PIP).

The system started with the establishment of the World Health Organization (WHO) in $1948^{\mathrm{xxiv}}$ and the first International Sanitary Regulations (ISR) of 1951. These institutions

\footnotetext{
xxiv The WHO Constitution was signed on June 1946. It entered into forced on April, 1948 (11).
} 
and norms have evolved ${ }^{\mathrm{xxv}}$, and in 1969, the WHO and its members renamed the ISR as the International Health Regulations (IHR), which were modified twice, first in 1973 and then in $1981(98,177)$. Despite the amendments to the norms, low levels of compliance and problems with disease notification were frequent, due to the fear of sanctions - such as quarantines, trade-related bans and restrictions in commercial relationships $(98,177)$. Additionally, the regulations addressed only a limited number of diseases, while emerging infectious diseases, such as SARS and H5N1, were creating new threats that these outdated regulations were unable to manage $(205,8)$.

\subsubsection{The SARS' outbreak and the reform of the IHRs}

The Severe Acute Respiratory Syndrome (SARS) epidemic in 2003 was the first EID of the XXI century. The SARS outbreak proved that the IHRs of 1969 were inadequate to manage and respond to pandemics $(251,252)$. The disease spread rapidly due to a combination of factors. The government of China did not recognize or address the outbreak when the virus emerged, leading to late notification. The delay limited the WHO's ability to issue warnings to the international community and postponed the participation of the Global Outbreak and Response Network (GOARN), the network of experts coordinated by the WHO to assess and respond to outbreaks $(253,254)$. The WHO only mobilized to assist China once the virus had already spread throughout several countries. Once China accepted experts from GOARN and the WHO, they were able to determine the virus' transmission mechanisms and

\footnotetext{
${ }^{x x v}$ In 1969 the ISR were renamed the International Health Regulations (IHRs) introducing broader requirements on all member states to manage and control of infectious diseases. This norm was primarily modified to monitor and control six serious infectious diseas es: cholera, plague, yellow fever, smallpox, relapsing fever and typhusInvalid source specified.. Under the 1969 IHRs, governments had to notify the WHO of any outbreak of these diseases within their territory Invalid source specified.. These regulations were two times modified: in 1973, to change provisions regarding cholera, as well as to exclude relapsing fever and typhus Invalid source specified.; and in 1981, to exclude smallpox from the list of notifiable diseases Invalid source specified.
} 
to establish medical measures (252). The late response, however, limited the assessment of cases and investigation of the event, resulting in 776 deaths and significant economic impact.

A man in Foshan City, Guangdong, was the first case, identified on November 16, 2002. The international transmission started in Guangdong when a doctor infected other guests from different places, including visitors from Canada and the USA $(255,256)$. Due to the severity of the symptoms, doctors called the head of the local WHO office, Dr. Carlo Urbani. After doctors were unable to determine the cause of the disease, Dr. Urbani informed WHO headquarters on March 6, 2003, about the severity of the situation $(256,255)$. The WHO issued a global alert on March 12, 2003, four months after the first case $(255,256)$.

Experts named the disease "SARS," a new type of coronavirus associated with upper respiratory illness $(257,252)$. Table 14 illustrates the main characteristics of the outbreak. Between November 2002 and July 2003, the virus spread to 26 countries with 8096 reported cases and a death toll of 774 people (122,252) (See Appendix B).

\begin{tabular}{|c|c|}
\hline & SARS 2003 \\
\hline Virus & Coronavirus \\
\hline Case Fatality Rate & $11 \%$ \\
\hline Reproductive ratio & $2-4$ \\
\hline Type of transmission & Human to human \\
\hline No. of cases & $8096^{\text {xxvi }}$ \\
\hline No. of affected countries & 26 \\
\hline Treatment & Unknown \\
\hline Vaccines & Ongoing research \\
\hline
\end{tabular}

Table 14. Main characteristics of the SARS outbreak. Various sources.

The outbreak severely impacted Canada, given the failure of China to share information on time and the overall uncertainty concerning the situation (258). The flow of information was slow, and for days, many health providers were not aware of the situation

${ }^{\text {xxvi }}$ Number of cases between November 2002 and July 2003 (122,252) 
beyond their hospitals. Health systems were unprepared, the virus was quickly spreading, and health care workers exposed to severely ill patients (255).

The WHO issued a series of travel alerts, affecting countries dealing with the outbreak $(255,259)$. Tourism and services sectors suffered damage in countries such as Canada, Singapore, Hong Kong, and China. The calculated global economic loss from SARS was around \$US 40 billion in $2003(259)^{\mathrm{xxvii}}$. Some scholars estimate that the outbreak cost Canada about 1.2 billion dollars (260).

After health experts identified the disease, containment of the outbreak was possible in less than four months (261). International collaboration was fundamental to stop the contagion $(261,251)$, as well as the participation of GOARN and its network of experts. Nonetheless, the international response to the outbreak was sub-optimal. Governments scrutinized global health governance, particularly the WHO, and the international norms surrounding infectious disease outbreaks. The WHO member states agreed to transform the system of governance for pandemic outbreaks, and, after a series of negotiations, they approved the updated International Health Regulations in 2005 (IHR 2005), which entered into force in June 2007.

\subsubsection{The updated IHR 2005 and the new governance for pandemics}

The IHR 2005 is legally binding under international law $(262,98)$, as the WHO Constitution of 1948 is an international treaty, and the IHRs are a mandate under this agreement $^{\mathrm{xx} x \mathrm{iii}}$. These norms are central to global efforts in disease surveillance,

xxvii W. J. McKibbin has presented estimations closer to \$US 80m billion (711).

xxviii The Articles 21 and 22 establish the authority of the World Health Assembly to adopt sanitary regulations as well as the obligation for member states to follow them. Article 21 establishes that "The Health Assembly shall have authority to adopt regulations concerning: a) sanitary and quarantine requirements and other procedures designed to prevent the international spread of disease; (...)". Article 22 also 
preparedness, and response to outbreaks $(8,263,98,177,264,265,266)$. A fundamental change in them was the addition of the "all-hazards" approach. Instead of having specific diseases listed in the regulations, now state parties must notify WHO of all infectious disease outbreaks and health events $(98,16)$. The response to a disease outbreak depends on the assessment of the epidemic. For this reason, the new IHRs incorporate a guide for notification, as well as an expert-led process to evaluate an epidemic. These mechanisms intend to improve the international management and control of disease outbreaks by providing better guidance for national governments and the WHO.

The regulations define two categories of notifiable events $(16,267)$. The first category considers critical diseases that can cause a "serious public health impact." These diseases are smallpox, poliomyelitis (due to wild-type poliovirus), human influenza (new subtypes), and severe acute respiratory syndrome (SARS). Member States are required to notify the WHO of an outbreak of these diseases in their territory, regardless of the number of people infected or the severity of the cases. These diseases represent a similar international health risk, most of them emerging or re-emerging infectious diseases (EIDs-REIDs), with pandemic potential $^{\mathrm{xxix}}(208,209,204,123)$.

The second category incorporates other diseases that might be subject to notification if they satisfy the criteria established in the decision instrument ${ }^{\mathrm{xxx}}$. The instrument is a guide

\footnotetext{
stipulates: "Regulations adopted pursuant to article 21 shall come into force for all members after due notice has been given of their adoption by the World Health Assembly (...)" (16).

xxix SARS and influenza viruses are zoonoses, which means they are transmitted from animals to humans.

$\mathrm{xxx}$ These criteria require governments to answer four general questions (16):

-Is the public health impact of the event serious?

-Is the event unusual or unexpected?

- Is there any significant risk of international spread?

- Is there any significant risk of international travel or trade restrictions?
} 
for the assessment of other events ${ }^{\mathrm{xxxi}}$ and includes outbreaks of diseases such as Ebola, Cholera, Plague, West Nile fever, among others. Countries must follow this instrument to assess whether they should notify an outbreak or not.

Once a State notifies the organization about a disease, the WHO and its member states should follow the guidelines established in the IHRs to be able to determine the severity of the outbreak. Under these regulations, severe outbreaks or the emergence of viruses with pandemic potential might constitute "a public health emergency of international concern" (PHEIC). The term PHEIC provides, for the first time, an attempt to categorize all those health events that might have an impact on global health, and that might require an immediate and coordinated international response. The decision to call an event PHEIC will be the responsibility of the WHO-DG, under the advice of an Emergency Committee.

The 2005 IHRs were intended to transform the system of global governance to manage pandemics. They created a structure to improve international coordination and collaboration during outbreaks as well as to reduce the negative consequences of diseases with pandemic potential (whether in the loss of human lives, the economy, health systems, society, etc.). Ten years after the regulations entered into force, however, these norms and institutions do not consistently lead to international cooperation.

The emergence of an infectious disease with pandemic potential requires not only clear regulations and institutions. It requires diplomats, politicians, bureaucrats, scientists and health experts around the world to work together through these governance mechanisms to confirm the outbreak, undertake surveillance, investigate cases, collect data, identify the

\footnotetext{
xxxi This category also includes chemical, biological, radiological events that might have a public health impact. However, they also have to go through an assessment under the referred criteria in order to determine their severity (16).
} 
population at risk through contact-tracing, identify pathogens, develop therapies and apply of control and prevention measures $(268,94,269,253)$. These actors became members of epistemic communities and increased their bureaucratic power due to their participation in the WHO and its expert groups. These communities influence and connect with the WHO facilitating the implementation of WHO policy goals and improving international cooperation.

\subsection{Epistemic communities in the international response to a disease outbreak}

International response to a disease outbreak requires the implementation of medical and non-medical measures to manage and control the epidemic. Health experts become essential in the application of these actions since all WHO state members have agreed on scientific advice ${ }^{\mathrm{xxxii}}$ to determine the implementation of measures (16)

The WHO requires scientific knowledge to create and support norms, using expert groups and funding research to generate it. Through these activities, the WHO establishes and coordinates coalitions of professionals in an issue-area, which become epistemic communities $(25,24)$.

\subsubsection{Epistemic communities and the International Health Regulations}

The IHRs 2005 established guidelines for the surveillance, report, notification, and management of outbreaks that can have a global impact. Even though the IHRs do not explicitly mention epistemic communities as key actors in the international system, they allocate a primary role to experts, scientific advice and evidence in all the tasks required for the implementation of the IHRs during the international response to an outbreak.

xxxii This specific reference is part of the International Health Regulations 2005, Part VIII General Provisions, Art. 43. Additional Health Measures. 
The regulations assign experts as advisors to the WHO DG to determine whether some outbreaks constitute a "Public Health Emergency of International Concern." The decision of declaring if an event fits into this category or not is the primary responsibility of the WHO DG. The IHR 2005, Article 12, establishes that the WHO DG, before any declaration, should consider the advice of an "Emergency Committee." An Emergency Committee (EC) is a group of experts that will assess the situation and provide recommendations to the WHO DG about those steps and measures that countries should follow and apply during an outbreak (16). The regulations state in Article 47 that the WHODG should establish a "Roster of Experts" in all relevant fields of expertise for the implementation of the IHRs 2005 (16). These experts will be called to participate in an EC when needed. Article 49 specifies that the WHO-DG should select from the roster of experts the people to incorporate an EC based on "their field of expertise and experience most relevant to the specific event that is occurring (16)". An EC may also include experts appointed by request of the most affected countries and for other international organizations. The EC will hold regular meetings for a continuing assessment of the situation during the outbreak until it decides to call off the emergency or the WHO DG considers the EC's advice is no longer necessary.

When the EC's members agree that the assessed outbreak meets the PHEICs conditions, the WHO DG will release a statement with recommendations and specific policies that affected and non-affected countries should implement. Therefore, the EC experts' participation becomes critical since their knowledge and recommendations will determine how coordinated international action can control the outbreak (16). All countries are expected to comply and implement these recommendations (16). Under the updated 
IHRs, the EC will consider formally calling for a coordinated international response only for those outbreaks defined as PHEICs. Nonetheless, if an outbreak is deemed not having the characteristics of a PHEIC, an international response is still possible. This response, however, it would likely include only affected countries, the WHO, and a smaller number of international partners (see MERS case).

Additionally, the IHRs 2005 in its Article 12 indicates that the WHO and its DG should consider scientific principles, available scientific evidence and information in the assessment of an outbreak, and all different components of the response (16). Therefore, groups of professionals with expertise in a specific issue-area, their knowledge, and information regarding the disease and the outbreak, are evidently at the centre of the response. These experts can also be incorporated into an epistemic community.

Some members of the epistemic community participate directly in the ground, overlapping their participation as experts and as frontline health workers through the Global Alert and Response Network (GOARN). The GOARN is an operational structure created in 2000 and coordinated by the WHO. It operates as a loose network that coordinates academics, universities, government scientists, non-governmental organizations, health associations, and health experts (270). GOARN members directly analyze events and deploy experts for the assessment, identification, and analysis of the outbreak (110). After an initial investigation, GOARN members provide advice on how to respond to the outbreak. The network coordinates more than 200 research institutions and specialist networks (see Appendix C). The GOARN Operational Support Team coordinates and supports the network's activities, and headquarters are in Geneva. The network also has a Steering Committee, which "is a representative body of 21 partner institutions that oversee the planning, implementation, and 
evaluation of the Network activities and strategic goals (271)". Not all the members of this network will participate in the response to all outbreaks; neither all of their members are part of a specific epistemic community. GOARN's member's participation, as well as the involvement of one particular epistemic community, will, therefore, depend on the type of outbreak.

\subsubsection{Epistemic communities' capabilities to influence international cooperation in the response to infectious diseases.}

An epistemic community's capacity and ability to influence cooperation during its participation in the international response to an individual disease outbreak will depend upon the epistemic community's characteristics. This research will assess the characteristics of an epistemic community, using the proposed indicators and adapting them to the requirements for an international response to disease outbreaks. The study first identifies if there was an epistemic community during the outbreak. For all these cases, the WHO established an Emergency Committee, and it deployed members of the GOARN. Therefore, these are the starting points for the identification of such an epistemic community.

In some cases, however, there are epistemic communities' networks established before the outbreak. This characteristic may increase the epistemic community to influence the international response. The interviewees agreed with the importance of history and past relationships, mostly because these factors help to build trust among members of the epistemic communities, which is fundamental for communication during the response (Interviews 5, 12). Table 15 presents the characteristics and the relevant indicators for the analysis of the epistemic community and in the international response to infectious diseases. 


\begin{tabular}{|c|c|c|}
\hline Characteristic & Indicator & Description \\
\hline \multirow[t]{2}{*}{ 1. Knowledge } & $\begin{array}{l}\text { Agreement on } \\
\text { a common } \\
\text { definition of } \\
\text { the problem } \\
\text { and possible } \\
\text { solutions }\end{array}$ & $\begin{array}{l}\text { Agreement on a problem and solutions also improves the } \\
\text { cohesiveness of the epistemic community and its position in the } \\
\text { policymaking process (Interview 12). } \\
\text { In this research, given that all the cases studied have been assessed } \\
\text { by the emergency committee established by the WHO, consensual } \\
\text { knowledge is measured on the definition of the problem: whether } \\
\text { the disease was considered a PHEIC or not and under which } \\
\text { circumstances. }\end{array}$ \\
\hline & $\begin{array}{c}\text { Clear } \\
\text { identification } \\
\text { of a common } \\
\text { policy goal }\end{array}$ & $\begin{array}{l}\text { It should be determined whether the network has worked together } \\
\text { previously and has a clearly stated this goal or if this was } \\
\text { something that developed during the outbreak. It is also possible } \\
\text { that the network did not formulate a policy goal. However, having } \\
\text { in advance something established helps to deal better with the } \\
\text { situation during an emergency (Interview 12). }\end{array}$ \\
\hline \multirow[b]{2}{*}{$\begin{array}{l}\text { 2.Socialization } \\
\text { of ideas }\end{array}$} & Structure & $\begin{array}{l}\text { There should be an identifiable network, with one central group } \\
\text { or many that are connected through the same goal and shared } \\
\text { knowledge. There should be evidence of interactions during the } \\
\text { outbreak; these interactions could be through meetings, } \\
\text { conferences, the internet, that are necessary to build the network } \\
\text { (Interview 10, 6). The size of the network refers to how broad is } \\
\text { its representations (international and at different levels), to } \\
\text { understand the scope of its influence and diffusion of its ideas } \\
\text { (Nodes). The denser a network, the better the cooperation and } \\
\text { communication }(272) \text {. }\end{array}$ \\
\hline & $\begin{array}{l}\text { Dissemination } \\
\text { mechanisms }\end{array}$ & $\begin{array}{l}\text { Global health policy usually requires these networks of experts to } \\
\text { participate in the definition of norms and regulations (Interview } \\
5,10 \text { ). Although governments and decision-makers are supposed } \\
\text { to adopt measures based on scientific evidence and followed the } \\
\text { advice of experts, this does not always occur ( ( } 98,273) \text {. The } \\
\text { network should have the ability to understand the policy } \\
\text { environment to make policymakers adopt their proposed } \\
\text { measures in working documents (guidelines, action plans) and } \\
\text { international organizations' decisions (resolutions). During the } \\
\text { outbreak, members of the epistemic community publish in the } \\
\text { most prestigious academic journals (and influential) such as the } \\
\text { Lancet, BMJ, Nature, Science, among others. Dissemination } \\
\text { implies that their knowledge is available, and it can be used during } \\
\text { the event. If the dissemination makes their knowledge available } \\
\text { to the right audiences, It will likely be used to address the } \\
\text { situation. It is also possible that experts withhold information } \\
\text { affecting the epistemic community effectiveness (Interview 5). }\end{array}$ \\
\hline
\end{tabular}

Table 15. Epistemic communities' characteristics and indicators for the analysis of their participation in the international response. 


\begin{tabular}{|c|c|c|}
\hline Characteristic & Indicator & Description \\
\hline $\begin{array}{l}\text { 2.Socialization of } \\
\text { ideas }\end{array}$ & $\begin{array}{l}\text { Participation in } \\
\text { the international } \\
\text { response }\end{array}$ & $\begin{array}{l}\text { In this topic, the active and direct participation in the } \\
\text { field, participating in the investigation and analysis of the } \\
\text { event. The epistemic community's participation directly } \\
\text { in the response facilitates communication with other } \\
\text { actors (Interview 5,12), to get information and to transmit } \\
\text { the epistemic community's knowledge. }\end{array}$ \\
\hline \multirow[b]{2}{*}{$\begin{array}{c}\text { 3.Institutionalization } \\
\text { of bureaucratic } \\
\text { power }\end{array}$} & $\begin{array}{l}\text { Participation in } \\
\text { the policy } \\
\text { process. }\end{array}$ & $\begin{array}{l}\text { To be able to influence the policy process and the actions } \\
\text { during the response, members of the epistemic } \\
\text { community should participate in the international } \\
\text { decision-making process. They should be part of key } \\
\text { bodies such as the Emergency Committee, Experts } \\
\text { Groups, Advisory Groups, and participate in international } \\
\text { meetings organized to discuss the outbreak where they } \\
\text { can exchange information with decision-makers and } \\
\text { other experts. These participations are relevant for } \\
\text { influencing the policy process and building collaboration } \\
\text { since people "learn to work with each other" (Interview } \\
\text { 12). }\end{array}$ \\
\hline & $\begin{array}{l}\text { Experts and other } \\
\text { professionals } \\
\text { from the } \\
\text { epistemic } \\
\text { community in } \\
\text { decision-making } \\
\text { positions }\end{array}$ & $\begin{array}{l}\text { The presence of members of the epistemic community in } \\
\text { crucial decision- making positions intervening in the } \\
\text { international response will increase the epistemic } \\
\text { community's ability to influence the process. } \\
\text { Professionals that are part of international networks are } \\
\text { more influential than those that are just at the national } \\
\text { level because they understand better another context and } \\
\text { the international dimension of them (interview 12). This } \\
\text { includes policy entrepreneurs, champions, and other } \\
\text { important actors endorsing proposals by the epistemic } \\
\text { community and/or sponsoring them (Interview } 6,10,11 \text { ). } \\
\text { Members of the epistemic community should be } \\
\text { identified as participants in expert groups created to } \\
\text { discuss policy options and discuss the event. They can } \\
\text { also be part of national delegations participating in } \\
\text { international conferences. Participation in these bodies } \\
\text { may have occurred before the outbreak (Interview 10, } \\
\text { 12). }\end{array}$ \\
\hline
\end{tabular}

Table 15. Characteristics epistemic communities (cont.).

Based on the Pareto frontier model, I argue that when a robust epistemic community participates in the international response and influence this process, they would move the outcome -international cooperation- closer to the Pareto Frontier. 


\section{Chapter 5: The A(H1N1) Influenza outbreak 2009}

\subsection{Introduction}

Influenza pandemics have a high political profile. The certainty that a new and deadly outbreak will occur has created a context in which policymakers try to predict possible scenarios to manage it and control it. Despite the knowledge that experts have accumulated about the disease, a new influenza virus can emerge and create a situation with high levels of uncertainty (274). Governments and international organizations would likely deal with circumstances in which information to understand the behaviour of the new strain, as well as data to formulate the appropriate policy choices for containing the outbreak, would be scarce (see Box 1 Influenza pandemic).

\section{Nature of the disease}

\section{Box 1. Influenza Pandemic}

The global fear of a new outbreak of pandemic influenza, as well as the design of policies for preparedness and response to it, are based on scientific evidence and historical experience. Scientifically defined as a respiratory infection, influenza is "characterized by the rapid onset of symptoms (117)". In 1957, scientists for the first-time categorized influenza viruses, dividing them into three types: $\mathrm{A}, \mathrm{B}$, and $\mathrm{C}$.

The type A virus can infect humans and animal species, which implies a higher number of "pathogen reservoirs (117)". Researchers determined that influenza sub-type A appeared due to two surface glycoprotein receptors - the sixteen haemagglutinin (HA 1-16) from a pool of influenza virus found in birds and three haemagglutinin (HI to H3) found in human virus - and nine neuraminidases (NA 1-9) (275). The A-type is a highly unstable virus that can mutate in minor ways (known as an antigenic drift), which means that the HA gene mutates. Type A viruses can also mutate in major ways (known as an antigenic shift), which refers to the process of avian gene segments from the circulating avian virus combining with the human-adapted virus to create an avian/human combination. These processes are "genetic reassortments which occur when human influenza and animal influenza viruses co-infect a human or an animal (such as pigs) (276,117)". Genetic re-assortment has provoked the most notable pandemics of the 20 th century.

\section{Global Threat}

According to the US Department of Health and Human Security, when a new influenza A virus emerges, a flu pandemic can quickly occur because the population has little to no immunity against it, and it spreads quickly from person to person worldwide (277). 


\section{Box 1. Influenza Pandemic (cont.)}

Studies have found that the A-type of influenza viruses, and their antigenic shifts, have been the cause of influenza pandemics registered over centuries (275), from the 1889 pandemic (caused by the H2 subtype) to the 1898 outbreak (caused by an H3) during the nineteenth century. While deadly, those outbreaks were minor in comparison to the worst pandemic ever recorded, the highly virulent 1918 "Spanish Flu" caused by an H1N1 virus, which the WHO estimates killed 40 to 50 million people worldwide $(175,278)$. After that, the world experienced an $\mathrm{H} 2 \mathrm{~N} 2$ pandemic virus in 1957-1958, an H3N2 virus pandemic in 1968-1969, and an H1N1 outbreak in 1977 (279).

Type $A(H 1 N 1)$ virus of 2009 resulted from several viruses circulating among pigs (the H3N2 virus from North America), the classical swine H1N1, and the Eurasian avianlike swine H1N1 virus (280).

Influenza viruses circulating in animals represent a threat to human health because humans can become ill when infected with viruses from animal sources (also known as the human-animal interface). The primary risk factor for human infection is direct or indirect exposure to infected live or dead animals or contaminated environments. The significant threat to human health from such avian-influence strains, therefore, lies in the potential of the virus to mutate into a form capable of sustained person to person transmission. In the case of the currently active $\mathrm{H} 5 \mathrm{~N} 1$, the virus managed to infect humans, improving its potential for mutation opportunities (278). Nevertheless, the spread of $\mathrm{H} 5 \mathrm{~N} 1$ has not yet reached pandemic proportions as the virus has not been efficient enough to become "a virulent pathogen capable of sustained human-to-human transmission (117)".

The medical community has tried to predict the likelihood of a new pandemic outbreak for decades, given all these circumstances. However, there is still no certainty of when a new pandemic will occur $(281,282,283,284,285,286,287)$

In this context, international cooperation is fundamental to prevent, control, contain, and manage an influenza outbreak with pandemic potential. Therefore, it is not surprising that in 2009 , the international community mobilized and collaborate in almost all the areas to manage the outbreak of the $\mathrm{A}(\mathrm{H} 1 \mathrm{~N} 1)$ influenza virus and reduce as much as possible the number of people affected by the disease.

Different factors could have influenced this level of cooperation, from the type of disease, the newly approve IHR 2005, the WHO, international trade, and national security interests, to the location where the outbreak started. The fact that it was an influenza outbreak may have been central to determine further actions to control and manage the epidemic. 
Influenza viruses are well known for their pandemic potential. The disease is endemic in multiple species; they spread fast and easily from animals to humans and humans to humans (288). There are numerous mechanisms to manage influenza outbreaks that have been in place since the 1950s. Years before the 2009 outbreak, the international community had expected an outbreak of the highly pathogenic H5N1 avian influenza, which influenced more worldwide preparation and improvement of the mechanisms to respond to an influenza pandemic (250).

The location where the outbreak originated also contributed to a rapid response given the importance of North America and the established national and regional capacities for responding. Everybody was expecting the outbreak to start in Asia due to the presence of the H5N1. Instead, the outbreak began in Mexico and the USA (289). These countries notified the outbreak on time, showing the importance of transparency, rapid information sharing, and collaboration (290).

Influenza pandemic is also one of the main drivers of the health security agenda. The disease is considered as a security threat $(278,141,291)$. This categorization helped to increase its political profile and allowed the involvement of other actors in the creation of global strategies to prevent and respond to outbreaks $(292,293)$. As well, influenza and other infectious diseases are subject of interest for the international trade agenda, and countries have tried to create better ways to deal with them without disturbing international trade (175). The interest in influenza pandemics due to trade and security, however, had more of a negative effect on the 2009 influenza outbreak. Countries acted following their national interest, establishing quarantines, limiting the transit of travelers, and affecting their human rights (289). 
Finally, the outbreak of 2009 was the first to be assessed under the IHRs 2005. The USA and Mexico followed the regulations, notifying the WHO, and the organization immediately called an Emergency Committee to evaluate the situation (294). The WHO acted upon the rules, plans, and methodologies established and approved by its member states. The response, however, ended up being criticized by countries who claimed the WHO overreacted, judging the severity of the virus higher than it was (289).

The combination of these factors shaped the level of cooperation during the international response. The political relevance of pandemic influenza, however, requires defining plans and policies supported by scientific evidence to outline interventions that will effectively reduce the damage $(134,141,94)$. Across all these factors, there was a constant demand for knowledge and expertise for the management of the disease and the creation of global policies. The WHO consistently recognized the importance of having technical and scientific knowledge up-to-date to guide the response (250).

The influenza epistemic community provided this knowledge and expertise needed to respond effectively to the potential threat posed by the novel virus. This group of experts had an authoritative claim on knowledge about the disease and its pandemic potential. Members of the community also occupied decision-making positions, and the community had built a network of highly connected. Therefore, analyzing the participation of the influenza epistemic community and its role in the international response to the outbreak will provide more information about how they influenced cooperation. Figure 11 summarizes the influenza epistemic community's characteristics and its influence in the international response. 


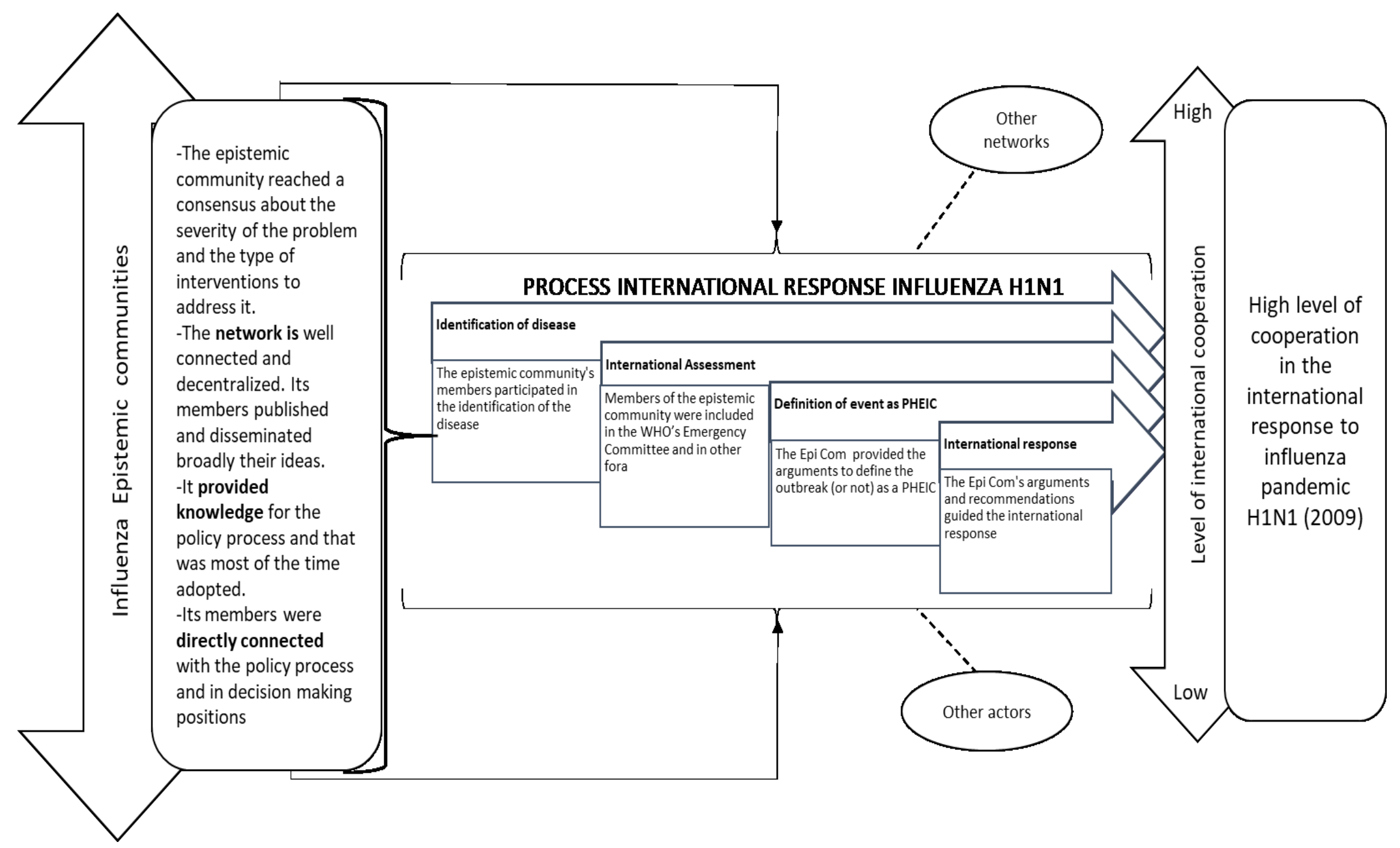

Figure 11. Relationship between a strong epistemic community and the level of cooperation in the influenza pandemic outbreak. 
This chapter presents an analysis of the influenza epistemic community and its participation in the international response to the $\mathrm{A}(\mathrm{H} 1 \mathrm{~N} 1)$ influenza pandemic. The document first explains the events in 2009 briefly, then it identifies and presents the characteristics of the influenza epistemic community, and it finally analysis the international response to the pandemic and the participation of the epistemic community.

\subsection{Influenza pandemic cooperation and the evolution of an epistemic community}

Given the burden that an influenza pandemic represents for governments and the certainty that a new pandemic could occur any time, the international community created mechanisms to deal with its potential effects in the 19th century, although the system was consolidated in the 20th century. The Office International d'Hygiene Publique (OIHP), established in 1907, was the first international institution to publish recommendations to manage a pandemic (295). Later in the 1940s, the World Health Organization, after replacing the OIHP, included influenza as a core issue in its directives. The WHO organized groups of experts to produce information and analyses that the WHO would adapt to its policy-making process. The experts' groups would also create documents that would become the basis for international guidelines and programs ${ }^{\mathrm{xxxiv}}$. The organization established the first specialized committees related to the influenza pandemic in the late $1940 \mathrm{~s}$ and early $1950 \mathrm{~s}^{\mathrm{xxxv}}$. These were the Expert Committee on International Epidemic Control and the Expert Committee on International Epidemiology and Quarantine (WHO Files) $)^{\text {xxxvi }}$. In 1950, the $3^{\text {rd }}$ World Health

\footnotetext{
xxxiv The WHO Constitution Art.2 establishes as part of the organization's functions "d) to furnish appropriate technical assistance and, in emergencies, necessary aid upon the request or acceptance of Governments" as well as " $\mathrm{j}$ ) to promote co-operation among scientific and professional groups which contribute to the advancement of health (109)".

xxxv The researcher had direct access to the WHO Catalogue of the Material, First generation and second generation of files, during her field work in headquarters of the WHO in Geneva, Switzerland from May 22nd to the $25^{\text {th }}$ in 2017

xxxvi This information is found in headquarters of the WHO in Geneva, Switzerland (Field research from May 22nd to the 25 th in 2017).
} 
Assembly (WHA) requested an Expert Committee on Influenza to draft guidelines for the WHO (94). The panel was created in 1952 to review the WHO Influenza Programme and to make "suggestions for more effective international collaboration (296)".

At the same time, active scientific research on influenza viruses started. In 1931 Dr. Richard Shope and Dr. Paul Lewis isolated and identified the porcine influenza virus, and, in 1933, Dr. Wilson Smith, Dr. Christopher Andrewes, and Dr. Patrick Laidlaw isolated and identified the human virus, named influenza A (141). Their contributions made it possible to develop the first vaccine in 1940 (141).

While scientific research was underway, the WHO was building a system of influenza governance based on scientific evidence and expertise. In the 1940s, it established the Regional Influenza Centres and a network of WHO Influenza Centres. In 1947, the World Influenza Centre (WIC) was based in London as a research centre on influenza $(141,134,94)$, and as the main body responsible for concentrating and distributing all the epidemiological information collected from the influenza centres (296). The WIC worked as part of the WHO Influenza Programme, helping to set-up a plan against the recurrence of future pandemics, developing control methods to limit the impact during an epidemic and to reduce as much as possible the economic impacts of the disease as well as of future pandemics (296). The creation of the program increased the number of experts at the WHO (296). The international network of laboratories and scientists directly collaborated with the WHO, sharing information on the latest influenza-related scientific discoveries. The network became the foundation of international efforts to control and mitigate the health impacts of influenza (141). The Global Influenza Surveillance Network (GISN) was central for the system of influenza governance at the WHO, and it evolved into the current Global Influenza 
Surveillance and Response System (GISRS).

The GISN formerly comprised 40 laboratories $(297,298)$ including laboratories designated as "WHO influenza centres" with experts in 42 countries (now National Influenza Centres or NICs). Dr. Andrewes, from the WIC, was appointed as the head of the first international influenza centre $(296,94)$. This network was the beginning of an influenza epistemic community, given that it connected for the first time to the most prominent experts worldwide. The experts worked together in influenza research, making it possible to incorporate their knowledge into the international policy-making process (see Appendix D). By 1954, the number of centres increased to over 50 in 42 countries, and in 1977 the GISN reached 98 NICs in 70 countries (297,299). In 2011, 135 institutions in 105 countries composed the GISN. After the approval of the Pandemic Influenza Preparedness (PIP) Framework in May 2011, the network changed its name to Global Influenza Surveillance and Response System (GISRS) and currently comprises 148 National Influenza Centres, 6 WHO Collaborating Centres for Influenza, 4 WHO Essential Regulatory Laboratories and 13 WHO H5 Reference Laboratories (300). The GISRS is the most important network for influenza surveillance, connecting a broad group of experts (295). Figure 12 presents a map of the geographical distribution of GISRS. 


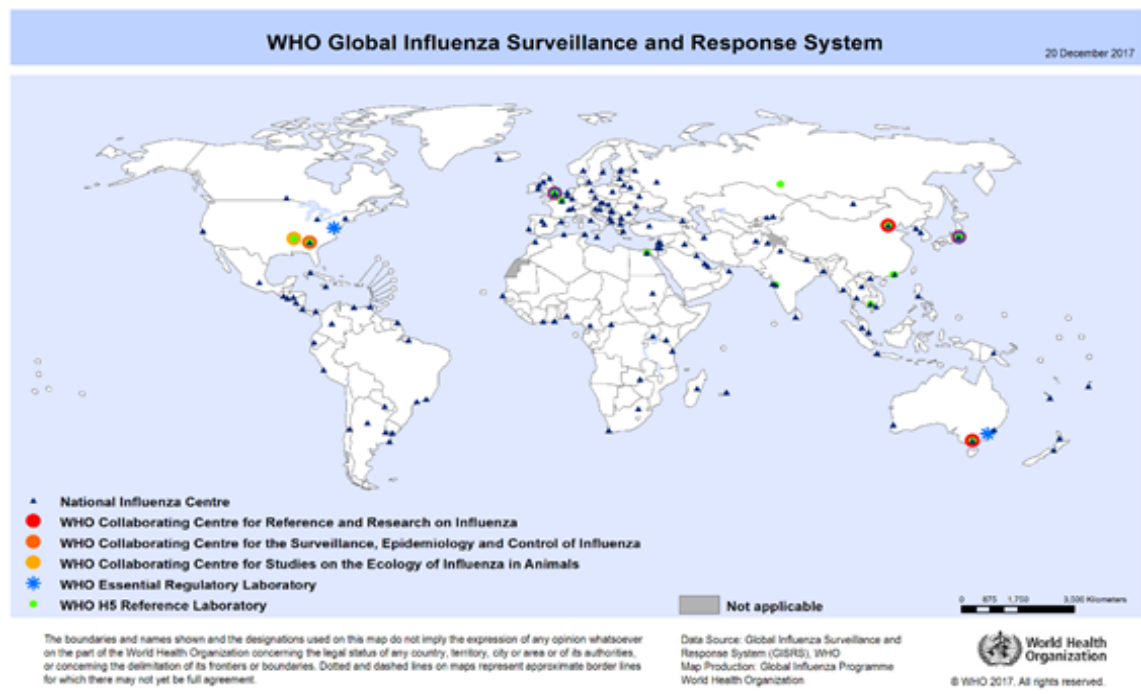

Figure 12. WHO Global Influenza Surveillance and Response System. Source: WHO (301)

The WHO's Expert Committee on Influenza and the Influenza Programme allowed public health professionals to become key advisors at the national and international levels. These experts have continuously collaborated in establishing and delineating global health policies in influenza prevention and control.

Therefore, it is possible to identify an epistemic community since the creation of the Expert Committee on Influenza in the 1950s and the GISRS. Members interact through different channels, mainly the WHO meetings (302). These experts are also part of smaller and regional networks, attending and contributing to academic conferences, and other expert meetings. They are part of national delegations participating in international summits and negotiations such as the World Health Assembly and the annual Consultation on the Composition of the Influenza Vaccine Table 16 presents some of the most recent meetings where members of GSIRS and the epistemic community have participated. 


\begin{tabular}{|c|c|}
\hline Meeting & Date/Place \\
\hline $\begin{array}{l}\text { GISRS } 65 \text { years. The anniversary meeting had as a goal to develop an } \\
\text { updated framework and global strategy on influenza. }\end{array}$ & $\begin{array}{l}\text { July } 2017 \\
\text { Geneva, Switzerland }\end{array}$ \\
\hline $\begin{array}{l}\text { Sustainable local production of influenza vaccines for pandemic } \\
\text { preparedness: synergies with other international efforts and improvement } \\
\text { of the current tool. }\end{array}$ & 14-15 June 2017 \\
\hline $\begin{array}{l}\text { WHO Expert Working Group Meeting on RSV Surveillance based on the } \\
\text { GISRS Platform. }\end{array}$ & 2-3 February 2016 \\
\hline Meetings of the PIP Advisory Group Meeting. & Since 2014 \\
\hline $\begin{array}{l}\text { Negotiations of the Pandemic Influenza Preparedness Framework for the } \\
\text { Sharing of Influenza Viruses and Access to Vaccines and Other Benefits } \\
\text { (PIP Framework). }\end{array}$ & $\begin{array}{l}\text { Between } 2007 \text { and } \\
2011\end{array}$ \\
\hline $\begin{array}{l}\text { Pandemic Preparedness and Response Guidance Revision Working Group } \\
\text { (as part of the Global Influenza Programme). }\end{array}$ & $\begin{array}{l}2007 \\
\text { Geneva, Switzerland }\end{array}$ \\
\hline $\begin{array}{l}\text { Pandemic Influenza Preparedness Planning WHO/European Commission } \\
\text { Workshop. }\end{array}$ & 24-26 October 2005 \\
\hline
\end{tabular}

Table 16. Recent meetings GISRS.

The epistemic community institutionalizes its experts' advice, gaining access to privileged information, and increasing its direct influence on the international policy process. For this community, constant interaction and continuous work on the topic have helped to build professional and personal relationships, which are very important for the epistemic community's collaboration (Interviews 1,2,3,5,12). These experts are also part of the academic and scientific community, and as such, they publish in the most influential journals of science and public health, and the community actively engages in discussions about the topic within the academy and policymaking.

\subsubsection{The fear of a new pandemic: H5N1}

The outbreak of the H5N1 virus in Asia strengthened the role of the epistemic community in pandemic influenza ${ }^{\mathrm{xxxvii}}$. The H5N1 avian influenza virus appeared for the first time in mainland China in 1996, infecting domestic poultry. By 1997, the disease spread out

\footnotetext{
xxxvii That same year another virus H7N7 was also detected in Netherlands, causing alarm due to its potential for human to human transmission (322).
} 
to Hong Kong to farm chickens. It was the first time the virus transferred from animal to human, infecting 18 people and killing 6 of them $(303,278)$. The outbreak alarmed the health community due to the assumption that a new pandemic would occur by the end of the 20th century. The outbreak renewed the interest in the WHO's Influenza Programme $(141,297)$, given the high fatality rate of H5N1 (around 33 percent) (117). One of the most prominent actors during this pandemic was Margaret Chan, who was serving as the Director of the Hong Kong Department of Health, and who later would become the WHO's Director-General. After this event, the virus went undetected for a few years, re-emerging in 2003 during the SARS outbreak.

Since 2003 the H5N1 strain has been spreading through wild, migratory birds and domestic poultry populations into Europe, India, Middle East, and Africa $(303,304)$. So far, it has shown a limited ability for human transmission, but reporting of cases has continued for over a decade. Between 2003 and February 2019, there were 860 confirmed cases and 454 deaths, across 16 countries $(305,306)$. Some of the events have been isolated incidents. However, countries such as Egypt, Indonesia, and Vietnam went through a state of emergency due to their limited ability to contain the outbreak in their territory. Table 17 summarizes the number of cases and deaths per country. 


\begin{tabular}{|l|c|c|}
\hline Country & No. of cases & No. of deaths \\
\hline Azerbaijan & 8 & 5 \\
\hline Bangladesh & 8 & 1 \\
\hline Cambodia & 56 & 37 \\
\hline Canada & 1 & 1 \\
\hline China & 53 & 31 \\
\hline Djibouti & 1 & 0 \\
\hline Egypt & 359 & 120 \\
\hline Indonesia & 200 & 168 \\
\hline Iraq & 3 & 2 \\
\hline Lao People's Democratic Republic & 2 & 2 \\
\hline Myanmar & 1 & 0 \\
\hline Nigeria & 1 & 1 \\
\hline Pakistan & 3 & 1 \\
\hline Thailand & 25 & 17 \\
\hline Turkey & 12 & 4 \\
\hline Viet Nam & 127 & 64 \\
\hline Total & 860 & 454 \\
\hline
\end{tabular}

Table 17. Influenza H5N1 cases in humans.

Source: WHO/GIP, data in HQ as of 12 February 2019 (World Health Organization, the cumulative number of confirmed human cases for avian influenza $A(H 5 N 1))(305,306)$.

The spread of H5N1 continues without reaching pandemic proportions yet since the virus is still incapable of sustained human-to-human transmission $(206,117,276)$. The fear of a pandemic remains due to estimations and concerns that it might cause a global death toll in the range of 2-million to 50-million people (307). Table 18 presents the main characteristics of the disease outbreak.

\begin{tabular}{|c|c|}
\hline Disease & Avian Influenza \\
\hline Virus & H5N1 \\
\hline Case fatality rate & Between $30-80 \%(308)$ \\
\hline Transmission & $\begin{array}{c}\text { Airborne (transmitted throughout air) } \\
\text { Animal to human mostly } \\
\text { Human to human is still inefficient }\end{array}$ \\
\hline Number of cases & 860 \\
\hline Outbreak duration & Since 1996 \\
\hline $\begin{array}{c}\text { No. of countries } \\
\text { infected }\end{array}$ & 16 countries \\
\hline Treatment & Experimental \\
\hline Status of vaccines & Ongoing research \\
\hline
\end{tabular}

Table 18. Main characteristics H5N1 outbreak.

Even though influenza H5N1 was not a pandemic yet, there was an international response after Hong Kong notified WHO of the outbreak in 2003 (309). Many countries have 
enforced new systems of surveillance, complying with WHO guidelines ${ }^{\text {xxxviii }}$ (175). In 2005, the WHO published the first document assessing the outbreak (310), giving steps towards more coordinated actions to fight the disease. The fear that this outbreak could escalate into a global pandemic also strengthened the influenza epistemic community. In 2004, the WHO created the WHO H5 Reference Laboratory Network as part of the GISRS, to increase surveillance of avian influenza (311). The network currently has 13 laboratories around the world.

The fear of a global spread of the disease when the disease re-emerged in 2003 increased because the outbreak fulfilled two out of three conditions for the occurrence of a pandemic $(312,313)^{\mathrm{xxxix}}$. This possibility motivated the creation of additional international, regional, and domestic mechanisms to manage the disease. Experts in epidemiology, emergency management, infectious diseases, surveillance, and laboratory specialists all became essential for policymaking. The relevance of the topic facilitated to incorporate more epistemic community members into relevant positions. For instance, in September 2005, the United Nations Secretary-General appointed the first UN System Influenza Coordinator "to support national, regional, and global efforts to address the threats posed by animal and pandemic influenza (314)". David Nabarro, the selected expert for this position, has been one of the most influential advocates for international collaboration to control this disease. He

xxxviii The WHO released its first official pandemic influenza preparedness guidelines in 1999 (141). It provided a planning tool for countries to adpat and to be ready for future influenza pandemics (175). The guidelines emphasized the importance of creating national preparedness plans (322). The WHO modified the guidelines in 2005 and 2009, but, since the first version, the organization envisioned to create a global system ready to work in case of an outbreak. xxix These conditions are:

(i) The emergence of a novel virus

(ii) the new virus can replicate and cause diseases in humans,

(iii) the new virus is transmitted efficiently from human-to-human (313). 
acted as a policy entrepreneur, promoting cooperation and calling for more investments in the area. As such, he was a key promoter of the international pledging conferences.

Other international organizations also incorporated programs and surveillance areas to prevent and manage future pandemic influenza, such as the Food and Agriculture Organization (FAO), the World Bank, the International Monetary Fund (IMF), the World Organization for Animal Health (OIE) (117,297). Along with this, other regional and subregional networks were created, including pandemic influenza as an essential topic in their agendas. Some of these are:

- The Global Health Security Initiative (GHSI) constituted in 2001 by the G-7 (Canada, Germany, France, Italy, Japan, the United States, and the United Kingdom) plus Mexico, the European Commission and WHO as an observer.

- The International Partnership on Avian and Pandemic Influenza (IPAPI), announced by the US President George W. Bush at the United Nations General Assembly on September 14, 2005.

- The North American Plan for Avian and Pandemic Influenza (NAPAPI) created in 2007 by the USA, Canada, and Mexico as part of the former Security and Prosperity Partnership (SPP).

- The APEC Health Working Group (HWG).

- The ASEAN Foundation Communication and Information Systems for the Control of Avian Influenza (CISCAI).

These networks incorporate professionals and experts in the different areas related to the containment, control, and management of influenza, institutionalizing their expert advice. Furthermore, these mechanisms have strengthened the epistemic community by providing a place for more interactions and exchange of information (Interviews 1, 2, and 3).

The fear of an $\mathrm{H} 5 \mathrm{~N} 1$ outbreak also increased the organization of international meetings outside the WHO, including multiple high-level meetings and expert forums related to avian influenza (Appendix E. Pledging Conferences on Avian and Human Influenza). The meetings were used by the epistemic community to mobilize financial and institutional 
resources to combat and control the spread of the disease to humans, as well as to promote more research and development ${ }^{\mathrm{x}}$. These meetings increased collaboration with policymakers to establish measures of control and management.

The outbreak of H5N1 allowed other epistemic communities to get involved, given that influenza pandemic has been considered an issue of national security, and the animalhuman interface (animal to human transmission) has become more relevant to control and prevent zoonotic diseases in human populations. As an example, in July 2006 the WHO, the World Organization for Animal Health (OIE) and the Food and Agriculture Organization of the United Nations (FAO) launched the Global Early Warning System for Major Animal Diseases, including Zoonoses (GLEWS). The partnership created a network of experts on Animal Influenza from OIE and FAO working with WHO (175). Other fields have also included influenza in their agendas (303).

\subsection{Influenza Outbreak H1N1-2009}

In 2009, the WHO enforced for the first time the updated International Health Regulations (IHRs 2005) to respond to the outbreak of influenza A(H1N1). On April 12 (in compliance with these regulations), the Mexican government reported to the WHO Regional Office of the Americas [the Pan-American Health Organization (PAHO)] an increasing occurrence of cases showing a severe respiratory disease $(274,315)$. Around the same time, the Centers for Disease Control and Prevention (CDC) in the United States announced that the US flu season exhibited some unique characteristics (316). Figure 13 shows the most important events during the first weeks of the outbreak.

\footnotetext{
${ }^{\mathrm{xl}}$ According to the US Department of State as of December 2007, international pledges of avian and pandemic influenza assistance totaled US \$2.7 billion.
} 
Seven countries report cases of H1N1:

Mexico, USA, Canada, New Zealand, United

Kingdom, Israel and Spain

$4 / 28 / 0$

WHO raises the pandemic phase to 5 due

$\checkmark$ to an imminent pandemic

4/29/09

Cases of influenza like-illness detected in La Gloria, Mexico $4 / 10 / 09$

WHO stops using the term "swine flu" and starts

$\triangle$ referring to the illness as influenza A (H1N1)

$4 / 30 / 09$

USA detects first case

$\nabla_{5 / 1 / 09}^{11}$ countries have reported cases to WHO

May

WHO declares a Phase 4 epidemic with

confirmed cases of human-to human

transmission

4/25/09

Emergency Committee Meeting, DG

Margaret Chan declares a PHEIC

4/24/09

PAHO deploys GOARN in Mexico

4/23/09

$\nabla_{\text {Laboratory Microbiology in Winnipeg confirms H1N1 }}$

"swine flu" in samples sent bv Mexico to Canada

4/20/09

Teleconference PAHO-Mexico-USA about cases

Figure 13. Timeline of events firsts weeks H1N1 outbreak. Sources: CDC Europe; Nature 2009; WHO 2011. 
Early in 2009, the Mexican National System of Epidemiological Surveillance detected an abnormal influenza season and cases of severe pneumonia in some communities. Reports of an increasing number of young people with influenza-like symptoms admitted to hospitals led to discovering an influenza A type virus $(317,318,315)$. The events activated the National Plan for Preparedness and Response during Influenza Pandemics, sending a national alert that increased epidemiological surveillance by requesting to all contact points to report any influenza-like case (317). The alert established a mandatory collection of samples and information at the local level. Data was necessary to understand the circumstances of the epidemic at the national level and to provide public health authorities with scientific evidence to asses the situation and establish measures to manage the outbreak $(317,319)$.

The new influenza strain spread quickly among the population, and the WHO declared the pandemic a Public Health Emergency of International Concern (PHEIC) on April 25, 2009 (175). After this announcement, several countries reported more cases. Table 19 presents the characteristics of the 2009 influenza outbreak.

\begin{tabular}{|c|c|}
\hline & H1N1 2009 \\
\hline Virus & Influenza \\
\hline Death Rate & $1 \%-2 \%$ \\
\hline Reproductive Ratio & Between 1 and 2 \\
\hline Type of transmission & Airborne \\
& Human to human \\
\hline No. of cases & More than 340,000 (Oct. 2009) \\
\hline No. of countries & 214 (Oct. 2010) \\
\hline Treatment & Tamiflu \\
\hline Vaccines & Available after six months \\
\hline
\end{tabular}

Table 19. Characteristics influenza 2009 A(H1N1) outbreak.

Mathematical models predicted that the outbreak could cause between 10 to 200 million cases (175). Young people, pregnant women, women who had recently given birth, and Indigenous people were at higher risk of severe illness and death (175). By August 2010, 
around 214 countries had reported more than 340,000 laboratory-confirmed cases of pandemic influenza $\mathrm{A}(\mathrm{H} 1 \mathrm{~N} 1)$ and over 18,449 deaths (320). Table 20 summarizes the number of deaths per region.

\begin{tabular}{|l|l|}
\hline Region & No. of deaths* \\
\hline WHO Regional Office for Africa (AFRO) & 168 \\
\hline WHO Regional Office for the Americas (AMRO) & $8533^{* *}$ \\
\hline $\begin{array}{l}\text { WHO Regional Office for the Eastern Mediterranean } \\
\text { (EMRO) }\end{array}$ & 1019 \\
\hline WHO Regional Office for South-East Asia (SEARO) & 1992 \\
\hline WHO Regional for the Western Pacific (WPRO) & 1858 \\
\hline WHO Regional Office for Europe (EURO) & $4879^{* *}$ \\
\hline Total & 18449 \\
\hline
\end{tabular}

*The number of deaths is estimated by the World Health Organization as of August 2010.

**The numbers might be underrepresented since not all cases were reported.

Table 20. Distribution of deaths by region 2009 A(H1N1) influenza outbreak. Source. WHO, GOARN.

After the PHEIC declaration, the WHO started to mobilize international action. The response was the result not only the implementation of new instruments for responding to pandemics, but it was also a consequence of previous planning and international coordination created as part of continuous international work in the field (321), and in which the epistemic community played a key role.

\subsection{The Influenza epistemic community}

Pandemic outbreaks require policymakers to confront the lack of knowledge of the scope of the problem and the expected outcomes, increasing their demand for technical expertise and specialized knowledge $(143,297,49,25,26,176,145,53)$. During a pandemic influenza outbreak, experts' knowledge and information are the primary sources to create policies to manage and control the disease (297).

Many members of the influenza epistemic community were working in governments and international organizations during the emergency (94). All collaborated during the response, providing on-time information, evidence, and technical advice to formulate 
medical and non-medical interventions.

It is necessary to identify the epistemic community, its members, and their resources, to analyze how much influence an epistemic community had in the level of cooperation seen during the international response to the influenza outbreak of 2009. In the case of an influenza pandemic, such identification requires us to review its evolution along with the mechanisms that have become available for the participation of experts in the definition of national and international policies to manage and control the disease.

Although this research refers to a single community for pandemic influenza, numerous subgroups of actors across countries and regions participate in this community. However, all of them can be considered as part of one global epistemic community because they share a common interest, normative beliefs, causal beliefs, epistemological criteria. Table 21 summarizes these elements.

\begin{tabular}{|l|l|}
\hline Common interest & To reduce the burden of seasonal and pandemic influenza. \\
\hline $\begin{array}{l}\text { Epistemological } \\
\text { belief }\end{array}$ & $\begin{array}{l}\text { Although members of the epistemic community have different backgrounds, they agree } \\
\text { that the scientific method should guide evidence to create policies (evidence-based } \\
\text { policies). They agree that influenza pandemics are unpredictable and recurrent. } \\
\text { Therefore, the possibility of having a new pandemic influenza outbreak is real } \\
\text { (Interview 1, 2, 5, 11) (322). Due to the unpredictable and uncertainty that influenza } \\
\text { pandemics can be, they agree that learning from past pandemics is vital to be prepared } \\
\text { and to manage a future outbreak. }\end{array}$ \\
\hline $\begin{array}{l}\text { Normative- } \\
\text { principled beliefs }\end{array}$ & To reduce the number of deaths and human suffering due to pandemic influenza. \\
\hline Causal beliefs & $\begin{array}{l}\text { To find the best methods to identify new influenza viruses as well as the best } \\
\text { interventions to reduce deaths and other costs associated with a pandemic, including } \\
\text { the development of a vaccine (Interview 2). }\end{array}$ \\
\hline $\begin{array}{l}\text { Notions } \\
\text { validity }\end{array}$ & $\begin{array}{l}\text { They have established norms, standards, and practices for the identification of } \\
\text { influenza viruses as well as standard methods to carry out research and development } \\
\text { of medical and non-medical interventions. }\end{array}$ \\
\hline
\end{tabular}

Table 21. The influenza pandemic epistemic community.

These are the unifying elements of all the experts working together to manage, control, and prevent future pandemic influenza outbreaks. 


\subsubsection{Characterizing the influenza epistemic community}

There is evidence of an epistemic community on influenza since the 1950s. As a group, it has evolved, increasing its membership and connectivity inside and expanding its influence outside the network. The epistemic community has improved the universal knowledge about the disease and has been working on researching and developing the best medical and nonmedical measures to control it.

This section applies the conceptual framework presented in Chapter 3 and measures three conditions of epistemic communities that are interrelated among themselves (knowledge, dissemination, the institutionalization of bureaucratic power), which will determine the influenza epistemic community's influence on the level of cooperation during the international response

\subsubsection{Knowledge}

The first condition refers to the knowledge created by the epistemic community, if the knowledge is consensual and if it has established a policy goal. The consensus in this community comes from decades of researching and examining influenza pandemics. Evidence-based medicine has allowed the epistemic community to create shared principled beliefs, causal beliefs, and common notions of validity in the management of influenza pandemic (94).

Dr. Andrewes published an extensive analysis of influenza outbreaks in Europe between 1948-1949. The document identified the different types of influenza viruses and their subgroups, and it established the difficulty of creating a single vaccine due to the heterogeneity of the strains (323). Another expert, Dr. T. Francis, reported on a vaccination campaign against influenza, also showing that vaccines failed to protect when they were 
made from different strains (324). The evidence collected in this research established the fundamentals to understand the behaviour of influenza viruses, the potential development and use of vaccines, and the management of outbreaks.

The WHO Influenza Programme, created in 1952, adopted the epistemic community's initial scientific consensus. M. M. Payne (as part of the Division of Communicable Disease at WHO) described that these experts' research helped to understand the "root of the problem (296)." These experts were also members of the WHO Influenza Centres (296) and their conclusions shaped the WHO Influenza Programme, including the importance of surveillance to detect early in the outbreak strains with pandemic potential (296). Thus, since the 1950s, scientific evidence and consensus have guided the development of international policies to fight influenza pandemics.

The study of influenza pandemics through history also established the consensual agreement that influenza viruses are unpredictable, that influenza pandemics will occur periodically, and that the global population is at risk $(325,326,327,328,329,330)$. Therefore, early in the outbreak, measures must be implemented to contain and manage it.

The epistemic community has acted together, developing strategies and guidelines to identify, prevent, manage, and control an outbreak. This knowledge has expanded widely, and influenza is one of the few diseases with pandemic potential recognized broadly in the medical field, since "every practitioner knows what the flu is (Interview 5)." The epistemic community's work is relevant because it is possible to work in preparedness at all levels, which facilitates the implementation of measures during a pandemic outbreak (interview 12).

The Influenza epistemic community, guided by the previously established consensual knowledge, recognized early that the 2009 outbreak was caused by an unknown strain 
$[\mathrm{A}(\mathrm{H} 1 \mathrm{~N} 1)]$, and therefore its behaviour, virulence, transmission capacity, origin and susceptibility to medicines were all unknown factors $(317,331,332)$. Due to these characteristics, the epistemic community agreed on the pandemic potential of the disease and the need to implement a quick global response $(175,317)$. This rationality guided the initial actions taken in the influenza outbreak.

The epistemic community's continuous collaboration also resulted in establishing an explicit policy goal during the pandemic outbreak: the creation of mechanisms for containing the influenza virus and limiting its worldwide spread $(333,334,335)$. Its members underlined that containment and limiting the spread of the virus is necessary to develop a vaccine, which is the only known medical intervention that will effectively stop an outbreak (Interview 2,8). Thus, the network established a common goal due to its shared understanding of the problem and its consensual knowledge.

The evolution of the epistemic community's collaboration, the study of past pandemics, and the interest in preventing a new deadly pandemic brought the development of consensual knowledge and the establishment of a clear policy goal.

\subsubsection{Socialization of ideas}

The epistemic community's ability to influence the international response also requires disseminating its consensual knowledge through channels that are accessible for policymaking. Moreover, dissemination of accurate data and scientific evidence during outbreaks is essential for guiding an international response. Thus, most of the activities that guided the response to the influenza outbreak were possible due to the availability of scientific evidence. Members of the epistemic community had access to different mechanisms to transmit, share, and socialize their ideas, such as: 
- Publications in scientific journals

- Participation in international conferences

- Providing evidence for technical guides

- Doing the research, analyzing the virus, collecting samples and producing epidemiological and laboratory data

Influenza experts have also developed a system for sharing data. The Consortium for the Standardization of Influenza Seroepidemiology coordinates the global community of researchers on influenza and in 2006, agreed on data sharing norms that facilitate on-time dissemination of data (110). In this case, the epistemic community tried to be as fast as possible in the provision of information that could improve the response and speed up the manufacture of a vaccine.

Several scientific journals also published about influenza during the outbreak. Using the search engine "google scholar," and searching for the words "h1n1 influenza outbreak 2009", the webpage reported 58,000 results. When in the web site, the time interval was specified to show only publications from the year 2009, the results changed to 4,700 (accessed April 10, 2018). Although these numbers may not be accurate, they provide an approximation of how experts disseminated their research and knowledge during the outbreak. Journals that published some of the most consulted studies included the American Journal of Public Health, the British Medical Journal, Emerging Infectious Diseases, Clinical Infectious Diseases, Journal of Infectious Diseases, the Lancet, MMWR, Nature, the New England Journal of Medicine, PLoS One, and Science.

The availability of producing and disseminating information per se does not influence the process if policymakers do not incorporate this knowledge into norms and regulations. In this case, the WHO has been the main channel for this, using many of the epistemic community's studies as the primary reference into working documents and policy papers that were 
published to guide the national and international responses (336).

The epistemic community also has a network structure that enables sharing its epistemic principles, values, and beliefs, and shared knowledge about the problem and solutions. The epistemic community includes people with technical and scientific expertise from all parts of the world, and different backgrounds, as well as experience in other areas relevant for influenza pandemic management (animal health, environment, food security, security, economy) (Interviews 2 and 9). In the $2009 \mathrm{~A}(\mathrm{H} 1 \mathrm{~N} 1)$ outbreak, it is possible to identify an epistemic community network at different levels and divided into subgroups participating in the response. Therefore, the analysis of the structure and integration of the network reveals three levels: global, regional or sub-regional, and national.

The global level. At this level, the epistemic community network collaborates directly with the WHO, as members of expert committees, government representatives, diplomats, and the organization's personnel. This research identifies its three main components: the GISRS, the GOARN, and the Global Initiative on Sharing All Influenza Data (GISAID) ${ }^{\mathrm{xli}}$. These networks connected directly with the Influenza Emergency Committee. The principal component in the influenza pandemic epistemic community is the GISRS. In 2009, there were 136 National Influenza Centres (NICs) in 106 countries, including the WHO Collaborating Centres (274). Figure 14 presents the global distribution of the network.

\footnotetext{
xli There may have been other international networks of professionals and experts in influenza that participated in the outbreak. Because tracking all of the possible participants is not feasible, I have chosen those that have been better documented and that had the characteristics to be identified as part of the epistemic community.
} 


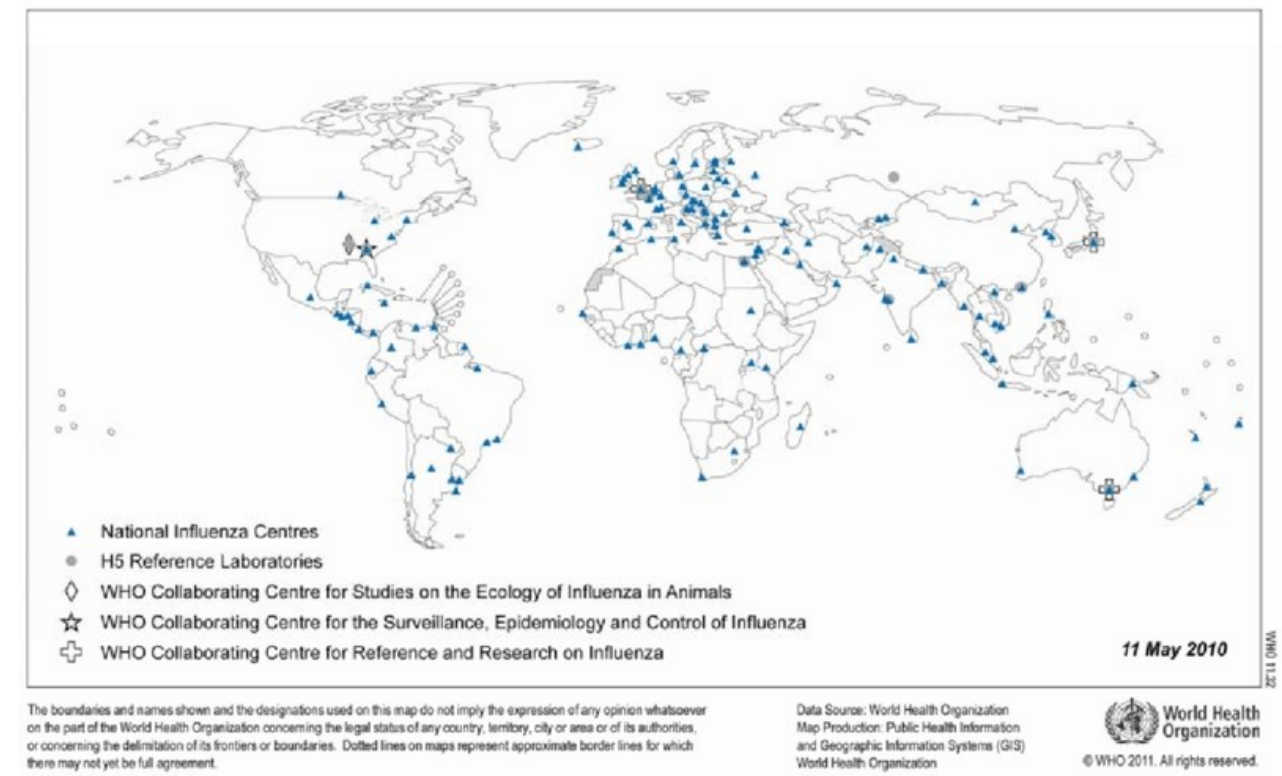

Figure 14. GISRS geographical distribution Influenza A(H1N1) outbreak. Source: WHO, 2010, (337).

The members of the GISRS meet twice a year primarily to analyze the information regarding the strains of the influenza virus detected during the year and to recommend the composition for the seasonal vaccine (338). Even though the people leading the centres change due to different circumstances, "several generations of scientists (338)" have been part of this network. The network's primary responsibility was researching and developing vaccines; however, it became the most important source of data about all the aspects related to the virus, information that was disseminated worldwide (339).

The next component is the GOARN, which included members of the GISRS and other experts worldwide. The GOARN coordinated the international response mobilizing technical resources, institutional mechanisms, and deployed experts where they were required $(274,340)$. These experts were deployed in different locations to assist the most vulnerable countries, with a total of 218 deployments (341). Whereas not all members of the epistemic community participated in GOARN, the network allowed the direct participation of some of 
them in some of the activities of the response.

A third element is the Global Initiative on Sharing All Influenza Data (GISAID), a public-private partnership. GISAID was launched in May 2008 in the World Health Assembly as an alternative mechanism for sharing viruses (for research and development of vaccines), given the previous controversies among states about the existing global system ${ }^{\text {xlii }}$. Two central bodies govern the initiative, a Scientific Advisory Council and Database Technical Group (342).

Finally, a fourth element is the Emergency Committee (EC). The WHO-DG organized an Emergency Committee (EC), as mandated by the IHRs 2005. The Influenza EC made decisions based on scientific evidence with political and financial consequences (274).

The regional and sub-regional levels. These are groups organized by regions or subregions, working in smaller networks that facilitate and expedite cooperation and exchange of information. In some cases, these networks have achieved a degree of integration within national health systems, allowing their counterparts in other countries to increase their knowledge about how the other national systems work and the resources they have available to confront an influenza pandemic. Some of these are also the networks created by the WHO regional offices. Therefore, they have their mechanisms and channels to connect at the global level and create synergies. Table 22 presents some of these networks.

\footnotetext{
xlii This initiative is part of the mechanisms created to solve the controversy started by Indonesia about virus sharing and its benefits that led to the PIP negotiation.
} 


\begin{tabular}{|c|c|c|}
\hline Network & Type & $\begin{array}{l}\text { No. of } \\
\text { Members }\end{array}$ \\
\hline $\begin{array}{l}\text { European Union Early Warning and Response } \\
\text { System (EUEWRS) }\end{array}$ & $\begin{array}{l}\text { Public-Governments and } \\
\text { International } \\
\text { Organizations }\end{array}$ & 29 \\
\hline $\begin{array}{l}\text { Pacific Public Health Surveillance Network } \\
\text { (PPHSN) }\end{array}$ & Public-Private & 21 \\
\hline EpiNorth, Europe & $\begin{array}{l}\text { Public-Governments and } \\
\text { International } \\
\text { Organizations }\end{array}$ & 10 \\
\hline Global Health Security Initiative (GHSI) & $\begin{array}{l}\text { Public-Governments and } \\
\text { International } \\
\text { Organizations }\end{array}$ & 10 \\
\hline EpiSouth, Europe & $\begin{array}{l}\text { Public-Governments and } \\
\text { International } \\
\text { Organizations }\end{array}$ & \\
\hline Southeast European Health Network (SEEHN) & $\begin{array}{l}\text { Public-Governments and } \\
\text { International } \\
\text { Organizations }\end{array}$ & 8 \\
\hline $\begin{array}{l}\text { Middle East Consortium of Infectious Disease } \\
\text { Surveillance (MECIDS) }\end{array}$ & Public-Private & 6 \\
\hline Mercado Común del Sur (UNASUR) & $\begin{array}{l}\text { Public-Governments and } \\
\text { International } \\
\text { Organizations }\end{array}$ & 5 \\
\hline $\begin{array}{l}\text { North American Plan for Avian and Pandemic } \\
\text { Influenza (NAPAPI) }\end{array}$ & Public-Governments & 3 \\
\hline APEC Health Working Group (HWG) & $\begin{array}{l}\text { Public-Governments and } \\
\text { International } \\
\text { Organizations }\end{array}$ & 20 \\
\hline $\begin{array}{l}\text { ASEAN Foundation Communication and } \\
\text { Information Systems for the Control of Avian } \\
\text { Influenza (CISCAI) and Health Group (ASEAN H) }\end{array}$ & $\begin{array}{l}\text { Public-Governments and } \\
\text { International } \\
\text { Organizations }\end{array}$ & 10 \\
\hline $\begin{array}{l}\text { Southeast European Centre for Surveillance and } \\
\text { Control of Infectious Diseases (SECID) }\end{array}$ & Public-Private & 19 \\
\hline $\begin{array}{l}\text { Mekong Basin Disease Surveillance Consortium } \\
\text { (MBDS) }\end{array}$ & Public-Private & 6 \\
\hline $\begin{array}{l}\text { South African Centre for Infectious Disease } \\
\text { Surveillance (SACIDS) }\end{array}$ & Public-Private & 8 \\
\hline $\begin{array}{l}\text { East African Integrated Disease Surveillance } \\
\text { Network (EAIDSNet) }\end{array}$ & Public-Private & 5 \\
\hline $\begin{array}{l}\text { Asian Partnership on Emerging Infectious Diseases } \\
\text { Research (APEIR) }\end{array}$ & Public-Private & 6 \\
\hline
\end{tabular}

Table 22. Influenza networks.

The WHO has six regional offices that are an essential component of the regional segment. These offices are important actors connecting within regions and with other 
networks. Table 23 includes the name of the office and the number of members.

\begin{tabular}{|l|c|}
\hline Regional Office WHO & $\begin{array}{l}\text { No. of } \\
\text { Members }\end{array}$ \\
\hline Regional Office for Africa (AFRO) & 48 \\
\hline Regional Office for the Americas (AMRO-PAHO) & 39 \\
\hline Regional Office for South-East Asia (SEARO) & 12 \\
\hline Regional Office for Europe (EURO) & 53 \\
\hline Regional Office for the Eastern Mediterranean (EMRO) & 23 \\
\hline Regional Office for the Western Pacific (WPRO) & 34 \\
\hline
\end{tabular}

Table 23. WHO Regional Offices.

During the influenza outbreak, the epistemic community worked through these networks, promoting collaboration among countries during the outbreak in places like North America, Asia, Middle East, and the European Union. Figure 15 presents the influenza networks' global membership by state.

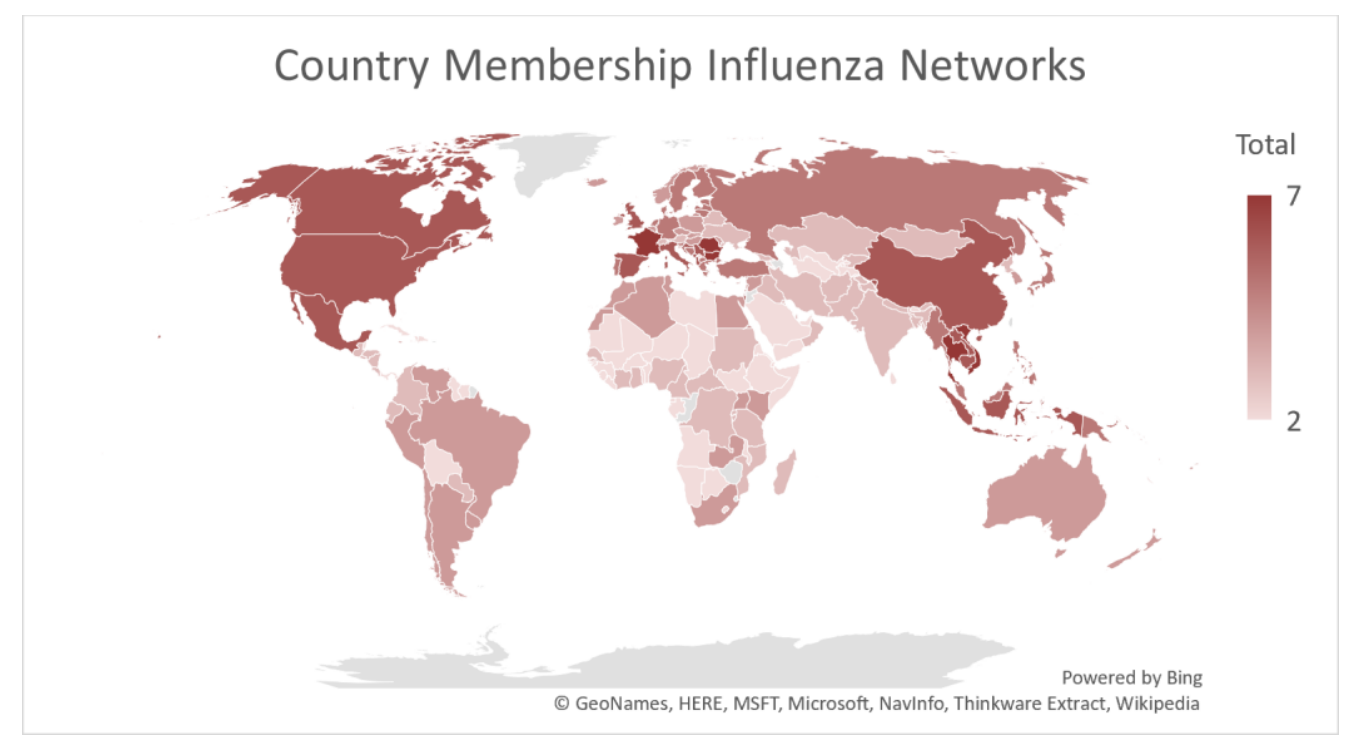

Figure 15. Geographical distribution of influenza networks' members

These networks were created after the H5N1 outbreak and strengthened the areas of preparedness and response to human and animal influenza.

The national-local level. The national-local level is composed mostly of professionals working for a local, state, or provincial Ministry of Health. These experts are epidemiologists, 
clinicians, laboratories, among others. They were key actors in the onset of the H1N1 outbreak, identifying influenza-like illness cases and notifying them to the national level $(318,317,343,344,345,346)$. They managed and guided local and national responses and provided information about the outbreak.

In some cases, they were connected through national networks of surveillance, providing information to the national level. Local and national experts connect with the global level through two main mechanisms: international norms guiding pandemic preparedness planning and the National Influenza Centres (NICs) as part of the WHO Global Influenza Surveillance Network. The WHO encouraged the development of those national networks.

Influenza pandemic planning has been a slow process at the national level. However, all countries understand to some extent what to do during an outbreak (Interviews 1 and 2). In general, family doctors and nurses know what influenza is, the symptoms associated with it, and how to identify cases (Interview 2). Health services have protocols in place to address an epidemic associated with influenza. Because national planning has followed international guidelines, there is some degree of coherence and consistency in the way countries respond to an outbreak.

The WHO’s Guidelines for National and Regional Planning have provided direction to states on how to prepare for pandemic influenza. They recommended establishing multidisciplinary National Pandemic Planning Committees to work together and develop a national strategy for a future influenza pandemic (347). In 2005, the updated guidelines incorporated lessons from SARS' experience (348). According to the WHO, before the H1N1 2009 influenza outbreak, 68 countries had developed a national plan under these 
guidelines (349).

These three levels form the influenza epistemic community. Its members interact and connect through different formal and informal mechanisms. Figure 16 represents the structure of the epistemic community and its interactions.

\section{Global}

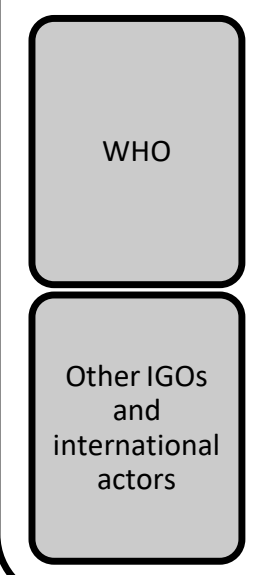

\section{Regional}

WHO Regional

Offices

Networks by

regions or subregions
National

NICs and other agencies
Local actors

Figure 16. Structure, connections, and interactions of the influenza epistemic community.

The structure, therefore, facilitates communication, the transmission of knowledge and information within the epistemic community and with other actors.

\subsubsection{Institutionalization of bureaucratic power}

Even though there are mechanisms and opportunities for influencing decision-making as well as the implementation and formation of norms, the possibility of having direct participation in the policy process and institutionalize its bureaucratic power are fundamental for an epistemic community. The influenza epistemic community structure also facilitates its participation in the policy process and to amass bureaucratic power.

At the global level, the epistemic community's participation in the policy process is 
mainly through the Emergency Committee. The Influenza EC's Members were selected by the WHO based on their expertise and experience relevant to the event in areas such as acute respiratory syndromes, influenza, virology, epidemiology, laboratory practices, outbreak modelling, antiviral drugs, drug resistance, infection control, vaccines, airports, ports, aviation and maritime issues (175). The members of the EC were direct or indirect members of the other three networks (representing themselves or their institutions). Table 24 presents the list of members of the Emergency Committee and their connection to the other three groups. 


\begin{tabular}{|c|c|c|c|c|c|c|c|}
\hline Country & Member & Position & Institution & $\begin{array}{l}\text { EC } \\
\text { Influenza }\end{array}$ & GISN 2010 & GOARN & GISAID \\
\hline Pakistan & $\begin{array}{l}\text { Muhammad Akbar } \\
\text { Chaudhry }\end{array}$ & Principal, Professor of Medicine & Fatima Jinnah Medical College & 1 & & & \\
\hline UK & Neil Morris Ferguson & $\begin{array}{l}\text { Department of Infectious Disease } \\
\text { Epidemiology }\end{array}$ & $\begin{array}{l}\text { Imperial College Faculty of } \\
\text { Medicine }\end{array}$ & 1 & & 1 & \\
\hline USA & Nancy Cox & Director Influenza Division & $\begin{array}{l}\text { Centers for Disease Control and } \\
\text { Prevention }\end{array}$ & 1 & 1 & 1 & 1 \\
\hline Australia & John Mackenzie & $\begin{array}{l}\text { Emergency Committee Chair, Professor of } \\
\text { Tropical Infectious Diseases }\end{array}$ & $\begin{array}{l}\text { Division of Health Sciences, } \\
\text { Curtin University }\end{array}$ & 1 & & & \\
\hline Senegal & André Basse & Counsellor & Embassy of Senegal in France & 1 & 1 & 1 & \\
\hline Canada & Claude Thibeault & $\begin{array}{l}\text { Consultant in Aviation Medicine and } \\
\text { Occupational Health and Medical Adviser }\end{array}$ & $\begin{array}{l}\text { International Air Transport } \\
\text { Association (IATA) }\end{array}$ & 1 & & & \\
\hline Canada & Anthony Evans & Chief, Aviation Medicine Section & $\begin{array}{l}\text { International Civil Aviation } \\
\text { Organization (ICAO) }\end{array}$ & 1 & & & \\
\hline Chile & Fernando Otaiza & National Infection Control Program & Ministry of Health & 1 & 1 & 1 & \\
\hline Ghana & Lawson Ahadzie & Former Head of Surveillance Department & Ministry of Health & 1 & & & \\
\hline Mexico & Rogelio Pérez Padilla & $\begin{array}{l}\text { Instituto Nacional de Enfermedades } \\
\text { Respiratorias "Ismael Cosío Villegas" }\end{array}$ & Ministry of Health & 1 & 1 & 1 & \\
\hline Thailand & Supamit Chunssuttiwat & $\begin{array}{l}\text { Department of Disease Control, Ministry of } \\
\text { Public Health }\end{array}$ & Ministry of Public Health & 1 & & & \\
\hline UK & John Wood & Division of Virology & $\begin{array}{l}\text { National Institute for Biological } \\
\text { Standards and Control }\end{array}$ & 1 & 1 & & \\
\hline Japan & Masato Tashiro & $\begin{array}{l}\text { WHO Collaborating Centre for Reference } \\
\text { and Research on Influenza }\end{array}$ & $\begin{array}{l}\text { National Institute of Infectious } \\
\text { Diseases }\end{array}$ & 1 & 1 & & 1 \\
\hline UK & Maria Zambon & $\begin{array}{l}\text { Respiratory Virus Unit, Virus Reference } \\
\text { Department }\end{array}$ & Public Health England & 1 & 1 & 1 & \\
\hline China & Wing Hong Seto & & Queen Mary Hospital & 1 & & & \\
\hline USA & Arnold Monto & & University of Michigan & 1 & & & \\
\hline
\end{tabular}

EC Influenza: Emergency Committee Influenza; GISN 2010: Global Influenza Surveillance Network 2010; GOARN: Global Alert and Response Network; GISAID: Global Initiative on Sharing All Influenza Data.

Table 24. List Emergency Committee members and overlapping with other groups. 
The centre of the global epistemic community was the Emergency Committee (EC) due to its connections with other groups, and that it was the main body advising the WHO during the outbreak. The Influenza EC held nine meetings during the outbreak and the aftermath. Each session required experts and government representatives to analyze the facts and assess the situation to determine actions to follow. In these meetings, other experts, officers from affected countries, and WHO's staff also participated, and consultations with headquarters and ministries would have occurred.

At the regional level, the identified regional and sub-regional hubs also connect the influenza epistemic community with the policy process. Members of these networks include government (Ministers of Health and Animal Health), international organizations, research institutions, universities, funding agencies. Therefore, experts have direct access to policymakers, strengthening personal and institutional linkages amongst those working in the health community and for increasing international cooperation (Interviews 1, 2, 12). Experts from these networks and countries, along with other professionals worldwide, worked together in the areas of surveillance, preparedness, and response to influenza pandemics. Therefore, they create connections at the institutional and personal levels.

At the national level, the National Influenza Centres (NICs), as part of the WHO GISRS, are a link between the national and international levels. During the onset of the outbreak, the epistemic community worked together to identify the virus and formulate measures for control, management, and containment. At the centre of this response was the NICs, which had the tools to detect the virus and notify it.

These centres are established by national governments to provide epidemiological 
surveillance and collect samples of influenza viruses. As part of the WHO GISRS, governments should provide the WHO with information about any influenza activity in the country and facilitate viruses' samples (350). To fulfill their duties with the organization, NICs rely on a national network of influenza surveillance, which provides the information they need to report to the global level.

During the 2009 outbreak, through these structures, the influenza epistemic community had direct participation in the policy decision making at the international, regional and national levels, providing the knowledge and analyzing the evidence to establish those measures that would help to manage the outbreak.

Members of the community have also long participated in expert groups and multiple international forums organized by governments and international organizations before, during, and after the outbreak, to assess the situation and to analyze the international response. The GISRS and NICs, along with the WHO Strategic Advisory Group of Experts on Immunization (SAGE) have traditionally provided advice to the WHO. These groups are the backbone of the Global Influenza Program (302). Using these groups as the pillars for the expert advice, the WHO organized the first group of experts in April 2009 to develop guidelines for clinical management of patients (336). This group interacted with policymakers through different meetings (336):

- $\quad$ WHO ad hoc scientific teleconference on the current influenza A(H1N1) situation 29 April 2009;

- WHO Technical Consultation on the Severity of Disease Caused by the new influenza A (H1N1) virus infections, May 5, 2009;

- WHO Strategic Advisory Group of Experts on Immunization (SAGE) held an extraordinary meeting on 7 July 2009 in Geneva, Switzerland (351); 
- Joint Scientific Consultation on potential risks of pandemic (H1N1) 2009 influenza virus at the human-animal interface (WHO-FAO-OIE), June 3, 2009;

- WHO Scientific Consultation on the suspension of classes and restriction of mass gatherings to mitigate the impact of epidemics caused by the new influenza A (H1N1) (teleconference), June 24, 2009;

- Modelling Network Meeting, July 2009, Geneva, Switzerland (WHO 2009:1) Weekly Epidemiological Records;

- Infection Prevention and Control Network Meeting to share information on the revision of Infection Control guidance for H1N1. September 8-9, 2009;

- Global teleconference on virological monitoring of the pandemic H1N1 virus with GISN members, regional offices, and other experts. October 7, 2009;

- WHO Global Consultation on the Clinical Aspects of Pandemic H1N1 Influenza. October 14-16, 2009 Washington D.C. PAHO with the participation of more than 100 experts in different areas;

- Technical consultation with WHO CCs to update them on H1N1 virus characterization; antiviral susceptibility monitoring; diagnostic kit and protocols development, availability, and distribution; and vaccine viruses and reagents, their development, availability, and distribution, November 3, 2009;

- 2009 meeting of National Influenza Centres, December 1-4, 2009, Geneva, Switzerland;

- WHO Consultation on the suspension of classes and restriction of mass gatherings to mitigate the impact of epidemics caused by influenza A (H1N1), teleconference, May 2009 (352).

These meetings were necessary to establish guidelines, make recommendations, provide updates on research and development, and deliver information that guided the Emergency Committee, the $\mathrm{WHO}$ and its member states during the response. Therefore, the epistemic community had a direct influence on the process and gained institutional power to provide advice.

Other consultations also increased the influence of the epistemic community members creating spaces where they interact with other key players and provided information and advice. In these fora, they were part of national delegations and international 
organizations, which gave them increased access to the response and the decision made in this area. Table 25 presents some of the most critical meetings.

\begin{tabular}{|c|c|c|}
\hline Meeting & Date and location & Description \\
\hline $\begin{array}{l}\text { The High-level Consultation } \\
\text { on Influenza A(H1N1) }\end{array}$ & $\begin{array}{l}\text { May 2009, Geneva, } \\
\text { Switzerland }\end{array}$ & $\begin{array}{l}\text { It was held during the } 62^{\text {nd }} \\
\text { World Health Assembly. }\end{array}$ \\
\hline $\begin{array}{l}\text { The Special Meeting on } \\
\text { Pandemic (H1N1) }\end{array}$ & $\begin{array}{l}\text { September 2009, Brussels, } \\
\text { Belgium }\end{array}$ & \\
\hline $\begin{array}{l}\text { The Influenza A(H1N1) } \\
\text { Lessons Learned on } \\
\text { Influenza organized by the } \\
\text { Minister of Health of } \\
\text { Canada, Secretary of Health } \\
\text { of the USA, and Secretary of } \\
\text { Health of Mexico. }\end{array}$ & $\begin{array}{l}\text { July 1-3, 2009, Cancun, } \\
\text { Mexico }\end{array}$ & $\begin{array}{l}\text { The conference had a high- } \\
\text { level meeting with the } \\
\text { participation of } 40 \text { countries } \\
\text { and a conference with experts } \\
\text { in different areas (surveillance, } \\
\text { laboratory, vaccines, } \\
\text { prevention, among others) } \\
\text { (353). }\end{array}$ \\
\hline $\begin{array}{l}\text { The academic journal The } \\
\text { Lancet organized an } \\
\text { international conference, } \\
\text { after the International } \\
\text { Scientific Symposium on } \\
\text { Influenza A (H1N1) } \\
\text { Pandemic Response and } \\
\text { Preparedness, organized by } \\
\text { the Ministry of Health, } \\
\text { China. }\end{array}$ & $\begin{array}{l}\text { August 22-23, 2009, Beijing, } \\
\text { China }\end{array}$ & $\begin{array}{l}\text { The conference had more than } \\
900 \text { delegates from } 20 \\
\text { countries, and its main goal } \\
\text { was to update scientific } \\
\text { knowledge about both seasonal } \\
\text { and pandemic influenza (354). }\end{array}$ \\
\hline
\end{tabular}

Table 25. Meetings Influenza A(H1N1) 2009

These meetings increased the epistemic community access to the policy process, and its members influence the definition of measures.

After analysing all the previous characteristics, it is possible to conclude that during the Influenza $\mathrm{A}(\mathrm{H} 1 \mathrm{~N} 1)$ outbreak, an active Influenza Epistemic Community participated. It institutionalized its bureaucratic power, and it was capable of contributing to the decisionmaking process at the local, national, and international levels, and to influence international cooperation. Table 26 summarizes these characteristics. 


\begin{tabular}{|c|c|c|}
\hline & Indicator & Influenza \\
\hline \multirow[b]{2}{*}{ 1. Knowledge } & $\begin{array}{l}\text { Agreement on a common } \\
\text { definition of the problem and } \\
\text { possible solutions }\end{array}$ & $\begin{array}{l}\text { The community had a consensual } \\
\text { agreement before the outbreak. }\end{array}$ \\
\hline & $\begin{array}{l}\text { Clear identification of a } \\
\text { common policy goal }\end{array}$ & $\begin{array}{l}\text { They had a common goal to control and } \\
\text { contain the spread of the influenza virus } \\
\text { in a short period. }\end{array}$ \\
\hline \multirow{3}{*}{ 2.Socialization of ideas } & Structure & $\begin{array}{l}\text { The epistemic community is a loose } \\
\text { structure with different nodes and } \\
\text { where the WHO is an important } \\
\text { participant. The size of the network } \\
\text { extends to all the world. It has a broad } \\
\text { global international representation at all } \\
\text { levels and includes professionals from } \\
\text { different areas. }\end{array}$ \\
\hline & Dissemination mechanisms & $\begin{array}{l}\text { They disseminate their knowledge } \\
\text { through scientific publications, } \\
\text { conferences, and other meetings. }\end{array}$ \\
\hline & $\begin{array}{l}\text { Participation in the international } \\
\text { response }\end{array}$ & $\begin{array}{l}\text { Many members of the Epistemic } \\
\text { Community participated in the } \\
\text { international response as members of } \\
\text { international organizations (such as } \\
\text { GOARN) and governments. }\end{array}$ \\
\hline \multirow[b]{2}{*}{$\begin{array}{l}\text { 3. Institutionalization } \\
\text { of bureaucratic power }\end{array}$} & $\begin{array}{l}\text { Participation in the policy } \\
\text { process. }\end{array}$ & $\begin{array}{l}\text { Members of the epistemic community } \\
\text { participated in groups of experts and } \\
\text { committees, directly influencing the } \\
\text { policymaking process. }\end{array}$ \\
\hline & $\begin{array}{l}\text { Experts and other professionals } \\
\text { from the epistemic community } \\
\text { in decision-making positions }\end{array}$ & $\begin{array}{l}\text { The epistemic community had many } \\
\text { members in crucial positions. They } \\
\text { were also members of the Emergency } \\
\text { Committee, the main body at the WHO } \\
\text { providing advise for the international } \\
\text { response. }\end{array}$ \\
\hline
\end{tabular}

Table 26. Characteristics influenza epistemic community.

The following section will examine how this epistemic community interacted and participated in the international response to the influenza outbreak.

\subsection{The international response and the influenza epistemic community}

A global system of influenza governance was in place by the time of the 2009 influenza outbreak, and the integration of an influenza epistemic community into this system 
facilitated the transmission of information, analysis of the situation, and timely notification of the emergency response. Figure 17 summarises the participation of the influenza epistemic community in the process of the international response.

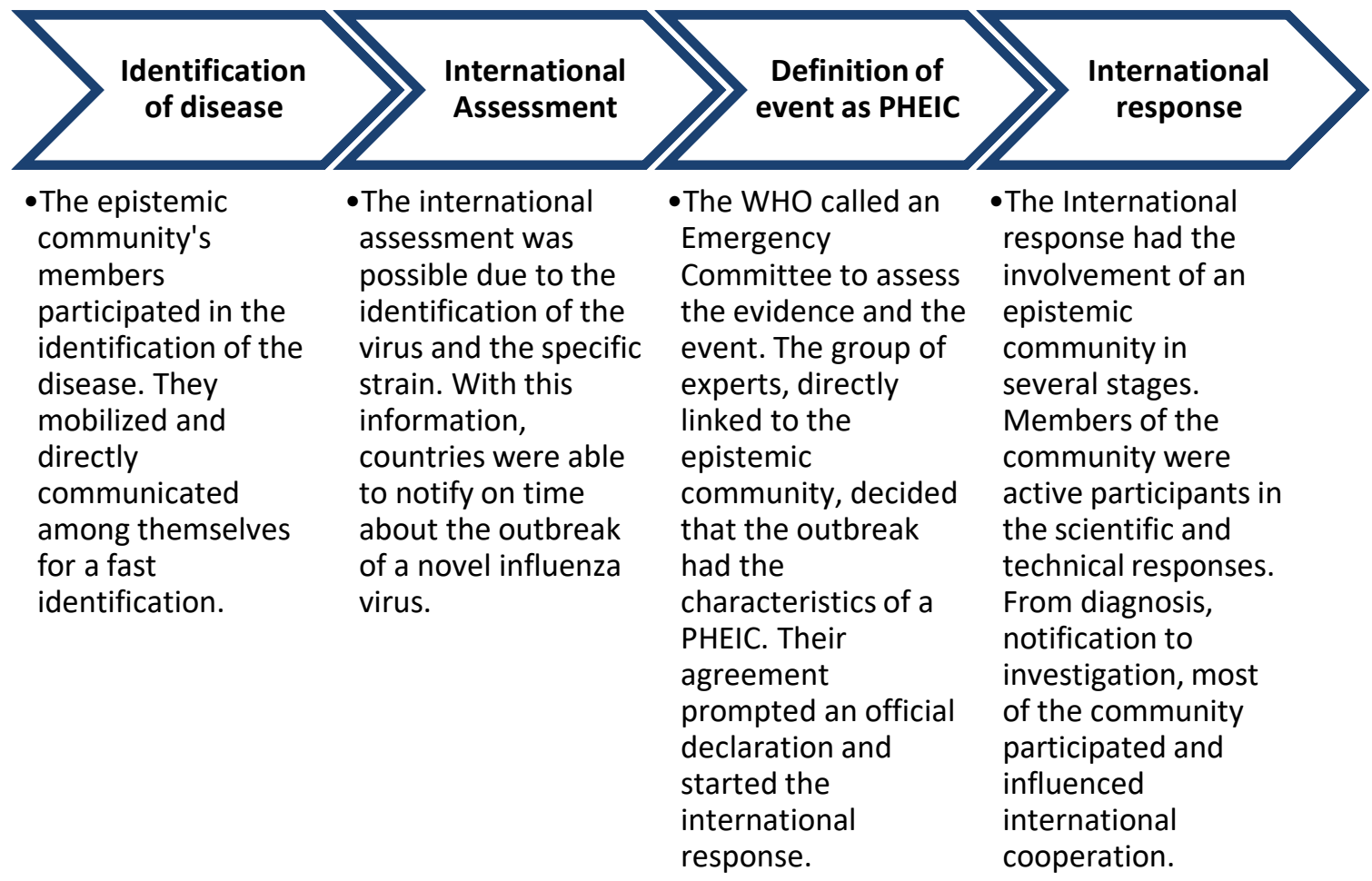

Figure 17. Participation of the influenza epistemic community in the international response.

Mexico and the United States were the first countries to notify cases of a new strain of influenza (346). Mexican national capacities for identification of the virus, however, were inadequate and insufficient (355). Due to these circumstances, the Head of the National Laboratory in Mexico sent electronic communications to the Head of the Winnipeg National Microbiology Laboratory in Canada, notifying him about the evidence of an unknown 
influenza virus circulating in Mexico ${ }^{\text {xiiii }}$. These officers had previously developed a professional and personal relationship. The heads of the laboratories participated in the GISRS as NICs and in groups such as the North America Plan for Avian and Pandemic Influenza (NAPAPI), the Global Health Security Initiative (GHSI), and other expert groups and governing bodies at the $\mathrm{WHO}$ (Interviews 1 and 3). They were part of a broader epistemic community devoted to working on issues related to an influenza pandemic. Appendix $\mathrm{H}$ presents the full list of people identified as part of the epistemic community, including the people that started the process of identification and notification of the virus.

The communication between the two heads of the Canadian and Mexican Laboratories underlines the close relationship and a level of confidence between two professionals and experts on the topic. These government representatives built trust and mutual understanding before the outbreak, due to their continuing interactions through the epistemic community (Interviews 1, 2, 6, 7). Therefore, the Mexican officer could directly talk to his Canadian colleague about the situation in Mexico ${ }^{\text {xliv }}$ and asked him to analyze samples of the virus in his laboratory. The Canadian health officer offered full cooperation and the assistance of the microbiology laboratory in identifying any samples sent to Canada from Mexico (316). Afterward, Mexico also received support from the head of the Influenza Program in the US CDC in Atlanta, the designated collaborative centre in the WHO laboratory network for influenza for the Americas (316). Flu samples from Mexico arrived

\footnotetext{
xliii There was an exchange of e-mails between personnel from the Microbiology Lab in Winnipeg and the Secretariat of Health in Mexico in this critical stage of the epidemic.

xliv Celia Alpuche, e-mail message to Frank Plummer, April 17, 2009.
} 
in Winnipeg on April 22, 2009. In six hours, the Canadian laboratory confirmed that the specimens contained a novel strain of influenza virus A (H1N1) with a swine virus component. On April 23, in a tri-national call conference among the heads of the three laboratories, the CDC confirmed that samples collected in California showed the same virus (316). Communication among the agencies and the experts was essential to determine the following steps and notify at the global level. During his speech to the $62^{\text {nd }}$ World Health Assembly of 2009, the Mexico Minister of Health acknowledged the work and collaboration of the network of professionals from Mexico, Canada, and the USA in identifying the virus and informing the international community. He also recognized that due to these experts, Mexico could notify the outbreak on time, complying with the IHR 2005 (356).

The identification of the virus allowed the Government of Mexico to determine the gravity of the situation and which actions to implement. On April 23, the government made an official announcement and established the measures to limit and contain the outbreak (355,317). The international community recognized the government of Mexico for acting with transparency (357). The WHO also contributed to a fast collection, sharing, and analysis of data through the Event Management System (EMS). During the first days of the emergency, the system registered 305 users from around the world (336).

After the USA and Mexico notified WHO of the outbreak, the WHO Director-General organized for the first time an Emergency Committee ${ }^{x l v}$ on April 25, 2009, with the participation of experts selected by the international organization and representatives of the

xlv The rules to establish an Emergency Committee are stated in the IHRs 2005, Article 48. 
most affected countries at that moment (USA, Canada, and Mexico). On the same day, the EC members agreed that, following the IHRs Article 12, the situation constituted a "Public Health Emergency of International Concern (PHEIC)." With the official declaration, the WHO requested all the NICs to be alert and to inform of any other outbreak. The following days more countries started notifying the presence of severe influenza illness, and later more countries confirmed the presence of the H1N1 virus in their territories.

With the PHEIC declaration, the international response officially started. The Americas mobilized the response through PAHO/WHO and GOARN. This network also coordinated response planning with the World Organization for Animal Health (OIE), the United Nations Food and Agriculture Organization (FAO), the Regional Office for the Western Pacific WPRO/WHO, and the Regional Office for the Eastern Mediterranean EMRO/WHO. By May 2009, the WHO published the Influenza A(H1N1) Global Pandemic Response Plan, with specific guidelines for the management of the outbreak (336).

The WHO and the UN System Influenza Coordination made an initial assessment of needs in countries requiring assistance. The assistance targeted two main areas: access to essential medicines and strengthening health systems. The WHO provided 4.7 million treatments of Oseltamivir to 128 countries (358) and established a mechanism to provide vaccines. The WHO delivered more than 70 million doses to 79 countries (358), along with other medical supplies and technical assistance. The second target included training of health workers, support for the development of operational plans for vaccine campaigns, and equipment supply. Mexico immediately received technical assistance from the WHO/PAHO and other countries around the world $(317,336)$. 
On April 29, 2009, the Antiviral Task Force was established to oversee the deployment of the Rapid Response Global Stockpile (336) located in Switzerland and the USA. On May 7th, 2009, the first shipment of antivirals arrived in African countries, and the last one was delivered on May $25^{\text {th }}, 2009$. The continued provision of supplies occurred between May and October 2009 (336). The assistance included 1,000 treatment courses to 46 African countries and 10,000 more that were made available to the Inter-country support teams in the region (336). The WHO assisted 62 least developed countries in procuring critical supplies, and equipment to build laboratory capacities (336)

Along with the material resources, financial assistance also spurred after the declaration. Donors provided around 1.2 billion in 2009 (359). The WHO and regional offices also received funds to respond, reaching a total of $\$ 137,126,601$ during the pandemic (359), even though there was a shortage of funs to cover the total needs in all areas (359).

On May $4^{\text {th }}, 2009$, Dr. Margaret Chan, the WHO DG, briefed the UN SecretaryGeneral and General Assembly on the H1N1 influenza situation. She emphasized the importance of scientific and technical knowledge to back up decision-making during the pandemic (360). In June of the same year, she recognized that the situation created "a demand for advice and reassurance in the midst of limited data and considerable scientific uncertainty (361)." Experts, therefore, became central in the response and provided information in four main areas: epidemiological, clinical, vaccine-drugs, and modeling (175).

The epistemic community contributed to determining the severity of the disease, the type of immunity in certain groups of the population, and to predict the speed at which the virus spread, leading to a rapid response by the international community. The epistemic 
community also helped answer some difficult questions such as the type of population that had to be vaccinated or if the vaccine that did not go through all the formal testing procedures had to be available immediately (Interview 12). Thus, the international response was guided for the experts' consensus, and the need to implement quick actions to avoid the worst-case scenario increased the demand for experts at different levels. In Mexico, where the outbreak started, the National Committee for Epidemiological Surveillance agreed the situation was of concern because of the characteristics of the disease (175). With the information provided by the National Committee, the President of Mexico ruled that the Minister of Health was in charge of dictating and implementing all the measures to confront the epidemic in the country. This instruction gave the specialized agency the power to guide the national response, coordinating actions with other domestic agencies, governments, and international organizations (362). The President also requested a special advisor to collaborate directly with the Ministry of Health and to work as a liaison for the presidential office (Interview 1). The advisor, a former public officer with previous experience working in influenza, was also a member of the epistemic community through the WHO and other sub-networks.

In the USA, the case was similar. The CDC identified the virus in the US territory and notified the WHO. In late June 2009, President Obama requested that his Council of Advisors on Science and Technology (PCAST) prepare an assessment of the 2009-H1N1 influenza A pandemic and the nation's response (346).

At the global level, the United Nations Secretary-General emphasized the World Health Organization's role as the agency leading the international response and requested the UN Member States to continue following the advice of this organization (363). The 
worldwide expectation that a new influenza pandemic could potentially cause millions of deaths in a matter of days made the WHO request expert consultations and international meetings to determine the course of action (274). Governments and the WHO knew about the threat that an emerging virus posed for the world, and they decided to implement measures based on the already available knowledge about influenza viruses $(175,317)$.

The epistemic community worked through the WHO as its primary advisor. Early in the international response, it established the importance of decision making based on scientific evidence (363). The network of experts assisted in determining the steps to follow and the way the international organization would perform and use its resources. The main representatives of the epistemic community were in the Emergency Committee. Decisions made by this committee and experts in the world guided the response led by the WHO and the recommendations provided to the international community. The WHO ensured that scientific principles and available scientific evidence were behind all its actions (175). Table 27 presents the summary of statements made by the DG-WHO, where she refers to decisions under the advice of the experts from the EC and other expert advisors.

After the Emergency Committee's $4^{\text {th }}$ meeting (June 11, 2009), the WHO declared the outbreak to be a global pandemic. This decision was a consequence of a consensual agreement that the virus had reached a pandemic status since it had spread across geographical regions $(175,364,276)$. 


\begin{tabular}{|c|c|}
\hline Meeting / Speech & Statement (Abstract) \\
\hline $\begin{array}{l}\text { Statement after the first } \\
\text { meeting of the } \\
\text { Emergency Committee } \\
\text { was held on Saturday, } 25 \\
\text { April 2009. }\end{array}$ & $\begin{array}{l}\text { "After reviewing available data on the current situation, Committee } \\
\text { members identified a number of gaps in knowledge about the clinical } \\
\text { features, epidemiology, and virology of reported cases and the appropriate } \\
\text { responses. } \\
\text { The Committee advised that answers to several specific questions were } \\
\text { needed to facilitate its work. } \\
\text { The Committee nevertheless agreed that the current situation constitutes a } \\
\text { public health emergency of international concern. } \\
\text { Based on this advice, the Director-General has determined that the current } \\
\text { events constitute a public health emergency of international concern under } \\
\text { the Regulations". }\end{array}$ \\
\hline $\begin{array}{l}\text { Statement after the Second } \\
\text { meeting of the Emergency } \\
\text { Committee held on } 27 \text { April } \\
2009 .\end{array}$ & $\begin{array}{l}\text { "On the advice of the Committee, the WHO Director-General decided on } \\
\text { the following. } \\
\text { The Director-General has raised the level of influenza pandemic alert from } \\
\text { the current phase } \\
\text { The change to a higher phase of pandemic alert indicates that the } \\
\text { likelihood of a pandemic has increased, but not that a pandemic is } \\
\text { inevitable. } \\
\text { This decision was based primarily on epidemiological data demonstrating } \\
\text { human-to-human transmission and the ability of the virus to cause } \\
\text { community-level outbreaks". }\end{array}$ \\
\hline $\begin{array}{l}\text { Influenza A(H1N1) } \\
\text { Statement by WHO } \\
\text { Director-General, Dr. } \\
\text { Margaret Chan } \\
29 \text { April } 2009\end{array}$ & $\begin{array}{l}\text { "Based on an assessment of all available information, and following } \\
\text { several expert consultations, I have decided to raise the current level of } \\
\text { influenza pandemic alert from phase } 4 \text { to phase } 5 " \text { ". }\end{array}$ \\
\hline $\begin{array}{l}\text { The world now at the start of } \\
2009 \text { influenza pandemic } \\
\text { Statement to the press by } \\
\text { WHO Director-General Dr. } \\
\text { Margaret Chan } \\
11 \text { June } 2009\end{array}$ & $\begin{array}{l}\text { "I have conferred with leading influenza experts, virologists, and public } \\
\text { health officials. In line with procedures set out in the International Health } \\
\text { Regulations, I have sought guidance and advice from an Emergency } \\
\text { Committee established for this purpose. } \\
\text { On the basis of the available evidence, and these expert assessments of the } \\
\text { evidence, the scientific criteria for an influenza pandemic have been met. } \\
\text { I have therefore decided to raise the level of influenza pandemic alert from } \\
\text { phase } 5 \text { to phase } 6 " \text { ". }\end{array}$ \\
\hline
\end{tabular}

Table 27. Statements WHO Director-General during A(H1N1) pandemic. Based on different sources

The Emergency Committee agreed on other recommendations that were issued by the WHO. Table 28 presents a summary of the temporary recommendations issued by the Influenza Emergency Committee during the pandemic. 


\begin{tabular}{|c|c|}
\hline Date & Recommendation \\
\hline $\begin{array}{l}25 \\
2009\end{array}$ & $\begin{array}{l}\text { "Concerning public health measures, in line with the Regulations, the Director-General is } \\
\text { recommending, on the advice of the Committee, that all countries intensify surveillance for } \\
\text { unusual outbreaks of influenza-like illness and severe pneumonia." }\end{array}$ \\
\hline $\begin{array}{l}27 \\
2009\end{array}$ & $\begin{array}{l}\text { "The Director-General recommended not to close borders and not to restrict international } \\
\text { travel. It was considered prudent for people who are ill to delay international travel and for } \\
\text { people developing symptoms following international travel to seek medical attention." } \\
\text { "The Director-General stressed that all measures should conform with the purpose and scope } \\
\text { of the International Health Regulations." }\end{array}$ \\
\hline $\begin{array}{l}24 \\
\text { September } \\
2009\end{array}$ & $\begin{array}{l}\text { "Having considered the views of the Emergency Committee, and the ongoing pandemic } \\
\text { situation, the Director-General determined it was appropriate to continue these temporary } \\
\text { recommendations, namely: } \\
\text { - Countries should not close borders or restrict international traffic and trade; } \\
\text { - Intensify surveillance of unusual flu-like illness and severe pneumonia; } \\
\text { - If ill, it is prudent to delay international travel; } \\
\text { - If ill after travel seek care." }\end{array}$ \\
\hline $\begin{array}{l}26 \\
\text { November } \\
2009\end{array}$ & $\begin{array}{l}\text { "Having considered the views of the Emergency Committee, and the ongoing pandemic } \\
\text { situation, the Director-General determined it was appropriate to continue all three temporary } \\
\text { recommendations, namely: } \\
\text { - Countries should not close borders or restrict international traffic and trade; } \\
\text { - Intensify surveillance of unusual flu-like illness and severe pneumonia; } \\
\text { With an updated third recommendation, namely: } \\
\text { - If ill, it is prudent to delay travel." }\end{array}$ \\
\hline $\begin{array}{l}24 \\
\text { February } \\
2010\end{array}$ & $\begin{array}{l}\text { "Having considered the views of the Emergency Committee, and the ongoing pandemic } \\
\text { situation, the Director-General determined it was appropriate to continue the three temporary } \\
\text { recommendations, as modified, namely: } \\
\text { - Countries should not close borders or restrict international traffic and trade; } \\
\text { - maintain surveillance of unusual flu-like illness and severe pneumonia; } \\
\text { - If ill, it is prudent to delay travel." }\end{array}$ \\
\hline
\end{tabular}

Table 28. Recommendations Influenza Emergency Committee.

Source: Report of the Review Committee on the Functioning of the International Health Regulations (2005) about Pandemic (H1N1) 2009, 5 May 2011, Document A64/10, WHO, p. 77 (175)

The adoption of the knowledge developed by the epistemic community was also possible for the quick dissemination of information and research — the WHO consistently reminded governments that scientific evidence had to guide the implementation of measures (290). Most governments and international organizations kept track of publications relevant to the outbreak in real-time, to have the most up-to-date information available for quick decision-making. To establish the importance of publishing and dissemination of data for the decision-making process during the outbreak, table 29 provides a sample of organizations 
that have in their websites reports directly referencing to the available research during the pandemic outbreak.

\begin{tabular}{|l|l|l|}
\hline Organization & Level & Reference \\
\hline $\begin{array}{l}\text { World Health Organization } \\
\text { Curopean Centre for Disease } \\
\text { Control and Prevention }\end{array}$ & Global & Pandemic (H1N1) Guidance Documents (366) \\
\hline $\begin{array}{l}\text { US Centers for Disease Control and } \\
\text { Prevention }\end{array}$ & National & $\begin{array}{l}\text { Epidemiological Publications Related to the } \\
\text { H1N1 Pandemic by CDC Influenza Division, } \\
\text { Epidemiology and Prevention Branch Authors } \\
\text { (368) }\end{array}$ \\
\hline $\begin{array}{l}\text { Ontario Agency of Health } \\
\text { Protection and Promotion }\end{array}$ & Local & $\begin{array}{l}\text { H1N1 "The Literature" - this week at a glance } \\
\text { June 5, 2009 (369) }\end{array}$ \\
\hline
\end{tabular}

Table 29. Sample of organizations publishing scientific references during the 2009 A(H1N1) outbreak.

Given the extent of the influenza epistemic community, it is impossible to track every single publication related to the influenza outbreak made by its members. Table 30 presents a sample of members from the epistemic community and the number of publications during the pandemic outbreak.

\begin{tabular}{|l|l|l|}
\hline Expert $^{\mathbf{x l v i}}$ & Affiliation & No. of publications $^{\mathbf{x l v i i}}$ \\
\hline $\begin{array}{l}\text { Nancy J. Cox } \\
\text { EC Member }\end{array}$ & $\begin{array}{l}\text { US Centers for Disease Control and Prevention } \\
\text { WHO Reference Laboratory }\end{array}$ & $60(2009-2010)$ \\
\hline $\begin{array}{l}\text { Rogelio Pérez Padilla } \\
\text { EC Member }\end{array}$ & National Institute for Respiratory Diseases, Mexico & $27(2009-2010)$ \\
\hline $\begin{array}{l}\text { Maria Zambon } \\
\text { EC Member }\end{array}$ & Public Health England & $53(2009-2010)$ \\
$\begin{array}{l}\text { Fernando Otazia } \\
\text { EC Member }\end{array}$ & National Infection Control Program, Chile & $11(2009-2010)$ \\
\hline $\begin{array}{l}\text { Francis A. Plummer } \\
\text { Celia Alpuche } \\
\text { Aranda }\end{array}$ & $\begin{array}{l}\text { Microbiology Laboratory, Canada } \\
\text { WHO NIC } \\
\text { Reftitute for Diagnosis and Epidemiological } \\
\text { WHO NIC }\end{array}$ & $20(2009-2010)$ \\
\hline
\end{tabular}

Table 30. Number of publications during the influenza outbreak selected experts. Source: Google

Scholar

\footnotetext{
${ }^{x l v i}$ Dr. Plummer and Dr. Alpuche facilitated cooperation between Canada and Mexico for the identification of the virus early in the outbreak

xlvii It refers to publications in peer reviewed journals, books or collaborations in scientific magazines.
} 
The Global Influenza Programme (GIP-WHO) organized a global consultation to develop a public health research agenda for influenza with more than 150 participants (public health decision-makers, researchers, and representatives from 76 institutions in 37 countries) (336). Besides, the WHO published a list of 59 guidance documents during the response, all of them providing scientific evidence and technical data from professionals in the area of influenza pandemics and response to emergencies (370). Many of them made a direct reference to scientific literature produced by members of the epistemic community. As an example, on April 28 the WHO published the "CDC protocol of real-time RT-PCR for influenza $\mathrm{A}(\mathrm{H} 1 \mathrm{~N} 1)$ ", the CDC is one of the WHO Collaborating Centres for Influenza and Dr. Nancy Cox, Head of the Centre and Influenza Program at the CDC, was one of the Emergency Committee members. The WHO published other documents, with direct policy implications, based on research coming from the epistemic community, such as the document "Characteristics of the emergent influenza A (H1N1) viruses and recommendations for vaccine development" (May 29, 2009). The report included as primary reference the study: "Pandemic Potential of a Strain of Influenza A (H1N1): Early Findings (331)" whose authors included people from Mexico who sent the virus samples to Canada and the USA, personnel working at the Global Influenza Programme from WHO and the Imperial College London.

Dissemination of information was also possible to the connections and structure of the network. The epistemic community at the three levels (national, regional, and global) simplified the exchange of information from the beginning of the outbreak and allowed a faster identification of the strain as well as its notification. Cooperation among Mexico, the United States, and Canada was possible because the officers of these countries had been 
working together in different influenza networks, as part of the pandemic influenza epistemic community (Interviews $1,2,11,12$ ). They have had constant interactions as a result of their participation in networks such as GISN, NAPAPI, GHSI, APEC, PAHO, and the WHO (68) (317).

The epistemic community was also directly involved in the international response at the operational level through two central bodies: GOARN and GISRS. The GOARN coordinated the international response at the technical level and facilitated the travel of experts to countries for investigating and controlling the outbreak (274). Over 44 partner institutions worldwide supported GOARN, which deployed 208 missions to 27 countries (341,336). Appendix F presents the list of partners, which include members of the National Influenza Centres, governments, universities, international organizations, and research institutions. The first responder was GOARN, who called experts from all around the world to help countries. WHO/PAHO provided technical assistance on infection control, field epidemiology, and risk assessment (336). GOARN worked with 44 partner institutions worldwide (336), deploying around 208 missions to 27 countries with 3288 person-days $(336,341)$.

The GISRS provided the "scientific foundation for many response measures" (336). The network with participants in 99 countries (including the National Influenza Centres, WHO Collaborating Centres for Reference and Research on Influenza, Essential Regulatory Laboratories, and WHO H5 Reference Laboratories) provided updated information about laboratory assays and reagents, analyzing the epidemiological situation and vaccine recommendations (336). 
Mexico (the least developed of the three most affected countries) received technical cooperation to identify the virus immediately after notifying the situation ${ }^{x l v i i i}$. This step was crucial in determining the measures to be followed during the international response - the WHO deployed the GOARN, providing technical and material assistance to manage the outbreak. There was an essential exchange of information worldwide, and flows of financial assistance increased to those countries that needed to invest in national capabilities for managing infectious diseases ${ }^{x l i x}$. In response to the outbreak, the international community was able to put in place and test the effectiveness of the new IHRs, created after the SARS and H5N1 outbreaks.

Surveillance was a core issue during the outbreak, given the existing regulatory framework and the infrastructure already in place to manage seasonal influenza. According to Castillo-Salgado, "the WHO, with the assistance of international collaborative centres and recognized academic and scientific leaders, prepared specific guidelines for the surveillance of human infection with influenza $\mathrm{A}(\mathrm{H} 1 \mathrm{~N} 1)$ virus. The use of networks and the internet has facilitated in a few hours the rapid dissemination of these guidelines around the globe (371)."

The epistemic community also institutionalized its bureaucratic power due to its participation directly in the NICs, committees, and expert groups. During the outbreak, this

\footnotetext{
xlviii The WHO sent a group of experts from GOARN to support different areas. Experts from Canada and the CDC went to Mexico to set

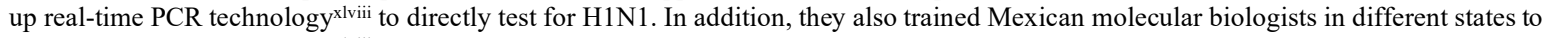

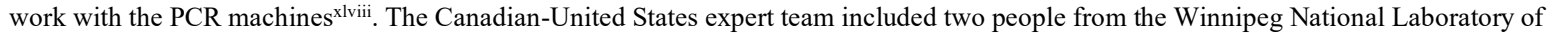
Microbiology, three epidemiologists, two laboratory technicians, and one logistic advisor from CDC Atlanta ${ }^{\text {xlviii. The United States provided }}$ the funding and technical assistance for the construction of a new National Laboratory BSL-3 (Biosecurity Level 3), which will improve Mexico's future capabilities in disease research.

xlix This cooperation included US\$0.68 millions under the concept of development assistance in 2010 to build laboratory capacities (DAC 2013). Other countries provided financial assistance as well. Australia provided a significant amount of money to support actions in South Asia.
} 
power was strengthened through the epistemic community's participation in international fora to discuss and analyze the events as well as to define future measures. The WHO and national governments organized these meetings, which were vital for international coordination and collaboration. For instance, in May 2009, under the celebration of the $62^{\text {nd }}$ WHA, the WHO organized the High-Level Consultation on New Influenza A (H1N1). The meeting had as main speakers the Minister of Health of Canada, the Secretary of Health of Mexico, and the Secretary of Health and Human Services of the USA. All WHO member states were able to send at least one representative to the session ${ }^{1}$. There, members of the epistemic communities (in their different roles- representing governments, international institutions, or the WHO experts) had direct access to the governance process at the global level and were able to participate in discussions directly. In this meeting, the WHO underscored the importance of "having good data for decision-making", and it advised on the importance if policy "to be based on scientific evidence" (290).

Derived from that meeting, the governments of Mexico, Canada, and the US organized another High-Level Consultation in Cancun in June 2009, creating another venue for an exchange of information between experts and policymakers. Their consultation included a high-level meeting and a technical conference. There were 40 Ministers of Health and representatives from other countries and international organizations. Appendix G shows the number of participants in this meeting by country or organization. The technical/scientific agenda included workshops and round tables by leading experts on the topics. There were

\footnotetext{
${ }^{1}$ The meeting was part of the 62th WHA Agenda. Thus, it is not possible to have a specific list of participants since all of them were part of the official delegations.
} 
side meetings, including a GHSI Senior Officials encounter and a high-level NAPAPI meeting ${ }^{\text {li }}$ The Director-General of the WHO, Margaret Chan, attended this meeting along with other WHO officials. PAHO sent a delegation of 20 people, including its Director. In her address, the DG-WHO again emphasized the importance of policies guided by scientific advice, mentioning to the participants that:

"We have the advantages of science, and of rational and rigorous investigation, on our side, supported today by tools for data collection, analysis, and communication that are unprecedented in their power" (372)

These high-level meetings facilitated direct interaction with key actors, and among the members of the epistemic community, and it helped with the dissemination of the epistemic community's research and knowledge.

Even though the epistemic community had a role in the response, its influence had some limits. The H1N1 influenza outbreak showed the realities of not having enough global capacity to supply vaccines during a pandemic. Due to limited availability, only those countries with resources and adequate production facilities (private or public) had access to vaccines in a prompt manner (373). The WHO, working with the scientific community, tried to address this issue years before the 2009 outbreak.

They established some guidelines to increase production and to make more efficient the distribution of vaccines to vulnerable populations (374). The vaccine was developed in the late spring-early summer of 2009. By then, pharmaceutical companies manufacturing it had already committed all their production to countries in Europe, the USA, and Canada. The

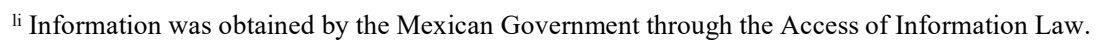


WHO established the WHO Pandemic Influenza A(H1N1) Vaccine Deployment Initiative to mobilize donations and to buy and supply the vaccine for developing countries (336). Thus, manufacturing companies and countries sourced some vaccines to the organization. The world demand was estimated in 4.9 million doses, but by December 2009, only 500 million had been produced (336). Given the demand and the limited production capacity in the world, many countries had to wait longer to access the vaccine $(175,375)$. The countries assisted by the WHO got the donations by December 2009, when developed countries had already started vaccinating their populations. The developed countries that got the vaccine first failed in donating it to the WHO (346).

The problem was not only to produce a vaccine in a short time but that vaccine production concentrated in a group of developed countries and that some countries secured contracts with companies to ensure access to the vaccine in case of a pandemic outbreak (374). Due to this problem, the epistemic community maintained the importance of distributing vaccines to vulnerable people to control the outbreak. Politics, driven by commercial and national interest, ignored the scientific advice and manufacturing companies sold their first stocks to developed countries that had a previous contract with them, regardless of their level of vulnerability. Instead of following a medical and scientific rationale, it was the international market (supply and demand) as well as the fear of the domestic consequences that guided the distribution of these products. Whereas developing countries were trying to access the vaccine, in countries where the vaccine was available, people refused to get it due to the fear of getting ill and the possible side effects (376). An adverse reaction to the vaccine occurred in almost all developed countries, even when experts 
argued that those vaccines were safe and a critical element to contain the outbreak.

There were other areas when governments did not follow the epistemic community's advice. Some countries imposed trade barriers to pork products against experts' advice. An early analysis of the virus showed that it had initially circulated among pigs. Therefore the H1N1 virus was initially named "swine flu" $(377,175)$. Experts researching the influenza animal-human interface from different countries and international organizations, such as FAO and OIE, declared that eating pork meat was safe. There was no scientific evidence to support that limiting exports from affected countries would reduce the risk of contagion (Interview 4). The fear of transmission through infected pigs with the "swine flu," however, caused countries to ban pork meat from Mexico, Canada, and the United States $(378,31,377)$. Russia, China, Indonesia, Thailand, the Philippines, Egypt were among the countries imposing embargos (378). The WHO reported that some countries admitted restricting the entry of animals and goods from most affected countries (175) (Interview 4). Governments established other measures against the WHO`s recommendations without a scientific rationale (175), including cancelation of flights going to affected countries. For instance, China quarantined a flight arriving from Mexico and forced all passengers to stay in a hotel for some days; the government also requested all passengers arriving at the country to report influenza-like symptoms (378). Even though quarantine was not an effective measure to stop transmission, China decided to implement it (Interview 1). The economy of many countries was affected due to these measures (379).

In general, the international response to the H1N1 outbreak had a high level of international cooperation. Based on the analytical model and indicators presented in chapter 
4, Table 31 breaks out the analysis of the international response to the influenza outbreak and provides a quantification of the level of cooperation; it also summarizes how the epistemic community contributed to that level of cooperation. 


\begin{tabular}{|c|c|c|c|c|}
\hline ACTIVITY & MEASURE & Epistemic Community & International Response to Influenza 2009 & $\begin{array}{c}\text { Level of } \\
\text { Cooperation }\end{array}$ \\
\hline \multicolumn{5}{|c|}{ I. International Participation } \\
\hline \multirow{2}{*}{ PROBLEM } & $\begin{array}{l}\text { 1. Timely meetings at } \\
\text { WHO and other } \\
\text { settings. }\end{array}$ & $\begin{array}{l}\text { The epistemic community provided its consensual } \\
\text { knowledge and disseminated it for assessing the } \\
\text { situation at the global level, recommending fast } \\
\text { action. }\end{array}$ & $\begin{array}{l}\text { The Emergency Committee was immediately convened } \\
\text { after notification of the outbreak. }\end{array}$ & 6 \\
\hline & $\begin{array}{l}\text { 2.If there were actions } \\
\text { implemented as a } \\
\text { result of those } \\
\text { meetings }\end{array}$ & $\begin{array}{l}\text { Members of the epistemic community were part of } \\
\text { the Emergency Committee and provided their advice } \\
\text { based on consensual knowledge. }\end{array}$ & $\begin{array}{l}\text { After the First Meeting of the Emergency Committee, the } \\
\text { influenza outbreak was declared a PHEIC, on April } 25^{\text {th }} \text {, } \\
2009 \text { (336). }\end{array}$ & 6 \\
\hline RESPONSE & $\begin{array}{c}\text { Time frame after } \\
\text { notification }\end{array}$ & $\begin{array}{l}\text { Members of the epistemic community participated in } \\
\text { GOARN's activities through the partnerships } \\
\text { established by this network and socialized its } \\
\text { knowledge. }\end{array}$ & $\begin{array}{l}\text { The response occurred immediately after notification. } \\
\text { The WHO deployed GOARN, and the regional offices } \\
\text { also provided direct assistance (336). The GOARN's } \\
\text { assistance to Mexico began on April 24, } 2009 \text { (336). }\end{array}$ & 6 \\
\hline $\begin{array}{l}\text { NO. OF } \\
\text { COUNTRIES }\end{array}$ & Level of participation & $\begin{array}{l}\text { The epistemic community supplied information on } \\
\text { time, provided information recommending } \\
\text { coordinated international action. }\end{array}$ & $\begin{array}{l}\text { Worldwide participation. The WHO Regional Offices } \\
\text { collaborated directly with states. All governments } \\
\text { implemented response actions and cooperated with the } \\
\text { organizations. }\end{array}$ & 6 \\
\hline \multicolumn{5}{|c|}{ II. International assistance } \\
\hline TECHNICAL A. & $\begin{array}{l}\text { Type of participation } \\
\text { in international } \\
\text { missions. }\end{array}$ & $\begin{array}{l}\text { Some members of the epistemic community } \\
\text { participated in these missions as part of the partner } \\
\text { organizations, socializing its ideas. }\end{array}$ & $\begin{array}{l}\text { The number of missions and experts involved made this } \\
\text { the second largest deployment in the history of GOARN } \\
(341) \text {. }\end{array}$ & 6 \\
\hline $\begin{array}{l}\text { FINANCIAL } \\
\text { ASSISTANCE }\end{array}$ & $\begin{array}{l}\text { The amount of money } \\
\text { provided as financial } \\
\text { assistance to address } \\
\text { the emergency }\end{array}$ & $\begin{array}{l}\text { It is not clear how an epistemic community could } \\
\text { have influenced this. However, these experts have } \\
\text { important actors during past pledging conferences } \\
\text { for H5N1. }\end{array}$ & $\begin{array}{l}\text { All activities related to Avian and Pandemic Influenza } \\
\text { have received continuous funding since } 2006 \text {. The H1N1 } \\
\text { outbreak increased donor assistance to finance the } \\
\text { response. }\end{array}$ & 6 \\
\hline TREATMENTS & $\begin{array}{l}\text { Type of population } \\
\text { getting treatments }\end{array}$ & $\begin{array}{l}\text { In this case, there were clear guidelines provided by } \\
\text { the epistemic community for the distribution of } \\
\text { vaccines to vulnerable communities, but they were } \\
\text { largely ignored. }\end{array}$ & $\begin{array}{l}\text { Countries in need received fast assistant for treatments } \\
\text { and medicines (by May } 7^{\text {th }} \text {, Africa received antivirals and } \\
\text { other supplies), but with the vaccine, these countries } \\
\text { were the last in getting them, given that the vaccine } \\
\text { production concentrates in developed countries and its } \\
\text { limited. There were also problems with access to } \\
\text { Tamiflu; the antiviral considered the most effective for } \\
\text { influenza (Interview 2). }\end{array}$ & 3 \\
\hline
\end{tabular}

Table 31. Levels of cooperation Influenza outbreak 


\begin{tabular}{|c|c|c|c|c|}
\hline ACTIVITY & MEASURE & Epistemic Community & International Response to Influenza 2009 & $\begin{array}{l}\text { Level of } \\
\text { Cooperation }\end{array}$ \\
\hline \multicolumn{5}{|c|}{ II. International assistance } \\
\hline \multirow{2}{*}{ PROVISION } & $\begin{array}{l}\text { 1. How fast was } \\
\text { the deployment } \\
\text { of assistance }\end{array}$ & $\begin{array}{l}\text { The epistemic community contributed to a fast } \\
\text { deployment by offering their collaboration and } \\
\text { willingness to assist affected countries. }\end{array}$ & $\begin{array}{l}\text { In general, the provision of essential health services to } \\
\text { countries in need was fast. The WHO mobilized resources } \\
\text { through its regional offices. }\end{array}$ & 6 \\
\hline & $\begin{array}{l}\text { 2.Type of } \\
\text { assistance }\end{array}$ & $\begin{array}{l}\text { The epistemic community participated and promoted } \\
\text { technical assistance for developing countries. Their } \\
\text { socialization of ideas and bureaucratic power helped to } \\
\text { promote assistance. }\end{array}$ & $\begin{array}{l}\text { The WHO and the UN System Influenza Coordination } \\
\text { provided medicines and technical assistance to strengthen } \\
\text { national health systems. }\end{array}$ & 6 \\
\hline \multicolumn{5}{|c|}{ III. Scientific response } \\
\hline SAMPLES & $\begin{array}{l}\text { If countries } \\
\text { have shared } \\
\text { virus samples }\end{array}$ & $\begin{array}{l}\text { The GISRS and NICs were the principal drivers of this } \\
\text { cooperation. These networks have helped to } \\
\text { institutionalize the epistemic community bureaucratic } \\
\text { power. }\end{array}$ & $\begin{array}{l}\text { Mexico shared the virus and donated it to the WHO ( } 317) \text {. } \\
\text { Other countries shared with the WHO } 19284 \text { specimens for } \\
\text { confirmatory diagnosis and characterization between April } \\
19 \text { and November } 28,2009(336,380) \text {. }\end{array}$ & 6 \\
\hline \multirow[t]{2}{*}{ R\&D } & $\begin{array}{l}\text { 1.If data is } \\
\text { disseminated on } \\
\text { time }\end{array}$ & $\begin{array}{l}\text { The scientific and academic community mobilized and } \\
\text { organized several workshops, presentations, and } \\
\text { conferences worldwide ( } 346) \text {. These venues helped to } \\
\text { socialize the epistemic community ideas and transmitted } \\
\text { to policymakers. }\end{array}$ & $\begin{array}{l}\text { Information was shared on real-time, including } \\
\text { epidemiological and clinical data, and there was constant } \\
\text { dissemination of information }(110,317,336) \text {. }\end{array}$ & 6 \\
\hline & $\begin{array}{l}\text { 2.Phases of the } \\
\text { research during } \\
\text { the outbreak }\end{array}$ & $\begin{array}{l}\text { There has been much information published related to } \\
\text { the H1N1 virus; many studies about treatments and } \\
\text { medicines were available during the outbreak. }\end{array}$ & $\begin{array}{l}\text { The Global Influenza Programme started a research agenda } \\
\text { on influenza H1N1, and international meetings were held to } \\
\text { review different topics: clinical management, management } \\
\text { of the pandemic, among others (336). }\end{array}$ & 6 \\
\hline \multicolumn{5}{|l|}{ IV. Policy adoption } \\
\hline SURVEILLANCE & $\begin{array}{l}\text { If countries } \\
\text { implemented } \\
\text { systems to } \\
\text { allowed } \\
\text { constant } \\
\text { notification of } \\
\text { possible cases }\end{array}$ & $\begin{array}{l}\text { The institutionalization of the epistemic community's } \\
\text { bureaucratic power and its network structure was } \\
\text { crucial for the continuous monitoring of influenza } \\
\text { viruses and its evolution, mainly through the Global } \\
\text { Influenza Surveillance Network (GISN) and the NICs } \\
\text { (336). }\end{array}$ & $\begin{array}{l}\text { Most countries implemented Real-time surveillance } \\
\text { systems in the influenza pandemic }(381,110) \text {. Countries } \\
\text { used different early warning and surveillance systems } \\
\text { already in place. The NICs informed and sent data to } \\
\text { FluNet, which by November } 2009 \text {, had received data from } \\
82 \text { countries ( } 336) \text {. }\end{array}$ & 6 \\
\hline
\end{tabular}

Table 31. Analysis level of cooperation Influenza 2009(H1N1) outbreak (Cont.) 


\begin{tabular}{|c|c|c|c|c|}
\hline ACTIVITY & MEASURE & Epistemic Community & International Response to Influenza 2009 & $\begin{array}{l}\text { Level of } \\
\text { Cooperation }\end{array}$ \\
\hline \multicolumn{5}{|l|}{ IV. Policy adoption } \\
\hline NOTIFICATION & $\begin{array}{l}\text { How long did } \\
\text { countries wait to } \\
\text { notify the WHO } \\
\text { after identifying } \\
\quad \text { the cases? }\end{array}$ & $\begin{array}{l}\text { Epistemic community socialization of ideas through a } \\
\text { network and the level of institutionalization of its } \\
\text { bureaucratic power made quick notification possible. } \\
\text { The collaboration of a network of experts from Mexico, } \\
\text { Canada, and the USA, who worked together to identify } \\
\text { the virus, permitted to inform the WHO promptly. }\end{array}$ & $\begin{array}{l}\text { The countries that detected the virus first were Mexico } \\
\text { and the USA. Both countries followed international } \\
\text { norms, the IHRs } 2009 \text {, and notified promptly to the } \\
\text { WHO ( } 98,382) \text {, within the } 24 \mathrm{hrs} \text { after identification. } \\
\text { After the first cases, other countries continued notifying } \\
\text { cases to the WHO. }\end{array}$ & 6 \\
\hline \multirow[b]{2}{*}{$\begin{array}{c}\text { POLICY } \\
\text { CONVERGENCE }\end{array}$} & $\begin{array}{l}\text { 1. How broad } \\
\text { were the } \\
\text { recommendations } \\
\text { adopted and } \\
\text { implemented? }\end{array}$ & $\begin{array}{l}\text { There were limits to the epistemic community's } \\
\text { socialization of ideas. Some countries did not follow } \\
\text { advice and recommendations from the Emergency } \\
\text { Committee and decided to implement actions without } \\
\text { scientific support (357). }\end{array}$ & $\begin{array}{l}\text { Countries imposed unilateral travel and trade restrictions } \\
\text { (357), including the USA (276). There were also cases } \\
\text { of quarantines and cancelation of flights. Many states } \\
\text { also disregarded expert reports and banned pork imports } \\
\text { from several countries }(98,378,31,357,377) \text {. }\end{array}$ & 2 \\
\hline & $\begin{array}{l}\text { 2. The degree of } \\
\text { adoption of } \\
\text { international } \\
\text { norms. }\end{array}$ & $\begin{array}{l}\text { The institutionalization of power through the years has } \\
\text { helped to improve the system of influenza governance } \\
\text { and the implementation of the IHRs in some countries. }\end{array}$ & $\begin{array}{l}\text { The most critical issue was the adoption and } \\
\text { implementation of the guidelines set by the IHRs } 2005 \\
\text { for notification, surveillance, and response. The most } \\
\text { affected countries (The USA, Canada, and Mexico) } \\
\text { followed the procedures. However, some countries } \\
\text { failed to comply and underreported or failed to report } \\
\text { cases (357). }\end{array}$ & 4 \\
\hline
\end{tabular}

Table 31. Analysis level of cooperation Influenza 2009(H1N1) outbreak (cont). 
Although there were some problems in the international response, it was on time and effectively managed the outbreak. Considering all these events, it is possible to categorize the level of cooperation in the international response as high, and there is evidence of an epistemic community participating and increasing the level of cooperation.

\subsection{Conclusions}

The analysis of international response to the influenza pandemic outbreak of 2009 based on the analytical model presented in chapter 3 provides evidence that the level of cooperation was high, and the participation of an epistemic community contributed to this level.

The analysis of the events concludes that the influenza epistemic community developed consensual knowledge and a policy goal. During the outbreak, it provided advice and knowledge about the situation and the process, and it had direct involvement in the policy-making process. The findings indicate that the epistemic community was a prominent actor during the influenza H1N1 outbreak. Its members acted in their role of experts in different positions and as decision-makers. They collected information, analyzed it, and generated evidence for the definition of the best interventions to manage and control the outbreak. Policymakers adopted and followed most of the recommendations suggested by this group. They framed the response and eased communication and collaboration among countries and with international organizations.

As members of an extensive network, with worldwide membership and branches that reached different levels (local, regional, global), they were able to connect and disseminate evidence-based policy advice. The provision of evidence-based policies and their implementation improved collaboration among countries. Their participation in the response 
as advisors and the field allowed the WHO to deliver appropriate guidance to the international community. The long history of the epistemic community and constant interactions of its members eased communication and enabled connections based on trust and shared understanding. The epistemic community`s members were able to connect fast and react to the situation, collaborating among them but also enabling cooperation among countries. The history of interactions, the size of the network and the work that it has done, helped to build a system of preparedness and response globally, where "even the poorest countries in the world have some systems to respond to influenza" (Interview 12).

Since epistemic communities are embedded in an international system formed by international organizations and nation-states, in this case, the WHO has facilitated the participation and influence of the epistemic community by creating a global system of influenza collaboration. The establishment of different networks long before the 2009 outbreak has allowed building strong relations, confidence, and trust among individuals and institutions (Interview 1, 2, 6). Members of the epistemic community have also created personal relationships that permit closer communication and cooperation. Through the WHO, these experts have direct access to the global system of influenza governance, and they have the power to persuade national governments about the importance of implementing global policies based on scientific evidence and guided by experts' knowledge.

The analysis of the characteristics of the influenza epistemic community also recognizes its direct connection with the process of the international response to a disease outbreak, which made it possible for the epistemic community to influence international cooperation. Therefore, we can conclude that the presence of an epistemic community, that provided consensual knowledge and a policy goal consonant with the policy process, with 
the channels to disseminate and reach policymakers and that was able to consolidate bureaucratic power in the system of influenza governance, likely improved international cooperation during the H1N1 influenza outbreak. 


\section{Chapter 6: Middle East Respiratory Syndrome MERS-CoV}

\subsection{Introduction}

The Middle East Respiratory Syndrome (MERS-CoV) was the second outbreak assessed under the IHRs 2005. MERS-CoV is a novel coronavirus that can cause a mild cold or more severe illness like SARS $(383,384,385)$. SARS and MERS-CoV have some similarities, such as being of zoonotic origin from the same family (386). In both cases, air travel facilitated global transmission $(386,387,388)$. Recent research shows, however, that MERS-CoV has been causing multiple transmission events from animals to humans, while SARS has been detected only twice since the virus was discovered (389). Furthermore, during the initial stages of the outbreak, MERS-CoV showed a higher mortality rate than SARS (55\% for MERS-CoV and 40\% for SARS) (386). Box 2 summarizes the disease characteristics.

\section{Box 2. Coronaviruses}

\section{Origin of coronaviruses}

Scientists first identified coronaviruses in animals in the late 1930s, including highly pathogenic viruses in livestock, laboratory animals, and pets (390). Coronaviruses, however, were, for a long time considered as not harmful to humans. Scientific and medical experts recognized the danger posed by these viruses with the SARS outbreak in 2002/2003 (391,390). After the SARS outbreak, other human coronaviruses have been detected: the HCoV NL63 and HCoV HKU1 in 2004 and 2005; and, more recently, the Middle East Respiratory Syndrome (MERS-CoV) (390,252).

The Coronavirus Study Group of the International Committee on Taxonomy of Viruses classifies coronaviruses in four species of Coronaviridae: Alphacoronavirus, Betacoronavirus, Gammacoronavirus, and Deltacoronavirus (389,391,390). The Alphacoronavirus contains two human coronaviruses associated with the common cold: HCoV-229E and HCoV NL63. Beta coronavirus has four subtypes $\mathrm{A}, \mathrm{B}, \mathrm{C}$, and $\mathrm{D}$, containing four coronaviruses associated with human infections: HCoV-OC43 and HKU1 (lineage A); SARS-CoV (lineage B); and MERS-CoV (lineage C) $(391,392,393,390)$. 


\section{Box 2. Coronaviruses (cont.)}

\section{Nature of the disease}

Evidence strongly supports that coronaviruses are from zoonotic sources, mostly found in wildlife $(252,391,390)$. After the SARS outbreak, viruses related to this strain were found in small mammalian species such as Himalayan palm civets, raccoon dogs, bats, and others $(390,252)$. The MERS-CoV is the first betacoronavirus in the $\mathrm{C}$ lineage associated with human infection, and it has been associated with other beta coronaviruses as well. Some evidence links the virus to animals like camels, goats, sheep, and farm animals. Scientists believed that the virus likely emerged in a natural reservoir. Evidence shows that it might be closely related to other betacoronaviruses in the $\mathrm{C}$ lineage found in bamboo bats and Japanese Pipistrelle bats, species captured in Hong Kong (391). Other novel coronaviruses have also been identified in bats (252).

Most research concentrates on bats since these animals are likely the host of these viruses $(391,392,394,395,390)$. Recent research also presents some evidence that these viruses switch from their host to other species, likely from bats to humans $(391,390)$. Nonetheless, in the case of MERS $\mathrm{CoV}$, a study by Haagmans et al. (2014) suggested that the virus was transmitted directly from dromedary camels to a person (392). Later, other scholars confirmed these findings $(389,396,397)$.

\section{Global Threat}

The novelty of coronaviruses makes it more difficult to find adequate medical interventions in this type of outbreak. During the SARS-CoV outbreak, the nucleotide (DNA) sequence was found a few weeks after the outbreak, and there was a lack of information and data on the structure of the virus (252). Most recent studies show some advances in the developing of drugs to fight coronaviruses like SARS (252). Scientists have made some advances to understand the genomic structure of SARS$\mathrm{CoV}$, which is imperative to understand the function of this type of viruses (252). Recently, the WHO included MERS-CoV in the list of priority diseases for the WHO R\&D Blueprint and Global Program. In one of the working group's meetings, experts discussed principles to design trials for specific treatments and a vaccine $(398,399)$.

Notification of cases has been constant since 2012. The last significant outbreak of MERS-CoV occurred in the Republic of Korea in 2015 with 185 cases. There has been a small response to the outbreak, although a global mobilization has not happened yet. The level of international cooperation, therefore, has been low to medium. The basis of the argument rests on the evidence that coronaviruses -like SARS- cause pandemics, and international cooperation is necessary to contain them and manage them. Although MERSCoV represents a threat to global health, the WHO and other organizations have limited their response to technical assistance to Middle East countries and the region to control and manage cases. What are the factors limiting the level of cooperation and an official 
declaration by the WHO of MERS as a PHEIC?

The reaction to the MERS outbreak could be due to a concentration of cases in Saudi Arabia. Experts blamed the authorities of this country for withholding information and for lack of transparency (400). Limited data has restricted research related to the virus, knowledge about the disease's transmission mechanics, and the development of better treatments.

In contrast, international travel and concerns for the spread of the virus through mass gatherings brought some attention to the MERS-CoV outbreak due to the influx of visitors to the Middle East every year during the Hajj pilgrimage and the potential for a massive epidemic during such an event $(134,386,388)$. Some of the measures that have been established to contain the outbreak have been the result of limiting cases during the pilgrimage and reducing the number of exported cases to more regions (401).

These contextual factors have impacted the level of cooperation seen during the international response to MERS-CoV. However, to what extent has an epistemic community influenced this cooperation? There is evidence of an epistemic community in coronavirus by the time of this outbreak started. The participation of the epistemic community, however, has also been affected by factors such as limited access to information and the level of secrecy kept by the government of Saudi Arabia (400). Although MERS-CoV is a new virus, it comes from a family of diseases already known and, to some degree, studied. This epistemic community, however, did not have a strong influence on the international response, and it has been unable to position itself as a key actor in the policymaking process at all levels. Figure 18 illustrates the MERS epistemic community connection with the low level of international cooperation. 


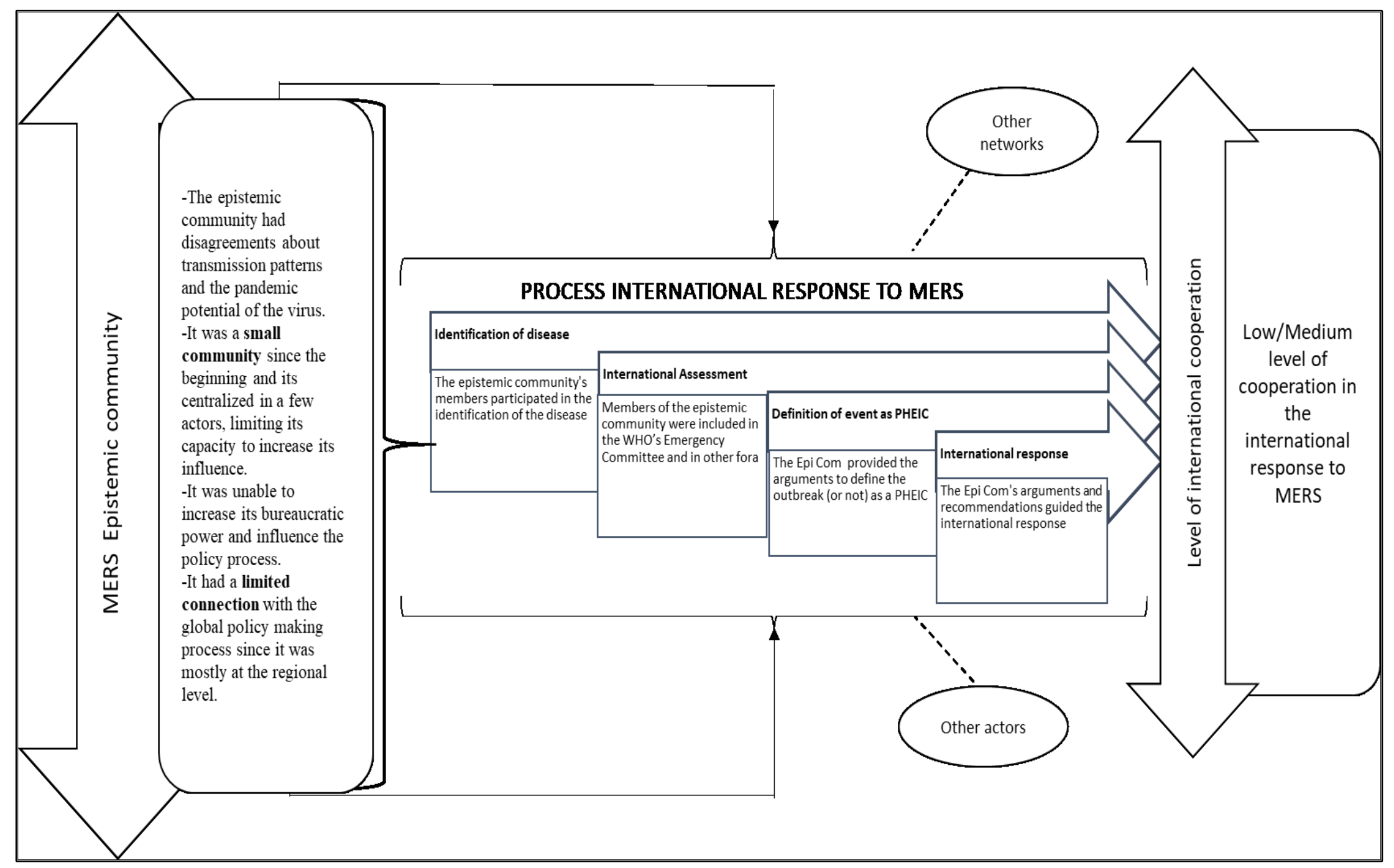

Figure 18. MERS epistemic community and its connection to the international response. 
Therefore, the research characterizes the MERS-CoV's epistemic community with a lower capacity to influence higher levels of international cooperation and a formal international response to the disease outbreak.

\subsection{The MERS-CoV outbreak}

In June 2012, health professionals identified the index case of MERS-CoV as a patient who died of acute pneumonia in Saudi Arabia $(383,395,402,403,394)$. The UK officially notified the first case to the WHO in September 2012, a patient originally from Qatar that had traveled to Saudi Arabia before getting ill (404). By the end of 2012, the UK, Jordan, and Saudi Arabia all reported cases and deaths due to the virus (405). Subsequent cases have mostly been detected in the Arab peninsula $(383,406,407,408)$.

The virus was initially detected in Saudi Arabia by the virologist Ali Mohamed Zaki. Dr. Zaki took samples from a patient at Dr. Soliman Fakeeh Hospital in Jeddah, who presented severe pneumonia and tested negative for all usual tests (409). The virologist sent the samples to the head of the Virology Lab at the Erasmus Medical Centre in Rotterdam $(410,409)$. Both Dr. Zaki and the Dutch Lab would later confirm that the virus was a novel type of coronavirus later named Middle East Respiratory Syndrome (MERS-CoV) (409). Given that a virus of this type caused the SARS outbreak in 2003, Dr. Zaki decided to publish a note on ProMED ${ }^{\text {lii }}$ to alert the research community and public health agencies.

The government of Saudi Arabia did not welcome Dr. Zaki's actions and the hospital where he was working decided to end his contract (409). Later the Ministry of Health, represented by its Deputy Health Ministry Dr. Zaid Al-Memish, claimed that the government

\footnotetext{
${ }^{\text {lii }}$ ProMED is the Program for Monitoring Emerging Diseases. An Internet-based reporting system, the program allows the global dissemination of information on outbreaks of infectious diseases on real time (716).
} 
did not consent to the sharing of the virus between the Saudi doctor and the Dutch laboratory. At the centre of this dispute was the fight for patent rights of the virus (410).

Saudi Arabia did not inform the WHO of this coronavirus case, and between June and September of 2012, more cases emerged in the country, but health officials remained silent. The circumstances changed when cases of MERS were detected outside the Arabia Peninsula, and the United Kingdom officially notified the first case to the WHO on September 22, 2012 (411). The St. Thomas's Hospital in London informed the former Health Protection Agency (now Public Health England) about a man who had arrived from Qatar with symptoms of a severe respiratory infection. Similar to the first case in Saudi Arabia, the patient tested negative for known diseases. Scientists in Public Health England found Dr. Zaki's note in ProMed and matched the symptoms in both patients.

Notification of the first case of MERS was only possible after a group of scientists isolated the virus in the Netherlands and published the results in November 2012 (412). The Public Health Protection Agency proceeded to identify the genetic sequence of the virus, and the results were almost identical to the virus already sequenced by the Erasmus Medical Centre (409). With this information, the government notified the WHO. By July $7^{\text {th }}, 2013$, the WHO confirmed 80 cases, including 44 deaths, in Jordan, Qatar, Saudi Arabia, the United Arab Emirates (UAE), France, Germany, Italy, Tunisia, and the United Kingdom (385). With more cases worldwide, the WHO alerted the international community (413).

One of the factors that impeded prompt action was the scarce information shared by Saudi Arabia. The WHO later requested all countries to share samples with the WHO immediately if unusual cases were detected (410). Saudi Arabia later agreed to share the 
samples with the U.S. Centres for Disease Control, in part due to the WHO's intervention (409).

Another major outbreak occurred in the Republic of Korea in 2015, with 185 cases. It was the first significant outbreak outside the Middle East. The outbreak in Korea highlighted how travel facilitated the transmission of the disease since all cases outside the Arab peninsula originated in people returning from this region $(402,394,387,384,414,408,415)$. People transmitted the virus to family and health workers in clusters, similar to the situation during the SARS outbreak $(416,402,394,417,418,419,420,421)$. The disease predominantly affected health care workers. This group was highly vulnerable due to the lack of information about the disease, and that medical workers were most of the time unable to recognize the symptoms $(422,407,417)$.

There is evidence to support human to human transmission; however, there is no conclusive evidence on how efficient this is $(383,394,384,423,403,393)$. As of March 2019, 27 countries reported 2374 laboratory-confirmed cases, including 823 associated deaths (424) (See Appendix I). Table 32 summarizes the characteristics of MERS.

\begin{tabular}{|c|c|}
\hline & MERS CoV 2012 \\
\hline Virus & Coronavirus \\
\hline Case Fatality Rate & $35 \%$ liii \\
\hline Type of transmission & Animal to Human \\
& Human to human \\
\hline No. of cases & 2374 (March 2019) \\
\hline No. of countries & 22 \\
\hline Treatment & Unknown \\
\hline Vaccines & None available yet \\
\hline
\end{tabular}

Table 32. Characteristics of the MERS-CoV outbreak.

\footnotetext{
liii This rate has varied during the outbreak, with peak periods of 50\% (715).
} 
The lack of knowledge about the MERS-CoV may increase the risk of transmission in the future due to the inadequate management of cases (415). Surveillance and notification of isolated cases, mostly from Saudi Arabia, continue. Countries will likely report more cases in the future (407). Nonetheless, the response concentrated on establishing a research agenda under the WHO R\&D Blueprint Initiative (397). In 2012, the WHO concluded the outbreak was not a PHEIC, and the organization did not call for a new Emergency Committee meeting to reassess the most up-to-date evidence nor the 2015 outbreak in Korea.

\subsection{The MERS epistemic community}

The MERS-CoV outbreak is the only case analysed in this research that was assessed by an Emergency Committee that decided not to characterize the event as a PHEIC. Therefore, the EC did not call for a formal international response under the IHRs 2005. There was a response, however, mostly at the regional level, organized by the most affected countries and closely coordinated by the WHO, the Food and Agriculture Organization (FAO), and the World Organization for Animal Health (OIE) given the zoonotic origins of the disease and the interest in the confirmed animal-human transmission. The following analysis will provide better evidence about the context, the MERS epistemic community, and its possible impact on the events.

\subsubsection{Origins of the MERS epistemic community: the Coronavirus epistemic} community.

After the SARS outbreak, the WHO established the Coronavirus Lab Network (CLN), a group of 11 laboratories in the world, the first of its kind. The network researches these pathogens and works in the development of a test for the rapid identification of the virus (425). Currently, the CLN has 13 members (426). This network has helped to advance 
our understanding of coronaviruses, thereby establishing the foundation of an epistemic community. As in other cases, the WHO is a central actor in this epistemic community and acts as coordinator of the group. Members of the coronavirus epistemic community are part of the WHO's body of expert advisors and had provided the organization with information to face other outbreaks. The coronavirus epistemic community, however, has not been able to strengthen its influence into the WHO and other institutions, in part because the interest in researching SARS and similar viruses lost traction due to lack of funding (252).

When MERS-CoV emerged, people from this network of institutions were called to participate in the expert groups that this research identifies as the core of the MERS-CoV epistemic community. These groups are:

- The Coronavirus Study Group (CSG) of the International Committee on Taxonomy of Viruses which unified the scientific community and research by agreeing on the new pathogen's name (393);

- The WHO MERS-CoV Research Group (402);

- The MERS Emergency Committee established in July 2013;

- Group of experts participating in WHO technical consultations on MERS-CoV, WHO Blueprint Programme (399).

The CLN participates with 7 of its 13 institutions in these expert groups. Each of these seven institutions participated in one or more of these core groups with at least one expert. Table 33 presents the CLN institutions with participating members in the MERS CoV epistemic community's core groups and the number of experts representing each CLN institution. 


\begin{tabular}{|l|l|c|c|c|c|c|c|c|}
\hline \multicolumn{1}{|c|}{ Country } & \multicolumn{1}{|c|}{ Institution } & CLN & $\begin{array}{c}\text { EC- } \\
\text { MERS }\end{array}$ & $\begin{array}{c}\text { MERS } \\
\text { CoV } \\
\text { RG }\end{array}$ & $\begin{array}{c}\text { CSG } \\
\text { ICTV }\end{array}$ & $\begin{array}{c}\text { WHO } \\
\text { MERS } \\
\text { R\&D }\end{array}$ & $\begin{array}{c}\text { WHO } \\
\text { BP } \\
\text { VT }\end{array}$ & $\begin{array}{c}\text { IC } \\
\text { MERS } \\
\text { CoV } \\
\text { EMRO }\end{array}$ \\
\hline Canada & $\begin{array}{l}\text { Public Health Agency } \\
\text { of Canada }\end{array}$ & 1 & 1 & & & & & \\
\hline UK & Public Health England & 1 & 1 & 2 & 2 & 1 & 1 & 1 \\
\hline USA & $\begin{array}{l}\text { Centres for Disease } \\
\text { Control and Prevention }\end{array}$ & 1 & 1 & 2 & & 1 & 2 & 4 \\
\hline China & China CDC & 2 & & & & 1 & & \\
\hline Netherlands & Erasmus MC & 1 & & 4 & 2 & 2 & & \\
\hline France & Institut Pasteur & 1 & & 3 & & 1 & & 1 \\
\hline Hong Kong & University of Hong & 2 & & 2 & 2 & & & 1 \\
\hline
\end{tabular}

CLN: Coronavirus Lab Network; EC-MERS: Emergency Committee; MERS CoV RG: MERS CoV Research Group; CSG ICTV: Coronavirus Study Group (CSG) of the International Committee on Taxonomy of Viruses; WHO MERS R\&D: WHO Consultation on MERS COV R\&D; WHO BP VT: WHO consultation on MERS-CoV vaccine and therapeutics

Table 33. Institutions with experts participating in the core groups of the epistemic community.

The coronavirus epistemic community led to the creation of the MERS-CoV epistemic community, given their expertise and knowledge obtained since 2003. To understand how much was able to influence the level of international cooperation in the international response to MERS, this section will analyse the epistemic community's characteristics.

\subsubsection{Characterizing the MERS epistemic community}

There is evidence that the previously organized coronaviruses epistemic community merged into the epistemic community for MERS-CoV. These experts, with experience in coronaviruses like SARS, joined efforts with experts from the most affected countries, mostly from the Arab Peninsula. This group has been growing over the years, and it has been continuously collaborating with the WHO. The group, however, has faced barriers to access information and internal disagreements.

\subsubsection{Knowledge}

When the WHO announced the first cases of MERS, scientists, experts in infectious 
diseases, and public health professionals faced more questions than they had answers (391). Besides some similarities with SARS (391), MERS-CoV was a mystery for the scientific community. There was no idea about where the virus originated from (host) and its transmission mechanism. By the time MERS-CoV appeared, research in coronaviruses had not sufficiently advanced to understand these pathogens or the outbreak, and there was insufficient data to develop quick treatments. Experts insisted on the need for more studies about the novel virus, the human-animal interface, risk factors, transmission, treatments, and vaccines $(252,427)$. MERS-CoV showed a case fatality rate up to 50 percent during some periods, for a disease that practitioners did not know how to treat $(416,391,428)$. The situation brought some concern, but some characteristics of the outbreak made some experts disagree with an immediate international response: the virus was showing only a limited human to human transmission $(416,403,391)$, and cases were mostly in the Middle East.

The existence of conflicting and insufficient evidence regarding the level of severity of MERS-CoV impeded the possibilities to reach a consensus within the epistemic community. Some scholars considered there was not enough evidence about the possibility of airborne transmission $(429,417,415)$. Other experts agreed that the evidence of sustained human-to-human transmission was scarce, dismissing MERS as having pandemic potential (418) whereas others did not discard this possibility, given that in South Korea the outbreak reached 184 cases in two months (430). This disagreement was strengthened by variation in the estimations of the pandemic potential of the disease. The first studies projected different reproductive numbers $\left(\mathrm{R}_{0}\right)$, between a range of 0.3 and $1.5(422)$. A $R_{0}$ of less than 1 indicates that there is no pandemic potential (383). Breban et al. presented two scenarios in the early stages of the outbreak, the optimistic one, with a $\mathrm{R}_{0}$ of 0.60 and a pessimistic with a $\mathrm{R}_{0}$ of 
0.69 (423). Later, Chowell et al. presented another model distinguishing between transmission by index cases and by secondary cases (422). The study found central estimates of $\mathrm{R}_{0}$ between 0.8 and 1.3 (402). In their model, they estimated a $\mathrm{R}_{0}$ of 0.88 for index cases while they concluded that secondary cases were less effective with a $\mathrm{R}_{0}$ of 0.36 (422). In another analysis, Cauchemez et al. (2014) calculated a $\mathrm{R}_{0}$ of 0.63 . These studies acknowledged the scarce data and the problem of underreporting $(402,418)$. Other studies warned of the risk of patients already infected but asymptomatic, that travel and increase the potential of a global pandemic (431). Some experts considered that MERS-CoV could evolve and increase its efficiency in human to human transmission as well as create a pandemic $(402,394,431,432)$. The WHO recognized the variability of the reproductive ratio (407).

Currently, the most important scientific consensus is the zoonotic origin of the virus. Dromedary camels are the main reservoir and source of zoonotic transmission to human populations $(433,397,392,432,434,435,436,437)$. It is still not clear, however, how the transmission occurs $(389,397,435)$. MERS cannot be clinically distinguished from other types of respiratory illnesses in its early stages (397). It can only be detected by laboratory tests that take several days to process, increasing the risk of transmission (397,391). This is a common challenge with many emerging infectious diseases: front line doctors and health workers are not familiar with the symptoms, creating a delay in diagnosis and treatment (Interview 11).

More research is needed to understand the clinical evolution of the disease and to improve diagnostic methods, which are currently available only with molecular diagnosis methods (PCR, sequencing, and molecular data) (438,396). Scientists agree that developing commercial tests is also necessary to make diagnostic tests more accessible $(397,402)$. There 
are no specific treatments for MERS-CoV, and some doctors use experimental ones developed for SARS (397), as well as treatments developed for other infectious diseases. There are new efforts to produce a vaccine, with a dozen in preclinical development $(397,429)$.

Since the international community was dealing with a new pathogen, it seemed logical that the most crucial step for delineating policies at any level was gathering information. Therefore, the epistemic community's policy goal focused on improving the global health response through investing in research; strengthening collaboration and coordination for improving information sharing $(397,439)$.

\subsubsection{Socialization of ideas}

To analyse how the epistemic community socialized its knowledge and use of diffusion mechanisms to influence the policy-making process, it is necessary first to understand its structure. The members of the MERS epistemic community included policymakers from affected governments and international organizations, scientists, epidemiologists, technicians, virologists, and health experts working on understanding the virus and developing effective measures to control the outbreak and treat the disease (Interview 4). Since SARS and influenza, the international collaboration to address zoonotic diseases increased, allowing a more multidisciplinary approach known as "One Health" (252). The initiative prompted closer collaboration among three UN agencies: the WHO, the FAO, and the OIE. Members of the three agencies have been an essential part of the epistemic community. The groups identified in table 31 (CLN; EC MERS CoV; MERS CoV REG;

CSG ICTV; WHO MERS R\&D; WHO BP VT; IC MERS CoV EMRO) had members in 35 countries concentrated in Europe, North America, and the Middle East. Figure 19 shows the 
geographical distribution.

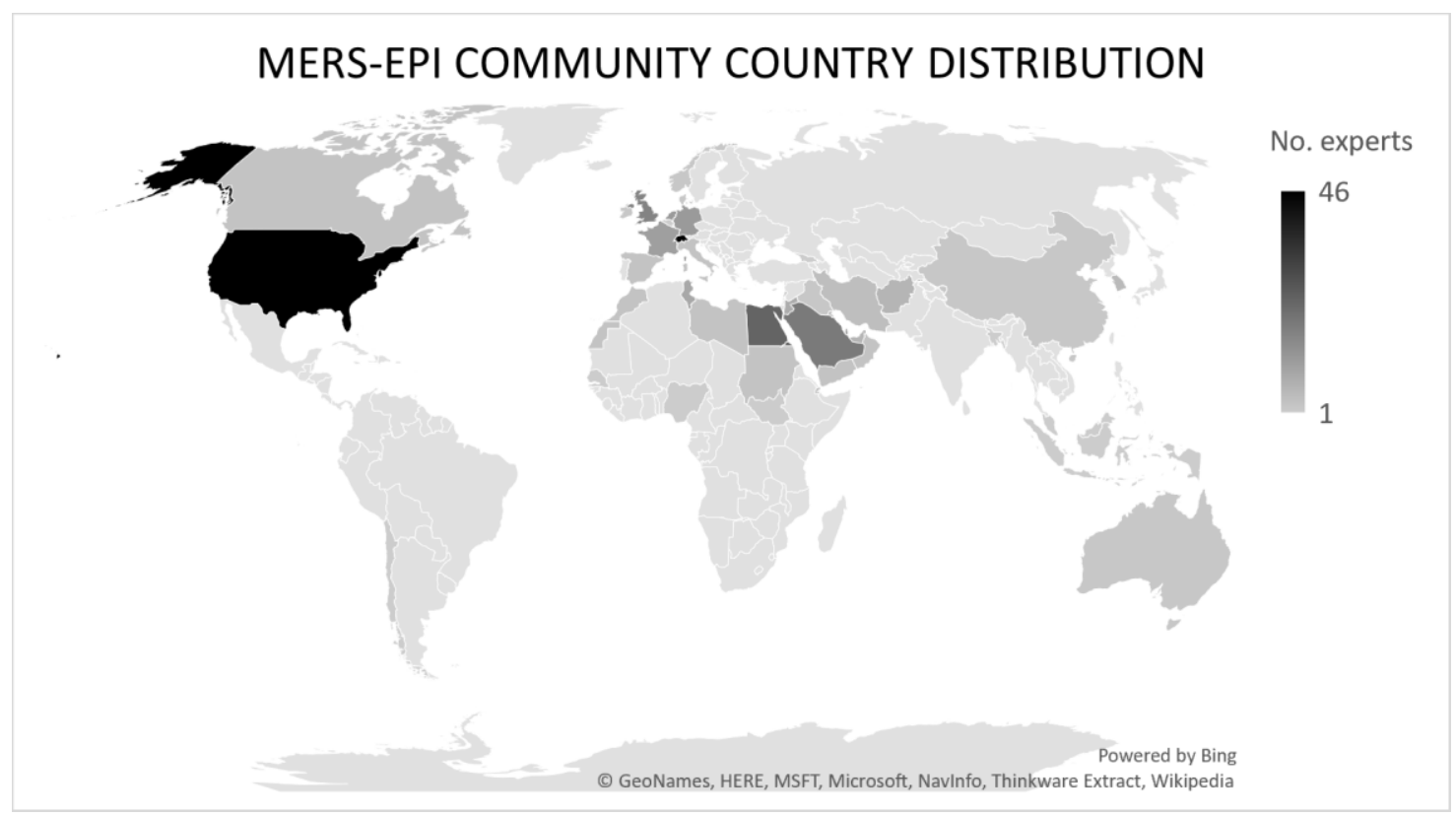

Figure 19. Geographical distribution of MERS CoV epistemic community main members.

Members of the epistemic community participated in multiple groups. Therefore, their overlapping participation created interconnections within the epistemic community. From all the members identified in the core groups, table 34 presents those members that participated in more than one. Appendix J includes the full list of members.

Even though the map shows an expanded network, through several regions, only a small group of institutions and countries continuously participate. The network includes health and animal experts from of Saudi Arabia, Qatar, United Arab Emirates, Kuwait, Oman, Egypt, Jordan, the US Centres for Disease Control and Prevention, Institute Pasteur of France, the Chinese University of Hong Kong, Erasmus Medical Centre-Erasmus University in Netherlands, University of Bonn in Germany and the WHO, FAO and OEI (See Appendix J). 


\begin{tabular}{|c|c|c|c|c|c|c|c|}
\hline Name & Country & Institution & $\begin{array}{c}\text { EC- } \\
\text { MERS }\end{array}$ & $\begin{array}{l}\text { MERS CoV } \\
\text { RG }\end{array}$ & $\begin{array}{l}\text { CSG } \\
\text { ICTV }\end{array}$ & $\begin{array}{l}\text { WHO MERS } \\
\text { R\&D }\end{array}$ & $\begin{array}{l}\text { WHO BP } \\
\text { VT }\end{array}$ \\
\hline Ziad Memish & Saudi Arabia & Ministry of Health & & & & & \\
\hline Maria Zambon & UK & Public Health England & & & & & \\
\hline Christian Drosten & Germany & University of Bonn Medical Centre & & & & & \\
\hline Bart L. Haagmans & Netherlands & Erasmus MC & & & & & \\
\hline Ron A. M. Fouchier & Netherlands & Erasmus MC & & & & & \\
\hline Maria Van Kerkhove & Switzerland & World Health Organization HQ & & & & & \\
\hline $\begin{array}{l}\text { Mohammed } \\
\text { Mohammed Al-Hajri }\end{array}$ & Qatar & Supreme Council of Health & & & & & \\
\hline Marion Koopmans & Netherlands & Erasmus Medical Centre & & & & & \\
\hline $\begin{array}{l}\text { Abdullah Mufareh } \\
\text { Assiri }\end{array}$ & Saudi Arabia & Ministry of Health & & & & & \\
\hline Cathy Roth & Switzerland & World Health Organization HQ & & & & & \\
\hline Peter Ben Embarek & Switzerland & World Health Organization HQ & & & & & \\
\hline Richard Pebody & UK & Public Health England & & & & & \\
\hline $\begin{array}{l}\text { Farida Ismail Al } \\
\text { Hosani }\end{array}$ & $\begin{array}{l}\text { United Arab } \\
\text { Emirates }\end{array}$ & Ministry of Health & & & & & \\
\hline Luis Enjuanes & Spain & $\begin{array}{l}\text { Campus de la Universidad Autonoma } \\
\text { de Madrid }\end{array}$ & & & & & \\
\hline Myoung-don Oh & South Korea & $\begin{array}{l}\text { National University College of } \\
\text { Medicine }\end{array}$ & & & & & \\
\hline Frederick G. Hayden & USA & $\begin{array}{l}\text { University of Virginia School of } \\
\text { Medicine }\end{array}$ & & & & & \\
\hline
\end{tabular}

EC-MERS: Emergency Committee; MERS CoV RG: MERS CoV Research Group; CSG ICTV: Coronavirus Study Group (CSG) of the International Committee on Taxonomy of Viruses; WHO MERS R\&D: WHO Consultation on MERS CoV R\&D; WHO BP VT: WHO consultation on MERS-CoV vaccine and therapeutics

Table 34. Members interconnecting the core epistemic community's groups. 
The MERS epistemic community started as a small group, but it increased its size over time. Members of the network, however, are mostly concentrated in the Middle East Region, the WHO, and some other countries with research and laboratory capacities. Staff and experts from the WHO Geneva and the Regional Office EMRO were constant members of the community, and they concentrated the core of the community. The CDC in the USA is the second most influential institution in the epistemic community.

The structure of the epistemic community affected their connexion with the policy process and the way it disseminated its knowledge. The epistemic community was highly centralized and concentrated in the WHO, with more than 60 experts participating through Geneva and the Regional Office, which means that all information and connections depended on it. The MERS CoV epistemic community was less flexible and less open than others, limiting its possibilities of expanding its membership and influence. These characteristics did not favor the dissemination of information when research and development of data were necessary to produce information and scientific evidence for guiding policy interventions $(440,427)$.

The 2012 MERS outbreak increased the scientific and academic interest in coronaviruses but still far from the levels seen with SARS. Perl and Savor Price identified only 475 scientific papers (peer-reviewed) after 33 months of the outbreak (427). They compared this response with SARS, for which, in the same period (33 months), scholars published 2854 papers (427). Another study focuses on the articles related to the outbreaks in Saudi Arabia; the authors found that 68 articles were published in total and that the WHO Epidemiological Bulletin only included six articles related to these outbreaks. The last figure is relevant since the Bulletin is the most important source of scientific information, and it directly targets 
policymakers (406).

These articles were published in 40 journals, including Emerging Infectious Diseases, the International Journal of Infectious Diseases, Clinical Infectious Diseases, the American Journal of Roentgenology, Eurosurveillance, mBio, Epidemics, The Lancet, New England Journal of Medicine and PLoS Current Outbreaks (406). Many of these publications appeared after the initial outbreak ended (406). Some members of the epistemic community were publishing and sharing information through different publications.

Dissemination was also affected by some scientists working with MERS that did not provide information on time or withhold data to be the first people publishing about the virus [ (98) Interview 5]. This problem hindered access to faster research. National governments contested free scientific exchange of MERS samples, given the problems with patent rights and access to benefits (410).

The direct participation of members of the epistemic community in the international response also influences the dissemination process. The WHO's response required collaboration for the detection and identification of the virus. Some members of the epistemic community participated in a small network of global partners for scientific and technical collaboration, presented in Table 35. 


\section{Members network global partners MERS-CoV}

World Health Organization, Geneva, Headquarters

WHO Regional Office Eastern Mediterranean Regional Office (EMRO)

Centers for Disease Control and Prevention, USA

Public Health England, England

Institute of Virology, University of Bonn Medical Centre, Germany

University of Hong Kong, Hong Kong

Robert Koch Institute, Germany

Ministry of Health, Jordan

Erasmus University, Netherlands

Ministry of Health, Kingdom of Saudi Arabia

Ministry of Health, Tunisia

Table 35. Global partners in the WHO's response to MERS-CoV between September 2012 and May

2014.

Source: Williams et al. 2015:313 (441).

Members of the epistemic community associated with those institutions participated in the identified core groups. Table 36 presents the number of people participating per institution in the core groups.

\begin{tabular}{|l|c|c|c|c|c|}
\hline Institution & $\begin{array}{c}\text { EC- } \\
\text { MER } \\
\text { S }\end{array}$ & $\begin{array}{c}\text { MERS } \\
\text { CoV } \\
\text { RG }\end{array}$ & $\begin{array}{c}\text { CSG } \\
\text { ICTV }\end{array}$ & $\begin{array}{c}\text { WHO } \\
\text { MERS } \\
\text { R\&D }\end{array}$ & $\begin{array}{c}\text { WHO } \\
\text { BP } \\
\text { VT }\end{array}$ \\
\hline $\begin{array}{l}\text { Centres for Disease Control and } \\
\text { Prevention }\end{array}$ & & 1 & & & 2 \\
\hline Erasmus University & 1 & 2 & 2 & 4 & 1 \\
\hline Ministry of Health Saudi Arabia & & 3 & & & \\
\hline Ministry of Health Jordan & & 1 & 1 & 1 & \\
\hline Public Health England & & 1 & 1 & 1 & \\
\hline University of Bonn Medical Centre & & 2 & 2 & & 1 \\
\hline University of Hong Kong & & 3 & & & \\
\hline Robert Koch Institute & & 19 & & 9 & 5 \\
\hline World Health Organization HQ & & 3 & & & \\
\hline $\begin{array}{l}\text { WHO Regional Office Eastern } \\
\text { Mediterranean Regional Office }\end{array}$ & & & & \\
\hline
\end{tabular}

Table 36. Global partners in the MERS-CoV response and their connections to the epistemic community's core groups.

EC-MERS: Emergency Committee; MERS CoV RG: MERS CoV Research Group; CSG ICTV: Coronavirus Study Group (CSG) of the International Committee on Taxonomy of Viruses; WHO MERS R\&D: WHO Consultation on MERS CoV R\&D; WHO BP VT: WHO consultation on MERS$\mathrm{CoV}$ vaccine and therapeutics 
The analysis of the outbreak under "One Health" opened the epistemic community to include experts from other areas (animal health, environment, food security), which improved technical advice to affected governments. Members from this interdisciplinary epistemic community participated in the following international missions:

- WHO and the Ministry of Health and Welfare mission took place in the Republic of Korea 8-13 June 2015.

- WHO mission on Middle East respiratory syndrome coronavirus (MERS-CoV) in Saudi Arabia, 13 September 2015.

- WHO concludes a MERS-CoV risk assessment mission in the United Arab Emirates A team from the WHO and technical partners from the Global Outbreak Alert and Response Network (GOARN) has concluded a 5-day mission in the United Arab Emirates (UAE). The team consisted of 6 experts in coordination, epidemiology, infection prevention and control, food safety and the human-animal interface, and risk communication June 1-6, 2014.

- WHO experts probe Middle-Eastern respiratory syndrome coronavirus (MERS-CoV) in Jeddah, Saudi Arabia, 2 May 2014 - A team of experts from WHO started a twoday mission yesterday in Jeddah to assist national health authorities to investigate the recent increase in the number of people infected by MERS-CoV. From mid-March 2014, 111 people have tested positive in the Jeddah area, the most significant single surge in the MERS-CoV outbreak since the new virus was detected in April 2012. Thirty-one persons have died.

- WHO's high-level mission to Saudi Arabia on Middle East respiratory syndrome coronavirus (MERS-CoV) 11-14, January 2016.

- WHO EMRO technical mission of the Ministry of Health officials from Saudi Arabia to Egypt in May 2017 to share surveillance and laboratory experiences.

- WHO EMRO review mission to Qatar to review preparedness and response processes from 9 to 15 May 2017.

Members from the epistemic community also participated in training programs, such

as the WHO Regional Office for Eastern Mediterranean (EMRO) workshop in Riyadh for surveillance of Severe Acute Respiratory Illness, held in Saudi Arabia from January 15 to 19, 2017. Besides, some international conferences brought together the scientific community and public health experts, such as the WHO and the University of Hong Kong informal meetings about the airborne transmission of MERS-CoV, held on 13-14 March 2017. All these meetings were essential venues to diffuse the epistemic community knowledge. 


\subsubsection{Institutionalization of bureaucratic power}

The MERS epistemic community reached a certain level of bureaucratic power by participation in groups that had a direct influence on the policy process. Its participation included the Coronavirus Study Group (CSG) of the International Committee on Taxonomy of Viruses, which unified the scientific community and research by agreeing on the new pathogen's name (393); the WHO MERS-CoV Research Group (402); and the MERS Emergency Committee, established in July 2013.

The MERS-CoV epistemic community contributed to expert groups organized by the WHO. These were oriented to research and development, as well as to developing a vaccine in the short term. Most of these meetings were regional consultations, with participants from the affected countries and their neighbors. Some institutions from Europe and the USA also sent experts, given their expertise in the area. Table 37 summarizes the most important groups and meetings.

\begin{tabular}{|c|c|}
\hline Group & Meetings \\
\hline Country meeting & $\begin{array}{l}\text { Intercountry meeting on the Middle East Respiratory Syndrome } \\
\text { Coronavirus (MERS-CoV) outbreak in the Eastern Mediterranean } \\
\text { Region } \\
\text { Cairo, Egypt 20-22 June } 2013 \text { (442) }\end{array}$ \\
\hline $\begin{array}{l}\text { The MERS-CoV Vaccine } \\
\text { Working Group -WHO }\end{array}$ & First meeting on November 14-15, 2015 in Saudi Arabia (443) \\
\hline $\begin{array}{l}\text { WHO R\&D Blueprint } \\
\text { Initiative }\end{array}$ & $\begin{array}{l}\text { WHO Consultation on MERS CoV R\&D: } \\
\text { Development of a Global MERS CoV R\&D Roadmap }-10-11 \\
\text { December } 2015\end{array}$ \\
\hline \multirow{6}{*}{$\begin{array}{l}\text { Technical Consultation on } \\
\text { MERS-CoV }\end{array}$} & $\begin{array}{l}\text { First meetings held in Saudi Arabia in January } 2013 \text { and December } \\
2013 \text { (443). }\end{array}$ \\
\hline & $\begin{array}{l}\text { Consultative meeting to determine the public research agenda, Cairo, } \\
\text { Egypt } 15-16 \text { December } 2013 \text { (444). }\end{array}$ \\
\hline & Second meeting held in Saudi Arabia, in March 2014 \\
\hline & $\begin{array}{l}\text { Third meeting held in Cairo in May 2015, Egypt from 5-6 May } 2015 \\
\text { (hosted by WHO/EMRO (443)) }\end{array}$ \\
\hline & $\begin{array}{l}\text { Fourth meeting, held in Doha, Qatar, on 27-29 April } 2015 \text { (hosted by } \\
\text { FAO and the Supreme Council of Health of Qatar) and in Cairo) (445) }\end{array}$ \\
\hline & $\begin{array}{l}\text { Regional Technical Consultative Meeting on MERS-CoV } \\
\text { Muscat, Oman, 20-21 May } 2014 \text { (439) }\end{array}$ \\
\hline
\end{tabular}

Table 37. Meetings MERS CoV. 
Conferences and technical groups provided a space for members of the epistemic community to get more involved in the process and to have more access to the domestic and global policy process. There was continuous interaction between policymakers, experts, bureaucrats, and other participants. Appendix $\mathrm{J}$ includes the full table of institutions participating in the different groups and meetings related to MERS CoV.

The importance of the outbreak in the Arab peninsula and the continued risk that this virus represents for these countries have allowed the participation of many experts from decision making positions in expert and technical groups. These professionals are part of the epistemic community.

Their participation through the MERS CoV Emergency Committee also included them in the global decision-making process. After their $10^{\text {th }}$ meeting, the Emergency Committee participation concluded that the outbreak did not have the characteristics of a PHEIC. Since then, the WHO has not organized another meeting, although the organization continues monitoring the situation and providing updates.

There were also some members of the community directly involved in both the epistemic community and the decision-making process. One of them, Dr. Ziad Al-Memish, acted first as Undersecretary to the Minister of Health in Saudi Arabia. Then, he was appointed in 2012 as the head of the WHO Collaborative Global Centre for Mass Gathering Medicine, the first in the world. The Centre has devoted many resources to MERS and has concentrated its work on analysing the risk that this disease represented for the celebration of the Ramadan. The Centre provided information to WHO, and Dr. Memish's expertise has influenced decision making in Saudi Arabia and the field of Mass Gathering Medicine $(446,447)$. As such, he has extensively published about MERS-CoV and mass gatherings, in 
collaboration with other members of the epistemic community [see references $(448,401,386,446,432,449,450)]$.

The MERS-CoV epistemic community includes members from national governments and international organizations (See Appendix J). Nevertheless, the participation has been mostly regional and with a less extended international membership. There are not enough professionals around the world with expertise in coronaviruses. Therefore, members of the epistemic community came mostly from the Middle East.

This geographical concentration of experts reduced the epistemic community capacity to influence a global response, and potentially respond to future outbreaks in other geographic regions. High-level officials and experts in the Eastern Mediterranean Region meeting in October 2018 expressed their concerns about the limited number of MERS experts in the world and the probability of a future outbreak. There would be limited expert capacity to address such a global outbreak (451).

These characteristics, summarized in table 38, depict an epistemic community that had problems with establishing consensual knowledge, with limited resources to socialize its ideas and that did not gain much power. 


\begin{tabular}{|c|c|c|}
\hline & Indicator & MERS \\
\hline \multirow{2}{*}{ 1. Knowledge } & $\begin{array}{l}\text { Agreement on a } \\
\text { common definition of } \\
\text { the problem and } \\
\text { possible solutions }\end{array}$ & $\begin{array}{l}\text { The community had some disagreements about the } \\
\text { pandemic potential. }\end{array}$ \\
\hline & $\begin{array}{l}\text { Clear identification of } \\
\text { a common policy } \\
\text { goal }\end{array}$ & $\begin{array}{l}\text { They established a common goal during the outbreak (to } \\
\text { improve the global health response through investing in } \\
\text { research; strengthening collaboration and coordination for } \\
\text { researching and improving information sharing) }\end{array}$ \\
\hline \multirow{3}{*}{ 2.Socialization of ideas } & Structure & $\begin{array}{l}\text { The epistemic community was small and centralized. Its } \\
\text { members were mostly from the affected region and a few } \\
\text { experts from countries that have research capabilities like } \\
\text { the USA, Canada, and Australia. }\end{array}$ \\
\hline & $\begin{array}{l}\text { Dissemination } \\
\text { mechanisms }\end{array}$ & $\begin{array}{l}\text { Before the outbreak, research in coronaviruses was scarce, } \\
\text { and even during the most critical days of the event, the } \\
\text { availability of information and studies were limited. There } \\
\text { were also problems with access to data and withholding of } \\
\text { information by members of the epistemic community. }\end{array}$ \\
\hline & $\begin{array}{l}\text { Participation in the } \\
\text { international response }\end{array}$ & $\begin{array}{l}\text { The participation of the community has been through the } \\
\text { WHO in activities related to research and development, } \\
\text { and in the field gathering information about the virus and } \\
\text { the outbreaks. }\end{array}$ \\
\hline \multirow{2}{*}{$\begin{array}{l}\text { 3. Institutionalization of } \\
\text { bureaucratic power }\end{array}$} & $\begin{array}{l}\text { Participation in the } \\
\text { policy process. }\end{array}$ & $\begin{array}{l}\text { MERS CoV was less important at the global level than } \\
\text { other outbreaks. There has been a small number of } \\
\text { committees, expert groups, and conferences related to } \\
\text { MERS. Experts from the epistemic community } \\
\text { participated, but it had a few opportunities to } \\
\text { institutionalize its influence. }\end{array}$ \\
\hline & $\begin{array}{l}\text { Experts and other } \\
\text { professionals from } \\
\text { the epistemic } \\
\text { community in } \\
\text { decision-making } \\
\text { positions }\end{array}$ & $\begin{array}{l}\text { The participation was mainly through the Emergency } \\
\text { Committee. }\end{array}$ \\
\hline
\end{tabular}

Table 38. Characteristics MERS CoV epistemic community.

\subsection{The international response}

The emergence of a new coronavirus in 2012 brought some initial uncertainty in part because of late notification, limited sharing of information, and ineffective collaboration by some countries $(440,452)$. During the $66^{\text {th }}$ World Health Assembly, Dr. Margaret Chan expressed her concern for the novel virus, given the lack of information about it $(416,394)$.

The WHO focused its response on working with Saudi Arabia, Qatar, and the UK (453). 
Samples from these countries were tested by one of the WHO Collaborating Centres for Emerging and Re-emerging Infectious Diseases (NAMRU - 3) (411).

The WHO Director-General organized an Emergency Committee (EC) to assess the outbreak in the Arab Peninsula. Following the IHRs 2005, the WHO put together a group of experts to compose the EC. The MERS CoV EC held its first meeting on Tuesday, 9 July 2013. Here the epistemic community faced a fundamental problem: experts could not agree on the severity of the outbreak (454).

A critical aspect stopping the declaration of MERS as a PHEIC was a lack of consensus within the epistemic community and other experts about the potential danger represented by the virus (454). The first meeting of the Emergency Committee organized by the WHO concluded that "the Committee considered that additional information was needed in a number of areas. The Committee also considered it needed time for further discussion and consideration (455)." Therefore, members of the committee decided not to declare the event a PHEIC, claiming that the available information was not enough to support such a decision (456). Given the scarce knowledge about the MERS-CoV, the epistemic community first tried to understand how it behaved and the risk it represented. Experts agreed on the urgency to develop better interventions for treating the disease, including the development of a vaccine $(403,397,396,441,457,395,458,459)$.

Due to the lack of a PHEIC declaration, an explicit international response never was required. Nonetheless, the WHO mobilized some resources to support the most affected countries and provide technical assistance. The WHO organized working groups and expert consultations with professionals from the epistemic community with the primary goal of increasing research and improving knowledge about the disease, as well as its management 
and treatment. The response was, therefore, mostly scientific and technical. The WHO provided recommendations to affected countries to prevent the spread and continued to provide technical assistance. Some countries outside the region collaborated to contain the disease, and the WHO recognized the importance of increasing global awareness (407).

Regardless of not having recommended a formal PHEIC, the Emergency Committee issued some measures to the WHO and its member states. Many of these were epidemiological, targeting transmission by improving case management in health facilities as well as increasing the protection of health workers. Although the last years the number of cases did not increase drastically, the WHO continued updating technical documents to provide guidelines for countries based on the most recent publications in relevant journals, country studies, clinical trials, among others (460). These documents include four categories:

1. Surveillance and investigation

2. Laboratory

3. Case management, infection prevention, and control

4. Travel and mass gatherings

The most recent documents are from 2018, and all of them include scientific evidence from ongoing research and development of the situation (424). The WHO regularly updated its reports and kept gathering data that could be necessary in case of another outbreak with information produced by members of the epistemic community.

The MERS-CoV Emergency Committee recommended measures to be followed by the international community for the control and management of future cases. In its last meeting, the EC noticed that many countries did not comply with the suggested measures: countries were not always reporting cases, sharing of information was limited, and research was slowly developed (461). They concluded their work with the next statement: 
The Committee felt it important to alert all relevant authorities, especially national public health, animal and agricultural agencies, to the continued and significant public health risks posed by MERS. These sectors must collaborate, among themselves and internationally, and follow the advice that has been issued by $\mathrm{WHO}(461)$.

The MERS-CoV EC had ten meetings between July 2013 and September 2015. In their last meeting, the group of experts acknowledged the need for more international collaboration in the development of vaccines and treatments as well as for more cooperation from national governments to share on-time information (461). During this period, there were different opinions about whether the outbreak should have been called a PHEIC or not, and renowned experts and WHO's officers, such as Keji Fukuda and David Heymann ${ }^{\text {liv }}$, defended the EC's decisions (454).

The response was mostly at the regional level, focused on assisting those countries with cases. The WHO also prompted scientific and technical collaboration to understand better the disease and to define effective medical and non-medical responses. The involvement of the MERS epistemic community increased due to the establishment of a global research agenda. Many of the activities were possible due to the use of the Program for Monitoring Emerging Diseases (ProMED), which is updated by the WHO, the US CDC ${ }^{\mathrm{lv}}$, and the European CDC $(383,441)$. With this program, the WHO aimed to increase the scientific knowledge of the virus and to develop treatments and interventions for managing future outbreaks.

\footnotetext{
liv Keji Fukuda was the WHO's Assistant Director General for Health Security and participated in most of the international meetings re lated to disease outbreaks. David Haymann was an Executive Director for Communicable Disease at the WHO, currently working as the Head of the Centre on Global Health Security at Chatham House. He was member of the Zika's Emergency Committee.

lv The MERS-CoV Working Group
} 
In September 2012, the WHO, CDC, and other global partners started assisting with detection and surveillance activities. That same month, the Institute of Virology, University of Bonn Medical Centre made available the first assay reagents. In November 2012, a group of international scientists published the complete genome sequence of the virus (441).

The zoonotic origin of the virus identified by experts $(436,446,402)$ and gaps in knowledge also facilitate the inclusion of the topic into the "One Health" approach. This perspective guided part of the response, focusing on the animal-human interface, "the interaction among animal and human health within an environmental context (441).”

The influence of the epistemic community in research and development is also observed its participation in technical meetings. Table 39 summarizes some meetings were the epistemic community had a direct influence on the outcome. 


\begin{tabular}{|c|c|c|}
\hline Group & Meetings & Outcome \\
\hline Country meeting & $\begin{array}{l}\text { Intercountry meeting on the Middle East } \\
\text { Respiratory Syndrome Coronavirus } \\
\text { (MERS-CoV) outbreak in the Eastern } \\
\text { Mediterranean Region } \\
\text { Cairo, Egypt 20-22 June } 2013 \text { (442) }\end{array}$ & $\begin{array}{l}\text { Participants agreed on a series of recommendations } \\
\text { including: } \\
\text { Increase detection through increased surveillance and } \\
\text { testing. Free and open data-sharing using a standard } \\
\text { questionnaire developed by WHO } \\
\text { Develop and participate in the further development of } \\
\text { diagnostic assays. } \\
\text { Ensure international cooperation and collaboration } \\
\text { (442) }\end{array}$ \\
\hline $\begin{array}{l}\text { The MERS-CoV } \\
\text { Vaccine } \\
\text { Working Group } \\
\text {-WHO }\end{array}$ & $\begin{array}{l}\text { First meeting on November 14-15, 2015, } \\
\text { in Saudi Arabia (443) }\end{array}$ & $\begin{array}{l}\text { They establish a collaborative model with key } \\
\text { partnerships, promoting transparency and sharing of } \\
\text { data (457). }\end{array}$ \\
\hline $\begin{array}{l}\text { WHO R\&D } \\
\text { Blueprint } \\
\text { Initiative }\end{array}$ & $\begin{array}{l}\text { WHO Consultation on MERS CoV } \\
\text { R\&D: } \\
\text { Development of a Global MERS CoV } \\
\text { R\&D Roadmap - 10-11 December } 2015\end{array}$ & $\begin{array}{l}\text { MERS-CoV is one of the eight pathogens included in } \\
\text { the WHO's blueprint list. They reviewed the current } \\
\text { status of the research, including therapeutics, vaccine, } \\
\text { diagnostics, epidemiology, and establish priorities } \\
\text { (397). }\end{array}$ \\
\hline \multirow{6}{*}{$\begin{array}{l}\text { Technical } \\
\text { Consultation on } \\
\text { MERS-CoV }\end{array}$} & $\begin{array}{l}\text { First meetings held in Saudi Arabia in } \\
\text { January } 2013 \text { and December } 2013 \text { (443). }\end{array}$ & $\begin{array}{l}\text { This was the first of a series of meetings in the region } \\
\text { to analyze the outbreak and the health response. }\end{array}$ \\
\hline & $\begin{array}{l}\text { Consultative meeting to determine the } \\
\text { public research agenda, Cairo, Egypt } \\
15-16 \text { December } 2013 \text { (444). }\end{array}$ & $\begin{array}{l}\text { Affected countries would participate in an } \\
\text { international multi-country } \\
\text { Case-control study. } \\
\text { Agreement on a "probable" case definition for } \\
\text { MERS-CoV for reporting purposes }\end{array}$ \\
\hline & $\begin{array}{l}\text { Second meeting held in Saudi Arabia, in } \\
\text { March } 2014\end{array}$ & There is no specific information about outcomes \\
\hline & $\begin{array}{l}\text { Third meeting held in Cairo in May } \\
\text { 2015, Egypt from 5-6 May } 2015 \text { (hosted } \\
\text { by WHO/EMRO (443)) }\end{array}$ & $\begin{array}{l}\text { The final protocol for the case-control study on MERS- } \\
\text { CoV was finalized and. }\end{array}$ \\
\hline & $\begin{array}{l}\text { Fourth meeting, held in Doha, Qatar, on } \\
27-29 \text { April } 2015 \text { (hosted by FAO and } \\
\text { the Supreme Council of Health of Qatar) } \\
\text { and in Cairo) (445) }\end{array}$ & $\begin{array}{l}\text { During the Doha and Cairo meetings, participants } \\
\text { shared published and unpublished research findings } \\
\text { "These meetings, including this fourth one, have } \\
\text { contributed immensely to improving our understanding } \\
\text { of the virus, its evolution and risk factors for } \\
\text { transmission, as well as identifying critical information } \\
\text { and knowledge gaps that can better guide an effective } \\
\text { global public health response," said WHO's Regional } \\
\text { Director Dr. Ala Alwan (WHO EMRO 2015). }\end{array}$ \\
\hline & $\begin{array}{l}\text { Regional Technical Consultative } \\
\text { Meeting on MERS-CoV } \\
\text { Muscat, Oman, 20-21 May } 2014 \text { (439) }\end{array}$ & It followed-up recommendations from past meetings \\
\hline
\end{tabular}

Table 39. MERS-CoV meetings and expert groups. Source: WHO/EMRO and various publications.

The relevance of research and gathering data required the active participation of the epistemic community. Figure 20 presents the participation of the epistemic community in the process of the international response to MERS-CoV. 


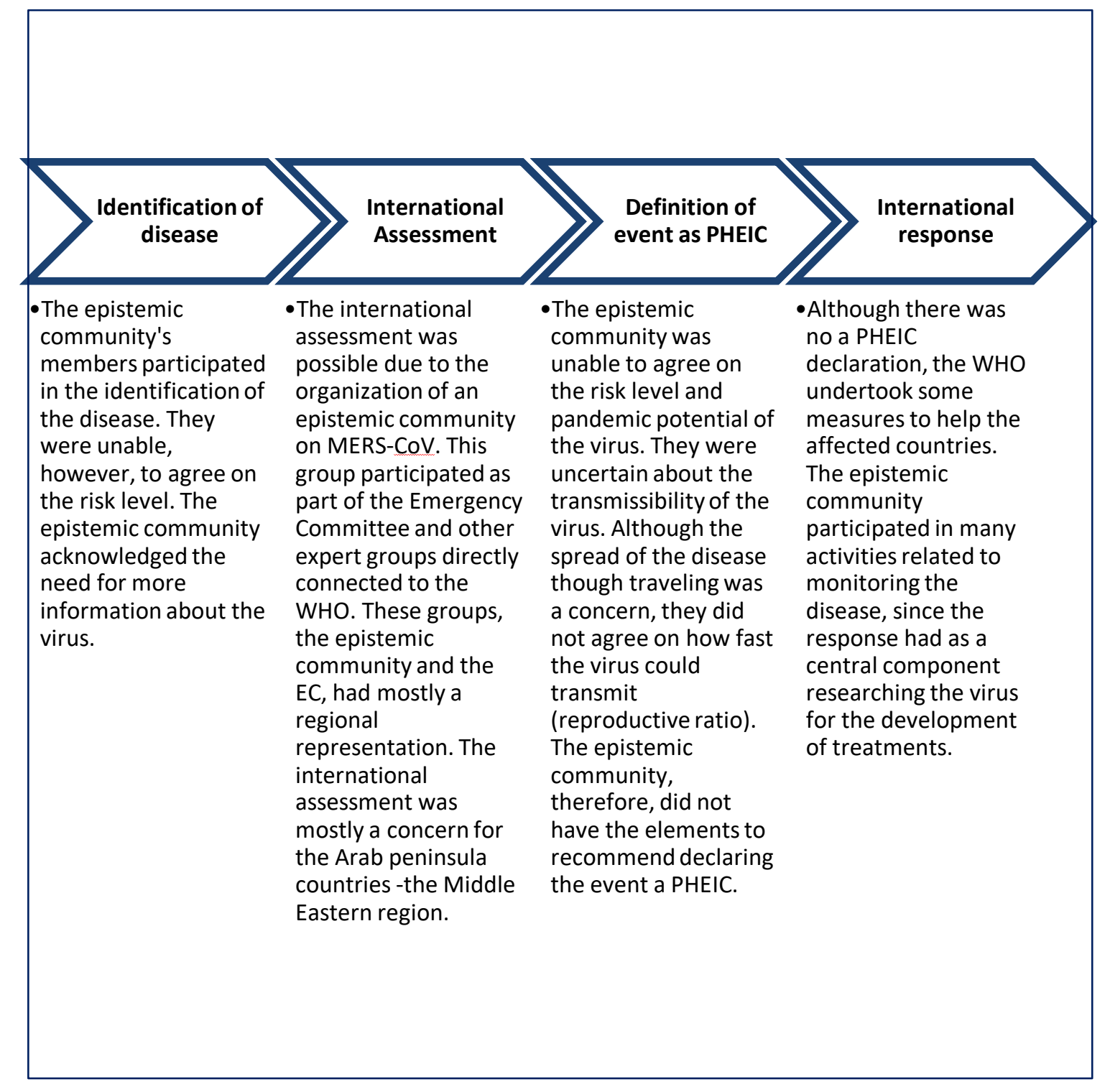

Figure 20. Process for the international response to MERS-CoV.

A few governments explicitly endorsed recommendations by the epistemic community. Saudi Arabia started following recommendations based on scientific evidence once the WHO established the Saudi Global Centre for Mass Gathering Medicine $(462,449)$. Some studies found that in Qatar, the response and communication strategy was based on documents developed and supported by scientific evidence, following the International Health Regulations 2005 guidelines (463). 
Countries that have experienced exported cases, like the USA, have also relied on their national experts to develop guidelines $(441,464)$. The CDC has been one of the main advisors to the WHO, and it also organized a national MERS-CoV Working Group to study the outbreak (441). Other countries, like Canada, have established expert working groups to guide the detection and management of possible MERS-CoV cases (465). Experts from these agencies were part of the global epistemic community.

Table 40 summarizes international cooperation during the MERS-CoV outbreak based on the framework presented in chapter 4. It also identifies how the epistemic community influenced this response. 


\begin{tabular}{|c|c|c|c|c|}
\hline ACTIVITY & MEASURE & Epistemic community & International Response MERS & $\begin{array}{c}\text { Level of } \\
\text { Cooperation }\end{array}$ \\
\hline \multicolumn{5}{|c|}{ I. International participation } \\
\hline \multirow[b]{2}{*}{ PROBLEM } & $\begin{array}{l}\text { 1.Timely meetings } \\
\text { at WHO and other } \\
\text { settings. }\end{array}$ & $\begin{array}{l}\text { Even though an epistemic community } \\
\text { participated in this activity, the lack } \\
\text { of consensual knowledge affected the } \\
\text { result of these meetings. }\end{array}$ & $\begin{array}{l}\text { The WHO called for an Emergency Committee, and it } \\
\text { organized its first meeting on July } 9,2013 \text {. There have been } \\
\text { ten more meetings to assess the situation ( } 455) \text {. These } \\
\text { meetings, however, started more than six months after the } \\
\text { cases were notified. }\end{array}$ & 3 \\
\hline & $\begin{array}{l}\text { 2.If there were } \\
\text { actions } \\
\text { implemented as a } \\
\text { result of those } \\
\text { meetings }\end{array}$ & $\begin{array}{l}\text { The epistemic community, with its } \\
\text { representatives in the EC, endorsed } \\
\text { those actions. The limited response } \\
\text { was related to the disagreements } \\
\text { about the pandemic potential of } \\
\text { MERS. }\end{array}$ & $\begin{array}{l}\text { MERS is the only disease assessed by an Emergency } \\
\text { Committee that has not been declared a PHEIC (127). As a } \\
\text { result, there was no call for an international response. There } \\
\text { have been some actions. However, these originated from } \\
\text { recommendations issued after these meetings. }\end{array}$ & 3 \\
\hline RESPONSE & $\begin{array}{c}\text { Time frame after } \\
\text { notification }\end{array}$ & $\begin{array}{l}\text { Experts helped to notify the outbreak, } \\
\text { but the epistemic community did not } \\
\text { have strong connections, and it did } \\
\text { not have enough power to influence } \\
\text { policymakers. }\end{array}$ & $\begin{array}{l}\text { The first Emergency Committee was convened in July } \\
\text { 2013, more than six months after the notification of the first } \\
\text { cases (466). The international response was partially } \\
\text { affected by the late notification. Saudi Arabia provided } \\
\text { notification to the WHO of the first case a few months after } \\
\text { it was identified (383). }\end{array}$ & 2 \\
\hline $\begin{array}{c}\text { NO. OF } \\
\text { COUNTRIES }\end{array}$ & $\begin{array}{c}\text { Level of } \\
\text { participation }\end{array}$ & $\begin{array}{l}\text { The epistemic community had a } \\
\text { small network. Therefore, the } \\
\text { socialization of its ideas was } \\
\text { concentrated on people from a few } \\
\text { countries. }\end{array}$ & $\begin{array}{l}\text { The level of international participation was low, given that } \\
\text { the outbreak was not declared a PHEIC. Countries with } \\
\text { research and development capacities participated in the } \\
\text { response, providing technical assistance and expertise to the } \\
\text { affected countries. }\end{array}$ & 1 \\
\hline \multicolumn{5}{|c|}{ II. International assistance } \\
\hline TECHNICAL A. & $\begin{array}{l}\text { Type of } \\
\text { participation in } \\
\text { international } \\
\text { missions. }\end{array}$ & $\begin{array}{l}\text { Some experts from the epistemic } \\
\text { community participated in these } \\
\text { activities. This helped to socialize its } \\
\text { ideas, but the impact was less visible } \\
\text { due to its disagreements. }\end{array}$ & $\begin{array}{l}\text { The WHO provided technical assistance through its } \\
\text { networks of experts. It supported the conducting of risk } \\
\text { assessments and joint investigations with national } \\
\text { authorities; convening scientific meetings, and developing } \\
\text { guidance and training for health authorities and technical } \\
\text { health agencies on interim surveillance recommendations } \\
\text { (467). }\end{array}$ & 2 \\
\hline
\end{tabular}

Table 40. Analysis levels of cooperation in the MERS-CoV response 


\begin{tabular}{|c|c|c|c|c|}
\hline ACTIVITY & MEASURE & Epistemic Community & MERS & $\begin{array}{l}\text { Level of } \\
\text { Cooperation }\end{array}$ \\
\hline \multicolumn{5}{|c|}{ II. International assistance } \\
\hline $\begin{array}{l}\text { FINANCIAL } \\
\text { ASSISTANCE }\end{array}$ & $\begin{array}{l}\text { Money } \\
\text { provided as } \\
\text { financial } \\
\text { assistance to the } \\
\text { emergency }\end{array}$ & $\begin{array}{l}\text { No evident participation of the epistemic } \\
\text { community. }\end{array}$ & $\begin{array}{l}\text { There are no records of financial assistance to the affected } \\
\text { countries nor information of specific funds settled down to } \\
\text { assist the R\&D efforts. }\end{array}$ & 0 \\
\hline TREATMENTS & $\begin{array}{l}\text { Type of } \\
\text { population } \\
\text { getting } \\
\text { treatments }\end{array}$ & $\begin{array}{l}\text { Research is in process, and the virus now } \\
\text { is considered a priority for the WHO } \\
\text { Blue Print initiative, where many experts } \\
\text { from the epistemic community } \\
\text { participate }(457,397) \text {. }\end{array}$ & $\begin{array}{l}\text { When the virus emerged, there were no specific treatments } \\
\text { for MERS, and the vaccine was not available ( } 468) \text {. }\end{array}$ & 2 \\
\hline \multirow[b]{2}{*}{ PROVISION } & $\begin{array}{l}\text { 1. How fast was } \\
\text { the deployment } \\
\text { of assistance }\end{array}$ & $\begin{array}{l}\text { No evident participation of the epistemic } \\
\text { community. }\end{array}$ & $\begin{array}{l}\text { Assistance has been provided mostly by WHO since } 2012 \\
\text { to some of the affected countries ( } 468) \text {. }\end{array}$ & 2 \\
\hline & $\begin{array}{l}\text { 2.Type of } \\
\text { assistance }\end{array}$ & $\begin{array}{l}\text { Some members of the epistemic } \\
\text { community participated in the response, } \\
\text { identifying the virus. The socialization } \\
\text { of ideas within the network helped for } \\
\text { sequencing and diagnosis. }\end{array}$ & $\begin{array}{l}\text { Technical assistance has been provided for laboratory } \\
\text { testing of cases, infection prevention and control, and } \\
\text { clinical management (467). }\end{array}$ & 2 \\
\hline \multicolumn{5}{|c|}{ III. Scientific response } \\
\hline SAMPLES & $\begin{array}{l}\text { If countries } \\
\text { have shared } \\
\text { virus samples }\end{array}$ & $\begin{array}{l}\text { The sharing of the virus happened } \\
\text { through experts participating in the } \\
\text { epistemic community network. Although } \\
\text { it was problematic. }\end{array}$ & $\begin{array}{l}\text { The sharing of the virus was controversial due to problems } \\
\text { with patent rights. This situation caused late access to virus } \\
\text { samples (410). }\end{array}$ & 1 \\
\hline \multirow[b]{2}{*}{ R\&D } & $\begin{array}{l}\text { 1.If data is } \\
\text { disseminated on } \\
\text { time }\end{array}$ & $\begin{array}{l}\text { Some members of the epistemic } \\
\text { community have been part of this } \\
\text { controversy. }\end{array}$ & $\begin{array}{l}\text { There have been problems with transparency in the } \\
\text { information }(98,410) \text {, and it has transmitted late, which has } \\
\text { affected the development of research studies }(456) \text {. }\end{array}$ & 2 \\
\hline & $\begin{array}{l}\text { 2.Phases of the } \\
\text { research during } \\
\text { the outbreak }\end{array}$ & $\begin{array}{l}\text { There have been many experts from the } \\
\text { epistemic community working on } \\
\text { research and development, using its } \\
\text { network to socialize its ideas and } \\
\text { potentially increased its power in the } \\
\text { process. The research process, however, } \\
\text { has been slow (393). }\end{array}$ & Research started during the outbreak, and it is still ongoing. & 3 \\
\hline
\end{tabular}

Table 40. Analysis levels of cooperation in the MERS-CoV outbreak (cont.) 


\begin{tabular}{|c|c|c|c|c|}
\hline ACTIVITY & MEASURE & Epistemic Community & MERS & $\begin{array}{l}\text { Level of } \\
\text { cooperation }\end{array}$ \\
\hline \multicolumn{5}{|l|}{ IV. Policy adoption } \\
\hline SURVEILLANCE & $\begin{array}{l}\text { If countries } \\
\text { implemented } \\
\text { systems to allowed } \\
\text { constant } \\
\text { notification of } \\
\text { possible cases }\end{array}$ & $\begin{array}{l}\text { The EC recommended increased } \\
\text { surveillance. This suggestion } \\
\text { derived from one of the epistemic } \\
\text { community's agreements. }\end{array}$ & $\begin{array}{l}\text { There has been continuous surveillance since } 2012 \text {, mostly by } \\
\text { affected countries. Notification of timely information, } \\
\text { however, has not been consistent ( } 456 \text { ). }\end{array}$ & 3 \\
\hline NOTIFICATION & $\begin{array}{l}\text { How long did } \\
\text { countries wait to } \\
\text { notify the WHO } \\
\text { after identifying } \\
\text { the cases? }\end{array}$ & $\begin{array}{l}\text { The epistemic community } \\
\text { network influenced the } \\
\text { notification. }\end{array}$ & $\begin{array}{l}\text { The WHO received notification of the first cases in } 2012 \text {. } \\
\text { Some countries have been doing this better than others at } \\
\text { notification ( } 456) \text {. Some considered that the data about the } \\
\text { epidemic was shared late (127). }\end{array}$ & 4 \\
\hline \multirow{2}{*}{$\begin{array}{c}\text { POLICY } \\
\text { CONVERGENCE }\end{array}$} & $\begin{array}{l}\text { How broad were } \\
\text { the } \\
\text { recommendations } \\
\text { adopted and } \\
\text { implemented? }\end{array}$ & $\begin{array}{l}\text { Even though the epistemic } \\
\text { community provided some } \\
\text { advice, its small and closed } \\
\text { network, as well as its weak } \\
\text { bureaucratic power, limited its } \\
\text { influence, especially at the } \\
\text { national level. }\end{array}$ & $\begin{array}{l}\text { In its } 10^{\text {th }} \text { meeting, the MERS-CoV EC noted that its advice } \\
\text { had not been entirely followed by countries (although the EC } \\
\text { did not mention explicitly which countries). In some cases, } \\
\text { reporting of cases was inaccurate, or it was not being done as } \\
\text { required (461). }\end{array}$ & 4 \\
\hline & $\begin{array}{l}\text { The degree of } \\
\text { adoption of } \\
\text { international } \\
\text { norms. }\end{array}$ & $\begin{array}{l}\text { The epistemic community limited } \\
\text { institutionalized power made it } \\
\text { more difficult to modify some } \\
\text { country's interests in } \\
\text { implementing the norms, even } \\
\text { with those countries that have } \\
\text { financial resources. }\end{array}$ & $\begin{array}{l}\text { Although affected countries have been working with the } \\
\text { WHO since the beginning, they still must improve their } \\
\text { surveillance and diagnostic ( } 467) \text {. }\end{array}$ & 4 \\
\hline
\end{tabular}

Table 40. Analysis levels of cooperation in the MERS-CoV outbreak (cont.) 
The analysis of the international response provides evidence that the level of international cooperation, in this case, was low to medium. Even though the outbreak impacted several countries, there was evidence of cases outside the region of origin, due to travel and lack of treatments. The international community, however, did not implement more coordinated actions to address the situation. An epistemic community participated during the outbreak and the response.

It had active participation in the international decision-making process, and it influenced some of the activities in the response. The lack of an agreement within the community of the level of severity, the management of the outbreak by some of the countries, and the need for more information, made this a technical and scientific response with a highly regional component.

\subsection{Influence of the epistemic community in the level of cooperation.}

The MERS-CoV epistemic community did not play a substantial role in the international response. This statement, however, does not dismiss its participation in the

process or its contribution to it. Evidence demonstrates that the MERS epistemic community faced some constraints with establishing itself as a more influential actor. It did not reach a scientific consensus about the risk posed by the MERS-CoV. Some researchers considered the MERS outbreak was not like the SARS outbreak; therefore, they concluded the likelihood of a pandemic was low (383), whereas other experts affirmed this virus had similar characteristics to the SARS coronavirus $(421,252)$. The partial consensus and lack of information affected the creation of consensual knowledge for decision making. Even though they were the primary providers of information, they could not offer specific guidance on how to address the situation. 
There were problems within the epistemic community that also affected the production of knowledge, such as the sharing of samples among experts to identify the virus. The Saudi virologist acted upon the public interest and tried to share information globally as soon as it was available. On-time notification, however, was hindered in part by competition and claims over property rights made by the Erasmus Medical Centre (ECM), which limited the access to samples (410). ECM was part of the epistemic community and acted as a barrier to collaboration among experts. In addition to this, political interference in the sample sharing process also delayed notification.

The structure of the epistemic community was small and regional rather than global. The WHO and its partners acted as the central nodes and providers of information, while the most affected countries in the Middle East were the direct recipients of assistance. The epistemic community members had many interactions, but most of them were in a closed group, which made it difficult to exchange information with others outside the epistemic community. The scarce research slowed down the diffusion process, creating barriers to improve guidelines and norms. There were problems in the diffusion of information and access to data. The centralization of the actions at the regional level restricted awareness at the global level. The fact that Dr. Al Memish was central in the epistemic community and, at the same time, protecting the interest of national governments, affected the interactions of the community with decisionmakers.

MERS-CoV continues circulating in the environment, without being considered a pandemic yet. Although person to person transmission is confirmed $(383,384)$, there is no consensus on the efficacy of its transmission $(423,392,393,252)$. Much information about the virus remains unknown. Experts are concerned about what could happen in the future, as well 
as in the lack of global interest and resources invested in this area $(252,384)$.

Coronaviruses seem to attract less attention from the scientific community due to the lack of incentives for research and funding (252). There is, however, a growing interest in developing a vaccine, and more resources have been invested for that $(457,458)$. Other areas (such as the human-animal interface) remain less popular among researchers (461).

In conclusion, this research identifies an epistemic community on MERS early in the outbreak. This network of professionals, however, had a lower capacity to influence more cooperation during the international response to the outbreak, given its inability to establish a consensus in the community and to position the topic in the global health agenda. The incapacity to position itself also as a reliable source of information, problems within the epistemic community due to divergent interests and problems to access to data, made it more difficult to institutionalize bureaucratic power at the global level. Fewer of the epistemic community's members were involved in the policy-making process, directly or indirectly, also limiting the network's influence. In some cases, political interest seemed to be a stronger driver during the process than scientific and technical considerations. 


\section{Chapter 7: Ebola Outbreak 2013-2016}

\subsection{Introduction}

Ebola has puzzled experts worldwide, given the type of pathogen and its characteristics. Today Ebola is known as one of the world's most lethal diseases, a threat for national security $(469,470,37,471,32)$, and is classified as a bioterrorist agent by the US CDC (See Box 3). The first-ever recorded outbreak of Ebola Hemorrhagic Fever occurred in 1976 (472). Since then, there have been 26 major outbreaks and other isolated individual cases (473).

\section{Box 3. Ebola virus disease (EVD) (Ebola Hemorrhagic Fever)}

\section{Origins of the disease}

The first cases of the Ebola virus emerged in 1976 in Zaire (now the Democratic Republic of Congo-DRC) and South Sudan. Before 2014, African countries had registered 25 outbreaks: DRC, Sudan, Republic of Congo, Ivory Coast, Sierra Leone, Guinea, Mali, and Liberia $(474,475,476,477,473)$.

The virus received the name of Ebola due to the Ebola River in Zaire (DRC), the place where the first case was detected $(478,479)$. Ebola is part of the Filoviridae family, which can cause severe hemorrhagic fevers in humans and primates. Scientists have identified three types: Cuevavirus, Marburgvirus, and Ebolavirus $(480,479,481,474)$. Ebolavirus is the most virulent of the family $(475,474)$. There are five Ebolavirus species known: Zaire, Bundibugyo, Sudan, Reston, and Tai Forest -all named after the location where they emerged $(475,481,479,482)$. Four of them have been found in Africa and one in Asia (474).

\section{Nature of the disease}

The virus is zoonotic, which means that the first case in an outbreak -or index case-, the virus will likely transmit from an animal to human $(477,475,483,479)$. Although it is still unclear which animal species is the main reservoir $(484,477,475,476)$, recent studies show that primates in Africa (gorillas, chimpanzees) have died from these viruses for a long time (474). There is evidence that these animals may be contracting the disease from fruit bats, species that also seem to be responsible for the human transmission $(474,475,485)$. Once the animal to human transmission occurs, sustainable human to human transmission can occur $(475,474)$.

People infected with the virus can have a fever, abdominal pain, headache, myalgia, sore throat, vomiting, diarrhea, maculopapular rash, limited renal and hepatic involvement, bleeding (hemorrhages), among others symptoms $(480,486,478,487,475)$. Given the number and variate of symptoms, doctors usually can confuse with Lassa and symptoms in early stages mimic malaria (endemic in the region). They can also confuse it with yellow fever, salmonella, typhoid fever, and meningitis $(478,488,479)$. 


\section{Box 3. Ebola virus disease (EVD) (Ebola Hemorrhagic Fever) (cont.)}

Person to person transmission occurs through direct contact with human fluids (through blood, saliva, sweat, semen, vaginal fluids, urine), organs, or contaminated surfaces and materials (bedding, syringes, needles) $(487,476,489,479,480,490)$. The most affected people are usually doctors, nurses, health workers, and people directly assisting ill people (491). These characteristics gave it the name of the "caregivers' disease" (492). Global health specialists are concerned about Ebolavirus, given that its fatality rates tend to vary between $25 \%$ to $90 \%(479,493,474)$. It is usually a fatal disease when adequate treatment is not provided on time $(479,483)$.

\section{Global Threat}

Since 1976 this disease has been studied, the virus isolated, and there is an extensive understanding of its transmission patterns, severity, surveillance, and management during and after an outbreak $(483,475)$. Thus, experts used to believe that Ebola outbreaks were localized and that they followed a specific trajectory: it suddenly appears, and, after some weeks, several cases continue appearing; later, the transmission chain stops, with a sudden decline in cases, starting a burnout phase $(494,475)$. Before the last outbreak, the possibility of a major international outbreak was remote since previous outbreaks were in isolated areas (475). The disease was relatively easy to contain with adequate protective equipment and isolated procedures. However, the outbreak of 2013 in West Africa followed a different trajectory, spreading across multiples villages and crossing international borders $(479,490)$.

On March 23th, 2014, the WHO announced the Ebola outbreak in Guinea (473). In the following months, the virus spread out to Sierra Leone and Liberia, and by October 2014, the three countries combined had more than 6500 cases (495). The humanitarian organization Médecins Sans Frontières (MSF), already assisting the government of Guinea to control an outbreak of Malaria, was involved early in the Ebola outbreak (241). The GOARN-WHO arrived at the country later, after the government notified the outbreak. The WHO, however, did not immediately call for an Emergency Committee to assess the epidemic (496). The outbreak spun out of control after a few months, showcasing the problems within the international system's capacity to respond to pandemics $(497,498,37)$.

The response to the 2014 Ebola outbreak is now broadly recognized as a failure $(499,110,473)$, with enough evidence to characterize it as having a low level of international 
cooperation, which contributed to the rapid spread of the virus and fatal consequences for the communities. The failure in the response to the outbreak and the subsequent problems can be attributed to multiple factors, from the location of the outbreak to political and social problems, as well as how the WHO addressed the situation.

Some attribute the failure to respond in part to the experience with past Ebola epidemics. Ebola outbreaks are frequent in Africa, in remote villages where they are usually easily contained $(241,473)$. The WHO initially considered the 2013-2014 outbreak in Africa small and isolated like previous ones (241). Therefore, the organization deemed it unnecessary to start an immediate international response. However, the rapid spread of the virus to neighboring countries and the number of cases exposed the consequences of globalization in its transmission, when a virus erupts in an area with the regular movement of people across borders (500).

Problems with the response were also attributed to the lack of interest in Africa, which translated into ignorance about the continent and its problems, as well as xenophobia and ethnocentrism towards the "African" (501). This lack of interest exacerbated feelings in the world population of anxiety and fear of the virus and the situation $(502,241,503)$. The fear was reinforced by continuous and regular air travel to the most affected countries and the probability of exporting the infection (504). As a consequence, some people did not want their countries involved in the region, and, instead, they supported more restrictive policies such as quarantines $(503,501,505)$, affecting the international responses to the outbreak

The affected countries also had domestic issues that slowed down the response. Sierra Leone and Liberia are post-conflict states, suffering the consequences of devastating civil wars that weakened their institutions $(506,507)$. Guinea did not have a civil war but has 
suffered from the instability of the region (507). This context has affected the countries' health systems, making them weak and more dependent on international assistance. Their governments are still unstable; people do not trust them $(501,507,506)$. During the outbreak, the combination of these factors affected domestic and international responses. The governments of Guinea and Sierra Leone recognized late the severity of the situation, delaying global notification due to the fear of causing panic, and the implications for international tourism and trade (241). In contrast, Liberia's government reported the cases in its territory immediately after they were detected. Nonetheless, Liberian people accused their government of exaggerating the situation to get more foreign aid, and they were reluctant to receive help due to the fear of intervention $(241,507)$.

In addition to that, the WHO also showed several organizational and structural problems due to budgetary cuts, not enough personnel for operations, and political interference (508). After the financial crisis of 2008, the WHO's budget has suffered significant cuts with the epidemic funding reduce by half in $2012(508,509)$. The reduced funding to assist countries during pandemics originated a reduction of WHO's staff in field operations (510). Besides, the politics and relationship with its member states played an important role in delaying actions (241). The WHO depends on its member states for funding, and they are the ones who decide how to allocate the money. Most of the budget is earmarked, eliminating the possibility of more flexibility in case of an emergency. As well, the organization requires its members to approve changes in its structure, making any necessary change to the operations a political process. Finally, the relationship between the headquarters and the regional offices also affected the WHO's participation $(508,509)$. The Director of the Regional Office for Africa was a political appointee, and he decided to make 
decisions based on politics instead of evidence. Presumably, he did not provide all the information to the WHO Geneva about the situation. However, others also blamed the WHO for denying evidence and the seriousness of the situation following the countries' requests $(509,241)$, postponing a response.

Finally, even when Ebola disease has been considered a priority for global health security, the outbreak did not prompt action under a global security agenda, and countries prioritized their national interests over international security $(511,469)$.

Given all these factors, how does the participation of the epistemic community fit in here? Figure 21 illustrates the relationship between the Ebola epistemic community and the level of cooperation in the international response. This chapter will analyze the epistemic community and will provide explanations to understand how an epistemic community contributed to this level of cooperation, given all other factors affecting the low levels of international cooperation.

For simplifying the analysis of the international response and the influence of an epistemic community, this research considers the outbreak had two pivotal moments. During the first one, the international community failed to respond quickly to unfolding events in West Africa. In the second phase, once the outbreak reached countries outside Africa, international alarm increased, leading to a coordinated international response. 


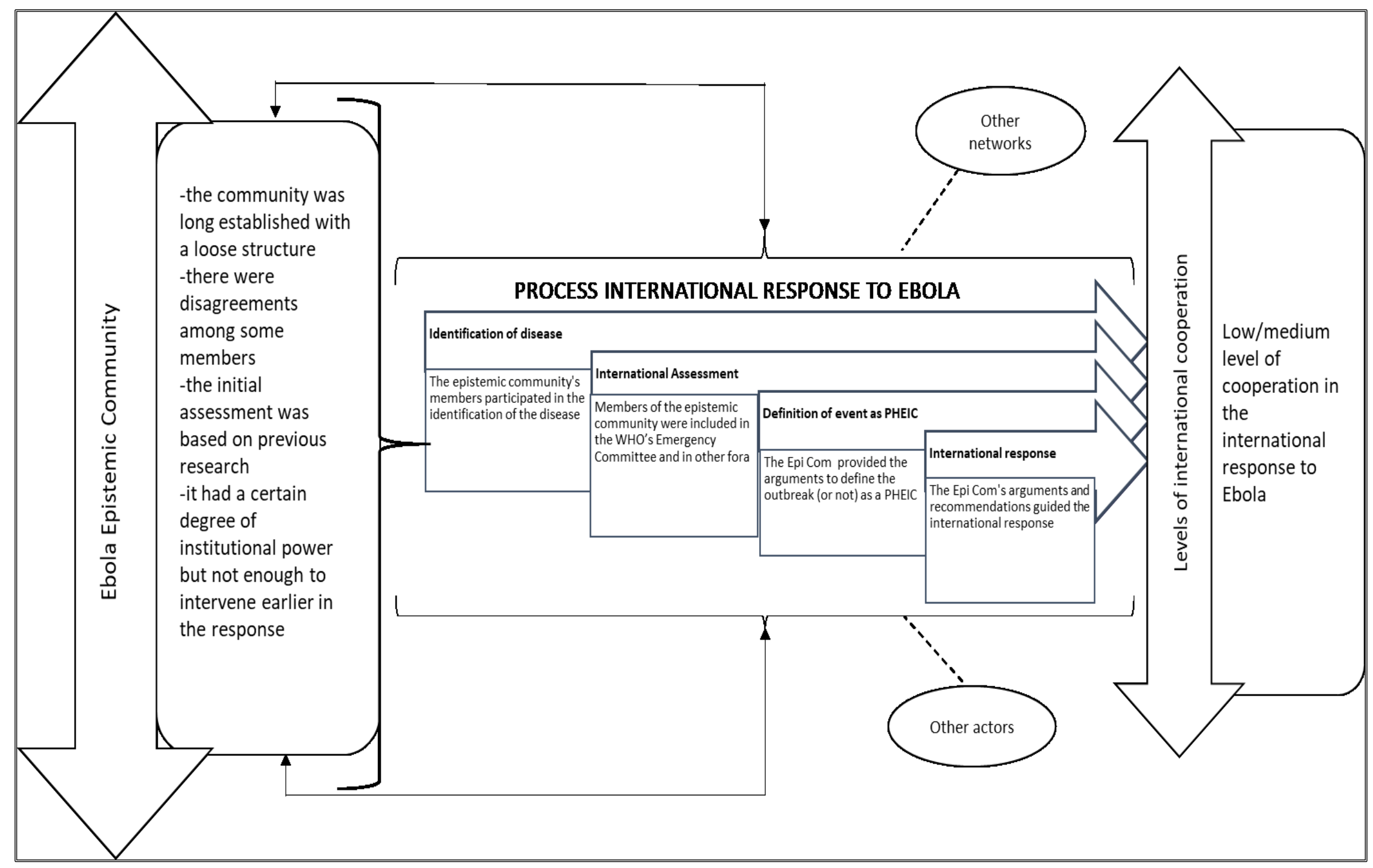

Figure 21. Ebola epistemic community and its participation in the international response 


\subsection{Ebola outbreak in West Africa 2013-2016}

The 2013 Ebola outbreak was the first one in West Africa from a Zaire Ebolavirus, one of the most deadly strains of Ebola (241). Ebola's case fatality rates have varied from period to location, fluctuating between 40 percent to 80 percent, with health workers usually being the most affected population $(512,513)$. Ebola outbreaks have shown a high mortality rate in the past $(493,479,479)$, and reproductive ratio $\mathrm{R}_{0}$ between 1.35 to $3.65(518,519,497)$. This was the same pattern documented in the West Africa outbreak; however, Ebola high case fatality rates estimations in this outbreak fluctuated between $50-90 \%$, due to underreporting $(512,487,493,474,516)$.

The WHO Ebola Response Team estimated a $\mathrm{R}_{0}$ of 1.71 in Guinea, a $\mathrm{R}_{0}$ of 2.02 in Sierra Leone, and a $\mathrm{R}_{0}$ of 1.837 in Liberia (513). The team analysed data reported by individual countries between December 30, 2013, and September 2014 (513). According to this analysis, these numbers were similar to the case fatality rates found in other recent outbreaks in Africa. The team of experts also confirmed that the epidemic had the same characteristics previously seen (513). Table 41 shows the characteristics of the 2013-2016 outbreak.

\begin{tabular}{|c|c|}
\hline & Ebolavirus (EVD) \\
\hline VIRUS & Zaire Ebolavirus \\
\hline CASE FATALITY RATE & $40-90 \%$ lvi \\
\hline TYPE OF TRANSMISSION & $\begin{array}{l}\text { Animal to human (index case) } \\
\text { Human to human (subsequent) }\end{array}$ \\
\hline NO. OF CASES & 28,616 (June 10, 2016) \\
\hline NO. OF DEATHS & 11,310 \\
\hline NO. OF COUNTRIES & $10^{\text {lviii }}$ \\
\hline TREATMENT & \\
\hline VACCINES & Non-existent during the outbreak ${ }^{\text {lix }}$ \\
\hline
\end{tabular}

Table 41. Characteristics Ebola outbreak West Africa 2013-2016.

\footnotetext{
${ }^{\text {lvi }}$ The case fatality rate initially was calculated $50 \%$.

lvii As reported in the latest Situation report published by the WHO on June 10, 2016

lviii Guinea, Liberia, Sierra Leone, Italy, Mali, Nigeria, Senegal, Spain, The United Kingdom and the United States

lix In December 2016 The Lancet published the results of a randomized trial of a vaccine that seems to provide high protection against the pathogen. The vaccines are called rVSV-ZEBOV, and the trial involved 11841 people in Guinea during 2015. (718) .
} 
Epidemiological evidence traced back the outbreak to December 2013, in Meliandou, Guinea. The WHO Ebola Response team found information that on December 26, 2013, a two-year-old boy was reported severely ill, presenting symptomatology of a mysterious disease and dying after two days $(110,382,111,483,517,518)$. Subsequent epidemiological investigations showed that the boy died of Zaire ebolavirus likely from contact with a bat (483). This patient is now considered the index case. According to information reported by the WHO, doctors in the village of Meliandou issued an official medical alert on January $24^{\text {th }}, 2014$, when they informed district authorities of various patients with severe and fatal diarrhea $(518,519)$. This report included the cases of people that were in contact with the boy and included his immediate family, midwives, and traditional healers. Health workers from the hospital in the Gueckedou District, where these patients received medical care, were also among the infected people (519). At that time, local health officials suspected cholera, although their investigation was inconclusive (519). The disease, however, spread out outside the village due to the traditional funerals that were attended by members of the boy's extended family, and who started transmission chains that soon reached the capital of Guinea, Conakry, which had its first cases in February 2014 (518,519).

On March $13^{\text {th }} ， 2013$, the Ministry of Health informed the WHO Regional Office about the situation. The same day the WHO opened an investigation suspecting first an outbreak of Lassa fever, a viral hemorrhagic fever endemic in the region $(518,241)$. The government of Guinea requested assistance from MSF to investigate the situation. The first MSF staff arrived in the village with suspected cases on March 18th $(241,473)$. MSF deployed more teams in Guinea and Sierra Leona when its senior epidemiologist, Dr. Michel Van Herp, suspected they were dealing with Ebola. Due to Dr. Van Herp's suggestion, on 
March $21^{\text {st, }}$ the organization sent virus samples to the Institut Pasteur in Lyon, France (a WHO Collaborating Centre) where scientists identified the virus on March 22, 2014 $(382,111)$. The same day the Ministry of Health of Guinea officially declared the outbreak as Ebola (241). The event was internationally reported on March $23^{\text {th }}, 2014$ by the WHO's Africa Regional Office (496). The WHO announced to the world that Ghinea notified and confirmed 49 cases and 29 deaths $(518,111)$.

Ebola symptoms are similar to malaria and Lassa fever in their early stages; diseases endemic in the region $(520,517,476)$. Thus, after the first case in Guinea, the disease quietly spread for months before being detected. Liberia confirmed two cases in the Foya District, close to the border with Guinea and Sierra Leone on March 30 2014 (473). Sierra Leone confirmed the outbreak on May $24^{\text {th }}, 2014$, and the first case in Kenema, a city closer to the border of both Liberia and Guinea (473). Between June and September of 2014, the number of cases detected increased exponentially.

After a few months of the outbreak, more countries notified cases (521). On September $30^{\text {th, }}$ the first case of Ebola outside Africa was detected in Spain when a nurse working in West Africa with Ebola patients became sick after returning to her country (518). The second case outside Africa occurred in the United States after a person flew from Liberia to Dallas and was hospitalized on September $25^{\text {th }}$ for what was later confirmed as Ebola (518). This patient died and transmitted the disease to two nurses. The imported cases to the USA increased the international alarm and fear of a massive worldwide spread of the disease (273). Figure 22 presents the chronology of the outbreak. 
Index case in

Meliandou, Guinea 12-12-2013

First official medical alert Meliandou case ]1-24-2014

Ebola reached Conakry, capital of Guinea 2-1-2014

Guinea Ministry of Health issued first alert to WHO regional office [3-13-2014

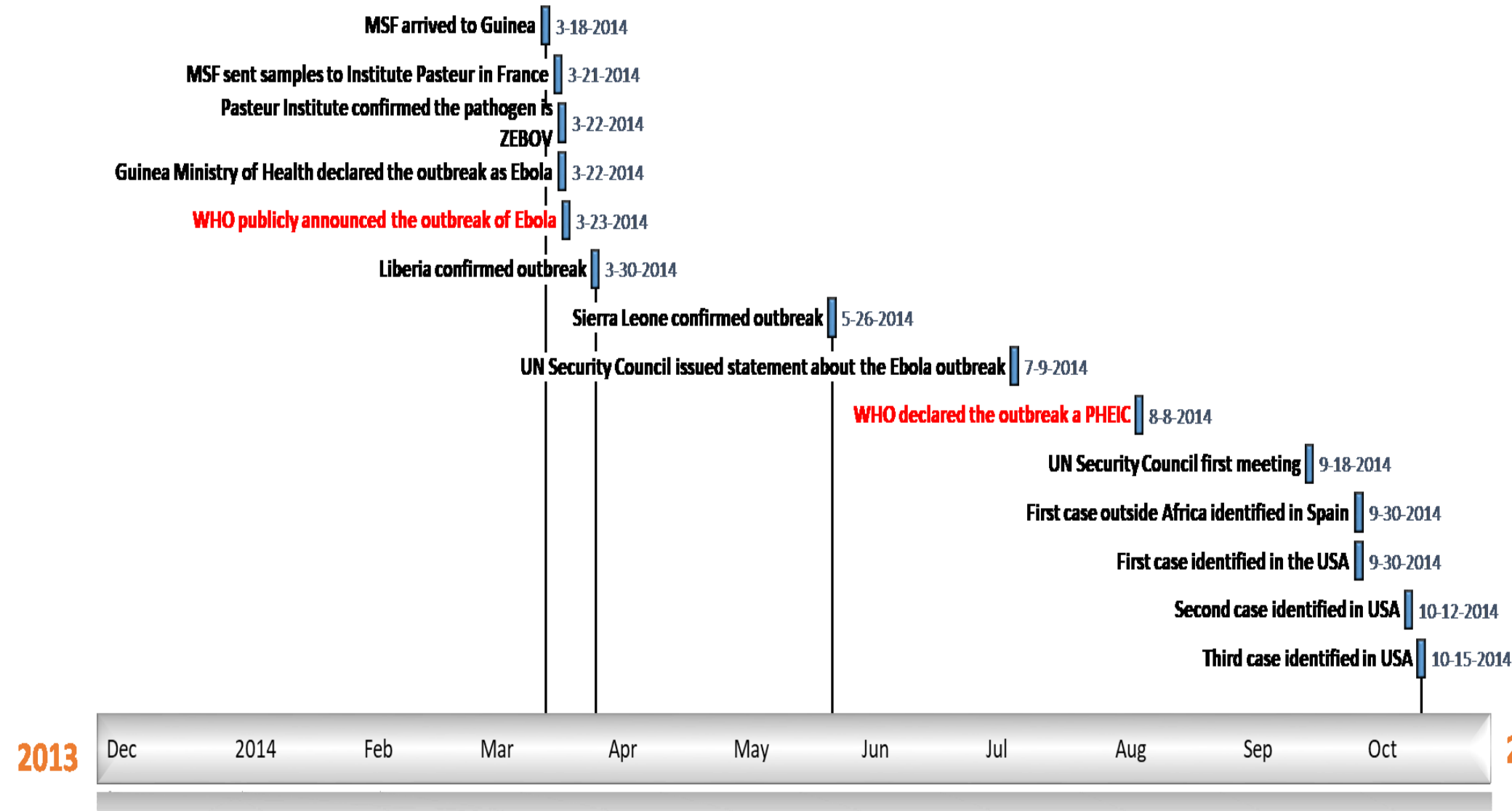

Figure 22. Chronology Ebola outbreak in West Africa 2013-2014 
At the beginning of the outbreak, scientists identified the animal to human transmission in some parts. However, most infections occurred due to human to human transmission $(483,518)$. The lack of information and knowledge about Ebola delayed notification and control measures, which increased the risk of transmission among health workers and caregivers (492).

Late notification, movement of infected people across borders, failure to undertake contact tracing, and traditional burial practices facilitated the spread of the disease, increasing the international concern for the pandemic potential of the outbreak. Figure 23 shows the geographical distribution of Ebola cases in October 2014.

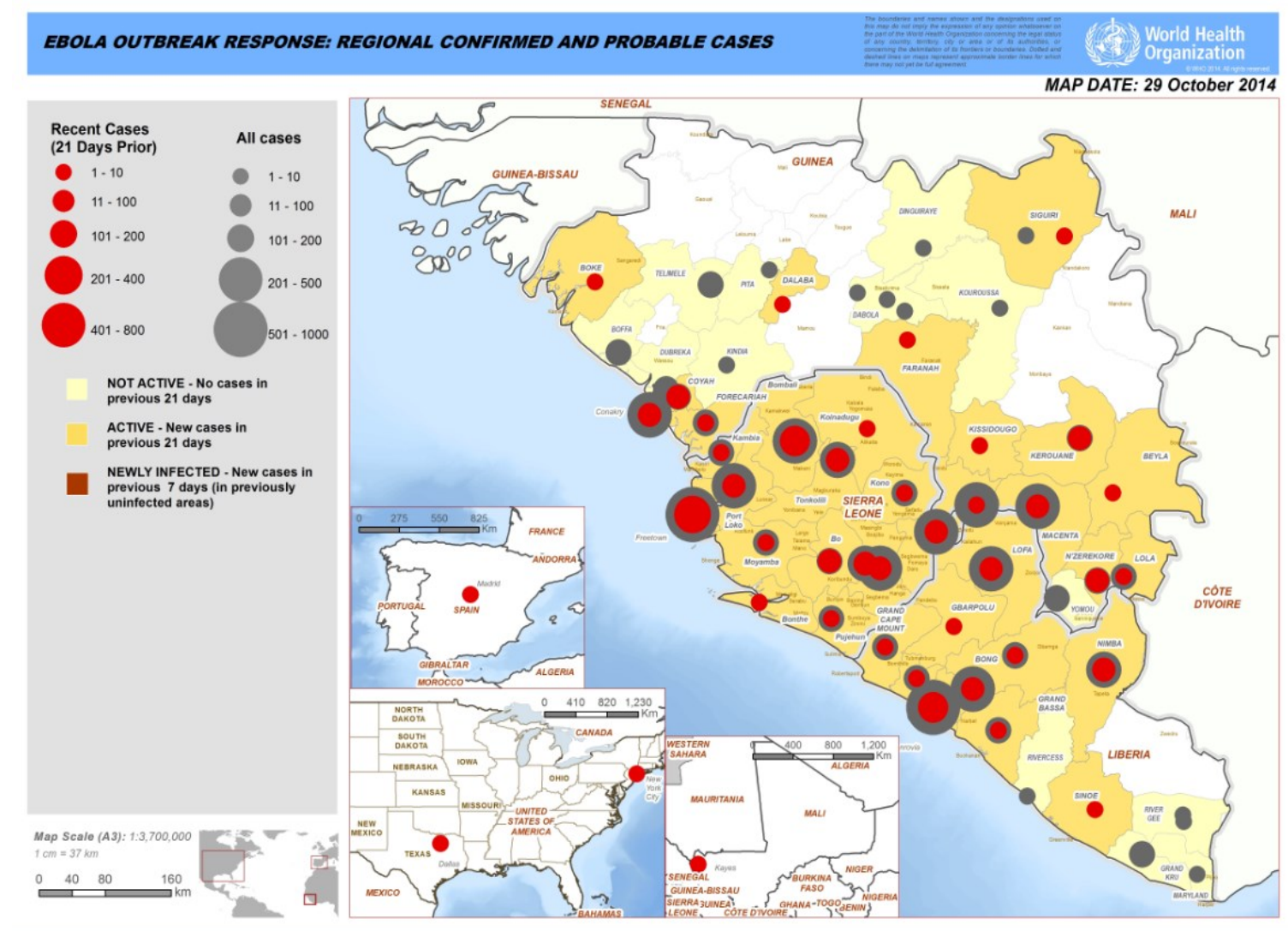

Figure 23. Geographical distribution of Ebola cases, October 2014.

Source: WHO Ebola Maps (http://www.who.int/csr/disease/ebola/maps-2014/en/) 
The events in West Africa and the Ebola outbreak brought to light problems with the global system of governance and the international response to pandemics. The impact of the epidemic changed from country to country, as a result of the number of people infected and the timing of the interventions, Sierra Leone being the most affected country (516).

\subsection{The Ebola epistemic community}

Analysing the epistemic community's characteristics will help to determine its influence on the level of cooperation seen during the West Africa outbreak.

\subsubsection{Origins of the Ebola epistemic community}

The epistemic community originally comprised experts that worked together when the first Ebola outbreak was detected in 1976 in Zaire (now DRC) and Sudan (now South Sudan). This outbreak had 318 confirmed cases and 280 deaths (478), with a case fatality rate of $88 \%$ (477). It started in patients at the Yambuku Mission Hospital, showing the vulnerability of health workers, where 11 of 17 staff members died of the disease $(478,476)$. The outbreak was initially concentrated in the Bumba zone of the Equator region. However, in Sudan, health authorities detected patients with Ebola near the border with Zambia; people traveling between communities probably transmitted the disease (478). The government of Zaire requested international assistance to control the outbreak in October 1976 (476), and the WHO organized the International Commission for the Investigation and Control of Ebola Hemorrhagic Fever $(478,476)$. The WHO called experts from recognized health institutions from Belgium, Canada, France, the Republic of Zaire, South Africa, the United States of America, and the World Health Organization to participate in the Commission (See Appendix $\mathrm{K}$ for the full list of experts). The Commission visited Yambuku for the first time on October 19 (478). By then, the area was in quarantine, and air services had stopped, limiting the access 
to medical equipment and other essential goods.

Countries faced a lack of materials for medical protections (mainly gloves and lab coats), as well as problems with inadequate cleansing of medical equipment (syringes, needles, surgical instruments) and inadequate treatment of possible cases (478). The Commission brought medical experts to inform and educate medical personnel about how to contain the disease and use protection when treating patients. They also established a team for researching possible cases and collecting samples, which later the US CDC in Atlanta used to isolate the virus (478).

Given the situation in the area, and the high mortality rate, the Commission returned a second time and "mobilized all available resources, national and international, to cope with a possible major threat to public health in Zaire and elsewhere" (478). The group of international experts established a total of ten surveillance teams by November 9, 1976. They visited 550 villages, interviewed around 34,000 families, and identified 231 probable cases (478). The International Commission advised lifting quarantine on December 16, six weeks after the last death from Ebola was reported (478). Experts that participated in the response to this first outbreak considered that quick recognition of the disease was crucial for controlling it (476).

Since 1976, there have been several Ebola outbreaks in Zaire/DRC and Uganda, showing a high mortality rate. The transmission, however, was concentrated in communities (community-based transmission), with index cases that usually had the first contact with animal reservoirs (animal-human transmission) (522). Before 2013, outbreaks were concentrated in central and eastern Africa (473). Table 42 summarizes the outbreaks and their main characteristics. 


\begin{tabular}{|c|c|c|c|c|c|}
\hline Year & Country & Ebolavirus species & Cases & Deaths & Case fatality \\
\hline 2012 Nov-2013 Jan & Uganda & Sudan virus & 6 & 3 & $50 \%$ \\
\hline 2012 & Democratic Republic of Congo & Bundibugyo & 57 & 29 & $51 \%$ \\
\hline 2012 & Uganda & Sudan & 7 & 4 & $57 \%$ \\
\hline 2012 & Uganda & Sudan & 24 & 17 & $71 \%$ \\
\hline 2011 & Uganda & Sudan & 1 & 1 & $100 \%$ \\
\hline 2008 & Democratic Republic of Congo & Zaire & 32 & 14 & $44 \%$ \\
\hline 2007 & Uganda & Bundibugyo & 149 & 37 & $25 \%$ \\
\hline 2007 & Democratic Republic of Congo & Zaire & 264 & 187 & $71 \%$ \\
\hline 2005 & Congo & Zaire & 12 & 10 & $83 \%$ \\
\hline 2004 & Sudan & Sudan & 17 & 7 & $41 \%$ \\
\hline 2003 (Nov-Dec) & Congo & Zaire & 35 & 29 & $83 \%$ \\
\hline 2003 (Jan-Apr) & Congo & Zaire & 142 & 128 & $90 \%$ \\
\hline 2001-2002 & Congo & Zaire & 59 & 44 & $75 \%$ \\
\hline 2001-2002 & Gabon & Zaire & 65 & 53 & $82 \%$ \\
\hline 2000 & Uganda & Sudan & 425 & 224 & $53 \%$ \\
\hline 1996 & South Africa (ex-Gabon) & Zaire & 1 & 1 & $100 \%$ \\
\hline 1996 (Jul-Dec) & Gabon & Zaire & 60 & 45 & $75 \%$ \\
\hline 1996 (Jan-Apr) & Gabon & Zaire & 31 & 21 & $68 \%$ \\
\hline 1995 & Democratic Republic of Congo & Zaire & 315 & 254 & $81 \%$ \\
\hline 1994 & Cote d'Ivoire & Taï Forest & 1 & 0 & $0 \%$ \\
\hline 1994 & Gabon & Zaire & 52 & 31 & $60 \%$ \\
\hline 1979 & Sudan & Sudan & 34 & 22 & $65 \%$ \\
\hline 1977 & Zaire & Zaire & 1 & 1 & $100 \%$ \\
\hline 1976 & Sudan & Sudan & 284 & 151 & $53 \%$ \\
\hline 1976 & Zaire & Zaire & 318 & 280 & $88 \%$ \\
\hline
\end{tabular}

Table 42. Ebola outbreaks over time.

Source: WHO Ebola Chronology; Outbreaks Chronology Ebola Virus Diseases CDC USA (523).

In December 1977, during the International Colloquium on Ebola Virus Infection and Other Haemorrhagic Fevers held in Antwerp, Belgium, experts recognized that new diseases occurring in remote areas far from research institutions were less likely to be investigated (524). Despite this recognition, only a few institutions initiated research programs related to hemorrhagic diseases. These institutions are found mostly in the USA and Canada, and research is guided by security precepts, due to the fear that Ebola can be used as a biological weapon $(525,110)$.

The group that included experts in the International Commission, and whose later participated in the International Colloquium, can be identified as the origins of the epistemic community in Ebola. Since the 1970s, the epistemic community has been working together, 
expanding its research to other Filoviruses. It has had continues interactions and disseminating their knowledge. Table 43 presents a list of international conferences and symposiums.

\begin{tabular}{|l|l|}
\hline Conference & Date and location \\
\hline $\begin{array}{l}\text { International Colloquium on Ebola Virus } \\
\text { Research }\end{array}$ & September 4-7, 1996, Antwerp, Belgium \\
\hline Russian-German Colloquium on Filoviruses & January 28-February 2, 1997, Koltsovo, Russia \\
\hline Symposium on Marburg and Ebola Viruses & October 1-4, 2000, Hesse, Germany \\
\hline $\begin{array}{l}\text { VRC Symposium on Viral Hemorrhagic Fevers } \\
\text { Outbreaks of Ebola Haemorrhagic Fevers in } \\
\text { Central Africa (2001-2003) }\end{array}$ & September 7-8, 2004, Paris, France \\
\hline $\begin{array}{l}\text { Workshop on Controlling the Impact of Ebola } \\
\text { on African Apes }\end{array}$ & March 10-11, 2005, Washington D.C., USA \\
\hline $\begin{array}{l}\text { Filoviruses: Recent Advances and Future } \\
\text { Challenges }\end{array}$ & September 17-19, 2006, Winnipeg, Canada \\
\hline
\end{tabular}

Table 43. Conferences related to Ebola and other Filoviruses (526).

The Ebola epistemic community has advanced our knowledge about the virus since the 1970s, and its research has been used to respond to different outbreaks. Since 1995, collaboration among experts has increased, and more scientists have shown interest in the virus (527). In the 2000s, the creation of the WHO Collaborating Centres for the diagnosis of Ebola or Marburg VHF institutionalized the Ebola epistemic community, increasing its participation at the WHO as technical advisors, who are involved in drafting policy documents $(528,527)$. Thus, in 2014 , an epistemic community existed. The network shared among its members' common interests, normative beliefs, causal beliefs, epistemological beliefs. Table 44 summarizes these characteristics. 


\begin{tabular}{|l|l|}
\hline Common interest & $\begin{array}{l}\text { They want to increase research on Ebola and improve its diagnosis } \\
\text { and treatments. }\end{array}$ \\
\hline Epistemological beliefs & $\begin{array}{l}\text { They considered that science should guide policies. They agree that } \\
\text { Ebola represents a risk and threat to humans. Therefore, vulnerable } \\
\text { populations should be better prepared to deal with future outbreaks. }\end{array}$ \\
\hline $\begin{array}{l}\text { Normative-principled } \\
\text { beliefs }\end{array}$ & $\begin{array}{l}\text { They are working on reducing the number of deaths and human } \\
\text { suffering due to Ebola. }\end{array}$ \\
\hline Causal beliefs & $\begin{array}{l}\text { Ebola is transmitted from animal hosts to humans, and human to } \\
\text { human transmission can be fast. }\end{array}$ \\
\hline Notions of validity & $\begin{array}{l}\text { They have established general practices for research and } \\
\text { development of medical and non-medical interventions. }\end{array}$ \\
\hline
\end{tabular}

Table 44. Characteristics Ebola epistemic community.

These elements have made possible the work of an Ebola epistemic community, which has produced consensual knowledge and a common policy goal.

\subsubsection{Characterizing the Ebola epistemic community}

The foundations of the Ebola epistemic community come from the first outbreak of Ebola registered in history and the formation of a group of professionals interested in advancing our knowledge about the disease. The characteristics of this community will be analysed to understand its participation during the response in the 2014 Ebola outbreak.

\subsubsection{Knowledge}

The epistemic community had developed its consensual knowledge before the outbreak in West Africa in 2014. Experts knew that the Ebola virus caused outbreaks with high mortality rates due to a hemorrhagic fever. Scientists also believed the disease was confined usually to remote areas, and it affected only certain countries in Africa. These characteristics made it easier to contain outbreaks, with the expectation of a low number of people infected $(517,489,513)$. Ebola epidemics, however, frequently started in countries with weak and unprepared health systems, where the health personnel was scarce, with limited knowledge about how to respond to the disease, making this group highly vulnerable $(489,529,491,530)$. 
When news on the West Africa outbreak started, many members of the epistemic community agreed that using the same strategies used in past outbreaks would work again [contact tracing, establishing quarantine and isolation of cases, infection control, and safe burial (513)]. In the end, these measures were not enough to contain the outbreak $(517,489)$. Others, however, believed the events required a different approach and demanded quick action and prompt intervention of the international community. This was the case of MSF's Ebola experts, who were an essential part of the international response. According to MSF reports, WHO experts initially disregarded MSF experts' suggestions about the emergency (241).

The disease spread quickly, and people moving across countries were transmitting the disease, causing micro-epidemics in clusters of cases. The quick transmission made it necessary to provide faster diagnostics. Because the virus incubates in 3 to 21 days, the focus shifted to improve the diagnosis, implement quarantine of infected people and containment, and educate people and health workers about essential sanitary measures $(517,513)$.

Once the outbreak was under control, the epistemic community recognized that the incident brought new lessons about the management and response of future epidemics (531). Experts agreed that this outbreak was different from others because of the context and lack of preparation in the countries (513). This was the first outbreak in a highly interconnected area where traveling increased the rate of transmission [ $(489,513)$, Interview 12]. Even though there was information about the disease and how to handle it, the context changed, and these professionals were unprepared to act faster (Interview 12).

Experts also agreed that a rapid response could effectively interrupt transmission (516). This was the case in Nigeria, where the outbreak was contained easily, and only 15 
people were infected (516). This last finding was not novel since experts had previously documented the importance of quick identification and notification $(476,475)$.

The epistemic community developed consensual knowledge that was used to guide the initial response, but it failed to recognize changes in the context (513). Besides, the epistemic community's policy goal was evident after the outbreak started. The policy goal appeared in the 2014 Strategic Plan designed with the WHO, which recognized Ebola as a public health issue in sub-Saharan Africa. Countries in that region, according to the report, require better tools, resilient health systems, and equipped workers to fight future outbreaks (532). When the outbreak spun out of control, this policy goal extended to a global concern, acknowledging widespread inexperience on dealing with Ebola outbreaks (496), and the limited knowledge about specific aspects of the disease, symptoms and transmission patterns.

\subsubsection{Socialization of ideas}

Having developed consensual knowledge and policy goals are not sufficient conditions to influence international cooperation if these are not socialized among members of the epistemic community and made accessible to policymakers. The Ebola epistemic community disseminated its consensual knowledge during the Ebola outbreak through its network structure, its participation in international conferences, and the publication of information and evidence.

The structure of the Ebola epistemic community, however, is smaller than the influenza epistemic community and closed. The WHO has acted as a loose coordinator, although, during the outbreak, the WHO concentrated a lot of the information and distributed it directly within the network (533). Having the WHO's experts collecting and managing most information, limited the capacity of other epistemic community's members to connect 
with experts outside the network (Interview 11).

The epistemic community also is a closed, rigid structure that restricts the integration of other experts. The WHO Collaborating Centres for the diagnosis of Ebola or Marburg VHF, the Ebola Emergency Committee, the Members of the WHO Advisory Group on the Ebola Virus Disease Response, and the GOARN were the groups that formed the core Ebola epistemic community. The WHO's experts, however, acted as the focal point for the network, and many decisions were centralized within the WHO's bureaucracy.

The epistemic community had several interactions before and during the outbreak through meetings and other mechanisms. For instance, the group of experts that analysed the outbreak and prepared the first guidelines, had meetings in Burkina Faso (Ouagadougou), Gabon (Libreville), and Republic of the Congo (Brazzaville) between 2004 and 2009 (532). Some of these experts were also part of the WHO Collaborating Centres for the diagnosis of Ebola or Marburg VHF. As well, the WHO organized the Emergency Committee in August 2014, which held nine meetings between August $8^{\text {th }}, 2014$, and March 29 ${ }^{\text {th }}, 2016$. The Members of the Advisory Group interacted with the Emergency Committee and the WHO for the response (534). The Advisory Group had thirteen meetings between October $15^{\text {th }}$, 2014, and January $12^{\text {th }}, 2016$.

The size of the epistemic community was not very big. The network, however, increased after the outbreak, and more professionals joined $(499,110)$. The epistemic community has also remained concentrated in the most affected countries and developed countries with research capacities. Figure 24 maps the epistemic community by country. 


\section{Country Membership Epistemic Community Ebola}

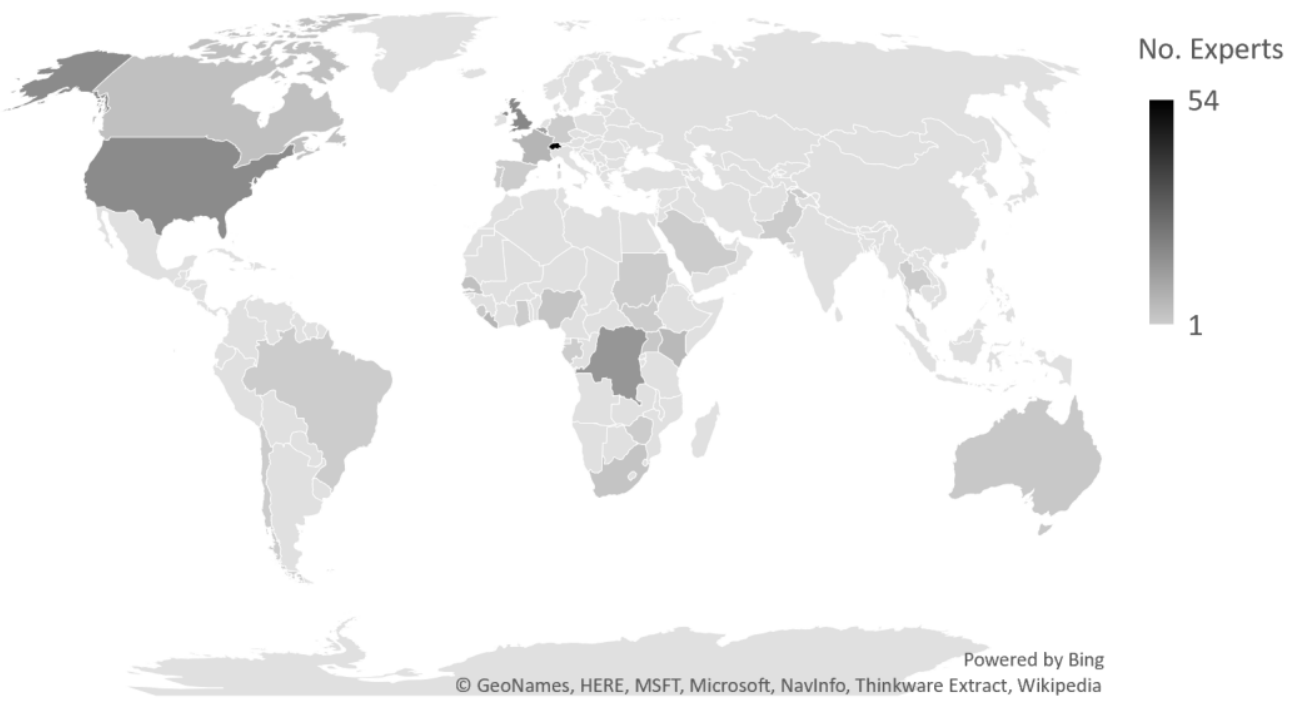

Figure 24. Geographical distribution epistemic community members Ebola.

The existence of an epistemic community, with consensual knowledge and a network connected to the main policy-making structure, are not enough elements to be able to influence international cooperation. The community must create knowledge, disseminate it, and make it useful for the policy process. One of the challenges of the community was to produce research to understand the events in West Africa. Although Ebola was identified in the late 70s, a recent study found that between the years 1976 and 2013, there were only 2485 publications with the word Ebola in the title, and 3081 in keywords and abstract. After 2013, more research was published about Ebola (485), mostly by experts in North America and Europe, and studies from scholars based in African countries were less common [mainly from Gabon, Republic of Congo, Central African Republic and Cameroon (485)]. Most research collaborations concentrated in Canada and the United States; two countries that have invested in research due to national security concerns and have most of the laboratories with a biosafety level 4 (BSL-4), facilities that are required to isolate dangerous pathogens (485). The availability of evidence supported by scientific research, the dissemination of 
information, and knowledge-sharing are critical activities for a pandemic response (476). During the first phase of the outbreak, there was limited information available about treatments and drugs, and the possibility of testing and producing a vaccine in a short time was unlikely $(110,241)$. The epistemic community was the primary source of information, and it needed to be able to disseminate it as soon as possible. Dissemination and sharing data, however, were problematic, and it took time to collect samples and develop research capacities $(517,127)$. Part of the problem originated in the affected countries for not having adequate systems for transmitting data, and information was not shared in a timely and open manner $(110,535,241)$. Some researchers also withheld some information, and other scientists were not credited for accessing it $(110,127,126,536)$. During the second stage of the outbreak, researchers prioritized the testing of vaccines and researching new drugs $(110,485)$.

The WHO was the central coordination and dissemination channel for the epistemic community, organizing meetings for data sharing and establishing norms that were included in a "blueprint" in which Ebola appears as one of the priority pathogens (110,537). In August 2014, members of the epistemic community collaborated with the WHO and published the document "Ebola and Marburg virus disease epidemics: preparedness, alert, control and evaluation." These experts were part of the WHO Collaborating Centres for the diagnosis of Ebola or Marburg VHF, who compiled the document based on the outbreaks recorded since 1995 (532). They, however, did not have relevant participation in the decision-making process at the beginning of the outbreak, and their role was limited to technical assistance. The WHO published around 80 technical documents to guide the response (270).

During the second stage of the outbreak, the WHO issued publications and policy 
documents, which included recommendations and information provided by the epistemic community. The Emergency Committee made the most important recommendations. Table 45 presents a summary of the most important of them.

\begin{tabular}{|c|c|}
\hline Date & Recommendation \\
\hline $\begin{array}{l}8 \text { August } 2014 \\
\text { First meeting } \\
\text { EC }\end{array}$ & $\begin{array}{l}\text { Recommended declaring the Ebola outbreak in West Africa a Public Health Emergency } \\
\text { of International Concern (PHEIC). The Director-General endorsed the Committee's } \\
\text { advice and issued them as Temporary Recommendations under IHR (2005) to reduce } \\
\text { the international spread of Ebola, effective } 8 \text { August } 2014 \text {. } \\
\text { The EC also suggested an immediate coordinated international response to stop and } \\
\text { reverse the international spread of Ebola. }\end{array}$ \\
\hline $\begin{array}{l}\text { 22 September } \\
2014 \\
2^{\text {nd }} \text { meeting EC }\end{array}$ & $\begin{array}{l}\text { The EC recommended "enhanced mobilization and coordination of resources to facilitate } \\
\text { response efforts; to engage the global research community and address key research } \\
\text { opportunities (e.g. virus mutation, modelling effects of entry/exit strategies, } \\
\text { effectiveness of various public health measures directly relevant to Ebola control } \\
\text { including health-care worker infection and protection, new/unregistered medical } \\
\text { interventions).." }\end{array}$ \\
\hline $\begin{array}{l}23 \text { October } 2014 \\
3^{\text {rd }} \text { meeting EC }\end{array}$ & $\begin{array}{l}\text { "The Committee reiterated its recommendation that there should be no general ban on } \\
\text { international travel or trade. A general travel ban is likely to cause economic hardship } \\
\text { and could consequently increase the uncontrolled migration of people from affected } \\
\text { countries, raising the risk of international spread of Ebola. The Committee emphasized } \\
\text { the importance of normalizing air travel and the movement of ships, including the } \\
\text { handling of cargo and goods, to and from the affected areas, to reduce the isolation and } \\
\text { economic hardship of the affected countries. Any necessary medical treatment should be } \\
\text { available ashore for seafarers and passengers (...)." }\end{array}$ \\
\hline $\begin{array}{l}21 \text { January } 2015 \\
4^{\text {th }} \text { meeting }\end{array}$ & $\begin{array}{l}\text { "The Committee reaffirmed the need to avoid unnecessary interference with } \\
\text { international travel and trade, as specified in Article } 2 \text { of the IHR 2005(...)" } \\
\text { "The Committee concluded that the primary emphasis must continue to be on 'getting to } \\
\text { zero' Ebola cases, by stopping the transmission of Ebola within the three most affected } \\
\text { countries. This action is the most important step in preventing international spread. } \\
\text { Complacency is the biggest risk of not getting to zero cases. Continued vigilance is } \\
\text { essential". }\end{array}$ \\
\hline $\begin{array}{l}7 \text { July } 2015 \\
6^{\text {th }} \text { meeting }\end{array}$ & $\begin{array}{l}\text { The Committee addressed the need for interagency collaboration, especially at the } \\
\text { community level, and that operational agency should have better communication with } \\
\text { communities. } \\
\text { Affected countries should make every effort to retain and retrain health workers and } \\
\text { ensure the engagement of communities in all aspects of the response. The Committee } \\
\text { emphasized the importance of providing social and psychosocial support to communities } \\
\text { and support to persons placed in quarantine. }\end{array}$ \\
\hline
\end{tabular}

Table 45. Emergency Committee summary recommendations Ebola outbreak. 


\begin{tabular}{|l|l|}
\hline Date & Recommendation \\
\hline 5 October 2015, & $\begin{array}{l}\text { The EC considered that Ebola contacts or cases should not travel unless the travel is part } \\
\text { of an appropriate medical evacuation. Its recommendations to minimize the risk of } \\
\text { international spread of virus included: } \\
\text { "Confirmed cases should immediately be isolated and treated in an Ebola Treatment } \\
\text { Centre with no national or international travel until 2 Ebola-specific diagnostic tests } \\
\text { conducted at least } 48 \text { hours apart are negative; } \\
\text { Contacts (which do not include adequately protected health workers and laboratory staff } \\
\text { who have had no unprotected exposure) should be monitored daily, with restricted } \\
\text { national travel and no international travel until 21 days after exposure; } \\
\text { Probable and suspect cases should immediately be isolated, and their travel should be } \\
\text { restricted in accordance with their classification as either a confirmed case or contact. } \\
\text { States should conduct exit screening of all persons at international airports, seaports and } \\
\text { major land crossings, for unexplained febrile illness consistent with potential Ebola } \\
\text { infection." } \\
\text { The EC also requested States implementing excessive or inappropriate travel and } \\
\text { transport measures that go beyond these Temporary Recommendations terminate them } \\
\text { by the end-October 2015. }\end{array}$ \\
\hline $\begin{array}{l}\text { 29 March 2016, } \\
\mathbf{9}^{\text {th }} \text { meeting EC } \\
\text { spread and that countries could respond rapidly to new outbreaks. "Accordingly, in the } \\
\text { Committee's view, the Ebola situation in West Africa no longer constitutes a Public }\end{array}$ \\
$\begin{array}{l}\text { Health Emergency of International Concern and the Temporary Recommendations } \\
\text { adopted in response should now be terminated. The Committee emphasized that there } \\
\text { should be no restrictions on travel and trade with Guinea, Liberia, and Sierra Leone and } \\
\text { that any such measures should be lifted immediately (538)". }\end{array}$ \\
\hline
\end{tabular}

Table 45. Emergency Committee summary recommendations Ebola outbreak (cont.).

During the outbreak, there were also different international conferences organized to

share information and provide updates on scientific knowledge for the response. The Informal

Consultation on how science can inform our response to the Ebola virus disease outbreak on

7 October 2014, was sponsored by different institutions, and it became an important forum

to exchange information. Some of the participants included:

- Dr. Sylvain Baize, Institut Pasteur

- Dr. Philippe Calain, MSF Switzerland

- Professor Jean-Francois Delfraissy, INSERM

- Dr. Scott Dowell, The Bill and Melinda Gates Foundation

- Dr. John Edmunds, The London School of Hygiene and Tropical Medicine

- Dr. Robert Fowler, Sunnybrook Medical Centre

- Professor Stephan Günther, BNI, University of Hamburg

- Dr. Lisa Hensley, US National Institutes of Health

- Dr. Peter Jahrling, US National Institutes of Health

- Dr. Gary Kobinger, Public Health Agency of Canada

- Dr. Mandy Kader Konde, Institute of Research Guinea 
- Dr. Stuart Nichol, US Centres for Disease Control and Prevention

- Professor Peter Piot, London School of Hygiene and Tropical Medicine

- Dr. Michel Van Herp, MSF Belgium

Many of these people were part of the epistemic community, and the conference allowed a high-level interaction with stakeholders, experts, and organizations involved in the topic and with decision making positions.

Some epistemic community members participated through the GOARN, which also faced some constraints due to budgetary cuts (110). The GOARN, as an operational and loose structure, gave access to members of the epistemic community to active participation in the field. After the PHEIC declaration, this participation also expanded due to the creation of the United Nations Mission for Ebola Emergency Response (UNMEER). There was an increasing number of partners and mobilization of extra resources from all over the world to support activities in the affected area. Other subnetworks of experts participating directly in the response were the Emerging and Dangerous Pathogens Laboratory Network (EDPLN), and the WHO Emergency Communication Network $(270,539)$.

\subsubsection{Institutionalization of bureaucratic power}

The Ebola epistemic community advised the WHO during the outbreak through committees and expert groups, but it did not depict a strong power to influence an early response. Participation in decision making was limited in the first stage of the outbreak. The centralization of decision making within the WHO and domestic politics reduced the impact that the epistemic community's input had. Once the PHEIC was declared, the epistemic community had more involvement.

During the second stage, the Emergency Committee acted as the leading consultant as well as the Advisory Group, a group of experts appointed to guide the response and to 
advise the WHO Director-General, the UN Special Envoy on Africa and the GOARN (540). These groups worked together with experts from the WHO Collaborating Centres, and some also were part of the 2014 WHO response team. However, some members of the epistemic community, with broad experience, were left outside the primary global decision-making process. For instance, experts from the WHO Collaborating Centres were not included as members of the Emergency Committee (EC), and only one of the members of the EC was part of the group that drafted the Ebola Strategy of 2014. Table 46 presents the list of the EC members and their relationship with the other groups. 


\begin{tabular}{|c|c|c|c|c|c|c|}
\hline Country & Member & Institution & $\mathbf{E C}$ & $\begin{array}{l}\text { WHO AG } \\
\text { Ebola Virus } \\
\text { Disease }\end{array}$ & $\begin{array}{l}\text { Ebola } \\
\text { Strategy } \\
2014\end{array}$ & $\begin{array}{l}\text { WHO } \\
\text { Collaborating } \\
\text { Centres Ebola. }\end{array}$ \\
\hline Australia & Chris Baggoley & Australian Government Department of Health & & & & \\
\hline Australia & Michael Selgelid & Monash University & & & & \\
\hline Canada & Anthony Evans & International Civil Aviation Organization & & & & \\
\hline Canada & Theresa Tam & Public Health Agency of Canada & & & & \\
\hline Chile & Fernando Otaiza & Ministry of Health & & & & \\
\hline DRC & $\begin{array}{l}\text { Jean-Jacques } \\
\text { Muyembe }\end{array}$ & National Institute of Biomedical Research & & & & \\
\hline France & Alain Epelboin & $\begin{array}{l}\text { National Centre for Scientific Research and } \\
\text { National Museum of Natural History }\end{array}$ & & & & \\
\hline Ghana & William Ampofo & University of Ghana & & & & \\
\hline Kenya & Vincent Anami & $\begin{array}{l}\text { University of the Health and Sciences, Friends } \\
\text { International Centre }\end{array}$ & & & & \\
\hline Nigeria & Oyewale Tomori & Redeemer's University & & & & \\
\hline Portugal & Maria João Martins & Ministry of Health & & & & \\
\hline $\begin{array}{l}\text { Saudi } \\
\text { Arabia }\end{array}$ & Abdullah Al-Assiri & Minister of Health for Preventive Health & & & & \\
\hline $\begin{array}{l}\text { Sierra } \\
\text { Leone }\end{array}$ & Amara Jambai & Ministry of Health and Sanitation & & & & \\
\hline $\begin{array}{l}\text { South } \\
\text { Africa }\end{array}$ & Lucille Blumberg & $\begin{array}{l}\text { National Institute for Communicable Diseases, } \\
\text { National Health Laboratory Service }\end{array}$ & & & & \\
\hline Spain & Dirk Glaesser & World Tourism Organization & & & & \\
\hline Switzerland & Robert Steffen & $\begin{array}{l}\text { WHO Collaborating Centre for Travellers' } \\
\text { Health University of Zurich }\end{array}$ & & & & \\
\hline Uganda & Sam Zaramba & Ministry of Health & & & & \\
\hline $\mathbf{U K}$ & Andrew Winbow & International Maritime Organization & & & & \\
\hline UK & Mark Salter & Public Health England & & & & \\
\hline USA & James LeDuc & University of Texas Medical Branch & & & & \\
\hline USA & Martin Cetron & Centres for Disease Control and Prevention & & & & \\
\hline USA & Vincent Covello & Centre for Risk Communication & & & & \\
\hline
\end{tabular}

Table 46. Overlapping of members in the epistemic community's core groups with the Ebola Emergency Committee (EC). 
At the institutional level (institutions with membership in the epistemic community), there was a better distribution and representation of the epistemic community. Table 47 presents institutions with multiple and overlapping representations.

\begin{tabular}{|c|c|c|c|c|c|c|c|c|c|}
\hline Country & Institution & EC & $\begin{array}{c}\text { WHO } \\
\text { AGEVDR }\end{array}$ & $\begin{array}{c}\text { ES } \\
2014\end{array}$ & $\begin{array}{c}\text { WHO } \\
\text { CCDEM }\end{array}$ & $\begin{array}{c}\text { ST } \\
1976\end{array}$ & $\begin{array}{c}\text { WHO } \\
\text { ERT2014 }\end{array}$ & IC 1976 & GOARN \\
\hline Switzerland & WHO/Headquarters & & & 16 & & & 37 & 2 & 3 \\
\hline \multirow{2}{*}{ USA } & Centres for Disease Control and Prevention & 1 & 1 & 1 & & & & 8 & 1 \\
\hline & WHO/AFRO, DPC/CSR & & & 12 & & & & & \\
\hline UK & Imperial College London & & & & & & 8 & & 1 \\
\hline Sudan & Ministry of Health & & & & & 8 & & & \\
\hline Liberia & Ministry of Health & & & & & & 7 & & \\
\hline UK & Microbiological Research Establishment & & & & & 5 & & & \\
\hline \multirow[t]{2}{*}{ Guinea } & Ministry of Health & & & & & & 4 & & \\
\hline & WHO/EMRO & & & 4 & & & & & \\
\hline Canada & $\begin{array}{l}\text { National Microbiology Laboratory/ } \\
\text { Public Health Agency of Canada }\end{array}$ & 1 & & 1 & 1 & & & & 1 \\
\hline Senegal & Institut Pasteur & & & & 1 & 1 & & & 1 \\
\hline UK & $\begin{array}{l}\text { London School of Hygiene and Tropical } \\
\text { Medicine }\end{array}$ & & & & & 2 & & & 1 \\
\hline Belgium & Médecins Sans Frontières & & & 2 & & & & & 1 \\
\hline Sierra Leone & Ministry of Health and Sanitation & 1 & & & & & 2 & & \\
\hline South Africa & $\begin{array}{l}\text { National Institute for Communicable } \\
\text { Diseases }\end{array}$ & 1 & & & 1 & & & & 1 \\
\hline
\end{tabular}

EC: Emergency Committee; WHOAGEVDR WHO Advisory Group on the Ebola Virus Disease Response; WHOCCDEM: WHO Collaborating Centres for the diagnosis of Ebola or Marburg VHF. ES2014: Ebola Strategy 2014; ST 1976 Study Team 1976; WHO ERT2014 WHO Ebola Response team 2014; IC1976 International Commission 1976

Table 47. Overlapping institutions with multiple representations in the epistemic community's core groups. 


\begin{tabular}{|c|c|c|c|c|c|c|c|c|c|}
\hline Country & Institution & EC & $\begin{array}{c}\text { WHO } \\
\text { AGEVD } \\
\text { R } \\
\end{array}$ & $\begin{array}{c}\text { ES } \\
2014\end{array}$ & $\begin{array}{l}\text { WHO } \\
\text { CCDEM }\end{array}$ & $\begin{array}{c}\text { ST } \\
1976\end{array}$ & $\begin{array}{c}\text { WHO } \\
\text { ERT2014 } \\
\end{array}$ & IC 1976 & GOARN \\
\hline UK & Public Health England & 1 & & & & & 1 & & 1 \\
\hline Zaire & Service d'Hygiene & & & & & & & 3 & \\
\hline Zaira & Universite Nationale du Zaire & & & & & & & 3 & \\
\hline Germany & $\begin{array}{l}\text { Bernhard-Nocht-Institut for Tropical } \\
\text { Medicine (BNI) }\end{array}$ & & & & 1 & & & & 1 \\
\hline USA & $\begin{array}{l}\text { Centre on Global Health Security, } \\
\text { Chatham House }\end{array}$ & & 1 & & & & & 1 & \\
\hline Belgium & Institut de Medecine Tropicale & & & & & & & 2 & \\
\hline France & Institut Pasteur & & & & & & & 1 & 1 \\
\hline Gabon & $\begin{array}{l}\text { Institute for Development Research } \\
\text { (IRD) International Centre for Medical } \\
\text { Research }\end{array}$ & & & 1 & 1 & & & & \\
\hline Belgium & $\begin{array}{l}\text { London School of Hygiene and Tropical } \\
\text { Medicine }\end{array}$ & & 1 & & & & & 1 & \\
\hline Switzerland & Médecins Sans Frontières & & & 1 & & & & & 1 \\
\hline France & Médecins Sans Frontières & & & & & & & & 2 \\
\hline Uganda & Ministry of Health & 1 & 1 & & & & & & \\
\hline Kenya & Ministry of Health & & & & & 2 & & & \\
\hline Nigeria & Ministry of Health & & & & & & 2 & & \\
\hline France & $\begin{array}{l}\text { National Centre for Scientific Research } \\
\text { and National Museum of Natural History }\end{array}$ & 1 & & 1 & & & & & \\
\hline Pakistan & National Emergency Operations Centre & & 1 & 1 & & & & & \\
\hline Congo & $\begin{array}{l}\text { National Institute of Biomedical } \\
\text { Research }\end{array}$ & 1 & 1 & & & & & & \\
\hline USA & University of Texas Medical Branch & 1 & & & & & & & 1 \\
\hline
\end{tabular}

EC: Emergency Committee; WHOAGEVDR WHO Advisory Group on the Ebola Virus Disease Response; WHOCCDEM: WHO Collaborating Centres for the diagnosis of Ebola or Marburg VHF. ES2014: Ebola Strategy 2014; ST 1976 Study Team 1976; WHO ERT2014 WHO Ebola Response team 2014; IC1976 International Commission 1976

Table 47. Overlapping institutions with multiple representations in the epistemic community's core groups (cont.). 
Table 47 also presents the number of experts participating from each institution in the core groups and including those from the epistemic community formed in 1976.

Other subgroups also emerged during the second phase of the outbreak with resources for R\&D. The WHO created the VSV Ebola Consortium (VEBCOM), which initiated studies phase 1 in the development of a vaccine that could progress rapidly into clinical trials. The VEBCOM used the candidate vaccine developed by the Canadian National Microbiology Laboratory rVsV-ZEBOV obtained from the Zaire Ebola virus (541). The Consortium included some members of the WHO Collaborating Centre for Arbovirus and Hemorrhagic Fever Reference and Research (541). Before the VEBCOM, the US National Institute of Allergy and Infectious Diseases launched a global collaboration in 2013, the Viral Hemorrhagic Fever Immunotherapeutic Consortium, which part of its work focused on finding therapies for viruses such as Ebola (542).

The Executive Board in January 2015 (during the outbreak) decided to create a panel of independent experts, requesting an interim assessment of the WHO response (Resolution EBSS3.R1). The WHO Ebola Interim Assessment Panel assessed the intervention of the organization and the mechanisms in place for an international response. This subgroup presented its findings before the end of the outbreak was declared making recommendations for changes in the system (499). The WHO Secretariat responded on 19 August 2015, and it made clear that most of those recommendations had to be approved by Member States (543).

The panel evaluated the situation and made recommendations to implement during the outbreak and to improve future responses. The Sixty-eighth World Health Assembly in May 2015 reviewed and discussed the Panel's first report, included in decision WHA68(10). Table 48 presents the people who participated in this panel. 


\begin{tabular}{|l|l|l|}
\hline Name & Position & Country \\
\hline Dame Barbara Stocking & $\begin{array}{l}\text { Chair of the Panel. Formerly Chief Executive of } \\
\text { Oxfam GB, where she led major humanitarian } \\
\text { responses. Currently President of Murray } \\
\text { Edwards College, University of Cambridge }\end{array}$ & United Kingdom \\
\hline $\begin{array}{l}\text { Professor Jean-Jacques } \\
\text { Muyembe-Tamfun }\end{array}$ & $\begin{array}{l}\text { Director-General of the National Institute for } \\
\text { Biomedical Research }\end{array}$ & $\begin{array}{l}\text { The Democratic } \\
\text { Republic of the } \\
\text { Congo }\end{array}$ \\
\hline Dr. Faisal Shuaib & $\begin{array}{l}\text { Head of the National Ebola Emergency } \\
\text { Operations Centre }\end{array}$ & Nigeria \\
\hline $\begin{array}{l}\text { Dr. Carmencita Alberto- } \\
\text { Banatin }\end{array}$ & $\begin{array}{l}\text { Independent consultant, and advisor on health } \\
\text { emergencies and disasters }\end{array}$ & Philippines \\
\hline Professor Julio Frenk & $\begin{array}{l}\text { Dean of the Faculty, Harvard T. H. Chan School } \\
\text { of Public Health }\end{array}$ & $\begin{array}{l}\text { United States of } \\
\text { America }\end{array}$ \\
\hline $\begin{array}{l}\text { Professor } \\
\text { Kickbusch }\end{array}$ & $\begin{array}{l}\text { Director of the Global Health Programme at the } \\
\text { Graduate Institute of International and } \\
\text { Development Studies }\end{array}$ & Switzerland \\
\hline
\end{tabular}

Table 48. Participants WHO Ebola Interim Assessment Panel (499).

Some members of the epistemic community worked directly with their national governments and international organizations to establish measures to follow. They participated in international fora as part of their national delegations and provided their advice and knowledge regarding the status of the pandemic.

During the second phase of Ebola, there were also some policy entrepreneurs from the epistemic community that had critical participation in the global decision-making process and were able to influence it. Some of them were:

i. David Nabarro: He was appointed UN System Senior Coordinator for Ebola Virus Disease; he was consulted together with the WHO D.G. to establish UNMEER (WHO). On September 23, 2014, he was appointed Special Envoy on Ebola and Anthony Banbury as his Special Representative and Head of UNMEER

ii. Bruce Aylward: The WHO D.G appointed him as the D.G. Special Representative for the Ebola Response, representing the WHO in the UNMEER meetings. He was responsible for analyzing the epidemiological data and used to drive the response across 
all the actors involved and help to provide technical direction (544). He also advocated for more resources for financing the response. He participated in the elaboration of the WHO Ebola Response Roadmap 2014.

iii. Peter Piot: Former UNAIDS Executive Director, he was a member of the WHO Commission sent to Zaire to investigate the first Ebola outbreak in 1977. He is considered one of the scientists who identified the pathogen. During the 2014 international response, he was part of the Advisory Group for Ebola.

iv. Dr. Anshu Banerjee: He was nominated by the WHO to be UNMEER's Director of Emergency Operations and Ebola Crisis Manager, who reports directly to the Special Representative of the Secretary-General.

The epistemic community developed a consensual knowledge that guided the initial response, but neither the WHO and its member states nor the epistemic community itself considered that the context of this outbreak could change the evolution of the outbreak. The epistemic community was able to disseminate its knowledge, but its structure limited the network's communication (small, concentrated in a few countries, coordinated by the WHO). The epistemic community was less efficient to institutionalize its bureaucratic power, although some of the epistemic community's prominent personalities had an active role during the outbreak, their influence was still limited. Table 49 summarized all these characteristics. 


\begin{tabular}{|c|c|c|}
\hline & Indicator & Ebola \\
\hline \multirow[t]{2}{*}{ 1. Knowledge } & $\begin{array}{l}\text { Agreement on a common } \\
\text { definition of the problem and } \\
\text { possible solutions }\end{array}$ & $\begin{array}{l}\text { There was some previous consensual } \\
\text { knowledge about the characteristics of the } \\
\text { outbreaks. During the outbreak, there were } \\
\text { disagreements about its severity. }\end{array}$ \\
\hline & $\begin{array}{l}\text { Clear identification of a } \\
\text { common policy goal }\end{array}$ & $\begin{array}{l}\text { The policy goal was reached when the } \\
\text { outbreak had not been declared a PHEIC. }\end{array}$ \\
\hline \multirow{3}{*}{ 2.Socialization of ideas } & Structure & $\begin{array}{l}\text { It is a small network with some international } \\
\text { participation, mostly from developed } \\
\text { countries. }\end{array}$ \\
\hline & Dissemination mechanisms & $\begin{array}{l}\text { Even though Ebola has been considered a } \\
\text { priority given its categorization as a } \\
\text { biological agent, research has been limited. } \\
\text { Before the outbreak, a few studies were } \\
\text { available. During the outbreak, research } \\
\text { increased. }\end{array}$ \\
\hline & $\begin{array}{l}\text { Participation in the } \\
\text { international response }\end{array}$ & $\begin{array}{l}\text { Many members of the Epistemic Community } \\
\text { participated in the international response } \\
\text { mainly through GOARN. }\end{array}$ \\
\hline \multirow[t]{2}{*}{$\begin{array}{l}\text { 3. Institutionalization } \\
\text { of bureaucratic power }\end{array}$} & $\begin{array}{l}\text { Participation in the policy } \\
\text { process. }\end{array}$ & $\begin{array}{l}\text { After the outbreak was declared a PHEIC, the } \\
\text { WHO created different groups and organized } \\
\text { meetings with experts and other actors to } \\
\text { discuss and address specific issues related to } \\
\text { the outbreak. Countries included experts as } \\
\text { part of the national delegations participating } \\
\text { in international conferences sponsored by } \\
\text { governments or international organizations. }\end{array}$ \\
\hline & $\begin{array}{l}\text { Experts and other } \\
\text { professionals from the } \\
\text { epistemic community in } \\
\text { decision-making positions }\end{array}$ & $\begin{array}{l}\text { The epistemic community participated } \\
\text { through the Emergency Committee and as an } \\
\text { advisory group to the WHO. There were also } \\
\text { important policy entrepreneurs in key policy } \\
\text { positions. }\end{array}$ \\
\hline
\end{tabular}

Table 49. Characteristics Ebola epistemic community.

\subsection{The international response}

The failure of the response was due to several factors from misinformation, lack of resources, to political issues. NGOs and domestic agencies had to deal with the outbreak with limited resources, inadequately trained personnel, and equipment to managed cases $(110,517)$. Governments delayed international notification due to the fear of economic sanctions (110). The outbreak also exhibited a limited commitment with the IHRs, since this international instrument failed in improving areas such as transparency, sharing of information as well as in incentivizing the building of capacities for reporting and 
surveillance $(110,545,110,499)$. There was an evident lack of compliance with international norms by the affected countries since the IHRs 2005 required them to establish a system of disease surveillance $^{\mathrm{lx}}(546,37,110,111)$. Limited surveillance capacities contributed to the spread of the virus. This area was critical for controlling previous outbreaks (524).

Many of these factors were more important than evidence-based decision making and expert knowledge. Therefore, the Ebola epistemic community faced several obstacles; it was unable to expand its ideas and disseminate them and had a reduced bureaucratic power. These factors limited its ability to influence the policy process and an earlier response. Figure 25 summarizes the participation of the epistemic community in the international response.

\begin{tabular}{|c|c|c|c|}
\hline$>\quad \begin{array}{c}\text { Identification of } \\
\text { disease }\end{array}$ & $\begin{array}{l}\text { International } \\
\text { Assessment }\end{array}$ & $\begin{array}{l}\text { Definition of event } \\
\text { as PHEIC }\end{array}$ & $\begin{array}{l}\text { International } \\
\text { response }\end{array}$ \\
\hline $\begin{array}{l}\text { - The virus was } \\
\text { sequenced in one of } \\
\text { the WHO } \\
\text { Collaborating Centres, } \\
\text { due to MSF. }\end{array}$ & $\begin{array}{l}\text {-The first assessment of } \\
\text { the outbreak was } \\
\text { internally made at the } \\
\text { WHO. The Emergency } \\
\text { Committee, where the } \\
\text { epistemic community has } \\
\text { representation, was } \\
\text { organized months later. }\end{array}$ & $\begin{array}{l}\text {-The WHO called an } \\
\text { Emergency Committee to } \\
\text { assess the evidence once } \\
\text { the outbreak had spun } \\
\text { out of control. The group } \\
\text { of experts decided that } \\
\text { the outbreak had the } \\
\text { characteristics of a } \\
\text { PHEIC. Their agreement } \\
\text { prompted an official } \\
\text { declaration and called for } \\
\text { an international } \\
\text { response. This, however, } \\
\text { started a few months } \\
\text { later. }\end{array}$ & $\begin{array}{l}\text {-The International } \\
\text { response had the } \\
\text { involvement of an } \\
\text { epistemic community in } \\
\text { several stages. Members } \\
\text { of the community were } \\
\text { active participants in the } \\
\text { scientific and technical } \\
\text { responses and in the } \\
\text { field with the GOARN } \\
\text { and other partners. }\end{array}$ \\
\hline
\end{tabular}

Figure 25. The process of the international response to the Ebola outbreak and the participation of an epistemic community.

\footnotetext{
${ }^{\mathrm{lx}}$ The problem with compliance has been in part a problem with funding since building these capacities requires investments.
} 
The first stage of the response occurred when the first cases emerged in December 2013, the notification by MSF and its response to the outbreak, the WHO initial confirmation of cases, and its initial participation providing technical assistance jointly with the CDC but without a global mobilization (382). The second stage started when the WHO convened an Emergency Committee to assess the situation and declared a PHEIC, followed by an official coordinated international response.

In the first stage, the response was limited. Context triggered a faster transmission than what was expected. The Guinean government issued the international alert on March 13, 2014, once the disease had reached the capital (519). The country's inability to detect it in time enabled the virus to spread across countries $(547,110)$, in an area inside the Guinean forest, near the borders with Liberia and Sierra Leone (489). These countries shared borders with few migration controls that enabled the transit of people from one country to another, facilitating the transmission of Ebola $(517,489)$. The context of poverty, lack of adequate health infrastructure, health personnel, mishandling of cases, and even denial of the situation aggravated the crisis $(547,492)$. Nevertheless, these countries did not have big international airports with a high flow of visitors, although an international transmission and imported cases occurred unexpectedly when a person from Nigeria carrying the disease traveled to the airport in Lagos (489).

When the outbreak started, the Ebola Epistemic Community was unable to have direct access to information, and its members' participation was limited. Some of the experts got involved early only because of their connections in the communities (Interview 11).

The political situation in the region caused poor handling of the situation; therefore, politics rather than science guided the response at the beginning (489). The WHO Regional 
Office in Africa, which got the early reports about the outbreak, did not provide accurate data. The WHO Regional Office was held responsible for failing on submitting reports to the WHO headquarters in Geneva, due to political decisions given that its representatives in West Africa "were politically appointed country directors, and they were downplaying the crisis (517)". This brought strong criticism to the WHO even by old collaborators such as Peter Piot, who later declared that the regional office was "really not competent" in the handling of the outbreak (548). Once the outbreak was out of control people involved in the response also blamed the WHO Regional Office for not allowing experts to assist local authorities, some reports affirmed that "they obstructed travel by experts, and they resisted offers of assistance from the Centers of Disease Control as well as from USAID (517).” The delay in responding to the outbreak was based mostly on political decisions rather than technical advice (517).

After the Institut Pasteur confirmed the presence of Zaire ebolavirus, MSF publicly declared on March 31, 2014, that the outbreak was "unprecedented" (241). The organization alerted the disease was spreading fast and into urban areas. Later, MSF claimed that on April $1^{\text {st }}, 2014$, the WHO Geneva's chief spokesperson challenged MSF's assessment. He based his comments on what experts already knew about Ebola outbreaks, and he objected that "the virus dynamics were not unlike those of past outbreaks, nor was the outbreak unprecedented (241)." In this declaration, there was an acknowledgment of the epistemic community's previously developed consensual knowledge.

The WHO's actions and initial response to the situation in West Africa were on the basis of that previously available knowledge. The WHO sent in May 2014 the organization's senior Ebola expert, Dr. Pierre Formenty, to Guinea. With the confirmation of Ebola as the 
virus causing Guinea's outbreak, he traced the first 14 cases in detail ${ }^{\text {lxi }}$. His investigation "yielded no strong or convincing hints, either from clinical features of the illness or the pattern of its transmission, or just what the causative agent might be, especially in a country with so much background noise from multiple other killer diseases (500)". Therefore, he did not think Ebola was the principal cause, recommending no further actions, and the WHO preferred to wait for the evolution of events $(110,499)$. The WHO then stated that: Alarm bells might have gone off had any doctor or health official in the country ever seen a case of Ebola. No one had. No alarm bells rang for the government or, for that matter, for the international public health community either (500).

Some reports also indicated that the WHO did not act promptly due to concerns about possible opposition from political leaders in West Africa $(110,499)$. Others, however, attribute this outcome to the criticisms of the WHO's management of the H1N1 2009 influenza outbreak (110).

Before the PHEIC declaration, the epistemic community participated mainly through the GOARN team based in the WHO and the CDC Atlanta (110). It was mostly humanitarian organizations that actively assisted the population in this phase (499). After notification in March 2014, the WHO mobilized its collaborating laboratory in Lyon, France, together with West African laboratories located in Doka, Guinea, Dakar, Senegal, and Kenema, Sierra Leone (270). The GOARN traveled to Guinea on 28 March. By 5 May, WHO had deployed 112 experts to West Africa to assist in the response, including 68 experts deployed through

\footnotetext{
lxi The WHO published on its website a note titled "Ground zero in Guinea: the Ebola outbreak smoulders - undetected - for more than 3 months. A retrospective on the first cases of the outbreaks" with the subtitle "Ebola at 6 months". It is unclear when exactly this report was published by the WHO, although it clearly refers to the months after the case that was later identified as the first one (the 2 -year-old boy).
} 
its global surge mechanism, ten external experts, and 33 international experts from GOARN (270). The experts included epidemiologists, laboratory experts, infection prevention and control professionals, clinical case management specialists, and experts in logistics, medical anthropology, risk communication, and social mobilization (270,549). Appendix L presents the full list of partners participating with GOARN. Once the international response started, these groups had to interact often during the outbreak to provide advice and guidance to the WHO and its member states.

Some experts involved in the response agreed that the centrality of the decisionmaking exercised at the WHO constrained the involvement of the epistemic community (Interview 1, 5, 11). Even though the WHO monitored the outbreak since March $22^{\text {nd }}, 2014$, it decided to organize the International Health Regulations' Emergency Committee until August $8^{\text {th }}, 2014$. By then, the outbreak had reached four countries (Guinea, Liberia, Nigeria, and Sierra Leone) with 1711 cases (1 070 confirmed, 436 probable, 205 suspected), and 932 deaths (more than $50 \%$ of the cases) (550).

As a result, the second phase started when the WHO finally decided to call an Emergency Committee for an assessment of the outbreak, an expert body that immediately recommended declaring it a Public Health Emergency of International Concern (PHEIC) (550). The declaration started an international response, although the mobilization of resources to the region officially began in September 2014. The WHO later recognized this Ebola outbreak was the "largest ever recorded" and "most complex" $(551,499)$. This delayed PHEIC notification prevented the most affected countries from having faster access to international assistance $(552,37,471,553)$. By the time the international response was 
declared necessary to control the outbreak, the WHO had reports of 4963 probable, confirmed and suspected cases of Ebola, and 2453 deaths.

Once the outbreak was considered a PHEIC, a global mobilization started. Between March 2014 and March 2015, GOARN deployed more than 2013 experts, including 600 epidemiologists, 76 field coordinators, 73 data managers, 242 laboratory technicians, 26 clinicians, 110 logisticians, 128 IPC specialists, 44 communications officers, 53 social mobilization and communication experts, and 15 anthropologists (270). GOARN deployed more than 1000 of these experts after August 2014 (127). Besides, 58 foreign medical teams from the African Union, China, Cuba, Denmark, France, Norway, Uganda, the United Kingdom, and the United States collaborated (110,270).

The UN Security Council approved resolution 2177 (2014) on the Ebola disease outbreak in Africa, declaring it a "threat to international peace and security (110)." The resolution included the creation of the UN Mission for Ebola Emergency Response (UNMEER) (240,554). The mechanism was formally organized in September of 2014, but its operations started later due to the lack of funding and inadequate coordination $(517,110)$. The UNMEER had to mobilize resources and logistic capacities in a short period, establishing targets of 30, 60, and 90 days (554). For this aim, the Operational Conference for Scaling up UN-System Approach to the Ebola Response was held in Accra from 15-18 October 2014. The Ebola Interim Assesment Panel concluded that this mission had little success in coordinating the response for the affected countries (499).

By October 2015, donors had disbursed US\$5.9 billion, 66 percent of the total amount pledged, US\$8.9 billion (555). From these funds, 80 percent of them were allocated to the response. Sixty-one countries pledged funds and sixteen organizations (NGOs, Banks, 
among others.). The money mobilized was used to pay for essential drugs, equipment, and materials for health workers, vehicles (556). The WHO also constructed 5 Ebola treatment units (ETUs) and 72 community care centres. The estimated cost for controlling the outbreak increased due to the late response and the severity of the situation (382).

The outbreak was declared a humanitarian crisis due to the precariousness of the situation, the lack of resources, and the risk perceived by actors such as MSF (such as social unrest in some places) $(557,558,127,558)$. NGOs assisting in the field and local agencies were overwhelmed with the situation while the fear of the people increased. The USA, UK, China, France, and Germany deployed more than 5,000 military personnel to support the actions in the field $(382,557)$. It was at that moment when the international response effectively started.

The actions implemented made it possible to control the outbreak and stop the transmission (499). International cooperation, however, was not optimal because the situation was already out of control, and there was an intense fear of importing cases. Scientific evidence guided part of the response; however, many recommendations were not broadly accepted by governments. The IHR required state parties to notify the implementation of measures and its rationale within 48 hours of their implementation. During the outbreak, WHO reported that 40 countries adopted additional measures to those recommended by the Emergency Committee, but only a few of them informed the WHO $(559,98,110)$. These measures included the closure of borders, temperature checks, questionnaires, screening methods, quarantines, and implementation of administrative controls, such as cancellation of flights. The WHO called for lifting such measures, but by December 2015, 34 countries were still enacting them (13). The WHO also had 570 reports 
or rumors of traveling and trade bans involving 69 countries as of April 2015 (127). Of those, 470 were assessed by the WHO, and it determined that they did not interfere with travel and transport (127). The implementation of protective measures for some countries aimed to limit the spread of the virus through different points of entry (air and seaports) (560). As a consequence, flights were halted to the affected area, limiting the access of health personnel and supplies $(517,496)$. Travel bans also affected scientists and researchers $(273,486)$, since some countries did not allow them to go to the region of West Africa.

In its fifth meeting, the Emergency Committee discussed the implementation by governments of inappropriate health measures not recommended by these experts. There was a concern that additional measures, such as quarantine of returning travelers, refusal of entry, cancellation of flights, and border closures could interfere significantly with international travel and transport and damage both the response and recovery efforts. There were also reports that some countries did not share information about international travelers, one of the main recommendations made by the Emergency Committee (98).

Countries and institutions decided to stop sending health workers under the argument that they could have been in danger (517). For them, there was an imminent risk that justified these measures (489). For instance, in the case of the United States, some states ordered quarantine without being supported by the scientific community. It was political leaders who decided to implement this course of action $(517,475,486)$. This brought severe consequences for affected countries, which could not get access to qualified personnel, health workers, and medical supplies (499).

In addition to these challenges, professionals from epistemic communities had to convince a very traditional population to change some cultural patterns to reduce contagion. 
The changes included eliminating burial and funeral practices such as body washing the corpse $(561,562)$. Modifying people's behaviour, and their traditions, was not easy, even when there was evidence that these religious practices were increasing the number of cases. In general, the population did not trust professionals and experts, and it took some time for them to accept the experts' recommendations (563).

The international response at the end was effective in containing and controlling the outbreak. The WHO declared that the Ebola outbreak was no longer considered a PHEIC on March 29, 2016. The World Bank (WB) estimated the economic impact of the outbreak for the region around US\$32.6 billion by the end of $2015(517,475)$. The WB also estimated losses of at least US\$2.2 billion in economic growth (556), Liberia and Sierra Leona being the most affected countries (564). For the UN, the cost of the response was more than US $\$ 4$ billion. Some calculations considered that if the outbreak had been controlled by April 2004, the cost would have been only $\$ 200$ million (382). Based on the indicators proposed in chapter 4, table 50 presents the summary and analysis of the level of cooperation in the response to Ebola. 


\begin{tabular}{|c|c|c|c|c|}
\hline ACTIVITY & MEASURE & EPISTEMIC COMMUNITY & EBOLA & $\begin{array}{c}\text { LEVEL OF } \\
\text { COOPERATION }\end{array}$ \\
\hline \multicolumn{5}{|c|}{ I.International participation } \\
\hline \multirow[t]{2}{*}{ PROBLEM } & $\begin{array}{l}\text { 1. Timely meetings } \\
\text { celebrated at WHO } \\
\text { and other settings. }\end{array}$ & $\begin{array}{l}\text { The epistemic community } \\
\text { participated in the investigation of } \\
\text { cases and provided information to } \\
\text { the international community. } \\
\text { There were disagreements about } \\
\text { the situation. }\end{array}$ & $\begin{array}{l}\text { The first meeting of the Emergency Committee was convened } \\
\text { on August 8, 2014. The WHO had conducted three } \\
\text { assessments in March- five months earlier }(127,112) \text {. The } \\
\text { first case traced back to December } 2013(551) \text {. }\end{array}$ & 0 \\
\hline & $\begin{array}{l}\text { 2.If there were } \\
\text { actions } \\
\text { implemented as a } \\
\text { result of those } \\
\text { meetings }\end{array}$ & $\begin{array}{l}\text { The participation of the epistemic } \\
\text { community was as part of the } \\
\text { Emergency Committee, but } \\
\text { decision-making was centralized } \\
\text { at the WHO. }\end{array}$ & $\begin{array}{l}\text { The PHEIC declaration was the result of the meeting (110) } \\
\text { five months after the outbreak, and the response started later. }\end{array}$ & 2 \\
\hline RESPONSE & $\begin{array}{l}\text { Time frame after } \\
\text { notification }\end{array}$ & $\begin{array}{l}\text { The epistemic community } \\
\text { participated late in the outbreak. }\end{array}$ & $\begin{array}{l}\text { The WHO started working with the affected countries in } \\
\text { March } 2014(112,110) \text {, but it later withdrew. The } \\
\text { international response started on August } 8^{\text {th }}, 2014 \text {, when the } \\
\text { Emergency Committee declared the outbreak a PHEIC, eight } \\
\text { months after the first cases appeared in Guinea. The } \\
\text { UNMEER started operations on September 19, } 2014 \\
(98,110) \text {. } \\
\text { However, the response, in general, is characterized as slow, } \\
\text { even after the PHEIC declaration, since funds and assistance } \\
\text { were delivered late. It also did not consider cultural and local } \\
\text { settings, and it was poorly coordinated }(112,110,565) \text {. }\end{array}$ & 1 \\
\hline $\begin{array}{l}\text { NO. OF } \\
\text { COUNTRIES }\end{array}$ & $\begin{array}{l}\text { Level of } \\
\text { participation }\end{array}$ & $\begin{array}{l}\text { The level of participation was } \\
\text { mainly motivated by the situation } \\
\text { and the urgent need to control the } \\
\text { outbreak. }\end{array}$ & $\begin{array}{l}\text { After the PHEIC declaration, the Security Council called the } \\
\text { outbreak "a threat to international peace and security." The } \\
\text { participation in the response of international organizations } \\
\text { and countries increased once the UN General Assembly } \\
\text { approved Resolution A/Res/ } 69 / 1 \text { as recommended by the } \\
\text { Security Council Resolution } 2177 \text { (S/Res/2177-2014), } \\
\text { unanimously adopted by } 134 \text { Member States }(112,127) \text {. }\end{array}$ & 5 \\
\hline \multicolumn{5}{|c|}{ II. International assistance } \\
\hline $\begin{array}{l}\text { TECHNICAL } \\
\text { A. }\end{array}$ & $\begin{array}{l}\text { Type of } \\
\text { participation in } \\
\text { international } \\
\text { missions. }\end{array}$ & $\begin{array}{l}\text { The epistemic community } \\
\text { participated in the response. This } \\
\text { helped to mobilize its ideas and } \\
\text { influence. }\end{array}$ & $\begin{array}{l}\text { The severity of the situation required a more comprehensive, } \\
\text { multi-sectoral, and multi-agency. Thus, the response also } \\
\text { included humanitarian, military, private-commercial } \\
\text { components (127). }\end{array}$ & 4 \\
\hline
\end{tabular}

Table 50. Analysis levels of cooperation in the international response to the Ebola outbreak in West Africa. 


\begin{tabular}{|c|c|c|c|c|}
\hline ACTIVITY & MEASURE & $\begin{array}{c}\text { EPISTEMIC } \\
\text { COMMUNITY }\end{array}$ & EBOLA & $\begin{array}{c}\text { LEVEL OF } \\
\text { COOPERATION }\end{array}$ \\
\hline \multicolumn{5}{|c|}{ II. International assistance } \\
\hline $\begin{array}{r}\text { FINANCIAL } \\
\text { ASSISTANCE }\end{array}$ & $\begin{array}{l}\text { The amount of } \\
\text { money provided } \\
\text { as financial } \\
\text { assistance to } \\
\text { address the } \\
\text { emergency }\end{array}$ & $\begin{array}{l}\text { No indications that the } \\
\text { epistemic community } \\
\text { influenced growth in funding. }\end{array}$ & $\begin{array}{l}\text { Once the international response started in October } 2014 \text {, financial } \\
\text { assistance was provided to help. The amount of money required was not } \\
\text { provided ( } 382) \text {. }\end{array}$ & 5 \\
\hline TREATMENTS & $\begin{array}{l}\text { Type of } \\
\text { population } \\
\text { getting the } \\
\text { treatments }\end{array}$ & $\begin{array}{l}\text { The epistemic community has } \\
\text { been mobilizing its ideas to } \\
\text { produce a vaccine and better } \\
\text { treatments. However, most of } \\
\text { its influence and participation } \\
\text { have been after the outbreak. }\end{array}$ & $\begin{array}{l}\text { There were no specific treatments for Ebola, and there were problems } \\
\text { with access to medicines. } \\
\text { Vaccines were not available during the outbreak, even though the virus } \\
\text { has been known since the late 1970s. However, Europe, Canada, and } \\
\text { the USA could accelerate the process for the testing of three possible } \\
\text { vaccines (110). There are now different prospects of going through } \\
\text { different phases. }\end{array}$ & 0 \\
\hline \multirow[t]{2}{*}{ PROVISION } & $\begin{array}{l}\text { 1. How fast was } \\
\text { the deployment } \\
\text { of assistance } \\
\text { once the } \\
\text { outbreak started }\end{array}$ & $\begin{array}{l}\text { Members of the epistemic } \\
\text { community participated in the } \\
\text { deployments. Its influence, } \\
\text { however, was marginal to } \\
\text { mobilize it faster. }\end{array}$ & $\begin{array}{l}\text { The UNMEER started operations on September 19, 2014, and other } \\
\text { substantial international assistance arrived in the affected countries by } \\
\text { October } 2014(382,127) \text {. }\end{array}$ & 1 \\
\hline & $\begin{array}{l}\text { 2.Type of } \\
\text { assistance }\end{array}$ & & $\begin{array}{l}\text { Given the situation in the most affected countries, the response } \\
\text { included medical personnel, provision of food security and nutrition, } \\
\text { access to essential health services, the supply of materials and } \\
\text { equipment, transport and fuel, medical care for responders (555). }\end{array}$ & 2 \\
\hline \multicolumn{5}{|c|}{ III. Scientific response } \\
\hline SAMPLES & $\begin{array}{l}\text { If countries } \\
\text { have shared } \\
\text { virus samples }\end{array}$ & & $\begin{array}{l}\text { Doctors without Borders (MSF) shared the first samples to identify the } \\
\text { virus. Governments made available samples of the virus by the end of } \\
2014 \text { when the international response was fully operative in the area } \\
(110) \text {. }\end{array}$ & 3 \\
\hline \multirow[t]{2}{*}{ R\&D } & $\begin{array}{l}\text { 1.If data is } \\
\text { disseminated on } \\
\text { time }\end{array}$ & & $\begin{array}{l}\text { Access to public health information and cases were not shared } \\
\text { immediately, and data was restricted }(110,127) \text {. }\end{array}$ & 3 \\
\hline & $\begin{array}{l}\text { 2.Phases of the } \\
\text { research during } \\
\text { the outbreak }\end{array}$ & & $\begin{array}{l}\text { After the late response and the severity of the situation, the WHO } \\
\text { established an accelerated development process to produce vaccines, } \\
\text { which during the outbreak reach a Phase III clinical trial. } \\
\text { Research and development of therapies and drugs also intensified as } \\
\text { well as diagnostic methods }(270,110) \text {. }\end{array}$ & 4 \\
\hline
\end{tabular}

Table 50. Levels of cooperation in the international response to the Ebola outbreak in West Africa. 


\begin{tabular}{|c|c|c|c|c|}
\hline ACTIVITY & MEASURE & $\begin{array}{c}\text { EPISTEMIC } \\
\text { COMMUNITY }\end{array}$ & EBOLA & $\begin{array}{c}\text { LEVEL OF } \\
\text { COOPERATION }\end{array}$ \\
\hline \multicolumn{5}{|l|}{ IV. Policy adoption } \\
\hline SURVEILLANCE & $\begin{array}{l}\text { If countries } \\
\text { implemented } \\
\text { systems to } \\
\text { allowed constant } \\
\text { notification of } \\
\text { possible cases }\end{array}$ & & $\begin{array}{l}\text { The late notification was the consequence of not having the right } \\
\text { tools in place for surveillance in the affected countries ( } 499) \text {. } \\
\text { Although this has been an aspect included in the IHR, countries } \\
\text { have not met the core capacities requirements yet under this } \\
\text { international agreement (110). }\end{array}$ & 2 \\
\hline NOTIFICATION & $\begin{array}{l}\text { How long did } \\
\text { countries wait to } \\
\text { notify the WHO } \\
\text { after identifying } \\
\text { the cases? }\end{array}$ & & $\begin{array}{l}\text { The notification was late; there was an initial denial of cases and } \\
\text { the extent of the outbreak (499). The first cases were notified in } \\
\text { March } 2014 \text { in West Africa (in a rural village in Guinea) } \\
(98,565,110) \text {, but reports of cases of people dying from a rare } \\
\text { condition were communicated to the government since January. }\end{array}$ & 4 \\
\hline \multirow[b]{2}{*}{$\begin{array}{c}\text { POLICY } \\
\text { CONVERGENCE }\end{array}$} & $\begin{array}{l}\text { 1. How broad } \\
\text { were the } \\
\text { recommendations } \\
\text { adopted and } \\
\text { implemented? }\end{array}$ & $\begin{array}{l}\text { The Ebola epistemic } \\
\text { community has less } \\
\text { bureaucratic power at the } \\
\text { national and } \\
\text { international levels. }\end{array}$ & $\begin{array}{l}\text { After the Emergency Committee declared the outbreak a PHEIC } \\
\text { on August } 8^{\text {th }}, 2014 \text {, the WHO recommended not to impose travel } \\
\text { bands or restrictions on international trade to the affected } \\
\text { countries (566), however, by April } 2015 \text {, the WHO had } 570 \\
\text { reports from } 69 \text { countries that were not following the advice } \\
\text { (127). }\end{array}$ & 2 \\
\hline & $\begin{array}{l}\text { The degree of } \\
\text { adoption of } \\
\text { international } \\
\text { norms. }\end{array}$ & $\begin{array}{l}\text { The epistemic } \\
\text { community has been less } \\
\text { influential in changing } \\
\text { norms and implementing } \\
\text { international } \\
\text { agreements. }\end{array}$ & $\begin{array}{l}\text { One of the major problems during the Ebola outbreak was the } \\
\text { limited technical capacities that the affected countries have. Even } \\
\text { though by } 2014 \text {, the IHRs should have had fully implemented, } \\
\text { there are still financial gaps that have affected the improvement } \\
\text { of core capacities to face pandemics. During the Ebola outbreak, } \\
\text { the lack of resources in the affected health systems delayed the } \\
\text { response and compliance with the international norm (127). } \\
\text { Countries were also afraid of the possible consequences of } \\
\text { notifying an outbreak (110). }\end{array}$ & 4 \\
\hline
\end{tabular}

Table 50. Levels of cooperation in the international response to the Ebola outbreak in West Africa (cont.) 
The level of cooperation in the international response was initially low, reaching a medium level by the end of the outbreak. Nonetheless, the response is considered a failure since many deaths could have been prevented.

\subsection{Influence of an epistemic community in the level of cooperation.}

The analysis of the level of cooperation, in this case, confirms that at the beginning of the outbreak, cooperation was low. After the disease spread outside the region, the international community reacted and dramatically increased the level of cooperation.

A network of professionals had worked in issues related to Ebola since the 1970s; however, during the first stage of the outbreak, it had limited participation due to factors such as:

- Lack of political will. The WHO's ability to coordinate and share information with members of the epistemic communities was constrained by its political position and the fact that it always must consult and respect its State Members' requests.

- Fear of economic consequences: countries with cases were fearful of the possible economic consequences of notification $(110,127,499)$, given that in the past countries had faced severe trade restriction and international backlash after notifying a disease outbreak with pandemic potential (Interview 5).

- WHO internal decision-making process: Even though the organization has six regional offices, most of them act under a central leadership in Geneva (the exception could be PAHO, partially due to its history as the first health multilateral agency in the world, created before the WHO). A delayed assessment by an Emergency Committee under the IHRs 2005, made it harder for experts to participate in this stage.

- The Ebola epistemic community had different perspectives about the outbreak, 
causing internal divisions. This was the case with MSF's Ebola experts who early in the outbreak insisted on implementing stronger measures and requested more international participation. Even though at the end, MSF's experts closely collaborated with the epistemic community through GOARN and other institutions.

These characteristics indicate that in the first stage of the outbreak, the epistemic community was weak and had limited access to the policy process. The WHO decided to implement measures based on the available knowledge of the disease, and without requesting additional advice from experts outside the WHO. Other experts' participation was possible in the second stage. Political issues, however, limited the epistemic community's ability to prevent international measures that hindered access to assistance.

The outbreak of 2014 also uncovered problems within the epistemic community itself, the lack of R\&D, and the still limited understanding of the disease. Ebola has been a known virus since the end of the 1970s, and since then, a small scientific community has been interested in it. In 2014, however, there were still questions about the transmission in the animal-human chain and the reservoirs of the virus. In part, the assumption that the disease was endemic only in Africa limited the research. The limited knowledge was mostly based on the virus's potential to become a biological weapon. This research was useful to speed up the testing of a vaccine during the outbreak, but the vaccines were still in trial phases $(530,110)$. The lack of international interest, however, affected the development of treatments and drugs to fight the diseases, as well as the possible development of a vaccine since 1977. These problems affected the epistemic community's level of cohesion, thereby making it more difficult for it to influence policymaking during the outbreak.

Additionally, the epistemic community was highly connected to the WHO. 
Sometimes communication among members depended on the WHO's mobilization mechanisms to interact. Besides, the network's centrality made it challenging to open it to other levels. It was concentrated at the global level, with scarce connections with national and local actors. The epistemic community understood that it was essential to expand the group beyond the global level since it could help prevent future outbreaks and respond to other epidemics (Interview 5; Interview 11). The WHO recognized the importance of more community involvement to reach the affected population, and to ensure better medical attention (112).

The epistemic community was essential to guide the response, providing evidencebased arguments and recommendations to manage and control the disease. This created a positive impact on international cooperation in the second phase, and the trust and reliance on this network of professionals allowed them to have more participation. Nonetheless, fear and distrust were common among the population, policymaker, and political actors, which affected the acceptance of the epistemic community's recommendations and the legitimacy of its advice. 


\section{Chapter 8: Zika Virus 2013-2016}

\subsection{Introduction}

The 2015 Zika virus outbreak began while the international response to the Ebola outbreak in Africa was still in progress. The outbreak is the first PHEIC due to a disease transmitted by a vector, which has expanded its habitat likely due to climate change $(214,567,568)$. It is also the first mosquito-borne virus capable of sexual transmission and severe congenital disabilities (569).

The mosquito Aedes aegypti transmits the Zika virus, as well as yellow fever and dengue. The vector is well-known in the region of the Americas, and it was almost eradicated in the 1960s through the widespread use of DDT (570). The mosquito proved resilient and returned to the region, acting as a vector for the return of dengue and yellow fever. In 2015, Aedes aegypti acted as the vector for the Zika virus.

The Zika virus was first identified in the 1940s. Before 2007, Zika presented as a mild disease, with only 16 cases notified worldwide $(571,572,573)$. The first recognized large outbreak of the Zika virus occurred in 2007 in Micronesia, where estimates calculate that 5,000 people out of a population of 6,700 people were affected by a Zika virus of Asian origin (574,575). In the Pacific Islands and French Polynesia, health services received around 28,000 people with possible Zika infection and 383 laboratories confirmed cases $(576,571,574,575,577,572)$.

The outbreak in the Pacific Islands was the first-time that health professionals associated Guillain-Barré Syndrome (GBS) and microcephaly with the virus $(578,576,571)$. After this outbreak, other islands reported more (567). The 2007 outbreak sparked scientific interest in the disease (See Box 4. Zika Virus). 


\section{Box 4. Zika virus}

\section{Nature of the virus}

The Zika virus is an arbovirus of the flavivirus type mosquito-born- (ZIKV) $(579,580,581)$, transmitted by the mosquito Aedes aegypti $(582,571,583)$. There are two main species of ZIKV, Asian and African (583). This mosquito is responsible for transmitting other diseases such as dengue, yellow fever, and chikungunya $(570,577,583)$. Studies have also identified the Aedes albopictus species and other mosquitos as a carrier of the disease $(584,585,567,583)$. The mosquito is common in tropical and subtropical regions. They feed during the day on human blood and breed in water-holding containers (577). Non-primates and primates are reservoirs, and transmission is human to vector to human (577). Recent research has shown that the virus can also be transmitted human to human via body fluids such as transplacental, perinatal, sexual, and blood-borne routes $(579,586)$; and at least ten countries documented sexual transmission (587).

The Zika virus was, for the first time identified in 1947 when it was isolated from a Macaca monkey in the Zika forest of Uganda $(578,588,589)$. The virus was later recovered from the mosquito Aedes Africanus (578,571). In 1952, the virus was isolated in humans from Uganda and Tanzania, in Africa, and India and Malaysia in Asia $(567,575,571,567,590)$. Some isolated cases were later found in Central Africa and South Asia (589).

\section{Characteristics of the disease}

The symptoms associated with this virus are mild compared to other similar diseases, such as Dengue $(580,591,588,575)$. People infected with Zika will have a fever, headache, and some people will present a maculopapular rash -skin eruption with flat and small lesions (592)-, conjunctivitis, or both (593). These symptoms will appear three to twelve days after the bite, and they will last for 2 to 7 days $(593,594,587)$. Some people will not develop symptoms at all; around $80 \%$ of infected people can be asymptomatic $(589,582)$. Since its symptoms are similar to dengue and other more severe diseases, health professionals have to discard these conditions first and perform a laboratory test by genetic sequence to confirm the Zika virus (582). As a result, the WHO believes Zika was under notified before 2007 (571). There are no known antiviral treatments for Zika virus; doctors will only treat symptoms, and infected people should be isolated (575,577). Currently, there are no vaccines available, but research started early in the outbreak $(584,588)$. Laboratories tested two possible candidates (595), and the Brazilian government is collaborating with the US for developing a vaccine (588).

\section{Global Threat}

For years, Zika was considered an "innocuous pathogen (568)." However, the confirmed association with microcephaly in newborns [the brain size is smaller than average, causing severe developmental and cognitive disorders (577)] and other neurological disorders such as Guillain-Barré Syndrome (GBS) have changed this status (596). Researchers expect a decline in the number of cases in 2 years, although it is likely that the disease will become endemic in America (595). 
Brazil reported the Zika virus in May 2015 and, after more than 20 countries in the Americas notified cases, the WHO organized an Emergency Committee and declared the outbreak a PHEIC on 1 February 2016 (597). After the declaration, the international response unfolded fast, being efficient enough to trigger worldwide participation for the outbreak's management.

Different factors could have influenced the level of cooperation in the international response. For instance, the epidemic started in Brazil, a powerful country in Latin America, strategic for the regional and global economy. In 2014, the country contributed to the global economy with $3 \%$ of the global GDP, ranking it as one of the tenth largest economies in the world (598). Brazil has a high level of development compared to other countries in the region, and it is highly active in the international arena. The strategic importance of Brazil contrasts with its level of poverty and social inequalities (599), and some considered that the response did not reach the most needed in the country (599), including poor people and women. Brazil also has the Amazonia, one of the most critical ecosystems in the world and a perfect setting for the reproduction of mosquitos, and the potential to affect thousands near the region.

Another explanation for the reasonably well-organized response was the potential for Zika to spread to the United States as well as Europe due to the Olympic Games. Brazil was set to host the Olympics in the summer of 2016 (600). Some experts argued that the Olympics heightened the level of international scrutiny and placed pressure on both Brazil and the international community to act quickly and decisively $(601,602)$, even though some experts considered there was a low risk of international spread (603).

Some scholars also claimed that the experience with Ebola led to a faster response to the Zika pandemic $(572,604)$. Due to the problems and delayed response to Ebola, 
governments, and advocates also increased their scrutiny of the WHO and the international system for managing pandemics. The WHO engaged in a reform process to become more transparent. In the case of Zika, the WHO facilitated open access to decisions related to the outbreak and the response, which enabled more open discussion among experts and improved access to information regarding the WHO's actions and recommendations (597).

While these factors facilitated a more effective response, the analysis shows that the role of the epistemic community was both critical and unique. As Zika had been a previously relatively obscure disease, no Zika-specific community existed. However, vector-borne diseases represented $17 \%$ of the global burden of infectious diseases (605), and a robust epistemic community on vector-borne diseases existed, mainly related to diseases carried by mosquitos [such as Malaria, which has a well-established epistemic community $(606,607)]$. As outlined below, this community was in a unique position of influence and was able to mobilize and respond to the Zika outbreak quickly.

The global response to Zika enabled the recently formed epistemic community to play an active role, given the limited knowledge about the disease, and that research became a crucial component in the overall response. Figure 26 presents the connection between the epistemic community and the level of international cooperation in the response. As outlined below, the international response to the Zika outbreak exhibited a medium to a high level of cooperation. 


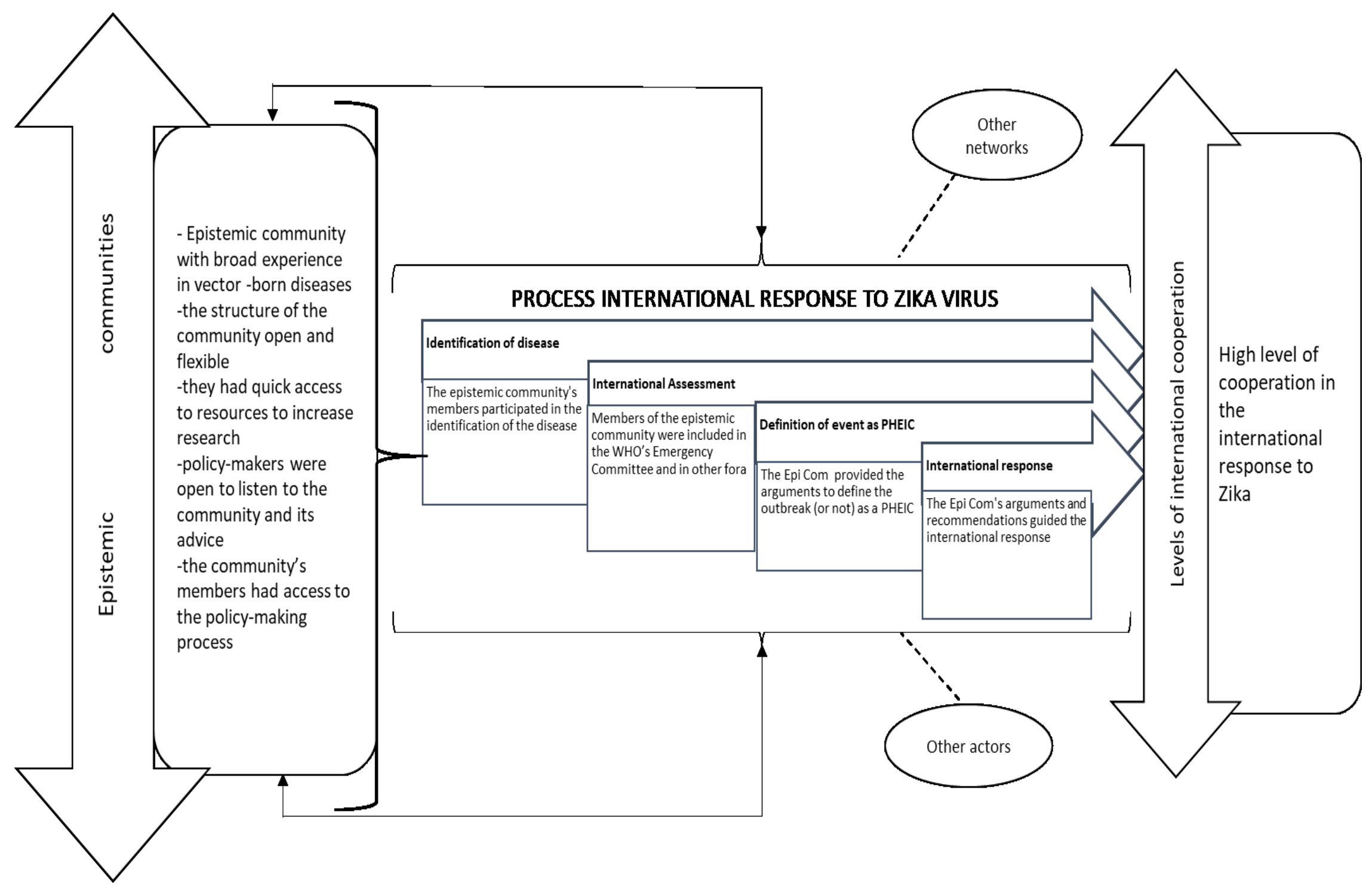

Figure 26. Zika epistemic community and its influence in the international response 


\subsection{Zika outbreak 2015 in the Americas}

In 2014, scientists detected the Zika virus directly transmitted ${ }^{1 x i i}$ by the mosquito Aedes aegypti in the Americas (582). Chile confirmed the first case found on Easter Island in February 2014 (582). Haiti, in 2014, also documented some cases (608).

In 2013, health officials in the northeast of Brazil started reporting to the Health System (Sistema Unico de Saude - SUS) cases of a disease caused by an unknown virus (608). In 2015, they found patients with dengue-like symptoms in the same area, and, in March of 2015, health workers sent samples of those patients at the Oswaldo Cruz Institute (609). Laboratory analysis identified the virus on April 30, 2015, and in May 2015, Brazil notified and confirmed indigenous transmission of Zika virus to PAHO $(582,572)$.

More dramatic was the regional increase in cases of newborn microcephaly, born to women who experienced fever and rash during their pregnancy due to the Zika virus (610,568). By October 2015, the Brazilian government reported an increased incidence of infant microcephaly (583) and an unusual cluster of microcephaly in the northeastern region (611). Laboratory confirmations later supported these findings (612). Other countries, including Slovenia, Spain, and the United States, reported cases of microcephaly among infants born to mothers with a travel history to countries where the vector was found (594). Later studies provided scientific evidence to confirm the relationship between Zika and microcephaly.

The Zika virus was also associated with neurological disorders $(613,594,614)$.

\footnotetext{
lxii This type of transmission is referred as indigenous or autochthonous and it is important to differentiate from those cases that are exported due to people traveling to the area where the vector lives.
} 
Doctors in Brazil identified an increase in Guillain-Barré syndrome (GBS) in the Zika affected region. Research on the outbreak in French Polynesia showed that 42 patients in hospital with Zika infection had also GBS, confirming the association of neurological disorders, microcephaly, and GBS to Zika infection. The risk of GBS was estimated to be 2.4 per 10,000 people infected (594). Countries reporting Zika cases in the Americas also reported an increase in GBS cases.

Given the increasing number of cases of the Zika virus and their potential link to cases of microcephaly, the Ministry of Health of Brazil published an order declaring a Public Health Emergency of National Importance on November 12, 2015 (Emergência de Saúde Pública de importância Nacional - ESPIN) $(583,608)$. In 2015, health officials reported Brazil had a Zika incidence of between 440,000 and 1,300,000 cases (583).

The strain of the Zika virus found in Brazil was closely related to the one found in French Polynesia. Therefore, experts believe that the mosquito probably originated in Asia and migrated to Brazil from French Polynesia $(589,609)$. The spread of the disease in Brazil, and throughout the rest of South America, was in part because of the Amazonia, an ecosystem that offers the perfect environment for the reproduction of mosquitos and makes vector control more difficult $(615,589)$. For instance, PAHO reported that Dengue cases in Brazil increased more than $200 \%$ in 2015 compared to $2014(616,617)$. There were reports of two waves of Zika infection that coincided with the rainy season in the area (608). Health authorities estimate that there have been more than 1 million cases of Zika in 25 countries in America since May 2015 (98).

By August 2017, 48 countries in the Americas had reported autochthonous 
transmission of Zika (individual to individual), five through sexual transmission $(618,568)$ ( See Appendix M for the distribution of cases in the Americas as of January 2018). Due to the lack of immunity in the Americas and the high density of the population, the WHO estimated 3 to 4 million cases of Zika infection (including asymptomatic cases) would appear in the continent in one year (572).

\subsection{The Zika Epistemic Community}

The Zika virus was expanding geographically. Although the Zika virus is associated with low mortality rates (593), as outlined above, evidence of neurological disorders, GBS, microcephaly, and congenital malformations associated with the virus alarmed the world $(571,572,619)$. This association also brought great scientific interest (613). There were no treatments or vaccines available to manage the outbreak (620). This degree of scientific uncertainty facilitated framing the situation as an urgent event, "demanding quick and effective solutions (613)".

The need for evidence increased the demand for experts, allowing the participation of an epistemic community in the response activities and influenced international cooperation. As outlined below, the epistemic community not only gathered information and provided scientific advice; they joined the decision-making process at the international and regional levels. Their participation and their research and scientific advice in the face of uncertainty became a core component of the response.

\subsubsection{History: Vector-control and the Zika epistemic community.}

Vector-borne diseases are common in tropical areas, affecting usually poor people living in precarious conditions and with insufficient access to sanitation. America (mostly 
Latin American countries), Asia, and Africa are the regions that struggle most with vector control. Health systems face many challenges controlling and eradicating vectors, and some practices, such as the use of certain chemicals were effective but controversial $(597,621)$. Climate change is also expanding the areas where insects can live, increasing their population worldwide, and creating more challenges for the control of vectors. There is a wide variety of diseases transmitted by vectors or insects like mosquitoes. Table 51 presents a list of these diseases.

\begin{tabular}{|c|c|c|}
\hline \multicolumn{3}{|c|}{ Vectors and the diseases that they can transmit } \\
\hline Vector & Specie & Diseases \\
\hline \multirow{5}{*}{ Mosquitoes } & Aedes aegypti & Dengue, Yellow fever, Chikungunya, Zika virus \\
\hline & Aedes albopictus & Chikungunya, Dengue, West Nile virus \\
\hline & $\begin{array}{l}\text { Culex } \\
\text { quinquefasciatus }\end{array}$ & Lymphatic Filariasis \\
\hline & $\begin{array}{l}\text { Anopheles (more } \\
\text { than } 60 \text { known } \\
\text { species transmit } \\
\text { diseases) }\end{array}$ & Malaria, Lymphatic Filariasis (in Africa) \\
\hline & Haemagogus & Yellow fever \\
\hline Sandflies & & Leishmaniasis \\
\hline $\begin{array}{l}\text { Triatomine } \\
\text { bugs }\end{array}$ & & Chagas disease \\
\hline Ticks & & $\begin{array}{l}\text { Crimean-Congo Haemorrhagic Fever, Tick-borne, } \\
\text { Encephalitis, Typhus, Lyme Disease }\end{array}$ \\
\hline Fleas & & Plague, Murine Typhus \\
\hline Flies & Various species & Human African Trypanosomiasis, Onchocerciasis \\
\hline
\end{tabular}

Table 51. Vectors and the diseases they transmit.

Source: World Health Organization (621)

For decades, the international community has trusted science and experts to find approaches to control vectors. In 1949, the WHO created the Expert Committee on Insecticides, since, for many years, experts and governments considered pesticides as the primary intervention tool (621). In 1976, this committee became the WHO Expert Committee on Vector Biology and Control, a group of "academics gathering which served as a focal 
point for the epistemic community working on this issue (622)." This group included experts from other UN agencies (UNDP, FAO, ILO) and other organizations. In addition to this committee, the WHO created the Pesticide Evaluation Scheme (WHOPES) [previously known as the WHO Pesticide Evaluation Program (1960)]. WHOPES consisted of a network of laboratories, universities, and industry (622). The WHO also expanded its mandate on vector control creating expert committees on malaria, schistosomiasis, filariasis, onchocerciasis, trypanosomiasis, and leishmaniasis. In particular, the Global Malaria Program has acquired a central role in vector control given that malaria is endemic in more than 90 countries, mostly in tropical regions, and the burden of the disease is still very high in some African countries $(623,624)$.

The complexity of vector control, however, required multiple strategies and a multisectoral approach. Therefore, in 2004, the Health and Environment Linkage Initiative sponsored by the WHO and the United Nations Environment Program (UNEP) created the Global Strategic Framework on Integrated Vector Management (IVM) $(625,626)$. This strategy was evidence-based and called for an integrated approach to include collaboration with other sectors (environment, education, tourism, development) and to increase knowledge about the ecosystem in areas with a high risk of transmission. As well, it required engagement with local communities and called experts to provide access to accurate information and evidence $(591,267,626)$. This program built the basis of a broader epistemic community working at all levels and with multiple sectors to create better collaborations and decision making based on science and evidence (626).

The Global Strategic Framework oriented the international community into a more 
integrated area, instead of focusing only on specific diseases, and some expert groups have included vector control as a specific goal. One of these initiatives, the RBM Partnership to End Malaria, founded in 1998 and with over 500 partner institutions worldwide, created the Vector Control Working Group in 2010. Participants in this partnership and working group closely collaborated with the Global Malaria Programme, the Programme for Research and Training in Tropical Diseases, and established the WHO Global Vector Control Response $(606,627)$, which included Zika.

\subsubsection{Characterizing the Zika epistemic community}

The Epistemic Community on the Zika virus naturally evolved from these larger vector control initiatives, as it included scientists and other experts working on vector control and infectious diseases. It also collaborated with other vector control expert groups such as the Vector Control Advisory Group created in 2012. This Advisory Group recommended new approaches for vector control and provided information to guide policy development (607). This group worked closely with the Emergency Committee on Zika (ECZ) and issued specific recommendations after the ECZ's second meeting (593).

\subsubsection{Knowledge}

The medical and scientific community did not invest in researching the Zika virus for over 50 years since it considered the pathogen mild and innocuous (584). When the 2015 outbreak was declared a PHEIC, scientific uncertainty surrounded the link between the Zika virus and microcephaly. Data from a previous outbreak in French Polynesia showed the likely link, evidence strong enough to declare the outbreak a PHEIC $(593,628)$

Despite the lack of knowledge, the scientific community mobilized to gather 
evidence. On June 14, 2016, during the WHO Emergency Committee $3^{\text {rd }}$ meeting, experts announced the international scientific consensus that the Zika virus can cause infection in the fetus, neurological complications such as microcephaly, other brain abnormalities, and GBS in newborns $(569,629,579,628,573,581,630)$.

Although this consensus was critical for the continued prioritization of Zika, as well as for guiding policy responses, there were some crucial disagreements. For instance, the Lancet (one of the most influential peer-reviewed journals in health) started a debate regarding the danger of having the Summer Olympic Games in Brazil in the middle of the outbreak. The editorial board of The Lancet Infectious Diseases analysed this situation and concluded that the virus represented a minimal threat to the games' visitors (631). In response to that editorial, Dr. Attaran from the University of Ottawa in Canada wrote a reply arguing the opposite and accusing the journal of endorsing an event that was potentially a risk to global health (632). Not only did the Lancet reply to Dr. Attaran's letter defending its position, but a group of Brazilian scholars published a response to him agreeing with the journal's assessment and calling the WHO Director-General not to endorse postponing or reallocating the Olympic Games $(602,633)$. This disagreement reflects the uncertainty in the epistemic community about the virus.

Experts recognized the need for more research to understand the virus and its full impact on people's health (568). There were gaps in knowledge, and the community agreed that more information was necessary to fill those gaps. For scientific experts, the lack of data itself represented a threat to public health (612). Thus, the one key policy goal was to increase understanding of the nature of the disease to guide the response (593). 


\subsubsection{Socialization of ideas}

When the international response to the Zika virus outbreak of 2015 started, the epistemic community was relatively small. This group mostly derives from the Vector Control epistemic community and some members from the Malaria epistemic community. It is possible, however, to identify core subgroups of experts that compose the community. These are:

- The Emergency Committee for Zika

- The Vector Control Advisory Group (VCAG)

- The Expert Advisory Group on Design of Epidemiological Trials for Vector Control Products

- The WHO Ad-hoc Advisory Group on aircraft disinsection for controlling the international spread of vector-borne diseases.

The ECZ's second meeting recommended that the WHO establish an ad-hoc Advisory Group on aircraft disinsection ${ }^{\text {lxii }}$ for controlling the international spread of vector-borne diseases, adding another component to the epistemic community. The group had to give specific recommendations about the effectiveness of aircraft disinsection and guidelines for its implementation (634). The VCAG also created the Expert Advisory Group on Design of Epidemiological Trials for Vector Control Products.

The WHO regional office PAHO also played an important role, and it became the regional hub for the Zika epistemic community by facilitating the formation of other groups. These included the Technical Advisory Group on Entomology of Public Health Vectors as well as the External Evaluator Group of New Technologies for the control of Aedes. Some of the people advising the Emergency Committee were already working with this regional

\footnotetext{
1xiii "Disinsection" refers to the elimination of insects by spraying inside an aircraft (634).
} 
organization, given the history of the region with Dengue and Chikungunya (593).

As outlined in table 52, both individuals and institutions overlap in some of these networks. There were other expert groups organized by the WHO during the outbreak and other organizations to review and assess different aspects of the disease ${ }^{\text {lxiv }}$ (See Appendix N for the individual lists of members).

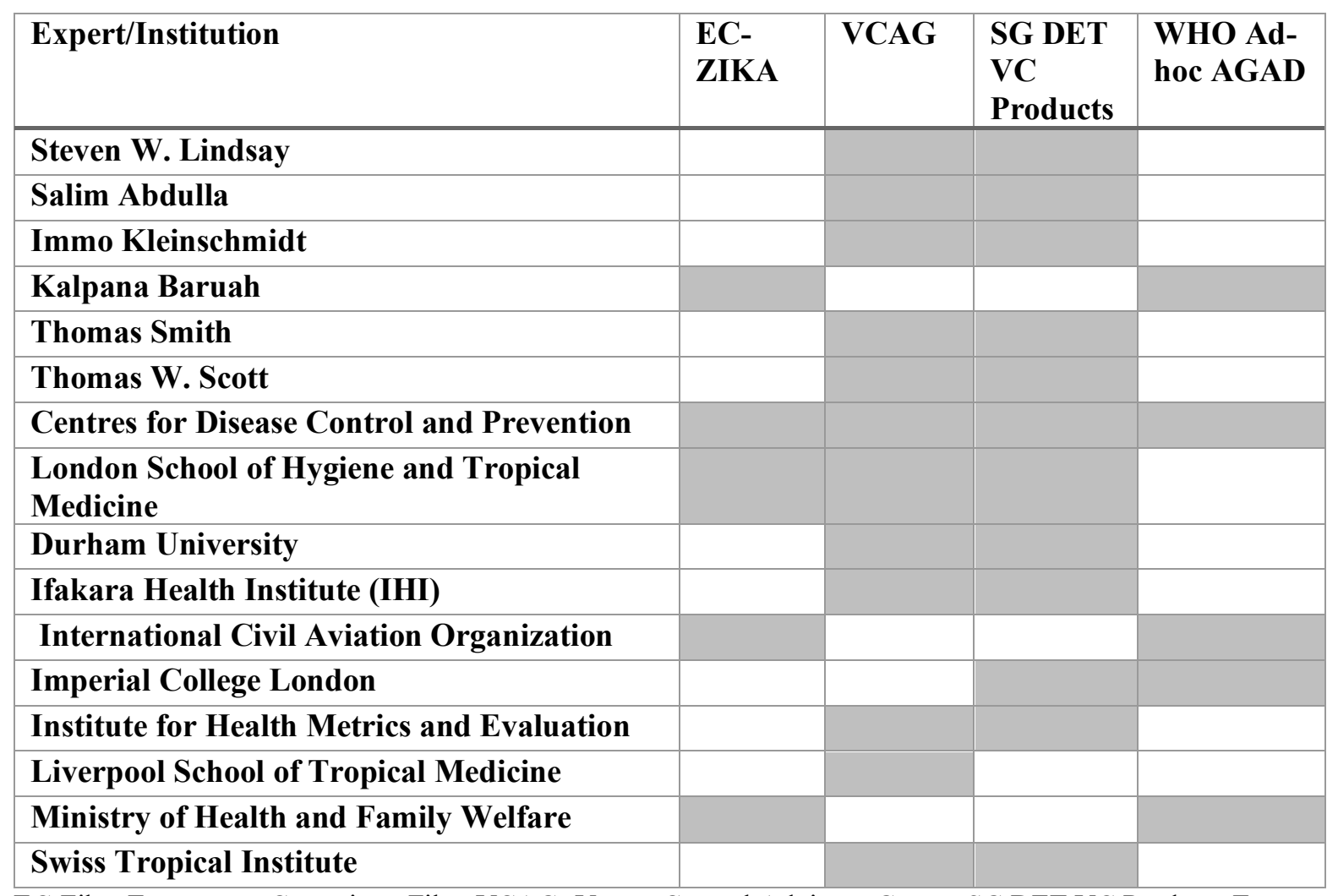

EC Zika: Emergency Committee Zika; VCAG: Vector Control Advisory Group; SG DET VC Products Expert Advisory Group on Design of Epidemiological Trials for Vector Control Products; WHO Ad-hoc AGAD: WHO Ad-hoc Advisory Group on aircraft disinsection for controlling the international spread of vector-borne diseases Table 52. Main institutions and participants in the Zika epistemic community.

Although the WHO staff members do not appear in this list, the Global Malaria Programme, the Department of Control of Neglected Tropical Diseases, and the Special 
Programme for Research and Training in Tropical Diseases were involved in the process and with the epistemic community. These departments have also been directly connected to the Vector Control Advisory Group (607). Besides the expert groups, GOARN and the Partners for the Zika Response were also essential components in the Zika epistemic community, given that some of their member-institutions were interconnected to the core of the community. Appendix $\mathrm{N}$ presents the list of all the institutions in the Zika response and their membership in the different groups of the Zika epistemic community. Table 53 and 54 include those institutions that participated in more than one core group of the epistemic community, GOARN, and Partners for the Zika Response. From these institutions, four central nodes connect through the network:

- World Health Organization (Geneva)

- Centers for Disease Control and Prevention (CDC-USA)

- London School of Hygiene and Tropical Medicine (LSHTM-UK)

- Institute Pasteur (Network- France)

It is also noticeable that all the WHO regional offices participated as individual members in the GOARN and the Partners for the Zika Response, and not as part of the WHO headquarters. 


\begin{tabular}{|c|c|c|c|c|c|c|c|}
\hline ORGANIZATION & COUNTRY & $\begin{array}{l}\text { P. ZIKA } \\
\text { RESP. }\end{array}$ & GOARN & EC-ZIKA & VCAG & $\begin{array}{l}\text { SG DET } \\
\text { VC } \\
\text { Products }\end{array}$ & $\begin{array}{l}\text { WHO Ad- } \\
\text { hoc AGAD }\end{array}$ \\
\hline Department of Health & Australia & & 1 & & & & 1 \\
\hline Durham University & UK & & & & 1 & 1 & \\
\hline $\begin{array}{l}\text { European Centre for Disease Prevention and } \\
\text { Control }\end{array}$ & Sweden & 1 & 1 & & & & \\
\hline European Virus Archive goes Global & France & 1 & 1 & & & & \\
\hline Ifakara Health Institute & Tanzania & & & & 1 & 1 & \\
\hline Imperial College London & UK & & & & & 1 & 1 \\
\hline Institut Pasteur, Dakar & Senegal & & 1 & 1 & & & \\
\hline Institut Pasteur (Network) & France & 1 & 1 & 1 & & & \\
\hline Institute for Health Metrics and Evaluation & USA & & & & 1 & 1 & \\
\hline $\begin{array}{l}\text { Institute of Environmental Science and Research } \\
\text { Limited }\end{array}$ & New Zealand & 1 & 1 & & & & \\
\hline Institute of Tropical Medicine & Belgium & & 1 & & 1 & & \\
\hline International Civil Aviation Organization & Canada & & & 1 & & & 1 \\
\hline $\begin{array}{l}\text { International Federation of Red Cross and Red } \\
\text { Crescent Societies }\end{array}$ & Switzerland & 1 & 1 & & & & \\
\hline International Organization for Migration & Switzerland & 1 & 1 & & & & \\
\hline $\begin{array}{l}\text { International Severe Acute Respiratory and } \\
\text { Emerging Infection Consortium Coordinating } \\
\text { Centre }\end{array}$ & UK & 1 & 1 & & & & \\
\hline Liverpool School of Tropical Medicine & UK & & & & 2 & & \\
\hline Ministry of Health and Family Welfare & India & & & 1 & & & 1 \\
\hline National Institute for Communicable Diseases & South Africa & 1 & 1 & & & & \\
\hline National Institute of Infectious Diseases & Japan & 1 & 1 & & & & \\
\hline Public Health Agency of Canada & Canada & 1 & 1 & & & & \\
\hline Swiss Tropical Institute & Switzerland & & & & 1 & 1 & \\
\hline UN High Commissioner for Refugees & Switzerland & 1 & 1 & & & & \\
\hline United Nations Food and Agriculture Organization & Italy & 1 & 1 & & & & \\
\hline University of Texas Medical Branch & USA & 1 & 1 & & & & \\
\hline
\end{tabular}

Table 53. Central institutions participating in the response to the Zika outbreak and the epistemic community. The table presents all the meetings or groups where these institutions had participants and the number of people representing them. 


\begin{tabular}{|c|c|c|c|c|c|c|c|}
\hline ORGANIZATION & COUNTRY & $\begin{array}{l}\text { P. ZIKA } \\
\text { RESP. }\end{array}$ & GOARN & EC-ZIKA & VCAG & $\begin{array}{c}\text { SG DET } \\
\text { VC } \\
\text { Products }\end{array}$ & $\begin{array}{l}\text { WHO Ad- } \\
\text { hoc AGAD }\end{array}$ \\
\hline WHO Regional Office for Africa & Congo & 1 & 1 & & & & \\
\hline WHO Regional Office for Europe & Denmark & 1 & 1 & & & & \\
\hline WHO Regional Office for South-East Asia & India & 1 & 1 & & & & \\
\hline WHO Regional Office for the Americas & USA & 1 & 1 & & & & \\
\hline $\begin{array}{l}\text { WHO Regional Office for the Eastern } \\
\text { Mediterranean }\end{array}$ & Egypt & 1 & 1 & & & & \\
\hline WHO Regional Office for the Western Pacific & Philippines & 1 & 1 & & & & \\
\hline WHO Headquarter & Switzerland & 1 & 1 & 1 & 1 & 1 & 1 \\
\hline UN International Children's Emergency Fund & USA & 1 & 1 & 1 & & & \\
\hline London School of Hygiene and Tropical Medicine & UK & & 1 & 1 & 1 & 1 & \\
\hline Centres for Disease Control and Prevention & USA & 1 & 1 & 1 & 3 & 2 & 2 \\
\hline
\end{tabular}

P. Zika Response: Partners Zika Response; GOARN: Global Alert and Response Network; EC Zila: Emergency Committee Zika; VCAG: Vector Control Advisory Group; SG DET VC Products Expert Advisory Group on Design of Epidemiological Trials for Vector Control Products; WHO Ad-hoc AGAD: WHO Ad-hoc Advisory Group on aircraft disinsection for controlling the international spread of vector-borne diseases.

Table 54. Central institutions participating in the response to the Zika outbreak and the epistemic community. The table presents all the meetings or groups where these institutions had participants and the number of people representing them. 
During the Zika outbreak, the four core groups were regularly advising the WHO and regional offices, providing analysis of the evidence and recent research. They connected and represented prestigious institutions that influence the global, regional, national and local levels. The experts had several interactions during the outbreak through face to face and virtual meetings. In the case of the VCAG, members of the group had constant interactions since its members meet twice a year in Geneva (nine meetings between 2012 and 2018) (607). The Ad-hoc Advisory Group on aircraft disinsection met once in April 2016, and the Emergency Committee had five meetings in 2016.

These groups also connected to a vector control epistemic community through the WHO and the Vector Control Working Group from the RBM Partnership. Figure 27 represents the connections among these groups. This connection is relevant because it recognizes that a vector control epistemic community was able to adapt its resources and network to the Zika response. The VCWG has been an active participant in the global vector control policy, promoting the implementation of WHO guidelines and contributing to the formulation of global policy, such as the Global Vector Control Response (606). 


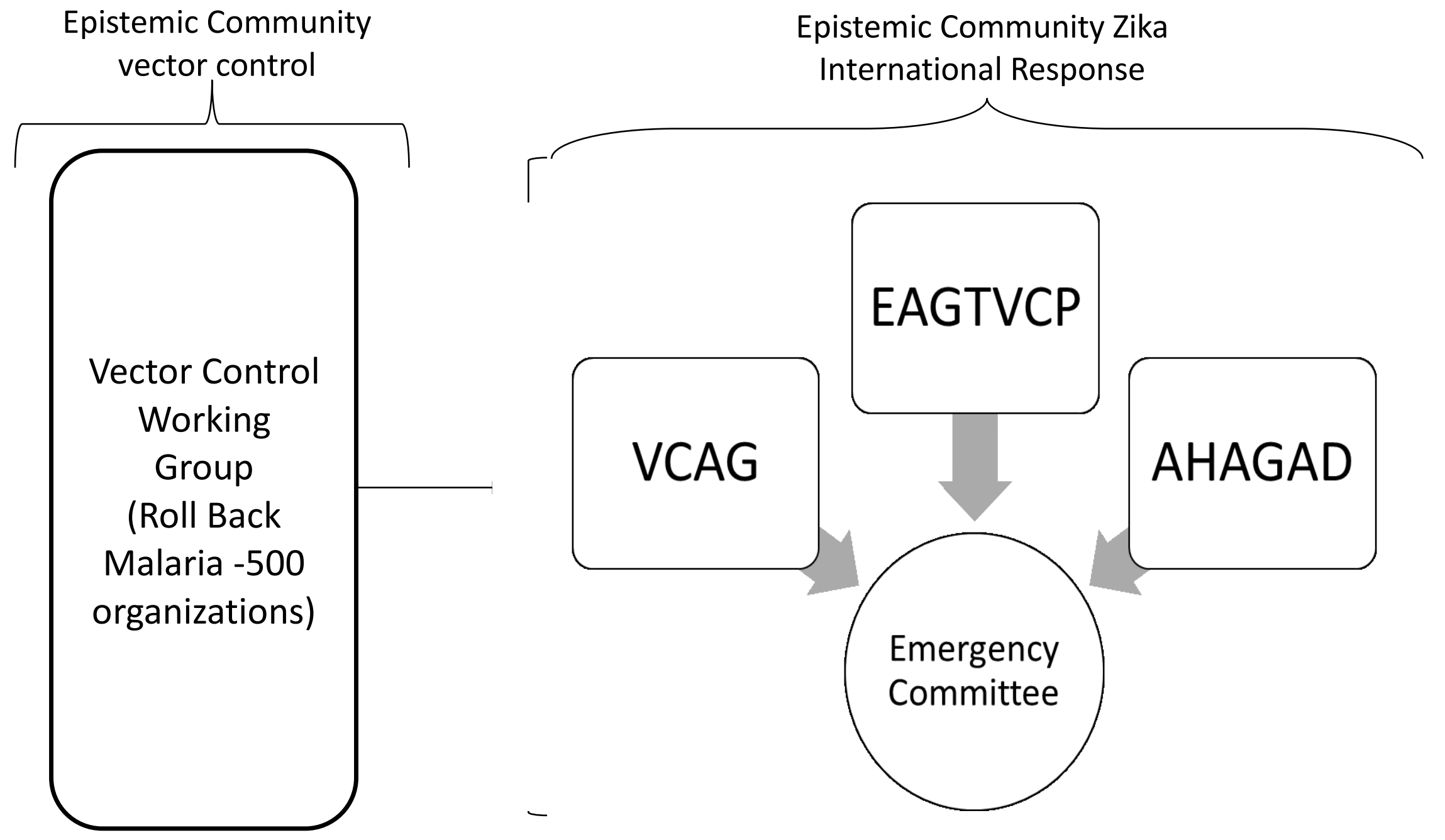

Figure 27. Connection between the Vector Control and Zika epistemic communities. 
The connection of the Vector Control Epistemic Community with the Zika Epistemic Community is evident as it is possible to identify the same participants in both communities. In this case, in 2016 and 2017, the VCWG (Roll Back Malaria) meetings had as part of their agenda discussions about the Zika outbreak. Some of the experts participating in the Zika expert groups (or institutions) partook in those meetings. From the 69 experts participating in the subgroups previously identified, 4 of them directly participated in the VCWG meetings, and 8 of the institutions represented in the Zika epistemic community sent one or more representatives to the VCWG meetings. Table 55 summarizes this information.

\begin{tabular}{|l|l|}
\hline $\begin{array}{c}\text { Expert or institution participating in VCWG and member of Zika } \\
\text { Epistemic Community }\end{array}$ & Country \\
\hline Mark Rowland & UK \\
\hline Molly Robertson & USA \\
\hline Steven W. Lindsay & UK \\
\hline Janet Hemingway & UK \\
\hline Ghana Health Service & Ghana \\
\hline Imperial College London & UK \\
\hline Centers for Disease Control and Prevention & USA \\
\hline London School of Hygiene and Tropical Medicine & UK \\
\hline University of Malaya & Malaysia \\
\hline Ministry of Health and Family Welfare & India \\
\hline UNICEF & USA \\
\hline Harvard T.H. Chan School of Public Health & USA \\
\hline
\end{tabular}

Table 55. Members of the Vector Control epistemic community directly participating in the Zika epistemic community.

In addition to these experts and institutions, Pedro Alonso, Director of the Global Malaria Programme at WHO, participated in these meetings, and he has been one of the most important actors in the Zika response and for the creation of a vector control strategy.

Dissemination of updated information and research was considered the basis of the response to Zika (573). The international response itself emphasized the importance of improving data sharing, research protocols, and in general, in the dissemination of research and development. Members of the core Zika epistemic community actively published and shared information to increase the global knowledge about the virus and the disease, as well 
provide better data for policymaking. Scholars such as David L. Heymann, Heather Ferguson, Annelies Wilder-Smith, Kamran Khan, Robert Steffen, Claudia Torres Codeco, and Immo Kleinschmidt published about the disease and related topics (vector control, travel medicine, malaria) during the outbreak.

Dissemination of research and findings by the epistemic community members was extensive and increased since 2015. According to Etienne et al., PubMed had records of only 112 journal articles mentioning Zika between 1952 and 2014 (568). After 2015, scholars published more than 1300 articles (568).

The WHO regularly consulted the epistemic community, and as a result, it issued more than 20 documents covering all aspects of the response (635). The WHO created the Zika Open Repository "to allow open and early access to Zika-related research manuscripts that are awaiting publication in peer-reviewed journals," this mechanism also improved dissemination (596). In addition to this initiative, the WHO, on 25 October 2016, presented the Zika Virus Research Agenda "to support the generation of the evidence needed to inform essential public health guidance and actions to prevent and limit the impact of Zika virus and its complications" $(636,567)$. The agenda identified critical areas of research and recognized the importance of science for guiding the response and targeting critical areas such as case investigations and ecological, case-control, and cohort studies (636). Finally, the WHO Blueprint for Action to Prevent Epidemics presented a strategy for facilitating and promoting more scientific research, in which Zika is a priority (568).

Dissemination processes also required access to data, and the samples from Brazil were critically important to understand the link between microcephaly and the Zika virus. 
There were some controversies regarding access to samples and use of data. Some experts blamed Brazil for not sharing the virus fast enough, whereas Brazilian scientists felt their foreign peers did not provide enough collaboration $(637,638)$.

Members of the epistemic community also participated directly in the response as members of the expert missions sent to countries affected by Zika. PAHO led around 83 missions with 177 experts, which included neurologists, neonatologists, obstetricians, epidemiologists, virologists, and experts in research and health services, to provide information and advice based on the most updated research $(639,573,568)$. The office also organized more than 20 technical workshops (567). The GOARN deployed experts in the Americas. It collaborated with Brazil to assess the situation and the cases with microcephaly (573). The Western Pacific Regional Office (WPRO) also deployed experts, including epidemiologists, entomologists, and risk communication experts (573). In Africa, the regional office sent a team to investigate and assess the situation in the continent with the participation of professionals from different disciplines (567).

Finally, the epistemic community participated through the Strategic Response Framework, which includes 60 partners, including governments, international organizations, NGOs, research institutions, and universities. Appendix N.1 outlines the participating institutions. All these partners included experts in their activities related to the response. The most significant contributors were the US CDC, which monitored and coordinated the response to Zika providing experts in different areas, including arboviruses (573). The CDC's staff was deployed in different parts of the world to collaborate at the local, national, and international levels in all the aspects of the outbreak (573). 


\subsubsection{Institutionalization of bureaucratic power}

As in previous cases, participation in decision making was mainly through the Emergency Committee. The influence of the epistemic community, however, extended beyond the WHO EC. For instance, after the EURO's consultation, the WHO European regional office developed a training curriculum to increase awareness of invasive mosquitoes and vector-borne diseases, following the publication of the Zika Risk Assessment for European Region (WHO Zika Response). Additionally, more than 2015 experts collaborated in guidance documents published by the WHO (567).

The WHO mobilized more than 250 experts at "meetings and in working groups to produce guidance, set research priorities, and advise on surveillance and response strategies" (596) The WHO and its regional offices also organized expert groups to tackle the outbreak.

Table 56 presents a list of these meetings.

\begin{tabular}{|c|c|c|}
\hline Meeting & Date and location & Comments \\
\hline $\begin{array}{l}\text { WHO Regional Office for } \\
\text { Europe (EURO) Regional } \\
\text { Technical Consultation on Zika } \\
\text { virus }\end{array}$ & $\begin{array}{l}\text { June 2016, Lisbon, } \\
\text { Portugal, }\end{array}$ & WHO Zika Response \\
\hline $\begin{array}{l}\text { Scientific Consultation on Zika } \\
\text { Virus Vaccine Development, } \\
\text { organized by National Institute } \\
\text { of Allergy and Infectious } \\
\text { Diseases (NIAID) and WHO }\end{array}$ & $\begin{array}{l}\text { 10-11 January 2017, } \\
\text { Geneva }\end{array}$ & List of participants Annex O \\
\hline $\begin{array}{l}\text { WHO workshop, Efficacy trials } \\
\text { of ZIKV Vaccines: endpoints, } \\
\text { trial design, site selection }\end{array}$ & $\begin{array}{l}\text { June 1-2, 2017, } \\
\text { Geneva. }\end{array}$ & $\begin{array}{l}\text { Group of about } 30 \text { experts in epidemiology, regulatory, } \\
\text { preclinical and clinical vaccine trials, and mathematical } \\
\text { modelling, in a workshop on planning for Zika vaccine } \\
\text { efficacy trials. List of participants Annex O }\end{array}$ \\
\hline $\begin{array}{l}\text { Sexual transmission of } \mathrm{ZIKV} \\
\text { meeting of experts }\end{array}$ & $\begin{array}{l}\text { Geneva, Switzerland, } \\
\text { 20-21 March } 2017\end{array}$ & List of participants annex $\mathrm{O}$ \\
\hline $\begin{array}{l}\text { Meeting of from PAHO / WHO, } \\
\text { producers/ developers of new } \\
\text { technologies, non-profit } \\
\text { organizations, universities, and } \\
\text { research institutes of the United } \\
\text { the External Evaluator Group of } \\
\text { New Technologies (GE) for the } \\
\text { control of Aedes spp. }\end{array}$ & $\begin{array}{l}\text { December } 5 \text { - 6, 2017, } \\
\text { in Washington, D.C. }\end{array}$ & $\begin{array}{l}\text { Created as a recommendation of the Technical Advisory } \\
\text { Group on Entomology of Public Health and Vector Control } \\
\text { of PAHO. GE's work is complementary to the WHO } \\
\text { Vector Control Advisory Group (VCAG / WHO) and } \\
\text { provides support and advice to PAHO evaluating new and } \\
\text { complementary tools for vector control. Twenty-five } \\
\text { people attended the meeting form the United States (USA), } \\
\text { Brazil, Mexico, the United Kingdom, and Colombia. }\end{array}$ \\
\hline
\end{tabular}

Table 56. Meetings Zika outbreak. 
Besides the meetings and derived from the Research Agenda, the WHO organized other technical consultations, including meetings from the Vector Control Advisory Group, presented in Table 57.

\begin{tabular}{|c|c|c|}
\hline Meeting & Date/Location & Comments \\
\hline $\begin{array}{l}\text { WHO global consultation on } \\
\text { research related to Zika virus } \\
\text { infection }\end{array}$ & Geneva, 7-9 March 2016. & $\begin{array}{l}\text { The meeting had } 130 \text { experts from } 27 \\
\text { countries, and its focus was on improving } \\
\text { surveillance and development of multi tests } \\
\text { for Zika, chikungunya, and dengue (640) }\end{array}$ \\
\hline $\begin{array}{l}\text { Management of complications } \\
\text { and development of the Zika } \\
\text { virus causality framework } \\
\text { meeting }\end{array}$ & $\begin{array}{l}\text { Geneva, 17-19 March } \\
\text { 2016), }\end{array}$ & $\begin{array}{l}\text { This group worked on the linkage of Zika } \\
\text { with neurological syndromes }\end{array}$ \\
\hline $\begin{array}{llr}\text { Vector } & \text { Control } & \text { Advisory } \\
\text { Group } & \text { meeting } & \text { (special } \\
\text { meeting) } & & \\
\end{array}$ & $\begin{array}{l}\text { Geneva, 14-15 March } \\
2016\end{array}$ & \\
\hline $\begin{array}{l}\text { Seventh meeting of the vector } \\
\text { control advisory group } \\
\text { (VCAG) }\end{array}$ & $\begin{array}{l}\text { Geneva, Switzerland, 24- } \\
26 \text { October } 2017\end{array}$ & \\
\hline WHO scoping meeting & $\begin{array}{l}\text { Geneva, 23-24 February } \\
2017\end{array}$ & $\begin{array}{l}\text { Ethical issues associated with vector-borne } \\
\text { diseases. }\end{array}$ \\
\hline 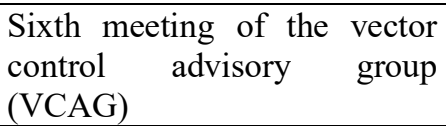 & $\begin{array}{l}\text { Geneva, Switzerland, 26- } \\
28 \text { April } 2017\end{array}$ & \\
\hline WHO Expert Advisory Group, & $\begin{array}{l}\text { Château de Penthes, } \\
\text { Geneva, 24-25 April } 2017\end{array}$ & $\begin{array}{l}\text { Design of epidemiological trials for vector } \\
\text { control products, }\end{array}$ \\
\hline $\begin{array}{l}\text { The fifth meeting of the vector } \\
\text { control advisory group } \\
\text { (VCAG) }\end{array}$ & $\begin{array}{l}\text { Geneva, Switzerland, 2-4 } \\
\text { November } 2016\end{array}$ & \\
\hline
\end{tabular}

Table 57. Meetings expert groups Zika.

In March 2016, the WHO launched a public consultation on research related to the Zika virus infection. During the three days of the meetings (7-9 March), experts from different areas and affiliations participated in accelerating the development of products for diagnostic and treatment of Zika virus disease. The group reflected on the difficulties of detecting a highly asymptomatic disease, and that represents a great danger for pregnant women (630). They discussed in vitro diagnostics, vector control, therapeutics, and data sharing and regulation $(596,567)$. Participants in this consultation developed target product profiles (TPP) to develop diagnostic tests in-vitro and laboratory evaluation requirements 
$(567,630)$. The experts and stakeholders in this meeting came from different institutions, including $^{\mathrm{lxv}}$ :

- World Health Organization (WHO)

- UNICEF Supply Division

- Pan American Health Organization (PAHO)

- Foundation for Innovative New Diagnostics (FIND)

- London School of Hygiene and Tropical Medicine (LSHTM)

- Medecins Sans Frontieres (MSF)

- TDR Special Programme for Research and Training in Tropical Diseases

- Fundacão Oswaldo Cruz (Fio-Cruz)

- The United States Human and Health Services (US HHS)

- Institute of Tropical Medicine (ITM), Belgium

- Gerência-Geral de Tecnología de Produtos para a Saude (ANVISA), Brazil

- Paul-Ehrlich-Institut, Germany

- Institut Pasteur, France

- Instituto de Diagnóstico y Referencia Epidemiológicas (InDRE), México

- Centers for Disease Control and Prevention (CDC), Puerto Rico

- Federal Service on surveillance in health care (Roszdravnadzor), Russia

- The National Institute for Biological Standards and Control (NIBSC), United Kingdom

- London School of Hygiene \& Tropical Medicine, United Kingdom

- Erasmus MC, The Netherlands

- Foundation for Innovative New Diagnostics, Switzerland

- US Food and Drug Administration, United States of America

- Instituto Evandro Chagas, Brazil

Members of the epistemic community from these institutions actively participated in expert groups and advised the WHO. With the results of this first public meeting, the WHO held a consultation for regulatory expectations and requirements of ZIKV vaccines for use during an emergency from 6-7 June 2016, in Geneva, Switzerland. The meeting brought experts together once again to discuss regulatory issues that would allow the development of

\footnotetext{
${ }^{\text {lxv }}$ Full list of participants is included in Annex O
} 
candidates for a vaccine in the short term (641) (See Appendix N for a full list of participants).

The International Zika Summit was held in Paris on 24-25 April 2016. It was cosponsored by the WHO, Institute Pasteur, and CDC. It included around 600 experts from different fields to share research that could be used for policymaking (642).

Experts were incorporated in national delegations during different conferences and events organized by the WHO, such as the WHA $70^{\text {th }}$, in which the Global Vector Control Response was approved and adopted by all member States. The inclusion of the topic in the OAS also increased the integration of members from the epistemic community into national delegations.

Key members of the epistemic community supported the actions implemented by the WHO but also underlined the importance of scientific evidence. One of them, Bruce Aylward, Assistant Director-General at WHO, actively participated in the international response to Zika. He guided the WHO's handling of travel advice, and he insisted on focusing on advising governments on the importance of providing information for lowering the risk of getting Zika, instead of promoting travel bans (572). Aylward was also involved in the drafting of a research agenda.

Another vital member was Anthony Fauci, Director of the National Institutes for Allergy and Infectious Diseases (NIAID) at the National Institutes of Health (NIH) in the USA, who led the NIAID efforts, along with the CDC, in the collaboration for developing effective diagnostic tools and a vaccine (572). He worked as the NIH's spokesperson and insisted on the importance of more research and funding on Zika. He is also a well-known scholar in the area of infectious diseases and has published a vast number of academic 
articles, including research and comments about the Zika outbreak $(643,644)$.

All these factors shape the Zika epistemic community and its capability to influence international cooperation during the response. Table 58 summarizes these characteristics.

\begin{tabular}{|c|c|c|}
\hline & Indicator & Zika \\
\hline \multirow[t]{2}{*}{ 1. Knowledge } & $\begin{array}{l}\text { Agreement on a common } \\
\text { definition of the problem and } \\
\text { possible solutions }\end{array}$ & $\begin{array}{l}\text { There was no initial agreement about the } \\
\text { link between Zika and neurological } \\
\text { conditions. There was an agreement, } \\
\text { however, about the risk that represented } \\
\text { the possible existence of this link. }\end{array}$ \\
\hline & $\begin{array}{l}\text { Clear identification of a } \\
\text { common policy goal }\end{array}$ & $\begin{array}{l}\text { There was a policy goal regarding } \\
\text { vector born diseases and the importance } \\
\text { of vector control. }\end{array}$ \\
\hline \multirow{3}{*}{ 2.Socialization of ideas } & Structure & $\begin{array}{l}\text { The structure has the WHO as the central } \\
\text { node. PAHO is a node for the Americas, } \\
\text { and the other regional offices also act as } \\
\text { nodes. Membership is broad and } \\
\text { worldwide. }\end{array}$ \\
\hline & Dissemination mechanisms & $\begin{array}{l}\text { Due to the lack of information, the } \\
\text { dissemination of scientific research has } \\
\text { been critical for the response. The } \\
\text { epistemic community has tried to } \\
\text { increase R\&D and provide as much } \\
\text { evidence as possible to establish control } \\
\text { measures. }\end{array}$ \\
\hline & $\begin{array}{l}\text { Participation in the } \\
\text { international response }\end{array}$ & $\begin{array}{l}\text { Many members of the Epistemic } \\
\text { Community participating in the } \\
\text { international response as experts and } \\
\text { advisors. }\end{array}$ \\
\hline \multirow{2}{*}{$\begin{array}{l}\text { 3.Institutionalization of } \\
\text { bureaucratic power }\end{array}$} & $\begin{array}{l}\text { Participation in the policy } \\
\text { process. }\end{array}$ & $\begin{array}{l}\text { The WHO and other international } \\
\text { organizations formed multiple expert } \\
\text { groups for increasing analysis and } \\
\text { generating evidence, where the } \\
\text { participation of the epistemic } \\
\text { community was critical. }\end{array}$ \\
\hline & $\begin{array}{l}\text { Experts and other } \\
\text { professionals from the } \\
\text { epistemic community in } \\
\text { decision-making positions }\end{array}$ & $\begin{array}{l}\text { Experts form an integral part of the } \\
\text { process mainly through the Emergency } \\
\text { Committee. Some policy entrepreneurs } \\
\text { in crucial positions also helped to } \\
\text { advance the epistemic community's } \\
\text { ideas. }\end{array}$ \\
\hline
\end{tabular}

Table 58. Characteristics Zika epistemic community. 


\subsection{The International Response}

Doctors in the northeast region of Brazil detected cases of unknown diseases since 2013. These professionals may have been the first to identify the symptoms of the Zika virus after reviewing reports of the 2013 outbreak in French Polynesia (637). These doctors notified the health authorities, but officers from the Brazilian Health Ministry were cautious and decided to wait and analyze all possible options before considering the possibility of Zika (637). The work of these experts, collecting and sending samples to the SUS, however, is praised as the action that allowed for the identification of the virus, and soon after, its notification (611).

Brazil notified the first cases to PAHO on May 2, 2015. On May 7, PAHO issued an “epidemiological alert" informing of the presence of cases of Zika virus in Brazil. Brazilian authorities ensured that scientific knowledge always guided the government's decisions.

Early in the outbreak, doctors dealing with the Zika virus-infected patients believed there was a link between the virus, the increase of cases with Guillain-Barré syndrome, and microcephaly. On November 17, 2015, the Oswaldo Cruz Foundation confirmed the presence of the virus in the amniotic fluid of an expectant mother whose baby showed signs of a viral infection. On November 28, the Brazilian government confirmed the link between the virus and microcephaly after testing another baby (637).

During this process, the Oswaldo Cruz Foundation requested collaboration from international partners. Scientists sent the information about the results to the US CDC in Atlanta for confirmation, but, according to some of these experts, the laboratory refused to accept Brazilian scientists' work and instead requested samples to perform the analysis by 
themselves (637).

As a result of its novelty, Zika brought a high level of uncertainty, mainly due to the link with neurological diseases (593). Faced with evidence of an outbreak yet uncertainty regarding its origin and projected impact, the PAHO and WHO pursued a decision-making process guided by science (568). The WHO deployed on November 30, a group of scientists from PAHO to investigate the situation in Brazil. The Pan American Health Organization (PAHO/WHO) issued an alert to intensify surveillance for Zika cases related to the Aedes aegypti mosquito, requesting governments to be vigilant of possible Zika infections $(568,597)$. As well, it mobilized experts to Brazil to support the local and national authorities investigating cases and their causes. The international response in the Americas, therefore, began before the PHEIC declaration, under the PAHO leadership $(597,567)$. The WHO, however, did not call an EC on Zika Virus until February 2016. Regardless of PAHO's work in the region, some scholars criticized the WHO for not convening an Emergency Committee soon after Brazil's notification of cases and not considering the outbreak an immediate global threat (597).

On February $1^{\text {st }}, 201$, the WHO Director-General organized the first meeting of the Emergency Committee. After this, the Zika EC recommended to the WHO Director-General to declare the Zika outbreak a PHEIC. The WHO made the official statement the same day, declaring the events in South America a PHEIC, due to evidence on the likelihood of congenital malformations and neurological disorders associated with the Zika virus $(594,568)$. According to EC members, "a causal relationship between Zika infection during pregnancy and microcephaly is strongly suspected, though not yet scientifically proven. All 
experts agreed on the urgent need to coordinate international efforts to investigate and understand this relationship better" (619). The members of the Emergency Committee made clear that the precautionary principle guided their initial recommendation, based on what they did not know about the virus (593).

After the EC recommendations, the WHO DG decided to start the international response and issued a formal declaration. The declaration derived from a global strategy to delineate actions and request financial resources for the international response. Countries also needed to determine if the virus was introduced to their territory, monitor the spread of the virus once detected, and monitor any complications (582). Using the National Focal Points established under the IHRs, countries notified the WHO of laboratory-confirmed cases (98).

The best available research guided the EC's recommendations. These included: stronger surveillance of Zika virus infection with the rapid development and sharing of diagnostics; improved communication about the risks of outbreaks of Zika; implementation of vector control measures to decrease exposure to bites from the Aedes aegypti mosquito; and guidance for pregnant women to enable them to make informed decisions regarding their pregnancy (593). Table 59 summarizes the main recommendations of the EC that show their effort to both. 


\begin{tabular}{|c|c|}
\hline Meetings & EC Main Recommendations \\
\hline $\begin{array}{l}\text { First meeting } \\
1 \text { February } \\
2016\end{array}$ & $\begin{array}{l}\text { Enhanced surveillance regarding microcephaly and other neurological disorders and to } \\
\text { research new clusters of microcephaly and determine if they are related to Zika } \\
\text { infection; } \\
\text { Surveillance of Zika cases and transmission; and development of diagnostic tools; } \\
\text { Increased risk communications; and provision of information to risk populations } \\
\text { (pregnant women and women considering getting pregnant). } \\
\text { Implementation of vector control measures to reduce exposure; } \\
\text { Intensified research for vaccines, treatments, and diagnostics; } \\
\text { No travel or trade restrictions necessary and continue sharing of data on all aspects of } \\
\text { the outbreak. }\end{array}$ \\
\hline $\begin{array}{l}\text { Second } \\
\text { meeting } \\
8 \text { March } 2016\end{array}$ & $\begin{array}{l}\text { Clinical care: following cases of pregnant women exposed to the virus; } \\
\text { Research \& product development: increased research and development efforts to } \\
\text { produce a vaccine and to find new control measures. }\end{array}$ \\
\hline $\begin{array}{l}\text { Third meeting } \\
14 \text { June } 2016\end{array}$ & $\begin{array}{l}\text { Updated its advice specifically for international traveling suggested advising pregnant } \\
\text { women no to travel to areas with ongoing outbreaks and to ensure safe sexual practices } \\
\text { for their partners in case of traveling to these places. } \\
\text { The Committee requested WHO provide regular updates on travel with recent } \\
\text { information on the nature and duration of risks associated with Zika virus infection. } \\
\text { The committee expressed that new evidence confirmed the virus could spread } \\
\text { internationally and establish new transmission chains in areas where the vector was } \\
\text { present. }\end{array}$ \\
\hline $\begin{array}{l}\text { Fourth } \\
\text { meeting } \\
2 \text { September } \\
2016\end{array}$ & $\begin{array}{l}\text { Reaffirmed previous recommendations and "acknowledge their concern for the long- } \\
\text { term impact of Zika virus and recommended developing an appropriate infrastructure } \\
\text { and response plan within the World Health Organization to provide longer-term } \\
\text { coordination and accountability for ensuring an effective response." } \\
\text { The Committee "emphasized the need for a better scientific understanding of Zika virus } \\
\text { epidemiology, clinical disease, and prevention, recommending a focus on several new } \\
\text { research issues along with other issues recommended previously" }\end{array}$ \\
\hline $\begin{array}{l}\text { Fifth meetings } \\
18 \text { November } \\
2016\end{array}$ & $\begin{array}{l}\text { Recommended establishing a longer-term response mechanism that delivers the } \\
\text { strategic objectives already identified in the Zika Strategic Response Plan. } \\
\text { Based on this advice, the Public Health Emergency of International Concern (PHEIC) } \\
\text { was ended. }\end{array}$ \\
\hline
\end{tabular}

Table 59. Summary recommendations Emergency Committee on Zika (645)

On February 14, 2016, the WHO launched the Strategic Response Framework and Joint Operations Plan in which the organization presented a comprehensive plan for preventing, detecting, and responding to Zika (WHO 2016). The strategy outlined the resources needed for its implementation, as well as the roles and responsibilities of several partners, including UN agencies, operating under overall WHO leadership. The strategy estimated the resources required to finance the response to this outbreak.

As part of the Plan, the UN created the UN Zika Response Multi-Partner Trust Fund 
(MPTF), a multi-agency pooled-funded mechanism to finance UN agencies involved in the response and the WHO. The MPTF supported the Zika Strategic Response Framework and provided a tool to finance critical priorities $(646,647)$. The MPTF aimed to provide a better allocation of resources and donor coordination by defining specific goals and areas of work (647). The international response included investment in resources for surveillance, diagnostics, and treatment, as well as education. The strategy emphasized investment in research and development to provide sound scientific evidence for policymaking and for guiding the response $(613,593)$. Between 2016-2017, the WHO/PAHO received US\$24.9 million in direct contributions (646). The UK created a Zika research fund with an initial budget of US\$1.4 million, and the US president requested US\$1.8 billion to Congress for Zika response activities (587).

Regardless of the scarce information, the lack of drugs and vaccines for treating the disease, and the probability that the mosquito could expand geographically, the WHO and its member states were able to increase their knowledge of the disease and established measures to control the outbreak (648). The EC provided recommendations, and governments complied with most of them. Measures were based on prevention of contagion by isolating cases and reducing vector-contact. Other recommendations were established, such as an increasing campaign in the media to advise of possible sexual transmission. Travel advisories were issued warning people going to tropical destinations and alerting them of the potential risks in case of being infected. In particular, women were warned of the danger of contracting the disease while pregnant, or if they were considering getting pregnant in the short-term $(569,582)$. 
In the region of the Americas, $\mathrm{PAHO} / \mathrm{WHO}-\mathrm{led}$ the response, conducting more than 86 missions to 30 countries with 177 experts $(568,639)$. In 2015 , the member of the Organization of American States (OAS) endorsed and publicly supported the activities already implemented by the WHO and the PAHO. They recognized the Strategic Response Framework and Joint Operations Plan as the main guidelines for the response and the expert guidance led by PAHO in the region. As well, it recognized the importance of collaboration at the technical level in different areas. The resolution was a political declaration in which the OAS member states recognized and endorsed the actions established by the epistemic community and committed themselves to facilitate this community's work to control the mosquito spreading Zika in the region (649). Countries in the Americas officially reported 753,703 cases as of March 2017 (568). The World Bank estimated in 2016 that economic losses for Latina America could reach US $\$ 3.5$ billion (650).

The limited information and fear of the consequences led some to consider Zika a threat to national security, and some countries used the military to combat the outbreak Brazil, Ecuador, and Cuba (650). This conceptualization may have helped to mobilize more resources in a short period (650).

The community was also able to influence changes in global norms with the adoption of the VCAG's proposal for a Global Vector Control Response, which was drafted in the context of the Zika outbreak. This document set the policy priorities for the period 20172030, encouraging WHO's State Members to implement a comprehensive strategy for vector control. It underlined the need for collaboration at the international, regional, local, and community levels as well as with other sectors using the "One Health" approach, more human 
resources for control activities, and investment in research (627). The strategy was unanimously adopted by all member states at the $70^{\text {th }}$ World Health Assembly in May 2017 under resolution WHA70.16. $(651,652)$. The strategy established as its main goal to reduce mortality by vector-borne disease at least $75 \%$ by 2030 (651).

In the case of Zika, the international community was less reluctant to adopt the measures proposed by the experts, providing this network with its support without questioning its recommendations. The WHO neither considered restrictions to travel nor trade, but it recommended advising pregnant women about traveling to areas where the mosquito was detected (572). Governments provided information to their citizens about the risk of Zika infections and their consequences. There were, however, some debates regarding global commitment with the international response and its adherence to scientific-based recommendations.

Some scholars criticized national responses, arguing that national governments supported their decision on political prerogatives rather than science. As an example, the Brazilian government was blamed for not establishing proper measures to protect the population and for not strengthening its work with international organizations for political reasons $(611,653)$. Similarly, in the United States, the measures implemented were seen as being opposed to the experts' recommendations. In this case, Dr. Anthony Fauci, the head of the National Institute of Allergy and Infectious Diseases in the National Institutes of Health, publicly declared that "we really need to up our game (654)", referring to the overall US response to Zika.

The measures that focused on pregnant women and those planning on getting 
pregnant, especially those living in the affected areas, were also questioned by some experts. Some believed that the WHO should have issued an advisory recommending women to delay pregnancy or even to seek abortion in those countries where cases of babies with congenital disabilities were increasing (637). Nonetheless, countries that suggested to their population not to get pregnant (Colombia and Ecuador) $(569,597,655,588)$ were under the scrutiny of women's rights, human rights, and gender equality advocates. Their claims questioned the lack of access to essential health services and abortion in many of these countries (650), and the countries' decisions that limited women's right to choose and decide over their bodies limiting their sexual and reproductive rights $(613,656)$. Some governments alerted pregnant women or whoever was trying to become pregnant about the risk of traveling to countries with the Zika virus. However, travel alerts were also controversial, given that they may result in economic loss due to a decrease in tourism.

The participation of an epistemic community was an important factor in influencing the levels of cooperation. To determine how the Zika Epistemic Community influenced the level of international cooperation requires connecting the analysis of the international response and the characteristics of the Zika epistemic community. The process defined in chapter 4 considers four main phases for the international response. All these phases were, to some degree, influenced by the participation of an epistemic community. Figure 28 presents the interconnection between the elements previously explained and the process of the international response to the Zika outbreak. 


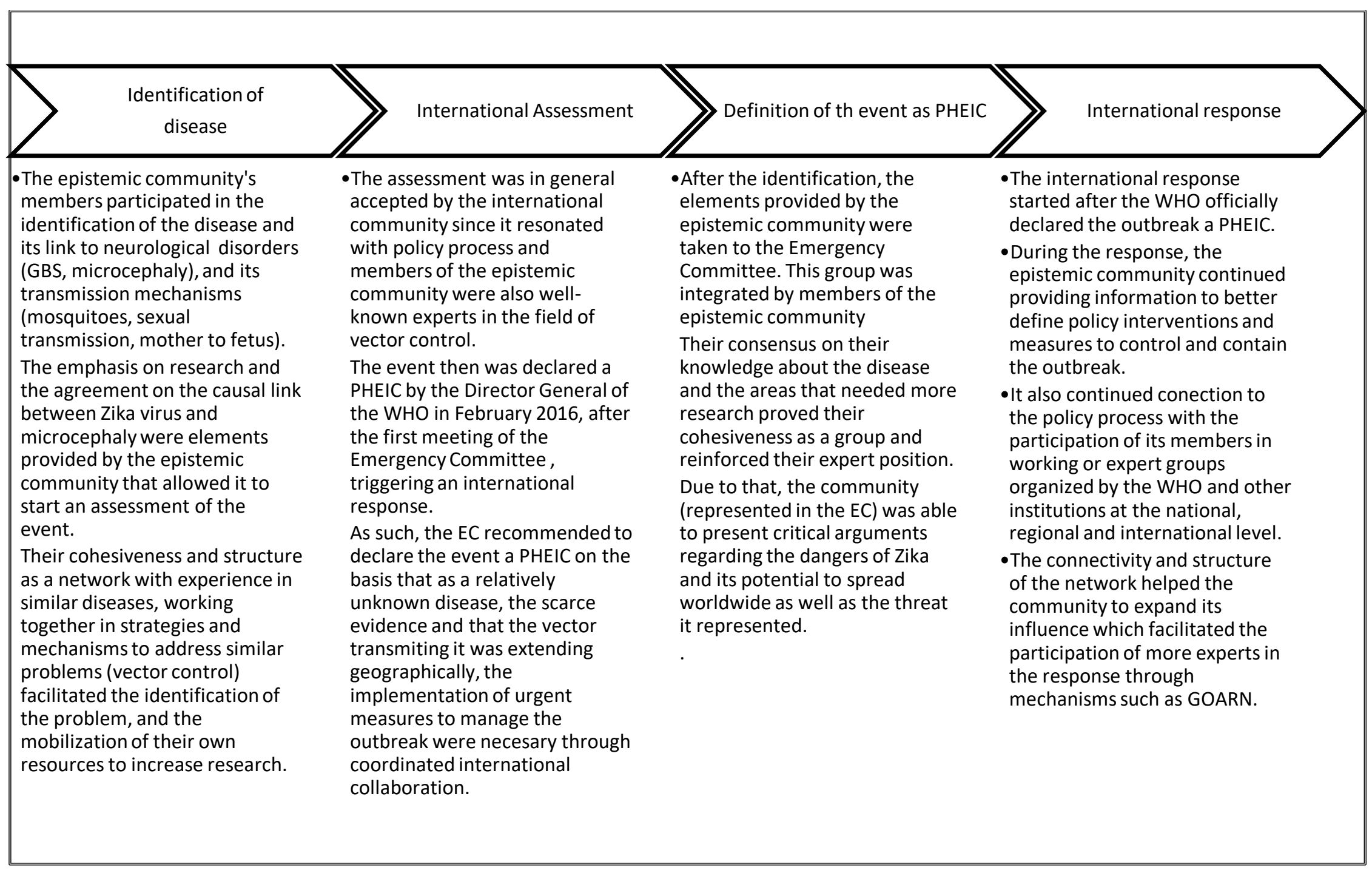

Figure 28. Process of the international response to the Zika outbreak and the epistemic community. 
The phases presented in this process are broken down in Table 60 into specific activities to measure the level of international cooperation in the international response. The arrangement of the activities in the analytical tool presented in chapter 4 , as well as the indicators, also permits us to specify how the epistemic community contributed to those activities. 


\begin{tabular}{|c|c|c|c|c|}
\hline ACTIVITY & MEASURE & $\begin{array}{l}\text { THE EPISTEMIC } \\
\text { COMMUNITY }\end{array}$ & ZIKA & $\begin{array}{c}\text { LEVELS OF } \\
\text { COOPERATION }\end{array}$ \\
\hline \multicolumn{5}{|c|}{ I. International Participation } \\
\hline \multirow{2}{*}{ PROBLEM } & $\begin{array}{l}\text { 1. Type of } \\
\text { meetings at } \\
\text { WHO and } \\
\text { other settings. }\end{array}$ & $\begin{array}{l}\text { The EC was composed of a } \\
\text { subgroup of the epistemic } \\
\text { community that had a } \\
\text { consensual agreement on the } \\
\text { importance of the possible } \\
\text { connection between the Zika } \\
\text { virus and those neurological } \\
\text { disorders. }\end{array}$ & $\begin{array}{l}\text { The Emergency Committee (EC) was convened by the Director- } \\
\text { General under the International Health Regulations (2005) on } 1 \\
\text { February } 2016 \text { (619) after Brazil provided notification of a recent } \\
\text { cluster of microcephaly and other neurological disorders later } \\
\text { found to be associated with Zika virus transmission (619). }\end{array}$ & 5 \\
\hline & $\begin{array}{l}\text { 2.If there were } \\
\text { actions } \\
\text { implemented } \\
\text { as a result of } \\
\text { those meetings }\end{array}$ & $\begin{array}{l}\text { Based on a consensus within } \\
\text { members of the epistemic } \\
\text { community, the EC agreed that } \\
\text { the outbreak had the } \\
\text { characteristics of a Public } \\
\text { Health Emergency of } \\
\text { International Concern } \\
\text { (PHEIC). }\end{array}$ & $\begin{array}{l}\text { After the First Meeting, the Committee advised the Director- } \\
\text { General that the recent cluster of microcephaly and other } \\
\text { neurologic disorders reported in Brazil should be called a PHEIC } \\
\text { (619). It was acknowledged that the relationship between these } \\
\text { disorders was suspected, but it had yet to be scientifically proven } \\
\text { (657), and the declaration would release more resources for R\&D. }\end{array}$ & 6 \\
\hline RESPONSE & $\begin{array}{l}\text { Time frame } \\
\text { after } \\
\text { notification }\end{array}$ & $\begin{array}{l}\text { The epistemic community } \\
\text { agreed that a fast response was } \\
\text { necessary, given the level of } \\
\text { uncertainty. This consensual } \\
\text { knowledge was transmitted to } \\
\text { the global level. }\end{array}$ & $\begin{array}{l}\text { The WHO launched the Global Zika Strategic Response } \\
\text { Framework and Joint Operations Plan, two weeks after the PHEIC } \\
\text { declaration. The EC advised that measures be immediately } \\
\text { implemented given the scarce evidence and necessity to gather } \\
\text { more information. }\end{array}$ & 4 \\
\hline $\begin{array}{c}\text { NO. OF } \\
\text { COUNTRIES }\end{array}$ & $\begin{array}{l}\text { Level of } \\
\text { participation }\end{array}$ & $\begin{array}{l}\text { The participation of these } \\
\text { actors also contributed to } \\
\text { increasing the epistemic } \\
\text { community's influence, given } \\
\text { that, through them, some } \\
\text { members of the group had } \\
\text { direct involvement in the } \\
\text { response (Chap. 8.4.2). }\end{array}$ & $\begin{array}{l}\text { According to the WHO at least } 60 \text { partners worked in the Zika } \\
\text { response (658) (including GOARN and the Partners for the Zika } \\
\text { response - a network of different organizations, governments, } \\
\text { universities, and NGOs). These partners took over different roles } \\
\text { and tasks in the response. }\end{array}$ & 4 \\
\hline
\end{tabular}

Table 60. Levels of cooperation in the international response to Zika outbreak 


\begin{tabular}{|c|c|c|c|c|}
\hline ACTIVITY & MEASURE & THE EPISTEMIC COMMUNITY & ZIKA & $\begin{array}{c}\text { LEVELS OF } \\
\text { COOPERATION }\end{array}$ \\
\hline \multicolumn{5}{|c|}{ II. International assistance } \\
\hline $\begin{array}{c}\text { TECHNICAL } \\
\text { A. }\end{array}$ & $\begin{array}{l}\text { Type of } \\
\text { participation in } \\
\text { international } \\
\text { missions. }\end{array}$ & $\begin{array}{l}\text { Members of the epistemic community } \\
\text { participated in some of these missions } \\
\text { directly or through the partner } \\
\text { organizations, which helped to socialize } \\
\text { their ideas and influence the process. }\end{array}$ & $\begin{array}{l}\text { By December 2016, the WHO/PAHO and } \\
\text { GOARN had deployed } 175 \text { experts on } 80 \text { separate } \\
\text { missions to } 30 \text { PAHO countries and territories. } \\
\text { PAHO organized } 22 \text { workshops at the regional } \\
\text { level (587). } \\
\text { In Africa, WHO/WHO Regional Office for Africa } \\
\text { deployed a multidisciplinary team to identify } \\
\text { operational gaps, support the country's response, } \\
\text { and help to finalize a national response plan (587). }\end{array}$ & 5 \\
\hline $\begin{array}{r}\text { FINANCIAL } \\
\text { ASSISTANCE }\end{array}$ & $\begin{array}{l}\text { The amount of } \\
\text { money provided } \\
\text { as financial } \\
\text { assistance to } \\
\text { address the } \\
\text { emergency }\end{array}$ & $\begin{array}{l}\text { Part of the funding was directed to increase } \\
\text { research, as a direct consequence of the } \\
\text { epistemic community recommendation to } \\
\text { produce more information about the virus } \\
\text { and the outbreak (policy goal). }\end{array}$ & $\begin{array}{l}\text { Immediately after the WHO declaration of Zika as } \\
\text { a PHEIC, countries started to provide funding to } \\
\text { assist different areas. }\end{array}$ & 4 \\
\hline TREATMENTS & $\begin{array}{l}\text { Type of } \\
\text { population getting } \\
\text { treatments }\end{array}$ & $\begin{array}{l}\text { The epistemic community had worked hard } \\
\text { to develop a vaccine in a short time, } \\
\text { disseminating its knowledge, and it has } \\
\text { contributed to improving research protocols } \\
\text { for vaccines at the WHO (635). }\end{array}$ & $\begin{array}{l}\text { The population had access to treatments, especially } \\
\text { in America. The vaccine is still not available (572), } \\
\text { and the candidates are currently under trials (659). }\end{array}$ & 3 \\
\hline \multirow[t]{2}{*}{ PROVISION } & $\begin{array}{l}\text { 1. How fast was } \\
\text { the deployment of } \\
\text { assistance once } \\
\text { the outbreak } \\
\text { started }\end{array}$ & $\begin{array}{l}\text { In Brazil, national experts collaborated } \\
\text { since the beginning with international } \\
\text { specialists and authorities through the } \\
\text { organizations and the epistemic community } \\
\text { (639). }\end{array}$ & $\begin{array}{l}\text { The WHO, through its regional office, mobilized } \\
\text { and deployed assistance to different countries. The } \\
\text { Regional Office of the Americas, PAHO, deployed } \\
\text { experts with the support of GOARN to assist Brazil } \\
\text { and other countries with outbreaks. }\end{array}$ & 6 \\
\hline & $\begin{array}{l}\text { 2.Medical } \\
\text { supplies and } \\
\text { materials }\end{array}$ & $\begin{array}{l}\text { There is no specific information about the } \\
\text { epistemic community participating in this } \\
\text { activity. }\end{array}$ & $\begin{array}{l}\text { Some of the international assistance also provided } \\
\text { medical supplies. PAHO provided material to } \\
\text { improve the detection of the virus in laboratories, } \\
\text { and it has built strategic warehouses in the } \\
\text { Bahamas to supply material to Caribbean countries } \\
(587) \text {. }\end{array}$ & 6 \\
\hline
\end{tabular}

Table 60. Levels of cooperation in the international response to the Zika outbreak (cont.) 


\begin{tabular}{|c|c|c|c|c|}
\hline ACTIVITY & MEASURE & $\begin{array}{l}\text { THE EPISTEMIC } \\
\text { COMMUNITY }\end{array}$ & ZIKA & $\begin{array}{l}\text { LEVELS OF } \\
\text { COOPERATION }\end{array}$ \\
\hline \multicolumn{5}{|c|}{ III. Scientific response } \\
\hline SAMPLES & $\begin{array}{l}\text { If countries have } \\
\text { shared virus } \\
\text { samples }\end{array}$ & $\begin{array}{l}\text { Members of the epistemic community } \\
\text { have insisted on the importance of } \\
\text { sharing data and research to speed up } \\
\text { this process and disseminate } \\
\text { information. They have been working on } \\
\text { the development of a vaccine (595). }\end{array}$ & $\begin{array}{l}\text { Given the importance placed on the development of a vaccine, } \\
\text { virus samples have been widely shared (659). }\end{array}$ & 4 \\
\hline \multirow[t]{2}{*}{ R\&D } & $\begin{array}{l}\text { 1.If data is } \\
\text { disseminated on } \\
\text { time }\end{array}$ & $\begin{array}{l}\text { The epistemic community has been } \\
\text { actively involved in this area since the } \\
\text { beginning, and it continues working to } \\
\text { produce information and scientific } \\
\text { evidence (660), including its } \\
\text { participation in the WHO Consultation } \\
\text { of 2016 about research on the Zika virus } \\
\text { (661). }\end{array}$ & $\begin{array}{l}\text { The WHO had played a significant role in ensuring that data and } \\
\text { information are disseminated on time to the public in general as } \\
\text { well to the people doing research, policymakers, doctors, etc. } \\
\text { The WHO also established in October } 2015 \text { the Zika Virus } \\
\text { Research Agenda to support the generation of evidence and } \\
\text { research to implement strategies (587,635). Zika is one of the } \\
\text { priority diseases in the new WHO Research and Development } \\
\text { Blueprint (398). }\end{array}$ & 4 \\
\hline & $\begin{array}{l}\text { 2.Phases of the } \\
\text { research during } \\
\text { the outbreak }\end{array}$ & $\begin{array}{l}\text { The epistemic community is } \\
\text { continuously producing research and } \\
\text { socializing its ideas through its } \\
\text { member's participation in the } \\
\text { internationalfora where these issues are } \\
\text { discussed. }\end{array}$ & $\begin{array}{l}\text { Research is ongoing, and WHO has led the research agenda by } \\
\text { publishing about } 20 \text { documents on topics related to the control } \\
\text { and management of the disease }(587) \text {. There are still many } \\
\text { aspects that are unknown and in the early stages of research. The } \\
\text { WHO has made clear that a vaccine would be developed in the } \\
\text { long term }(572,641) \text {. }\end{array}$ & 4 \\
\hline \multicolumn{5}{|l|}{ IV. Policy adoption } \\
\hline SURVEILLANCE & $\begin{array}{l}\text { If countries } \\
\text { implemented } \\
\text { systems to } \\
\text { allowed constant } \\
\text { notification of } \\
\text { possible cases }\end{array}$ & $\begin{array}{l}\text { Since some of the members of the } \\
\text { epistemic community are part of } \\
\text { governments and work directly in areas } \\
\text { in charge of epidemiology and } \\
\text { surveillance, the epistemic community } \\
\text { has reached an exceptional level of } \\
\text { institutionalization of its bureaucratic } \\
\text { power, and this helped to increase the } \\
\text { awareness in their own countries. }\end{array}$ & $\begin{array}{l}\text { In general, countries have complied with IHRs and the WHO, } \\
\text { continuously reporting cases, and reinforcing their surveillance } \\
\text { system (594). }\end{array}$ & 5 \\
\hline NOTIFICATION & $\begin{array}{l}\text { How long did } \\
\text { countries wait to } \\
\text { notify the WHO } \\
\text { after identifying } \\
\text { the cases? }\end{array}$ & $\begin{array}{l}\text { Since there was no Zika epistemic } \\
\text { community at that moment, experts from } \\
\text { other areas were involved in the } \\
\text { diagnoses and analyses of the virus. }\end{array}$ & $\begin{array}{l}\text { The Zika virus was detected in the Americas for the first time in } \\
\text { 2014. The virus was isolated in Brazil in late March } 2015 \text {. In } \\
\text { October 2015, the Brazilian Ministry of Health notified the } \\
\text { WHO about the occurrence of the increased number of infant } \\
\text { microcephaly on October } 23,2015 \text { (583). }\end{array}$ & 5 \\
\hline
\end{tabular}




\begin{tabular}{|c|c|c|c|c|}
\hline ACTIVITY & MEASURE & $\begin{array}{l}\text { THE EPISTEMIC } \\
\text { COMMUNITY }\end{array}$ & ZIKA & $\begin{array}{c}\text { LEVELS OF } \\
\text { COOPERATION }\end{array}$ \\
\hline \multicolumn{5}{|l|}{ IV. Policy adoption } \\
\hline \multirow[t]{2}{*}{$\begin{array}{c}\text { POLICY } \\
\text { CONVERGENCE }\end{array}$} & $\begin{array}{l}\text { How broad were the } \\
\text { recommendations } \\
\text { adopted and } \\
\text { implemented? }\end{array}$ & $\begin{array}{l}\text { The recommendations } \\
\text { regarding specific measures to } \\
\text { be adopted in countries with } \\
\text { outbreaks have been broadly } \\
\text { accepted and, similarly, other } \\
\text { countries followed measures } \\
\text { suggested by the WHO } \\
(662,648) \text {. The power gained } \\
\text { by the epistemic community } \\
\text { helped to influence this. }\end{array}$ & $\begin{array}{l}\text { Since the beginning, the WHO announced } \\
\text { its adherence to scientific evidence, and the } \\
\text { Plan reflected the importance of that and the } \\
\text { integration of experts as an essential } \\
\text { component for the response. }\end{array}$ & 5 \\
\hline & $\begin{array}{l}\text { The degree of adoption } \\
\text { of international norms. }\end{array}$ & $\begin{array}{l}\text { Most of the domestic and } \\
\text { international responses were } \\
\text { guided by scientific evidence } \\
\text { and the epistemic community } \\
\text { advice. }\end{array}$ & $\begin{array}{l}\text { There has been a general acceptance of the } \\
\text { measures proposed by the WHO, and most } \\
\text { countries have complied and adopted the } \\
\text { measures suggested (662). }\end{array}$ & 4 \\
\hline
\end{tabular}

Table 60. Levels of cooperation in the international response to the Zika outbreak (cont.). 
The analysis of the level of cooperation in the international response to the Zika virus permits establishing a measure of the level of cooperation. In general, this cooperation can be described as medium/high. It is also possible to identify the participation of an epistemic community in most parts of the process.

\subsection{Influence of an epistemic community in the level of cooperation.}

The case of Zika displays a medium/high level of cooperation. Although there may have been other factors influencing this level of cooperation, this research found evidence of an epistemic community that contributed to increased cooperation to make this response a successful one. The epistemic community originated from the network of professionals working in vector control. The Zika epistemic community formed during the outbreak; however, the members of the group had worked together for years with vector-borne diseases, and they were able to transfer that knowledge to respond to Zika. The community's members knew each other and had previously developed connections within and outside the network. Although their interactions in the past were not related to Zika, they were connected and interrelated by their expertise and work in the broad field of vector control. They used their connections to socialize the epistemic community's ideas, disseminate its knowledge, and reach policymakers.

The community had limited knowledge about the virus and its health effects as well as a less clear policy goal regarding the disease. This group of people, however, agreed on the importance of the initial evidence, and the probable link between the Zika virus and neurological syndromes. They were convinced that the possibility of such a relationship required maximizing international efforts to promote more research to be able to control the outbreak. Their arguments were fundamental to convincing the WHO and its member states 
to start a coordinated response.

The Zika epistemic community structure was centralized in the WHO as part of the general vector control strategy. The WHO regional offices, however, worked as a hub not only for supporting the work of WHO in the region but also for the epistemic community, facilitating its participation in the Americas. The epistemic community's work was aligned with the policy process, which enabled the integration of its advice and policy recommendations to the international response.

The exchange of information and the promotion of research activities helped to speed up the identification of cases and take preventive measures. Increasing research for understanding the disease and developing treatments and vaccines became the central component of the outbreak's international response. The epistemic worked to produce information to fill the gaps in R\&D necessary for the international response.

The Zika outbreak brought international attention to an area neglected by policymakers and researchers. Therefore, it renewed the global interest in diseases that are transmitted by vectors, and given current globalization phenomena (climate change, urbanization, conflict), these diseases are increasing their threat level worldwide. The Zika epistemic community influenced cooperation. It provided information and knowledge (and it continues to do so) related to the virus and the conditions associated with it. It was able to create coherence with the policy system and influence the policy process. 


\section{Chapter 9: Conclusions}

Scholars have previously explored the relevance of epistemic communities' characteristics in influencing international cooperation. This research broadens the understanding of how these actors can affect variation in the level of cooperation, introducing a theoretical framework consistent with Haas' approach. The proposed model centred in those characteristics that these actors possess to modify the international policymaking process, given that epistemic communities are embedded in the system of global health governance.

This research applied the theoretical framework to analyse the international response to four recent infectious disease outbreaks. The international response to disease outbreaks requires a mix of elements to make this a successful activity. The response, however, does not always achieve an optimal level of cooperation. To establish variation across cases, the study designed a model, conceptualizing cooperation as a spectrum divided into six levels.

The present chapter summarizes the findings of the four cases and explains how epistemic communities contribute to different levels of international cooperation in each one of the international responses. Then, it will analyse if the evidence is consistent with the proposed theoretical framework. Finally, it will explain the implications of this study and its relevance.

\subsection{Comparison of the international response among the four cases}

With the instrument designed to analyse cooperation (chapters 3 and 4), the study examined the components of the international responses selected for this research. The data obtained from each case made it possible to compare the level of cooperation. Table 61 presents the assessment on the level of cooperation in the international response across cases. 


\begin{tabular}{|c|c|c|c|c|}
\hline \multirow[t]{2}{*}{ MEASURE } & \multicolumn{4}{|c|}{ OUTBREAK- INTERNATIONAL RESPONSE } \\
\hline & H1N1 2009 & MERS 2012 & Ebola 2014 & ZIKA 2015 \\
\hline \multicolumn{5}{|c|}{ I.INTERNATIONAL PARTICIPATION } \\
\hline PROBLEM 1 & 6 & 3 & 0 & 5 \\
\hline PROBLEM 2 & 6 & 3 & 2 & 6 \\
\hline RESPONSE & 6 & 2 & 1 & 4 \\
\hline NO. OF COUNTRIES & 6 & 1 & 5 & 4 \\
\hline \multicolumn{5}{|c|}{ II.INTERNATIONAL ASSISTANCE } \\
\hline TECHNICAL ASSISTANCE & 6 & 2 & 4 & 5 \\
\hline FINANCIAL ASSISTANCE & 6 & 0 & 5 & 4 \\
\hline TREATMENTS & 3 & 2 & 0 & 3 \\
\hline PROVISION 1 & 6 & 2 & 1 & 6 \\
\hline PROVISION 2 & 6 & 2 & 2 & 6 \\
\hline \multicolumn{5}{|c|}{ III.SCIENTIFIC RESPONSE } \\
\hline SAMPLES & 6 & 1 & 3 & 4 \\
\hline R\&D 1 & 6 & 2 & 3 & 4 \\
\hline R\&D 2 & 6 & 3 & 4 & 4 \\
\hline \multicolumn{5}{|c|}{ IV. POLICY CONVERGENCE } \\
\hline SURVEILLANCE & 6 & 3 & 2 & 5 \\
\hline NOTIFICATION & 6 & 4 & 4 & 5 \\
\hline POLICY CONVERGENCE 1 & 2 & 4 & 2 & 5 \\
\hline POLICY CONVERGENCE 2 & 4 & 4 & 4 & 4 \\
\hline
\end{tabular}

Table 61. Comparison levels of cooperation in the international response to four disease outbreaks.

After measuring the aggregate level of cooperation, the results exhibit the presence of different levels for each case. Table 62 presents an aggregate measure of cooperation for each case.

\begin{tabular}{|c|c|}
\hline OUTBREAK & $\begin{array}{c}\text { AVERAGE LEVEL OF } \\
\text { COOPERATION }\end{array}$ \\
\hline A(H1N1) Influenza & 5.43 \\
\hline MERS & 2.37 \\
\hline EBOLA & 2.62 \\
\hline ZIKA & 4.62 \\
\hline
\end{tabular}

Table 62. The aggregate level of international cooperation in the response to four disease outbreaks.

For the purpose of comparison, this research provides similar weights for all elements of the response. Due to this, the level of cooperation assigned to the Ebola case is in a 
medium-low range, since the model took into consideration the actions undertaken by the international community after the outbreak had spun out of control.

\subsection{Epistemic communities' characteristics and their effects in variation in}

\section{international cooperation}

To analyse the presence of variation across the four cases, my model of epistemic communities measured three main characteristics of an epistemic community -knowledge, socialization of ideas, and institutionalization of bureaucratic power. In the four cases, the study established the existence of an epistemic community, and all of them displayed the characteristics described in chapter 4 . However, measuring these characteristics, the study found evidence that these varied across cases. Table 63 summarizes these conclusions.

\begin{tabular}{|c|c|c|c|c|c|}
\hline & Indicator & Influenza & MERS & Ebola & Zika \\
\hline \multirow[b]{2}{*}{ Knowledge } & $\begin{array}{l}\text { Agreement on } \\
\text { a common } \\
\text { definition of } \\
\text { the problem } \\
\text { and possible } \\
\text { solutions }\end{array}$ & $\begin{array}{l}\text { Explicit } \\
\text { agreement } \\
\text { and } \\
\text { consensual } \\
\text { knowledge } \\
\text { about the } \\
\text { issue and } \\
\text { solutions. }\end{array}$ & $\begin{array}{l}\text { Some } \\
\text { disagreements } \\
\text { about the } \\
\text { pandemic } \\
\text { potential. }\end{array}$ & $\begin{array}{l}\text { Partial } \\
\text { consensual } \\
\text { knowledge } \\
\text { about the } \\
\text { characteristics } \\
\text { of the outbreaks } \\
\text { - with } \\
\text { disagreements } \\
\text { about the level } \\
\text { of severity. }\end{array}$ & $\begin{array}{l}\text { Consensual } \\
\text { knowledge about } \\
\text { the potential risk } \\
\text { of the virus and } \\
\text { the need to } \\
\text { implement quick } \\
\text { actions. }\end{array}$ \\
\hline & $\begin{array}{l}\text { Clear } \\
\text { identification } \\
\text { of a common } \\
\text { policy goal }\end{array}$ & $\begin{array}{l}\text { The } \\
\text { common } \\
\text { goal has } \\
\text { been for a } \\
\text { long time to } \\
\text { control and } \\
\text { contain the } \\
\text { spread of the } \\
\text { influenza } \\
\text { virus in a } \\
\text { short period. }\end{array}$ & $\begin{array}{l}\text { The common } \\
\text { goal was } \\
\text { established } \\
\text { later in the } \\
\text { outbreak. }\end{array}$ & $\begin{array}{l}\text { The policy goal } \\
\text { was reached } \\
\text { when the } \\
\text { outbreak had } \\
\text { not been } \\
\text { declared a } \\
\text { PHEIC. }\end{array}$ & $\begin{array}{l}\text { The policy goal } \\
\text { regarding the } \\
\text { importance of } \\
\text { vector control was } \\
\text { assumed as the } \\
\text { policy goal for } \\
\text { Zika epistemic } \\
\text { community }\end{array}$ \\
\hline
\end{tabular}

Table 63. Characteristics epistemic communities across cases. 


\begin{tabular}{|c|c|c|c|c|c|}
\hline & Indicator & Influenza & MERS & Ebola & Zika \\
\hline \multirow{3}{*}{$\begin{array}{l}\text { Socialization } \\
\text { of ideas }\end{array}$} & Structure & $\begin{array}{l}\text { Network } \\
\text { structure } \\
\text { with } \\
\text { different } \\
\text { nodes, and } \\
\text { the WHO as } \\
\text { an essential } \\
\text { participant. } \\
\text { Subnetworks } \\
\text { also } \\
\text { facilitated } \\
\text { the } \\
\text { transmission } \\
\text { of } \\
\text { information. }\end{array}$ & $\begin{array}{l}\text { Small } \\
\text { epistemic } \\
\text { community, its } \\
\text { members, are } \\
\text { mostly found } \\
\text { in Middle East } \\
\text { countries and } \\
\text { in places that } \\
\text { have research } \\
\text { capabilities } \\
\text { like the USA, } \\
\text { Canada, and } \\
\text { Australia. }\end{array}$ & $\begin{array}{l}\text { Network } \\
\text { depended highly } \\
\text { on the WHO's } \\
\text { information. It } \\
\text { was small with } \\
\text { some } \\
\text { international } \\
\text { participation but } \\
\text { mostly from } \\
\text { developed } \\
\text { countries. }\end{array}$ & $\begin{array}{l}\text { The WHO was the } \\
\text { central node. } \\
\text { PAHO is a node } \\
\text { for the Americas, } \\
\text { and the other } \\
\text { regional offices } \\
\text { also act as nodes. } \\
\text { Membership is } \\
\text { broad and } \\
\text { worldwide. }\end{array}$ \\
\hline & $\begin{array}{l}\text { Dissemination } \\
\text { mechanisms }\end{array}$ & $\begin{array}{l}\text { Use of } \\
\text { multiple } \\
\text { mechanisms } \\
\text { to } \\
\text { disseminate } \\
\text { their } \\
\text { knowledge } \\
\text { through } \\
\text { scientific } \\
\text { publications, } \\
\text { experts' } \\
\text { conferences, } \\
\text { and directly } \\
\text { in meetings } \\
\text { with } \\
\text { decision- } \\
\text { makers. }\end{array}$ & $\begin{array}{l}\text { Limited use of } \\
\text { mechanisms, } \\
\text { fewer studies } \\
\text { available, } \\
\text { mostly at the } \\
\text { regional level. } \\
\text { There were } \\
\text { also problems } \\
\text { with access to } \\
\text { data and } \\
\text { withholding of } \\
\text { information }\end{array}$ & $\begin{array}{l}\text { Limited research } \\
\text { disseminated } \\
\text { throughout a few } \\
\text { publications. } \\
\text { Before the } \\
\text { outbreak, a few } \\
\text { studies were } \\
\text { available. } \\
\text { During the } \\
\text { outbreak, } \\
\text { research } \\
\text { increased. }\end{array}$ & $\begin{array}{l}\text { Dissemination of } \\
\text { scientific research } \\
\text { has been critical } \\
\text { for the response } \\
\text { and one of the } \\
\text { main goals. The } \\
\text { epistemic } \\
\text { community has } \\
\text { tried to increase } \\
\text { R\&D to establish } \\
\text { control measures. }\end{array}$ \\
\hline & $\begin{array}{l}\text { Participation } \\
\text { in the } \\
\text { international } \\
\text { response }\end{array}$ & $\begin{array}{l}\text { Broad } \\
\text { involvement } \\
\text { of epistemic } \\
\text { community's } \\
\text { members in } \\
\text { international } \\
\text { organization } \\
\text { s and } \\
\text { governments } \\
\text { including } \\
\text { GOARN. } \\
\end{array}$ & $\begin{array}{l}\text { Participation } \\
\text { of the } \\
\text { community } \\
\text { has been } \\
\text { through the } \\
\text { WHO- } \\
\text { GOARN }\end{array}$ & $\begin{array}{l}\text { Participation in } \\
\text { the international } \\
\text { response mainly } \\
\text { through } \\
\text { GOARN. }\end{array}$ & $\begin{array}{l}\text { Participation of } \\
\text { many members of } \\
\text { the Epistemic } \\
\text { Community as } \\
\text { experts and } \\
\text { advisors. }\end{array}$ \\
\hline
\end{tabular}

Table 63. Characteristics epistemic communities across cases (cont.) 


\begin{tabular}{|c|c|c|c|c|c|}
\hline & Indicator & Influenza & MERS & Ebola & Zika \\
\hline \multirow[t]{2}{*}{$\begin{array}{l}\text { Institutionalization } \\
\text { bureaucratic power }\end{array}$} & $\begin{array}{l}\text { Participation } \\
\text { in the policy } \\
\text { process. }\end{array}$ & $\begin{array}{l}\text { Members of } \\
\text { the epistemic } \\
\text { community } \\
\text { were the main } \\
\text { participants in } \\
\text { multiple } \\
\text { conferences } \\
\text { and experts' } \\
\text { groups } \\
\text { organized to } \\
\text { guide the } \\
\text { international } \\
\text { response. }\end{array}$ & $\begin{array}{l}\text { There was a } \\
\text { small } \\
\text { number of } \\
\text { international } \\
\text { conferences } \\
\text { devoted to } \\
\text { MERS-CoV, } \\
\text { although the } \\
\text { community } \\
\text { was } \\
\text { continually } \\
\text { participating } \\
\text {. }\end{array}$ & $\begin{array}{l}\text { After the } \\
\text { PHEIC } \\
\text { declaration, } \\
\text { members of } \\
\text { the } \\
\text { epistemic } \\
\text { community } \\
\text { participated } \\
\text { in the } \\
\text { WHO's } \\
\text { technical } \\
\text { and } \\
\text { scientific } \\
\text { groups. }\end{array}$ & $\begin{array}{l}\text { The WHO and } \\
\text { other international } \\
\text { organizations } \\
\text { formed multiple } \\
\text { expert groups for } \\
\text { increasing } \\
\text { analysis and } \\
\text { generating } \\
\text { evidence. }\end{array}$ \\
\hline & $\begin{array}{l}\text { Experts and } \\
\text { other } \\
\text { professionals } \\
\text { from the } \\
\text { epistemic } \\
\text { community } \\
\text { in decision- } \\
\text { making } \\
\text { positions }\end{array}$ & $\begin{array}{l}\text { The epistemic } \\
\text { community } \\
\text { had many } \\
\text { members in } \\
\text { crucial } \\
\text { positions, and } \\
\text { they were } \\
\text { central actors } \\
\text { in the } \\
\text { Emergency } \\
\text { Committee. }\end{array}$ & $\begin{array}{l}\text { The } \\
\text { participation } \\
\text { was mainly } \\
\text { through the } \\
\text { Emergency } \\
\text { Committee. }\end{array}$ & $\begin{array}{l}\text { The } \\
\text { epistemic } \\
\text { community } \\
\text { participated } \\
\text { through the } \\
\text { Emergency } \\
\text { Committee } \\
\text { and as an } \\
\text { advisory } \\
\text { group to the } \\
\text { WHO. }\end{array}$ & $\begin{array}{l}\text { Experts } \\
\text { participated in the } \\
\text { Emergency } \\
\text { Committee. Some } \\
\text { policy } \\
\text { entrepreneurs in } \\
\text { crucial positions } \\
\text { also helped to } \\
\text { advance the } \\
\text { epistemic } \\
\text { community's } \\
\text { ideas. }\end{array}$ \\
\hline
\end{tabular}

Table 63. Characteristics epistemic communities across cases (cont.)

These characteristics suggest that the influenza pandemic epistemic community is a well-established community. Its members have worked together for decades, increasing the network's connections over time, expanded its roles, and improving the transmission of information inside and outside the network. The evolution and growing importance of the topic of influenza over time has attracted more members to the community, increasing the number of experts working in the subject, and participating directly in the decision-making process. The strategic interest in the influenza pandemic has also promoted the emergence of regional and sub-regional networks in the field. These networks work together and create synergies with the WHO but do not depend on the organization to connect and collaborate. The WHO, however, remains as the coordinator in the process of influenza pandemic governance. 
The influenza epistemic community's consensual knowledge guided most of the medical and non-medical interventions throughout a structure that facilitated the exchange of information among its members. The network's interactions have also increased over time, creating trust and more personal relationships, improving its members' understanding of the problem, and their willingness to work together to find solutions. The influenza epistemic community is embedded in the system of influenza governance; as such, its members have prominent positions in the policy-making process that have helped them to institutionalize its bureaucratic power. These characteristics made it possible for the network to have a central role in the international response to the influenza outbreak of 2009. Its members participated in policymaking positions facilitating their governments' involvement in the response and influencing the level of cooperation by assuming a central role in the implementation of actions and decisions. Therefore, the influenza epistemic community was a powerful actor in the response to pandemic influenza.

The influenza epistemic community has been vital in the creation, implementation, and translation of norms at the national and international levels. Their expertise and technical understanding of the problem, their research, and the analysis of influenza viruses and past outbreaks have been essential for the building of an international system of influenza governance. The epistemic community has improved the system by supporting actions to strengthen it.

In contrast, the Ebola epistemic community included professionals that had worked together for years, but the community remained as a small group, linked mainly through the WHO. The Ebola epistemic community members were less directly involved in policymaking and dependent on the WHO's information. During the pandemic outbreak in 
West Africa, the epistemic community had problems participating in the response, given its limited access to other actors outside the WHO. There were disagreements among its members, notable with experts from MSF, that weakened the epistemic community's influence. Before the outbreak, the epistemic community's members were mostly located at the global level, with no participants at the local or regional levels. The lack of connections and participation at these levels provided fewer opportunities to diffuse the epistemic community's ideas and limited the access of domestic health workers to international experts' advice. The epistemic community increased its membership and improved its connections after the outbreak spun out of control, and the international community had to implement urgent measures. In this stage, the Ebola epistemic community strengthened its position, improving its connections with other actors- such as NGOs- and actively participated in the international mobilization. The epistemic community increased its influence power at the end of the outbreak, but it did not necessarily influence more cooperation.

In the Ebola case, the level of international cooperation in the second stage was mostly a consequence of an urgent need to manage a situation that was already out of control and the fears of having more cases outside West Africa. This prompted the implementation of different actions aiming to contain the virus in the region and to avoid more exported cases. The epistemic community's influence on the level of cooperation was, therefore, marginal since it could not intervene earlier in the outbreak. It neither helped to reduce the number of deaths early in the epidemic nor contributed to halting the transmission sooner. At the end of the epidemic, the level of cooperation increased as a result of the international deployment led by the UN. Finally, the late intervention had to go beyond treating the situation as a global health issue, requiring the mobilization of humanitarian and military 
actors to control the events.

The Ebola epistemic community has had a lower success in influencing a stronger system to address Ebola outbreaks. The risk created by recent outbreaks, however, has increased awareness and interest in the disease.

In the case of MERS-CoV, the epistemic community participating in the response was relatively young. Members of the coronaviruses epistemic community merged into this community early in the outbreak. The network was small, with fewer interactions and reduced connectivity. As a community, it was unable to create an initial consensus. Instead, it provided contradictory arguments about the risk associated with the disease. Problems with access to data, competition, and lack of trust among its members impacted its organization. This epistemic community's capacity to influence and be part of the policymaking process was then affected by its problems to produce comprehensible and consensual technical and scientific arguments strong enough to convince others. It was a small structure, with a few members and confined participation in the field. The epistemic community was also centralized in the Arab peninsula, and a lot of its work was affected by political interference. Its involvement in response to the outbreak was overshadowed by other circumstances that effected its influence in the level of cooperation. The MERS epistemic community has gained influenced in the Middle East, but its participation has not had a significant impact on international cooperation to address this type of disease.

In contrast, the Zika epistemic community was able to influence and guide the response to the outbreak, even with the limited knowledge about the disease, its potential complications, and transmission mechanisms. This network found a great demand for its advice and information from the beginning of the outbreak. The epistemic community, 
however, early in the outbreak, established a consensus about the potential risk of the disease. Its arguments were strong enough to prompt an international response. The network was more technically and scientifically oriented, with broad experience in diseases transmitted by vectors. This helped it out to quickly produce the scientific evidence required for policymaking in the Zika outbreak. The epistemic community's advice was translated promptly into international actions that were accepted by the international community, leading to a high level of cooperation.

The Zika epistemic community originated from the Vector Control epistemic community, which showed an exceptional level of flexibility to adapt its expertise and its influence to prompt an international response. The Zika epistemic community was able to build strong and coherent arguments, showing a high level of cohesiveness and an explicit internal consensus. Even though Zika's outbreak brought a new and challenging scenario, the epistemic community was able to translate and adapt existing policies, norms, and agreements to address the situation and convince the international community to act.

These cases showed consistent results, even when all the outbreaks originated from diseases that had pandemic potential, and the same norms and institutions were implemented to manage them, the epistemic communities showed heterogeneity. Figure 29 illustrates this relationship. 


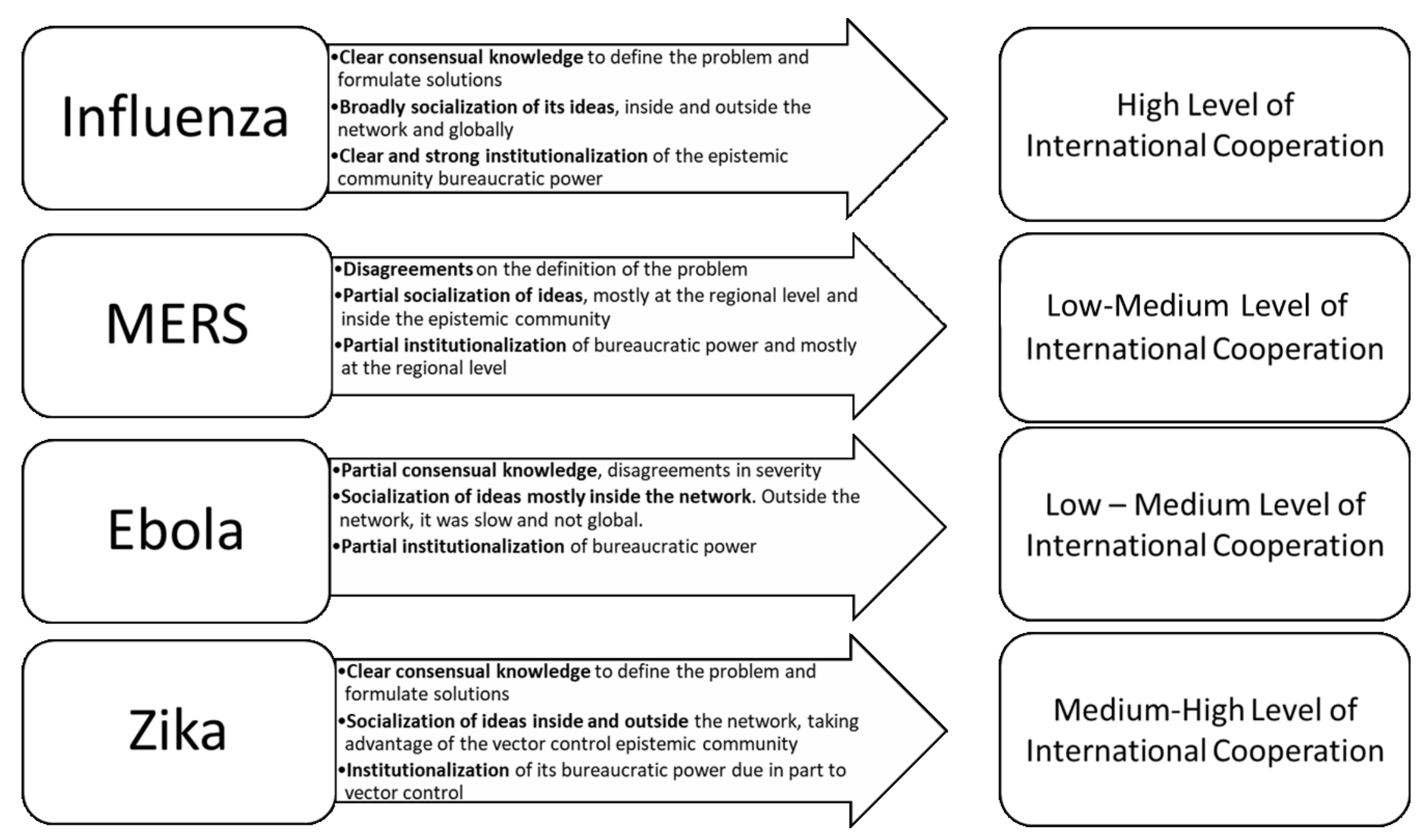

Figure 29. Relationship epistemic communities and the level of international cooperation for each case. 
Epistemic communities influenced a high level of cooperation when there was a proven consensual knowledge and policy goal. They socialized their ideas inside and outside their networks to reach policymakers and institutionalized their bureaucratic power. Epistemic communities with problems to achieve consensus in the risk level of the outbreak, with less ability to influence and limited access to the policy process, were less successful in inducing higher levels of cooperation. Each one had different capacities, causing an unequal impact on the level of cooperation in each outbreak.

\subsection{The WHO and epistemic communities in global health}

In the field of infectious diseases, an on-time, well-coordinated, international response to a disease outbreak with high levels of cooperation becomes crucial to reduce the negative impact of a sudden epidemic that can quickly spread out of control. The experience with the SARS in 2003 was a clear example of the importance of international cooperation in the control of emerging and re-emerging diseases. It reinforced the importance of establishing and following measures that are provided in an open and transparent environment, based on science and clear evidence rather than on fear and secrecy. With that in mind, governments have trusted the WHO as the global leader to produce policies based on scientific evidence, and all actors in the international system usually agree to implement them. As such, more professionals participate in the WHO's decision-making process, taking advantage of new technologies for sharing data, and connecting across the world (593). The WHO, however, has a dual role. It can be the enabler and promoter of epistemic communities' participation in the policymaking process, but it also protects countries' national interests, which can limit the epistemic communities' strength.

There are different reasons why this occurs. For instance, epistemic communities in 
global health, as networks, are embedded in international organizations and governments. Global epistemic communities related to infectious diseases are mainly connected through the WHO (Interviews 1, 2, 6, 12). This entity usually coordinates and organizes activities and interventions by the network. When the epistemic community depends highly on the WHO, it can weaken its capacity to improve cooperation; whereas when the epistemic community has connections at different levels, and its relationship and coherence with the policy process depends less on the WHO, it can reach other actors (Interview 6). The WHO also works for nation-states, and it represents their interests, and it responds to their demands. It must guarantee that its resources are used following these actors' interests.

Even though it is in the best interest of this organization to have access to the best and most updated specialized advice and provide evidence-based policies, it tends to rely on a group of experts from specific institutions. These experts frequently are the same people forming epistemic communities, and they rely on the WHO to have access to the system of global governance and other experts. Because of the WHO's predisposition to consult a specific group of institutions, it frequently leaves out others who can contribute to the system of governance and enhance the epistemic community's position and connectivity (Interview 1,2). This problem was evident in the Ebola response. Dr. Matshidiso Moeti, the WHO Regional Director for Africa, pointed out that the WHO “needed to improve our (the WHO's) internal capacity and we (the WHO) need to mobilize regional and global expertise from other institutions or individuals who know WHO's tools and can be deployed rapidly when the need arises (549)".

The failure in the Ebola response, however, might have changed the paradigm in the international response to infectious diseases. One aspect that this disease brought to the light 
is the changing nature of infectious diseases, their patterns of adaptation, and the real impact of globalization, interconnections, and international travel. A well-known disease whose experts can recognize and treat due to what they know about it, suddenly changes because of the human interactions, modifying its transmission patterns. This was also the case with Zika. Therefore, Ebola opened a discussion about how to create a system that can respond and adapt to these changes (interview 12).

As part of this debate, there is an increasing concern for more integration of the local level to the international level. The influenza pandemic epistemic community has moved towards this since professionals all around the world are connected to the system of influenza governance due to the scope of the network. The disconnection between the national-local levels and the international levels required the integration of more experts to these networks and the creation of subnetworks that can effectively communicate during outbreaks. One of the experts interviewed suggested that the first way to do this is through the education of family doctors and using technology to connect them (Interview 12). It is also important to make global health policy accessible to local actors without having to depend on national governments exclusively.

\subsubsection{The system of pandemic governance and politics}

Another important consideration is the interference of politics in the response to pandemics. Global health has increased its political profile. The WHO was created to hold technical and political negotiations (663), combining technical experts and decision-makers. There has been an effort to depoliticize the WHO, but the efforts have not been successful (663). In pandemic outbreaks, however, decisions should be guided by sound scientific knowledge and technical advice from professionals with expert knowledge, so "it is 
important that political authorities at the highest level understand obligations and commitments that they have made when adopting the International Health Regulations (549)'”.

Political support is necessary to access information and share it with professionals. The WHO has as a disadvantage, however, that many times, governments appeal to national sovereignty to limit cooperation and intervention from international organizations (98). In this regard, Laud Boateng, District Director of Health Services in Ghana, mentioned: “only what gets political support gets measured (98)". This was also stated by the Review Committee on the Role of the IHRs 2005 in the Ebola Outbreak Response, which mentions in its report that "Lack of political and government authority can lead to delays in information-sharing, notification and other reporting (...)" (127).

The influenza epistemic community has been one of the few able to downplay this problem. In some cases, the influenza experts seem to be highly involved in global health politics (as an example is the PIP negotiation, which was highly political and where the epistemic community was vital for the result $\left.{ }^{66}\right)$. This has facilitated to move forward the epistemic community's agenda and increased its influence, but it has also made it less flexible even when its resources and position have the potential to improve the system of governance for infectious diseases. This aspect, however, needs to be explored further.

Therefore, epistemic communities' influence in the level of international cooperation can be constrained by contextual and systemic factors, the traditional role of the WHO, the

\footnotetext{
${ }^{66}$ The PIP's outcome is considered a success given that it reached an agreement for a potential mechanism that transfers benefits to countries where influenza samples originated. Nonetheless, some scholars questioned if this agreement will actually work during an emergency $(99,722)$
} 
system of global governance, and the politics within the WHO and among its member states.

\subsection{The relevance of the study and policy implications}

The results presented in this study uncovered factors that are relevant to the study of international cooperation and epistemic communities. In this regard, this research:

1. Provided an analysis of the characteristics of epistemic communities. These characteristics have been previously discussed in the literature, but most of the time, they are identified as fixed features. This research, however, identified that the characteristics making an epistemic community capable of influencing a policy process vary across them.

2. Presented a model to measure epistemic communities. Having an instrument with qualitative indicators improves the analysis of an epistemic community. With this model, the research was able to categorize each of the four epistemic communities analyzed and to compare them.

3. Provides a precise analysis of the relationship between the epistemic community and changes in policy outcomes. The model that qualifies and measures an epistemic community's characteristics provides a feasible instrument to understand this link better and allows a more in-depth analysis of how these networks can modify policy outcomes and to what extent they can do it.

4. Provides new clues of how non-state actors can influence policymaking and modify outcomes at the international level. In this case, the study of epistemic communities emphasizes that these networks are embedded in the system of global health governance. Therefore, they have access to the process and opportunity to influence it and, potentially, to change it. 
5. Does not imply that epistemic communities by themselves can entirely change international cooperation. The findings, however, show that some epistemic communities can potentially improve cooperation.

6. Recognizes the potential that some epistemic communities have and provides a framework to continue studying these actors.

7. Demonstrates the potential of studying international cooperation as a spectrum. The categorization of cooperation at different levels increases the potential to analyse how to improve cooperation, not merely facilitate it.

These elements are essential considerations to continue the study of epistemic communities and international cooperation. At the policy level, information derived from this analysis could potentially be applied to changing the system of global health governance.

For instance, the current system of global health governance has the WHO as its centre. This organization has continuously worked as a technical actor trying to build international consensus in global health policy. The WHO, however, is having a crisis in governance, given the increasing number of global health problems that require the organization's active involvement while it is going through a financial crisis, and its resources are declining. Along with this, the WHO is facing a dilemma concerning its role in global health. This problem is particularly noticeable in the international response to infectious diseases where the WHO must act as the worldwide coordinator guided by technical and scientific rationales, a role that is usually constrained by hierarchy, politics, lack of transparency, among other things. In this conflicting system of governance, epistemic communities are actors with the potential to cut across politics and organizations if the WHO effectively decentralizes its technical roles. This could be possible by endowing the WHO 
regional offices with more resources and decision-making control and reducing the central control performed by the WHO in Geneva. As well, the WHO could contribute to the creation of more regional or sub-regional networks of experts, without having to control them. The WHO is starting a process where it seems that the organization favours the building of more of these networks (13).

Another policy implication that has also been recognized at the WHO is the need to connect the global and local levels. In the management of a disease outbreak, connectivity across levels of governance can potentially improve the global response. When local actors understand that disease outbreaks can have global repercussions, they will be able to look for information and collaboration in different places and levels. To increase the engagement of local actors with the global system of governance, first, it is necessary to review the education system and to ensure that all health science students have a general understanding of the global health system of governance and its connections to the local and national levels. In this regard, epistemic communities are structures that include professionals from different fields and levels of governance.

Given that epistemic communities are embedded in the system of global health governance, the decentralization of the technical functions held by the WHO could also help to increase the number of epistemic communities and to strengthen them. The WHO should open its system to collaborate with experts from all around the world regardless of where they come from or if the institution they are part of is recognized or famous. Paradoxically, even though the WHO is an organization created for nation-states with worldwide representation, at the technical level, it collaborates only with a selected number of institutions. There are nodes -academic and institutional- working with the WHO, central in 
the formation of epistemic communities in global health such as the LSHTM, Institute Pasteur, or the US CDC. Whether this could be justified or not, in the end, it has limited the participation of other professionals and other institutions that have the expertise to advance global health policy.

In terms of the isolation of politics from the participation of an epistemic community, the cases show that it is hard to eliminate political influence during the response to disease outbreaks. At the same time, it is essential to recognize that politics play a critical role, and they facilitate the participation of epistemic communities. The fact that experts, however, are not apolitical also creates challenges for the analysis of their role and for the creation of policies and mechanisms that can provide technical solutions. Therefore, this research recognizes the importance of politics, but it also acknowledges that more research is necessary to understand better the role of experts with political interest and how politics influences an epistemic community's participation in the policy process.

Finally, although some epistemic communities, such as the influenza network, have a clear global representation, others are more centralized in specific regions such as in developed countries. Consequently, experts from places like Africa are less likely to participate in these networks, even though many infectious diseases with pandemic potential severely affect this continent. It is important then to understand the concentration of these actors in certain countries or institutions and the repercussion of the future of international cooperation in global health in the face of more complex challenges. 


\section{Appendices}

\section{Appendix A. Semi-structured interview guide}

\section{A. General}

1) Do you consider yourself as part of a community of experts/policymakers working in the area of infectious diseases?

2) Would you consider a member of a community working specifically with a disease (which one?) or in general?

3) Where and how often do you meet?

4) Who organizes the meeting?

5) How do the members of the network convene?

6) Who are members of the network?

7) How could you describe collaboration within this network/community?

8) What type of mechanisms do you use to work together?

9) Would you consider these mechanisms formal or informal (informal being mostly based on personal relationships)?

10) Do you consider that as a community, do you act together to influence policymaking at the national or international level?

11) How would you qualify the power level that as a community you have for influencing policymaking?

12) Do you consider that some individual members of the community have more power to influence policymaking than others? Why?

13) Would you consider that during a health emergency such as a pandemic, the community has a stronger power to influence decision making at the national and international levels? If the answer is yes, could you elaborate on why or how this happens?

\section{B. Case studies general (Influenza pandemic/Ebola/MERS/Zika)}

- In general terms, on a scale of 0 to 6 (being cero an indication of a lack o response with non-or almost non-collaboration/ international cooperation and six a response with the 
highest possible level of collaboration) how would you assess the response to the H1N1 influenza outbreak in 2009/Ebola 2014/MERS 2012/Zika 2015? Why would you consider that?

- Could you compare the previously mentioned outbreaks and explain, in your opinion, how the international system to respond to pandemics has improved or not? What has been different since the first outbreak assessed under the 2005 IHR?

-Would you consider there is a consensual agreement in the community regarding the risk of influenza pandemic/Ebola/MERS/Zika? Yes/No Why?

-Were you collaborating or working directly with a government or international organization during any of these outbreaks?

- Which one? /What was your role there?

- To what extent your opinions and advice were incorporated into the response?

- Did your advice and opinions were previously discussed with other experts or participants in the response that are also members of the community? If yes, could you explain how and if it did happen previous to the emergency or during the emergency?

- How would you describe the role of this community in the craft of international policies related to the topic?

-Which have been the areas of major disagreements among the expert's community?

-Which have been the areas/topics of consensual agreement among the expert's community?

- How would you describe this community's ability to promote collaboration among countries in this topic?

- What is the extent of collaboration that exists between your country and the WHO (in this topic)?

- What is the extent of influence that your opinion as an expert has had in the definition of your country's national position?

- Did you participate in international meetings related to the outbreak? Which ones? Could you explain how those meetings were relevant for the response and decision making?

- After the outbreak, have you continued interacting with experts and other colleges to assess the outbreak and/or to elaborate policies to prevent future outbreaks?

- How often does interaction occur? 
- How would you assess the role of the WHO as the main coordinator of the international response to these outbreaks?

- From your point of view, how would you assess states' collaboration during the international response to these outbreaks?

- Regardless of the level of collaboration that existed during these outbreaks, do you consider that experts and other professionals intervening in the emergency were the main factors promoting these collaborations (rather than the institutions)?

- If your answer is yes to the previous question, would you consider this happened because of the formal mechanisms in place to built networks of international collaboration or because of the informal ties that these actors have developed through a constant interaction over time, working in these areas? Please elaborate.

- How do you believe scientific collaboration has influenced the response and, in general, decision

making? 


\section{Appendix B. Distribution of cases SARS per country}

\begin{tabular}{|c|c|c|}
\hline Country/ Area & $\begin{array}{l}\text { No. of } \\
\text { cases }\end{array}$ & $\begin{array}{l}\text { No. of } \\
\text { deaths }\end{array}$ \\
\hline Australia & 6 & 0 \\
\hline Canada & 251 & 43 \\
\hline China & 5327 & 349 \\
\hline China, Hong Kong Special Administrative Region & 1755 & 299 \\
\hline China, Macao Special Administrative Region & 1 & 0 \\
\hline China, Taiwan & 346 & 37 \\
\hline France & 7 & 1 \\
\hline Germany & 9 & 0 \\
\hline India & 3 & 0 \\
\hline Indonesia & 2 & 0 \\
\hline Italy & 4 & 0 \\
\hline Kuwait & 1 & 0 \\
\hline Malaysia & 5 & 2 \\
\hline Mongolia & 9 & 0 \\
\hline New Zealand & 1 & 0 \\
\hline Philippines & 14 & 2 \\
\hline Republic of Ireland & 1 & 0 \\
\hline Republic of Korea & 3 & 0 \\
\hline Romania & 1 & 0 \\
\hline Russian Federation & 1 & 0 \\
\hline Singapore & 238 & 33 \\
\hline South Africa & 1 & 1 \\
\hline Spain & 1 & 0 \\
\hline Sweden & 5 & 0 \\
\hline Switzerland & 1 & 0 \\
\hline Thailand & 9 & 2 \\
\hline United Kingdom & 4 & 0 \\
\hline United States & 27 & 0 \\
\hline Viet Nam & 63 & 5 \\
\hline Total & 8096 & 774 \\
\hline
\end{tabular}

Distribution of SARS cases and deaths per country.

Source: WHO 2003, Global Alert and Response (GOARN) 


\section{Appendix C. GOARN Worldwide partners}

\begin{tabular}{|c|c|}
\hline ORGANIZATION & COUNTRY \\
\hline Institut Pasteur (IP), Algeria & Algeria \\
\hline $\begin{array}{l}\text { Instituto Nacional de Enfermedades Virales Humanas J.MAIZTEGUI } \\
\text { (INEVH) }\end{array}$ & Argentina \\
\hline ARM Network (Australian Response MAE Network) & Australia \\
\hline $\begin{array}{l}\text { Australasian College for Infection Prevention and Control (ACIPC), } \\
\text { formerly AICA }\end{array}$ & Australia \\
\hline Burnet Institute for Medical Research and Public Health & Australia \\
\hline $\begin{array}{l}\text { College of Public Health, Medical and Veterinary Sciences, James Cook } \\
\text { University }\end{array}$ & Australia \\
\hline CSIRO Australian Animal Health Laboratory & Australia \\
\hline Doctors Without Borders - Australia (MSF) & Australia \\
\hline Doherty Institute & Australia \\
\hline Faculty of Health Sciences, Curtin University of Technology & Australia \\
\hline $\begin{array}{l}\text { Institute for Glycomics - Griffith University, Gold Coast Campus, } \\
\text { Queensland }\end{array}$ & Australia \\
\hline $\begin{array}{l}\text { National Centre for Epidemiology and Population Health (NCEPH), The } \\
\text { Australian National University (ANU) }\end{array}$ & Australia \\
\hline Office of Health Protection, Department of Health (DOHA) & Australia \\
\hline PathWest Laboratory Medicine WA & Australia \\
\hline The University of New South Wales, Sydney & Australia \\
\hline Westmead Hospital & Australia \\
\hline Medical University of Vienna, Centre for Public Health & Austria \\
\hline Institute of Epidemiology, Disease Control and Research (IEDCR) & Bangladesh \\
\hline International Centre for Diarrhoeal Disease Research, Bangladesh (icddr,b) & Bangladesh \\
\hline The University of the West Indies & Barbados \\
\hline Federal Public Service - Health, Food Chain Safety and Environment (FPS) & Belgium \\
\hline Institute of Tropical Medicine (ITM) & Belgium \\
\hline Médecins Sans Frontières - Belgium (MSF Belgium) & Belgium \\
\hline Médecins Sans Frontières - International Office (MSF) & Belgium \\
\hline Scientific Institute of Public Health Belgium & Belgium \\
\hline Instituto Evandro Chagas (IEC) & Brazil \\
\hline ProEpi & Brazil \\
\hline Universidade Federal do Rio de Janeiro & Brazil \\
\hline Centre National de Transfusion Sanguine (CNTS) - Burkina Faso & Burkina Faso \\
\hline Institut Pasteur (IP), Cambodia & Cambodia \\
\hline Public Health Agency of Canada (PHAC) & Canada \\
\hline Chinese Centre for Disease Control and Prevention (China CDC) & China \\
\hline Guangdong Provincial Centre for Disease Control and Prevention & China \\
\hline Centre for Health Protection (CHP), Department of Health & Hong Kong SAR \\
\hline The Chinese University of Hong Kong & Hong Kong SAR \\
\hline
\end{tabular}




\begin{tabular}{|c|c|}
\hline ORGANIZATION & COUNTRY \\
\hline University of Hong Kong & Hong Kong SAR \\
\hline WHO Regional Office for Africa (AFRO) & Congo \\
\hline Institut National de Recherche Biomédicale (INRB) & $\begin{array}{l}\text { The Democratic Republic of } \\
\text { the Congo }\end{array}$ \\
\hline Statens Serum Institut (SSI) & Denmark \\
\hline WHO Regional Office for Europe (EURO) & Denmark \\
\hline $\begin{array}{l}\text { Direction of Epidemiology and Health Information, Ministry of Health } \\
\text { Djibouti }\end{array}$ & Djibouti \\
\hline CDC Egypt Country Office- NAMRU-3 & Egypt \\
\hline Naval Medical Research Unit, NAMRU-3 & Egypt \\
\hline WHO Regional Office for the Eastern Mediterranean (EMRO) & Egypt \\
\hline Africa Centres for Disease Control and Prevention & Ethiopia \\
\hline National Institute for Health and Welfare (THL) & Finland \\
\hline Aix-Marseille University & France \\
\hline $\begin{array}{l}\text { Association pour le développement de l'épidémiologie de terrain } \\
\text { (EPITER) }\end{array}$ & France \\
\hline Centre d'épidémiologie et de santé publique des armées (CESPA) & France \\
\hline EPICENTRE & France \\
\hline EPIET Alumni Network (EAN) & France \\
\hline $\begin{array}{l}\text { Etablissement de Préparation et de Réponse aux Urgences Sanitaires } \\
\text { (EPRUS) }\end{array}$ & France \\
\hline European Virus Archive goes Global (EVAg) & France \\
\hline Fondation Merieux & France \\
\hline Inserm - European Union West Africa Mobile Lab (EUWAM Lab) & France \\
\hline Institut Pasteur (IP), International & France \\
\hline Institut Pasteur (IP), Lyon & France \\
\hline Laboratory P4 Inserm Jean Merieux & France \\
\hline Médecins Sans Frontières - France (MSF France) & France \\
\hline Museum national d histoire naturelle (MNHN) & France \\
\hline Santé Publique France & France \\
\hline World Organisation for Animal Health (OIE) & France \\
\hline Centre International de Recherches Médicales de Franceville (CIRMF) & Gabon \\
\hline Bernhard Nocht Institute for Tropical Medicine & Germany \\
\hline Bundeswehr Institute of Microbiology & Germany \\
\hline $\begin{array}{l}\text { Deutsche Gesellschaft für Internationale Zusammenarbeit (GIZ) GmbH - } \\
\text { SEEG }\end{array}$ & Germany \\
\hline European Mobile Laboratory (EMLab) & Germany \\
\hline $\begin{array}{l}\text { Friedrich-Loeffler-Institut - Federal Research Institute for Animal Health } \\
\text { (FLI) }\end{array}$ & Germany \\
\hline German Armed Forces Medical Service, GER Ministry of Defence & Germany \\
\hline Institut fuer Virologie, Philipps-Universität Marburg & Germany \\
\hline Institute of Virology, Charité Berlin & Germany \\
\hline Johanniter-Unfall-Hilfe e.V. Headquarters Berlin & Germany \\
\hline
\end{tabular}




\begin{tabular}{|c|c|}
\hline ORGANIZATION & COUNTRY \\
\hline Medical Mission Institute, Department of Tropical Medicine & Germany \\
\hline Robert Koch Institut (RKI) & Germany \\
\hline University Hospital Düsseldorf & Germany \\
\hline $\begin{array}{l}\text { National School of Public Health, Central Public Health Laboratory, } \\
\text { Greece }\end{array}$ & Greece \\
\hline $\begin{array}{l}\text { Centro Nacional de Epidemiología, Ministerio de Salud Pública y } \\
\text { Asistencia Social }\end{array}$ & Guatemala \\
\hline Institut Pasteur (IP), Guyane & Guyana \\
\hline National Centre for Disease Control (NCDC), India & India \\
\hline National Institute of High-Security Animal Disease, Bhopal, India & India \\
\hline National Institute of Virology (NIV), India & India \\
\hline The INCLEN Trust International & India \\
\hline WHO Regional Office for South-East Asia (SEARO) & India \\
\hline $\begin{array}{l}\text { Centre for Communicable Diseases Control (CDC) Iran, Ministry of Health } \\
\text { and Medical Education (MOH\&ME) }\end{array}$ & Iran \\
\hline Institute Pasteur (IP), Iran & Iran \\
\hline Health Protection Surveillance Centre (HPSC) & Ireland \\
\hline National University of Ireland, Galway & Ireland \\
\hline Israeli Medical Association (IMA) & Israel \\
\hline Istituto Superiore di Sanita (ISS) & Italy \\
\hline National Institute for Infectious Diseases Lazzaro Spallanzani (INMI) & Italy \\
\hline United Nations Food and Agriculture Organization (FAO) & Italy \\
\hline Association of Medical Doctors of Asia (AMDA) & Japan \\
\hline Centre for Infectious Diseases, Nara Medical University & Japan \\
\hline Department of Public Health, Osaka City University Faculty of Medicine & Japan \\
\hline Department of Virology, Tohoku University, School of Medicine & Japan \\
\hline $\begin{array}{l}\text { Division of Tuberculosis and Infectious Disease Control, Ministry of } \\
\text { Health, Labour and Welfare }\end{array}$ & Japan \\
\hline Hokkaido University Research Centre for Zoonosis Control & Japan \\
\hline Institute of Tropical Medicine, Nagasaki University & Japan \\
\hline International Medical Centre of Japan & Japan \\
\hline $\begin{array}{l}\text { Japan International Cooperation Agency JICA, Japan Disaster Relief Team } \\
\text { (JDR) }\end{array}$ & Japan \\
\hline Japanese Red Cross Wakayama Medical Centre & Japan \\
\hline Kurume University & Japan \\
\hline Mie National Hospital & Japan \\
\hline National Centre for Global Health and Medicine, Japan & Japan \\
\hline National Institute of Infectious Diseases (NIID) & Japan \\
\hline Osaka University & Japan \\
\hline Our Lady of Snow Medical Juridical Corporation St. Marys Hospital & Japan \\
\hline School of Medicine, Niigata University & Japan \\
\hline Eastern Mediterranean Public Health Network (EMPHNET) & Jordan \\
\hline Jordan Food and Drug Administration & Jordan \\
\hline
\end{tabular}




\begin{tabular}{|c|c|}
\hline ORGANIZATION & COUNTRY \\
\hline Amref Health Africa & Kenya \\
\hline Kenya Medical Research Institute (KEMRI) & Kenya \\
\hline American University of Beirut Medical Centre & Lebanon \\
\hline Faculty of Public Health - Lebanese University & Lebanon \\
\hline Ministry of Public Health, Lebanon & Lebanon \\
\hline Epidemiology Intelligence Program (EIP), Malaysia & Malaysia \\
\hline $\begin{array}{l}\text { Institute of Health and Community Medicine (IHCM) Universiti Malaysia } \\
\text { Sarawak }\end{array}$ & Malaysia \\
\hline $\begin{array}{l}\text { National Centre for Epidemiological Surveillance and Disease Control, } \\
\text { Ministry of Health Mexico }\end{array}$ & Mexico \\
\hline Directory of Epidemiology and Control Diseases (DELM) /MOH Morocco & Morocco \\
\hline Institut Pasteur (IP), Morocco & Morocco \\
\hline National Public Health Laboratory, Nepal & Nepal \\
\hline Sukra Raj Tropical and Infectious Disease Hospital & Nepal \\
\hline Erasmus MC & Netherlands \\
\hline Médecins Sans Frontières - Holland (MSF Holland) & Netherlands \\
\hline RIVM, National Institute for Public Health and the Environment & Netherlands \\
\hline Royal Tropical Institute (KIT), KIT Biomedical Research & Netherlands \\
\hline Secretariat of the Pacific Community (SPC) & New Caledonia \\
\hline Institute of Environmental Science and Research Limited (ESR) & New Zealand \\
\hline Federal University Oye Ekiti & Nigeria \\
\hline Nigeria Centre for Disease Control (NCDC) & Nigeria \\
\hline Norwegian Armed Forces Medical Services & Norway \\
\hline Norwegian Institute of Public Health (NIPH) & Norway \\
\hline $\begin{array}{l}\text { Directorate General for Disease Surveillance and Control, Ministry of } \\
\text { Health Oman }\end{array}$ & Oman \\
\hline National Institute of Health - NIH Pakistan & Pakistan \\
\hline Papua New Guinea Institute of Medical Research (PNG IMR) & Papua New Guinea \\
\hline Instituto Nacional de Salud (NIH Peru) & Peru \\
\hline $\begin{array}{l}\text { National Epidemiology Centre, Department of Health, Ministry of Health } \\
\text { Philippines }\end{array}$ & Philippines \\
\hline WHO Regional Office for the Western Pacific (WPRO) & Philippines \\
\hline Ministry of Health Portugal, Office of the Director General of Health & Portugal \\
\hline National Institute of Health Dr. Ricardo Jorge (NIH Portugal) & Portugal \\
\hline $\begin{array}{l}\text { JW LEE Centre for Global Medicine, Seoul National University College of } \\
\text { Medicine }\end{array}$ & Republic of Korea \\
\hline Korea Centres for Disease Control and Prevention (KCDC) & Republic of Korea \\
\hline Reseau des Experts Sanitaires des Eaux (RESEaux) & Reunion \\
\hline Stavropol Antiplague Research Institute & Russian Federation \\
\hline King Abdulaziz Medical City, National Guard Health Affairs & Saudi Arabia \\
\hline
\end{tabular}




\begin{tabular}{|c|c|}
\hline ORGANIZATION & COUNTRY \\
\hline Institut Pasteur (IP), Dakar & Senegal \\
\hline Ministry of Health, Singapore & Singapore \\
\hline National University of Singapore (NUS) & Singapore \\
\hline $\begin{array}{l}\text { Program in Emerging Infectious Diseases, Duke-NUS Graduate Medical } \\
\text { School }\end{array}$ & Singapore \\
\hline Singapore General Hospital & Singapore \\
\hline Tan Tock Seng Hospital & Singapore \\
\hline $\begin{array}{l}\text { Institute of Virology, Biomedical Research Centre, Slovak Academy of } \\
\text { Sciences }\end{array}$ & Slovakia \\
\hline $\begin{array}{l}\text { Institute of Microbiology and Immunology, Faculty of Medicine, } \\
\text { University of Ljubljana }\end{array}$ & Slovenia \\
\hline Infection Control Africa Network (ICAN) & South Africa \\
\hline National Institute for Communicable Diseases (NICD), South Africa & South Africa \\
\hline Instituto de Salud Carlos III (ISCIII) & Spain \\
\hline Médecins Sans Frontières - Spain (MSF Spain) & Spain \\
\hline MediPIET & Spain \\
\hline Ministry of Health Social Services and Equality, Spain & Spain \\
\hline Ministry of Health Sudan, National Public Health Laboratory (NPHL) & Sudan \\
\hline European Centre for Disease Prevention and Control (ECDC) & Sweden \\
\hline European Programme for Intervention Epidemiology Training (EPIET) & Sweden \\
\hline Public Health Agency of Sweden & Sweden \\
\hline GOARN Secretariat & Switzerland \\
\hline International Committee of the Red Cross (ICRC) & Switzerland \\
\hline International Council of Nurses (ICN) & Switzerland \\
\hline International Federation of Red Cross and Red Crescent Societies (IFRC) & Switzerland \\
\hline International Organization for Migration (IOM) & Switzerland \\
\hline Medecins Sans Frontieres - Switzerland (MSF Switzerland) & Switzerland \\
\hline Spiez Laboratory, Federal Office for Civil Protection (FOCP) & Switzerland \\
\hline Staff Health \& Wellbeing Services (SHW), World Health Organization & Switzerland \\
\hline $\begin{array}{l}\text { Swiss Humanitarian Aid Unit (SHA), Swiss Agency for Development and } \\
\text { Cooperation (SDC) }\end{array}$ & Switzerland \\
\hline United Nations High Commission for Refugees (UNHCR) & Switzerland \\
\hline The University of Geneva, Faculty of Medicine (HUG) & Switzerland \\
\hline WHO Department of Evidence and Policy on Environmental Health (EPE) & Switzerland \\
\hline WHO Department of Food Safety, Zoonoses, and Foodborne Diseases & Switzerland \\
\hline WHO Emerging and Dangerous Pathogens Laboratory Network (EDPLN) & Switzerland \\
\hline $\begin{array}{l}\text { WHO Epidemic Diseases Clinical Assessment and Response Network } \\
\text { (EDCARN) }\end{array}$ & Switzerland \\
\hline WHO Global Infection Prevention and Control Network (GIPCN) & Switzerland \\
\hline WHO The International Food Safety Authorities Network (INFOSAN) & Switzerland \\
\hline WHO Virtual Interdisciplinary Advisory Group on Mass Gathering & Switzerland \\
\hline WHO Country Health Emergency Preparedness \& IHR (CPI) & Switzerland \\
\hline WHO Emergency Operations (EMO) & Switzerland \\
\hline
\end{tabular}




\begin{tabular}{|c|c|}
\hline ORGANIZATION & COUNTRY \\
\hline WHO Executive Director Office & Switzerland \\
\hline WHO Global Task Force on Cholera Control (GTFCC) & Switzerland \\
\hline WHO Health Emergency Information \& Risk Assessment (HIM) & Switzerland \\
\hline WHO Infectious Hazard Management (IHM) & Switzerland \\
\hline WHO Management \& Administration (MGA) & Switzerland \\
\hline WHO Operations Support and Logistics & Switzerland \\
\hline Armed Forces Research Institute for Medical Sciences (AFRIMS) & Thailand \\
\hline $\begin{array}{l}\text { Bureau of Epidemiology, Surveillance and Response Unit, Ministry of } \\
\text { Health Thailand }\end{array}$ & Thailand \\
\hline Dengue Unit, Queen Sirikit National Institute of Child Health (QSNICH) & Thailand \\
\hline International FETP, Thailand & Thailand \\
\hline Mekong Basin Disease Surveillance (MBDS) & Thailand \\
\hline $\begin{array}{l}\text { Division des laboratoires - Ministère de la Santé et de la Protection } \\
\text { Sociale }\end{array}$ & Togo \\
\hline Institut National d'Hygiène & Togo \\
\hline Caribbean Public Health Agency (CARPHA) & Trinidad and Tobago \\
\hline Institut Pasteur (IP), Tunis & Tunisia \\
\hline African Field Epidemiology Network (AFENET) & Uganda \\
\hline $\begin{array}{l}\text { Ministry of Health and Prevention, Emergency - Crisis - Disaster } \\
\text { Operations Centre }\end{array}$ & United Arab Emirates \\
\hline Animal and Plant Health Agency (APHA) & United Kingdom \\
\hline $\begin{array}{l}\text { ISARIC - International Severe Acute Respiratory and Emerging Infection } \\
\text { Consortium }\end{array}$ & United Kingdom \\
\hline London School of Hygiene and Tropical Medicine (LSHTM) & United Kingdom \\
\hline $\begin{array}{l}\text { MRC Centre for Outbreak Analysis and Modelling, Imperial College } \\
\text { London }\end{array}$ & United Kingdom \\
\hline Public Health England (PHE) & United Kingdom \\
\hline Save the Children International & United Kingdom \\
\hline $\begin{array}{l}\text { East African Integrated Disease Surveillance (EAIDSNet), National } \\
\text { Institute for Medical Research (NIMR) }\end{array}$ & United Republic of Tanzania \\
\hline APEC Emerging Infections Network (EINET) & United States of America \\
\hline Armed Forces Health Surveillance Branch (AFHSB) & United States of America \\
\hline Association of Public Health Laboratories (APHL) & United States of America \\
\hline $\begin{array}{l}\text { Centre for Infection and Immunity, Mailman School of Public Health of } \\
\text { Columbia University }\end{array}$ & United States of America \\
\hline Centers for Disease Control and Prevention (CDC) & United States of America \\
\hline Chan Zuckerberg Biohub & United States of America \\
\hline International Epidemiological Association (IEA) & United States of America \\
\hline International Rescue Committee (IRC) & United States of America \\
\hline Johns Hopkins University & United States of America \\
\hline mWater & United States of America \\
\hline
\end{tabular}




\begin{tabular}{|l|l|}
\hline ORGANIZATION & COUNTRY \\
\hline $\begin{array}{l}\text { Training Programmes in Epidemiology and Public Health Interventions } \\
\text { Network (TEPHINET) }\end{array}$ & United States of America \\
\hline Tulane School of Public Health and Tropical Medicine & United States of America \\
\hline U.S. Army Medical Research Institute of Infectious Diseases (USAMRIID) & United States of America \\
\hline United Nations Children's Fund (UNICEF) & United States of America \\
\hline University of Nebraska Medical Centre & United States of America \\
\hline University of Texas Medical Branch (UTMB) & United States of America \\
\hline WHO Regional Office for the Americas (AMRO) & United States of America \\
\hline Clinical Research Unit, Hospital for Tropical Diseases & Viet Nam \\
\hline National Institute of Hygiene and Epidemiology (NIHE) & Viet Nam \\
\hline REACTing & \\
\hline
\end{tabular}




\section{Appendix D. GSIN member countries and experts in 1952}

\begin{tabular}{|c|c|c|}
\hline Country & Institution & Lead experts \\
\hline \multicolumn{3}{|c|}{ WHO INFLUENZA CENTRES } \\
\hline \multirow[t]{2}{*}{ WHO } & World Influenza Centre & Dr. C. H. Andrewes \\
\hline & Strain Study Centre for the Americas & Dr. T. P. Magill \\
\hline NIGERIA & Virus Research Institute & \\
\hline \multirow{2}{*}{$\begin{array}{l}\text { UNION OF } \\
\text { SOUTH AFRICA }\end{array}$} & The South African Institute for Medical Research & Dr. J. H. S. Gear \\
\hline & University of Cape Town & $\begin{array}{l}\text { Prof. M. van den } \\
\text { Ende }\end{array}$ \\
\hline ARGENTINA & Instituto Bacteriologico Carlos G. Malbran & Dr. A. S. Parodi \\
\hline BRAZIL & Instituto Oswaldo Cruz & Dr. J. G. Lacorte \\
\hline \multirow[t]{2}{*}{ CANADA } & Laboratory of Hygiene, Department of National Health and Welfare & Dr. F. P. Nagler \\
\hline & The Connaught Medical Research Laboratories, University of Toronto & Dr. C. E. van Rooyen \\
\hline CHILE & Instituto Bacteriologico de Chile & Dr. Raul Palacios \\
\hline JAMAICA & Department of Pathology, University College of the West Indies & Dr. L. Grant \\
\hline MEXICO & Instituto de Salubridad y Enfermedades Tropicales & Dr. Gerardo Varela \\
\hline PUERTO RICO & $\begin{array}{l}\text { School of Tropical Medicine, University of Puerto Rico School of } \\
\text { Medicine }\end{array}$ & Dr. J. E. Perez \\
\hline \multirow{8}{*}{$\begin{array}{l}\text { UNITED STATES } \\
\text { OF AMERICA }\end{array}$} & Influenza Information Centre, National Institutes of Health & Dr. Dorland J. Davis \\
\hline & Communicable Disease Centre, US Public Health Service & Dr. M. F. Schaeffer \\
\hline & Division of Laboratories, California State Department of Public Health & Dr. E. H. Lennette \\
\hline & State University of Iowa & Dr. A. P. McKee \\
\hline & Boston City Hospital & Dr. M. Finland \\
\hline & $\begin{array}{l}\text { Department of Epidemiology, University of Michigan School of } \\
\text { Hygiene and Public Health }\end{array}$ & Dr. T. Francis, Jr. \\
\hline & $\begin{array}{l}\text { Division of Laboratories and Research, New York State Department } \\
\text { of Health }\end{array}$ & Dr. I. J. Gordon \\
\hline & University of Pittsburgh School of Medicine & Dr. J. E. Salk \\
\hline EGYPT & Serum and Vaccine Laboratory & $\begin{array}{l}\text { Dr. Mohamed Aly } \\
\text { Dr. I. M. Hassan }\end{array}$ \\
\hline ISRAEL & Hadassah Medical School, The Hebrew University & Dr. H. Bernkopf \\
\hline AUSTRIA & Bundesstaatliche bakteriologisch-serologische Untersuchungsanstalt & Dr. E. Petrowsky \\
\hline BELGIUM & Laboratoire Central d'Hygiene & Dr. P. Nelis \\
\hline DENMARK & Statens Seruminstitut & $\begin{array}{l}\text { Dr. J. Orskov } \\
\text { Dr. P. von Magnus }\end{array}$ \\
\hline FINLAND & Valtion Serumlaitos & Dr. Kari J. Penttinen \\
\hline FRANCE & Mlle G. Cateigne, Institut Pasteur & $\begin{array}{l}\text { Prof. R. Dujarric de la } \\
\text { Riviere } \\
\text { Prof. Pierre Lupine }\end{array}$ \\
\hline \multirow{2}{*}{$\begin{array}{l}\text { GERMANY } \\
\text { (WEST) }\end{array}$} & Hygienisches Institut der Universitat Marburg & Prof. K. Herzberg \\
\hline & Bernhard-Nocht-Institut fur Schiffs- und Tropenkrankheiten & Prof. E. G. Nauck \\
\hline (BERLIN-WEST) & Robert Koch Institut fur Hygiene und Infektionskrankheite & Prof.D. Henneberg \\
\hline
\end{tabular}

GSIN Members 1952 


\begin{tabular}{|c|c|c|}
\hline Country & Institution & Lead experts \\
\hline GREECE & Central Public Health Laboratory, Ministry of Hygiene & Dr. S. G. Pavlidis \\
\hline ICELAND & University of Iceland Institute for Experimental Pathology & Dr. B. Sigurdsson \\
\hline IRELAND & St. Vincent's Hospital & Dr. P. N. Meenan \\
\hline ITALY & Istituto Superiore di Sanita & Prof. I. Archetti \\
\hline \multirow[t]{2}{*}{ NETHERLANDS } & Instituut voor Praeventieve Geneeskunde & Prof. J. D. Verlinde \\
\hline & Interne Universiteitskliniek & Prof. J. Mulder \\
\hline NORWAY & K. W. Wilhelmsen og frues Bakteriologiske institutt & Prof. Th. ThjOtta \\
\hline PORTUGAL & $\begin{array}{l}\text { Dr. Ricardo Jorge Laboratorio de Bacteriologia Sanitaria do Instituto } \\
\text { Superior de Higiene }\end{array}$ & $\begin{array}{l}\text { Dr. A. A. C. } \\
\text { Sampaio }\end{array}$ \\
\hline SPAIN & Escuela Nacional de Sanidad & $\begin{array}{l}\text { Dr. F. Perez } \\
\text { Gallardo }\end{array}$ \\
\hline SWEDEN & Statens bakteriologiska laboratorium & Dr. A. Svedmyr \\
\hline \multirow[t]{2}{*}{ SWITZERLAND } & Institut d'Hygiene, Universite de Geneve & Prof. E. Grasset \\
\hline & Institut fur Hygiene und Bakteriologie & Prof. C. Hallauer \\
\hline TURKEY & Refik Saydam Central Institute of Hygiene & Dr. Niyazi Erzin \\
\hline \multirow{3}{*}{$\begin{array}{l}\text { UNITED } \\
\text { KINGDOM }\end{array}$} & Public Health Laboratory, General Hospital & Dr. L. Hoyle \\
\hline & Bacteriology Department & Dr. R. H. A. Swain \\
\hline & Central Public Health Laboratory & $\begin{array}{l}\text { Dr. F. } 0 . \\
\text { MacCallum }\end{array}$ \\
\hline \multirow[t]{2}{*}{ YUGOSLAVIA } & Bakteriolosko Odelenje, Savezni Epidemiologki Institut & Dr. A. Terzin \\
\hline & Institute of Microbiology, University of Zagreb & $\begin{array}{l}\text { Dr. Jeltka } \\
\text { Vesenjak }\end{array}$ \\
\hline \multirow[t]{2}{*}{ INDIA } & Coonoor & Dr. I. G. K. Menon \\
\hline & Haffkine Institute & Dr. D. W. Soman \\
\hline \multirow[t]{2}{*}{ AUSTRALIA } & The Commonwealth Serum Laboratories, Department of Health & Dr. W. J. O'Connor \\
\hline & Walter and Eliza Hall Institute for Medical Research & $\begin{array}{l}\text { Sir Macfarlane } \\
\text { Burnet }\end{array}$ \\
\hline JAPAN & National Institute of Health of Japan & Dr. Saburo Kojima \\
\hline \multicolumn{3}{|c|}{ WHO INFLUENZA OBSERVERS } \\
\hline BOLIVIA & Instituto Nacional de Epidemiologia & \\
\hline $\begin{array}{l}\text { DOMINICAN } \\
\text { REPUBLIC }\end{array}$ & $\begin{array}{l}\text { Laboratorio de Salud Pública, Secretaria de Estado de Sanidad y } \\
\text { Asistencia Publica }\end{array}$ & Dr. J. J. Ravelo \\
\hline ECUADOR & Instituto Nacional de Higiene & \\
\hline PAKISTAN & Bureau of Laboratories, Military Hospital & $\begin{array}{l}\text { Dr. M. M. Siddiq } \\
\text { Husain }\end{array}$ \\
\hline CEYLON & Medical Research Institute & Dr. K. G. B. Stork \\
\hline $\begin{array}{l}\text { FEDERATION } \\
\text { OF MALAYA }\end{array}$ & Institute for Medical Research & Dr. S. R. Savoor \\
\hline \multirow{3}{*}{$\begin{array}{l}\text { NEW } \\
\text { ZEALAND }\end{array}$} & Division of Public Hygiene, Department of Health & Dr. F. S. MacLean \\
\hline & University of Otago Medical School & $\begin{array}{l}\text { Sir Charles Hercus, } \\
\text { D.S.O., O.B.E. }\end{array}$ \\
\hline & Auckland Hospital & Dr. Selwyn Hills \\
\hline PHILIPPINES & Division of Laboratories, Department of Health & \\
\hline
\end{tabular}

GSIN Members 1952 


\section{Appendix E. International Pledging Conferences on Avian and Human Influenza}

- Meeting on Case Management and Research on Human Influenza A/H5, Hanoi, May 2005

- $60^{\text {th }}$ United Nations General Assembly, September 2005.

- Meeting of the International Partnership on Avian and Pandemic Influenza Washington, DC, October 6-7, 2005

- Meeting of Health Ministers in Ottawa, Canada on Global Influenza Readiness, October 24-25, 2005.

- Meeting on Avian Influenza and Human Pandemic Influenza, Geneva, Switzerland, 7-9 November 2005.

- Japan-WHO joint meeting on Early Response to Potential Influenza Pandemic, Tokyo, Japan, 12-13 January 2006.

- The International Pledging Conference, Beijing, China, 17-18 January 2006.

- The Vienna Senior Officials Meeting on Avian and Human Pandemic Influenza, 6-7 June 2006

- The 4th International Conference on Avian Influenza, 6-8 December 2006, Bamako, Mali.

- International Technical Meeting on Avian Influenza 27-29 June 2007 Rome, Italy.

- New Delhi International Ministerial Conference on Avian Influenza, 4-6 December 2007, India.

- Sixth International Ministerial Conference on Avian and Pandemic Influenza, 24-26 October 2008, Sharm el-Sheikh, Egypt

- The Seventh International Ministerial Conference Animal and Pandemic Influenza, April 2010, Hanoi, Viet Nam.

- High-Level Technical Meeting to Address Health Risks at the Human-AnimalEcosystems Interfaces, Mexico City, November 2011. 


\section{Appendix F. GOARN partners for pandemic influenza H1N1}

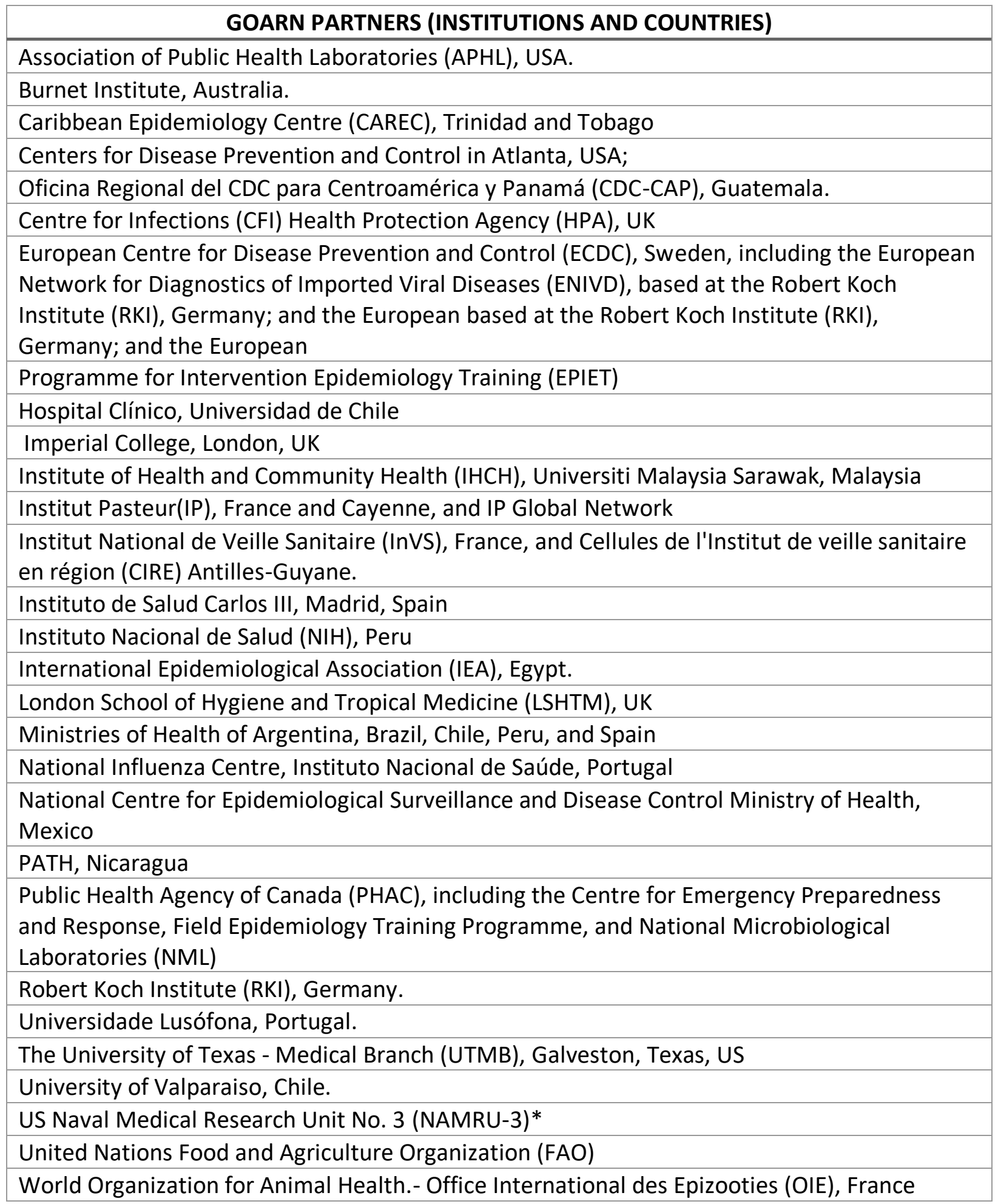




\begin{tabular}{|l|}
\hline \multicolumn{1}{|c|}{ GOARN PARTNERS (INSTITUTIONS AND COUNTRIES) } \\
\hline $\begin{array}{l}\text { Medecins Sans Frontieres (MSF) Belgium, France, Holland, Spain, Switzerland, and MSF } \\
\text { International }\end{array}$ \\
\hline International Federation of Red Cross and Red Crescent Societies (IFRC), Switzerland \\
\hline International Rescue Committee (IRC), USA \\
\hline WHO HQ, PAHO, WPRO, and Country Offices in Brazil, Bolivia, Chile, Columbia, Costa Rica, \\
Ecuador, Honduras, Mexico Nicaragua, Panama, and Uruguay. \\
\hline WHO Clinical Network \\
\hline WHO Emerging and Dangerous Pathogens Laboratory Network (EDPLN) \\
\hline WHO Infection Prevention and Control Network \\
\hline WHO Global Influenza Programme and GISN \\
\hline WHO Health Action in Crisis, Emergency Response, and Operations \\
\hline WHO Health Security and Environment \\
\hline WHO Mediterranean Centre for Vulnerability Reduction (WMC) \\
\hline WHO Pan American Health Organization (PAHO) \\
\hline WHO Regional Office for Africa, AFRO \\
\hline WHO Regional Office for Eastern Mediterranean, EMRO \\
\hline WHO Regional Office for Europe, EURO \\
\hline WHO Regional Office for South East Asia, SEARO \\
\hline WHO Regional Office for the Western Pacific, WPRO \\
\hline
\end{tabular}


Appendix G. Participants meeting A(H1N1) influenza Cancun 2009

\begin{tabular}{|c|c|c|c|c|c|}
\hline ID & Country/Organization & $\begin{array}{l}\text { No. of } \\
\text { participants }\end{array}$ & ID & Country/Organization & $\begin{array}{l}\text { No. of } \\
\text { participants }\end{array}$ \\
\hline 1 & Germany & 8 & 26 & India & 1 \\
\hline 2 & Argentina & 3 & 27 & Indonesia & 2 \\
\hline 3 & $\begin{array}{l}\text { Interamerican Development } \\
\text { Bank }\end{array}$ & 3 & 28 & Israel & 2 \\
\hline 4 & World Bank & 1 & 29 & Jamaica & 1 \\
\hline 5 & Belgium & 1 & 30 & Japan & 2 \\
\hline 6 & Belize & 2 & 31 & Arab League & 2 \\
\hline 7 & Bolivia & 1 & 32 & Mexico & 122 \\
\hline 8 & Brazil & 3 & 33 & Nicaragua & 4 \\
\hline 9 & Canada & 10 & 34 & Nigeria & 5 \\
\hline 10 & CARICOM & 1 & 35 & OIE & 2 \\
\hline 11 & USA & 38 & 36 & WHO & 5 \\
\hline 12 & Chile & 6 & 37 & WHO-PAHO & 23 \\
\hline 13 & China & 9 & 38 & Panama & 2 \\
\hline 14 & COMISCA & 2 & 39 & Paraguay & 1 \\
\hline 15 & South Korea & 3 & 40 & Peru & 1 \\
\hline 16 & Costa Rica & 4 & 41 & PNUD & 1 \\
\hline 17 & Cuba & 2 & 42 & Portugal & 1 \\
\hline 18 & Ecuador & 2 & 43 & UK & 5 \\
\hline 19 & Egypt & 8 & 44 & Czech Republic & 1 \\
\hline 20 & El Salvador & 3 & 45 & Dominican Republic & 1 \\
\hline 21 & Spain & 5 & 46 & Sweden & 6 \\
\hline 22 & European Commission & 2 & 47 & Switzerland & 2 \\
\hline 23 & France & 3 & 48 & Thailand & 1 \\
\hline 24 & Guatemala & 2 & 49 & Trinidad and Tobago & 1 \\
\hline \multirow[t]{2}{*}{25} & Honduras & 1 & 50 & Uruguay & 1 \\
\hline & & & 51 & Venezuela & 1 \\
\hline
\end{tabular}


Appendix H. Pandemic Influenza Epistemic Community Members

\begin{tabular}{|c|c|c|c|c|c|c|c|c|c|c|}
\hline Country & Member & Institution & $\begin{array}{l}\text { GISN } \\
2010\end{array}$ & $\begin{array}{l}\text { Collabor. } \\
\text { Centres } \\
2018\end{array}$ & $\begin{array}{l}\text { Cancun } \\
\text { Influenza } \\
2009\end{array}$ & $\begin{array}{l}\text { EC } \\
\text { Influenza }\end{array}$ & $\begin{array}{l}\text { CRIHR } \\
\text { Influenza }\end{array}$ & $\begin{array}{l}\text { Review } \\
\text { H1N1 }\end{array}$ & GSAID & GHSI \\
\hline Afghanistan & Naseer Stanikzai a.i. & Central Public Health Laboratory & & 1 & & & & & & \\
\hline Albania & Silvia Bino & Institute of Public Health & & 1 & & & 1 & & & \\
\hline Algeria & Fawzi Derrar & Institut Pasteur d'Algérie & & 1 & & & & & & \\
\hline Argentina & $\begin{array}{l}\text { Jorge Augusto } \\
\text { Camara }\end{array}$ & Instituto de Virologia & 1 & 1 & & & & & & \\
\hline Argentina & Karina Balbuena & Ministry of Health & & & & & & 1 & & \\
\hline Argentina & Vilma Savy & $\begin{array}{l}\text { Instituto Nacional de } \\
\text { Enfermedades Infecciosas }\end{array}$ & 1 & & & & & & & \\
\hline Argentina & Carlos Alberto Soratti & Ministry of Health & & & 1 & & & & & \\
\hline Argentina & Elsa Baumeister & $\begin{array}{l}\text { Instituto Nacional de } \\
\text { Enfermedades Infecciosas }\end{array}$ & & 1 & & & & & & \\
\hline Argentina & Oreste Luis Carlino & $\begin{array}{l}\text { Ministerio de Salud de la } \\
\text { Republica de Argentina }\end{array}$ & & & 1 & & & & & \\
\hline Argentina & Osvaldo Uez & $\begin{array}{l}\text { Intituto Nacional de } \\
\text { Epidemiologia }\end{array}$ & & 1 & & & & & & \\
\hline Australia & Gary Grohmann & $\begin{array}{l}\text { Therapeutic Goods } \\
\text { Administration }\end{array}$ & & & & & & 1 & & \\
\hline Australia & Ian Barr & $\begin{array}{l}\text { Peter Doherty Institute for } \\
\text { Infection \& Immunity WHO } \\
\text { Collaborating Centre for } \\
\text { Reference and Research on } \\
\text { Influenza }\end{array}$ & 1 & & & & & & 1 & \\
\hline Australia & Jennifer Bryant & Department of Health and Ageing & & & & & & 1 & & \\
\hline Australia & Jim Bishop & Department of Health and Ageing & & & & & & 1 & & \\
\hline Australia & John Mackenzie & $\begin{array}{l}\text { Division of Health Sciences, } \\
\text { Curtin University }\end{array}$ & & & & 1 & & 1 & & \\
\hline
\end{tabular}




\begin{tabular}{|c|c|c|c|c|c|c|c|c|c|c|}
\hline Country & Member & Institution & $\begin{array}{l}\text { GISN } \\
2010\end{array}$ & $\begin{array}{l}\text { Collabor. } \\
\text { Centres } \\
2018\end{array}$ & $\begin{array}{l}\text { Cancun } \\
\text { Influenza } \\
2009\end{array}$ & $\begin{array}{l}\text { EC } \\
\text { Influenza }\end{array}$ & $\begin{array}{l}\text { CRIHR } \\
\text { Influenza }\end{array}$ & $\begin{array}{l}\text { Review } \\
\text { H1N1 }\end{array}$ & GSAID & GHSI \\
\hline Australia & Julian Druce & $\begin{array}{l}\text { Virus Identification Laboratory, } \\
\text { Victorian Infectious Diseases } \\
\text { Reference Laboratory (VIDRL) }\end{array}$ & & 1 & & & & & & \\
\hline Australia & Mary Murnane & Department of Health and Ageing & & & & & & 1 & & \\
\hline Australia & Naomi Komadina & $\begin{array}{l}\text { Peter Doherty Institute for } \\
\text { Infection \& Immunity }\end{array}$ & & & & & & & 1 & \\
\hline Australia & David Smith & PathWest Laboratory Medicine & & 1 & & & & & & \\
\hline Australia & Dominic Dwyer & $\begin{array}{l}\text { Institute of Clinical Pathology and } \\
\text { Medical Research (ICPMR), } \\
\text { Westmead Hospital }\end{array}$ & & 1 & & & & & & \\
\hline Austria & Franz X. Heinz & Medical University of Vienna & & 1 & & & & & & \\
\hline Azerbaijan & Vagif Abdullayev & $\begin{array}{l}\text { Republican Centre of Hygiene } \\
\text { and Epidemiology }\end{array}$ & & & & & & 1 & & \\
\hline Bahrain & Amjad Zaed & Public Health Laboratory & & 1 & & & & & & \\
\hline Bangladesh & Mahmudur Rahman & $\begin{array}{l}\text { Ministry of Health and Family } \\
\text { Welfare }\end{array}$ & & 1 & & & 1 & & & \\
\hline Belarus & Liudmila Naroichyk & $\begin{array}{l}\text { Republican Centre for Hygiene, } \\
\text { Epidemiology and Public Health }\end{array}$ & & & & & & 1 & & \\
\hline Belarus & Natalia Gribkova & $\begin{array}{l}\text { Republican Research \& Practical } \\
\text { Centre for Epidemiology and } \\
\text { Microbiology }\end{array}$ & & 1 & & & & & & \\
\hline Belgium & Dirk Cuypers & Ministry of Health & & & 1 & & & & & \\
\hline Belgium & Isabelle Thomas & $\begin{array}{l}\text { Scientific Institute of Public } \\
\text { Health }\end{array}$ & & 1 & & & & & & \\
\hline Belize & Pablo Marín & Ministry of Health & & & 1 & & & & & \\
\hline Belize & Paul Edwards & Ministry of Health & & & 1 & & & & & \\
\hline Bolivia & $\begin{array}{l}\text { Jorge Ramiro Tapia } \\
\text { Sainz }\end{array}$ & Ministry of Health & & & 1 & & & & & \\
\hline Brazil & Agenor Alvarez & ANVISA & & & 1 & & & & & \\
\hline Brazil & Eduardo Hage Carmo & Ministry of Health & & & & & 1 & & & \\
\hline
\end{tabular}




\begin{tabular}{|c|c|c|c|c|c|c|c|c|c|c|}
\hline Country & Member & Institution & $\begin{array}{l}\text { GISN } \\
2010\end{array}$ & $\begin{array}{l}\text { Collabor. } \\
\text { Centres } \\
2018\end{array}$ & $\begin{array}{l}\text { Cancun } \\
\text { Influenza } \\
2009\end{array}$ & $\begin{array}{l}\text { EC } \\
\text { Influenza }\end{array}$ & $\begin{array}{l}\text { CRIHR } \\
\text { Influenza }\end{array}$ & $\begin{array}{l}\text { Review } \\
\text { H1N1 }\end{array}$ & GSAID & GHSI \\
\hline Brazil & $\begin{array}{l}\text { Carlos Felipe Almeida } \\
\text { de Oliveira }\end{array}$ & Ministry of Health & & & 1 & & & & & \\
\hline Brazil & Cristiano Gregis & $\begin{array}{l}\text { Agencia Nacional de Vigilancia } \\
\text { Sanitaria }\end{array}$ & & & 1 & & & & & \\
\hline Brazil & $\begin{array}{l}\text { Terezinha Maria de } \\
\text { Paiva }\end{array}$ & $\begin{array}{l}\text { National Influenza Centre, } \\
\text { Instituto Adolfo Lutz }\end{array}$ & & 1 & & & & & & \\
\hline Brazil & $\begin{array}{l}\text { Wyller Alencar de } \\
\text { Mello }\end{array}$ & $\begin{array}{l}\text { National Influenza } \\
\text { Centre,Instituto Evandro Chagas, } \\
\text { SVS-MS }\end{array}$ & 1 & 1 & & & & & & \\
\hline Brazil & Marilda Siqueira & Instituto Oswaldo Cruz & & 1 & & & & & & \\
\hline Bulgaria & Neli Korsun & $\begin{array}{l}\text { National Laboratory "Influenza } \\
\text { and ARD" }\end{array}$ & & 1 & & & & & & \\
\hline Cambodia & Philippe Dussart & Institut Pasteur in Cambodia & & 1 & & & & & & \\
\hline Cameroon & Richard Njouom & Centre Pasteur du Cameroun & 1 & 1 & & & & & & \\
\hline Canada & Anthony Evans & $\begin{array}{l}\text { International Civil Aviation } \\
\text { Organization (ICAO) }\end{array}$ & & & & 1 & & 1 & & \\
\hline Canada & Arlene King & $\begin{array}{l}\text { Ontario Ministry of Health and } \\
\text { Long-Term Care }\end{array}$ & & & & & 1 & & & \\
\hline Canada & Claude Thibeault & $\begin{array}{l}\text { International Air Transport } \\
\text { Association (IATA) }\end{array}$ & & & & 1 & & 1 & & \\
\hline Canada & David Butler-Jones & Public Health Agency of Canada & & & 1 & & & 1 & & 1 \\
\hline Canada & Jane Billings & Public Health Agency of Canada & & & 1 & & & & & 1 \\
\hline Canada & Michael Aubie, & Ministry of Health & & & 1 & & & & & \\
\hline Canada & Yan Li & Public Health Agency of Canada & & 1 & & & & & & \\
\hline Canada & Brian Evans & Canada Food Inspection Agency & & & 1 & & & & & \\
\hline Canada & Elaine Chatigny & Public Health Agency of Canada & & & 1 & & & & & 1 \\
\hline Canada & Francis A. Plummer & Public Health Agency of Canada & & & 1 & & & & & 1 \\
\hline Canada & Leona Aglukkaq & Ministry of Health & & & 1 & & & & & 1 \\
\hline Canada & Ross Upshur & University of Toronto & & & 1 & & & & & \\
\hline
\end{tabular}




\begin{tabular}{|c|c|c|c|c|c|c|c|c|c|c|}
\hline Country & Member & Institution & $\begin{array}{l}\text { GISN } \\
2010\end{array}$ & $\begin{array}{l}\text { Collabor. } \\
\text { Centres } \\
2018\end{array}$ & $\begin{array}{l}\text { Cancun } \\
\text { Influenza } \\
2009\end{array}$ & $\begin{array}{l}\text { EC } \\
\text { Influenza }\end{array}$ & $\begin{array}{l}\text { CRIHR } \\
\text { Influenza }\end{array}$ & $\begin{array}{l}\text { Review } \\
\text { H1N1 }\end{array}$ & GSAID & GHSI \\
\hline CARICOM & Edwin W. Carrington & CARICOM & & & 1 & & & & & \\
\hline $\begin{array}{l}\text { Central } \\
\text { African } \\
\text { Republic }\end{array}$ & $\begin{array}{l}\text { Emmanuel Nakouné } \\
\text { a.i. }\end{array}$ & Institute Pasteur de Bangui & & 1 & & & & & & \\
\hline Chile & Álvaro Erazo Latorre & Ministry of Health & & & 1 & & & & & \\
\hline Chile & Cecilia Morales & Ministry of Health & & & 1 & & & & & \\
\hline Chile & Claudia González & Universidad del Desarrollo & & & 1 & & 1 & & & \\
\hline Chile & Fernando Otaiza & Ministry of Health & & & & 1 & & & & \\
\hline Chile & Jeanette Dabanch & & & & 1 & & & & & \\
\hline Chile & Maritza Garcia & Ministry of Health & & & & & & 1 & & \\
\hline Chile & Rodrigo Fasce & $\begin{array}{l}\text { Laboratorio de Virus } \\
\text { Respiratorios y } \\
\text { Exantematicos, Instituto de Salud } \\
\text { Publica de Chile }\end{array}$ & 1 & 1 & & & & & & \\
\hline Chile & Rosanna Lagos & Ministry of Health & & & 1 & & & & & \\
\hline Chile & Pedro Astudillo & Ministry of Health & & & 1 & & & & & \\
\hline Chima & Yuelong Shu & Sun Yat-sen University & & & & & & & 1 & \\
\hline China & Dayan Wang & & 1 & 1 & & & & & & \\
\hline China & George Fu Gao & $\begin{array}{l}\text { Chinese Centre for Disease } \\
\text { Control and Prevention }\end{array}$ & & & & & & & 1 & \\
\hline China & Hualan Chen & $\begin{array}{l}\text { Ministry of Agriculture, Harbin } \\
\text { Veterinary Research Institute }\end{array}$ & & & & & & & 1 & \\
\hline China & Li Qiuting & $\begin{array}{l}\text { International Development } \\
\text { Ministry }\end{array}$ & & & 1 & & & & & \\
\hline China & Li Xiang & Ministry of Health & & & 1 & & & & & \\
\hline China & Ren Minghui & Ministry of Health & & & 1 & & & & & \\
\hline China & Wing Hong Seto & Queen Mary Hospital & & & & 1 & & & & \\
\hline China & Yu Lan & Chinese National Influenza Centre & & & & & & & 1 & \\
\hline
\end{tabular}




\begin{tabular}{|c|c|c|c|c|c|c|c|c|c|c|}
\hline Country & Member & Institution & $\begin{array}{l}\text { GISN } \\
2010\end{array}$ & $\begin{array}{l}\text { Collabor. } \\
\text { Centres } \\
2018\end{array}$ & $\begin{array}{l}\text { Cancun } \\
\text { Influenza } \\
2009\end{array}$ & $\begin{array}{l}\text { EC } \\
\text { Influenza }\end{array}$ & $\begin{array}{l}\text { CRIHR } \\
\text { Influenza }\end{array}$ & $\begin{array}{l}\text { Review } \\
\text { H1N1 }\end{array}$ & GSAID & GHSI \\
\hline China & Yu Wang & $\begin{array}{l}\text { Chinese Centre for Disease } \\
\text { Control and Prevention }\end{array}$ & & & & & 1 & & & \\
\hline China & Chen Xianyi & & & & 1 & & & & & \\
\hline China & Chen Zhu & Ministry of Health & & & 1 & & & & & \\
\hline China & Shu Yuelong & $\begin{array}{l}\text { Chinese Centre for Disease } \\
\text { Control and Prevention }\end{array}$ & & & 1 & & & & & \\
\hline China & Xiao Donglou & Ministry of Health & 1 & & 1 & & & & & \\
\hline China & Yang Weizhong & $\begin{array}{l}\text { Chinese Centre for Disease } \\
\text { Control and Prevention }\end{array}$ & & & 1 & & & & & \\
\hline Colombia & $\begin{array}{l}\text { Juliana Barbosa } \\
\text { Ramirez }\end{array}$ & $\begin{array}{l}\text { Instituto Nacional de Salud de } \\
\text { Colombia }\end{array}$ & & 1 & & & & & & \\
\hline Costa Rica & Jenny Lara & $\begin{array}{l}\text { Laboratorio Nacional de } \\
\text { Influenza }\end{array}$ & & 1 & & & & & & \\
\hline Costa Rica & Daniel Salas Peraza & & & & 1 & & & & & \\
\hline Costa Rica & Marcela Hernández & Hospital Nacional de Ninos & & & 1 & & & & & \\
\hline Costa Rica & $\begin{array}{l}\text { María Luisa Ávila } \\
\text { Agüero }\end{array}$ & Ministry of Health & & & 1 & & & & & \\
\hline Costa Rica & $\begin{array}{l}\text { Rossana Garcia } \\
\text { Gonzalez }\end{array}$ & Ministry of Health & & & 1 & & & & & \\
\hline Côte d'Ivoire & $\begin{array}{l}\text { Paul Odehouri- } \\
\text { Koudou }\end{array}$ & $\begin{array}{l}\text { National Institute of Public } \\
\text { Hygiene }\end{array}$ & & & & & 1 & & & \\
\hline Côte d'Ivoire & Hervé Kadjo & Institut Pasteur de Côte d'Ivoire & & 1 & & & & & & \\
\hline Croatia & Vladimir Drazenovic & $\begin{array}{l}\text { Croatian Institute of Public } \\
\text { Health }\end{array}$ & 1 & 1 & & & & & & \\
\hline Cuba & Betsy Acosta Herrera & $\begin{array}{l}\text { Instituto de Medicina Tropical } \\
\text { "Pedro Kourí" }\end{array}$ & 1 & 1 & & & & & & \\
\hline Cuba & Alina Llop Hernández & $\begin{array}{l}\text { Instituto Medico Tropical "Pedro } \\
\text { Kuri" de Cuba }\end{array}$ & & & 1 & & & & & \\
\hline Cuba & Luis Estruch Rancaño & & & & 1 & & & & & \\
\hline $\begin{array}{l}\text { Czech } \\
\text { Republic }\end{array}$ & Dana Juraskova & Ministry of Health & & & 1 & & & & & \\
\hline
\end{tabular}




\begin{tabular}{|c|c|c|c|c|c|c|c|c|c|c|}
\hline Country & Member & Institution & $\begin{array}{l}\text { GISN } \\
2010\end{array}$ & $\begin{array}{l}\text { Collabor. } \\
\text { Centres } \\
2018\end{array}$ & $\begin{array}{l}\text { Cancun } \\
\text { Influenza } \\
2009\end{array}$ & $\begin{array}{l}\text { EC } \\
\text { Influenza }\end{array}$ & $\begin{array}{l}\text { CRIHR } \\
\text { Influenza }\end{array}$ & $\begin{array}{l}\text { Review } \\
\text { H1N1 }\end{array}$ & GSAID & GHSI \\
\hline $\begin{array}{l}\text { Czech } \\
\text { Republic }\end{array}$ & Martina Havlickova & $\begin{array}{l}\text { National Institute of Public } \\
\text { Health, Centre for Epidemiology } \\
\text { and Microbiology }\end{array}$ & 1 & 1 & & & & & & \\
\hline $\begin{array}{l}\text { Democratic } \\
\text { People's } \\
\text { Republic of } \\
\text { Korea }\end{array}$ & K. Dong Guy & $\begin{array}{l}\text { Central Hygienic Anti-epidemic } \\
\text { Station }\end{array}$ & & 1 & & & & & & \\
\hline Denmark & Caroline Brown & EURO & 1 & & & & & & & \\
\hline Denmark & Dimitriy Pereyaslov & EURO & 1 & & & & & & & \\
\hline Denmark & Thea Kølsen Fischer & Statens Serum Institut & & 1 & & & & & & \\
\hline Denmarl & Benjamin Turner & QIAGEN Bioinformatics & & & & & & & 1 & \\
\hline $\begin{array}{l}\text { Dominican } \\
\text { Republic }\end{array}$ & $\begin{array}{l}\text { Nelson Rodríguez } \\
\text { Monegro }\end{array}$ & Ministry of Health & & & 1 & & & & & \\
\hline Ecuador & $\begin{array}{l}\text { Ricardo Cañizares } \\
\text { Fuentes }\end{array}$ & Ministry of Health & & & 1 & & & & & \\
\hline Ecuador & $\begin{array}{l}\text { Alfredo Bruno } \\
\text { Caicedo }\end{array}$ & $\begin{array}{l}\text { Instituto Nacional de } \\
\text { Investigación en Salud Pública }\end{array}$ & & 1 & & & & & & \\
\hline Ecuador & Eulalia Narvaez & Ministry of Health & & & 1 & & & & & \\
\hline Egypt & Ali Mafi & EMRO/WHO & 1 & & & & & & & \\
\hline Egypt & $\begin{array}{l}\text { Amel Mohamed } \\
\text { Naguib }\end{array}$ & Central Public Health Laboratory & & 1 & & & & & & \\
\hline Egypt & $\begin{array}{l}\text { Amr Mohamed } \\
\text { Kandeel }\end{array}$ & Ministry of Health & & & 1 & & 1 & & & \\
\hline Egypt & Claire A. Cornelius & $\begin{array}{l}\text { US Naval Medical Research Unit } \\
\text { No. } 3 \text { (NAMRU-3) }\end{array}$ & 1 & & & & & & & \\
\hline Egypt & Hassan El Bushra & EMRO/WHO & 1 & & & & & & & \\
\hline Egypt & Nagwa El Kholy & $\begin{array}{l}\text { Egyptian Organisation for } \\
\text { Biological Products and Vaccines } \\
\text { (VACSERA) }\end{array}$ & 1 & & & & & & & \\
\hline Egypt & $\begin{array}{l}\text { Samir Abdel Aziz El } \\
\text { Rafie }\end{array}$ & Ministry of Health & & & & & & 1 & & \\
\hline
\end{tabular}




\begin{tabular}{|c|c|c|c|c|c|c|c|c|c|c|}
\hline Country & Member & Institution & $\begin{array}{l}\text { GISN } \\
2010\end{array}$ & $\begin{array}{l}\text { Collabor. } \\
\text { Centres } \\
2018\end{array}$ & $\begin{array}{l}\text { Cancun } \\
\text { Influenza } \\
2009\end{array}$ & $\begin{array}{l}\text { EC } \\
\text { Influenza }\end{array}$ & $\begin{array}{l}\text { CRIHR } \\
\text { Influenza }\end{array}$ & $\begin{array}{l}\text { Review } \\
\text { H1N1 }\end{array}$ & GSAID & GHSI \\
\hline Egypt & Samir Elrfaey & & & & 1 & & & & & \\
\hline Egypt & $\begin{array}{l}\text { Hatem Mostafa El- } \\
\text { Gabaly }\end{array}$ & Ministry of Health and Population & & & 1 & & & & & \\
\hline Egypt & $\begin{array}{l}\text { Iman Fawzy } \\
\text { Mahmoud Farghal }\end{array}$ & $\begin{array}{l}\text { Egyptian Holding Company for } \\
\text { Biological Products and Vaccines } \\
\text { (VACSERA) }\end{array}$ & & 1 & & & & & & \\
\hline Egypt & Moukhtar Wereida & & & & 1 & & & & & \\
\hline Egypt & Seham Sadek & & & & 1 & & & & & \\
\hline El Salvador & $\begin{array}{l}\text { Eduardo Suarez } \\
\text { Castañeda }\end{array}$ & $\begin{array}{l}\text { Ministry of Public Health and } \\
\text { Social Assistance }\end{array}$ & & & 1 & & & & & \\
\hline El Salvador & $\begin{array}{l}\text { Fatima Trinidad Valle } \\
\text { de Zuñiga }\end{array}$ & Universidad del El Salvador & & & 1 & & & & & \\
\hline El Salvador & Patricia Alberto & $\begin{array}{l}\text { Comisión Nacional de la Influenza } \\
\text { y Colaboradora Técnica de la } \\
\text { Unidad de Epidemiología de El } \\
\text { Salvador }\end{array}$ & & & 1 & & & & & \\
\hline El Salvador & $\begin{array}{l}\text { Mónica Jeannette } \\
\text { Barahona de Gámez }\end{array}$ & $\begin{array}{l}\text { Laboratorio Central Ministerio de } \\
\text { Salud Publica "Dr Max Bloch" }\end{array}$ & & 1 & & & & & & \\
\hline Estonia & Kaie Otsmaa & NIC Estonia, Tallinn, Estonia & 1 & & & & & & & \\
\hline Estonia & Natalja Kuznetsova & $\begin{array}{l}\text { Laboratory for Communicable } \\
\text { Diseases }\end{array}$ & & 1 & & & & & & \\
\hline $\begin{array}{l}\text { European } \\
\text { Union }\end{array}$ & Angus Nicoll & $\begin{array}{l}\text { European Centre for Disease } \\
\text { Prevention and Control }\end{array}$ & & & & & & 1 & & \\
\hline $\begin{array}{l}\text { European } \\
\text { Union }\end{array}$ & Marc Sprenger & $\begin{array}{l}\text { European Centre for Disease } \\
\text { Prevention and Control }\end{array}$ & & & & & & 1 & & \\
\hline Fiji & Eric Rafai & $\begin{array}{l}\text { Centre for Communicable Disease } \\
\text { Control }\end{array}$ & & 1 & & & & & & \\
\hline Finland & Thedi Ziegler & NIC Finland, Helsinki, Finland & 1 & & & & & & & \\
\hline Finland & Niina Ikonen & $\begin{array}{l}\text { National Institute for Health and } \\
\text { Welfare }\end{array}$ & & 1 & & & & & & \\
\hline
\end{tabular}




\begin{tabular}{|c|c|c|c|c|c|c|c|c|c|c|}
\hline Country & Member & Institution & $\begin{array}{l}\text { GISN } \\
2010\end{array}$ & $\begin{array}{l}\text { Collabor. } \\
\text { Centres } \\
2018\end{array}$ & $\begin{array}{l}\text { Cancun } \\
\text { Influenza } \\
2009\end{array}$ & $\begin{array}{l}\text { EC } \\
\text { Influenza }\end{array}$ & $\begin{array}{l}\text { CRIHR } \\
\text { Influenza }\end{array}$ & $\begin{array}{l}\text { Review } \\
\text { H1N1 }\end{array}$ & GSAID & GHSI \\
\hline France & Alex Thiermann & $\begin{array}{l}\text { Terrestrial Animal Health Code } \\
\text { Commission / World Organisation } \\
\text { for Animal Health (OIE) }\end{array}$ & & & & & & 1 & & \\
\hline France & Atika Abelin & Sanofi Pasteur & & & & & & 1 & & \\
\hline France & Didier Houssin & Ministry of Health & & & & & & 1 & & 1 \\
\hline France & Jacques Berger & Sanofi Pasteur & & & & & & 1 & & \\
\hline France & $\begin{array}{l}\text { José Joaquín } \\
\text { Oreamuno }\end{array}$ & $\begin{array}{l}\text { World Organisation for Animal } \\
\text { Health }\end{array}$ & & & 1 & & & & & \\
\hline France & Kate Glynn & $\begin{array}{l}\text { World Organisation for Animal } \\
\text { Health }\end{array}$ & & & & & & 1 & & \\
\hline France & Keith Hamilton & $\begin{array}{l}\text { World Organisation for Animal } \\
\text { Health }\end{array}$ & 1 & & & & & & & \\
\hline France & Patricia Leung-Tack & Sanofi Pasteur SA & 1 & & & & & 1 & & \\
\hline France & Paul Benkimoun & Le Monde & & & & & & 1 & & \\
\hline France & Sylvie van der WERF & Pasteur Institute & & & & & & & 1 & \\
\hline France & Bruno Lina & $\begin{array}{l}\text { Centre National de Référence du } \\
\text { Virus Influenza Région Sud }\end{array}$ & & 1 & & & & & & \\
\hline France & Daniel Camus & Ministry of Health and Sports & & & 1 & & & & & \\
\hline France & Sylvie Van der Werf & Institut Pasteur & & 1 & & & & & & \\
\hline $\begin{array}{l}\text { France - } \\
\text { Cayenne }\end{array}$ & Dominique Rousset & Institut Pasteur de la Guyane & 1 & 1 & & & & & & \\
\hline $\begin{array}{l}\text { France-New } \\
\text { Caledonia - }\end{array}$ & $\begin{array}{l}\text { Dominique Baudon } \\
\text { a.i. }\end{array}$ & $\begin{array}{l}\text { Institut Pasteur de Nouvelle- } \\
\text { Calédonie }\end{array}$ & & 1 & & & & & & \\
\hline Gabon & $\begin{array}{l}\text { Jean Damascène } \\
\text { Khouilla }\end{array}$ & $\begin{array}{l}\text { Director General of Public Health, } \\
\text { Health Agency }\end{array}$ & & & & & & 1 & & \\
\hline Georgia & Ann Machablishvili & $\begin{array}{l}\text { Centre for Disease Control and } \\
\text { Public Health }\end{array}$ & 1 & 1 & & & & & & \\
\hline Germany & Albercht Schad & Ministry of Health & & & 1 & & & & & \\
\hline Germany & Brunhilde Schweiger & NIC Germany, Berlin, Germany & 1 & & & & & & & \\
\hline
\end{tabular}




\begin{tabular}{|c|c|c|c|c|c|c|c|c|c|c|}
\hline Country & Member & Institution & $\begin{array}{l}\text { GISN } \\
2010\end{array}$ & $\begin{array}{l}\text { Collabor. } \\
\text { Centres } \\
2018\end{array}$ & $\begin{array}{l}\text { Cancun } \\
\text { Influenza } \\
2009\end{array}$ & $\begin{array}{l}\text { EC } \\
\text { Influenza }\end{array}$ & $\begin{array}{l}\text { CRIHR } \\
\text { Influenza }\end{array}$ & $\begin{array}{l}\text { Review } \\
\text { H1N1 }\end{array}$ & GSAID & GHSI \\
\hline Germany & Gérard Krause & $\begin{array}{l}\text { National Public Health Institute, } \\
\text { Robert Koch }\end{array}$ & & & 1 & & & 1 & & \\
\hline Germany & Joachim Büch & $\begin{array}{l}\text { Computational Biology and } \\
\text { Applied Algorithmics }\end{array}$ & & & & & & & 1 & \\
\hline Germany & Lars Schaade & Robert Koch Institute & & & & & & 1 & & \\
\hline Germany & Martin Beer & $\begin{array}{l}\text { Friedrich-Loeffler-Institute, } \\
\text { Federal Institute for Animal } \\
\text { Health }\end{array}$ & & & & & & & 1 & \\
\hline Germany & Ralf Dürrwald a.i. & Robert Koch-Institute & & 1 & & & & & & \\
\hline Germany & $\begin{array}{l}\text { Thomas C. } \\
\text { Mettenleiter }\end{array}$ & $\begin{array}{l}\text { Friedrich-Loeffler-Institute, } \\
\text { Federal Institute for Animal } \\
\text { Health }\end{array}$ & & & & & & & 1 & \\
\hline Germany & Thomas Lengauer & $\begin{array}{l}\text { Computational Biology and } \\
\text { Applied Algorithmics }\end{array}$ & & & & & & & 1 & \\
\hline Germany & Thorsten Wolff & Robert Koch Institute & & & & & & & 1 & \\
\hline Germany & $\begin{array}{l}\text { Karin Knufmann } \\
\text { Happe }\end{array}$ & Ministry of Health & & & 1 & & & & & \\
\hline Germany & Klaus Theo Schröder & Federal Ministry of Health & & & 1 & & & & & 1 \\
\hline Germany & Timo Ulrichs & Ministry of Health & & & 1 & & & & & \\
\hline Ghana & Lawson Ahadzie & Ministry of Health & & & & 1 & & & & \\
\hline Ghana & $\begin{array}{l}\text { William Kwabena } \\
\text { Ampofo }\end{array}$ & $\begin{array}{l}\text { National Influenza Laboratory, } \\
\text { University of Ghana }\end{array}$ & 1 & 1 & & & & & & \\
\hline Greece & Angeliki Melidou & NIC Greece & 1 & & & & & & & \\
\hline Greece & Andreas Mentis & Institut Pasteur Hellénique & & 1 & & & & & & \\
\hline Greece & Anna Papa-Konidari & $\begin{array}{l}\text { National Influenza Centre for N. } \\
\text { Greece }\end{array}$ & & 1 & & & & & & \\
\hline Guatemala & Nivaldo Linares & $\begin{array}{l}\text { Centres for Disease Control and } \\
\text { Prevention }\end{array}$ & & & 1 & & & & & \\
\hline Guatemala & Jesús Oliva Leal & Universidad de San Carlos & & & 1 & & & & & \\
\hline
\end{tabular}




\begin{tabular}{|c|c|c|c|c|c|c|c|c|c|c|}
\hline Country & Member & Institution & $\begin{array}{l}\text { GISN } \\
2010\end{array}$ & $\begin{array}{l}\text { Collabor. } \\
\text { Centres } \\
2018\end{array}$ & $\begin{array}{l}\text { Cancun } \\
\text { Influenza } \\
2009\end{array}$ & $\begin{array}{l}\text { EC } \\
\text { Influenza }\end{array}$ & $\begin{array}{l}\text { CRIHR } \\
\text { Influenza }\end{array}$ & $\begin{array}{l}\text { Review } \\
\text { H1N1 }\end{array}$ & GSAID & GHSI \\
\hline Guatemala & Leticia Castillo Signor & $\begin{array}{l}\text { Centro Nacional de Influenza, } \\
\text { Laboratorio Nacional de Salud }\end{array}$ & & 1 & & & & & & \\
\hline Guatemala & Víctor Guerra & $\begin{array}{l}\text { Viceministro de Salud de } \\
\text { Guatemala }\end{array}$ & & & 1 & & & & & \\
\hline Honduras & $\begin{array}{l}\text { Carlos Roberto } \\
\text { Aguilar Pineda }\end{array}$ & Ministry of Health & & & 1 & & & & & \\
\hline Honduras & Rudvelinda Rivera & Ministry of Health & & 1 & & & & & & \\
\hline Hong Kong & Janice Lo & $\begin{array}{l}\text { National Influenza Centre, Centre } \\
\text { for Health Protection }\end{array}$ & & 1 & & & & & & \\
\hline Hong Kong & Wilina Lim & $\begin{array}{l}\text { Centre for Health Protection, } \\
\text { Hong Kong, China S.A.R }\end{array}$ & 1 & & & & & & & \\
\hline Hungary & Istvan Jankovics & $\begin{array}{l}\text { B. Johan National Centre for } \\
\text { Epidemiology }\end{array}$ & & 1 & & & & & & \\
\hline Iceland & Arthur Löve & Landspitali - University Hospital & & 1 & & & & & & \\
\hline India & Akhilesh C. Mishra & National Institute of Virology & & & & & & & 1 & \\
\hline India & Ghulam Nabi Azad & $\begin{array}{l}\text { Ministry of Health and Family } \\
\text { Welfare }\end{array}$ & & & 1 & & & & & \\
\hline India & Jagvir Singh & $\begin{array}{l}\text { National Centre for Disease } \\
\text { Control }\end{array}$ & 1 & & & & & & & \\
\hline India & Mandeep Chadha & NIC India & 1 & & & & & & & \\
\hline India & Palliri Ravindran & Ministry of Health & & & & & 1 & & & \\
\hline India & Ranjana Deshmukh & Department of Virology & & 1 & & & & & & \\
\hline India & Suresh Jadhav & $\begin{array}{l}\text { Serum Institute of India and } \\
\text { former President of the } \\
\text { Developing Countries Vaccine } \\
\text { Manufacturers' Network }\end{array}$ & & & & & & 1 & & \\
\hline India & D T Mourya a.i. & National Institute of Virology & & 1 & & & & & & \\
\hline India & Usha Soren Singh & $\begin{array}{l}\text { National Influenza Centre, Central } \\
\text { Research Institute }\end{array}$ & & 1 & & & & & & \\
\hline
\end{tabular}




\begin{tabular}{|c|c|c|c|c|c|c|c|c|c|c|}
\hline Country & Member & Institution & $\begin{array}{l}\text { GISN } \\
2010\end{array}$ & $\begin{array}{l}\text { Collabor. } \\
\text { Centres } \\
2018\end{array}$ & $\begin{array}{l}\text { Cancun } \\
\text { Influenza } \\
2009\end{array}$ & $\begin{array}{l}\text { EC } \\
\text { Influenza }\end{array}$ & $\begin{array}{l}\text { CRIHR } \\
\text { Influenza }\end{array}$ & $\begin{array}{l}\text { Review } \\
\text { H1N1 }\end{array}$ & GSAID & GHSI \\
\hline Indonesia & Agus Purwandianto & $\begin{array}{l}\text { Research and Development in } \\
\text { Health Council }\end{array}$ & & & 1 & & & & & \\
\hline Indonesia & Novilia Sjari Bachtiar & $\begin{array}{l}\text { PT. Bio Farma Bandung, } \\
\text { Indonesia }\end{array}$ & 1 & & & & & & & \\
\hline Indonesia & Ondri Dwi Sampurno & NIC Indonesia, Jakarta, Indonesia & 1 & & & & & & & \\
\hline Indonesia & $\begin{array}{l}\text { Professor Tjandra } \\
\text { Aditama }\end{array}$ & Ministry of Health & & & & & 1 & & & \\
\hline Indonesia & Rini Mulia Sari & $\begin{array}{l}\text { PT. Bio Farma Bandung, } \\
\text { Indonesia }\end{array}$ & 1 & & & & & & & \\
\hline Indonesia & Vivi Setiawaty & $\begin{array}{l}\text { National Institute of Health, } \\
\text { Research \& Development }\end{array}$ & & & & & & & 1 & \\
\hline Indonesia & Pretty Multihartina & $\begin{array}{l}\text { Centre for Biomedical and Basic } \\
\text { Technology of Health, National } \\
\text { Institute of Health Research and } \\
\text { Development }\end{array}$ & & 1 & & & & & & \\
\hline Indonesia & $\begin{array}{l}\text { Sunarno Ranu } \\
\text { Widjojo }\end{array}$ & & & & 1 & & & & & \\
\hline Iran & $\begin{array}{l}\text { Mohammad Mehdi } \\
\text { Gouya }\end{array}$ & $\begin{array}{l}\text { Ministry of Health and Medical } \\
\text { Education }\end{array}$ & & & & & 1 & & & \\
\hline Iran & Talat Mokhtari-Azad & $\begin{array}{l}\text { Iranian National Influenza Centre, } \\
\text { School of Public Health }\end{array}$ & & 1 & & & & & & \\
\hline Iraq & Imam M. Aufi & National Influenza Centre & & 1 & & & & & & \\
\hline Ireland & Cillian De Gascun & $\begin{array}{l}\text { National Virus Reference } \\
\text { Laboratory }\end{array}$ & & 1 & & & & & & \\
\hline Israel & Avi Israeli & Ministry of Health & & & 1 & & & & & \\
\hline Israel & Michal Mandelboim & Ministry of Health & & 1 & & & & & & \\
\hline Italy & Ilaria Capua & $\begin{array}{l}\text { Istituto Zooprofilattico } \\
\text { Sperimentale Delle Venezie }\end{array}$ & & & & & & & 1 & \\
\hline Italy & Isabella Donatelli & NIC Italy, Rome, Italy & 1 & & & & & & & \\
\hline Italy & Isabella Monne & $\begin{array}{l}\text { Istituto Zooprofilattico } \\
\text { Sperimentale delle Venezie }\end{array}$ & & & & & & & 1 & \\
\hline
\end{tabular}




\begin{tabular}{|c|c|c|c|c|c|c|c|c|c|c|}
\hline Country & Member & Institution & $\begin{array}{l}\text { GISN } \\
2010\end{array}$ & $\begin{array}{l}\text { Collabor. } \\
\text { Centres } \\
2018\end{array}$ & $\begin{array}{l}\text { Cancun } \\
\text { Influenza } \\
2009\end{array}$ & $\begin{array}{l}\text { EC } \\
\text { Influenza }\end{array}$ & $\begin{array}{l}\text { CRIHR } \\
\text { Influenza }\end{array}$ & $\begin{array}{l}\text { Review } \\
\text { H1N1 }\end{array}$ & GSAID & GHSI \\
\hline Italy & Simona Puzelli & NIC Italy, Rome, Italy & 1 & & & & & & & \\
\hline Italy & Thomas Jefferson & Cochrane Vaccines Field & & & & & & 1 & & \\
\hline Italy & Maria Rita Castrucci & Istituto Superiore di Sanità & & 1 & & & & & & \\
\hline Jamaica & Aundré Franklin & Ministry of Health & & & 1 & & & & & \\
\hline Jamaica & Sandra Jackson & NIC Jamaica, Kingston, Jamaica & 1 & & & & & & & \\
\hline Jamaica & Monica Smikle a.i. & $\begin{array}{l}\text { Virology Laboratory, University of } \\
\text { the West Indies University of the } \\
\text { West Indies }\end{array}$ & & 1 & & & & & & \\
\hline Japan & Hiroyuku Hori & $\begin{array}{l}\text { Centro para la Influenza } \\
\text { Pandémica de Japón }\end{array}$ & & & 1 & & & & & \\
\hline Japan & Masato Mugitani & $\begin{array}{l}\text { Ministry of Health, Labor and } \\
\text { Welfare }\end{array}$ & & & 1 & & & 1 & & \\
\hline Japan & Masato Tashiro & $\begin{array}{l}\text { National Institute of Infectious } \\
\text { Diseases, National Institute of } \\
\text { Health }\end{array}$ & 1 & & & 1 & & & 1 & \\
\hline Japan & Nobuhiko Okabe & $\begin{array}{l}\text { National Institute of Infectious } \\
\text { Diseases }\end{array}$ & & & & & 1 & & & \\
\hline Japan & Seiichiro Fujisaki & $\begin{array}{l}\text { National Institute of Infectious } \\
\text { Diseases }\end{array}$ & & & & & & & 1 & \\
\hline Japan & Takato Odagiri & $\begin{array}{l}\text { National Institute of Infectious } \\
\text { Diseases, Influenza Virus } \\
\text { Research Centre }\end{array}$ & & 1 & & & & & 1 & \\
\hline Jordan & Kamel Abusal & Ministry of Health & & & & & & 1 & & \\
\hline Jordan & Asia Adwan a.i. & Laboratory Directorate & & 1 & & & & & & \\
\hline Kazakhstan & Gauhar Nusupbaeva & $\begin{array}{l}\text { Research-Practical Centre of } \\
\text { Sanitary-Epidemiological } \\
\text { Expertise and Monitoring }\end{array}$ & & 1 & & & & & & \\
\hline Kenya & Japeth Magana & Centre for Virus Research & & 1 & & & & & & \\
\hline Kenya & Philip Muthoka & Ministry of Health & & & & & & 1 & & \\
\hline Kirghizstan & Kaliya Kasymbekova & NIC Kirghizstan & 1 & & & & & & & \\
\hline
\end{tabular}




\begin{tabular}{|c|c|c|c|c|c|c|c|c|c|c|}
\hline Country & Member & Institution & $\begin{array}{l}\text { GISN } \\
2010\end{array}$ & $\begin{array}{l}\text { Collabor. } \\
\text { Centres } \\
2018\end{array}$ & $\begin{array}{l}\text { Cancun } \\
\text { Influenza } \\
2009\end{array}$ & $\begin{array}{l}\text { EC } \\
\text { Influenza }\end{array}$ & $\begin{array}{l}\text { CRIHR } \\
\text { Influenza }\end{array}$ & $\begin{array}{l}\text { Review } \\
\text { H1N1 }\end{array}$ & GSAID & GHSI \\
\hline Kuwait & Sarah Al-Qabandi a.i. & Public Health Laboratory & & 1 & & & & & & \\
\hline Kyrgyzstan & $\begin{array}{l}\text { Gulbarchyn Saparova } \\
\text { a.i. }\end{array}$ & $\begin{array}{l}\text { National Virology Laboratory, } \\
\text { Ministry of Health }\end{array}$ & & 1 & & & & & & \\
\hline Lao & $\begin{array}{l}\text { Phengta } \\
\text { Vongphrachanh }\end{array}$ & $\begin{array}{l}\text { National Centre for Laboratory } \\
\text { and Epidemiology }\end{array}$ & & 1 & & & & & & \\
\hline Latvia & Natalija Zamjatina & $\begin{array}{l}\text { National Microbiology Reference } \\
\text { Laboratory, Riga East University } \\
\text { Hospital }\end{array}$ & 1 & 1 & & & & & & \\
\hline Lebanon & $\begin{array}{l}\text { Pierre Zalloua / } \\
\text { Nisrine Jamal a.i. }\end{array}$ & National Influenza Centre & & 1 & & & & & & \\
\hline Lithuania & Vilnele Lipnickiene & $\begin{array}{l}\text { National Public Health } \\
\text { Surveillance Laboratory }\end{array}$ & & 1 & & & & & & \\
\hline Luxemburg & Matthias Opp & Laboratoire National de Santé & 1 & 1 & & & & & & \\
\hline Madagascar & Jean-Michel Heraud & Institut Pasteur de Madagascar & 1 & 1 & & & & & & \\
\hline Malaysia & Jamal I-Ching Sam & University of Malaya & & 1 & & & & & & \\
\hline Malaysia & Zainah Saat & $\begin{array}{l}\text { Virology Unit, Institute of Medical } \\
\text { Research }\end{array}$ & & 1 & & & & & & \\
\hline Maldives & Geela Ali & Health Agency & & & & & & 1 & & \\
\hline Malta & Christopher Barbara & Mater Dei Hospital & & 1 & & & & & & \\
\hline Mauritius & Sanjiv Rughooputh & $\begin{array}{l}\text { Department of Molecular Biology } \\
\text { and Virology Central Health } \\
\text { Laboratory }\end{array}$ & & 1 & & & & & & \\
\hline Mexico & Dante Salazar & PAHO/WHO & & & 1 & & & & & \\
\hline Mexico & Gisela Barrera Badillo & Ministry of Health & 1 & & & & & & & \\
\hline Mexico & $\begin{array}{l}\text { Hugo Lopez-Gatell } \\
\text { Ramirez }\end{array}$ & Ministry of Health & & & 1 & & & 1 & & 1 \\
\hline Mexico & J.J Gomez-Camacho & Ministry of Foreign Affairs & & & & & & 1 & & \\
\hline Mexico & $\begin{array}{l}\text { Jose Ángel Cordova } \\
\text { Villalobos }\end{array}$ & Ministry of Health & & & 1 & & & & & 1 \\
\hline
\end{tabular}




\begin{tabular}{|c|c|c|c|c|c|c|c|c|c|c|}
\hline Country & Member & Institution & $\begin{array}{l}\text { GISN } \\
2010\end{array}$ & $\begin{array}{l}\text { Collabor. } \\
\text { Centres } \\
2018\end{array}$ & $\begin{array}{l}\text { Cancun } \\
\text { Influenza } \\
2009\end{array}$ & $\begin{array}{l}\text { EC } \\
\text { Influenza }\end{array}$ & $\begin{array}{l}\text { CRIHR } \\
\text { Influenza }\end{array}$ & $\begin{array}{l}\text { Review } \\
\text { H1N1 }\end{array}$ & GSAID & GHSI \\
\hline Mexico & $\begin{array}{l}\text { Jose Francisco } \\
\text { Mauricio Garcia }\end{array}$ & Ministry of Health & & & 1 & & & & & \\
\hline Mexico & José Ignacio Santos & $\begin{array}{l}\text { National Autonomous University } \\
\text { of Mexico }\end{array}$ & & & & & 1 & & & \\
\hline Mexico & Julio Manuel Suárez & PAHO/WHO & & & 1 & & & & & \\
\hline Mexico & $\begin{array}{l}\text { Magdy Martínez- } \\
\text { Solimán }\end{array}$ & PNUD & & & 1 & & & & & \\
\hline Mexico & $\begin{array}{l}\text { Mauricio Hernandez } \\
\text { Avila }\end{array}$ & Ministry of Health & & & 1 & & & & & 1 \\
\hline Mexico & Pablo Kuri Morales & Mexican Society of Public Health & & & 1 & & & & & 1 \\
\hline Mexico & Philippe Lamy & PAHO/WHO & & & 1 & & & & & \\
\hline Mexico & Rogelio Pérez Padilla & Ministry of Health & & & 1 & 1 & & & & \\
\hline Mexico & Sergio Garay & PAHO/WHO & & & 1 & & & & & \\
\hline Mexico & Celia Alpuche & Ministry of Health & & & 1 & & & & & 1 \\
\hline Mexico & $\begin{array}{l}\text { Alejandro Macias } \\
\text { Hernandez }\end{array}$ & $\begin{array}{l}\text { National Institute Medical } \\
\text { Sciences and Nutrition }\end{array}$ & & & 1 & & & & & \\
\hline Mexico & Irma Lopez Martinez & Ministry of Health & & 1 & & & & & & \\
\hline Mexico & $\begin{array}{l}\text { Samuel Ponce de } \\
\text { Leon }\end{array}$ & BIRMEX & & & 1 & & & & & \\
\hline Mongolia & Pagbajab Nymadawa & $\begin{array}{l}\text { NIC Mongolia, Ulaanbaatar, } \\
\text { Mongolia }\end{array}$ & 1 & & & & & & & \\
\hline Mongolia & Y. Buyanjargal a.i. & $\begin{array}{l}\text { National Centre for } \\
\text { Communicable Diseases, Ministry } \\
\text { of Health }\end{array}$ & & 1 & & & & & & \\
\hline Montenegro & Zoran Vratnica & $\begin{array}{l}\text { Public Health Institute of } \\
\text { Montenegro }\end{array}$ & & 1 & & & & & & \\
\hline Morocco & Amal Barakat & Institut National d'Hygiène & & 1 & & & & & & \\
\hline Morocco & Fatima El Falaki & NIC Morocco, Rabat, Morocco & 1 & & & & & & & \\
\hline Morocco & Omar El Menzhi & Ministry of Health & & & & & 1 & & & \\
\hline Myanmar & Htay Htay Tin a.i. & National Health Laboratory & & 1 & & & & & & \\
\hline
\end{tabular}




\begin{tabular}{|c|c|c|c|c|c|c|c|c|c|c|}
\hline Country & Member & Institution & $\begin{array}{l}\text { GISN } \\
2010\end{array}$ & $\begin{array}{l}\text { Collabor. } \\
\text { Centres } \\
2018\end{array}$ & $\begin{array}{l}\text { Cancun } \\
\text { Influenza } \\
2009\end{array}$ & $\begin{array}{l}\text { EC } \\
\text { Influenza }\end{array}$ & $\begin{array}{l}\text { CRIHR } \\
\text { Influenza }\end{array}$ & $\begin{array}{l}\text { Review } \\
\text { H1N1 }\end{array}$ & GSAID & GHSI \\
\hline Nepal & Bishnu Upadhyay & NIC Nepal, Kathmandu, Nepal & 1 & & & & & & & \\
\hline Nepal & Garib Das Thakur & Department of Health Services & & & & & & 1 & & \\
\hline Nepal & Geeta Shakya & $\begin{array}{l}\text { National Public Health } \\
\text { Laboratory }\end{array}$ & & 1 & & & & & & \\
\hline Netherlands & Jan De Jong & $\begin{array}{l}\text { NIC Netherlands, Rotterdam, } \\
\text { Netherlands }\end{array}$ & 1 & & & & & & & \\
\hline Netherlands & Ron A.M. Fouchier & Erasmus Medical Centre & & & & & & & 1 & \\
\hline Netherlands & Marion Koopmans & Erasmus Medical Centre & & 1 & & & & & & \\
\hline New Zealand & Andrew Forsyth & Ministry of Health & & & & & 1 & & & \\
\hline New Zealand & Sue Huang & $\begin{array}{l}\text { National Influenza Centre, } \\
\text { Institute of Environmental } \\
\text { Science and Research }\end{array}$ & & 1 & & & & & & \\
\hline New Zealand & Margaret C. Croxson & Auckland City Hospital & & 1 & & & & & & \\
\hline Nicaragua & $\begin{array}{l}\text { Angel Balmaceda } \\
\text { Echeverria }\end{array}$ & Ministry of Health & & 1 & & & & & & \\
\hline Nicaragua & $\begin{array}{l}\text { Guillermina Maria } \\
\text { Kuan Montes }\end{array}$ & $\begin{array}{l}\text { Centrode Salud "Socrates Flores" } \\
\text { de la Ciudad de Managua }\end{array}$ & & & 1 & & & & & \\
\hline Nicaragua & $\begin{array}{l}\text { Guillermo González } \\
\text { González }\end{array}$ & Ministry of Health & & & 1 & & & & & \\
\hline Nicaragua & Miguel Orozco & $\begin{array}{l}\text { Universidad Nacional Autónoma } \\
\text { de Nicaragua }\end{array}$ & & & 1 & & & & & \\
\hline Nicaragua & $\begin{array}{l}\text { Wendy Cecilia } \\
\text { Idiaquez Mendoza }\end{array}$ & Ministry of Health & & & 1 & & & & & \\
\hline Nigeria & Abdulsalami Nasidi & Federal Ministry of Health & & & & & 1 & & & \\
\hline Nigeria & D. Olaleye & University College Hospital & & 1 & & & & & & \\
\hline Nigeria & $\begin{array}{l}\text { Babatunde } \\
\text { Osotimehin }\end{array}$ & Ministry of Health & & & 1 & & & & & \\
\hline Nigeria & Henry Akpan & Ministry of Health & & & 1 & & & & & \\
\hline Nigeria & J. I. Jiya & Ministry of Health & & & 1 & & & & & \\
\hline
\end{tabular}




\begin{tabular}{|c|c|c|c|c|c|c|c|c|c|c|}
\hline Country & Member & Institution & $\begin{array}{l}\text { GISN } \\
2010\end{array}$ & $\begin{array}{l}\text { Collabor. } \\
\text { Centres } \\
2018\end{array}$ & $\begin{array}{l}\text { Cancun } \\
\text { Influenza } \\
2009\end{array}$ & $\begin{array}{l}\text { EC } \\
\text { Influenza }\end{array}$ & $\begin{array}{l}\text { CRIHR } \\
\text { Influenza }\end{array}$ & $\begin{array}{l}\text { Review } \\
\text { H1N1 }\end{array}$ & GSAID & GHSI \\
\hline Nigeria & Shaibu Belgore & Ministry of Health & & & 1 & & & & & \\
\hline Norway & Bente Angell-Hansen & Ministry of Foreign Affairs & & & & & & 1 & & \\
\hline Norway & Bjørn Iversen & $\begin{array}{l}\text { Norwegian Institute of Public } \\
\text { Health }\end{array}$ & & & & & & 1 & & \\
\hline Norway & Else JB Andersen & $\begin{array}{l}\text { Ministry of Health and Care } \\
\text { Service }\end{array}$ & & & & & & 1 & & \\
\hline Norway & Ine Máreng, & Ministry of Foreign Affairs & & & & & & 1 & & \\
\hline Norway & Morten Randmæl & Directorate of Health & & & & & & 1 & & \\
\hline Norway & Olav Hungnes & $\begin{array}{l}\text { Norwegian Institute of Public } \\
\text { Health }\end{array}$ & 1 & 1 & & & & & & \\
\hline Norway & Preben Aavitsland & $\begin{array}{l}\text { Norwegian Institute of Public } \\
\text { Health }\end{array}$ & & & & & 1 & & & \\
\hline Oman & $\begin{array}{l}\text { Said Ali Saif Al } \\
\text { Baqlani }\end{array}$ & NIC Oman & 1 & & & & & & & \\
\hline Oman & Amina Al Jardani & Central Public Health Laboratory & & 1 & & & & & & \\
\hline Pakistan & $\begin{array}{l}\text { Muhammad Akbar } \\
\text { Chaudhry }\end{array}$ & Fatima Jinnah Medical College & & & & 1 & & & & \\
\hline Pakistan & Birjees Mazher Kazi & National Institute of Health & & 1 & & & & & & \\
\hline Panama & $\begin{array}{l}\text { Brechla Moreno A. } \\
\text { a.i. }\end{array}$ & $\begin{array}{l}\text { Instituto Conmemorativo Gorgas } \\
\text { de Estudios de la Salud }\end{array}$ & & 1 & & & & & & \\
\hline Panama & Eduardo Lucas Mora & Ministry of Health & & & 1 & & & & & \\
\hline Panama & Gladys Guerrero & Ministry of Health & & & 1 & & & & & \\
\hline $\begin{array}{l}\text { Papua New } \\
\text { Guinea }\end{array}$ & Amanda Lang a.i. & Institute of Medical Research & & 1 & & & & & & \\
\hline Paraguay & Esperanza Martínez & $\begin{array}{l}\text { Ministry of Health and Social } \\
\text { Assistance }\end{array}$ & & & 1 & & & & & \\
\hline Paraguay & Cynthia Vazquez a.i. & $\begin{array}{l}\text { Laboratorio Central de Salud } \\
\text { Publica }\end{array}$ & & 1 & & & & & & \\
\hline Perú & Oscar Ugarte Ubilluz & Ministerio de Salud & & & 1 & & & & & \\
\hline
\end{tabular}




\begin{tabular}{|c|c|c|c|c|c|c|c|c|c|c|}
\hline Country & Member & Institution & $\begin{array}{l}\text { GISN } \\
2010\end{array}$ & $\begin{array}{l}\text { Collabor. } \\
\text { Centres } \\
2018\end{array}$ & $\begin{array}{l}\text { Cancun } \\
\text { Influenza } \\
2009\end{array}$ & $\begin{array}{l}\text { EC } \\
\text { Influenza }\end{array}$ & $\begin{array}{l}\text { CRIHR } \\
\text { Influenza }\end{array}$ & $\begin{array}{l}\text { Review } \\
\text { H1N1 }\end{array}$ & GSAID & GHSI \\
\hline Peru & $\begin{array}{l}\text { Victoria Guttierez } \\
\text { Peceros a.i. }\end{array}$ & Instituto Nactional de Salud & & 1 & & & & & & \\
\hline Philippines & Marilla G. Lucero & NIC Philippines & 1 & & & & & & & \\
\hline Philippines & Socorro P Lupisan & $\begin{array}{l}\text { Research Institute for Tropical } \\
\text { Medicine }\end{array}$ & & 1 & & & & & & \\
\hline Poland & Lidia B. Brydak & National Influenza Centre & & 1 & & & & & & \\
\hline Portugal & Francisco George & Ministry of Health & & & 1 & & & & & \\
\hline Portugal & Raquel Guiomar & $\begin{array}{l}\text { National Influenza Reference } \\
\text { Laboratory }\end{array}$ & & 1 & & & & & & \\
\hline Qatar & Ajayeb Al-Nabet & Hamad Medical Corporation & & 1 & & & & & & \\
\hline $\begin{array}{l}\text { Republic of } \\
\text { Korea }\end{array}$ & Chun Kang a.i. & $\begin{array}{l}\text { Centres for Laboratory Control of } \\
\text { Infectious Disease }\end{array}$ & & 1 & & & & & & \\
\hline $\begin{array}{l}\text { Republic of } \\
\text { Moldova }\end{array}$ & Constantin Spinu & National Influenza Centre & & 1 & & & & & & \\
\hline Romania & C. Apetrei & $\begin{array}{l}\text { University of Medicine \& } \\
\text { Pharmacy }\end{array}$ & & 1 & & & & & & \\
\hline Romania & Viorel Alexandrescu & Cantacuzino Institute & & 1 & & & & & & \\
\hline Romania & Costin Cernescu & Romanian Academy & & 1 & & & & & & \\
\hline $\begin{array}{l}\text { Russian } \\
\text { Federation }\end{array}$ & $\begin{array}{l}\text { Andrey B. } \\
\text { Komissarov }\end{array}$ & Research Institute of Influenza & & & & & & & 1 & \\
\hline $\begin{array}{l}\text { Russian } \\
\text { Federation }\end{array}$ & Elena Burtseva & NIC Russian Federation & 1 & & & & & & & \\
\hline $\begin{array}{l}\text { Russian } \\
\text { Federation }\end{array}$ & Ludmila Tsybalova & NIC Russian Federation & 1 & & & & & & & \\
\hline $\begin{array}{l}\text { Russian } \\
\text { Federation }\end{array}$ & $\begin{array}{l}\text { Petr Grigorievich } \\
\text { Deryabin }\end{array}$ & $\begin{array}{l}\text { D.I. Ivanovsky Research Institute } \\
\text { of Virology, Ministry of Health }\end{array}$ & & 1 & & & & & & \\
\hline $\begin{array}{l}\text { Russian } \\
\text { Federation }\end{array}$ & Yuri Fedorov & $\begin{array}{l}\text { Federal Service for Surveillance of } \\
\text { Consumer Rights Protection and } \\
\text { Human Well-Being }\end{array}$ & & & & & 1 & & & \\
\hline $\begin{array}{l}\text { Russian } \\
\text { Federation }\end{array}$ & Anna A. Sominina & Ministry of Health & & 1 & & & & & & \\
\hline
\end{tabular}




\begin{tabular}{|c|c|c|c|c|c|c|c|c|c|c|}
\hline Country & Member & Institution & $\begin{array}{l}\text { GISN } \\
2010\end{array}$ & $\begin{array}{l}\text { Collabor. } \\
\text { Centres } \\
2018\end{array}$ & $\begin{array}{l}\text { Cancun } \\
\text { Influenza } \\
2009\end{array}$ & $\begin{array}{l}\text { EC } \\
\text { Influenza }\end{array}$ & $\begin{array}{l}\text { CRIHR } \\
\text { Influenza }\end{array}$ & $\begin{array}{l}\text { Review } \\
\text { H1N1 }\end{array}$ & GSAID & GHSI \\
\hline Samoa & $\begin{array}{l}\text { Palanitina } \\
\text { Tuipuimatagi Toelupe }\end{array}$ & Ministry of Health & & & & & 1 & & & \\
\hline Senegal & Aboubacry Fall & Ministry of Health & & & & & & 1 & & \\
\hline Senegal & André Basse & Embassy of Senegal in France & & & & 1 & & & & \\
\hline Senegal & $\begin{array}{l}\text { Mbayame Ndiaye } \\
\text { Niang }\end{array}$ & Institut Pasteur de Dakar & 1 & 1 & & & & & & \\
\hline Serbia & Jasminka Nedeljkovic & $\begin{array}{l}\text { Institute of Immunology, Vaccine } \\
\text { and Sera "Torlak" }\end{array}$ & 1 & 1 & & & & & & \\
\hline Serbia & Vera Jerant-Patic & Institute of Public Health & & 1 & & & & & & \\
\hline Singapore & $\begin{array}{l}\text { Sebastian Maurer- } \\
\text { Stroh }\end{array}$ & $\begin{array}{l}\text { Bioinformatics Institute, Agency } \\
\text { for Science, Technology, and } \\
\text { Research }\end{array}$ & & & & & & & 1 & \\
\hline Singapore & Soo Sim Lee & $\begin{array}{l}\text { Regional Emerging Disease } \\
\text { Intervention Centre (REDI) }\end{array}$ & 1 & & & & & & & \\
\hline Singapore & Raymon Lin Tzer Pin & Ministry of Health & & 1 & & & & & & \\
\hline Slovakia & Edita Staroňová & $\begin{array}{l}\text { Public Health Authority of the } \\
\text { Slovak Republic }\end{array}$ & & 1 & & & & & & \\
\hline Slovenia & Katarina Prosenc & $\begin{array}{l}\text { Laboratory for Public Health } \\
\text { Virology, National Laboratory for } \\
\text { Health, Environment, and Food }\end{array}$ & 1 & 1 & & & & & & \\
\hline South Africa & Diana Hardie & University of Cape Town & & 1 & & & & & & \\
\hline South Africa & Florette Treurnicht & $\begin{array}{l}\text { National Institute for } \\
\text { Communicable Diseases }\end{array}$ & 1 & 1 & & & & & & \\
\hline South Africa & Kuku Voyi, & University of Pretoria & & & & & 1 & & & \\
\hline South Korea & Jae-Hee Jeon & $\begin{array}{l}\text { Ministry of Health, Welfare, and } \\
\text { Family Affairs }\end{array}$ & & & 1 & & & & & \\
\hline South Korea & Kim You Churl & Ministry of Health & & & 1 & & & & & \\
\hline South Korea & Lee Jong Koo & Korena CDC & & & 1 & & & & & \\
\hline Spain & Carmen Amela Heras & $\begin{array}{l}\text { Ministry of Health and Social } \\
\text { Policy and National IHR Focal } \\
\text { Point }\end{array}$ & & & & & & 1 & & \\
\hline
\end{tabular}




\begin{tabular}{|c|c|c|c|c|c|c|c|c|c|c|}
\hline Country & Member & Institution & $\begin{array}{l}\text { GISN } \\
2010\end{array}$ & $\begin{array}{l}\text { Collabor. } \\
\text { Centres } \\
2018\end{array}$ & $\begin{array}{l}\text { Cancun } \\
\text { Influenza } \\
2009\end{array}$ & $\begin{array}{l}\text { EC } \\
\text { Influenza }\end{array}$ & $\begin{array}{l}\text { CRIHR } \\
\text { Influenza }\end{array}$ & $\begin{array}{l}\text { Review } \\
\text { H1N1 }\end{array}$ & GSAID & GHSI \\
\hline Spain & $\begin{array}{l}\text { Carmen Varela } \\
\text { Santos }\end{array}$ & Eurpean CDC & & & 1 & & & & & \\
\hline Spain & Dirk Glaesser & $\begin{array}{l}\text { United Nations World Tourism } \\
\text { Organization; }\end{array}$ & & & & & & 1 & & \\
\hline Spain & $\begin{array}{l}\text { Ildefonso Hernández } \\
\text { Aguado }\end{array}$ & Ministry of Health & & & 1 & & & & & \\
\hline Spain & Jaime Segura Social & Ministry of Health & & & 1 & & & & & \\
\hline Spain & $\begin{array}{l}\text { María Jesús García } \\
\text { González }\end{array}$ & & & & 1 & & & & & \\
\hline Spain & Raúl Ortiz de Lejarazu & Universidad de Valladolid & & 1 & & & & & & \\
\hline Spain & Tomàs Pumarola & Universidad de Barcelona & 1 & 1 & & & & & & \\
\hline Spain & $\begin{array}{l}\text { Trinidad Jiménez } \\
\text { Garcí-Herrera }\end{array}$ & Ministry of Health & & & 1 & & & & & \\
\hline Spain & Inmaculada Casas & $\begin{array}{l}\text { Centro Nacional de } \\
\text { Microbiología, ISCIII }\end{array}$ & & 1 & & & & & & \\
\hline Sri Lanka & $\begin{array}{l}\text { Geethani } \\
\text { Wickramasinghe }\end{array}$ & NIC Sri Lanka & 1 & & & & & & & \\
\hline Sri Lanka & Jude Jayamaha a.i. & Medical Research Institute & & 1 & & & & & & \\
\hline Sudan & Babiker Magboul & Federal Ministry of Health & & & & & & 1 & & \\
\hline Sudan & $\begin{array}{l}\text { Hayat Salah Eldin } \\
\text { Khogali a.i. }\end{array}$ & Federal Ministry of Health & & 1 & & & & & & \\
\hline Sweden & Eeva Broberg, & $\begin{array}{l}\text { European Centre for Disease } \\
\text { Prevention and Control (ECDC) }\end{array}$ & 1 & & & & & & & \\
\hline Sweden & Frederik Lennartsson & Ministry of Health & & & 1 & & & & & \\
\hline Sweden & $\begin{array}{l}\text { Irene Nilsson- } \\
\text { Carlsson }\end{array}$ & Ministry of Health & & & 1 & & & & & \\
\hline Sweden & Maria Brytting & NIC Sweden, Solna, Sweden & 1 & & & & & & & \\
\hline Sweden & María Larsson & Ministry of Health & & & 1 & & & & & \\
\hline Sweden & Mia Brytting & $\begin{array}{l}\text { Institute for Communicable } \\
\text { Disease Control }\end{array}$ & & & & & & & 1 & \\
\hline
\end{tabular}




\begin{tabular}{|c|c|c|c|c|c|c|c|c|c|c|}
\hline Country & Member & Institution & $\begin{array}{l}\text { GISN } \\
2010\end{array}$ & $\begin{array}{l}\text { Collabor. } \\
\text { Centres } \\
2018\end{array}$ & $\begin{array}{l}\text { Cancun } \\
\text { Influenza } \\
2009\end{array}$ & $\begin{array}{l}\text { EC } \\
\text { Influenza }\end{array}$ & $\begin{array}{l}\text { CRIHR } \\
\text { Influenza }\end{array}$ & $\begin{array}{l}\text { Review } \\
\text { H1N1 }\end{array}$ & GSAID & GHSI \\
\hline Sweden & Mia Brytting & Public Health Agency Sweden & & 1 & & & & & & \\
\hline Switzerland & Amos Bairoch & University of Geneva & & & & & & & 1 & \\
\hline Switzerland & Andrin Oswald & Novartis & & & & & & 1 & & \\
\hline Switzerland & Anne Huvos & World Health Organization HQ & 1 & & & & & & & \\
\hline Switzerland & Anthony Mounts & World Health Organization $\mathrm{HQ}$ & 1 & & & & & & & \\
\hline Switzerland & Belinda Hall & World Health Organization $\mathrm{HQ}$ & 1 & & & & & & & \\
\hline Switzerland & Bruce Plotkin & World Health Organization $\mathrm{HQ}$ & & & 1 & & & & & \\
\hline Switzerland & Catherine Steele & F. Hoffman-La Roche Ltd & & & & & & 1 & & \\
\hline Switzerland & Christian Fuster & World Health Organization $\mathrm{HQ}$ & 1 & & & & & & & \\
\hline Switzerland & Cindy Aiello & World Health Organization $\mathrm{HQ}$ & 1 & & & & & & & \\
\hline Switzerland & Daniel Koch & World Health Organization $\mathrm{HQ}$ & & & 1 & & & & & \\
\hline Switzerland & David Reddy & F. Hoffman-La Roche Ltd & & & & & & 1 & & \\
\hline Switzerland & Ellah Frodeman & World Health Organization $\mathrm{HQ}$ & 1 & & & & & & & \\
\hline Switzerland & Guenael Rodier & World Health Organization $\mathrm{HQ}$ & & & 1 & & & & & \\
\hline Switzerland & Hande Harmanci & World Health Organization HQ & 1 & & & & & & & \\
\hline Switzerland & $\begin{array}{l}\text { Helena Rebelo de } \\
\text { Andrade }\end{array}$ & World Health Organization $\mathrm{HQ}$ & 1 & & & & & & & \\
\hline Switzerland & Ian Smith & World Health Organization $\mathrm{HQ}$ & & & 1 & & & & & \\
\hline Switzerland & $\begin{array}{l}\text { Javier Penalver } \\
\text { Herrero }\end{array}$ & World Health Organization $\mathrm{HQ}$ & 1 & & & & & & & \\
\hline Switzerland & Katelijn Vandemaele & World Health Organization $\mathrm{HQ}$ & 1 & & & & & & & \\
\hline Switzerland & Keiji Fukuda & World Health Organization $\mathrm{HQ}$ & & & 1 & & & & & \\
\hline Switzerland & Maja Lièvre & World Health Organization $\mathrm{HQ}$ & 1 & & & & & & & \\
\hline Switzerland & Margaret Chan & World Health Organization $\mathrm{HQ}$ & & & 1 & & & & & \\
\hline Switzerland & Niteen Wairagkar & World Health Organization $\mathrm{HQ}$ & 1 & & & & & & & \\
\hline Switzerland & Richard Neher & $\begin{array}{l}\text { Computational Modeling of } \\
\text { Biological Processes }\end{array}$ & & & & & & & 1 & \\
\hline
\end{tabular}




\begin{tabular}{|c|c|c|c|c|c|c|c|c|c|c|}
\hline Country & Member & Institution & $\begin{array}{l}\text { GISN } \\
2010\end{array}$ & $\begin{array}{l}\text { Collabor. } \\
\text { Centres } \\
2018\end{array}$ & $\begin{array}{l}\text { Cancun } \\
\text { Influenza } \\
2009\end{array}$ & $\begin{array}{l}\text { EC } \\
\text { Influenza }\end{array}$ & $\begin{array}{l}\text { CRIHR } \\
\text { Influenza }\end{array}$ & $\begin{array}{l}\text { Review } \\
\text { H1N1 }\end{array}$ & GSAID & GHSI \\
\hline Switzerland & Sylvie Briand & World Health Organization HQ & 1 & & & & & & & \\
\hline Switzerland & Terry Besselaar & World Health Organization HQ & 1 & & & & & & & \\
\hline Switzerland & Thomas Zeltner & Ministry of Public Health & & & 1 & & & & & \\
\hline Switzerland & Tristan Chevignard & World Health Organization $\mathrm{HQ}$ & 1 & & & & & & & \\
\hline Switzerland & Un-Yeong Go & World Health Organization $\mathrm{HQ}$ & 1 & & & & & & & \\
\hline Switzerland & Varja Grabovac & World Health Organization $\mathrm{HQ}$ & 1 & & & & & & & \\
\hline Switzerland & Wenqing Zhang & World Health Organization HQ & 1 & & & & & & & \\
\hline Switzerland & Wenqing Zhang & World Health Organization $\mathrm{HQ}$ & & & & & & & 1 & \\
\hline Switzerland & Samuel Cordey & University of Geneva Hospitals & & 1 & & & & & & \\
\hline $\begin{array}{l}\text { Syrian Arab } \\
\text { Republic }\end{array}$ & Hazzaa Al Khalaf & Public Health Laboratories & & 1 & & & & & & \\
\hline Tanzania & Fausta Mosha & $\begin{array}{l}\text { National Health Laboratory } \\
\text { Quality Assurance and Training } \\
\text { Centre }\end{array}$ & & 1 & & & & & & \\
\hline Tanzania & Miriam Mantoya & NIC Tanzania & 1 & & & & & & & \\
\hline Thailand & Kumnuan Ungchusak & Ministry of Public Health & & & & & 1 & & & \\
\hline Thailand & $\begin{array}{l}\text { Malinee } \\
\text { Chittakanpitch }\end{array}$ & $\begin{array}{l}\text { National Influenza Centre, } \\
\text { National Institute of Health }\end{array}$ & 1 & 1 & & & & & & \\
\hline Thailand & $\begin{array}{l}\text { Pathom } \\
\text { Sawanpanyalert }\end{array}$ & $\begin{array}{l}\text { National Institute of Health } \\
\text { Department of Medical Sciences }\end{array}$ & & & & & & & 1 & \\
\hline Thailand & $\begin{array}{l}\text { Supamit } \\
\text { Chunssuttiwat }\end{array}$ & Ministry of Public Health & & & & 1 & & & & \\
\hline Thailand & $\begin{array}{l}\text { Tawee } \\
\text { Chotpityasunondh }\end{array}$ & Ministry of Health & & & 1 & & & & & \\
\hline $\begin{array}{l}\text { Trinidad and } \\
\text { Tobago }\end{array}$ & $\begin{array}{l}\text { Victoria Morris } \\
\text { Glasgow }\end{array}$ & Caribbean Epidemiology Centre & 1 & 1 & & & & & & \\
\hline Tunisia & Awatef El Moussi & Laboratory of Microbiology & 1 & & & & & & & \\
\hline Tunisia & Amine Slim & Laboratoire de Microbiologie & 1 & 1 & & & & & & \\
\hline
\end{tabular}




\begin{tabular}{|c|c|c|c|c|c|c|c|c|c|c|}
\hline Country & Member & Institution & $\begin{array}{l}\text { GISN } \\
2010\end{array}$ & $\begin{array}{l}\text { Collabor. } \\
\text { Centres } \\
2018\end{array}$ & $\begin{array}{l}\text { Cancun } \\
\text { Influenza } \\
2009\end{array}$ & $\begin{array}{l}\text { EC } \\
\text { Influenza }\end{array}$ & $\begin{array}{l}\text { CRIHR } \\
\text { Influenza }\end{array}$ & $\begin{array}{l}\text { Review } \\
\text { H1N1 }\end{array}$ & GSAID & GHSI \\
\hline Turkey & Gulay Korukluoglu & $\begin{array}{l}\text { National Influenza Centre, } \\
\text { Ministry of Health }\end{array}$ & & 1 & & & & & & \\
\hline Uganda & Sam Zaramba & Ministry of Health & & & & & 1 & & & \\
\hline Uganda & Julius Lutwama & $\begin{array}{l}\text { Uganda Virus Research Institute } \\
\text { (UVRI) }\end{array}$ & & 1 & & & & & & \\
\hline Ukraine & Alla Mironenko & $\begin{array}{l}\text { National Academy of Medical } \\
\text { Science of Ukraine }\end{array}$ & 1 & 1 & & & & & & \\
\hline UK & Ian Brown & $\begin{array}{l}\text { International Reference } \\
\text { Laboratory for Avian Influenza, } \\
\text { Animal and Plant Health Agency }\end{array}$ & & & & & & & 1 & \\
\hline UK & Catherine Thompson & Public Health England & 1 & & & & & & & \\
\hline UK & Rod Daniels & $\begin{array}{l}\text { WHO Collaborating Centre for } \\
\text { Reference and Research on } \\
\text { Influenza }\end{array}$ & 1 & & & & & & & \\
\hline UK & Alan J. Hay & The Francis Crick Institute & & & & & & & 1 & \\
\hline UK & Patricia Ann Troop & Public Health England & & & & & 1 & & & \\
\hline UK & Pamela Molyneaux & Aberdeen Royal Infirmary & & 1 & & & & & & \\
\hline UK & Paul Flynn & $\begin{array}{l}\text { United Kingdom Labour Party and } \\
\text { Representative at the Council of } \\
\text { Europe }\end{array}$ & & & & & & 1 & & \\
\hline UK & Penelope Irving & Ministry of Health & & & 1 & & & & & \\
\hline UK & Peter Coyle & $\begin{array}{l}\text { Regional Virus Laboratory, Royal } \\
\text { Victoria Hospital }\end{array}$ & & 1 & & & & & & \\
\hline UK & Andrew Rambaut & University of Edinburgh & & & & & & & 1 & \\
\hline UK & Anthony Waddell & Durham & 1 & & & & & & & \\
\hline UK & B. Carman & Gartnavel General Hospital & & 1 & & & & & & \\
\hline UK & David Harper & Department of Health & & & 1 & & & 1 & & 1 \\
\hline UK & David L. Heymann & $\begin{array}{l}\text { Centre on Global Health Security, } \\
\text { Chatham House }\end{array}$ & & & & & & 1 & & \\
\hline UK & David Salisbury & Department of Health & & & & & & 1 & & \\
\hline
\end{tabular}




\begin{tabular}{|c|c|c|c|c|c|c|c|c|c|c|}
\hline Country & Member & Institution & $\begin{array}{l}\text { GISN } \\
2010\end{array}$ & $\begin{array}{l}\text { Collabor. } \\
\text { Centres } \\
2018\end{array}$ & $\begin{array}{l}\text { Cancun } \\
\text { Influenza } \\
2009\end{array}$ & $\begin{array}{l}\text { EC } \\
\text { Influenza }\end{array}$ & $\begin{array}{l}\text { CRIHR } \\
\text { Influenza }\end{array}$ & $\begin{array}{r}\text { Review } \\
\text { H1N1 }\end{array}$ & GSAID & GHSI \\
\hline UK & Fiona Godlee & British Medical Journal & & & & & & 1 & & \\
\hline UK & Jo Newstead & Public Health England & & & 1 & & & & & \\
\hline UK & John W. McCauley & The Francis Crick Institute London & 1 & & & & & & 1 & \\
\hline UK & John Wood & $\begin{array}{l}\text { National Institute for Biological } \\
\text { Standards and Control }\end{array}$ & & & & 1 & & & & \\
\hline UK & Tony Colgate & IFPMA/ Novartis & 1 & & & & & 1 & & \\
\hline UK & Vicki Gregory & The Francis Crick Institute & & & & & & & 1 & \\
\hline UK & Maria Zambon & Public Health England & & 1 & & 1 & & & & \\
\hline UK & Meirion Evans & Universidad de Cardiff & & & 1 & & & & & \\
\hline UK & Neil Morris Ferguson & $\begin{array}{l}\text { Imperial College Faculty of } \\
\text { Medicine }\end{array}$ & & & & 1 & & & & \\
\hline UK & Nigel Lightfoot & Public Health England & & & 1 & & & & & 1 \\
\hline UK & Norbert Hehme & GlaxoSmithKline & & & & & & 1 & & \\
\hline USA & Giselle Santos Burgoa & USAID & & & 1 & & & & & \\
\hline USA & Calvin Teel & USAID & & & 1 & & & & & \\
\hline USA & Alba Ma. Ropero & PAHO/WHO & & & 1 & & & & & \\
\hline USA & Alexander Klimov & $\begin{array}{l}\text { Centers for Disease Control and } \\
\text { Prevention }\end{array}$ & 1 & & & & & & & \\
\hline USA & Ann C. Moen & $\begin{array}{l}\text { Centers for Disease Control and } \\
\text { Prevention }\end{array}$ & 1 & & & & & & & \\
\hline USA & Carlos del Río & $\begin{array}{l}\text { Centers for Disease Control and } \\
\text { Prevention }\end{array}$ & & & 1 & & & & & \\
\hline USA & Catherine B. Smith & $\begin{array}{l}\text { Centers for Disease Control and } \\
\text { Prevention }\end{array}$ & & & & & & & 1 & \\
\hline USA & César Ramírez & PAHO/WHO & & & 1 & & & & & \\
\hline USA & Ciro Ugarte & PAHO/WHO & & & 1 & & & & & \\
\hline USA & Craig N. Shapiro & State Department & & & 1 & & & & & \\
\hline USA & $\begin{array}{l}\text { Cuahtémoc Ruiz } \\
\text { Matus }\end{array}$ & $\mathrm{PAHO} / \mathrm{WHO}$ & & & 1 & & & & & \\
\hline
\end{tabular}




\begin{tabular}{|c|c|c|c|c|c|c|c|c|c|c|}
\hline Country & Member & Institution & $\begin{array}{l}\text { GISN } \\
2010\end{array}$ & $\begin{array}{l}\text { Collabor. } \\
\text { Centres } \\
2018\end{array}$ & $\begin{array}{r}\text { Cancun } \\
\text { Influenza } \\
2009\end{array}$ & $\begin{array}{l}\text { EC } \\
\text { Influenza }\end{array}$ & $\begin{array}{l}\text { CRIHR } \\
\text { Influenza }\end{array}$ & $\begin{array}{l}\text { Review } \\
\text { H1N1 }\end{array}$ & GSAID & GHSI \\
\hline USA & Daniel S. Miller & $\begin{array}{l}\text { Centers for Disease Control and } \\
\text { Prevention }\end{array}$ & & & 1 & & & & & \\
\hline USA & Emerson Edwards & State Department & & & 1 & & & & & \\
\hline USA & Emily Carter & $\begin{array}{l}\text { Inter-American Development } \\
\text { Bank }\end{array}$ & & & 1 & & & & & \\
\hline USA & Gary Brunette & $\begin{array}{l}\text { Centers for Disease Control and } \\
\text { Prevention }\end{array}$ & & & 1 & & & & & \\
\hline USA & Gerardo Chowell & $\begin{array}{l}\text { Escuela de Evolución Humana y } \\
\text { Cambio Social }\end{array}$ & & & 1 & & & & & \\
\hline USA & Harvey V. Fineberg & Institute of Medicine & & & & & 1 & & & \\
\hline USA & Humberto Montiel & PAHO WHO & & & 1 & & & & & \\
\hline USA & Jay McAuliffe & $\begin{array}{l}\text { Centers for Disease Control and } \\
\text { Prevention }\end{array}$ & & & 1 & & & & & \\
\hline USA & Jean Luc Poncelet & $\mathrm{PAHO} / \mathrm{WHO}$ & & & 1 & & & & & \\
\hline USA & Jon Andrus & $\mathrm{PAHO} / \mathrm{WHO}$ & & & 1 & & & & & \\
\hline USA & José Luis Varela & PAHO/WHO & & & 1 & & & & & \\
\hline USA & Juan Ignacio López & State Department & & & 1 & & & & & \\
\hline USA & Kathleen Sebelius & $\begin{array}{l}\text { US Department of Human Health } \\
\text { and Services }\end{array}$ & & & 1 & & & & & 1 \\
\hline USA & Katryn Kohl & $\begin{array}{l}\text { Centers for Disease Control and } \\
\text { Prevention }\end{array}$ & & & 1 & & & & & \\
\hline USA & Kei Kawabata & $\begin{array}{l}\text { Inter-American Development } \\
\text { Bank }\end{array}$ & & & 1 & & & & & \\
\hline
\end{tabular}




\begin{tabular}{|c|c|c|c|c|c|c|c|c|c|c|}
\hline Country & Member & Institution & $\begin{array}{l}\text { GISN } \\
2010\end{array}$ & $\begin{array}{l}\text { Collabor. } \\
\text { Centres } \\
2018\end{array}$ & $\begin{array}{l}\text { Cancun } \\
\text { Influenza } \\
2009\end{array}$ & $\begin{array}{l}\text { EC } \\
\text { Influenza }\end{array}$ & $\begin{array}{l}\text { CRIHR } \\
\text { Influenza }\end{array}$ & $\begin{array}{l}\text { Review } \\
\text { H1N1 }\end{array}$ & GSAID & GHSI \\
\hline USA & Leano Romeo & USAID & & & 1 & & & & & \\
\hline USA & Lupita Vázquez & USAID & & & 1 & & & & & \\
\hline USA & M. Anne Yu & $\begin{array}{l}\text { Centers for Disease Control and } \\
\text { Prevention }\end{array}$ & & & 1 & & & & & \\
\hline USA & Ma. Teresa Rivera & PAHO WHO & & & 1 & & & & & \\
\hline USA & Martin Cetron & $\begin{array}{l}\text { Centers for Disease Control and } \\
\text { Prevention }\end{array}$ & & & & & 1 & & & \\
\hline USA & Mary Hoelscher & $\begin{array}{l}\text { Centers for Disease Control and } \\
\text { Prevention }\end{array}$ & 1 & & & & & & & \\
\hline USA & Mike Osterholm & University of Minnesota & & & & & & 1 & & \\
\hline USA & Mirta Roses Periago & PAHO/WHO & & & 1 & & & & & \\
\hline USA & Nancy Alvey & USAID & & & 1 & & & & & \\
\hline USA & Nancy Cox & $\begin{array}{l}\text { Centers for Disease Control and } \\
\text { Prevention }\end{array}$ & & & 1 & 1 & & & 1 & \\
\hline USA & Natasha Jessn & $\begin{array}{l}\text { Inter-American Development } \\
\text { Bank }\end{array}$ & & & 1 & & & & & \\
\hline USA & Otavio Oliva & AMOR & 1 & & & & & & & \\
\hline USA & Peter Houck & $\begin{array}{l}\text { Centers for Disease Control and } \\
\text { Prevention }\end{array}$ & & & 1 & & & & & \\
\hline USA & $\begin{array}{l}\text { Radm W. Craig } \\
\text { Vanderwagen }\end{array}$ & State Department & & & 1 & & & & & 1 \\
\hline USA & Ray R. Arthur & $\begin{array}{l}\text { Centers for Disease Control and } \\
\text { Prevention }\end{array}$ & & & 1 & & & & & \\
\hline USA & Rebecca Garten & $\begin{array}{l}\text { Centers for Disease Control and } \\
\text { Prevention }\end{array}$ & & & & & & & 1 & \\
\hline USA & Richard J. Webby & $\begin{array}{l}\text { St. Jude Children's Research } \\
\text { Hospital }\end{array}$ & & & & & & & 1 & \\
\hline USA & Rick Bright & $\begin{array}{l}\text { Biomedical Advanced Research } \\
\text { and Development Authority }\end{array}$ & 1 & & & & & & & \\
\hline USA & Robert Blanchard & USAID & 1 & & & & & & & \\
\hline
\end{tabular}




\begin{tabular}{|c|c|c|c|c|c|c|c|c|c|c|}
\hline Country & Member & Institution & $\begin{array}{l}\text { GISN } \\
2010\end{array}$ & $\begin{array}{l}\text { Collabor. } \\
\text { Centres } \\
2018\end{array}$ & $\begin{array}{l}\text { Cancun } \\
\text { Influenza } \\
2009\end{array}$ & $\begin{array}{l}\text { EC } \\
\text { Influenza }\end{array}$ & $\begin{array}{l}\text { CRIHR } \\
\text { Influenza }\end{array}$ & $\begin{array}{l}\text { Review } \\
\text { H1N1 }\end{array}$ & GSAID & GHSI \\
\hline USA & Robert G. Lofties & State Department & & & 1 & & & & & \\
\hline USA & Robert Lee & PAHO WHO & & & 1 & & & & & \\
\hline USA & Rodger Garner & USAID & & & 1 & & & & & \\
\hline USA & Stacey Schultz-Cherry & $\begin{array}{l}\text { WHO Collaborating Centre for } \\
\text { Studies on the Ecology of } \\
\text { Influenza }\end{array}$ & 1 & & & & & & & \\
\hline USA & Stephen Blount & $\begin{array}{l}\text { Centers for Disease Control and } \\
\text { Prevention }\end{array}$ & & & 1 & & & & & \\
\hline USA & Stephen Redd & $\begin{array}{l}\text { Centers for Disease Control and } \\
\text { Prevention }\end{array}$ & & & 1 & & & 1 & & \\
\hline USA & Steve Waterman & $\begin{array}{l}\text { Centers for Disease Control and } \\
\text { Prevention }\end{array}$ & & & 1 & & & & & \\
\hline USA & Steven Adams & $\begin{array}{l}\text { Centers for Disease Control and } \\
\text { Prevention }\end{array}$ & & & 1 & & & & & \\
\hline USA & Thomas R. Frieden & $\begin{array}{l}\text { Centers for Disease Control and } \\
\text { Prevention }\end{array}$ & & & 1 & & & & & \\
\hline USA & Timothy M. Uyeki & $\begin{array}{l}\text { Centers for Disease Control and } \\
\text { Prevention }\end{array}$ & & & 1 & & & & & \\
\hline USA & Trevor Bedford & $\begin{array}{l}\text { Fred Hutchinson Cancer Research } \\
\text { Centre }\end{array}$ & & & & & & & 1 & \\
\hline USA & Viridiana Cruz & PAHO/WHO & & & 1 & & & & & \\
\hline USA & Winston Hide & Harvard School of Public Health & & & & & & & 1 & \\
\hline USA & Xiyan Xu & $\begin{array}{l}\text { Centers for Disease Control and } \\
\text { Prevention }\end{array}$ & 1 & & & & & & & \\
\hline USA & Christoph Kurowski & World Bank & & & 1 & & & & & \\
\hline USA & H.F. Maassab & & & 1 & & & & & & \\
\hline USA & L. Grady & $\begin{array}{l}\text { Virology Diagnostic Services } \\
\text { Laboratory of Zoonotic } \\
\text { Diseasesvice and Virology, New } \\
\text { York State Department of Health }\end{array}$ & & 1 & & & & & & \\
\hline
\end{tabular}




\begin{tabular}{|c|c|c|c|c|c|c|c|c|c|c|}
\hline Country & Member & Institution & $\begin{array}{l}\text { GISN } \\
2010\end{array}$ & $\begin{array}{l}\text { Collabor. } \\
\text { Centres } \\
2018\end{array}$ & $\begin{array}{l}\text { Cancun } \\
\text { Influenza } \\
2009\end{array}$ & $\begin{array}{l}\text { EC } \\
\text { Influenza }\end{array}$ & $\begin{array}{l}\text { CRIHR } \\
\text { Influenza }\end{array}$ & $\begin{array}{l}\text { Review } \\
\text { H1N1 }\end{array}$ & GSAID & GHSI \\
\hline USA & John Janda & $\begin{array}{l}\text { Viral and Rickettsial Disease } \\
\text { Laboratory }\end{array}$ & & 1 & & & & & & \\
\hline USA & Arnold Monto & University of Michigan & & & & 1 & & & & \\
\hline USA & David Nabarro & $\begin{array}{l}\text { United Nations System Influenza } \\
\text { Coordination }\end{array}$ & & & & & & 1 & & \\
\hline Uruguay & Raquel Rosa & Ministry of Public Health & & & 1 & & & & & \\
\hline Uruguay & Hector Chiparelli & Ministry of Health & & 1 & & & & & & \\
\hline Venezuela & $\begin{array}{l}\text { Esperanza Briceño } \\
\text { a.i. }\end{array}$ & Instituto Nacional de Higiene & & 1 & & & & & & \\
\hline Viet Nam & Dang Quang Tan & Ministry of Health & & & & & & 1 & & \\
\hline Viet Nam & Dang Tho Nguyen & $\begin{array}{l}\text { National Centre for Veterinary } \\
\text { Diagnostics }\end{array}$ & 1 & & & & & & & \\
\hline Viet Nam & Mai Le & NIC Viet Nam & 1 & & & & & & & \\
\hline Viet Nam & Le Quynh Mai & $\begin{array}{l}\text { National Institute of Hygiene and } \\
\text { Epidemiology }\end{array}$ & & 1 & & & & & & \\
\hline Viet Nam & Nguyen Thanh Long & Pasteur Institute & & 1 & & & & & & \\
\hline Zambia & Andros Theo & Virology/Immunology Lab & 1 & & & & & & & \\
\hline Zambia & Mwaka Monze & Ministry of Health & & 1 & & & & & & \\
\hline Egypt & Ali Yahaya & AFRO/WHO & 1 & & & & & & & \\
\hline Philippines & Jeffrey Partridge & WPRO/WHO & 1 & & & & & & & \\
\hline India & Rajesh Bhatia & SEARO/WHO & 1 & & & & & & & \\
\hline
\end{tabular}




\section{Appendix I. MERS-CoV number of cases}

\begin{tabular}{|c|c|}
\hline Country & $\begin{array}{l}\text { Number of laboratory-confirmed cases } \\
\text { MERS CoV }\end{array}$ \\
\hline Algeria & 2 \\
\hline Austria & 2 \\
\hline Bahrain & 1 \\
\hline China & 1 \\
\hline Egypt & 1 \\
\hline France & 1 \\
\hline Germany & 3 \\
\hline Greece & 1 \\
\hline Iran & 6 \\
\hline Italy & 1 \\
\hline Jordan & 28 \\
\hline Kuwait & 4 \\
\hline Lebanon & 2 \\
\hline Malaysia & 3 \\
\hline Netherlands & 2 \\
\hline Oman & 12 \\
\hline Philippines & 2 \\
\hline Qatar & 19 \\
\hline Republic of Korea & 185 \\
\hline Saudi Arabia & 1768 \\
\hline Thailand & 3 \\
\hline Tunisia & 3 \\
\hline Turkey & 1 \\
\hline United Kingdom & 4 \\
\hline United Arab Emirates & 86 \\
\hline United States of America & 2 \\
\hline Yemen & 1 \\
\hline Total & 2144 \\
\hline
\end{tabular}

Countries reporting MERS cases. Source: The World Health Organization website (460) 


\section{Appendix J. MERS-CoV Epistemic Community}

\begin{tabular}{|c|c|c|c|c|c|c|c|c|}
\hline Country & Name & Institution & $\begin{array}{l}\text { EC- } \\
\text { MERS }\end{array}$ & $\begin{array}{l}\text { MERS } \\
\text { CoV } \\
\text { RG }\end{array}$ & $\begin{array}{l}\text { CSG } \\
\text { ICTV }\end{array}$ & $\begin{array}{l}\text { WHO } \\
\text { MERS } \\
\text { R\&D }\end{array}$ & $\begin{array}{l}\text { WHO } \\
\text { BP } \\
\text { VT }\end{array}$ & $\begin{array}{l}\text { Inter } \\
\text { country } \\
\text { meeting }\end{array}$ \\
\hline Afghanistan & $\begin{array}{l}\text { Adel Salman } \\
\text { Alsayyad }\end{array}$ & Ministry of Health & & & & & & 1 \\
\hline Afghanistan & $\begin{array}{l}\text { Ghulam Eshan } \\
\text { Sharifi }\end{array}$ & $\begin{array}{l}\text { Ministry of Public } \\
\text { Health }\end{array}$ & & & & & & 1 \\
\hline Afghanistan & $\begin{array}{l}\text { MAmjad } \\
\text { Ghanim } \\
\text { Mohamed }\end{array}$ & $\begin{array}{l}\text { Ministry of Health } \\
\text { Manama }\end{array}$ & & & & & & 1 \\
\hline Afghanistan & $\begin{array}{l}\text { Muna Sayed } \\
\text { Jawad Al } \\
\text { Musawi }\end{array}$ & Ministry of Health & & & & & & 1 \\
\hline Afghanistan & $\begin{array}{l}\text { Naqibullah } \\
\text { Ziar }\end{array}$ & $\begin{array}{l}\text { Ministry of Public } \\
\text { Health }\end{array}$ & & & & & & 1 \\
\hline Afghanistan & $\begin{array}{l}\text { Zahra Jasim } \\
\text { Hasan Khamis }\end{array}$ & $\begin{array}{l}\text { Public Health } \\
\text { Laboratory Ministry } \\
\text { of Health }\end{array}$ & & & & & & 1 \\
\hline Australia & $\begin{array}{l}\text { John } \\
\text { Lowenthal, }\end{array}$ & $\begin{array}{l}\text { Emerging Infectious } \\
\text { Diseases, CSIRO } \\
\text { Animal Health } \\
\text { Laboratory }\end{array}$ & & & & 1 & & \\
\hline Australia & Chris Baggoley & $\begin{array}{l}\text { Australian } \\
\text { Department of } \\
\text { Health and Ageing }\end{array}$ & 1 & & & & & \\
\hline Bangladesh & $\begin{array}{l}\text { Mahmudur } \\
\text { Rahman }\end{array}$ & $\begin{array}{l}\text { Institute of } \\
\text { Epidemiology, } \\
\text { Disease Control and } \\
\text { Research and } \\
\text { National Influenza } \\
\text { Centre, Ministry of } \\
\text { Health and Family } \\
\text { Welfare }\end{array}$ & 1 & & & & & \\
\hline Belgium & $\begin{array}{l}\text { Birgit Van } \\
\text { Tongelen, }\end{array}$ & $\begin{array}{l}\text { European } \\
\text { Commission }\end{array}$ & & & & 1 & & \\
\hline Canada & $\begin{array}{l}\text { Neill K. } \\
\text { Adhikari }\end{array}$ & $\begin{array}{l}\text { Centre Sunnybrook } \\
\text { Research Institute }\end{array}$ & & & & & 1 & \\
\hline Canada & $\begin{array}{l}\text { Robert A. } \\
\text { Fowler }\end{array}$ & $\begin{array}{l}\text { Director, Clinical } \\
\text { Epidemiology and } \\
\text { Health Care } \\
\text { Research Institute } \\
\text { of Health Policy, } \\
\text { Management and } \\
\text { Evaluation Dalla } \\
\text { Lana School of } \\
\text { Public Health }\end{array}$ & & & & & 1 & \\
\hline Canada & Theresa Tam & $\begin{array}{l}\text { Public Health } \\
\text { Agency of Canada }\end{array}$ & 1 & & & & & \\
\hline
\end{tabular}




\begin{tabular}{|c|c|c|c|c|c|c|c|c|}
\hline Country & Name & Institution & $\begin{array}{l}\text { EC- } \\
\text { MERS }\end{array}$ & $\begin{array}{l}\text { MERS } \\
\text { CoV } \\
\text { RG }\end{array}$ & $\begin{array}{l}\text { CSG } \\
\text { ICTV }\end{array}$ & $\begin{array}{l}\text { WHO } \\
\text { MERS } \\
\text { R\&D }\end{array}$ & $\begin{array}{l}\text { WHO } \\
\text { BP } \\
\text { VT }\end{array}$ & $\begin{array}{l}\text { Inter } \\
\text { country } \\
\text { meeting }\end{array}$ \\
\hline Canada & & Mont Sinai Hospital & & & & & & \\
\hline Chile & $\begin{array}{l}\text { Claudia } \\
\text { Gonzalez }\end{array}$ & $\begin{array}{l}\text { Clínica Alemana- } \\
\text { Universidad del } \\
\text { Desarrollo, and } \\
\text { Partner-Director } \\
\text { Epi-Sur Consultores }\end{array}$ & 1 & & & & & \\
\hline China & Linqi Zhang, & $\begin{array}{l}\text { Department of } \\
\text { Basic Medical } \\
\text { Sciences, Tsinghua } \\
\text { University }\end{array}$ & & & & 1 & & \\
\hline China & Wenjie Tan, & China CDC & & & & 1 & & \\
\hline China & & Faculty of Medicine & & & & & & \\
\hline Denmark & $\begin{array}{l}\text { Caroline Sarah } \\
\text { Brown }\end{array}$ & $\begin{array}{l}\text { WHO Regional } \\
\text { Office for Europe }\end{array}$ & & & 1 & & & 1 \\
\hline Djibouti & $\begin{array}{l}\text { Houssein } \\
\text { Youssouf } \\
\text { Darar }\end{array}$ & Ministry of Health & & & & & & 1 \\
\hline Djibouti & $\begin{array}{l}\text { Neima Moussa } \\
\text { Ali }\end{array}$ & Ministry of Health & & & & & & 1 \\
\hline Djibouti & $\begin{array}{l}\text { Robleh } \\
\text { Mahmoud } \\
\text { Barreh }\end{array}$ & Ministry of Health & & & & & & 1 \\
\hline Djibouti & $\begin{array}{l}\text { Souleiman } \\
\text { Nour Ayeh }\end{array}$ & $\begin{array}{l}\text { Peltier Hospital, } \\
\text { Ministry of Health }\end{array}$ & & & & & & 1 \\
\hline Egypt & $\begin{array}{l}\text { Abeer } \\
\text { Eltelmissany }\end{array}$ & $\begin{array}{l}\text { World Health } \\
\text { Organization } \\
\text { Regional Office for } \\
\text { the Eastern } \\
\text { Mediterranean }\end{array}$ & & & & & & 1 \\
\hline Egypt & $\begin{array}{l}\text { Ahmed } \\
\text { Abdelwahab }\end{array}$ & $\begin{array}{l}\text { World Health } \\
\text { Organization } \\
\text { Regional Office for } \\
\text { the Eastern } \\
\text { Mediterranean }\end{array}$ & & & & & & 1 \\
\hline Egypt & Ala Alwan & $\begin{array}{l}\text { World Health } \\
\text { Organization } \\
\text { Regional Office for } \\
\text { the Eastern } \\
\text { Mediterranean }\end{array}$ & & & & & & 1 \\
\hline Egypt & $\begin{array}{l}\text { Amel } \\
\text { Mohamed } \\
\text { Najeib Hasanin }\end{array}$ & $\begin{array}{l}\text { Public Health } \\
\text { Laboratories Cairo }\end{array}$ & & & & & & 1 \\
\hline Egypt & $\begin{array}{l}\text { Amina } \\
\text { Benyahia } \\
\text { Chaieb }\end{array}$ & $\begin{array}{l}\text { World Health } \\
\text { Organization } \\
\text { Regional Office for } \\
\text { the Eastern } \\
\text { Mediterranean }\end{array}$ & & & & & & 1 \\
\hline
\end{tabular}




\begin{tabular}{|c|c|c|c|c|c|c|c|c|}
\hline Country & Name & Institution & $\begin{array}{l}\text { EC- } \\
\text { MERS }\end{array}$ & $\begin{array}{l}\text { MERS } \\
\text { CoV } \\
\text { RG }\end{array}$ & $\begin{array}{l}\text { CSG } \\
\text { ICTV }\end{array}$ & $\begin{array}{l}\text { WHO } \\
\text { MERS } \\
\text { R\&D }\end{array}$ & $\begin{array}{l}\text { WHO } \\
\text { BP } \\
\text { VT }\end{array}$ & $\begin{array}{l}\text { Inter } \\
\text { country } \\
\text { meeting }\end{array}$ \\
\hline Egypt & $\begin{array}{l}\text { Dalia } \\
\text { Samhouri }\end{array}$ & $\begin{array}{l}\text { World Health } \\
\text { Organization } \\
\text { Regional Office for } \\
\text { the Eastern } \\
\text { Mediterranean }\end{array}$ & & & & & & 1 \\
\hline Egypt & David Bramley & $\begin{array}{l}\text { World Health } \\
\text { Organization } \\
\text { Regional Office for } \\
\text { the Eastern } \\
\text { Mediterranean }\end{array}$ & & & & & & 1 \\
\hline Egypt & $\begin{array}{l}\text { Omneya Aboul } \\
\text { Seoud }\end{array}$ & $\begin{array}{l}\text { World Health } \\
\text { Organization } \\
\text { Regional Office for } \\
\text { the Eastern } \\
\text { Mediterranean }\end{array}$ & & & & & & 1 \\
\hline Egypt & $\begin{array}{l}\text { Samir Abdel } \\
\text { Aziz Reffaey }\end{array}$ & $\begin{array}{l}\text { Ministry of Health } \\
\text { and Population }\end{array}$ & & & & & & 1 \\
\hline Egypt & $\begin{array}{l}\text { Samir Ben } \\
\text { Yahmed }\end{array}$ & $\begin{array}{l}\text { World Health } \\
\text { Organization } \\
\text { Regional Office for } \\
\text { the Eastern } \\
\text { Mediterranean }\end{array}$ & & & & & & 1 \\
\hline Egypt & $\begin{array}{l}\text { Zein Elabideen } \\
\text { El Taher El } \\
\text { Kamel }\end{array}$ & & & & & & & 1 \\
\hline Egypt & $\begin{array}{l}\text { Guenael R. } \\
\text { Rodier }\end{array}$ & $\begin{array}{l}\text { World Health } \\
\text { Organization } \\
\text { Regional Office for } \\
\text { the Eastern } \\
\text { Mediterranean }\end{array}$ & & & & & & 1 \\
\hline Egypt & Hala Esmat & $\begin{array}{l}\text { World Health } \\
\text { Organization } \\
\text { Regional Office for } \\
\text { the Eastern } \\
\text { Mediterranean }\end{array}$ & & & & & & 1 \\
\hline Egypt & Heidi Rizk & $\begin{array}{l}\text { World Health } \\
\text { Organization } \\
\text { Regional Office for } \\
\text { the Eastern } \\
\text { Mediterranean }\end{array}$ & & & & & & 1 \\
\hline Egypt & $\begin{array}{l}\text { Jaouad } \\
\text { Mahjour }\end{array}$ & $\begin{array}{l}\text { World Health } \\
\text { Organization } \\
\text { Regional Office for } \\
\text { the Eastern } \\
\text { Mediterranean }\end{array}$ & & & & & & 1 \\
\hline
\end{tabular}




\begin{tabular}{|c|c|c|c|c|c|c|c|c|}
\hline Country & Name & Institution & $\begin{array}{l}\text { EC- } \\
\text { MERS }\end{array}$ & $\begin{array}{l}\text { MERS } \\
\text { CoV } \\
\text { RG }\end{array}$ & $\begin{array}{l}\text { CSG } \\
\text { ICTV }\end{array}$ & $\begin{array}{l}\text { WHO } \\
\text { MERS } \\
\text { R\&D }\end{array}$ & $\begin{array}{l}\text { WHO } \\
\text { BP } \\
\text { VT }\end{array}$ & $\begin{array}{l}\text { Inter } \\
\text { country } \\
\text { meeting }\end{array}$ \\
\hline Egypt & Jehane Khadr & $\begin{array}{l}\text { World Health } \\
\text { Organization } \\
\text { Regional Office for } \\
\text { the Eastern } \\
\text { Mediterranean }\end{array}$ & & & & & & 1 \\
\hline Egypt & $\begin{array}{l}\text { Kareem } \\
\text { Elhadary }\end{array}$ & $\begin{array}{l}\text { World Health } \\
\text { Organization } \\
\text { Regional Office for } \\
\text { the Eastern } \\
\text { Mediterranean }\end{array}$ & & & & & & 1 \\
\hline Egypt & $\begin{array}{l}\text { Mona Aly } \\
\text { Yassin }\end{array}$ & $\begin{array}{l}\text { World Health } \\
\text { Organization } \\
\text { Regional Office for } \\
\text { the Eastern } \\
\text { Mediterranean }\end{array}$ & & & & & & 1 \\
\hline Egypt & $\begin{array}{l}\text { Weaam El } \\
\text { Metenawy }\end{array}$ & $\begin{array}{l}\text { World Health } \\
\text { Organization } \\
\text { Regional Office for } \\
\text { the Eastern } \\
\text { Mediterranean }\end{array}$ & & & & & & 1 \\
\hline Egypt & Ali R. Mafi & $\begin{array}{l}\text { World Health } \\
\text { Organization } \\
\text { Regional Office for } \\
\text { the Eastern } \\
\text { Mediterranean }\end{array}$ & & 1 & & & & \\
\hline Egypt & Ali M. Zaki & $\begin{array}{l}\text { Ain Shams } \\
\text { University }\end{array}$ & & & 1 & & & \\
\hline Egypt & $\begin{array}{l}\text { Catherine } \\
\text { Smallwood }\end{array}$ & $\begin{array}{l}\text { World Health } \\
\text { Organization } \\
\text { Regional Office for } \\
\text { the Eastern } \\
\text { Mediterranean }\end{array}$ & & 1 & & & & 1 \\
\hline Egypt & $\begin{array}{l}\text { Langoya } \\
\text { Opoka }\end{array}$ & $\begin{array}{l}\text { World Health } \\
\text { Organization } \\
\text { Regional Office for } \\
\text { the Eastern } \\
\text { Mediterranean }\end{array}$ & & 1 & & & & 1 \\
\hline Egypt & $\begin{array}{l}\text { Mamunur } \\
\text { Malik }\end{array}$ & $\begin{array}{l}\text { World Health } \\
\text { Organization } \\
\text { Regional Office for } \\
\text { the Eastern } \\
\text { Mediterranean }\end{array}$ & & 1 & & & & 1 \\
\hline France & Didier Che & $\begin{array}{l}\text { French Institute for } \\
\text { Public Health } \\
\text { Surveillance }\end{array}$ & & & & & & 1 \\
\hline France & François Salicis & Minister of Health & & & & & & 1 \\
\hline France & $\begin{array}{l}\text { Arnaud } \\
\text { Fontanet }\end{array}$ & Institut Pasteur & & 1 & & & & \\
\hline
\end{tabular}




\begin{tabular}{|c|c|c|c|c|c|c|c|c|}
\hline Country & Name & Institution & $\begin{array}{l}\text { EC- } \\
\text { MERS }\end{array}$ & $\begin{array}{l}\text { MERS } \\
\text { CoV } \\
\text { RG }\end{array}$ & $\begin{array}{l}\text { CSG } \\
\text { ICTV }\end{array}$ & $\begin{array}{l}\text { WHO } \\
\text { MERS } \\
\text { R\&D }\end{array}$ & $\begin{array}{l}\text { WHO } \\
\text { BP } \\
\text { VT }\end{array}$ & $\begin{array}{l}\text { Inter } \\
\text { country } \\
\text { meeting }\end{array}$ \\
\hline France & $\begin{array}{l}\text { Sylvie van der } \\
\text { Werf }\end{array}$ & $\begin{array}{l}\text { Institut Pasteur, } \\
\text { CNRS and } \\
\text { University Paris } \\
\text { Diderot Sorbonne } \\
\text { Paris Cité }\end{array}$ & & 1 & & & & \\
\hline France & $\begin{array}{l}\text { Grounalan } \\
\text { Pavade }\end{array}$ & $\begin{array}{l}\text { World Organization } \\
\text { for Animal Health } \\
\text { (OIE) }\end{array}$ & & & & 1 & & \\
\hline France & $\begin{array}{l}\text { Maria Van } \\
\text { Kerkhove, }\end{array}$ & $\begin{array}{l}\text { Centre for Global } \\
\text { Health, Institut } \\
\text { Pasteur, Paris }\end{array}$ & & & & 1 & & \\
\hline France & Bernard Faye & $\begin{array}{l}\text { French Agricultural } \\
\text { Research Centre for } \\
\text { International } \\
\text { Development }\end{array}$ & 1 & & & & & \\
\hline France & Benoît Guéry & $\begin{array}{l}\text { Universitaire de } \\
\text { Lille Paris }\end{array}$ & & 1 & & & & 1 \\
\hline France & $\begin{array}{l}\text { Jean-Claude } \\
\text { Manuguerra }\end{array}$ & Institut Pasteur & & 1 & & & & 1 \\
\hline Georgia & Paata Imnadze & $\begin{array}{l}\text { National Centre for } \\
\text { Disease Control and } \\
\text { Public Health }\end{array}$ & 1 & & & & & \\
\hline Germany & $\begin{array}{l}\text { Brunhilde } \\
\text { Schweiger }\end{array}$ & Robert Koch Institut & & & & & & 1 \\
\hline Germany & $\begin{array}{l}\text { Clemens } \\
\text { Wendtner }\end{array}$ & Klinikum Schwabing & & & & & & 1 \\
\hline Germany & $\begin{array}{l}\text { Osamah } \\
\text { Hamouda }\end{array}$ & Robert Koch Institut & & & & & & 1 \\
\hline Germany & Anna Kuehne & $\begin{array}{l}\text { Robert Koch } \\
\text { Institute }\end{array}$ & & 1 & & & & \\
\hline Germany & $\begin{array}{l}\text { Benjamin } \\
\text { Blümel }\end{array}$ & $\begin{array}{l}\text { Robert Koch } \\
\text { Institute }\end{array}$ & & 1 & & & & \\
\hline Germany & Udo Buchholz & $\begin{array}{l}\text { Robert Koch } \\
\text { Institute }\end{array}$ & & 1 & & & & \\
\hline Germany & John Ziebuhr & $\begin{array}{l}\text { Justus Liebig } \\
\text { University Giessen }\end{array}$ & & & 1 & & & \\
\hline Germany & $\begin{array}{l}\text { Christoph } \\
\text { Conrad }\end{array}$ & $\begin{array}{l}\text { Paul-Ehrlich- } \\
\text { Institut }\end{array}$ & & & & 1 & & \\
\hline Germany & $\begin{array}{l}\text { Michael } \\
\text { Muhleback }\end{array}$ & $\begin{array}{l}\text { Paul Ehrlich } \\
\text { Institute }\end{array}$ & & & & 1 & & \\
\hline Germany & $\begin{array}{l}\text { Christian } \\
\text { Drosten }\end{array}$ & $\begin{array}{l}\text { University of Bonn } \\
\text { Medical Centre }\end{array}$ & & 1 & 1 & 1 & & \\
\hline Hong Kong & David SC Hui & $\begin{array}{l}\text { The Chinese } \\
\text { University of Hong } \\
\text { Kong }\end{array}$ & & 1 & & & & \\
\hline Hong Kong & $\begin{array}{l}\text { J. S. Malik } \\
\text { Peiris }\end{array}$ & $\begin{array}{l}\text { The University of } \\
\text { Hong Kong }\end{array}$ & & 1 & & & & \\
\hline
\end{tabular}




\begin{tabular}{|c|c|c|c|c|c|c|c|c|}
\hline Country & Name & Institution & $\begin{array}{l}\text { EC- } \\
\text { MERS }\end{array}$ & $\begin{array}{l}\text { MERS } \\
\text { CoV } \\
\text { RG }\end{array}$ & $\begin{array}{l}\text { CSG } \\
\text { ICTV }\end{array}$ & $\begin{array}{l}\text { WHO } \\
\text { MERS } \\
\text { R\&D }\end{array}$ & $\begin{array}{l}\text { WHO } \\
\text { BP } \\
\text { VT }\end{array}$ & $\begin{array}{l}\text { Inter } \\
\text { country } \\
\text { meeting }\end{array}$ \\
\hline Hong Kong & Leo L.M.Poon & $\begin{array}{l}\text { The University of } \\
\text { Hong Kong }\end{array}$ & & & 1 & & & \\
\hline Hong Kong & $\begin{array}{l}\text { Patrick C. Y. } \\
\text { Woo }\end{array}$ & $\begin{array}{l}\text { The University of } \\
\text { Hong Kong }\end{array}$ & & & 1 & & & \\
\hline Hong Kong & Malik Peiris & $\begin{array}{l}\text { University of Hong } \\
\text { Kong, Faculty of } \\
\text { Medicine, Hong } \\
\text { Kong }\end{array}$ & & & & & 1 & \\
\hline Indonesia. & $\begin{array}{l}\text { Tjandra } \\
\text { Aditama }\end{array}$ & Ministry of Health & 1 & & & & & \\
\hline Iran & $\begin{array}{l}\text { Adnan Nawar } \\
\text { Khistawi }\end{array}$ & Ministry of Health & & & & & & 1 \\
\hline Iran & $\begin{array}{l}\text { Mohammad } \\
\text { Nasr Dadras }\end{array}$ & $\begin{array}{l}\text { Ministry of Health } \\
\text { and Medical } \\
\text { Education }\end{array}$ & & & & & & 1 \\
\hline Iran & $\begin{array}{l}\text { Payman } \\
\text { Hemmati }\end{array}$ & $\begin{array}{l}\text { Ministry of Health } \\
\text { and Medical } \\
\text { Education }\end{array}$ & & & & & & 1 \\
\hline Iran & $\begin{array}{l}\text { Talat Mokhtar- } \\
\text { azad }\end{array}$ & $\begin{array}{l}\text { School of Public } \\
\text { Health Teheran } \\
\text { University of } \\
\text { Medical Sciences }\end{array}$ & & & & & & 1 \\
\hline Iraq & $\begin{array}{l}\text { Hayder } \\
\text { Hashim Naser }\end{array}$ & Ministry of Health & & & & & & 1 \\
\hline Iraq & $\begin{array}{l}\text { Muthana } \\
\text { Ibrahim Abdul } \\
\text { Kareem Al } \\
\text { Dulaimi }\end{array}$ & Ministry of Health & & & & & & 1 \\
\hline Ireland & $\begin{array}{l}\text { Anton } \\
\text { Tikhonov, }\end{array}$ & Organic Vaccines & & & & 1 & & \\
\hline Ireland & $\begin{array}{l}\text { Patrick } \\
\text { Rambaud, }\end{array}$ & Organic Vaccines & & & & 1 & & \\
\hline Italy & $\begin{array}{l}\text { Giovanni } \\
\text { Rezza }\end{array}$ & $\begin{array}{l}\text { Istituto Superiore di } \\
\text { Sanità }\end{array}$ & & 1 & & & & \\
\hline Italy & $\begin{array}{l}\text { Isabella } \\
\text { Donatelli }\end{array}$ & $\begin{array}{l}\text { Istituto Superiore di } \\
\text { Sanità }\end{array}$ & & 1 & & & & \\
\hline Italy & $\begin{array}{l}\text { Moulay } \\
\text { Ahmed El } \\
\text { Idrissi Hamzi, }\end{array}$ & $\begin{array}{l}\text { Food and } \\
\text { Agriculture } \\
\text { Organization of the } \\
\text { United Nations }\end{array}$ & & & & 1 & & \\
\hline Jordan & $\begin{array}{l}\text { Assad Yahya } \\
\text { Rahhal }\end{array}$ & Ministry of Health & & & & & & 1 \\
\hline Jordan & $\begin{array}{l}\text { Najwa Hamed } \\
\text { Jarour }\end{array}$ & Ministry of Health & & & & & & 1 \\
\hline Jordan & $\begin{array}{l}\text { Aktham Jeries } \\
\text { Haddadin }\end{array}$ & Ministry of Health & & 1 & & & & 1 \\
\hline
\end{tabular}




\begin{tabular}{|c|c|c|c|c|c|c|c|c|}
\hline Country & Name & Institution & $\begin{array}{l}\text { EC- } \\
\text { MERS }\end{array}$ & $\begin{array}{l}\text { MERS } \\
\text { CoV } \\
\text { RG }\end{array}$ & $\begin{array}{l}\text { CSG } \\
\text { ICTV }\end{array}$ & $\begin{array}{l}\text { WHO } \\
\text { MERS } \\
\text { R\&D }\end{array}$ & $\begin{array}{l}\text { WHO } \\
\text { BP } \\
\text { VT }\end{array}$ & $\begin{array}{l}\text { Inter } \\
\text { country } \\
\text { meeting }\end{array}$ \\
\hline Jordan & $\begin{array}{l}\text { Mohammad } \\
\text { Mousa } \\
\text { Abdallat }\end{array}$ & Ministry of Health & & 1 & & & & 1 \\
\hline Jordan & $\begin{array}{l}\text { Sultan } \\
\text { Mohammed } \\
\text { Abdalla Al } \\
\text { Qasrawi }\end{array}$ & Ministry of Health & & 1 & & & & 1 \\
\hline Kuwait & $\begin{array}{l}\text { Maher Younes } \\
\text { Saleh }\end{array}$ & & & & & & & 1 \\
\hline Kuwait & $\begin{array}{l}\text { Mussab } \\
\text { Ibrahim Al- } \\
\text { Saleh }\end{array}$ & Ministry of Health & & & & & & 1 \\
\hline Kuwait & Qais Alduwairi & Ministry of Health & & & & & & 1 \\
\hline Kuwait & Sami Al Nasser & Ministry of Health & & & & & & 1 \\
\hline Lebanon & $\begin{array}{l}\text { Hassan } \\
\text { Mohamad } \\
\text { Mallah }\end{array}$ & $\begin{array}{l}\text { Ministry of Public } \\
\text { Health }\end{array}$ & & & & & & 1 \\
\hline Lebanon & $\begin{array}{l}\text { Layal Hussein } \\
\text { Cheaitani }\end{array}$ & $\begin{array}{l}\text { Ministry of Public } \\
\text { Health }\end{array}$ & & & & & & 1 \\
\hline Lebanon & Rita Farah & $\begin{array}{l}\text { Ministry of Public } \\
\text { Health }\end{array}$ & & & & & & 1 \\
\hline Libya & $\begin{array}{l}\text { Abdunnabi } \\
\text { Ahmed Rayes }\end{array}$ & Ministry of Health & & & & & & 1 \\
\hline Libya & $\begin{array}{l}\text { Mohamed } \\
\text { Najeb Smeo }\end{array}$ & Ministry of Health & & & & & & 1 \\
\hline Libya & $\begin{array}{l}\text { Omar } \\
\text { Ramadan } \\
\text { ElAhmer }\end{array}$ & Ministry of Health & & & & & & 1 \\
\hline Malaysia & $\begin{array}{l}\text { Fadzilah } \\
\text { Kamaludin }\end{array}$ & Ministry of Health & 1 & & & & & \\
\hline Morocco & $\begin{array}{l}\text { Abdel Aziz } \\
\text { Barkia }\end{array}$ & Ministry of Health & & & & & & 1 \\
\hline Morocco & $\begin{array}{l}\text { Mohamed } \\
\text { Rhajaoui }\end{array}$ & & & & & & & 1 \\
\hline Morocco & $\begin{array}{l}\text { Naima El } \\
\text { Mdaghri }\end{array}$ & $\begin{array}{l}\text { Pasteur, Ministry of } \\
\text { Health }\end{array}$ & & & & & & 1 \\
\hline Netherlands & Ab Osterhaus & Erasmus MC & & 1 & & & & \\
\hline Netherlands & $\begin{array}{l}\text { Chantal } \\
\text { Reusken }\end{array}$ & & & 1 & & & & \\
\hline Netherlands & $\begin{array}{l}\text { Alexander E. } \\
\text { Gorbalenya, }\end{array}$ & $\begin{array}{l}\text { Leiden University } \\
\text { Medical Centre }\end{array}$ & & & 1 & & & \\
\hline Netherlands & Eric J. Snijder & $\begin{array}{l}\text { Leiden University } \\
\text { Medical Centre }\end{array}$ & & & 1 & & & \\
\hline Netherlands & $\begin{array}{l}\text { Raoul J. de } \\
\text { Groot }\end{array}$ & $\begin{array}{l}\text { Faculty of } \\
\text { Veterinary } \\
\text { Medicine, Utrecht } \\
\text { University }\end{array}$ & & & 1 & & & \\
\hline
\end{tabular}




\begin{tabular}{|c|c|c|c|c|c|c|c|c|}
\hline Country & Name & Institution & $\begin{array}{l}\text { EC- } \\
\text { MERS }\end{array}$ & $\begin{array}{l}\text { MERS } \\
\text { CoV } \\
\text { RG }\end{array}$ & $\begin{array}{l}\text { CSG } \\
\text { ICTV }\end{array}$ & $\begin{array}{l}\text { WHO } \\
\text { MERS } \\
\text { R\&D }\end{array}$ & $\begin{array}{l}\text { WHO } \\
\text { BP } \\
\text { VT }\end{array}$ & $\begin{array}{l}\text { Inter } \\
\text { country } \\
\text { meeting }\end{array}$ \\
\hline Netherlands & $\begin{array}{l}\text { Ron A. M. } \\
\text { Fouchier }\end{array}$ & Erasmus MC & & 1 & 1 & & & \\
\hline Netherlands & $\begin{array}{l}\text { Marion } \\
\text { Koopmans }\end{array}$ & $\begin{array}{l}\text { Erasmus Medical } \\
\text { Centre }\end{array}$ & & 1 & & 1 & & \\
\hline Netherlands & $\begin{array}{l}\text { Bart L. } \\
\text { Haagmans }\end{array}$ & Erasmus MC & & 1 & 1 & 1 & & \\
\hline Nigeria & $\begin{array}{l}\text { Oyewale } \\
\text { Tomori }\end{array}$ & $\begin{array}{l}\text { Redeemer's } \\
\text { University }\end{array}$ & 1 & & & & & \\
\hline Norway & $\begin{array}{l}\text { Nadia G. } \\
\text { Tornieporth, }\end{array}$ & $\begin{array}{l}\text { CEPI - Coalition for } \\
\text { Epidemic } \\
\text { Preparedness } \\
\text { Innovations }\end{array}$ & & & & & 1 & \\
\hline Norway & $\begin{array}{l}\text { Bjørn-Inge } \\
\text { Larsen }\end{array}$ & $\begin{array}{l}\text { Ministry of Health } \\
\text { and Care Services }\end{array}$ & 1 & & & & & \\
\hline Oman & $\begin{array}{l}\text { Idris Saleh Ali } \\
\text { Al-Obaidani }\end{array}$ & & & & & & & 1 \\
\hline Oman & $\begin{array}{l}\text { Said Al Baqlani } \\
\text { Acting }\end{array}$ & Ministry of Health & & & & & & 1 \\
\hline Oman & $\begin{array}{l}\text { Salah T. Al } \\
\text { Awaidy }\end{array}$ & Ministry of Health & 1 & & & & & \\
\hline Palestine & $\begin{array}{l}\text { Abdallah } \\
\text { Daoud Zahran }\end{array}$ & Ministry of Health & & & & & & 1 \\
\hline Palestine & $\begin{array}{l}\text { Diaa Obeid } \\
\text { Hjaija }\end{array}$ & Ministry of Health & & & & & & 1 \\
\hline Palestine & $\begin{array}{l}\text { Ibrahim } \\
\text { Mohamed } \\
\text { Salem }\end{array}$ & Ministry of Health & & & & & & 1 \\
\hline Palestine & $\begin{array}{l}\text { Nedal } \\
\text { Ghuneim }\end{array}$ & Ministry of Health & & & & & & 1 \\
\hline Qatar & $\begin{array}{l}\text { Muna } \\
\text { A.Rahman Al } \\
\text { Maslamani }\end{array}$ & $\begin{array}{l}\text { Hamad Medical } \\
\text { Corporation }\end{array}$ & & & & & & 1 \\
\hline Qatar & $\begin{array}{l}\text { Said Hamed } \\
\text { Said Al Dhahry }\end{array}$ & $\begin{array}{l}\text { Hamad Medical } \\
\text { Corporation }\end{array}$ & & & & & & 1 \\
\hline Qatar & $\begin{array}{l}\text { Hamad Eid Al- } \\
\text { Romaihi }\end{array}$ & $\begin{array}{l}\text { Supreme Council of } \\
\text { Health }\end{array}$ & & 1 & & & & \\
\hline Qatar & $\begin{array}{l}\text { Said H.S. Al } \\
\text { Dhahry }\end{array}$ & $\begin{array}{l}\text { Hamad Medical } \\
\text { Corporation }\end{array}$ & & 1 & & & & \\
\hline Qatar & $\begin{array}{l}\text { Adeel A. Butt } \\
\text { Medicine } \\
\text { Department }\end{array}$ & $\begin{array}{l}\text { Hamad Medical } \\
\text { Corporation }\end{array}$ & & & & & 1 & \\
\hline Qatar & $\begin{array}{l}\text { Elmoubasher } \\
\text { Abu Baker Abd } \\
\text { Farag }\end{array}$ & $\begin{array}{l}\text { Ministry of Public } \\
\text { Health }\end{array}$ & & & & & 1 & \\
\hline
\end{tabular}




\begin{tabular}{|c|c|c|c|c|c|c|c|c|}
\hline Country & Name & Institution & $\begin{array}{l}\text { EC- } \\
\text { MERS }\end{array}$ & $\begin{array}{l}\text { MERS } \\
\text { CoV } \\
\text { RG }\end{array}$ & $\begin{array}{l}\text { CSG } \\
\text { ICTV }\end{array}$ & $\begin{array}{l}\text { WHO } \\
\text { MERS } \\
\text { R\&D }\end{array}$ & $\begin{array}{l}\text { WHO } \\
\text { BP } \\
\text { VT }\end{array}$ & $\begin{array}{l}\text { Inter } \\
\text { country } \\
\text { meeting }\end{array}$ \\
\hline Qatar & $\begin{array}{l}\text { Mohammed } \\
\text { Mohammed } \\
\text { Al-Hajri }\end{array}$ & $\begin{array}{l}\text { Supreme Council of } \\
\text { Health }\end{array}$ & & 1 & & 1 & 1 & 1 \\
\hline $\begin{array}{l}\text { Republic of } \\
\text { Korea }\end{array}$ & In-Kyu Yoon & $\begin{array}{l}\text { International } \\
\text { Vaccine Institute }\end{array}$ & & & & 1 & & \\
\hline $\begin{array}{l}\text { Republic of } \\
\text { Korea }\end{array}$ & $\begin{array}{l}\text { Jerome H. } \\
\text { Kim, }\end{array}$ & $\begin{array}{l}\text { International } \\
\text { Vaccine Institute }\end{array}$ & & & & 1 & & \\
\hline $\begin{array}{l}\text { Republic of } \\
\text { Korea }\end{array}$ & Joel Maslow, & $\begin{array}{l}\text { GeneOne Life } \\
\text { Science Inc, }\end{array}$ & & & & 1 & & \\
\hline $\begin{array}{l}\text { Republic of } \\
\text { Korea }\end{array}$ & Young Park, & $\begin{array}{l}\text { GeneOne Life } \\
\text { Science, Inc. }\end{array}$ & & & & 1 & & \\
\hline $\begin{array}{l}\text { Republic of } \\
\text { Korea }\end{array}$ & $\begin{array}{l}\text { Youngmee } \\
\text { Jee, }\end{array}$ & $\begin{array}{l}\text { Centre for } \\
\text { Immunology and } \\
\text { Pathology, Centre } \\
\text { for Disease Control } \\
\text { and Prevention }\end{array}$ & & & & 1 & & \\
\hline Saudi Arabia & $\begin{array}{l}\text { Fahad Al } \\
\text { Rabiah }\end{array}$ & & & & & & & 1 \\
\hline Saudi Arabia & $\begin{array}{l}\text { Hatem } \\
\text { Makhdom } \\
\text { Qadhy }\end{array}$ & Ministry of Health & & & & & & 1 \\
\hline Saudi Arabia & $\begin{array}{l}\text { Jaafar Al } \\
\text { Tawfik }\end{array}$ & Ministry of Health & & & & & & 1 \\
\hline Saudi Arabia & $\begin{array}{l}\text { Khalid } \\
\text { Marghlani }\end{array}$ & Ministry of Health & & & & & & 1 \\
\hline Saudi Arabia & $\begin{array}{l}\text { Gwen M. } \\
\text { Stephens }\end{array}$ & Ministry of Health & & & 1 & & & \\
\hline Saudi Arabia & $\begin{array}{l}\text { Abdulaziz Bin } \\
\text { Saeed }\end{array}$ & Ministry of Health & & & & 1 & & \\
\hline Saudi Arabia & $\begin{array}{l}\text { Ahmad Salah } \\
\text { Hersi }\end{array}$ & Ministry of Health & & & & 1 & & \\
\hline Saudi Arabia & $\begin{array}{l}\text { Hail Mater } \\
\text { Alabdely }\end{array}$ & Ministry of Health & & & & 1 & & \\
\hline Saudi Arabia & $\begin{array}{l}\text { Ahmed } \\
\text { Mohammed } \\
\text { Hakawi, }\end{array}$ & $\begin{array}{l}\text { Infection } \\
\text { Prevention and } \\
\text { Control Directorate, } \\
\text { Ministry of Health }\end{array}$ & & & & & 1 & \\
\hline Saudi Arabia & $\begin{array}{l}\text { Yaseen M. } \\
\text { Arabi }\end{array}$ & $\begin{array}{l}\text { Ministry of the } \\
\text { National Guard, } \\
\text { Health Affairs }\end{array}$ & & & & & 1 & \\
\hline Saudi Arabia & $\begin{array}{l}\text { Raafat Faisal } \\
\text { Alhakeem }\end{array}$ & & & 1 & & & & 1 \\
\hline Saudi Arabia & $\begin{array}{l}\text { Abdullah } \\
\text { Mufareh } \\
\text { Assiri }\end{array}$ & Ministry of Health & & 1 & & 1 & & 1 \\
\hline Saudi Arabia & Ziad Memish & Ministry of Health & 1 & 1 & 1 & & & 1 \\
\hline Scotland & J Kenneth Baillie & University of Edinburgh & & 1 & & & & \\
\hline
\end{tabular}




\begin{tabular}{|c|c|c|c|c|c|c|c|c|}
\hline Country & Name & Institution & $\begin{array}{l}\text { EC- } \\
\text { MERS }\end{array}$ & $\begin{array}{l}\text { MERS } \\
\text { CoV } \\
\text { RG }\end{array}$ & $\begin{array}{l}\text { CSG } \\
\text { ICTV }\end{array}$ & $\begin{array}{l}\text { WHO } \\
\text { MERS } \\
\text { R\&D }\end{array}$ & $\begin{array}{l}\text { WHO } \\
\text { BP } \\
\text { VT }\end{array}$ & $\begin{array}{l}\text { Inter } \\
\text { country } \\
\text { meeting }\end{array}$ \\
\hline Senegal & $\begin{array}{l}\text { Babacar } \\
\text { Ndoye }\end{array}$ & & 1 & & & & & \\
\hline Singapore & $\begin{array}{l}\text { Christine } \\
\text { Qiuhan Gao }\end{array}$ & $\begin{array}{l}\text { Singapore Armed } \\
\text { Forces }\end{array}$ & & 1 & & & & \\
\hline Singapore & Junxiong Pang & $\begin{array}{l}\text { National University } \\
\text { of Singapore }\end{array}$ & & 1 & & & & \\
\hline Singapore & Karen Tan & & 1 & & & & & \\
\hline South Korea & Yae-Jean Kim & $\begin{array}{l}\text { Sungkyunkwan } \\
\text { University School of } \\
\text { Medicine, South } \\
\text { Korea }\end{array}$ & & & & & 1 & \\
\hline South Korea & $\begin{array}{l}\text { Myoung-don } \\
\text { Oh }\end{array}$ & $\begin{array}{l}\text { Department of } \\
\text { Internal Medicine, } \\
\text { National University } \\
\text { College of Medicine }\end{array}$ & & & & 1 & 1 & \\
\hline South Sudan & $\begin{array}{l}\text { Gregory Wani } \\
\text { Dumo }\end{array}$ & Ministry of Health & & & & & & 1 \\
\hline Spain & Isabel Sola & $\begin{array}{l}\text { Spanish National } \\
\text { Research Council }\end{array}$ & & & 1 & & & \\
\hline Spain & Luis Enjuanes & $\begin{array}{l}\text { Campus de la } \\
\text { Universidad } \\
\text { Autonoma de } \\
\text { Madrid }\end{array}$ & & & 1 & 1 & & \\
\hline Sudan & $\begin{array}{l}\text { Ahmed Hagar } \\
\text { Ahmed }\end{array}$ & Ministry of Health & & & & & & 1 \\
\hline Sudan & $\begin{array}{l}\text { Dina } \\
\text { AbdulHammed } \\
\text { Abdulla }\end{array}$ & & & & & & & 1 \\
\hline Sudan & $\begin{array}{l}\text { Sara Ahmed El } \\
\text { Tigani El Hag } \\
\text { Abdalla }\end{array}$ & Ministry of Health & & & & & & 1 \\
\hline Switzerland & Keiji Fukuda & $\begin{array}{l}\text { World Health } \\
\text { Organization } \mathrm{HQ}\end{array}$ & & & & & & 1 \\
\hline Switzerland & Sergey Eremin & $\begin{array}{l}\text { World Health } \\
\text { Organization } \mathrm{HQ}\end{array}$ & & & & & & 1 \\
\hline Switzerland & $\begin{array}{l}\text { Gregory Anton } \\
\text { Hartl }\end{array}$ & $\begin{array}{l}\text { World Health } \\
\text { Organization } \mathrm{HQ}\end{array}$ & & & & & & 1 \\
\hline Switzerland & $\begin{array}{l}\text { Maurizio } \\
\text { Barbeschi }\end{array}$ & $\begin{array}{l}\text { World Health } \\
\text { Organization } \mathrm{HQ}\end{array}$ & & & & & & 1 \\
\hline Switzerland & $\begin{array}{l}\text { Christopher } \\
\text { John Oxenford }\end{array}$ & $\begin{array}{l}\text { World Health } \\
\text { Organization }\end{array}$ & & 1 & & & & \\
\hline Switzerland & $\begin{array}{l}\text { Elizabeth } \\
\text { Mumford }\end{array}$ & $\begin{array}{l}\text { World Health } \\
\text { Organization }\end{array}$ & & 1 & & & & \\
\hline Switzerland & Erika Garcia & $\begin{array}{l}\text { World Health } \\
\text { Organization }\end{array}$ & & 1 & & & & \\
\hline Switzerland & $\begin{array}{l}\text { Gilles } \\
\text { Poumerol }\end{array}$ & $\begin{array}{l}\text { World Health } \\
\text { Organization }\end{array}$ & & 1 & & & & \\
\hline
\end{tabular}




\begin{tabular}{|c|c|c|c|c|c|c|c|c|}
\hline Country & Name & Institution & $\begin{array}{l}\text { EC- } \\
\text { MERS }\end{array}$ & $\begin{array}{l}\text { MERS } \\
\text { CoV } \\
\text { RG }\end{array}$ & $\begin{array}{l}\text { CSG } \\
\text { ICTV }\end{array}$ & $\begin{array}{l}\text { WHO } \\
\text { MERS } \\
\text { R\&D }\end{array}$ & $\begin{array}{l}\text { WHO } \\
\text { BP } \\
\text { VT }\end{array}$ & $\begin{array}{l}\text { Inter } \\
\text { country } \\
\text { meeting }\end{array}$ \\
\hline Switzerland & $\begin{array}{l}\text { Maxwell } \\
\text { Charles } \\
\text { Hardiman }\end{array}$ & $\begin{array}{l}\text { World Health } \\
\text { Organization }\end{array}$ & & 1 & & & & \\
\hline Switzerland & Molly Siwula & $\begin{array}{l}\text { World Health } \\
\text { Organization }\end{array}$ & & 1 & & & & \\
\hline Switzerland & Nicolas Isla & $\begin{array}{l}\text { World Health } \\
\text { Organization }\end{array}$ & & 1 & & & & \\
\hline Switzerland & $\begin{array}{l}\text { Sebastien } \\
\text { Bruno Francois } \\
\text { Cognat }\end{array}$ & $\begin{array}{l}\text { World Health } \\
\text { Organization }\end{array}$ & & 1 & & & & \\
\hline Switzerland & $\begin{array}{l}\text { Sergey } \\
\text { Romualdovich } \\
\text { Eremin }\end{array}$ & $\begin{array}{l}\text { World Health } \\
\text { Organization }\end{array}$ & & 1 & & & & \\
\hline Switzerland & $\begin{array}{l}\text { Stéphane } \\
\text { Alexandre L. } \\
\text { Hugonnet }\end{array}$ & $\begin{array}{l}\text { World Health } \\
\text { Organization }\end{array}$ & & 1 & & & & \\
\hline Switzerland & $\begin{array}{l}\text { Stéphane De } \\
\text { La Rocque }\end{array}$ & $\begin{array}{l}\text { World Health } \\
\text { Organization }\end{array}$ & & 1 & & & & \\
\hline Switzerland & $\begin{array}{l}\text { Bernadette } \\
\text { Murgue }\end{array}$ & $\begin{array}{l}\text { World Health } \\
\text { Organization } \mathrm{HQ}\end{array}$ & & & & 1 & & \\
\hline Switzerland & David Wood, & $\begin{array}{l}\text { World Health } \\
\text { Organization } \mathrm{HQ}\end{array}$ & & & & 1 & & \\
\hline Switzerland & Davide Corti, & Humabs BioMed SA & & & & 1 & & \\
\hline Switzerland & $\begin{array}{l}\text { Marie-Paule } \\
\text { Kieny }\end{array}$ & $\begin{array}{l}\text { World Health } \\
\text { Organization } \mathrm{HQ}\end{array}$ & & & & 1 & & \\
\hline Switzerland & Nadia Passini & Humabs BioMed SA & & & & 1 & & \\
\hline Switzerland & Peter Beyer & $\begin{array}{l}\text { World Health } \\
\text { Organization } \mathrm{HQ}\end{array}$ & & & & 1 & & \\
\hline Switzerland & Sylvie Briand, & $\begin{array}{l}\text { World Health } \\
\text { Organization } \mathrm{HQ}\end{array}$ & & & & 1 & & \\
\hline Switzerland & Tony Stewart, & $\begin{array}{l}\text { World Health } \\
\text { Organization } \mathrm{HQ}\end{array}$ & & & & 1 & & \\
\hline Switzerland & $\begin{array}{l}\text { Vasee } \\
\text { Moorthy, }\end{array}$ & $\begin{array}{l}\text { World Health } \\
\text { Organization } \mathrm{HQ}\end{array}$ & & & & 1 & & \\
\hline Switzerland & $\begin{array}{l}\text { Ana Maria } \\
\text { Henao } \\
\text { Restrepo }\end{array}$ & $\begin{array}{l}\text { World Health } \\
\text { Organization } \mathrm{HQ}\end{array}$ & & & & & 1 & \\
\hline Switzerland & $\begin{array}{l}\text { Cassandra } \\
\text { Kelly-Cirino }\end{array}$ & FIND & & & & & 1 & \\
\hline Switzerland & Karene Yeung & $\begin{array}{l}\text { World Health } \\
\text { Organization } \mathrm{HQ}\end{array}$ & & & & & 1 & \\
\hline Switzerland & $\begin{array}{l}\text { Konstantin } \\
\text { Volkmann }\end{array}$ & $\begin{array}{l}\text { World Health } \\
\text { Organization } \mathrm{HQ}\end{array}$ & & & & & 1 & \\
\hline Switzerland & $\begin{array}{l}\text { Maria Van } \\
\text { Kerkhove }\end{array}$ & $\begin{array}{l}\text { World Health } \\
\text { Organization } \mathrm{HQ}\end{array}$ & & & & & 1 & \\
\hline Switzerland & $\begin{array}{l}\text { Pierre- } \\
\text { Stéphane Gsell }\end{array}$ & $\begin{array}{l}\text { World Health } \\
\text { Organization } \mathrm{HQ}\end{array}$ & & & & & 1 & \\
\hline
\end{tabular}




\begin{tabular}{|c|c|c|c|c|c|c|c|c|}
\hline Country & Name & Institution & $\begin{array}{l}\text { EC- } \\
\text { MERS }\end{array}$ & $\begin{array}{l}\text { MERS } \\
\text { CoV } \\
\text { RG }\end{array}$ & $\begin{array}{l}\text { CSG } \\
\text { ICTV }\end{array}$ & $\begin{array}{l}\text { WHO } \\
\text { MERS } \\
\text { R\&D }\end{array}$ & $\begin{array}{l}\text { WHO } \\
\text { BP } \\
\text { VT }\end{array}$ & $\begin{array}{l}\text { Inter } \\
\text { country } \\
\text { meeting }\end{array}$ \\
\hline Switzerland & $\begin{array}{l}\text { Anthony } \\
\text { Wayne M. }\end{array}$ & $\begin{array}{l}\text { World Health } \\
\text { Organization } \mathrm{HQ}\end{array}$ & & 1 & & & & 1 \\
\hline Switzerland & $\begin{array}{l}\text { Bruce Jay } \\
\text { Plotkin }\end{array}$ & $\begin{array}{l}\text { World Health } \\
\text { Organization } \mathrm{HQ}\end{array}$ & & 1 & & & & 1 \\
\hline Switzerland & $\begin{array}{l}\text { Nahoko } \\
\text { Shindo }\end{array}$ & $\begin{array}{l}\text { World Health } \\
\text { Organization }\end{array}$ & & 1 & & & & 1 \\
\hline Switzerland & $\begin{array}{l}\text { Patrick } \\
\text { Anthony Drury }\end{array}$ & $\begin{array}{l}\text { World Health } \\
\text { Organization } \mathrm{HQ}\end{array}$ & & 1 & & & & 1 \\
\hline Switzerland & $\begin{array}{l}\text { Pierre B.H. } \\
\text { Formenty }\end{array}$ & $\begin{array}{l}\text { World Health } \\
\text { Organization } \mathrm{HQ}\end{array}$ & & 1 & & & & 1 \\
\hline Switzerland & Cathy Roth & $\begin{array}{l}\text { World Health } \\
\text { Organization } \mathrm{HQ}\end{array}$ & & 1 & & 1 & & 1 \\
\hline Switzerland & $\begin{array}{l}\text { Peter Ben } \\
\text { Embarek }\end{array}$ & $\begin{array}{l}\text { World Health } \\
\text { Organization } \mathrm{HQ}\end{array}$ & & 1 & & 1 & & 1 \\
\hline Tunisia & Habib Ghedira & & & & & & & 1 \\
\hline Tunisia & $\begin{array}{l}\text { Mohamed } \\
\text { Besbes }\end{array}$ & Ministry of Health & & & & & & 1 \\
\hline Tunisia & $\begin{array}{l}\text { Mokhtar } \\
\text { Mohamed } \\
\text { Zorraga }\end{array}$ & Ministry of Health & & & & & & 1 \\
\hline Tunisia & $\begin{array}{l}\text { Noureddine } \\
\text { Achour }\end{array}$ & Ministry of Health & & & & & & 1 \\
\hline Tunisia & Fekri Abroug & $\begin{array}{l}\text { Fattouma } \\
\text { Bourguiba Hospital }\end{array}$ & & 1 & & & & \\
\hline Tunisia & Afif Ben Salah & $\begin{array}{l}\text { Institut Pasteur de } \\
\text { Tunis }\end{array}$ & & 1 & & & & 1 \\
\hline Tunisia & Amine Slim & $\begin{array}{l}\text { Charles Nicolle } \\
\text { Hospital }\end{array}$ & & 1 & & & & 1 \\
\hline UK & $\begin{array}{l}\text { Maria D. Van } \\
\text { Kerkhove }\end{array}$ & $\begin{array}{l}\text { Imperial College } \\
\text { London }\end{array}$ & & 1 & & & & \\
\hline UK & $\begin{array}{l}\text { Neil M. } \\
\text { Ferguson }\end{array}$ & $\begin{array}{l}\text { Imperial College } \\
\text { London }\end{array}$ & & 1 & & & & \\
\hline UK & $\begin{array}{l}\text { Benjamin W. } \\
\text { Neuman }\end{array}$ & $\begin{array}{l}\text { University of } \\
\text { Reading }\end{array}$ & & & 1 & & & \\
\hline UK & $\begin{array}{l}\text { Monica } \\
\text { Galiano }\end{array}$ & $\begin{array}{l}\text { Public Health } \\
\text { England (formerly } \\
\text { Health Protection } \\
\text { Agency) }\end{array}$ & & & 1 & & & \\
\hline UK & Eric Pelfrene & $\begin{array}{l}\text { Anti-Infectives and } \\
\text { Vaccines, European } \\
\text { Medicines Agency }\end{array}$ & & & & 1 & & \\
\hline UK & Ruth Harvey & $\begin{array}{l}\text { Department of } \\
\text { Virology, National } \\
\text { Institute for } \\
\text { Biological Standards } \\
\text { and Control, Health } \\
\text { Protection Agency }\end{array}$ & & & & 1 & & \\
\hline
\end{tabular}




\begin{tabular}{|c|c|c|c|c|c|c|c|c|}
\hline Country & Name & Institution & $\begin{array}{l}\text { EC- } \\
\text { MERS }\end{array}$ & $\begin{array}{l}\text { MERS } \\
\text { CoV } \\
\text { RG }\end{array}$ & $\begin{array}{l}\text { CSG } \\
\text { ICTV }\end{array}$ & $\begin{array}{l}\text { WHO } \\
\text { MERS } \\
\text { R\&D }\end{array}$ & $\begin{array}{l}\text { WHO } \\
\text { BP } \\
\text { VT }\end{array}$ & $\begin{array}{l}\text { Inter } \\
\text { country } \\
\text { meeting }\end{array}$ \\
\hline UK & $\begin{array}{l}\text { Simon } \\
\text { Cauchemez }\end{array}$ & $\begin{array}{l}\text { Imperial College } \\
\text { London }\end{array}$ & & & & 1 & & \\
\hline UK & Marco Cavaleri & & & & & & 1 & \\
\hline UK & $\begin{array}{l}\text { Peter W. } \\
\text { Horby }\end{array}$ & $\begin{array}{l}\text { University of } \\
\text { Oxford, UK }\end{array}$ & & & & & 1 & \\
\hline UK & $\begin{array}{l}\text { W. John } \\
\text { Edmunds }\end{array}$ & $\begin{array}{l}\text { London School of } \\
\text { Hygiene and } \\
\text { Tropical Medicine }\end{array}$ & & & & & 1 & \\
\hline UK & $\begin{array}{l}\text { Richard } \\
\text { Pebody }\end{array}$ & $\begin{array}{l}\text { Public Health } \\
\text { England }\end{array}$ & & 1 & & & 1 & 1 \\
\hline UK & Maria Zambon & $\begin{array}{l}\text { Public Health } \\
\text { England }\end{array}$ & 1 & 1 & 1 & & & 1 \\
\hline UMG & Gerd Sutter & $\begin{array}{l}\text { Institute for } \\
\text { Infectious Diseases } \\
\text { and Zoonoses } \\
\text { Ludwig- } \\
\text { Maximilians- } \\
\text { Universität }\end{array}$ & & & & 1 & & \\
\hline $\begin{array}{l}\text { United Arab } \\
\text { Emirates }\end{array}$ & $\begin{array}{l}\text { Fatma } \\
\text { Mahmood El } \\
\text { Attar }\end{array}$ & Health Authority & & & & & & 1 \\
\hline $\begin{array}{l}\text { United Arab } \\
\text { Emirates }\end{array}$ & $\begin{array}{l}\text { Laila Hussain } \\
\text { El Jasmi }\end{array}$ & Ministry of Health & & & & & & 1 \\
\hline $\begin{array}{l}\text { United Arab } \\
\text { Emirates }\end{array}$ & $\begin{array}{l}\text { Mahmoud } \\
\text { Mohamed } \\
\text { Fikri }\end{array}$ & Ministry of Health & & & & & & 1 \\
\hline $\begin{array}{l}\text { United Arab } \\
\text { Emirates }\end{array}$ & $\begin{array}{l}\text { Farida Ismail } \\
\text { Al Hosani, }\end{array}$ & Ministry of Health & & 1 & & & 1 & 1 \\
\hline USA & Kashef ljaz & $\begin{array}{l}\text { Centers for Disease } \\
\text { Control and } \\
\text { Prevention }\end{array}$ & & & & & & 1 \\
\hline USA & $\begin{array}{l}\text { Maria } \\
\text { Morales- } \\
\text { Betoulle }\end{array}$ & $\begin{array}{l}\text { Centers for Disease } \\
\text { Control and } \\
\text { Prevention }\end{array}$ & & & & & & 1 \\
\hline USA & $\begin{array}{l}\text { Mayar Maged } \\
\text { Said }\end{array}$ & $\begin{array}{l}\text { U.S. Naval Medical } \\
\text { Research Unit No. } 3 \\
\text { (NAMRU-3) }\end{array}$ & & & & & & 1 \\
\hline USA & $\begin{array}{l}\text { Rana A. Hajjeh } \\
\text { Director }\end{array}$ & $\begin{array}{l}\text { Centers for Disease } \\
\text { Control and } \\
\text { Prevention }\end{array}$ & & & & & & 1 \\
\hline USA & $\begin{array}{l}\text { Alice M. } \\
\text { Shumate }\end{array}$ & $\begin{array}{l}\text { Centers for Disease } \\
\text { Control and } \\
\text { Prevention }\end{array}$ & & 1 & & & & \\
\hline USA & Lisa E Hensley & & & 1 & & & & \\
\hline USA & Thomas Briese & & & 1 & & & & \\
\hline USA & W. Ian Lipkin & Columbia University & & 1 & & & & \\
\hline
\end{tabular}




\begin{tabular}{|c|c|c|c|c|c|c|c|c|}
\hline Country & Name & Institution & $\begin{array}{l}\text { EC- } \\
\text { MERS }\end{array}$ & $\begin{array}{l}\text { MERS } \\
\text { CoV } \\
\text { RG }\end{array}$ & $\begin{array}{l}\text { CSG } \\
\text { ICTV }\end{array}$ & $\begin{array}{l}\text { WHO } \\
\text { MERS } \\
\text { R\&D }\end{array}$ & $\begin{array}{l}\text { WHO } \\
\text { BP } \\
\text { VT }\end{array}$ & $\begin{array}{l}\text { Inter } \\
\text { country } \\
\text { meeting }\end{array}$ \\
\hline USA & $\begin{array}{l}\text { William B. } \\
\text { Karesh }\end{array}$ & EcoHealth Alliance & & 1 & & & & \\
\hline USA & Ralph Baric & $\begin{array}{l}\text { University of North } \\
\text { Carolina }\end{array}$ & & & 1 & & & \\
\hline USA & $\begin{array}{l}\text { Stanley } \\
\text { Perlman }\end{array}$ & University of lowa & & & 1 & & & \\
\hline USA & Susan Baker & $\begin{array}{l}\text { Loyola University } \\
\text { Medical Centre }\end{array}$ & & & 1 & & & \\
\hline USA & $\begin{array}{l}\text { Andrea } \\
\text { Gambotto }\end{array}$ & $\begin{array}{l}\text { University of } \\
\text { Pittsburgh, School } \\
\text { of Medicine }\end{array}$ & & & & 1 & & \\
\hline USA & $\begin{array}{l}\text { Barney S. } \\
\text { Graham }\end{array}$ & $\begin{array}{l}\text { National Institutes } \\
\text { of Health }\end{array}$ & & & & 1 & & \\
\hline USA & David Kaslow & PATH & & & & 1 & & \\
\hline USA & Eddie Sullivan & $\begin{array}{l}\text { SAB } \\
\text { Biotherapeutics, } \\
\text { INC }\end{array}$ & & & & 1 & & \\
\hline USA & Erik Stemmy & DMID/NIAID & & & & 1 & & \\
\hline USA & $\begin{array}{l}\text { James } \\
\text { Cummings }\end{array}$ & $\begin{array}{l}\text { Emerging Infectious } \\
\text { Diseases, Novavax }\end{array}$ & & & & 1 & & \\
\hline USA & $\begin{array}{l}\text { Kayvon } \\
\text { Modjarrad }\end{array}$ & $\begin{array}{l}\text { US Military HIV } \\
\text { Research Program, } \\
\text { Walter Reed Army } \\
\text { Institute of } \\
\text { Research }\end{array}$ & & & & 1 & & \\
\hline USA & $\begin{array}{l}\text { Kent Tseng } \\
\text { Chien-Te }\end{array}$ & University of Texas & & & & 1 & & \\
\hline USA & Mary Kosinski & $\begin{array}{l}\text { U.S. Department of } \\
\text { Health and Human } \\
\text { Services }\end{array}$ & & & & 1 & & \\
\hline USA & Matt Freiman & $\begin{array}{l}\text { University of } \\
\text { Maryland School of } \\
\text { Medicine }\end{array}$ & & & & 1 & & \\
\hline USA & Rick Bright & $\begin{array}{l}\text { Biomedical } \\
\text { Advanced Research } \\
\text { \& Development } \\
\text { Authority (BARDA), } \\
\text { US Health and } \\
\text { Human Services }\end{array}$ & & & & 1 & & \\
\hline USA & $\begin{array}{l}\text { Robin } \\
\text { Robinson }\end{array}$ & $\begin{array}{l}\text { Biomedical } \\
\text { Advanced Research } \\
\text { and Development } \\
\text { Authority, Deputy } \\
\text { Assistant Secretary } \\
\text { for Preparedness }\end{array}$ & & & & 1 & & \\
\hline USA & $\begin{array}{l}\text { Sebastian } \\
\text { Wanless }\end{array}$ & Brighton Biotech & & & & 1 & & \\
\hline
\end{tabular}




\begin{tabular}{|c|c|c|c|c|c|c|c|c|}
\hline Country & Name & Institution & $\begin{array}{l}\text { EC- } \\
\text { MERS }\end{array}$ & $\begin{array}{l}\text { MERS } \\
\text { CoV } \\
\text { RG }\end{array}$ & $\begin{array}{l}\text { CSG } \\
\text { ICTV }\end{array}$ & $\begin{array}{l}\text { WHO } \\
\text { MERS } \\
\text { R\&D }\end{array}$ & $\begin{array}{l}\text { WHO } \\
\text { BP } \\
\text { VT }\end{array}$ & $\begin{array}{l}\text { Inter } \\
\text { country } \\
\text { meeting }\end{array}$ \\
\hline USA & Tomas Cihlar & & & & & 1 & & \\
\hline USA & Uwe Staerz & Geffex Inc. & & & & 1 & & \\
\hline USA & $\begin{array}{l}\text { Wayne } \\
\text { Marasco }\end{array}$ & $\begin{array}{l}\text { Harvard Medical } \\
\text { School }\end{array}$ & & & & 1 & & \\
\hline USA & Amy C. Sims & $\begin{array}{l}\text { University of North } \\
\text { Carolina }\end{array}$ & & & & & 1 & \\
\hline USA & Ira M. Longini & $\begin{array}{l}\text { University of } \\
\text { Florida, }\end{array}$ & & & & & 1 & \\
\hline USA & $\begin{array}{l}\text { John T. } \\
\text { Watson }\end{array}$ & $\begin{array}{l}\text { Centers for Disease } \\
\text { Control and } \\
\text { Prevention USA }\end{array}$ & & & & & 1 & \\
\hline USA & $\begin{array}{l}\text { Martha C. } \\
\text { Nason }\end{array}$ & $\begin{array}{l}\text { National Institute of } \\
\text { Allergy and } \\
\text { Infectious Diseases }\end{array}$ & & & & & 1 & \\
\hline USA & Natalie E. & $\begin{array}{l}\text { Department of } \\
\text { Biostatistics } \\
\text { University of Florida }\end{array}$ & & & & & 1 & \\
\hline USA & Peter M. Dull & $\begin{array}{l}\text { Bill and Melinda } \\
\text { Gates Foundation }\end{array}$ & & & & & 1 & \\
\hline USA & $\begin{array}{l}\text { Philip R. } \\
\text { Krause }\end{array}$ & $\begin{array}{l}\text { Center for Biologics } \\
\text { Evaluation and } \\
\text { Research, US Food } \\
\text { and Drug } \\
\text { Administration }\end{array}$ & & & & & 1 & \\
\hline USA & $\begin{array}{l}\text { Susan S. } \\
\text { Ellenberg }\end{array}$ & $\begin{array}{l}\text { University of } \\
\text { Pennsylvania } \\
\text { Perelman School of } \\
\text { Medicine }\end{array}$ & & & & & 1 & \\
\hline USA & $\begin{array}{l}\text { Thomas R. } \\
\text { Fleming }\end{array}$ & $\begin{array}{l}\text { School of Public } \\
\text { Health, University } \\
\text { of Washington }\end{array}$ & & & & & 1 & \\
\hline USA & Tim Uyeki & $\begin{array}{l}\text { National Centre for } \\
\text { Immunization and } \\
\text { Respiratory } \\
\text { Diseases Centres for } \\
\text { Disease Control and } \\
\text { Prevention }\end{array}$ & & & & & 1 & \\
\hline USA & Maha Talaat & $\begin{array}{l}\text { Disease Prevention, } \\
\text { Global Disease } \\
\text { Detection and } \\
\text { Response Centre, } \\
\text { United States Naval } \\
\text { Medical Research } \\
\text { Unit, No.3. Egypt }\end{array}$ & 1 & & & & & \\
\hline USA & Martin Cetron & $\begin{array}{l}\text { Centres for Disease } \\
\text { Control and } \\
\text { Prevention }\end{array}$ & 1 & & & & & \\
\hline
\end{tabular}




\begin{tabular}{|c|c|c|c|c|c|c|c|c|}
\hline Country & Name & Institution & $\begin{array}{l}\text { EC- } \\
\text { MERS }\end{array}$ & $\begin{array}{l}\text { MERS } \\
\text { CoV } \\
\text { RG }\end{array}$ & $\begin{array}{l}\text { CSG } \\
\text { ICTV }\end{array}$ & $\begin{array}{l}\text { WHO } \\
\text { MERS } \\
\text { R\&D }\end{array}$ & $\begin{array}{l}\text { WHO } \\
\text { BP } \\
\text { VT }\end{array}$ & $\begin{array}{l}\text { Inter } \\
\text { country } \\
\text { meeting }\end{array}$ \\
\hline USA & $\begin{array}{l}\text { Gabriel N. } \\
\text { Defang }\end{array}$ & $\begin{array}{l}\text { U.S. Naval Medical } \\
\text { Research Unit No. } 3 \\
\text { (NAMRU-3) }\end{array}$ & & 1 & & & & 1 \\
\hline USA & $\begin{array}{l}\text { Susan I. } \\
\text { Gerber }\end{array}$ & $\begin{array}{l}\text { Centres for Disease } \\
\text { Control and } \\
\text { Prevention }\end{array}$ & & 1 & & & & 1 \\
\hline USA & $\begin{array}{l}\text { Frederick G. } \\
\text { Hayden }\end{array}$ & $\begin{array}{l}\text { Division of } \\
\text { Infectious Diseases } \\
\text { and International } \\
\text { Health, University } \\
\text { of Virginia School of } \\
\text { Medicine }\end{array}$ & & & & 1 & 1 & \\
\hline Yemen & $\begin{array}{l}\text { Abdulhakim } \\
\text { Ali Al Kuhlani }\end{array}$ & $\begin{array}{l}\text { Ministry of Public } \\
\text { Health and } \\
\text { Population }\end{array}$ & & & & & & 1 \\
\hline Yemen & $\begin{array}{l}\text { Mahmoud } \\
\text { Abdullah } \\
\text { Ogaili }\end{array}$ & $\begin{array}{l}\text { Ministry of Public } \\
\text { Health and } \\
\text { Population }\end{array}$ & & & & & & 1 \\
\hline Yemen & $\begin{array}{l}\text { Mohammed } \\
\text { Abdullah Al } \\
\text { Dawla }\end{array}$ & & & & & & & 1 \\
\hline
\end{tabular}

EC-MERS: Emergency Committee; MERS CoV RG: MERS CoV Research Group; CSG ICTV: Coronavirus Study Group (CSG) of the International Committee on Taxonomy of Viruses; WHO MERS R\&D: WHO Consultation on MERS CoV R\&D; WHO BP VT: WHO consultation on MERS-CoV vaccine and therapeutics 
Appendix K. Ebola Epistemic Community

\begin{tabular}{|c|c|c|c|c|c|c|c|c|c|c|}
\hline Country & Member & Institution & $\begin{array}{l}\text { EC } \\
\text { Ebola }\end{array}$ & $\begin{array}{l}\text { WHO } \\
\text { AGEVDR }\end{array}$ & ES2014 & $\begin{array}{l}\text { WHO } \\
\text { CCDEM }\end{array}$ & $\begin{array}{l}\text { ST } \\
1976\end{array}$ & $\begin{array}{l}\text { WHO } \\
\text { ERT } \\
2014\end{array}$ & $\begin{array}{l}\text { IC } \\
1976\end{array}$ & $\begin{array}{l}\text { Informal } \\
\text { Consultation } \\
\text { Ebola } \\
\text { outbreak } \\
2014\end{array}$ \\
\hline Australia & Chris Baggoley & $\begin{array}{l}\text { Australian Government } \\
\text { Department of Health }\end{array}$ & 1 & & & & & & & \\
\hline Australia & Michael Selgelid & Monash University & 1 & & & & & & & \\
\hline Belgium & D. Thonon & Fonds Medical Tropical & & & & & & & 1 & \\
\hline Belgium & G. Van Der Groen & Institut de Medicine Tropicale & & & & & & & 1 & \\
\hline Belgium & J. Burke, & Fonds Medical Tropical & & & & & & & 1 & \\
\hline Belgium & J. F. Ruppol & Fonds Medical Tropical & & & & & & & 1 & \\
\hline Belgium & Michel Van Herp & Médecins Sans Frontières & & & 1 & & & & & 1 \\
\hline Belgium & Peter Piot & $\begin{array}{l}\text { London School of Hygiene } \\
\text { and Tropical Medicine }\end{array}$ & & 1 & & & & & 1 & 1 \\
\hline Belgium & R. Declerq & Fonds Medical Tropical & & & & & & & 1 & \\
\hline Belgium & Rosa Crestani & Médecins Sans Frontières & & & 1 & & & & & \\
\hline Belgium & S. R. Pattyn & $\begin{array}{l}\text { Institut de Medecine } \\
\text { Tropicale, }\end{array}$ & & & & & & & 1 & \\
\hline Belgium & $\begin{array}{l}\text { S. Van } \\
\text { Nieuwenhove }\end{array}$ & Fonds Medical Tropical & & & & & & & 1 & \\
\hline Belgium & $\begin{array}{l}\text { Sister G. } \\
\text { Ghysebrechts }\end{array}$ & Catholic Mission & & & & & & & 1 & \\
\hline Belgium & Sister M. Ronsmans & Catholic Mission & & & & & & & 1 & \\
\hline Belgium & $\begin{array}{l}\text { Sister M. } \\
\text { Witvrouwen }\end{array}$ & Catholic Mission & & & & & & & 1 & \\
\hline Brazil & Luiz Loures & UNAIDS & & 1 & & & & & & \\
\hline Canada & Anthony Evans & $\begin{array}{l}\text { International Civil Aviation } \\
\text { Organization }\end{array}$ & 1 & & & & & & & \\
\hline
\end{tabular}




\begin{tabular}{|c|c|c|c|c|c|c|c|c|c|c|}
\hline Country & Member & Institution & $\begin{array}{l}\text { EC } \\
\text { Ebola }\end{array}$ & $\begin{array}{l}\text { WHO } \\
\text { AGEVDR }\end{array}$ & ES2014 & $\begin{array}{l}\text { WHO } \\
\text { CCDEM }\end{array}$ & $\begin{array}{l}\text { ST } \\
1976\end{array}$ & $\begin{array}{l}\text { WHO } \\
\text { ERT } \\
2014\end{array}$ & $\begin{array}{l}\text { IC } \\
1976\end{array}$ & $\begin{array}{l}\text { Informal } \\
\text { Consultation } \\
\text { Ebola } \\
\text { outbreak } \\
2014\end{array}$ \\
\hline Canada & Gary Kobinger & $\begin{array}{l}\text { National Microbiology } \\
\text { Laboratory, Public Health } \\
\text { Agency of Canada }\end{array}$ & & & 1 & 1 & & & & 1 \\
\hline Canada & Sgt G. Colbourne & Royal Canadian Army & & & & & & & 1 & \\
\hline Canada & Theresa Tam & $\begin{array}{l}\text { Public Health Agency of } \\
\text { Canada }\end{array}$ & 1 & & & & & & & \\
\hline Canada & Robert Fowler & Sunnybrook Medical Centre & & & & & & & & 1 \\
\hline Chile & Fernando Otaiza & Ministry of Health & 1 & & & & & & & \\
\hline $\begin{array}{l}\text { Democratic } \\
\text { republic of } \\
\text { Congo }\end{array}$ & $\begin{array}{l}\text { Jean-Jacques } \\
\text { Muyembe }\end{array}$ & $\begin{array}{l}\text { National Institute of } \\
\text { Biomedical Research }\end{array}$ & 1 & 1 & & & & & & \\
\hline $\begin{array}{l}\text { Democratic } \\
\text { Republic of } \\
\text { Sudan }\end{array}$ & Ali Ahmed Idris & Ministry of Health & & & & & 1 & & & \\
\hline $\begin{array}{l}\text { Democratic } \\
\text { Republic of } \\
\text { Sudan }\end{array}$ & Anthony Lagu Gillo & Ministry of Health & & & & & 1 & & & \\
\hline $\begin{array}{l}\text { Democratic } \\
\text { Republic of } \\
\text { Sudan }\end{array}$ & Babiker el Tahir & Ministry of Health & & & & & 1 & & & \\
\hline $\begin{array}{l}\text { Democratic } \\
\text { Republic of } \\
\text { Sudan }\end{array}$ & Isiaih Mayom Deng & Ministry of Health & & & & & 1 & & & \\
\hline $\begin{array}{l}\text { Democratic } \\
\text { Republic of } \\
\text { Sudan }\end{array}$ & Noel Logo Warille & Ministry of Health & & & & & 1 & & & \\
\hline $\begin{array}{l}\text { Democratic } \\
\text { Republic of } \\
\text { Sudan }\end{array}$ & Oliver Duku & Ministry of Health & & & & & 1 & & & \\
\hline $\begin{array}{l}\text { Democratic } \\
\text { Republic of } \\
\text { Sudan }\end{array}$ & Pacifico Lolik & Ministry of Health & & & & & 1 & & & \\
\hline
\end{tabular}




\begin{tabular}{|c|c|c|c|c|c|c|c|c|c|c|}
\hline Country & Member & Institution & $\begin{array}{l}\text { EC } \\
\text { Ebola }\end{array}$ & $\begin{array}{l}\text { WHO } \\
\text { AGEVDR }\end{array}$ & ES2014 & $\begin{array}{l}\text { WHO } \\
\text { CCDEM }\end{array}$ & $\begin{array}{l}\text { ST } \\
1976\end{array}$ & $\begin{array}{l}\text { WHO } \\
\text { ERT } \\
2014\end{array}$ & $\begin{array}{l}\text { IC } \\
1976\end{array}$ & $\begin{array}{l}\text { Informal } \\
\text { Consultation } \\
\text { Ebola } \\
\text { outbreak } \\
2014 \\
\end{array}$ \\
\hline $\begin{array}{l}\text { Democratic } \\
\text { Republic of } \\
\text { Sudan }\end{array}$ & $\begin{array}{l}\text { William Renzi } \\
\text { Tembura }\end{array}$ & Ministry of Health & & & & & 1 & & & \\
\hline Denmark & Christiana Salvi & WHO/EURO & & & 1 & & & & & \\
\hline Denmark & Guenael Rodier & WHO/EURO & & & 1 & & & & & \\
\hline Egypt & $\begin{array}{l}\text { Hassan El Bushra } \\
\text { Ahmed }\end{array}$ & WHO/EMRO & & & 1 & & & & & \\
\hline Egypt & Martin Opoka & WHO/EMRO & & & 1 & & & & & \\
\hline $\begin{array}{l}\text { Federal } \\
\text { Republic of } \\
\text { Germany }\end{array}$ & J. Knobloch & Tropeninstitut & & & & & 1 & & & \\
\hline France & Alain Epelboin & $\begin{array}{l}\text { National Centre for Scientific } \\
\text { Research and National } \\
\text { Museum of Natural History }\end{array}$ & 1 & & 1 & & & & & \\
\hline France & D. Courtois, & Hopital " A Laveran " & & & & & & & 1 & \\
\hline France & G. Dujeu & Institut de Medecine Tropicale & & & & & & & 1 & \\
\hline France & G. Raffier & Mission Medicale Francaise & & & & & & & 1 & \\
\hline France & M. Germain & $\begin{array}{l}\text { Office de la Recherche } \\
\text { scientifique et technique } \\
\text { outre-mer }\end{array}$ & & & & & & & 1 & \\
\hline France & Noël Tordo & $\begin{array}{l}\text { Department of Virology, Unit } \\
\text { of the Biology of Emerging } \\
\text { Viral Infections (UBIVE), } \\
\text { National Reference Centre - } \\
\text { Institut Pasteur, Lyon }\end{array}$ & & & & 1 & & & & \\
\hline France & P. Sureau, & Institut Pasteur & & & & & & & 1 & \\
\hline France & Sylvain Baize & Institutet Pasteur & & & & & & & & 1 \\
\hline France & $\begin{array}{l}\text { Jean-Francois } \\
\text { Delfraissy }\end{array}$ & INSERM & & & & & & & & 1 \\
\hline
\end{tabular}




\begin{tabular}{|c|c|c|c|c|c|c|c|c|c|c|}
\hline Country & Member & Institution & $\begin{array}{l}\text { EC } \\
\text { Ebola }\end{array}$ & $\begin{array}{l}\text { WHO } \\
\text { AGEVDR }\end{array}$ & ES2014 & $\begin{array}{l}\text { WHO } \\
\text { CCDEM }\end{array}$ & $\begin{array}{l}\text { ST } \\
1976\end{array}$ & $\begin{array}{l}\text { WHO } \\
\text { ERT } \\
2014\end{array}$ & $\begin{array}{l}\text { IC } \\
1976\end{array}$ & $\begin{array}{l}\text { Informal } \\
\text { Consultation } \\
\text { Ebola } \\
\text { outbreak } \\
2014\end{array}$ \\
\hline Gabon & Eric Leroy & $\begin{array}{l}\text { Institute for Development } \\
\text { Research (IRD) International } \\
\text { Centre for Medical Research } \\
\text { in Franceville }\end{array}$ & & & 1 & 1 & & & & \\
\hline Germany & Stephan Gunther & $\begin{array}{l}\text { Bernhard-Nocht-Institut for } \\
\text { Tropical Medicine (BNI), } \\
\text { University of Hamburg }\end{array}$ & & & & 1 & & & & 1 \\
\hline Ghana & William Ampofo & University of Ghana & 1 & & & & & & & \\
\hline Ghinea & Keita Sakoba & Ministry of Health & & & & & & 1 & & \\
\hline Guinea & Boubacar Diallo & Ministry of Health & & & & & & 1 & & \\
\hline Guinea & Emmanuel Heleze & Ministry of Health & & & & & & 1 & & \\
\hline Guinea & $\begin{array}{l}\text { Mandy Kader } \\
\text { Konde, }\end{array}$ & Institute of Research Guinea & & & & & & & & 1 \\
\hline Guinea & Pepe Bilivogui & Ministry of Health & & & & & & 1 & & \\
\hline Kenya & B. Teelock & World Health Organization & & & & & 1 & & & \\
\hline Kenya & C. R. Jones & Ministry of Health & & & & & 1 & & & \\
\hline Kenya & D. H. Smith & Ministry of Health & & & & & 1 & & & \\
\hline Kenya & R. B. Highton & Medical Research Council & & & & & 1 & & & \\
\hline Kenya & Vincent Anami & $\begin{array}{l}\text { Centre for Disaster and } \\
\text { Humanitarian Assistance } \\
\text { Medicine, Uniformed Services } \\
\text { University of the Health and } \\
\text { Sciences, Friends } \\
\text { International Centre }\end{array}$ & 1 & & & & & & & \\
\hline Liberia & John Mike Mulba & Ministry of Health & & & & & & 1 & & \\
\hline Liberia & Luke Bawo & Ministry of Health & & & & & & 1 & & \\
\hline Liberia & Moses Massaquoi & Ministry of Health & & & & & & 1 & & \\
\hline Liberia & Moussa Koné & Ministry of Health & & & & & & 1 & & \\
\hline
\end{tabular}




\begin{tabular}{|c|c|c|c|c|c|c|c|c|c|c|}
\hline Country & Member & Institution & $\begin{array}{l}\text { EC } \\
\text { Ebola }\end{array}$ & $\begin{array}{l}\text { WHO } \\
\text { AGEVDR }\end{array}$ & ES2014 & $\begin{array}{l}\text { WHO } \\
\text { CCDEM }\end{array}$ & $\begin{array}{l}\text { ST } \\
1976\end{array}$ & $\begin{array}{l}\text { WHO } \\
\text { ERT } \\
2014\end{array}$ & $\begin{array}{l}\text { IC } \\
1976\end{array}$ & $\begin{array}{l}\text { Informal } \\
\text { Consultation } \\
\text { Ebola } \\
\text { outbreak } \\
2014\end{array}$ \\
\hline Liberia & Sakoba Keita & Ministry of Health & & & & & & 1 & & \\
\hline Liberia & Stephen Gbanyan & Ministry of Health & & & & & & 1 & & \\
\hline Liberia & Tolbert Nyenswah & Ministry of Health & & & & & & 1 & & \\
\hline Nenya & Rosemary Sang & $\begin{array}{l}\text { Kenya Medical Research } \\
\text { Institute (KEMRI) }\end{array}$ & & & & 1 & & & & \\
\hline Nigeria & Abdusalam Nasidi & Ministry of Health & & & & & & 1 & & \\
\hline Nigeria & Faisal Shuaib & Ministry of Health & & & & & & 1 & & \\
\hline Nigeria & Oyewale Tomori & Redeemer's University & 1 & & & & & & & \\
\hline Pakistan & Michael Ryan & $\begin{array}{l}\text { National Emergency } \\
\text { Operations Centre }\end{array}$ & & 1 & 1 & & & & & \\
\hline Portugal & Maria João Martins & Ministry of Health & 1 & & & & & & & \\
\hline $\begin{array}{l}\text { Republic of } \\
\text { Congo }\end{array}$ & Adama Berthé & WHO/AFRO, DPC/CSR & & & 1 & & & & & \\
\hline $\begin{array}{l}\text { Republic of } \\
\text { Congo }\end{array}$ & $\begin{array}{l}\text { Adamou Alzouma } \\
\text { Yada }\end{array}$ & WHO/AFRO, DPC/CSR & & & 1 & & & & & \\
\hline $\begin{array}{l}\text { Republic of } \\
\text { Congo }\end{array}$ & Ali Ahmed Yahaya & WHO/AFRO, DPC/CSR & & & 1 & & & & & \\
\hline $\begin{array}{l}\text { Republic of } \\
\text { Congo }\end{array}$ & Bréhima Koumaré & WHO/AFRO, DPC/CSR & & & 1 & & & & & \\
\hline $\begin{array}{l}\text { Republic of } \\
\text { Congo }\end{array}$ & Celia Woodfil & WHO/AFRO, DPC/CSR & & & 1 & & & & & \\
\hline $\begin{array}{l}\text { Republic of } \\
\text { Congo }\end{array}$ & Denis Kandolo, & WHO/AFRO, DPC/CSR & & & 1 & & & & & \\
\hline $\begin{array}{l}\text { Republic of } \\
\text { Congo }\end{array}$ & Florimond Tshioko & WHO/AFRO, DPC/CSR & & & 1 & & & & & \\
\hline $\begin{array}{l}\text { Republic of } \\
\text { Congo }\end{array}$ & Kader Kondé & WHO/AFRO, DPC/CSR & & & 1 & & & & & \\
\hline $\begin{array}{l}\text { Republic of } \\
\text { Congo }\end{array}$ & $\begin{array}{l}\text { Mamadou-Lamine } \\
\text { Koné }\end{array}$ & WHO/AFRO, DPC/CSR & & & 1 & & & & & \\
\hline
\end{tabular}




\begin{tabular}{|c|c|c|c|c|c|c|c|c|c|c|}
\hline Country & Member & Institution & $\begin{array}{l}\text { EC } \\
\text { Ebola }\end{array}$ & $\begin{array}{l}\text { WHO } \\
\text { AGEVDR }\end{array}$ & ES2014 & $\begin{array}{l}\text { WHO } \\
\text { CCDEM }\end{array}$ & $\begin{array}{l}\text { ST } \\
1976\end{array}$ & $\begin{array}{l}\text { WHO } \\
\text { ERT } \\
2014\end{array}$ & $\begin{array}{l}\text { IC } \\
1976\end{array}$ & $\begin{array}{l}\text { Informal } \\
\text { Consultation } \\
\text { Ebola } \\
\text { outbreak } \\
2014\end{array}$ \\
\hline $\begin{array}{l}\text { Republic of } \\
\text { Congo }\end{array}$ & $\begin{array}{l}\text { Mamoudou } \\
\text { Djingarey }\end{array}$ & WHO/AFRO, DPC/CSR & & & 1 & & & & & \\
\hline $\begin{array}{l}\text { Republic of } \\
\text { Congo }\end{array}$ & Nestor Ndayimirije & WHO/AFRO, DPC/CSR & & & 1 & & & & & \\
\hline $\begin{array}{l}\text { Republic of } \\
\text { Congo }\end{array}$ & $\begin{array}{l}\text { Yokouidé } \\
\text { Allarangar }\end{array}$ & WHO/AFRO, DPC/CSR & & & 1 & & & & & \\
\hline $\begin{array}{l}\text { Republic of } \\
\text { Zaire }\end{array}$ & M. L. Muyingi & Clinique Kinoise & & & & & & & 1 & \\
\hline $\begin{array}{l}\text { Republic of } \\
\text { Zaire }\end{array}$ & A. Koth & Service d'Hygiene & & & & & & & 1 & \\
\hline $\begin{array}{l}\text { Republic of } \\
\text { Zaire }\end{array}$ & Dr Mandiangu & $\begin{array}{l}\text { Fonds National d'Action } \\
\text { Medicale et Sociale }\end{array}$ & & & & & & & 1 & \\
\hline $\begin{array}{l}\text { Republic of } \\
\text { Zaire }\end{array}$ & Dr. Omombo & Service d'Hygiene & & & & & & & 1 & \\
\hline $\begin{array}{l}\text { Republic of } \\
\text { Zaire }\end{array}$ & Dr. Tshibamba & Service d'Hygiene & & & & & & & 1 & \\
\hline $\begin{array}{l}\text { Republic of } \\
\text { Zaire }\end{array}$ & K. Nguete & $\begin{array}{l}\text { Commissaire d'Etat de la } \\
\text { Sante Publique }\end{array}$ & & & & & & & 1 & \\
\hline $\begin{array}{l}\text { Republic of } \\
\text { Zaire }\end{array}$ & Kintoki Vita & Universite Nationale du Zaire & & & & & & & 1 & \\
\hline $\begin{array}{l}\text { Republic of } \\
\text { Zaire }\end{array}$ & M. Massamba & & & & & & & & 1 & \\
\hline $\begin{array}{l}\text { Republic of } \\
\text { Zaire }\end{array}$ & M. Matundu & Service d'Hygiene & & & & & & & 1 & \\
\hline $\begin{array}{l}\text { Republic of } \\
\text { Zaire }\end{array}$ & M. Mbuyi & Universite Nationale du Zaire & & & & & & & 1 & \\
\hline $\begin{array}{l}\text { Republic of } \\
\text { Zaire }\end{array}$ & M. Miatudila & $\begin{array}{l}\text { Fonds Medical de } \\
\text { Coordination }\end{array}$ & & & & & & & 1 & \\
\hline $\begin{array}{l}\text { Republic of } \\
\text { Zaire }\end{array}$ & Muyembe Tamfum & Universite Nationale du Zaire & & & & & & & 1 & \\
\hline Saudi Arabia & Abdullah Al-Assiri & $\begin{array}{l}\text { Minister of Health for } \\
\text { Preventive Health }\end{array}$ & 1 & & & & & & & \\
\hline
\end{tabular}




\begin{tabular}{|c|c|c|c|c|c|c|c|c|c|c|}
\hline Country & Member & Institution & $\begin{array}{l}\text { EC } \\
\text { Ebola }\end{array}$ & $\begin{array}{l}\text { WHO } \\
\text { AGEVDR }\end{array}$ & ES2014 & $\begin{array}{l}\text { WHO } \\
\text { CCDEM }\end{array}$ & $\begin{array}{l}\text { ST } \\
1976\end{array}$ & $\begin{array}{l}\text { WHO } \\
\text { ERT } \\
2014\end{array}$ & $\begin{array}{l}\text { IC } \\
1976\end{array}$ & $\begin{array}{l}\text { Informal } \\
\text { Consultation } \\
\text { Ebola } \\
\text { outbreak } \\
2014\end{array}$ \\
\hline Senegal & M. Comet & Institut Pasteur, Dakar & & & & & 1 & & & \\
\hline Senegal & Amadou Sall & $\begin{array}{l}\text { Institut Pasteur, WHO } \\
\text { Collaborating Centre for } \\
\text { arboviruses and viral } \\
\text { hemorrhagic fevers }\end{array}$ & & & & 1 & & & & \\
\hline Senegal & $\begin{array}{l}\text { Awa Marie Coll } \\
\text { Seck }\end{array}$ & Ministry of Health & & 1 & & & & & & \\
\hline Senegal & $\begin{array}{l}\text { Cheikh Ibrahima } \\
\text { Niang }\end{array}$ & Cheikh Anta Diop University & & 1 & & & & & & \\
\hline Sierra Leone & Amara Jambai & $\begin{array}{l}\text { Ministry of Health and } \\
\text { Sanitation }\end{array}$ & 1 & & & & & 1 & & \\
\hline Sierra Leone & Roland M. Conteh & Ministry of Health & & & & & & 1 & & \\
\hline South Africa & Janusz Paweska & $\begin{array}{l}\text { National Institute for } \\
\text { Communicable Diseases, } \\
\text { WHO Collaborating Centre } \\
\text { for Reference and Research } \\
\text { on Viral Haemorrhagic Fevers } \\
\text { and Arboviruses }\end{array}$ & & & & 1 & & & & \\
\hline South Africa & Lucille Blumberg & $\begin{array}{l}\text { National Institute for } \\
\text { Communicable Diseases, } \\
\text { National Health Laboratory } \\
\text { Service, Johannesburg, South } \\
\text { Africa }\end{array}$ & 1 & & & & & & & \\
\hline South Africa & M. Isaacson & $\begin{array}{l}\text { South African Institute for } \\
\text { Medical Research }\end{array}$ & & & & & & & 1 & \\
\hline South Sudan & P. L. Giacometti & World Health Organization & & & & & 1 & & & \\
\hline Spain & Dirk Glaesser & World Tourism Organization & 1 & & & & & & & \\
\hline Sudan & R. Khan & World Health Organization & & & & & 1 & & & \\
\hline Switzerland & $\begin{array}{l}\text { Albert Mbule } \\
\text { Kadiobo }\end{array}$ & WHO & & & & & & 1 & & \\
\hline Switzerland & Alex Gasasira & WHO & & & & & & 1 & & \\
\hline
\end{tabular}




\begin{tabular}{|c|c|c|c|c|c|c|c|c|c|c|}
\hline Country & Member & Institution & $\begin{array}{l}\text { EC } \\
\text { Ebola }\end{array}$ & $\begin{array}{l}\text { WHO } \\
\text { AGEVDR }\end{array}$ & ES2014 & $\begin{array}{l}\text { WHO } \\
\text { CCDEM }\end{array}$ & $\begin{array}{l}\text { ST } \\
1976\end{array}$ & $\begin{array}{l}\text { WHO } \\
\text { ERT } \\
2014\end{array}$ & $\begin{array}{l}\text { IC } \\
1976\end{array}$ & $\begin{array}{l}\text { Informal } \\
\text { Consultation } \\
\text { Ebola } \\
\text { outbreak } \\
2014\end{array}$ \\
\hline Switzerland & Alice Croisier & WHO & & & & & & 1 & & \\
\hline Switzerland & Andreas Reis & $\begin{array}{l}\text { WHO/Headquarters, } \\
\text { IER/ETH }\end{array}$ & & & 1 & & & & & \\
\hline Switzerland & $\begin{array}{l}\text { Asiya Odugleh- } \\
\text { Kolev }\end{array}$ & $\begin{array}{l}\text { WHO/Headquarters, } \\
\text { HSE/GAR }\end{array}$ & & & 1 & & & & & \\
\hline Switzerland & Bruce Aylward & WHO & & & & & & 1 & & \\
\hline Switzerland & $\begin{array}{l}\text { Carmen Pessoa- } \\
\text { Silva, }\end{array}$ & $\begin{array}{l}\text { WHO/Headquarters, } \\
\text { HSE/GAR }\end{array}$ & & & 1 & & & & & \\
\hline Switzerland & Caroline Fuhrer & WHO & & & & & & 1 & & \\
\hline Switzerland & Cathy Roth & $\begin{array}{l}\text { WHO/Headquarters, } \\
\text { HSE/GAR }\end{array}$ & & & 1 & & & & & \\
\hline Switzerland & Christopher Dye & WHO & & & & & & 1 & & \\
\hline Switzerland & Daniel Kertesz & WHO & & & & & & 1 & & \\
\hline Switzerland & Deo Nshimirimana, & WHO & & & & & & 1 & & \\
\hline Switzerland & Dominique Legros, & $\begin{array}{l}\text { WHO/Headquarters, } \\
\text { HSE/GAR }\end{array}$ & & & 1 & & & & & \\
\hline Switzerland & Emmanuel Musa & WHO & & & & & & 1 & & \\
\hline Switzerland & Eric Bertherat & $\begin{array}{l}\text { WHO/Headquarters, } \\
\text { HSE/GAR }\end{array}$ & & & 1 & & & 1 & & \\
\hline Switzerland & Eric Nilles & WHO & & & & & & 1 & & \\
\hline Switzerland & Francis Kasolo & WHO & & & & & & 1 & & \\
\hline Switzerland & Isabelle Nuttall & WHO & & & & & & 1 & & \\
\hline Switzerland & Jean-Christophe Azé & $\begin{array}{l}\text { WHO/Headquarters, } \\
\text { HSE/GAR }\end{array}$ & & & 1 & & & & & \\
\hline Switzerland & Jean-Marie Dangou & WHO & & & & & & 1 & & \\
\hline Switzerland & Jered Markoff & WHO & & & & & & 1 & & \\
\hline Switzerland & $\begin{array}{l}\text { Jethro Magwati } \\
\text { Chakauya }\end{array}$ & WHO & & & & & & 1 & & \\
\hline Switzerland & Joel Myhre & WHO & & & & & & 1 & & \\
\hline
\end{tabular}




\begin{tabular}{|c|c|c|c|c|c|c|c|c|c|c|}
\hline Country & Member & Institution & $\begin{array}{l}\text { EC } \\
\text { Ebola }\end{array}$ & $\begin{array}{l}\text { WHO } \\
\text { AGEVDR }\end{array}$ & ES2014 & $\begin{array}{l}\text { WHO } \\
\text { CCDEM }\end{array}$ & $\begin{array}{l}\text { ST } \\
1976\end{array}$ & $\begin{array}{l}\text { WHO } \\
\text { ERT } \\
2014\end{array}$ & $\begin{array}{l}\text { IC } \\
1976\end{array}$ & $\begin{array}{l}\text { Informal } \\
\text { Consultation } \\
\text { Ebola } \\
\text { outbreak } \\
2014\end{array}$ \\
\hline Switzerland & Jonathan Polonsky & WHO & & & & & & 1 & & \\
\hline Switzerland & Jordi Sacristan & $\begin{array}{l}\text { WHO/Headquarters, } \\
\text { HSE/GAR }\end{array}$ & & & 1 & & & & & \\
\hline Switzerland & Kamal Ait-Ikhlef & $\begin{array}{l}\text { WHO/Headquarters, } \\
\text { HSE/GAR }\end{array}$ & & & 1 & & & & & \\
\hline Switzerland & Keiji Fukuda & WHO & & & & & & 1 & & \\
\hline Switzerland & Kennedy Chitala & WHO & & & & & & 1 & & \\
\hline Switzerland & $\begin{array}{l}\text { Marie-Charlotte } \\
\text { Bouësseau }\end{array}$ & $\begin{array}{l}\text { WHO/Headquarters, } \\
\text { IER/ETH }\end{array}$ & & & 1 & & & & & \\
\hline Switzerland & $\begin{array}{l}\text { Mark Humphrey } \\
\text { Van Ommeren }\end{array}$ & $\begin{array}{l}\text { WHO/Headquarters, } \\
\text { NMH/MSD/MER }\end{array}$ & & & 1 & & & & & \\
\hline Switzerland & Mikiko Senga & WHO & & & & & & 1 & & \\
\hline Switzerland & Neil M. Ferguson & WHO & & & & & & 1 & & \\
\hline Switzerland & $\begin{array}{l}\text { Niluka Wijekoon } \\
\text { Kannangarage }\end{array}$ & WHO & & & & & & 1 & & \\
\hline Switzerland & Olivier Ronveaux & WHO & & & & & & 1 & & \\
\hline Switzerland & Olushayo Olu & WHO & & & & & & 1 & & \\
\hline Switzerland & Patrick Drury & $\begin{array}{l}\text { WHO/Headquarters, } \\
\text { HSE/GAR }\end{array}$ & & & 1 & & & & & \\
\hline Switzerland & Peter Graaff & WHO & & & & & & 1 & & \\
\hline Switzerland & Philippe Barboza & WHO & & & & & & 1 & & \\
\hline Switzerland & Philippe Calain & Médecins Sans Frontières & & & 1 & & & & & 1 \\
\hline Switzerland & Pierre Formenty & $\begin{array}{l}\text { WHO/Headquarters, } \\
\text { HSE/GAR }\end{array}$ & & & 1 & & & 1 & & \\
\hline Switzerland & R. Collas & World Health Organization & & & & & & & 1 & \\
\hline Switzerland & $\begin{array}{l}\text { Ravi Santhana } \\
\text { Gopala Krishnan }\end{array}$ & WHO & & & & & & 1 & & \\
\hline Switzerland & Rick Brennan & WHO & & & & & & 1 & & \\
\hline
\end{tabular}




\begin{tabular}{|c|c|c|c|c|c|c|c|c|c|c|}
\hline Country & Member & Institution & $\begin{array}{r}\text { EC } \\
\text { Ebola }\end{array}$ & $\begin{array}{l}\text { WHO } \\
\text { AGEVDR }\end{array}$ & ES2014 & $\begin{array}{l}\text { WHO } \\
\text { CCDEM }\end{array}$ & $\begin{array}{l}\text { ST } \\
1976\end{array}$ & $\begin{array}{l}\text { WHO } \\
\text { ERT } \\
2014\end{array}$ & $\begin{array}{l}\text { IC } \\
1976\end{array}$ & $\begin{array}{l}\text { Informal } \\
\text { Consultation } \\
\text { Ebola } \\
\text { outbreak } \\
2014\end{array}$ \\
\hline Switzerland & Robert Steffen & $\begin{array}{l}\text { WHO Collaborating Centre } \\
\text { for Travellers' Health, } \\
\text { University of Zurich }\end{array}$ & 1 & & & & & & & \\
\hline Switzerland & Rui Vaz & WHO & & & & & & 1 & & \\
\hline Switzerland & S. Adrien & World Health Organization & & & & & & & 1 & \\
\hline Switzerland & Scott Pendergast & $\mathrm{WHO}$ & & & & & & 1 & & \\
\hline Switzerland & Sergey Eremin & $\begin{array}{l}\text { WHO/Headquarters, } \\
\text { HSE/GAR }\end{array}$ & & & 1 & & & & & \\
\hline Switzerland & Stéphane Hugonnet & $\begin{array}{l}\text { WHO/Headquarters, } \\
\text { HSE/GAR }\end{array}$ & & & 1 & & & & & \\
\hline Switzerland & Sylvie Briand & $\mathrm{WHO}$ & & & & & & 1 & & \\
\hline Switzerland & Thibaut Jombart & WHO & & & & & & 1 & & \\
\hline Switzerland & Thomas Grein & $\begin{array}{l}\text { WHO/Headquarters, } \\
\text { HSE/GAR }\end{array}$ & & & 1 & & & & & \\
\hline Switzerland & Tim Eckmanns & WHO & & & & & & 1 & & \\
\hline Switzerland & William Perea, & WHO & & & & & & 1 & & \\
\hline Switzerland & Zabulon Yoti & WHO & & & & & & 1 & & \\
\hline Thailand & $\begin{array}{l}\text { Viroj } \\
\text { Tangcharoensathien }\end{array}$ & Ministry of Public Health & & 1 & & & & & & \\
\hline Uganda & Julius Lutwama & $\begin{array}{l}\text { Uganda Virology Research } \\
\text { Institute }\end{array}$ & & & & 1 & & & & \\
\hline Uganda & Sam Zaramba & Ministry of Health & 1 & 1 & & & & & & \\
\hline $\mathbf{U K}$ & Anne Cori & Imperial College London & & & & & & 1 & & \\
\hline UK & Chris Lane & Public Health England & & & & & & 1 & & \\
\hline UK & Christl A. Donnelly & Imperial College London & & & & & & 1 & & \\
\hline $\mathbf{U K}$ & Harriet Mills & Imperial College London & & & & & & 1 & & \\
\hline $\mathbf{U K}$ & Isobel Blake & Imperial College London & & & & & & 1 & & \\
\hline
\end{tabular}




\begin{tabular}{|c|c|c|c|c|c|c|c|c|c|c|}
\hline Country & Member & Institution & $\begin{array}{l}\text { EC } \\
\text { Ebola }\end{array}$ & $\begin{array}{l}\text { WHO } \\
\text { AGEVDR }\end{array}$ & ES2014 & $\begin{array}{l}\text { WHO } \\
\text { CCDEM }\end{array}$ & $\begin{array}{l}\text { ST } \\
1976\end{array}$ & $\begin{array}{l}\text { WHO } \\
\text { ERT } \\
2014\end{array}$ & $\begin{array}{l}\text { IC } \\
1976\end{array}$ & $\begin{array}{l}\text { Informal } \\
\text { Consultation } \\
\text { Ebola } \\
\text { outbreak } \\
2014\end{array}$ \\
\hline UK & $\begin{array}{l}\text { Maria D. Van } \\
\text { Kerkhove }\end{array}$ & Imperial College London & & & & & & 1 & & \\
\hline UK & Pierre Nouvellet & Imperial College London & & & & & & 1 & & \\
\hline $\mathbf{U K}$ & Steven Riley & Imperial College London & & & & & & 1 & & \\
\hline UK & Tini Garske & Imperial College London & & & & & & 1 & & \\
\hline UK & A. Baskerville & $\begin{array}{l}\text { Microbiological Research } \\
\text { Establishment }\end{array}$ & & & & & 1 & & & \\
\hline UK & Andrew Winbow & $\begin{array}{l}\text { International Maritime } \\
\text { Organization }\end{array}$ & 1 & & & & & & & \\
\hline UK & C. C. Draper & $\begin{array}{l}\text { London School of Hygiene } \\
\text { and Tropical Medicine }\end{array}$ & & & & & 1 & & & \\
\hline UK & D. I. H. Simpson & $\begin{array}{l}\text { London School of Hygiene } \\
\text { and Tropical Medicine }\end{array}$ & & & & & 1 & & & \\
\hline UK & D. S. Ridley & Hospital for Tropical Diseases & & & & & 1 & & & \\
\hline UK & E. T. W. Bowen & $\begin{array}{l}\text { Microbiological Research } \\
\text { Establishment }\end{array}$ & & & & & 1 & & & \\
\hline UK & G. Lloyd & $\begin{array}{l}\text { Microbiological Research } \\
\text { Establishment }\end{array}$ & & & & & 1 & & & \\
\hline UK & G. S. Platt & $\begin{array}{l}\text { Microbiological Research } \\
\text { Establishment }\end{array}$ & & & & & 1 & & & \\
\hline UK & John Edmunds & $\begin{array}{l}\text { London School of Hygiene } \\
\text { and Tropical Medicine }\end{array}$ & & & & & & & & 1 \\
\hline UK & L. McArdle & $\begin{array}{l}\text { Microbiological Research } \\
\text { Establishment }\end{array}$ & & & & & 1 & & & \\
\hline UK & Mark Salter & Public Health England & 1 & & & & & & & \\
\hline USA & D. Conn & US Peace Corps & & & & & & & 1 & \\
\hline USA & D. P. Francis & $\begin{array}{l}\text { Harvard School of Public } \\
\text { Health }\end{array}$ & & & & & 1 & & & \\
\hline USA & David L. Heymann & $\begin{array}{l}\text { Centre on Global Health } \\
\text { Security, Chatham House } \\
\text { (Centers for Disease Control) }\end{array}$ & & 1 & & & & & 1 & \\
\hline
\end{tabular}




\begin{tabular}{|c|c|c|c|c|c|c|c|c|c|c|}
\hline Country & Member & Institution & $\begin{array}{l}\text { EC } \\
\text { Ebola }\end{array}$ & $\begin{array}{l}\text { WHO } \\
\text { AGEVDR }\end{array}$ & ES2014 & $\begin{array}{l}\text { WHO } \\
\text { CCDEM }\end{array}$ & $\begin{array}{l}\text { ST } \\
1976\end{array}$ & $\begin{array}{l}\text { WHO } \\
\text { ERT } \\
2014\end{array}$ & $\begin{array}{l}\text { IC } \\
1976\end{array}$ & $\begin{array}{l}\text { Informal } \\
\text { Consultation } \\
\text { Ebola } \\
\text { outbreak } \\
2014\end{array}$ \\
\hline USA & Dr. Scott Dowell, & $\begin{array}{l}\text { The Bill and Melinda Gates } \\
\text { Foundation }\end{array}$ & & & & & & & & 1 \\
\hline USA & H. Wulff & $\begin{array}{l}\text { Centers for Disease Control } \\
\text { and Prevention }\end{array}$ & & & & & & & 1 & \\
\hline USA & J. B. McCormick & $\begin{array}{l}\text { Centers for Disease Control } \\
\text { and Prevention }\end{array}$ & & & & & & & 1 & \\
\hline USA & J. G. Breman & $\begin{array}{l}\text { Centers for Disease Control } \\
\text { and Prevention }\end{array}$ & & & & & & & 1 & \\
\hline USA & J. Kennedy & USAID & & & & & & & 1 & \\
\hline USA & J. V. Lange & $\begin{array}{l}\text { Centers for Disease Control } \\
\text { and Prevention }\end{array}$ & & & & & & & 1 & \\
\hline USA & James LeDuc & $\begin{array}{l}\text { University of Texas Medical } \\
\text { Branch }\end{array}$ & 1 & & & & & & & \\
\hline USA & K. M. Johnson & $\begin{array}{l}\text { Centers for Disease Control } \\
\text { and Prevention }\end{array}$ & & & & & & & 1 & \\
\hline USA & Lisa Hensley & National Institutes of Health & & & & & & & & 1 \\
\hline USA & M.K. White & $\begin{array}{l}\text { Centers for Disease Control } \\
\text { and Prevention }\end{array}$ & & & & & & & 1 & \\
\hline USA & Martin Cetron & $\begin{array}{l}\text { Centers for Disease Control } \\
\text { and Prevention }\end{array}$ & 1 & & & & & & & \\
\hline USA & P.A. Webb & $\begin{array}{l}\text { Centers for Disease Control } \\
\text { and Prevention }\end{array}$ & & & & & & & 1 & \\
\hline USA & Peter Jahrling & National Institutes of Health & & & & & & & & 1 \\
\hline USA & Pierre Rollin & $\begin{array}{l}\text { Centres for Disease Control } \\
\text { and Prevention }\end{array}$ & & & 1 & & & & & \\
\hline USA & S. 0. Foster & $\begin{array}{l}\text { Centers for Disease Control } \\
\text { and Prevention }\end{array}$ & & & & & & & 1 & \\
\hline
\end{tabular}




\begin{tabular}{|c|c|c|c|c|c|c|c|c|c|c|}
\hline Country & Member & Institution & $\begin{array}{l}\text { EC } \\
\text { Ebola }\end{array}$ & $\begin{array}{l}\text { WHO } \\
\text { AGEVDR }\end{array}$ & ES2014 & $\begin{array}{r}\text { WHO } \\
\text { CCDEM }\end{array}$ & $\begin{array}{l}\text { ST } \\
1976\end{array}$ & $\begin{array}{l}\text { WHO } \\
\text { ERT } \\
2014\end{array}$ & $\begin{array}{l}\text { IC } \\
1976\end{array}$ & $\begin{array}{l}\text { Informal } \\
\text { Consultation } \\
\text { Ebola } \\
\text { outbreak } \\
2014\end{array}$ \\
\hline USA & Stuart Nichol & $\begin{array}{l}\text { Viral Special Pathogens } \\
\text { Branch, National Centre for } \\
\text { Emerging and Zoonotic } \\
\text { Infectious Diseases, Centres } \\
\text { for Disease Control and } \\
\text { Prevention }\end{array}$ & & & & 1 & & & & 1 \\
\hline USA & Vincent Covello & $\begin{array}{l}\text { Centre for Risk } \\
\text { Communication }\end{array}$ & 1 & & & & & & & \\
\hline USA & William H. Foege & $\begin{array}{l}\text { Centers for Disease Control } \\
\text { and Prevention }\end{array}$ & & 1 & & & & & & \\
\hline Zaire & H. Berquist & Hospital Karawa & & & & & & & 1 & \\
\hline Zaire & W. Close & Fonds Medical Tropical & & & & & & & 1 & \\
\hline Zimbabwe & $\begin{array}{l}\text { Nyaradzayi } \\
\text { Gumbonzvanda }\end{array}$ & World YWCA & & 1 & & & & & & \\
\hline
\end{tabular}

EC: Emergency Committee; WHOAGEVDR WHO Advisory Group on the Ebola Virus Disease Response; WHOCCDEM: WHO Collaborating Centres for the diagnosis of Ebola or Marburg VHF. ES2014: Ebola Strategy 2014; ST 1976 Study Team 1976; WHO ERT2014 WHO Ebola Response team 2014; IC1976 International Commission 1976 


\section{Appendix L. GOARN Partners Ebola response}

GOARN partners responding to the Ebola outbreak 2014-2015

African Field Epidemiology Network

Agence régionale de santé, Pays de la Loire, France

Agence régionale de santé, Rhône-Alpes, France

Agence régionale de santé, île-de-France, France

Association pour le développement de l'épidémiologie de terrain

Australasian College for Infection Prevention and Control

Australian Response ARM Network

Bernhard Nocht Institute for Tropical Medicine

Bundeswehr Institute of Microbiology

Burnet Institute for Medical Research and Public Health

Caribbean Public Health Agency

Centre for Disease Control, Iran

Centre for Infection and Immunity, Mailman School of Public Health of Columbia University

Centers for Disease Control and Prevention, USA

Centre de Coopération Internationale en Recherche Agronomique pour le développement

Centre International de Recherches Médicales de Franceville

Chinese Centre for Disease Control and Prevention, China

Communicable Disease Control Directorate, Western Australia

Croatian National Institute of Public Health

Department of Public Health, Osaka City University Faculty of Medicine, Japan

Department of Tropical Medicine, Tulane School of Public Health and Tropical Medicine

Department of Virology, Tohoku University, School of Medicine

Division of Tuberculosis and Infectious Disease Control, Ministry of Health, Labour and Welfare

Eastern Mediterranean Public Health Network

École des hautes études en santé publique

Epicentre research and epidemiology

European Programme for Intervention Epidemiology Training, Alumni Network

Etablissement de Préparation et de Réponse aux Urgences Sanitaires

European Centre for Disease Prevention and Control

European Mobile Laboratory Consortium

European Network for Diagnostics of Imported Viral Diseases, Robert Koch Institute

European Programme for Intervention Epidemiology Training

European Virus Archive 
GOARN partners responding to the Ebola outbreak 2014-2015

Faculty of Health Sciences, Curtin University of Technology

Federal Ministry of Health, Sudan

Federal Public Service, Health, Food Chain Safety, and Environment

Field Epidemiology Training Program, Malaysia

Field Epidemiology Training Program, Mongolia

Field Epidemiology Training Program, Egypt

French Health Agency for the Indian Ocean

German Armed Forces Medical Service, Ministry of Defence

Health Protection Surveillance Centre

Hokkaido University Research Centre for Zoonosis Control, Japan

Institut de Santé Publique d'Épidémiologie et de Développement

Institut de Veille Sanitaire

Institut Pasteur, Lyon, France

Institut Pasteur, Dakar, Senegal

Institut Pasteur International

Institute of Microbiology and Immunology, Faculty of Medicine, University of Ljubljana

Institute of Tropical Medicine

Institute of Tropical Medicine, Nagasaki University

Instituto de Salud Carlos III

Instituto Nacional de Enfermedades Virales Humanas

International Epidemiological Association

International Federation of Red Cross and Red Crescent Societies

International Medical Centre of Japan

IS Global, Barcelona

Korea Centres for Disease Control and Prevention

Laboratory Inserm Jean Merieux

London School of Hygiene and Tropical Medicine, UK

Médecins Sans Frontières, Belgium

Médecins Sans Frontières, France

Médecins Sans Frontières

Médecins Sans Frontières, Spain

Medecins Sans Frontieres, Switzerland

Ministry of Public Health, Lebanon

Ministry of Health, Brazil

MRC Centre for Outbreak Analysis and Modelling, Imperial College London

Museum National d Histoire Naturelle 
GOARN partners responding to the Ebola outbreak 2014-2015

National Centre for Epidemiological Surveillance and Disease Control, Ministry of Health

National Centre for Global Health and Medicine, Japan

National Centre for Epidemiology and Population Health, Australian National University

National Institute for Communicable Diseases, South Africa

National Institute for Infectious Diseases Lazzaro Spallanzani

National Institute of Infectious Diseases

National University of Singapore

Norwegian Institute of Public Health

New South Wales Ministry of Health

Office of Health Protection, Department of Health and Ageing, DOHA

Ontario Medical Association

Ontario Ministry of Health

Osaka University

Pasteur Institute of Iran

PathWest Laboratory Medicine

Public Health Agency of Canada

Public Health England

Robert Koch Institut

Royal Perth Hospital

Ryerson University

Save the Children International

School of Public Health and Community Medicine, University of New South Wales

Shizuoka Cancer Centre Hospital

Spiez Laboratory, Federal Office for Civil Protection

Statens Serum Institut

Tan Tock Seng Hospital

The International Rescue Committee

The University of the West Indies

Training Programmes in Epidemiology and Public Health Interventions Network

U.S. Army Medical Research Institute of Infectious Diseases

United Nations Children's Fund

United Nations Food and Agriculture Organization

United Nations High Commission for Refugees

University Hospital Düsseldorf

University Hospital Limerick

University Hospital of Heidelberg 


\begin{tabular}{|l|}
\hline GOARN partners responding to the Ebola outbreak 2014-2015 \\
\hline University Hospital of South Manchester \\
\hline University of Geneva \\
\hline University of Nebraska Medical Centre \\
\hline University of Texas Medical Branch \\
\hline United Nations Office for Project Services \\
\hline Vancouver Coastal Health \\
\hline WHO Emerging and Dangerous Pathogens Laboratory Network \\
\hline WHO Global Infection Prevention and Control Network \\
\hline WHO Virtual Interdisciplinary Advisory Group on Mass Gathering \\
\hline World Organisation for Animal Health \\
\hline
\end{tabular}




\section{Appendix M. Distribution of Zika cases in the Americas as of January 2018}

\begin{tabular}{|c|c|c|c|c|c|}
\hline Country/Territory & $\begin{array}{l}\text { Autochthonous } \\
\text { cases confirmed }\end{array}$ & $\begin{array}{l}\text { Imported } \\
\text { cases }\end{array}$ & $\begin{array}{l}\text { Incidence } \\
\text { Rate }\end{array}$ & Deaths & $\begin{array}{c}\text { Confirmed } \\
\text { congenital } \\
\text { syndrome } \\
\text { associated with } \\
\text { Zika }\end{array}$ \\
\hline Bermuda & 0 & 6 & 0.00 & 0 & 0 \\
\hline Canada & 0 & 544 & 0.00 & 0 & 1 \\
\hline $\begin{array}{l}\text { United States of } \\
\text { America }\end{array}$ & 227 & 5,335 & 0.07 & 0 & 102 \\
\hline Mexico & 11,805 & 15 & 9.18 & 0 & 20 \\
\hline Belize & 355 & 0 & 636.12 & 0 & 0 \\
\hline Costa Rica & 2,008 & 32 & 200.57 & 0 & 19 \\
\hline El Salvador & 51 & 0 & 192.61 & 0 & 4 \\
\hline Guatemala & 1,032 & 0 & 29.62 & 0 & 140 \\
\hline Honduras & 308 & 0 & 399.18 & 0 & 8 \\
\hline Nicaragua & 2,795 & 3 & 45.20 & 0 & 2 \\
\hline Panama & 1,253 & 42 & 172.91 & 0 & 17 \\
\hline Cuba & 187 & 58 & 1.64 & 0 & 0 \\
\hline Dominican Republic & 335 & 0 & 49.07 & 0 & 85 \\
\hline French Guiana & 483 & 10 & 3979.35 & 0 & 1 \\
\hline Guadeloupe & 382 & 0 & 6615.89 & 0 & 5 \\
\hline Haiti & 5 & 0 & 27.12 & 0 & 1 \\
\hline Martinique & 21 & 0 & 9267.93 & 0 & 5 \\
\hline Puerto Rico & 40,562 & 137 & 1101.93 & 5 & 47 \\
\hline Saint Barthelemy & 61 & 0 & 10660.00 & 0 & 0 \\
\hline Saint Martin & 200 & 0 & 9675.00 & 0 & 1 \\
\hline Bolivia & 811 & 4 & 31.75 & 0 & 14 \\
\hline Colombia & 9,927 & 0 & 223.49 & 0 & 248 \\
\hline Ecuador & 2,397 & 15 & 38.48 & 0 & 14 \\
\hline Peru & 1,530 & 22 & 28.55 & 0 & 0 \\
\hline Venezuela & 2,413 & 0 & 198.49 & 0 & 0 \\
\hline Brazil & 137,288 & 0 & 176.10 & 11 & 2,952 \\
\hline Argentina & 278 & 41 & 1.85 & 0 & 5 \\
\hline Chile & 0 & 34 & 0.00 & 0 & 0 \\
\hline Paraguay & 20 & 0 & 10.93 & 0 & 2 \\
\hline Uruguay & 0 & 1 & 0.00 & 0 & 0 \\
\hline Anguilla & 23 & 1 & 317.65 & 0 & 0 \\
\hline Antigua and Barbuda & 25 & 2 & 601.06 & 0 & 0 \\
\hline Aruba & 703 & 7 & 1676.32 & 0 & 0 \\
\hline Bahamas & 25 & 3 & 140.76 & 0 & 0 \\
\hline Barbados & 150 & 0 & 296.23 & 0 & 1 \\
\hline
\end{tabular}




\begin{tabular}{|c|c|c|c|c|c|}
\hline Country/Territory & $\begin{array}{l}\text { Autochthonous } \\
\text { cases confirmed }\end{array}$ & $\begin{array}{l}\text { Imported } \\
\text { cases }\end{array}$ & $\begin{array}{l}\text { Incidence } \\
\text { Rate }\end{array}$ & Deaths & $\begin{array}{c}\text { Confirmed } \\
\text { congenital } \\
\text { syndrome } \\
\text { associated with } \\
\text { Zika }\end{array}$ \\
\hline $\begin{array}{c}\text { Bonaire, St Eustatius } \\
\text { and Saba }\end{array}$ & 437 & 0 & 2688.00 & 0 & 0 \\
\hline Cayman Islands & 30 & 11 & 460.34 & 0 & 0 \\
\hline Curacao & 2,049 & 0 & 4379.19 & 0 & 0 \\
\hline Dominica & 79 & 0 & 1666.22 & 0 & 0 \\
\hline Grenada & 118 & 0 & 408.11 & 0 & 2 \\
\hline Guyana & 37 & 0 & 4.79 & 0 & 3 \\
\hline Jamaica & 203 & 0 & 284.01 & 0 & 0 \\
\hline Montserrat & 5 & 0 & 460.00 & 0 & 0 \\
\hline Saint Kitts and Nevis & 33 & 0 & 1107.55 & 0 & 0 \\
\hline Saint Lucia & 50 & 0 & 528.48 & 0 & 0 \\
\hline $\begin{array}{l}\text { Saint Vincent and the } \\
\text { Grenadines }\end{array}$ & 83 & 0 & 579.41 & 0 & 0 \\
\hline $\begin{array}{l}\text { Sint Maarten (Dutch } \\
\text { part) }\end{array}$ & 149 & 0 & 957.14 & 0 & 0 \\
\hline Suriname & 724 & 0 & 637.23 & 4 & 4 \\
\hline Trinidad and Tobago & 718 & 1 & 52.52 & 0 & 17 \\
\hline $\begin{array}{l}\text { Turks and Caicos } \\
\text { Islands }\end{array}$ & 25 & 3 & 438.46 & 0 & 0 \\
\hline Virgin Islands (UK) & 53 & 0 & 362.86 & 0 & 0 \\
\hline Virgin Islands (US) & 1,024 & 2 & 2125.24 & 0 & 0 \\
\hline TOTAL & 223,477 & 6,329 & 80.41 & 20 & 3,720 \\
\hline
\end{tabular}

Zika cumulative cases. SOURCE: PAHO/WHO as presented in Cumulative 04 January 2018, Cases reported by the IHR National Focal Points to the WHO IHR Regional Contact Point for the Americas and through the Ministry of Health websites, 2016-17 


\section{Appendix N. Zika Epistemic Community}

\begin{tabular}{|c|c|c|c|c|c|c|}
\hline Country & Name & Institution & $\begin{array}{l}\text { EC- } \\
\text { ZIKA }\end{array}$ & $\begin{array}{l}\text { Vector } \\
\text { Control } \\
\text { Advisory } \\
\text { Group }\end{array}$ & $\begin{array}{l}\text { SG DET } \\
\text { VC } \\
\text { Products }\end{array}$ & $\begin{array}{l}\text { WHO } \\
\text { Ad- } \\
\text { hoc } \\
\text { AGAD }\end{array}$ \\
\hline Albania & Silvia Bino & Institute of Public Health & 1 & & & \\
\hline Argentina & Fernando Althabe & $\begin{array}{l}\text { Institute for Clinical Effectiveness and } \\
\text { Health Policy }\end{array}$ & 1 & & & \\
\hline Australia & Thomas R. Burkot & $\begin{array}{l}\text { Australian Tropical Medicine and } \\
\text { Rehabilitation Sciences }\end{array}$ & & 1 & & \\
\hline Australia & Jenny Firman & Department of Health & & & & 1 \\
\hline Australia & Michael Selgelid & Monash University & 1 & & & \\
\hline Australia & Richard Russell & Sydney Medical School & & & & 1 \\
\hline Australia & Eva-Maria Bennet & & & 1 & & \\
\hline Belgium & Marc Coosemans & Institute of Tropical Medicine & & 1 & & \\
\hline Brazil & $\begin{array}{l}\text { Pedro Fernando da } \\
\text { Costa Vasconcelos }\end{array}$ & $\begin{array}{l}\text { National Institute for Viral } \\
\text { Hemorrhagic Fevers }\end{array}$ & 1 & & & \\
\hline Brazil & $\begin{array}{l}\text { Claudia Torres } \\
\text { Codeço }\end{array}$ & Oswaldo Cruz Foundation & 1 & & & \\
\hline Brazil & $\begin{array}{l}\text { Estefânia } \\
\text { Gastaldello Moreira }\end{array}$ & Universidade Estadual de Londrina & & & & 1 \\
\hline Brazil & $\begin{array}{l}\text { João Bosco Siqueira } \\
\text { Jr }\end{array}$ & Universidade Federal de Goiás & & & 1 & \\
\hline Canada & Ansa Jordaan & $\begin{array}{l}\text { International Civil Aviation } \\
\text { Organization }\end{array}$ & & & & 1 \\
\hline Canada & Anthony Evans & $\begin{array}{l}\text { International Civil Aviation } \\
\text { Organization }\end{array}$ & 1 & & & \\
\hline Canada & Kamran Khan & $\begin{array}{l}\text { University of Toronto, and Clinician- } \\
\text { Scientist St. Michael's Hospital }\end{array}$ & 1 & & & \\
\hline Colombia & $\begin{array}{l}\text { Maria Mercedes } \\
\text { Muñoz Ramírez }\end{array}$ & $\begin{array}{l}\text { Ministry of Health and Welfare, } \\
\text { Colombia }\end{array}$ & 1 & & & \\
\hline France & Frédéric Jourdain & Centre IRD de Montpellier & & & & 1 \\
\hline France & Fabrice Chandre & $\begin{array}{l}\text { Institut de Recherche pour le } \\
\text { développement }\end{array}$ & & 1 & & \\
\hline France & $\begin{array}{l}\text { Férechté Encha- } \\
\text { Razavi }\end{array}$ & $\begin{array}{l}\text { Necker-Sick Children's Hospital, Paris, } \\
\text { France }\end{array}$ & 1 & & & \\
\hline Germany & $\begin{array}{l}\text { Anita Plenge- } \\
\text { Boning }\end{array}$ & $\begin{array}{l}\text { Institute for Hygiene and Environment, } \\
\text { City of Hamburg }\end{array}$ & & & & 1 \\
\hline Ghana & Abraham Hodgson & Ghana Health Service & 1 & & & \\
\hline India & Kalpana Baruah & Ministry of Health and Family Welfare & 1 & & & 1 \\
\hline India & Ashwani Kumar & National Institute of Malaria Research & & 1 & & \\
\hline Indonesia & Nyoman Kandun & Ministry of Health, Indonesia & 1 & & & \\
\hline Iran & Hassan Vatandoost & School of Public Health & & 1 & & \\
\hline Malaysia & Indra Vythilingam & University of Malaya & & 1 & & \\
\hline Morocco & Mohamed Moussif & Ministry of Health, Morocco & & & & 1 \\
\hline
\end{tabular}




\begin{tabular}{|c|c|c|c|c|c|c|}
\hline Country & Name & Institution & $\begin{array}{l}\text { EC- } \\
\text { ZIKA }\end{array}$ & $\begin{array}{l}\text { Vector } \\
\text { Control } \\
\text { Advisory } \\
\text { Group }\end{array}$ & $\begin{array}{l}\text { SG DET } \\
\text { VC } \\
\text { Products }\end{array}$ & $\begin{array}{r}\text { WHO } \\
\text { Ad } \\
\text { hoc } \\
\text { AGAD }\end{array}$ \\
\hline New Zealand & Steven Gay & $\begin{array}{l}\text { New Zealand Ministry for Primary } \\
\text { Industries, Auckland Biosecurity } \\
\text { Centre }\end{array}$ & & & & 1 \\
\hline Nicaragua & Teresa Rodriguez & $\begin{array}{l}\text { Universidad Nacional Autónoma de } \\
\text { Nicaragua }\end{array}$ & & & & 1 \\
\hline Nigeria & Oyewale Tomori & Redeemer's University & & & & 1 \\
\hline Pakistan & Ghazala Mahmud & Fazia Medical College & 1 & & & \\
\hline $\begin{array}{l}\text { People's } \\
\text { Republic of } \\
\text { China }\end{array}$ & Jianning Zheng & $\begin{array}{l}\text { Ningbo entry-exit inspection and } \\
\text { quarantine bureau of PRC }\end{array}$ & & & & 1 \\
\hline Rwanda & John I. Githure & Ministry of Health & & 1 & & \\
\hline Senegal & Amadou Alpha Sall & Institut Pasteur de Dakar & 1 & & & \\
\hline Singapore & Duane J. Gubler & Duke-Nus Graduate Medical School & 1 & & & \\
\hline Singapore & K.U. Menon & $\begin{array}{l}\text { Ministry of Communications and } \\
\text { Information }\end{array}$ & 1 & & & \\
\hline Singapore & $\begin{array}{l}\text { Annelies Wilder- } \\
\text { Smith }\end{array}$ & $\begin{array}{l}\text { Nanyang Technological University, } \\
\text { Singapore }\end{array}$ & 1 & & & \\
\hline Spain & Dirk Glaesser & World Tourism Organization & 1 & & & \\
\hline Switzerland & Robert Steffen & Biostatistics and Prevention Institute & & & & 1 \\
\hline Switzerland & Thomas Smith & Swiss Tropical Institute & & 1 & 1 & \\
\hline Tanzania & Salim Abdulla & Ifakara Health Institute (IHI) & & 1 & 1 & \\
\hline Tanzania & Leonard Mboera & National Institute for Medical Research & 1 & & & \\
\hline UK & Steven W. Lindsay & Durham University & & 1 & 1 & \\
\hline UK & Azra Ghani & Imperial College London & & & 1 & \\
\hline UK & Alan Boobis & $\begin{array}{l}\text { Imperial College London, The } \\
\text { Hammersmith Hospital }\end{array}$ & & & & 1 \\
\hline UK & Janet Hemingway & Liverpool School of Tropical Medicine & & 1 & & \\
\hline UK & Hilary Ranson & Liverpool School of Tropical Medicine & & 1 & & \\
\hline UK & David L. Heymann & $\begin{array}{l}\text { London School of Hygiene and Tropical } \\
\text { Medicine }\end{array}$ & 1 & & & \\
\hline UK & Mark Rowland & $\begin{array}{l}\text { London School of Hygiene and Tropical } \\
\text { Medicine }\end{array}$ & & & 1 & \\
\hline UK & Immo Kleinschmidt & $\begin{array}{l}\text { London School of Hygiene and Tropical } \\
\text { Medicine }\end{array}$ & & 1 & 1 & \\
\hline UK & Heather Ferguson & University of Glasgow & & 1 & & \\
\hline USA & Robert Reiner & $\begin{array}{l}\text { Institute for Health Metrics and } \\
\text { Evaluation }\end{array}$ & & 1 & & \\
\hline USA & $\begin{array}{l}\text { Jennifer Erin } \\
\text { Staples }\end{array}$ & $\begin{array}{l}\text { Centres for Disease Control and } \\
\text { Prevention }\end{array}$ & 1 & & & \\
\hline USA & John Painter & $\begin{array}{l}\text { Centres for Disease Control and } \\
\text { Prevention }\end{array}$ & & & 1 & \\
\hline
\end{tabular}




\begin{tabular}{|c|c|c|c|c|c|c|}
\hline Country & Name & Institution & $\begin{array}{l}\text { EC- } \\
\text { ZIKA }\end{array}$ & $\begin{array}{r}\text { Vector } \\
\text { Control } \\
\text { Advisory } \\
\text { Group }\end{array}$ & $\begin{array}{l}\text { SG DET } \\
\text { VC } \\
\text { Products }\end{array}$ & $\begin{array}{l}\text { WHO } \\
\text { Ad- } \\
\text { hoc } \\
\text { AGAD }\end{array}$ \\
\hline USA & Kim A. Lindblade & $\begin{array}{l}\text { Centres for Disease Control and } \\
\text { Prevention }\end{array}$ & & 1 & & \\
\hline USA & Michael Johansson & $\begin{array}{l}\text { Centres for Disease Control and } \\
\text { Prevention }\end{array}$ & & & & 1 \\
\hline USA & Ryan Wiegand & $\begin{array}{l}\text { Centers for Disease Control and } \\
\text { Prevention }\end{array}$ & & & 1 & \\
\hline USA & Audrey Lenhart & $\begin{array}{l}\text { Centers for Disease Control and } \\
\text { Prevention }\end{array}$ & & 1 & & \\
\hline USA & Gary Brunette & $\begin{array}{l}\text { Centers for Disease Control and } \\
\text { Prevention }\end{array}$ & & & & 1 \\
\hline USA & Roger Nasci & $\begin{array}{l}\text { Centers for Disease Control and } \\
\text { Prevention }\end{array}$ & & 1 & & \\
\hline USA & Till Baernighausen & $\begin{array}{l}\text { Harvard T.H. Chan School of Public } \\
\text { Health }\end{array}$ & & & 1 & \\
\hline USA & Bobby Reiner & $\begin{array}{l}\text { Institute for Health Metrics and } \\
\text { Evaluation (IHME), University of } \\
\text { Washington }\end{array}$ & & & 1 & \\
\hline USA & James Meegan & $\begin{array}{l}\text { National Institute of Allergy and } \\
\text { Infectious Diseases, National Institutes } \\
\text { of Health, }\end{array}$ & 1 & & & \\
\hline USA & Molly Robertson & PATH & & & 1 & \\
\hline USA & David O’Brochta & $\begin{array}{l}\text { The Foundation for the National } \\
\text { Institutes of Health }\end{array}$ & & 1 & & \\
\hline USA & Rafael Obregón & UNICEF & 1 & & & \\
\hline USA & David O. Freedman & University of Alabama at Birmingham & 1 & & & \\
\hline USA & John C. Beier & University of Miami & & 1 & & \\
\hline USA & Thomas W. Scott & & & 1 & 1 & \\
\hline
\end{tabular}

EC Zika: Emergency Committee Zika; VCAG:Vector Control Advisory Group; SG DET VC Products Expert Advisory Group on Design of Epidemiological Trials for Vector Control Products; WHO Ad-hoc AGAD: WHO Adhoc Advisory Group on aircraft disinsection for controlling the international spread of vector-borne diseases 


\section{N.1. Zika participating institutions in the Epistemic Community.}

\begin{tabular}{|c|c|c|c|c|}
\hline Institution & $\begin{array}{l}\text { EC- } \\
\text { ZIKA }\end{array}$ & $\begin{array}{l}\text { Vector } \\
\text { Control } \\
\text { Advisory } \\
\text { Group }\end{array}$ & $\begin{array}{l}\text { SG DET } \\
\text { VC } \\
\text { Products }\end{array}$ & $\begin{array}{l}\text { WHO } \\
\text { Ad-hoc } \\
\text { AGAD }\end{array}$ \\
\hline Centres for Disease Control and Prevention & 1 & 3 & 2 & 2 \\
\hline London School of Hygiene and Tropical Medicine & 1 & 1 & 1 & \\
\hline Durham University & & 1 & 1 & \\
\hline Ifakara Health Institute (IHI) & & 1 & 1 & \\
\hline International Civil Aviation Organization & 1 & & & 1 \\
\hline Imperial College London & & & 1 & 1 \\
\hline $\begin{array}{l}\text { Institute for Health Metrics and Evaluation (IHME), University of } \\
\text { Washington }\end{array}$ & & 1 & 1 & \\
\hline Liverpool School of Tropical Medicine & & 2 & & \\
\hline Ministry of Health and Family Welfare & 1 & & & 1 \\
\hline Swiss Tropical Institute & & 1 & 1 & \\
\hline Institute of Tropical Medicine & & 1 & & \\
\hline Liverpool School of Tropical Medicine & & 1 & & \\
\hline Nanyang Technological University, Singapore & 1 & & & \\
\hline National Institute of Malaria Research & & 1 & & \\
\hline Necker-Sick Children's Hospital, Paris, France & 1 & & & \\
\hline Oswaldo Cruz Foundation & 1 & & & \\
\hline Australina Tropical Medicine and Rehabilitation Sciences & & 1 & & \\
\hline Biostatistics and Prevention Institute & & & & 1 \\
\hline Centre IRD de Montpellier & & & & 1 \\
\hline Department of Health & & & & 1 \\
\hline Duke-Nus Graduate Medical School & 1 & & & \\
\hline Fazia Medical College & 1 & & & \\
\hline Ghana Health Service & 1 & & & \\
\hline Harvard T.H. Chan School of Public Health & & & 1 & \\
\hline Institut de Recherche pour le développement & & 1 & & \\
\hline Institut Pasteur de Dakar, Senegal & 1 & & & \\
\hline Institute for Clinical Effectiveness and Health Policy & 1 & & & \\
\hline Institute for Hygiene and Environment, City of Hamburg & & & & 1 \\
\hline Institute of Public Health & 1 & & & \\
\hline Ministry of Communications and Information & 1 & & & \\
\hline Ministry of Health & & 1 & & \\
\hline Ministry of Health and Welfare, Colombia & 1 & & & \\
\hline Ministry of Health, Indonesia & 1 & & & \\
\hline Ministry of Health, Morocco & & & & 1 \\
\hline
\end{tabular}




\begin{tabular}{|c|c|c|c|c|}
\hline Institution & $\begin{array}{l}\text { EC- } \\
\text { ZIKA }\end{array}$ & $\begin{array}{l}\text { Vector } \\
\text { Control } \\
\text { Advisory } \\
\text { Group }\end{array}$ & $\begin{array}{l}\text { SG DET } \\
\text { VC } \\
\text { Products }\end{array}$ & $\begin{array}{l}\text { WHO } \\
\text { Ad-hoc } \\
\text { AGAD }\end{array}$ \\
\hline Monash University & 1 & & & \\
\hline National Institute for Medical Research, Dar es Salaam,Tanzania & 1 & & & \\
\hline National Institute for Viral Hemorrhagic Fevers & 1 & & & \\
\hline $\begin{array}{l}\text { National Institute of Allergy and Infectious Diseases, National } \\
\text { Institutes of Health }\end{array}$ & 1 & & & \\
\hline $\begin{array}{l}\text { New Zealand Ministry for Primary Industries, Auckland Biosecurity } \\
\text { Centre }\end{array}$ & & & & 1 \\
\hline Ningbo entry-exit inspection and quarantine bureau of PRC & & & & 1 \\
\hline PATH & & & 1 & \\
\hline Redeemer's University & & & & 1 \\
\hline School of Public Health & & 1 & & \\
\hline Sydney Medical School & & & & 1 \\
\hline The Foundation for the National Institutes of Health & & 1 & & \\
\hline UNICEF & 1 & & & \\
\hline Universidad Nacional Autónoma de Nicaragua & & & & 1 \\
\hline Universidade Estadual de Londrina & & & & 1 \\
\hline Universidade Federal de Goiás & & & 1 & \\
\hline University of Alabama at Birmingham & 1 & & & \\
\hline University of Glasgow & & 1 & & \\
\hline University of Malaya & & 1 & & \\
\hline University of Miami & & 1 & & \\
\hline University of Toronto, and Clinician-Scientist St. Michael's Hospital & 1 & & & \\
\hline World Tourism Organization & 1 & & & \\
\hline
\end{tabular}

EC Zika: Emergency Committee Zika; VCAG:Vector Control Advisory Group; SG DET VC Products Expert Advisory Group on Design of Epidemiological Trials for Vector Control Products; WHO Ad-hoc AGAD: WHO Adhoc Advisory Group on aircraft disinsection for controlling the international spread of vector-borne diseases 


\section{References}

1. Katz R, Sorrell E. Preparedness and Resilience in Public Health Emergencies. In Youde J, Rushton S, editors. Routledge Handbook of Global Health Security. New York: Routledge Handbooks; 2015. p. 201-214.

2. Doshi P. The elusive definition of pandemic influenza. Bull World Health Organization. 2011; 89: p. 532-538.

3. Kaufmann S. The new plagues. Pandemics and poverty in a globalized world.: The sustainability project: Haus Publishing ; 2007.

4. Brown T. Vulnerability is universal: considering the place of security and vulnerability within contemporary global health discourse. Social Science \& Medicine. 2011;(72): p. 319-326.

5. Bhutta Z, Sommerfeld J, Lassi Z, Salam R, Das R. Global burden, distribution, and interventions for infectious diseases of poverty. Infectious Diseases of Poverty. 2014; 3(21): p. 1-7.

6. Fidler D. Germs, governance, and global public health in the wake of SARS. J Clin Invest. 2004; 113(6): p. 799-804.

7. Hoffman S. The Evolution, Etiology and Eventualities of the Global Health Security Regime.. Health Policy and Planning. 2010; 25(6): p. 510-522.

8. Michaud J. Governance implications of Emerging Infectious disease surveillance and response as global public goods.. Global Health Governance. 2010; 3(2): p. 1-16.

9. Brundtland GH. Global Health and International Security. Global Governance: A Review of Multilateralism and International Organizations. 2003 August 2003; 9(4): p. 417-423.

10. Jones B. Bio-Security, Nonstate Actors, and the Need for Global Cooperation. Ethics \& International Affairs. 2006; 20(2).

11. World Health Organization. The World Health Report 2007. A safer future: Global Public Health Security in the 21st century. 1st ed. Geneva: WHO; 2007.

12. Leeds BA, Davis D. Beneath the Surface: Regime Type and International Interaction, 195378. Journal of Peace Research. 1999; 36(1): p. 5-21. 
13. World Health Organization. A69/21 Implementation of the International Health Regulations (2005), Sixty-Ninth World Health Assembly. Geneva:; 2016 May 113.

14. World Health Organization. Situation Report. Ebola Virus Disease. ; June 10, 2016.

15. World Health Organization. Middle East Respiratory Syndrome Coronavirus MERS-CoV. [Online].; 2019 [cited 2018. Available from: http://www.who.int/emergencies/merscov/en/.

16. World Health Organization. International Health Regulations 2005. Second edition. ed. Geneva: World Health Organization:; 2008b.

17. Underdal A. Explaining compliance and defection: three models.. European Journal of International Relations. 1998; 4(1): p. 5-30.

18. Kurowska X, Kratochwill F. The Social Constructivism Sensibility and CSDP Research. In Breuer XKaF, editor. Explaining the EU's common security and defence policy. Theory in Action. London: Palgrave MacMillan; 2012.

19. Haas P. Epistemic Communities and International Policy Coordination. International Organization. 1992; 46(1): p. 1-35.

20. Haas P. Obtaining International Environmental Protection through Epistemic Consensus.. Millennium. 1990; 19(3): p. 347-363.

21. Deacon B. The Social Policy of International Non-State Actors. In Global Social Policy \& Government. Los Angeles: Sage; 2007. p. 88-108.

22. Jenson J. Diffusing ideas for After Neoliberalism: the social investment perspective in Europe and Latin America. Global Social Policy 10:1. 2010;(10).

23. Sebenius JK. Challenging conventional explanations of international cooperation: negotiation analysis and the case of epistemic communities. International Organization. 1992; 46(1): p. 323-365.

24. Haas PM. Do regimes matter? Epistemic communities and Mediterranean pollution control. International Organization. 1989 Summer; 43(3).

25. Haas PM. Introduction: Epistemic Communities and International Policy Coordination. International Organization. 1992; 46(1): p. 1-35. 
26. Haas P. When does power listen to truth? A constructivist approach to the policy process. Journal of Eurpean Public Policy. 2004 August; 11(4): p. 569-592.

27. Kaufmann S. The new plagues. Pandemics and poverty in a globalized world. 1st ed.: The sustainability Project: Haus Publishing.; 2007.

28. Enemark C. Disease Surveillance and response: update on the Biological Weapons Convention. Australia and New Zealand Journal of Public Health. 2005;(29): p. 484-486.

29. Price-Smith A. The Colorado College. [Online]. Denver: The Colorado College; 2010.

30. Fidler DP. The globalization of Public Health: Emerging Diseases and International Relations.. Global Legal Studies Journal. 1997; 5(11): p. 11-51.

31. Huang Y. Pandemics and Security. In Youde J, Rushton S, editors. Routledge Handbook of Global Health Security. New York: Routledge Handbooks; 2015. p. 83-91.

32. McInnes C\&RMA. From security to risk: reframing global health threats. International Affairs. 2017; 93(6): p. 1313-1337.

33. Ingram A. The New Geopolitics of Disease: Between Global Health and Global Security.. Geopolitics. 2005;(10): p. 522-545.

34. McInnes, C.; Lee, K.. Health, security and foreign policy. Review of International Studies. 2006; 32(1): p. 5-23..

35. French MA. Woven of War-Time Fabrics: The Globalization of Public HealthSurveillance. Surveillance \& Society. 2009; 6(2): p. 101-115.

36. Davies, Sara E. Securitizing infectious disease. International Affairs. 2008 March; 84(2): p. 295-313.

37. Fidler DP. Epic failure of ebola and global health security. The Brown Journal of World Affairs. 2015; 21(2): p. 180-198.

38. Heymann, David L. et. al. Global health security: the wider lessons from the est African Ebola virus disease epidemic. The true scope of health securoty. The Lancet. 2015 May; 385: p. 1884-1887.

39. Drager N, Filder D. Foreign policy, trade and health: at the cutting edge of global health diplomacy. Bull World Health Organization. 2007 March; 85(3). 
40. Zacher MW, Keefe TJ. The politics of global health governance. United by Contagion. New York: Palgrave Macmillan; 2007.

41. Frenk J, Moon S. Governance Challenges in Global Health. New England Journal of Medicine. 2013; 368(10): p. 936-942.

42. Dodgson R, Lee K. Global Health Governance: a conceptual review, in Global Governance. Critical perspectives Pp. 92-110 Hughes S, Wilson R, editors. New York: Routledge; 2002.

43. Fidler DP. The challenges of global health governance. First Edition ed. New York: Council on Foreign Relations.; 2010.

44. Dingwerth K, Pattberg P. Global Governance as a Perspective on World Politics. Global Governance. 2006; 12(2006): p. 185-203.

45. Shiffman J, Quissell K, Schmitz HP, Pelletier DL, Smith SL, Berlan D, et al. A framework on the emergence and effectiveness of global health networks. Health Policy and Planning. 2016;(31): p. i3-i16.

46. Davis Cross MK. Security integration in Europe: how knowledge-based networks are transforming the European Union Ann Arbor.: University of Michigan Press; 2011.

47. Löblová O. When Epistemic Communities Fail: Exploring the Mechanism of Policy Influence. Policy Studies Journal. 2018; 46(1): p. 160-189.

48. Haas PM. Epistemic Communities, Constructivism, and International Environmental Politics. 1st ed. New York: Routledge; 2015.

49. Karlsson M. Epistemic communities and cooperative security: The case of communicable disease control in the Baltic Sea Region. Journal of International and Area Studies. 2004; 11(1): p. 79-100.

50. Jaeger RG, Halliday TR. On Confirmatory versus Exploratory Research. Points of View on Contemporary Education in Herpetology. 1998 June; 54(Supplement).

51. George AL, Bennett A. Case studies and theory development in social sciences. Cambdrige: MIT Press; 2005.

52. Van Evera S. Guide to Methods for Students of Political Science. New York: Cornell University Press; 1997. 
53. Davis Cross MK. Rethinking epistemic communities twenty years later. Review of International Studies. 2013;(39): p. 137-160.

54. Ulriksen MS, Dadalauri N. Single case studies and theory-testing: the knots and dots of the process-tracing method. International Journal of Social Research Methodology. 2016; 19(2): p. 223-239.

55. King G, Keohane RO, Verba S. Designing Social Inquiry: Scientific Inference in Qualitative Research Princeton, New Jersey: Princeton University Press; 1994.

56. Beach D. Process-Tracing Methods in Social Science. In Oxford Research Encyclopedia of Politics.: Oxford University Press; 2017. p. 1-31.

57. Del Rio C, Hernandez-Avila M. Lessons from Previous Influenza Pandemics and from the Mexican Response to the Current Influenza Pandemic. Archives of Medical Research. 2009;(40): p. 677-680.

58. World Health Organization. Poliomyelitis. [Online].; 2019 [cited 2018. Available from: https://www.who.int/news-room/fact-sheets/detail/poliomyelitis.

59. Heale R, Forbes D. Understading Triangulation in Research. Evidence-Based Nursing. 2013 August.

60. Duffy ME. Methodological Triangulation: A Vehicle for Merging Quantitative and Qualitative Research Methods. The Journal of Nursing Scholarship. 1987;(19): p. 130-133.

61. Palys TaAC. Research Decisions: Quantitative and Qualitative Perspectives. 4th ed. Toronto: Harcourt Brace \& Company Canada; 2007.

62. Topp SM, Chipukum JM. A qualitative study of the role of workplace and interpersonal trust in shaping service quality and responsiveness in Zambian primary health centres. Health Policy and Planning. 2016;(31): p. 192-204.

63. Fereday J, Muir-Cochrane E. Demonstrating Rigor Using Thematic Analysis: A Hybrid Approach of Inductive and Deductive Coding and Theme Development. International Journal of Qualitative Methods. 2006; 5(1): p. 80-92.

64. Petersen Ih. Facilitators and obstacles to cooperation in international development networks: a network approach. Development in Practice. 2016; 26(3): p. 360-374. 
65. Palmer S, Hochman D. A Canada-Brazil Network in the Global Eradication of Smallpox. Canadian Journal of Public Health 101 (2). 2010; 101(2): p. 113-114.

66. Wipfli HL, Fujimoto K, Valente TW. Global tobacco control diffusion: The case of the framework convention on tobacco control. American Journal of Public Health. 2010; 100(7): p. 1260-1266.

67. Walt G, Lush L, Ogden J. International organizations in transfer of infectious diseases: Iterative loops of adoption, adaptation, and marketing. Governance: An International Journal of Policy, Administration, and Institutions. 2004; 17(2).

68. Gresham L, Ramlawi A, Briski J, Richardson M, Taylor T. Trust Across Borders: Responding to 2009 H1N1 Influenza in the Middle East. Biosecurity and Bioterrorism: Biodefense Strategy, Practice, and Science. 2009; 7(4): p. 399-404.

69. Gordenker L, Coate RA, Jonsson C, Soderholm P. International cooperation in response to AIDS. 1st ed. New York: Pinter; 1995.

70. Ribhi Shawar Y. The Impact of Internal Characteristics on Global Health Epistemic Community Effectiveness: The Cases of Global Surgery, Early Childhood Developmentn and Urban Health Washington D.C.: American University; 2016.

71. Axelrod R, Keohane R. Achieving cooperation under anarchy: strategies and institutions. World Politics. 1985;(38): p. 54-336.

72. Axelrod R. Evolution of cooperation. 1st ed. New York: Basic Books; 1984.

73. North DC. Institutions, institutional change and economic performance. New York: Cambridge University Press; 1990.

74. Greif A. Cultural beliefs and the organization of society: A historical and theoretical reflection on collectivist and individualist societies. Journal of Political Economy. 1994; 102(5): p. 912-950.

75. Martin LL, Simmons BA. Theories and Empirical Studies of International Institutions. International Organization. 1998 Autumn; 52(4): p. 729-757.

76. Keohane R. After Hegemony: Cooperation and Discord in the World Political Economy Princeton, NJ: Princeton University Press; 1984. 
77. Dai X, Snidal D, Sampson M. International Cooperation Theory and International Institutions. In Oxford Research Encyclopedia of International Studies.: Oxford University Press; 2017. p. 1-38.

78. Mearsheimer JJ. "The False Promise of International Institutions. International Security. 1994-95; 19(3): p. 5-49.

79. Greif A. Institutions and Impersonal Exchange: From Communal to Individual Responsibility. Journal of Institutional and Theoretical Economics. 2002; 158(1).

80. Krasner S. Structural Causes and Regime Consequences: Regimes as Intervening Variables. International Regimes. Ithaca, NY: Cornell University Press; 1983.

81. Krasner SD. Global communications and National Power. Life on the Pareto Frontier. World Politics. 1991;(43): p. 336-366.

82. Keohane RO, Martin LL. The Promise of Institutionalist Theory. International Security. 1995; 20(1): p. 39-51.

83. Dai X. International Institutions and National Politics. Cambridge: Cambridge University Press; 2007.

84. Young OR. International Cooperation. Ithaca New York: Cornell University Press.; 1989.

85. Martin LL. Interests, Power, and Multilateralism. International Organization. 1992; 46(4): p. 765-792.

86. Fearon JD, Wendt A. Rationalism v. constructivism: A skeptical view. In Carlsnaes TR\&BAS, editor. Handbook of international relations. Oxford: Oxford University Press.; 2002. p. 57.

87. Hoffmann MJ. Norms and social constructivism in international relations. In The International Studies Encyclopedia. Oxford: Oxford University Press; 2010. p. 5410-5426.

88. Drezner D. Bargaining, Enforcement, and Multilateral Sanctions: When is cooperation counterproductive? International Organization. 2000; 54(1): p. 73-102.

89. Snidal D. Relative Gains and the Pattern of International Cooperation. The American Political Science Review. 1991; 85(3): p. 701-726. 
90. Haas P. When does power listen to truth? A constructivist approach to the policy process. Journal of European Public Policy. 2004; 11(4): p. 569-592.

91. Davis Cross MK. Rethinking epistemic communities twenty years later. Review of International Studies. 2013; I(39): p. 137-160.

92. Ruggie JG. Constructing the world polity: Essays on International Institutionalization London: Routledge; 1998.

93. Abbot KW, Snidal D. Pathways to international cooperation. In Benvenisti E, Hirsch M, editors. The Impact of International Law on International Cooperation. Theoretical Perspectives. Cambridge: Cambridge University Press; 2004. p. 50-84.

94. Kamradt-Scott A. The Politics of Medicine and the Global Governance of Pandemic Influenza. International Journal of Health Services. 2013; 43(1): p. 105-121.

95. Sedyaningsih ER, Al. e. Towards Mutual Trust, Transparency and Equity in Virus Sharing Mechanism: The Avian Influenza Case of Indonesia. Ann Acad Med Singapore. 2008;(37): p. 482-488.

96. Lakoff A. Two Regimes of Global Health. Humanity. 2010; 1(1): p. 59-79.

97. Fidler D. A Theory of Open-Source Anarchy. Indiana Journal of Global Legal Studies. $2008 ; 15(1)$.

98. Gostin LO, Katz R. The International Health Regulations: The Governing Framework for Global Health Security. The Milkbank Quarterly. 2016; 94(2): p. 264-313.

99. Kamradt-Scott A, Lee K. The 2011 Pandemic Influenza Preparedness Framework: Global Health Secured or a Missed Opportunity. Political Studies. 2011; 59: p. 831-47.

100. Gostin L, Phelan A, Stoto M, Kraemer J, Reddy S. Virus sharing, genetic sequencing, and global health security. Science. 2014 September; 345(6202): p. 1295-1296.

101. McCormick JM. Intergovernmental Organizations and Cooperation among Nations. International Studies Quarterly. 1980; 24(1): p. 75-98.

102. Kahler M. Organization and Cooperation: International Institutions and Policy Coordination. Journal of Public Policy. 1988; 8(3/4): p. 375-401. 
103. Vabulas F, Snidal D. Organization without delegation: Informal intergovernmental organizations (IIGOs) and the spectrum of intergovernmental arrangements. Rev Int Organ. 2013;(8): p. 193-220.

104. Dinar A, Rahman SM, Larson DF, Ambrosi P. Local actions, Global impacts: International Cooperation and the CDM. Global Environmental Politics. 2011; 11(4): p. 108-133.

105. Thacher PS. Multilateral Cooperation and Global Change. Journal of International Affairs. 1991; 44(2): p. 433-455.

106. Jamison D, Frenk J, Knaul F. International collective action in health: objectives, functions and rationale. The Lancet. 1998 February; 351: p. 514-517.

107. Yach D, Bettcher DW. The globalization of public health II: The convergence of selfinterest and altruism.. American Journal of Public Health. 1998; 88(5): p. 738-741.

108. Gostin LO, Mok EA. Grand challenges in global health governance. British Medical Bulletin. 2009;(90): p. 7-18.

109. World Health Organization. Basic Documents. 46th ed. Geneva: WHO; 2007.

110. Moon S, Sridhar D, Pate MA, Jha AK, Clinton C, Delaunay S, et al. Will Ebola change the game? Ten essential reforms before the next pandemic. The report of the Harvard-LSHTM Independent Panel on the Global Response to Ebola. The Lancet. 2015; 386(1): p. 22042221.

111. WHO Review Committee on the Role of the IHR 2005. Implementation of the International Health Regulations 2005. In ; 2016; Geneva: World Health Assembly 69, World Health Organization.

112. World Health Organization. A68/22 Implementation of the International Health Regulations (2005). Sixty-eighth World Health Assembly. 2015 May $15 .$.

113. Dandurand Y, Colombo G, Passas N. Measures and mechanisms to strengthen international cooperation among prosecution services. Crime Law Soc Change. 2007;(47): p. 261-289.

114. World Health Organization. Managing epidemics. Key facts about major deadly diseases. Luxemburg: WHO; 2018. 
115. Cooper GF, Villamarin R, Tsui FC(, Millett N, Espino JU, Wagner M. A Method for Detecting and Characterizing Outbreaks of Infectious Diseases from Clinical Reports. J Biomed Inform. 2015 February;(53): p. 15-26.

116. Cogburn D. Partners or Pawns?: The impact of Elite Decision-Making and Epistemic Communities in Global Information Policy on Developing Countries and Transnational Civil Society. Knowledge, Technology, \& Policy. 2005 Summer; 18(2): p. 52-81.

117. Lee L, Fidler D. Avian and pandemic influenza: Progress and problems with global health governance. Global Public Health. 2007; 2(3): p. 215-234.

118. Giorgetti C. International Health Emergencies in Failed and Failing States. Georgetown Journal of International Law. 2013; 44: p. 1347-1386.

119. Heritage Z, Green, Geoff. European National Healthy City Networks: The Impact of an Elite Epistemic Community. Journal of Urban Health: Bulletin of the New York Academy of Medicine. 2012;(90): p. S154-S166.

120. Van Damme WIM, Van Lerberghe WIM, Boelaert M. Primary Health Care Vs. Emergency Medical Assistance: A Conceptual Framework. Health Policy and Planning. 2002 March; 17(1): p. 49-60.

121. Foladori G. The Challenge of Infectious Diseases to the Biomedical Paradigm. Bulletin of Science, Technology \& Society. 2005 April; 25(2): p. 145-158.

122. Oshitani H. Lessons Learned from International Responses to Severe Acute Respiratory Syndrome (SARS). Environmental Health and Preventive Medicine. 2005 September;(10): p. 251-254.

123. World Health Organization. Communicable disease surveillance and response systems. Guide to monitoring and evaluating. Geneva:, Epidemic and Pandemic Alert and Response; 2006. Report No.: WHO/CDS/EPR/LYO/2006.2.

124. Partridge J, Kieny MP. Global production of seasonal and pandemic (H1N1) influenza vaccines in 2009-2010 and comparison with previous estimates and global action plan targets. Vaccine. 2010; 28: p. 4709-4712.

125. Oshitani H, Kamigaki T, Suzuki A. Major Issues and Challenges of Infl uenza Pandemic Preparedness in Developing Countries. Emerging Infectious Diseases. 2008 June; 14(6): p. 875-880. 
126. Gostin L, Lucey D, Phelan A. The Ebola Epidemic. A global Health Emergency. JAMA. 2014 September; 312(11): p. 1095-1096.

127. World Health Organization. A69/21 Implementation of the International Health Regulations (2005), Sixty-Ninth World Health Assembly. 2016 May $113 .$.

128. Ridley RG. Comentary: Research on infectious diseases requires better coordination. Nature Medicine Supplement. 2004; 10(12): p. S137-S140.

129. Enemark C. Life Science Research as a Security Risk. In Youde J, Rushton S, editors. Routledge Handbook of Global Health Security. New York: Routledge Handbooks; 2015. p. $130-140$.

130. Floret D. Les vaccins pandemiques. Archives de Pediatrie. 2010;(17).

131. Luke C, Subbarao K. Vaccines for pandemic influenza. Emerging Infectious Diseases. 2006 January; 12(1): p. 66-72.

132. Tabak R, Reis R, Wilson P, Brownson R. Dissemination of Health-Related Research among Scientists in Three Countries: Access to Resources and Current Practices. BioMed Research International. 2015 April; 2015: p. 1-9.

133. Coomarasamy A, Gee H, Publicover M, Khan KS. Medical journals and effective dissemination of health research. Health Information and Libraries Journal. 2001;(18): p. 183-191.

134. Kamran Khan Sea. Infectious disease surveillance and modelling across geograpich frontiers and scientific specialties. The Lancet. 2012;(12): p. 222-230.

135. Castillo-Salgado C. Trends and Directions of Global Public Health Surveillance. Epidemiological Review. 2010;(32): p. 93-109.

136. Butler D. Disease Surveillance Needs a Revolution. Nature. 2006 March; 440(2): p. 6-7.

137. Berkelman R, Bryan R, Osterholm M, LeDuc J, Hughes J. Infectious Disease Surveillance: A Crumbling Foundation. Science. 1994 April; 264: p. 368-370.

138. Heymann DL, Rodier GR. Hot spots in a wired word: WHO surveillance of emerging and re-emerging infectious diseases.. The Lancet. 2001; 1: p. 345-353. 
139. Bennett CJ. What Is Policy Convergence and What Causes It? British Journal of Political Science. 1991 April; 21(2): p. 215-233.

140. Haas PM. UN Conferences and Constructivist Governance of the Environment. Global Governance. 2002 January-March; 8(1): p. 73-91.

141. Kamradt-Scott A. Changing Perceptions of Pandemic Influenza and Public Health Responses. Public Health Then and Now. 2012 January; 102(1): p. 90-98.

142. Ruggie JG. International responses to technology: concepts and trends. International organization. $1975 ; 29(3)$ : p. 557-583.

143. Antoniades A. Epistemic Communities, Epistemes and the Construction of World Politics. Global Society. 2003; 1(17): p. 21-38.

144. Birn A. The stages of international (global) health: Histories of success or successes of history? Global Public Health. 2009; 4(1): p. 50-68.

145. Weiss TG, Carayannis T, Jolly R. The Third United Nations. Global Governance. 2009; 15(1): p. 123-142.

146. Adler E. The emergence of cooperation: National epistemic communities and the international evolution of the idea of nuclear arms control.. International Organization. 1992; 1(46): p. 101-145.

147. Mitchell NJ, al e. Elite beliefs, epistemic communities and the Atlantic Divide: Scientists' Nuclear Policy Preferences in the United States and European Union. British Journal of Political Science. 2007; 37(4): p. 753-764.

148. Morin JF. Paradigm shift in the global IP regime: The agency of academics. Review of International Political Economy. 2014; 21(2): p. 275-309.

149. Stone D. Global Public Policy, Transnational Policy Communities, and Their Networks. The Policy Studies Journal. 2008; 36(1): p. 19-38.

150. Walt G, Lush L, Ogden J. International organizations in transfer of infectious diseases: Iterative loops of adoption, adaptation, and marketing. Governance: An International Journal of Policy, Administration, and Institutions. 2004; 17(2).

151. Stone D. Knowledge networks and policy expertise in the global polity. In Higgott Oa, editor. Towards a Global Polity. New York; 2002. p. 125-144. 
152. Biermann R. Towards a theory of inter-organizational networking. The Euro-Atlantic security institutions interacting.. Rev. International Organizations. 2008;(3): p. 151-177.

153. Löblová O. Epistemic communities and experts in health policy-making. European Journal of Public Health. 2018; 28(Supplement).

154. Zito A. Instrument constituencies and epistemic community theory. Policy and Society. 2018; 37(1).

155. Dalglish S, George A, Shearer JC, Bennett S. Epistemic communities in global health and the development of child survival policy: a case study of iCCM. Health Policy and Planning. 2015 April; 30(Supplement).

156. Botcheva L. Expertise and International Governance: Eastern Europe and the Adoption of European Union Environmental Legislation. Global Governance. 2001 April-June; 7(2): p. 197-224.

157. Andresen S, Skodvin T, Underdal A, Wettestad J. Science and Politics in International Environmental Regimes Andresen S, Skodvin T, Underdal A, Wettestad J, editors. Manchester: Manchester University Press; 2000.

158. Clark WC, Majone G. The critical appraisal of scientific inquiries with policy implications. Science, Technology and Human Values. 1985; 10(3): p. 6-19.

159. Adler E, Haas P. Epistemic Communities, World-Order, And The Creation Of A Reflective Research-Program - Conclusion. International Organization. 1992; 46(1): p. 367-390.

160. Whelan C. Networks and National Security. Dynamics, Effectiveness and Organisation. Burlington : Ashgate; 2012.

161. Maoz Z. How network analysis can inform the study of international relations. Conflict Management and Peace Science. 2012; 29(3): p. 247-256.

162. Maoz Z. Networks of Nations. The Evolution, and Impact of International Networks, 18162001. 1st ed. New York: Cambridge University Press.; 2011.

163. Monge PR, Contrator NS. Theories of Communication Networks New York: Oxford University Press; 2003. 
164. Petersen E, et a. Rapid Spread of Zika Virus in the Americas-Implications for Public Health Preparedness for Mass Gatherings at the 2016 Brazil Olympic Games. International Journal of Infectious Diseases. 2016;(44): p. 11-15.

165. Hafner-Burton EM, Kahler M, Montgomery AH. Network analysis for international relations. International Organization. 2009;(63): p. 559-592.

166. Kali R, Reyes J. The architecture of globalization: A network approach to international economic integration. Journal of International Business Studies. 2007; 38(4): p. 595-620.

167. Van den Bossche P, Segers M. Transfer of training: Adding insight through social network analysis. Educational Research Review. 2013;(8): p. 37-47.

168. M. K, Sikkink K. Transnational advocacy networks in international and regional politics.. ISSJ. 1999;(159): p. 89-101.

169. Dolowitz D, Marsh D. Who Learns What from Whom: a Review of the Policy Transfer Literature. Political Studies. 1996;(XLIV): p. 343-357.

170. Karch A. Emerging Issues and Future Directions in State Policy Diffusion Research. State Politics \& Policy Quarterly. 2007; 7(1): p. 54-80.

171. Youde J. Is universal access to antiretroviral drugs an emerging international norm? Journal of International Relations and Development. 2008;(11): p. 415-440.

172. Mintrom M. Policy Entrepreneurs and the Diffusion of Innovation. American Journal of Political Science. 1997 July; 41(3): p. 738-770.

173. Stone D. Transfer and translation of policy. Policy Studies. 2012 November; 33(6): p. 483499.

174. Stoett PaOT. Bilateral and Trilateral Natural Resource and Biodiversity Governance in North America: Organization, Networks and Inclusion. Review of Policy Research. 2015; 32(1): p. 1-18.

175. A64/10 Review Committee IHR RCotFotIHR(irtPH2. Strenthening Response to Pandemics and other Public Health Emergencies. Committee Report. Geneva:; 2011.

176. Keck M, Sikkink K. Transnational advocacy networks in international and regional politics. ISSJ. 1999;(159): p. 89-101. 
177. Kamradt-Scott A, Rushton S. The revised international health regulations: Socialization, compliance and changing norms of global health security.. Global Change, Peace \& Security. 2012; 24(1): p. 57-70.

178. Dunlop C. Policy Transfer as Learning: Capturing Variation in What Decision-Makers Learn from Epistemic Communities. Policy Studies. 2009; 30(3): p. 289-311.

179. Dimitrov R. Knowledge, Power, and Interests in Environmental Regime Formation. International Studies Quaterly. 2003;(47): p. 123-150.

180. Youde J. The development of a counter-epistemic community: AIDS, South Africa, and international regimes. International Relations. 2005; 19(4): p. 421-439.

181. Shibuya K, Ciecierski C, Guindon E, Bettcher DW, Evans DB, Murray C. WHO framework convention on tobacco control: Development of an evidence based global public health treaty. BMJ. 2003 July; 327: p. 154-157.

182. Mamudu H, Gonzalez ME, Glantz S. The Nature, Scope, and Development of the Global Tabacco Control Epistemic Community. Public Health Then and Now. 2011 November; 101(11): p. 2044-2054.

183. Beaglehole R, R B, R H, C A, G A, P A, et al. Priority actions for the non-communicable disease crisis. The Lancet. 2011 April; 377(9775): p. 1438-1447.

184. World Health Organization. WHO Framework Convention on Tobacco Control. [Online].; 2017. Available from: https://www.who.int/fctc/en/.

185. Roemer R, Taylor AL, Lariviere J. Origins of the WHO framework convention on tobacco control.. American Journal of Public Health. 2005; 95(6): p. 936-938.

186. US Department of Health and Human Services. The Health Consequences of Smoking. 50 Years of Progress. A Report of the Surgeon General. Rockville:, DHHS; 2014.

187. World Health Organization. The Limitation of Smoking. WHO Chronicle. 1971 October; 25(10): p. 452-457.

188. Joossens L. From public health to international law: Possible protocols for inclusion in the framework convention on tobacco control. Bulletin of the World Health Organization. 2000; 78(7): p. 930-937. 
189. Taylor A, Bettcher D. WHO Framework Convention on Tobacco Control: a global good for public health. Bulletin of the World Health Organization. 2000; 78(7): p. 920-927.

190. Hipple B, Lando H, Klein J, Winickoff J. Global teens and tobacco: A review of the globalization of the tobacco epidemic.. Curr Probl Pediatr Adolesc Health Care. 2011 September;(41): p. 216-230.

191. Collin J, Lee K, Bissell K. The framework convention on tobacco control: The politics of global health governance.. Third World Quarterly. 2002; 23(2): p. 265-282.

192. Organization WH. History of the World Health Organization Framework Convention on Tobacco Control Geneva: World Health Organization; 2009.

193. Terry LL. Smoking, and Health: Report of the Advisory Committee of the Surgeon General of the Public Health Service. Washington D.C.: US Department of Health, Education, and Welfare, Surgeon General of the United States.; 1964.

194. Services UDoHaH. The Health Consequences of Smoking- 50 years of progress. A report of the Surgeon General Rockville: US Department of Health and Human Services; 2014.

195. World Health Organization. WHA23.32 Health Consequences of Smoking. [Online].; 1970 [cited 2015. Available from:

http://www.who.int/tobacco/framework/wha eb/wha23 32/en/.

196. Health and Education Journal. Seconf World Conference on Smoking and Health. Health and Education Journal. 1970; 29(1): p. 25.

197. World Conference on Tobacco or Health. World Conference on Tobacco or Health. [Online].; 2016. Available from: https://wctoh.org/.

198. WHO FCTC. Framework Convention on Tobacco Control. [Online]. Available from: http://www.who.int/fctc/publications/techseries/en/.

199. World Health Organization. Information about the hearings and the full list of participants. [Online].; 2000 [cited 2015. Available from: http://www.who.int/tobacco/framework/public hearings/submissions/en/.

200. Chung-Hall J, Craig L, Gravely S, Sansone N, Fong GT. Impact of the WHO Framework Convention on Tobacco Control on the Implementation and Effectiveness of Tobacco 
Control Measures: A Global Evidence Review. Waterloo, Ontario: ITC Project. University of Waterloo; June 2016.

201. World Health Organization. WHO Framework Convention for Tobacco Contro. [Online].; 2009 [cited 2015. Available from: http://www.who.int/fctc/.

202. Morens DM, Folkers GK, Fauci AS. The challenge of emerging and re-emerging infectious diseases. Nature. 2004 July; 430: p. 242-249.

203. Fauci AS. Emerging and Reemerging Infectious Diseases: The Perpetual Challenge. Academic Medicine. 2005 December; 80(12): p. 1079-1085.

204. Coker R, BM H, JW R, M L, P. H. Emerging infectious diseases in Southeast Asia: Regional challenges to control. The Lancet. 2011;(377): p. 599-609.

205. Ear S. Mexico's handling of A/H1N1 in comparative perspective.. Politics and the Life Sciences. 2012; 31(2): p. 52-66.

206. Lashley F. Factors Contributing to the Occurrence of Emerging Infectious Diseases. Biological Research for Nursing. 2003 April; 4(4).

207. World Health Organization. WHO Global Health Influenza Programme, Pandemic Influenza Preparedness and Response. A WHO guidance document. Lyon:; 2010.

208. Bhatia R, Narani J. The challenge of emerging zoonosis in Asia-Pacific. Asia-Pacific Journal of Public Health. 2010; 22(4): p. 388-394.

209. Seimenis A. Capacity building for zoonotic and foodborne diseases in the Mediterranean and Middle East regions (an intersectoral WHO/MZCP proposed strategy). International Journal of Antimicrobial Agents. 2010; 36S: p. S75-S79.

210. Centers for Disease Control and Prevention. Addressing emerging infectious disease threats: a prevention strategy for the United States (Executive Summary). MMWR No. RR5. Atlanta:; 1994.

211. Jonas O. Pandemic Risk. World Develoment Report. Washingto D.C.: World Bank; 2013.

212. Frenk J, Gómez-Dantés O. Globalization And The Challenges To Health Systems. Health Affairs. 2002; 21(3): p. 160-165. 
213. Chigas D, Fairman D, McClintock E, Najam A. Negotiating across Boundaries: Promoting Health in a Globalized World. In Blouin C, Heymann J, Drager N, editors. Trade and Health. Montreal and Kingston: McGill-Queen's University Press; 2007. p. 325-346.

214. Costello Aea. Managing the health effects of climate change. The Lancet. 2009;(373): p. 1693-1733.

215. Elbe S. Security and Global Health Cambridge, UK: Polity; 2010.

216. Labonte R, Gagnon ML. Framing health and foreign policy: lessons for global health diplomacy. Globalization and Health. 2010; 6(14): p. 1-19.

217. Marano N, Arguin PM, Pappaioanou M. Impact of globalization and animal trade on infectious disease ecology. Emerging infectious diseases. 2007 December; 13(12): p. 18071809.

218. Karesh WB, Cook RA, Bennett EL, Newcomb J. Wildlife trade and global disease emergence. Emerging infectious diseases. 2005 July; 11(7): p. 1000-1002.

219. Wilson, ME. Travel and the emergence of infectious diseases. Emerging Infectious Diseases. 1995 April-June; 1(2): p. 39-46.

220. Alirol E, Getaz L, Stoll B, Chappuis F, Loutan L. Urbanisation and infectious diseases in a globalised world. The Lancet Infectious Diseases. 2010; 10: p. 131-141.

221. Saker L, Lee K, Cannito B, Gilmore A, Campbell-Lendrum D. Globalization and infectious diseases : a review of the linkages Geneva: WHO; 2004.

222. Fidler DP, Drager N. Foreign Policy, Trade and Health: At the Cutting Edge of Global Health Diplomacy. Bulletin of the World Health Organization. 2007 March; 85(3): p. 162.

223. Smith R, al e. Communicable disease control: a Global Public Good perspective. Health Policy and Planning. 2004; 19(5): p. 271-278.

224. Lee K. Shaping the future of global health cooperation: where can we go from here. The Lancet. 1998;(351): p. 899-902.

225. Hein W. The New Dynamics of Global Health Governance. In Kickbusch I, al. e. Global Health Diplomacy: Concepts, Issues, Actors, Instruments, Fora, and Cases. New York: Springer Science; 2013. p. 55-72. 
226. Tomes N. The Private Side of Public Health: Sanitary Science, Domestic Hygiene, and the Germ Theory 1870-1900. Bull. Hist. Med. 1990;(64): p. 509-539.

227. Buchen L. The New Germ Theory. Nature. 2010 November; 468: p. 492-495.

228. Eckardt I. Challenging Complexity Conceptual Issues in an Approach to New Disease. Anals New York Academy of Science. 1994;: p. 408-417.

229. Sigelma C, Alfeld-Liro C, Lewin C, Derenowski E, Woods T. The Role of Germs and Viruses in Children`s Theories of AIDS. Health Education \& Behavior. 1997 April; 24(2): p. 191-200.

230. Stewart, G.T. Limitations of the Germ Theory. The Lancet. 1968 May;: p. 1077-1079.

231. Ghani AC; Donnelly CA; Cox DR; Griffin JT; Fraser C; Lam TH; Ho LM; Chan WS; Anderson RM; Hedley AJ; Leung GM. Methods for estimating the case fatality ratio for a novel, emerging infectious disease. American Journal of Epidemiology. 2005 September; 162(5): p. 479-486.

232. Ridenhour B, Kowalik JM, Shay DK. Unraveling R0: Considerations for Public Health Applications. American Journal of Public Health. 2014 February; 104(2): p. e32-e41.

233. Heffernan J, Smith R, Wahl L. Perspectives on the basic reproductive ratio. J.R.Soc.Interface. 2005;(2): p. 281-293.

234. Woolhouse M, Brierley L, McCaffery C, Lycett S. Assessing the epidemic potential of RNA and DNA Viruses. Emerging Infectious Diseases. 2016 December; 22(12): p. 20372044.

235. Organizacion Mundial de la Salud. Examen cientifico de las investigaciones sobre el virus variolico 1999-2010. Ginebra:; 2011.

236. Putnam RD. Diplomacy and domestic politics: The logic of two-level games. International Organization. 1998; 42(3): p. 427-460.

237. Milner HV. The assumption of anarchy in international relations theory: A critique. Review of International Studies. 1991; 17(1): p. 67-85.

238. Fidler D, Gostin L. Biosecurity in the Global Age. Biological weapons, public health, and the rule of law. Stanford Law and Politics. 2008. 
239. Price-Smith AT. The Health of Nations. 1st ed. Cambridge: Massachusetts Institute of Technology Press.; 2002.

240. Gostin L, Friedman E. A restrospective and prospective analysis of the west African Ebola virus disease epidemic: robust national health systems at the foundation and an empowered WHO at the apex. The Lancet. 2015 May; 385: p. 1902-1910.

241. Medecins Sans Frontieres. Pushed to the Limit and Beyond. A year into the largest ever Ebola outbreak. Brussels: MSF; 2014.

242. Caballero-Anthony N. Non-traditional security and infectious diseases in ASEAN: going beyond the rhetoric of securitization to deeper institutionalization.. The Pacific Review. 2008; 21(4): p. 507-525.

243. Smith RD. Responding to global infectious disease outbreaks: Lessons from SARS on the role of risk perception, communication and management. Social Science and Medicine. 2006;(63): p. 3113-3123.

244. Garrett L. The Return of Infectious Disease. Foreign Affairs. 1996 January/February.

245. Agenda GHS. Global Health Security Agenda. [Online].; 2018. Available from: https://www.ghsagenda.org/about.

246. Balajee SA, Arthur R, Mounts AW. Global Health Security: Building Capacities for Early Event Detection, Epidemiologic Workforce and Laboratory Response. Health Security. 2016; 14(6): p. 424-432.

247. Aldis W. Health security as a public health concept: a critical analysis. Health Policy and Planning. 2008; 23: p. 369-375.

248. Kimball AM. Risky trade New York: Routledge; 2006.

249. Peabody JW. An Organizational Analysis of the World Health Organization: Narrowing the GAP between promise and performance. Soc. Sci. Med. 1995; 40(6): p. 731-742.

250. World Health Organization. Address by the Director-General. In 62 World Health Assembly - Verbatim Record; 2009; Geneva. p. 35.

251. Syed AM, Hjarnoe L, Krumkamp R, Reintjes R, Aro AR. Developing policy options for SARS and SARS-like diseases - a Delphi study. Global Public Health. 2010; 5(6): p. 663675. 
252. Hilgenfeld R, Peiris M. From SARS to MERS: 10 years of research on highly pathogenic human coronaviruses.. Antiviral Research. 2013;(100): p. 286-295.

253. Condon R, Patel M. Response of the Western Pacific Regional Office. In SARS How a global epidemic was stopped. Geneva: World Health Organization Western Pacific Region; 2006. p. 49-55.

254. Huang Y. The SARS epidemic and its aftermath in China: a political perspective. In Knobler S, Mahmoud A, Lemon S, Mack A, Sivitz L, K. Oberholtzer. Learning from SARS. Washington D.C.: The National Academy Press p. 116-136.

255. Health Canada. SARS in Canada, Anatomy of an Outbreak. In Learning from SARS. Renewal of Public Health in Canada. Ottawa: Health Canada; 2003. p. 23-42.

256. Whaley F, D MO. SARS Chronology. In SARS How a global epidemic was stopped. Geneva: World Health Organization Western Pacific Region; 2006. p. 3-48.

257. Jao-Yiu Sung J. Clinical features. In SARS How a global epidemic was stopped. Geneva: World Health Organization Western Pacific Region; 2006. p. 175-184.

258. Mackenzie, JS; Drury P; Ellis A et al. The WHO response to SARS and preparation for the Future. In Knobler S, Mahmoud A, Lemon S, Mack A, Sivitz L, Oberholtzer K, editors. Learning from SARS: Preparing for the Next Disease Outbreak. Washington DC: Institute of Medicine, US National Academies; 2004. p. 42-50.

259. Lee J, McKibbin W. Estimating the Global Economic Costs of SARS. In Knobler S, Mahmoud A, Lemon S, al e, editors. Learning from SARS: Preparing for the Next Disease Outbreak: Workshop Summary. Washington D.C.: National Academy Press, Institute of Medicine (US) Forum on Microbial Threats; 2004.

260. Zylberman P. Le SRAS, une épidémie postmoderne ? La Recherche. 2004;(371): p. 46-47.

261. Mackenzie JS, Drury P, Ellis A, Grein T, Leitmeyer KC, Mardel S, et al. "The WHO Response to SARS and Preparations for the Future". In Learning from SARS: Preparing for the Next Disease Outbreak; 2004; 42-56.

262. Kamradt-Scott A. Disease outbreaks and health governance in the Asia-Pacific: Australia's role in the region. Australian Journal of International Affairs. 2009; 63(4): p. 550-570. 
263. Castillo-Salgado C. Trends and Directions of Global Public Health Surveillance. Epidemiological Review. 2010;(32): p. 93-109.

264. Davis SE, Youde J. The IHR (2005), disease surveillance, and the individual in global health politics.. The International Journal of Human Rights. 2013; 17(1).

265. Calain P. Exploring the international arena of global public health surveillance. Health Policy and Planning. 2006;(22): p. 2-12.

266. Hoffman S. Making the International Health Regulations Matter. In Youde J, Rushton S, editors. Routledge Handbook of Global Health Security. New York: Routledge Handbooks; 2015. p. 239-251.

267. World Health Organization. WHO event management for international public health security. Operational Procedures Geneva: World Health Organization; 2008c.

268. McKee M, Gilmore AB, Schwalbe. International cooperation and health. Part 1. Issues and concepts. J Epidemiol Community Health. 2005;(59): p. 628-631.

269. World Health Organization. A framework for global outbreak alert and response. Geneva: WHO; 2000.

270. World Health Organization. Key events in the WHO response to the Ebola outbreak. One year into the Ebola epidemic. Geneva: World Health Organization; 2015.

271. World Health Organization. GOARN website. [Online].; 2018. Available from: https://extranet.who.int/goarn/content/goarn-steering-committee.

272. Shumate M, Fulk J, Monge P. Predictors of the International HIV-AIDS INGO Network over time. Human Communication Research. 2005 October; 31(4): p. 482-510.

273. The Lancet Infectious Diseases. Ebola in West Africa. The Lancet. 2014 September; 14.

274. World Health Organization. Strengthening response to pandemics and other public health emergencies. Report of the Review Committee on the functioning of the IHR 2005 and on Pandemic Influenza H1N1 2009. Geneva:; 2011.

275. Robertson JS, Inglis SC. Prospects for controlling future pandemics of influenza. Virus Research. 2011 Septiembre;(162): p. 39-46. 
276. Avery DH. The North American Plan for Avian and Pandemic Influenza: A Case Study of Regional Health Security in the 21st Century. Global Health Governance. 2010 Spring; III(2).

277. DHHS, US. Official web site of the Department of Health and Human Services for Pandemic Influenza, "Flu net". [Online].; 2012 [cited 2012 March. Available from: www.flu.gov.

278. Enemark C. Is Pandemic Flu a Security Threat? Survival. 2009; 51(1): p. 193.

279. Kilbourne ED. Influenza Pandemics of the 20th Century. Emerging Infectious Diseases. 2006 January; 12(1): p. 9-14.

280. Girard M, Tam J, Assossou O, Kieny MP. The 2009 A (H1N1) influenza virus pandemic: A review. Vaccine. 2010;(28): p. 4895-4902.

281. Viboud C, Boëlle PY, Carrat F, Valleron AJ, Flahault A. Prediction of the Spread of Influenza Epidemics by the Method of Analogues. American Journal of Epidemiology. 2003; 158(10): p. 996-1006.

282. Gao J, Wang K, Ding T, Zhu S. Forecasting influenza A pandemic outbreak using protein dynamical network biomarkers. BMC Systems Biology. 2017; 11(85): p. 113-119.

283. Yang W, Lipsitch M, Shaman J. Inference of seasonal and pandemic influenza transmission dynamics. PNAS. 2015 March; 112(9): p. 2723-2728.

284. Hayward A, Fragaszy EB, Bermingham A, Wang L, Copas A, Edmunds J, et al. Comparative community burden and severity of seasonal and pandemic infl uenza: results of the Flu Watch cohort study. The Lancet Resp Med. 2014 March; 2: p. 445-454.

285. Chretien JP, George D, Shaman J, Chitale RA, McKenzie FE. Influenza Forecasting in Human Populations: A Scoping Review. PLoS One. 2014 April; 9(4): p. 1-8.

286. Yang W, Karspeck A, Shaman J. Comparison of Filtering Methods for the Modeling and Retrospective Forecasting of Influenza Epidemics. PLOS Computational Biology. 2014 April; 10(4): p. 1-15.

287. Nsoesie E, Brownstein J, Ramakrishnan N, Marath M. A systematic review of studies on forecasting the dynamics of influenza outbreaks. Influenza and Other Respiratory Viruses. 2014; 8(3): p. 309-316. 
288. Fineberg HV. Pandemic Preparedness and Response - Lessons from the H1N1 Influenza of 2009. The New England Journal of Medicine. 2014 April;(370).

289. Fidler DP. H1N1 after action review: learning from the unexpected, the success and the fear. Future Microbiology. 2009 September; 4(7).

290. World Health Organization. High Level Consultation A(H1N1). In World Health Assembly 62nd; 2009; Geneva. p. 1-9.

291. Palmore J. More on Avian Influenza A/H5N1 Threats in Light of Recent Statistics. Defense and Security Analysis. 2008 February; 4(2).

292. Fidler DP. Epic Failure of Ebola and Global Health Security. The Brown Journal of World Affairs. 2015 Summer; XXI(II).

293. Khan A, Lurie N. Health security in 2014: building on preparedness knowledge for emerging health threats. The Lancet. 2014 July; 384(9937).

294. Gostin LO. Influenza A(H1N1) and Pandemic Preparedness Under the Rule of International Law. JAMA. 2009 June; 301(22).

295. Shapshak P, Chiappelli F, Somboonwit C, Sinnott J. The Influenza Pandemic of 2009. Mol Diagn Ther. 2011; 15(2): p. 63-81.

296. Payne AMM. The Influenza Programme of WHO. Bulletin World Health Organization. 1953;(8): p. 755-774.

297. Kamradt-Scott A. Evidence-based medicine and the governance of pandemic influenza. Global Public Health. 2012 December; 7(S2): p. S111-S126.

298. Jensen K, Hogan R. Laboratory diagnosis of Asian Influenza. Public Health Reports. 1958 February; 73(2): p. 140-144.

299. Pereira MS. Global Surveillance of Influenza. British Medical Bulletin. 1979 February; 35(1): p. 9-14.

300. WHO Global Influenza Programme. [Online]. [cited 2016 June 10. Available from: http://www.who.int/influenza/gisrs_laboratory/en/. 
301. World Health Organization. Influenza. Global Influenza Surveillance and Response System. [Online].; 2017 [cited 2019. Available from:

https://www.who.int/influenza/gisrs laboratory/GISRSmap.png?ua=1.

302. World Health Organization. Influenza. [Online].; 2017 [cited 2017 December 19. Available from: http://www.who.int/influenza/gisrs_laboratory/nic meeting_2017/en/.

303. Cromie R, Davidson N, Galbraith C, Hagemeijer W, Horwitz P, Lee R, et al. Responding to emerging challenges: Multilateral environmental agreements and highly pathogenic avian influenza H5N1. Journal of International Wildlife Law \& Policy. 2011;(14): p. 206-242.

304. World Health Organization. Cumulative number of confirmed human cases for avian influenza A(H5N1) reported to WHO 2003-2012. Geneva: WHO; 2012.

305. World Health Organization. Cumulative number of confirmed human cases for avian influenza A(H5N1) reported to WHO, 2003-2017. Geneva: WHO, WHO/GIP; 2017.

306. World Health Organization. Cumulative number of confirmed human cases of avian influenza A(H5N1) reported to WHO. [Online].; 2019 [cited 2019 April 1. Available from: https://www.who.int/influenza/human_animal_interface/2019 02 12 tableH5N1.pdf?ua=1.

307. Marshall SJ. Governments in a dilemma over bird flu. Bulletin of the World Health Organization. 2005 May; 83(5): p. 325-326.

308. Osterholm MT, Kelley NS. H5N1 influenza virus seroepidemiological studies: The facts revisited. Proceedings of the National Academy of Sciences. 2012 May; 109(21): p. E1332.

309. World Health Organization. Influenza. Avian and other zoonotic influenza. [Online].; 2019 [cited 2019 April 1. Available from: https://www.who.int/influenza/human animal interface/en/.

310. World Health Organization. Avian Influenza: assessing the pademic threat Geneva: WHO; 2005.

311. World Health Organization. Influenza. WHO H5 Reference Laboratories. [Online].; 2019 [cited 2019 April 1. Available from: https://www.who.int/influenza/gisrs laboratory/h5 reflabs/en/. 
312. Kuri-Morales P, Betancourt-Cravioto M, Velazquez-Monroy O, Alvarez-Lucas C, TapiaConyer R. Pandemia de Influenza: la respuesta de Mexico. Salud Publica de Mexico. 2006 Enero-Febrero; 48(1): p. 72-79.

313. Government of Malasya. National Influenza Pandemic Preparedness Plan. Kuala Lumpur: Minister of Health Malasya; 2006.

314. World Health Organization. WHO expert to work with the UN system on avian and human influenza. [Online].; 2005 [cited 2018 May 25. Available from: https://www.who.int/mediacentre/news/releases/2005/pr45/en/.

315. Jiménez Corona MEea. Epidemiología de la influenza A(H1N1). In José A. Córdova Villalobos JLVaSPdL, editor. La Epidemia de Influenza A/H1N1 en México. Mexico City: Editorial Médica Panamericana p. 2010.

316. Cohen J. Exclusive: Interview with head of Mexico's Top Swine Flu Lab. Science Now. 2009 May 1st.

317. Cordova-Villalobos JA, Sarti E, Arzoz-Padres J, Manuell-Lee G, Romero-Mendes J, KuriMorales P. The influenza A(H1N1) epidemic in Mexico. Lessos Learned. Health Research Policy and Systems. 2009 September 28; 7(21): p. 1-7.

318. Cordova-Villalobos J, Valdespino-Gomez J, Ponce de Leon-Rosales S. La Epidemia de Influenza A(H1N1) en Mexico Mexico City: Editorial Medica Panamericana; 2010.

319. Macias Aea. La influenza epidemica en Mexico: el dogma roto y sus lecciones. Revista de Investigacion Clinica. 2009 Marzo-Abril; 61(2): p. 94-97.

320. World Health Organization. Pandemic (H1N1)2009. [Online].; 2009 [cited 2011 June 15. Available from: https://www.who.int/csr/disease/swineflu/en/.

321. World Health Organization. WHO's Emergency Response Framework. Geneva: World Health Organization; 2011.

322. Webby R, Webster R. Are we ready for Pandemic Influenza. Science. 2003 November; 302(5650): p. 1519-1522.

323. Chu CM, Andrewes CH, Gledhill AW. Influenza in 1948-1949. Bulletin World Health Organization. 1950 May;(3): p. 187-214. 
324. Francis Tj, J.E. S, J.J. Q. Experience with Vaccination Against Influenza in the Spring of 1947. American Journal of Public Health. 1947 August; 37: p. 1013-1016.

325. Fauci A. Seasonal and Pandemic Influenza Preparedness: Science and Countermeasures. The Journal of Infectious Diseases. 2006 November; 194(Supplement 2).

326. Ghendon Y. Introduction to pandemic influenza through history. European Journal of Epidemiology. 1994 August; 10(4): p. 451-453.

327. Gatherer D. The 2009 H1N1 influenza outbreak in its historical context. Journal of Clinical Virology. 2009 July; 45(3).

328. Zimmer S, Burke D. Historical Perspective - Emergence of Influenza A (H1N1) Viruses. The New England Journal of Medicine. July 2009; 361: p. 279-285.

329. J.K. T, D.M. M. 1918 influenza: the mother of all pandemics.. Emerg Infect Dis. 2006 January; 12(1).

330. E.D. K. Influenza pandemics of the 20th century. Emerg Infect Dis. 2006 January; 12(1).

331. Stephane Hugonnet; Cathy Roth; Apluche-Aranda; Ietza Bojorquez Chapela; Ethel Palacios Zavala; Dulce Ma. Espejo Guevara; Francesco Checchi; Erika Garcia; Francois Balloux; Azra C. Ghani; Neil M. Ferguson; Andrew Rambaut; Oliver G. Pybus; Hugo Lopez-Gatell. Pandemic Potential of a Strain of Influenza A (H1N1) : Early Findings. Science. 2009 May.

332. Meltzer MI, Cox NJ, Fukuda K. Modeling the economic impact of pandemic influenza in the United States: implications for setting priorities for intervention. Background Paper. Centers for Disease Control and Prevention; 2009.

333. Ferguson N. Strategies for containing an emerging influenza pandemic in Southeast Asia. Nature. 2005; 1(437): p. 209-214.

334. Longini IJ. Containing Pandemic Influenza at the Source. Science. 2005; 1(309): p. 10831087.

335. World Health Organization. WHO interim protocol: rapid operations to contain the initial emergency of pandemic influenza. [Online].; 2007 [cited 201804 6. Available from: www.who.int/csr/disease/avian_influenza/guidelines/RapidContProtOct15.pdf.

336. World Health Organization. Draft Report Pandemic Influenza H1N1 2009. Geneva: World Health Organization; March 2011. 
337. Ly, Sovann; Arashiro, Takeshi; Ieng, Vanra; Tsuyuoka, Reiko; Parry, Amy; Horwood, Paul; Heng, Seng; Hamid, Sarah; Vandemaele, Katelijn; Chin, Savuth; Sar, Borann; Arima, Yuzo. Establishing seasonal and alert influenza thresholds in Cambodia using the WHO method: implications for effective utilization of influenza surveillance in the tropics and subtropics. Western Pacific Surveillance and Response Journal. 2017 April;(8): p. 22-32.

338. Zhang W, Webster R. Can we beat influenza? Science. 2017 July; 357(6347): p. 111.

339. Monto A. Reflections on The Global Influenza Surveillance and Response System (GISRS) at 65 Years: An Expanding Framework for Influenza Prevention, Detection and Control. Influenza and Other Respiratory Viruses. 2018 January; 12(1): p. 10-12.

340. Sondorp E, Ansell C, Hartley Stevens R, Denton E. Independent Evaluation of the Global Alert and Response Network. Geneva: World Health Organization, Global Alert and Response Network; 2011. Report No.: WHO/HSE/GCR/GOARN/2011.2.

341. Mackenziea JS, Drury P, Arthur RR, Ryan MJ, Grein T, Slattery R, et al. The Global Outbreak Alert and Response Network. Global Public Health. 2014; 9(9): p. 1023-1039.

342. GISAID. Governance and Expertise. [Online].; 2008-2019 [cited 2019 April 1. Available from: https://www.gisaid.org/about-us/governance/.

343. CIDA, USAID, OPS. Report Proceedings Sub-regional Meeting. In Pandemic Influenza Preparedness and Response: Caribbean Experience and Lessons Learned; 2009; Barbados.

344. Moore M, Dausey D. Response to the 2009-H1N1 influenza pandemic in the Mekong Basin: surveys of country health leaders. BMC Research Notes. 2011; 4(361).

345. Australian Government. Australia's Health Sector Response to Pandemic (H1N1) 2009. Sydney:, Department of Health and Ageing; 2011.

346. Relman D, Choffnes E, Mack A. The Domestic and International Impacts of the 2009H1N1 Influenza A Pandemic. In Global Challenges, Global Solutions; 2010; Washington, D.C. p. $1-83$.

347. World Health Organization. Influenza Pandemic Plan. The Role of WHO and Guidelines for National and Regional Planning. Geneva: WHO, Communicable Disease Surveillance and Response; 1999. Report No.: WHO/CDS/CSR/EDC/99.1. 
348. World Health Organization W. WHO Checklist for influenza pandemic preparedness planning. In ; 2005; Geneva: Department of Communicable Diseases, Global Influenza Programme.

349. World Health Organization. Strategic Partnership for International Health Regulations (2005) and Health Security (SPH). [Online].; 2018 [cited 2018. Available from: https://extranet.who.int/sph/influenza-plan.

350. World Health Organization. WHO Terms of Reference for National Influenza Centers of the Global Influenza Surveillance and Response System. [Online].; 2017 [cited 2018 May. Available from:

https://www.who.int/influenza/gisrs laboratory/national_influenza_centres/tor_nic.pdf.

351. World Health Organization. Strategic Advisory Group of Experts on Immunization - report of the extraordinary meeting on the infl uenza A (H1N1) 2009 pandemic, 7 July 2009. Weekly Epidemiological Review. 2009 July; 84(30): p. 301-308.

352. World Health Organization. Human infection with new infl uenza A (H1N1) virus: WHO Consultation on suspension of classes and restriction of mass gatherings to mitigate the impact of epidemics caused by infl uenza A (H1N1), May 2009. Weekly Epidemiological Review. 2009 July; 84(27): p. 269-270.

353. World Health Organization. Influenza H1N1 2009 Lessons. [Online].; 2009. Available from: http://www.who.int/dg/speeches/2009/influenza_h1n1_lessons_20090702/en/.

354. McConnell J. Influenza in the Asia-Pacific. The Lancet. 2009 October; 9: p. 590-591.

355. Alpuche-Aranda CM. Editorial. Salud Publica de Mexico. 2009; 51(Suplemento 3): p. S373-S376.

356. Organization WH. Verbatim Records 62 WHA. In 62 World Health Assembly; 2009; 2009. p. 20-23.

357. Mackey TK, Liang BA. Lessons from SARS and H1N1/A: Employing a WHO-WTO forum to promote optimal economic-public health pandemic response. Journal of Public Health Policy. 2012; 33(1): p. 119-130.

358. WHO; UNCHA; UNSIC. Urgent Support for Developing Countries Responses to the H1N1 Influenza Pandemic. Geneva: World Health Organization, UN Office for the Coordination of Humanitarian Affairs, UN System Influenza Coordination; June 2010. 
359. WB, UNSIC. Animal and Pandemic Influenza. A framework for sustaining momentum. Fifth Global Progress Report. Washington D.C.: World Bank; UN System Influenza Coordinator; July 2010.

360. World Health Organization. Statement made at the Secretary-General's briefing to the United Nations General Assembly on the H1N1 influenza situation. [Online].; 2009 [cited 2019. Available from: https://www.who.int/dg/speeches/2009/influenza_a_h1n1_situation_20090504/en/.

361. World Health Organization. Statement by Director General, Dr. Margaret Chan. World now at the start of 2009 influenza pandemic. [Online].; 2009 [cited 201804 6. Available from:

www.who.int/mediacenter/news/statements/2009/h1n1_pandemic phase6_20090611/en/.

362. Gobernacion Sd. Decreto por el que se ordenan diversas acciones en materia de salubridad general, para prevenir, controlar y combatir la existencia y transmision del virus de influenza estaciona epidemica. 2009 April 25.

363. Secretary-General U. Secretary-General's remarks to Member States on Influenza A(H1N1). In United Nations General Assembly; 2009; New York: United Nations. p. 2.

364. Potter CW, Jennings R. A definition for influenza pandemics based on historical records. Journal of Infection. 2011 May;(63): p. 252-259.

365. World Health Organization. Emergencies preparedness, response. [Online].; 2009 [cited 2019 May. Available from: https://www.who.int/csr/disease/swineflu/statement/en/.

366. World Health Organization. Emergency Preparedness and Response. Pandemic (H1N1) 2009 Guidance Documents. [Online].; 2009 [cited 2015 May 25. Available from: https://www.who.int/csr/resources/publications/swineflu/en/.

367. Eurepean Centre for Disease Control and Prevention. 2009 Influenza A (H1N1) Pandemic. [Online].; 2009-2019 [cited 2019 April. Available from: https://ecdc.europa.eu/en/seasonalinfluenza/2009-influenza-h1n1.

368. Centers for Disease Control and Prevention. Epidemiological Publications Related to the H1N1 Pandemic by CDC Influenza Division, Epidemiology and Prevention Branch Authors. [Online].; 2009 [cited April 1 2019. Available from: https://www.cdc.gov/h1n1flu/pubs/h1n1_epi_pubs.htm. 
369. Ontario Agency for Health Protection and Promotion. H1N1 The Literature-This Week at Glance. Toronto: Ontario Government; 2009.

370. Organization WH. WHO Pandemic 2009 guidance documents. [Online].; 2009 [cited 2016 July. Available from: http://www.who.int/csr/resources/publications/swineflu/en/.

371. Castillo-Salgado C. Trends and Directions of Global Public Health Surveillance. Epidemiological Review. 2010;(32): p. 93-109.

372. World Health Organization. Dr. Margatey Chan, Keynote speech at a high-level meeting on influenza $\mathrm{A}(\mathrm{H} 1 \mathrm{~N} 1)$ : lessons learned and preparedness. In Influenza $\mathrm{A}(\mathrm{H} 1 \mathrm{~N} 1)$ : lessons learned and preparedness; 2009; Cancun.

373. Broadbent AJ, Subbarao K. Influenza Virus Vaccines: Lessons form the 2009 H1N1 pandemic. Curr Opin Virol. 2011 October; 1(4): p. 254-262.

374. Fedson DS. Pandemic Influenza and the Global Vaccine Supply. Clinical Infectious Diseases. 2003 June; 36(12): p. 1552-1561.

375. Fidler DP. Negotiating Equitable Access to Influenza Vaccines: Global Health Diplomacy and the Controversies Surrounding Avian Influenza H5N1 and Pandemic Influenza H1N1. PLoS Medicine. 2010 May; 7(5): p. 1-4.

376. Henrich N, Holmes B. What the Public Was Saying about the H1N1 Vaccine: Perceptions and Issues Discussed in On-Line Comments during the 2009 H1N1 Pandemic. PLoS ONE. 2011 April; 6(4): p. 1-12.

377. Heymann D, West A. Emerging Infections. In Youde J, Rushton S, editors. Routledge Handbook of Global Health Security. New York: Routledge Handbooks; 2015. p. 92-104.

378. Warren A, Bell M, Budd L. Surveillamce networks and spaces of governance: Technological openess and international cooperation during the $2009 \mathrm{H} 1 \mathrm{~N} 1$ pandemic. London:; 2010.

379. Bell M, Warren A, Budd L. Scales ofgovernance:The role of surveillance in facilitating new diplomacy during the 2009-2010 H1N1 pandemic. Health \& Place. 2012;: p. 1404-1411.

380. Leung GM, Nicoll A. Reflections on Pandemic (H1N1) 2009 and the International Response. PLoS Medicine. 2010 October; 7(10): p. 1-6. 
381. Chan EH, Brewer TF, Madoff LC, Pollack MP, Sonricker AL, Keller M, et al. Global Capacity for emerging infectious disease detection. PNAS. 2010 December 14; 107(50): p. 21701-21706.

382. Brahmbhatt M, Jonas O. International Cooperative Responses to Pandemic Threats: A Critical Analysis. The Brown Journal of World Affairs. 2015; XXI(2): p. 163-178.

383. Assiri Aea. Epidemiological, demographic, and clinical characteristics of 47 cases of Middle East respiratory syndrome coronavirus disease from Saudi Arabia: a descriptive study. The Lancet. 2013;(13): p. 752-760.

384. Lim LP, Lee TH, Rowe EK. Middle East Respiratory Syndrome coronavirus (MERS CoV): Update 2013. Curr Infect Dis Resp. 2013;(15): p. 295-298.

385. WHO. Middle East respiratory syndrome coronavirus (MERS-CoV) - update. [Online].; 2013 [cited 2018 April 17. Available from: http:/www.who.int/csr/don/2013 06 26/en/.

386. Al-Tawfiq JA, Zumla A, Memish ZA. Travel implications of emerging coronaviruses: SARS and MERS-CoV. Travel Medicine and Infectious Disease. 2014;(12): p. 422-428.

387. Hon KL. Severe respiratory syndromes: travel history matters. Travel Medicine and Infectious Disease. 2013;(11): p. 285-287.

388. Zumla A, Alagaili AN, Cotten M, Azhar E. Infectious diseases epidemic threats and mass gatherings: refocusing global attention on the continuing spread of the Middle East Respiratory Syndrome coronavirus (MERS-CoV. BMC Medicine. 2016; 14(132): p. 1-4.

389. Du L, Han GZ. Deciphering MERS-CoV Evolution in Dromedary Camels. Trends in Microbiology. 2016 February; 24(2): p. 87-89.

390. Drexler JF, Corman VM, Drosten C. Ecology, evolution and classification of bat coronaviruses in the aftermath of SARS. Antiviral Research. 2014;(101): p. 45-56.

391. Fuk-Woo Chan J, Kar-Pui Lau S, Chiu-Yat Woo P. The emerging novel Middle East respiratory syndrome coronavirus: The "Knowns" and "unknowns". Journal of the Formosan Medical Association. 2013;(112): p. 372-381.

392. Haagmans B, et a. Middle East respiratory syndrome coronavirus in dromedary camesl: an outbreak investigation. The Lancet. 2014 February; 14: p. 140-145. 
393. De Groot RJ, al e. Middle East Respiratory Syndrome Coronavirus (MERS-CoV): Announcement of the Coronavirus Study Group. Journal of Virology. 2013 July; 87(14): p. 7790-7792.

394. Lu L, Liu Q, Du L, Jiang S. Middle East respiratory syndrome coronavirus (MERS-CoV): challenges in identifying its source and controlling its spread. Microbes and Infection. 2013;(15): p. 625-629.

395. The Lancet Infectious Diseases. Need for global cooperation in control of MERS-CoV. The Lancet. 2013 August; 13: p. 639.

396. Modjarrad K. MERS-CoV vaccine candidates in development: The current landscape. Vaccine. 2016 April;(34): p. 2982-2987.

397. Modjarrad K, Moorthy V, Embarek PB, Van Kerkhove M, Kim J, Kieny MP. A roadmap for MERS-CoV research and product development: report from a World Health Organization consultation. Nature Medicie. 2016 July; 22(7): p. 701-705.

398. World Health Organization. Annual review of diseases prioritized under the Research and Development Blueprint. Meeting Report. Geneva: WHO Research and Development Blueprint ; 2018.

399. World Health Organization. WHO Consultation on MERS CoV Clinical Trial Design. Report. Geneva: Blue Print, Health Emergencies Programme; 2018.

400. Branswell H. Learning from Ebola: Why the world needs to take MERS more seriously. STAT. December 2015.

401. Memish Z. A career in a Kingdom: Journeys in infection, Mass Gathering Medicine and public health diplomacy". Human Vaccines \& Immunotherapeutics. 2017 September; 13(3): p. 494-498.

402. The WHO MERS-CoV Research Group. State of knowledge and Data Gaps of Middle East Respiratory Syndrome Coronavirus (MERS-CoV) in Humans. PLOS Current Outbreaks. 2013 November.

403. Al-Tawfiq JA. Middle East Respiratory Syndrome-Coronavirus Infection: An overview. Journal of Infection and Public Health. 2013;: p. 319-322. 
404. WHO. Novel coronavirus infection in the United Kingdom. [Online].; 2012 [cited 2018 April 17. Available from: http://www.who.int/csr/don/2012 09 23/en/.

405. WHO. Novel coronavirus infection - update. [Online].; 2012 [cited 2018 April 17. Available from: http://www.who.int/csr/don/2012_11_30/en/.

406. Rabaan AA, Al-Ahmed SH, Bazzi AM, Al-Tawfiq JA. Dynamics of scientific publications on the MERS-CoV outbreaks in Saudi Arabia. Journal of Infection and Public Health. 2017;(10): p. 702-710.

407. World Health Organization. Middle East respiratory syndrome coronavirus (MERS-CoV) WHO MERS-CoV Global Summary and Assessment of Risk. Geneva: World Health Organization; July 2017. Report No.: WHO/MERS/RA.

408. Subramaniam TSS, Thayan R, Yusof MA, Suppiah J, Rashid TRTA, Zawawi ZM, et al. Sharing experiences from a reference laboratory in the public health response for Ebola viral disease, MERS-CoV and H7N9 influenza virus investigations. Asian Pacific Journal of Tropical Medicine. 2016 January; 9(2): p. 201-203.

409. Sample I. Coronavirus: is this the next pandemic? The Guardian. 2013 March, 15.

410. Garrett L. Why a Saudi Virus Is Spreading Alarm. Council onn Foreign Relations - Global Health Program. 2013 May.

411. WHO. Novel coronavirus infection - update. [Online].; 2012 [cited 2018 April 17. Available from: http://www.who.int/csr/don/2012_09_25/en/.

412. Moh Z, al e. Isolation of a novel coronavirus from a man with pneumonia in Saudi Arabia.. New England Journal of Medicine. 2012 November; 367(19): p. 1814-1820.

413. WHO. [Online]; 2013 [cited 2018 April 17. Available from: http://www.who.int/csr/don/2013 $02 \quad 11 \mathrm{~b} / \mathrm{en} /$.

414. Pavli A, Tsiodras S, Maltezou HC. Middle East Respiratory Syndrome Coronavirus (MERS-CoV): Prevention in travelers. Travel Medicine and Infectious Diseases. 2014;(12): p. 602-608.

415. World Health Organization. MERS CoV Summary of Current Situation, Literature Update and Risk Assessment. Geneva: WHO; 2015, July. Report No.: WHO/MERS/RA/15.1. 
416. Bennet N. Alarm bells over MERS coronavirus.. The Lancet Infectious Diseases. 2013;(13): p. 573-574.

417. Zumla A, Hui DS. Infection control and MERS-CoV in health-care workers. The Lancet. 2014 May 31; 383: p. 1869-1871.

418. Cauchemez S, Fraser C, Kerkhove MDV, Donnelly CA, Riley S, Rambaut A, et al. Middle East respiratory syndrome coronavirus:quantifi cation of the extent of the epidemic, surveillance biases, and transmissibility. The Lancet Infectious Diseases. 2014 January; 14: p. 50-56.

419. Sharif-Yakan A, Kanj S. Emergence of MERS-CoV in the Middle East: Origins, Transmission, Treatment, and Perspectives. PLoS Pathog. 2014; 10(12): p. e1004457.

420. Oboho IK, Tomczyk SM, Al-Asmari AM, Banjar AA, Al-Mugti H, Aloraini MS, et al. 2014 MERS-CoV Outbreak in Jeddah - A Link to Health Care Facilities. The New England Journal of Medicine. 2015 February; 372(9): p. 846-854.

421. Cauchemeza S, Nouvelletd P, Corid A, Jombartd T, Garsked T, Claphame H, et al. Unraveling the drivers of MERS-CoV transmission. PNAS. 2016 August; 113(32): p. 9081 9086.

422. Chowell G, Blumberg S, Simonsen L, Miller MA, Viboud C. Synthesizing data and models for the spread of MERS-CoV, 2013: Key role of index cases and hospital transmission. Epidemics. 2014;: p. 40-51.

423. Breban R, Riou J, Fontanet A. Inter-human transmissibility of Middle East Respiratory Syndrome coronavirus: Estimation of pandemic risk.. The Lancet. 2013;(382): p. 694-699.

424. World Health Organization. Middle East respiratory syndrome coronavirus (MERS-CoV). [Online].; 2019 [cited 2019 March 28. Available from: https://www.who.int/emergencies/mers-cov/en/.

425. World Health Organization Multicentre Collaborative Network for Severe Acute Respiratory Syndrome (SARS) Diagnosis. A multicentre collaboration to investigate the cause of severe acute respiratory syndrome. The Lancet. 2003; 361(1): p. 1730-1733.

426. World Health Organization. WHO collaborative multi-centre research project on Severe Acute Respiratory Syndrome (SARS) diagnosis. [Online].; 2019 [cited 2019 March 28. Available from: https://www.who.int/csr/sars/project/en/. 
427. Perl T, Savor Price C. Orchestrated Scientific Collaboration: Critical to the Control of MERS-CoV. Annals of Internal Medicine. 2015 August; 163(4): p. 313-314.

428. Eifan SA, Nour I, Hanif A, Zamzam AMM, AlJohani SM. A pandemic risk assessment of middle east respiratory syndrome coronavirus (MERS-CoV) in Saudi Arabia. Saudi Journal of Biological Sciences. 2017 November; 24(7): p. 1631-1638.

429. Muller MA. MERS-CoV. BMC Infectious Diseases. 2014; 14(22): p. S22.

430. Zumla, Alimuddin, Abdulaziz N. Alagaili, Matthew Cotten, and Esam I. Azhar. Infectious diseases epidemic threats and mass gatherings: refocusing global attention on the continuing spread of the Middle East Respiratory syndrome coronavirus (MERS-CoV). BMC Medicine. 2016; 14(1).

431. Coburn B, Blower S. Predicting the potential for within-flight transmission and global dissemination of MERS. The Lancet. 2014 February; 14: p. 99.

432. Memish ZA, Cotten M, Meyer B, Watson SJ, Alsahafi AJ, Al Rabeeah AA, et al. Human Infection with MERS coronavirus after exposure to infected camels, Saudi Arabia, 2013. Emerging Infectious Diseases. 2014 June; 20(6): p. 1012-1015.

433. Alqahtani A, Rashid H, Basyouni MH, Alhawassi TM, BinDhim N. Public response to MERS CoV in the Middle East: iPhone survey in six countries. Journal of Infection and Public Health. 2017;(10): p. 534-540.

434. Ferguson NM, Van Kerkhove MD. Identification of MERS-CoV in dromedary camels. The Lancet Infectious Diseases. 2014 February; 14(2): p. 93-94.

435. Tang, X., Agnihothram, S.S., Jiao, Y., Stanhope, J., Graham, R.L., Peterson, E.C., Avnir, Y., Aimee St. Clair Tallarico, Sheehan, J., Zhu, Q., Baric, R.S. \& Marasco, W.A. Identification of human neutralizing antibodies against MERS-CoV and their role in virus adaptive evolution". Proceedings of the National Academy of Sciences. 2014 May; 11(19): p. E2018-E2026.

436. Liljander, A; Meyer, B; Jores, J; Müller, MA; Lattwein, E; Njeru, I; et al. MERS-CoV Antibodies in Humans, Africa, 2013-2014. Emerg Infect Dis. 2016; 22(6): p. 1086-1089.

437. WHO Regional Office for the Eastern Mediterranean. Consultative meeting to determine the public health research agenda on MERS-CoV. Meeting Report. Riyadh, Saudi Arabia: World Health Organization; 2015. Report No.: WHO-EM/CSR/093/E. 
438. Al Johani S, Hajeer AH. MERS-CoV diagnosis: An update. Journal of Infection and Public Health. 2016;(9): p. 216-219.

439. Food and Agriculture Organization. Muscat Declaration. Middle East Respiratory Syndrome Coronavirus (MERS-CoV) in Animal Species.. Muscat, Oman:; 2014.

440. McCloskey B, Dar O, Zumla A, Heymann DL. Emerging infectious diseases and pandemic potential: status quo and reducing risk of global spread. The Lancet. 2014 October; 14: p. 1001-1010.

441. Williams HA, Dunville R, Gerber S, Erdman D, Pesik N, Kuhar D, et al. CDC's Early Response to a Novel Viral Disease, Midle East Respiratory Syndrome Coronavirus (MERSCoV), September 2012-May 2014. Public Health Reports. 2015 July-August; 130: p. 307317.

442. Regional Office for the Eastern Mediterranean, World Health Organization. Report on the Intercountry meeting on the Middle East Respiratory Syndrome Coronavirus (MERSCoV) outbreak in the Eastern Mediterranean Region. Cairo: WHO; 2013. Report No.: WHO$\mathrm{EM} / \mathrm{CSR} / 063 / \mathrm{E}$.

443. Regional Office for the Eastern Mediterranean, World Health Organization. Summary report on the International scientific meeting on Middle East respiratory syndrome coronavirus (MERS-CoV). Cairo: WHO; 2015. Report No.: WHO-EM/CSR/100/E.

444. Regional Office for the Eastern Mediterranean/ World Health Organization. Consultative meeting to determine public health research agenda on MERS CoV. Summary Report. Cairo: WHO/EMRO; 2013. Report No.: WHO-EM/CSR/068/E.

445. Abu Baker Farag, E; Nour, M; El Idrissi, A; Berrada, J; Moustafa, A; Mehmood, M; et al. Survey on implementation of One Health approach for MERS-CoV preparedness and control in Gulf Cooperation Council and Middle East countries. Emerging Infectious Diseases. 2019 March; 25(3).

446. Cotten M, Watson SJ, Kellam P, Al-Rabeeah AA, Makhdoom HQ, Assiri A, et al. Transmission and evolution of the Middle East respiratory syndrome coronavirus in Saudi Arabia: a descriptive genomic study. The Lancet. 2013 September; 383(9909): p. 19932002.

447. Das P2"LTv3n9pee. Ziad Memish: father of mass gatherings medicine. The Lancet. 2014 June; 383(9934). 
448. Memish ZA. Call to Action for improved case definition and contact tracing for MERSCoV. Journal of travel medicine. 2019.

449. Memish ZA, Zumla A, Alhakeem RF, Assiri A, Turkestani A, Al Harby KD, et al. Hajj: infectious disease surveillance and control. The Lancet. 2014 May; 838(9934): p. 2073 2082.

450. Al-Tawfiq JA, Memish ZA. Lack of seasonal variation of Middle East Respiratory Syndrome Coronavirus (MERS-CoV). Travel Medicine and Infectious Disease. 2019 January-February; 27: p. 125-126.

451. Regional Office for the Eastern Mediterranean/World Health Organization. EMRO-MERS CoV. [Online].; 2018 [cited 2018 June 20. Available from: http://www.emro.who.int/pandemic-epidemic-diseases/news/pool-of-mers-experts-fordeployment-established-by-whos-eastern-mediterranean-regional-office.html.

452. The Lancet. Political commitment to MERS-CoV in Saudi Arabi. The Lancet. 2014 May; 383: p. 1522.

453. WHO. Novel coronavirus infection - update. [Online].; 2012 [cited 2018 April 17. Available from: http://www.who.int/csr/don/2012 09 28/en/.

454. Kupferschmidt K. MERS Situation More Serious but Not an Emergency Yet, WHO Panel Says. Science. 2014 May, 14.

455. World Health Organization. Middle East respiratory syndrome coronavirus (MERS-CoV), Statement by the WHO Director General. [Online].; 2013 [cited 216 April 26. Available from: https://www.who.int/ihr/procedures/statements_20130709/en/.

456. World Health Organization. WHO 2015 Emergency Committee on MERS, September 3rd, 2015. [Online].; 2015. Available from: http://www.who.int/mediacentre/news/statements/2015/ihr-emergency-committee-mers/en/.

457. Excler J, Delvecchio C, Wiley R, Williams M, Yoon I, Modjarrad K, et al. Toward Developing a Preventive MERS-CoV Vaccine-Report from a Workshop Organized by the Saudi Arabia Ministry of Health and International Vaccine Institute, Riyadh, Saudi Arabia, November 14-15, 2015. Emerging Infectious Diseases. 2016 August; 22(8): p. e1-e5.

458. Wang L, Shi W, Joyce MG, Modjarrad K, Zhang Y, Leung K, et al. Evaluation of candidate vaccine approaches for MERS-CoV. Nature communications. 2015 July; 6(1): p. 7712. 
459. Banik GR, Khandaker G, Rashid H. Middle East respiratory syndrome coronavirus "MERS-CoV": current knowledge gaps. Paediatric respiratory reviews. 2015 June; 16(3): p. 197-202.

460. World Health Organization. MERS CoV. WHO/MERS/RE 2017. Geneva:; 2017.

461. World Health Organization. WHO statement on the tenth meeting of the IHR Emergency Committee regarding MERS. [Online].; 2015 [cited 2017 May 25. Available from: https://www.who.int/mediacentre/news/statements/2015/ihr-emergency-committee$\underline{\text { mers/en/. }}$.

462. Memish ZA, Assiri A, Alhakeem R, Yezli S, Almasri M, Zumla A. Middle East Respiratory Syndrome Corona virus, MERS-CoV. Conclusions. International Journal of Infectious Diseases. 2014; 2014(24): p. 51-53.

463. Nour M, Alhajri M, Farag EABA, Al-Romaihi HE, Al-Thani M, Al-Marri S, et al. How Do the First Days Count? A Case Study of Qatar Experience in Emergency Risk Communication during the MERS-CoV Outbrea. International journal of environmental research and public health, vol. 14, no. 12. 2017 November; 14(12): p. 1-16.

464. Bialek, SR; Allen D; Alvarado-Ramy F; Arthur R, Balajee A; Bell D; Best S; Blackmore C; Breakwell L; Cannons A; Brown C; Cetron M; Chea N; Chommanard C; Cohen N; Conover C; Crespo A; Creviston J; Curns AT; Dahl R; Dearth S; DeMaria A; Echols F; Erdman DD. First confirmed cases of Middle East respiratory syndrome coronavirus (MERS-CoV) infection in the United States, updated information on the epidemiology of MERS-CoV infection, and guidance for the public, clinicians, and public health authorities May 2014. MMWR Morb Mortal Wkly. 2014 May; 63(19): p. 431-436.

465. Public Health Agency of Canada. Infection Prevention and Control Guidance for Middle East Respiratory Syndrome Coronavirus (MERS-CoV) in Acute Care Settings. Ottawa: Government of Canada, PHAC; 2016.

466. World Health Organization. WHO Background and summary of novel coronavirus infection - as of 21 December 2012. [Online].; 2012 [cited 2017 May 21. Available from: http://www.who.int/csr/disease/coronavirus_infections/update_20121221/en/.

467. World Health Organization. WHO Fact Sheet MERS-CoV May 2017. [Online].; 2017 [cited 2017 June 30. Available from: http://www.who.int/mediacentre/factsheets/merscov/en/. 
468. World Health Organization. WHO Frequent asked questions on MERS. [Online].; 2014 [cited 2017 July 28. Available from:

http://www.who.int/csr/disease/coronavirus_infections/faq/en/.

469. Heymann

DL,CL,TK,FDP,TJW,TMJ,KTA,FTR,YD,NS,KA,OPL,HP,TE,GLO,NSM,CD,RS,L. Global health security: the wider lessons from the west African Ebola virus disease epidemic. The Lancet. 2015; 385(9980): p. 1884-1901.

470. Hood A. Ebola : a threat to the parameters of a threat to the peace? Melbourne Journal of International Law. 2015; 16(1): p. 29-55.

471. Annas GJ. Ebola and Human Rights: Post-9/11 Public Health and Safety in Epidemics. American Journal of Law \& Medicine. 2016; 42(2-3): p. 333-355.

472. Kinsman J. "A time of fear": local, national and international responses to a large Ebola outbreak in Uganda. Globalization and Health. 2012; 8(12): p. 1-12.

473. Coltart C, B L, Ghinai I, Johnson A, Heymann D. The Ebola outbreak, 2013-2016: old lessons for new epidemics. Philosophical Transactions B. 2017 January; 372.

474. Pigott DM, Golding N, Mylne A, Huang Z, Henry A, Weiss D, et al. Mapping the zoonotic niche of Ebola virus disease in Africa. eLife. 2014; 1(1): p. 1-29.

475. Kalra S, Kelkar D, Galwankar SC, J. PT, Stawicki SP, Arguilla B, et al. The Emergence of Ebola as a Global Health Security Threat: From Lessons Learned to Coordinated Multilateral Containment Efforts. Journal of Global Infectious Diseases. 2014; 6(4): p. 164177.

476. Breman JG, Heymann DL, Lloyd G, McCormick JB, Miatudila M, Murphy F, et al. Discovery and Description od Ebola Zaire Virus in 1976 and Relevance to the West African Epidemic During 2013-2016. The Journal of Infectious Diseases. 2016; 2016(214): p. S93S101.

477. Centers for Disease Control and Prevention. About Ebola virus disease. [Online].; 2016 [cited 2017 November 28. Available from: https://www.cdc.gov/vhf/ebola/about.html.

478. International Commission. Ebola haemorrhagic fever in Zaire 1976. Bulletin of the World Health Organization. 1978; 56(2): p. 271-293. 
479. World Health Organization. Ebola virus disease. [Online].; 2017 [cited 20171128. Available from: http:/www.who.int/mediacentre/factsheets/fs103/en/.

480. Lamunu M, Lutwama JJ, J. K, A. O, Nambooze J, Ndayimirije N, et al. Containing Hemorrhagic Fever Epidemic, The Ebola Experience in Uganda (October 2000-January 2001). In ; 2002; Singapore: International Congress on Infectious Diseases. p. 3.

481. Centers for Disease Control and Prevention. Filoviridae. [Online].; 2014 [cited 20171128. Available from: https://www.cdc.gov/vhf/virus-families/filoviridae.html.

482. De la Vega MA, Stein D, Kobinger GP. Ebolavirus Evolution: Past and Present. Pathogens. 2015; 11(11): p. 1-10.

483. Ebola Response Team W. After Ebola in West Africa-Unpredictable Risks, Preventable Epidemics. The New England Journal of Medicine. 2016 August 11; 375(6): p. 587-596.

484. J. Legrand RFGPYBAJVaAF. Understanding the Dynamics of Ebola Epidemics. Epidemiology and Infection. 2007 Mayo; 135(4): p. 610-621.

485. Quarcoo D, Bruggmann D, al. e. Ebola and Its Global Researcg Architecture-Need for an Improvement. PLOS Neglected Tropical Diseases. 2015 September;: p. 1-10.

486. The Lancet Infectious Diseases. Rationality and coordination for Ebola outbreak in west Africa. The Lancet. 2014 December; 14.

487. Ebola Response Team W. Ebola Virus DIsease in West Africa - The first 9 Months of the Epidemic and Forwad Projections. The New England Journal of Medicine. 2014; 371(16): p. 1481-1495.

488. Bres P. Ebola Haemorragic Fever: A Public Health Problem. In ; 1977; Antwerp: Elsevier.

489. Houssin D. La cooperation sanitaire internationale abolie par Ebola? Politique etrangere. 2014 Hiver;(4): p. 85-95.

490. Keita M, Duraffour Sea. Unusual Ebola Virus Chain of Transmission, Conakry, Guinea, 2014-2015. Emerging Infectious Diseases. 2016; 22(12): p. 2149-2152.

491. Gostin L. Ebola: Towards a Health Systems Fund. The Lancet. 2014 October; 384: p. e49e51.

492. Farmer P. The Caregivers' Disease. London Review of Books. 2015 May 21: p. 25-28. 
493. House T. Epidemiological dynamics of Ebola outbreaks. eLife. 2014; 1(1): p. 1-8.

494. Baden LR, R. K, E.W. C, Morrissey S, Rubin EJ, Drazen JM. Ebola- an ongoing crisis. The New England Journal of Medicine. 2014; 371(15): p. 1458-1459.

495. Prevention CfDCa. 2014 Ebola Outbreak in West Africa Epidemic Curves. [Online].; 20142019 [cited 2019 January. Available from: https://www.cdc.gov/vhf/ebola/history/20142016-outbreak/cumulative-cases-graphs.html.

496. World Health Organization W. Emergency preparedness and reponse, Ebola disease en Guinea. [Online].; 2014 [cited 2018 February 27. Available from: http://www.who.int/csr/don/2014_03_23 ebola/en/.

497. Phillips M, Markham A. Ebola: a failure of international collective action. The Lancet. 2014; 384(1): p. 1181.

498. Lancet T. Ebola: a failure of international collective action. The Lancet. 2014; 384(1): p. 387.

499. World Health Organization-Panel of Independet Experts. Report of the Ebola Interim Assessment Panel. Geneva:, Emergency preparedness and response; July 2015.

500. World Health Organization. Ground zero in Guinea: the Ebola outbreak smoulders undetected - for more than 3 months. [Online].; 2014 [cited 2019 May 30. Available from: https://www.who.int/csr/disease/ebola/ebola-6-months/guinea/en/.

501. Dionne KY, Seay L. Perceptions about Ebola in America: Othering and the role of knowledge about Africa. PS. 2015 January.

502. Weiss ML. Mobilizing around another plague. PS. 2015 January.

503. Casey LS. Emotions and the politics of Ebola. PS. 2015 January.

504. Bogoch I, Creatore M, Brownstein J, Pesik N, Miniota J, Tam T, et al. Assessment of the potential for international dissemination of Ebola virus via commercial air travel during the 2014 west African outbreak. The Lancet. 2015 January; 385: p. 29-35.

505. Albertson B, Gadarian S. Ebola, anxiety, and public support for protective policies. PS. 2015 January.

506. Sherrill K, Somerville CM. AIDS, Ebola, and Politics. PS. 2015 January. 
507. Benton A, Dionne KY. International Political Economy and the 2014 West African Ebola Outbreak. African Studies Review. 2015 April; 58(1).

508. Youde J. The World Health Organization and Responses to Global Health Emergencies. PS. 2015 January.

509. Busby J, Grepin KA. What accounts for the World Health Organization's failure on Ebola? PS. 2015 January.

510. Fink S. Cuts at WHO Hurt Response to Ebola Crisis. New York Times. 2014 September.

511. Fidler DP. Epic Failure of Ebola and Global Health Security. The Brown Journal of World Affairs. 2015 Spring/Summer; XXI(II): p. 180-198.

512. Kucharski AJ, Edmunds JW. Case fatality rate for Ebola virus disease in west Africa. The Lancet. 2014; 384(1): p. 1260.

513. WHO Ebola Response Team. Ebola Virus Disease in West Africa-The First 9 Months of the Epidemic and Forward Projections. The New England Journal of Medicine. 2014 October; 371(16): p. 1481-1495.

514. Doucleff M. No, Seriously, How Contagious is Ebola? NPR. 2014 October: p. 02.

515. Chowell G, Nishiura H. Transmission dynamics and control of Ebola virus disease: A review. BMC Medicine. 2014; 12(196): p. 1-12.

516. WHO Ebola Response Team. After Ebola in West Africa-Unpredictable Risks, Preventable Epidemics. The New England Journal of Medicine. 2016 August; 375(6): p. 587-596.

517. Committe on Foreign Affairs HoRU. Hearing on Africa, Global Health, Global Human Rights, and International Organizations. Washington D.C; 2014.

518. Kaner J, Schaack S. Understanding Ebola: the 2014 epidemic. Globalization and Health. 2016; 12(53).

519. World Health Organizartion. One year into the Ebola Epidemic: A Deadly, Tenacious and Unforgiving Virus. Geneva: World Health Organization; 2015.

520. Gostin L, Friedman E. A retrospective and prospective analysis of the west African Ebola virus disease epidemic: robust national health systems at the foundation and an empowered WHO at the apex. The Lancet. 2015; 385(1): p. 1902-1909. 
521. World Health Organization. WHO Strategic Response Plan. West Africa Ebola Outbreak. Geneva: World Health Organization; 2015.

522. Organization WH. Outbreaks of Ebola haemorrhagic fever, Congo and Gabon, October 2001-July 2002. Weekly epidemiological record. Geneva: World Health Organization; 2003. Report No.: 26.

523. CDC. Outbreaks Chronology: Ebola Virus Disease. [Online].; 2017 [cited 2018 October 25. Available from: www.cdc.gov/mmwr/ebola_reports.html.

524. Smith GC. Introductory Remarks. In International Colloquium on Ebola Virus Infection and Other Haemorrhagic Fevers; 1977; Antwerp. p. 13-14.

525. Cruz-Calderon Sea. Correspondence. Travel Medicine and Infectious Disease. 2015; 1(13): p. 202-204.

526. Kuhn JH. Filoviruses. 1st ed. New York: Springer Wien; 2008.

527. World Health Organization. Ebola Strategy. Geneva: WHO; 2014. Report No.: WHO/HSE/PED/CED/2014.05.

528. World Health Organization/ Centers for Disease Control and Prevention. Technical Guidelines for Integrated Disease Surveillance and Response in the African Region. Brazzaville and Atlanta: WHO/CDC; 2010.

529. Salaam-Blytherd T. U.S. and International Health Responses to the Ebola Outbreak in West Africa. US Congress, Congressional Research Service; 2014.

530. Piot P. Ebola in west Africa: from disease outbreak to humanitarian crisis. The Lancet. 2014 November; 14: p. 1034-1035.

531. Jacobsen K, Aguirre A, Bailey C, Baranova A, Crooks A, Croitoru A, et al. Lessons from the Ebola Outbreak: Action Items for Emerging Infectious Disease Preparedness and Response. EcoHealth. 2016 February;(13): p. 200-212.

532. World Health Organization. Ebola and Marburg virus disease epidemics: preparedness, alert, control, and evaluation. Ebola Strategy. Geneva: WHO; 2014. Report No.: $\mathrm{WHO} / \mathrm{HSE} / \mathrm{PED} / \mathrm{CED} / 2014.05$.

533. Kim K, Andrew SA, Jung K. Public Health Networl Structure and Collaboration Effectiveness during the 2015 MERS Outbreal in South Korea: An Institutional Collective 
Action Framework. International Journal of Environmental Research and Public Health. 2017 September; 14(1064): p. 1-15.

534. Organization WH. Emergencies preparedness, response. Members of the WHO Advisory Group on the Ebola Virus Disease Response. [Online].; 2015 [cited 201802 28. Available from: http://www.who.int/csr/disease/ebola/advisory-groups/members/en/.

535. Ross E. WHO hails 'swift and positive response' to Zika dta-sharing initiative. The Guardian. 2016 April.

536. Yozwiak NL, Schaffner SF, Sabeti PC. Data sharing: Make outbreak research open access. Nature. 2015 February.

537. Organization WH. WHO 2015 report on prioritization of pathogens. [Online].; 2015. Available from: http://www.who.int/medicines/ebola-treatment/WHO-list-of-top-emergingdiseases/en/.

538. The Lancet Infectious Diseases. Ebola PHEIC is over but the emergency continues. The Lancet. 2016 May; 16.

539. World Health Orgnization. Emerging and Dangerous Pathogens Laboratory Network. Geneva: World Health Organization, Pandemic and epidemic diseases; 2016.

540. World Health Organization. WHO Advisory Group on the Ebola Virus Disease Response: Terms of reference. [Online].; 2016 [cited 2017 May. Available from: http://www.who.int/csr/disease/ebola/advisory-groups/tor/en/)..

541. Agnandji ST, et a. Phase 1 Trials of rVSV Ebola Vaccine in Africa and Europe-Preliminary Report. The New England Journal of Medicine. 2015 April.

542. Ollman Saphire E, Dye J, Kobinger G, Zeitlin L, Chandran K, Garry R. How to turn competitors into collaborators. Nature. 2017 January;(541): p. 283-285.

543. World Health Organization. WHO Secretariat Response to the report of the Ebola Interim Assessment Panel. Geneva:, WHO Secretariat; August 2015.

544. Aylward B. At the forefront - getting to zero. June 2015. Change@WHO.

545. Gostin L. Ebola: A crisi in global health leadership. The Lancet. 2014 October; 384: p. 1523-1525. 
546. Gostin L(. Rules of the Road. 2016 February 1 ..

547. Butler Y. Ebola Virus: Exposing the Inadequacies of Public Health in Liberia. Mayo Clinic Proceedings. 2014; 89(12): p. 1596-1598.

548. Crone J. Inter view with Peter Piot. "It took 1,000 dead Africans before they did anything': Scientist who discovered Ebola virus slams WHO for taking FIVE months to declare state of emergency". The Daily Mail. 2014 October.

549. Moeti M. A better WHO. May 2015. Change@ WHO.

550. Organization WH. Statement on the 1st meeting of the IHR Emergency Committee on the 2014 Ebola outbreak in West Africa. [Online].; 2014 [cited 201802 27. Available from: http://www.who.int/mediacentre/news/statements/2014/ebola-20140808/en/.

551. Briand S, Bertherat E, Cox P, Formenty P, Kieny MP, Myhre J, et al. The International Ebola Emergency. The New England Journal of Medicine. 2014 September; 371(13): p. 1180-1183.

552. Piot P. Failure of leadership (Interview). 2016 february $1 .$.

553. Sridhar D. Failing Grade (Interview). 2016 February 1..

554. World Health Organization. The role of WHO within the United Nations Mission for Ebola Emergency Response. Geneva:; 2014.

555. Office of the United Nations Special Envoy on Ebola. Resources for Results V. Geneva: Office of the United Nations Special Envoy on Ebola; 2015.

556. World Bank. World Bank Group Ebola Response Fact Sheet. [Online].; 2016 [cited 2016 September 30. Available from: www.worldbank.org/es/topic/health/brief/world-bankgroup-ebola-fact-sheet.

557. Kamradth-Scott A, Harman S, Wenham C. Civil-military cooperation in Ebola and beyond. The Lancet. 2015 October; 387.

558. Piot P, Muyembe JJ, Edmunds WJ. Ebola in West Africa: from disease outbreak to humanitarian crisis. The Lancet. 2014 November; 14.

559. World Health Organization. WHO 2014 IHR and Ebola. Special Session of the Executive Board on the Ebola Emergency. Document EBSS/3/INF.4, January 9, 2015. ; 2015. 
560. Glynn, Boland. Ebola, Zika and the International Health Regulations - implications for Port Health Preparedness. Globalization and Health. 2016; 12(74): p. 1-5.

561. World Health Organization. Ebola WHO 2018 Key Facts. [Online];; 2018d. Available from: https://www.who.int/en/news-room/fact-sheets/detail/ebola-virus-disease.

562. Hawkes N. Ebola outbreak is a public health emergency of international concer, WHO warns. BMJ. 2014 August;(349): p. 1-2.

563. Manguvo A, Mafuvadze B. The impact of traditional and religious practices on the spread of Ebola in West Africa: time for a strategic shift. Pan African Medical Journal. 2015 October; 22(1).

564. International Bank for Reconstruction and Development / The World Bank. The Economic Impact of the 2014 Ebola Epidemic. Washington D.C,: The World Bank Group; 2014.

565. Standley CJ, Sorrell EM, Kornblet S, Vaunght A, Fisher JE, Katz R. Linking funds to actions for health emergencies. Science. 2015 May 15; 348(6236): p. 762-763.

566. World Health Organization. WHO Statement First Meeting Emergency Committee. [Online].; 2014 [cited 2015. Available from: http://www.who.int/mediacentre/news/statements/2014/ebola-20140808/en/.

567. World Health Organization. The Strategic Response Framework. Zika Virus. Geneva:; 2016. Report No.: WHO/ZIKV/SRF/16.3.

568. Etienne C, dos Santos T, Espinal MA. Keynote Address (November 2016): Zika Virus Disease in the Americas: A Storm in the Making. Am. J. Trop. Med. Hyg. 2017; 97(1): p. 16-18.

569. Frieden TR, Schuchat A, Petersen L. Zika Virus 6 Months Later. Journal of the American Medical Association. 2016 October; 316(14): p. 1443-1444.

570. Diseases TLI. Infetious disease emergencies: taking the long-term view. The Lancet Infectious Diseases. 2016 December; 16(1).

571. Kindhauser MK, Allen T, Frank V, Santhanaa RS, Dyea C. Zika: the origin and spread of a mosquito-borne virus. Bulletin World Health Organization. 2016;(94): p. 675-686C.

572. Samarasekera U, Triunfol M. Concern over Zika virus grips the world. The Lancet. 2016; 387: p. 521-524. 
573. World Health Oganization. Zika Virus Outbreak Global Response. Interim Report. Geneva:; 27 May 2016. Report No.: WHO/ZIKV/SRF/16.2.

574. Musso D, Nilles EJ, Cao-Lormeau VM. Rapid spread of emerging Zika virus in the Pacific area. Clinical Microbiology and Infection. 2014; 20(10): p. O595-O596.

575. Duong VP, Dussart PB. Zika virus in Asia. International Journal of Infectious Diseases. 2017; 54: p. 121-128.

576. Cauchemez, al e. Association between Zika virus and microcephaly in French Polynesia, 2013-15: a retrospective study. The Lancet. 2016; 387: p. 2125-2132.

577. Hafiz MY, Mahmood SU, Shoaib M, Yusuf FH. Concern over Zika virus outbreak: another alarming global threat. Infection and Drug Resistance. 2016;(9): p. 149-151.

578. Petersen LR, Jamieson DJ, Powers AM, Honein MA. Zika Virus. The New England Journal of Medicine. 2016 April; 374(16): p. 1552-1558.

579. Ozkurt Z, Tanriverdi EC. Global Alert: Zika Virus-an Emerging Arbovirus. The Eurasian Journal of Medicine. 2017;(49): p. 142-147.

580. Fauci A, Morens D. Zika Virus in the Americas - Yet Another Arbovirus Threat. The New England Journal of Medicine. 216; 374(7): p. 601-604.

581. World Health Organization. Strategic Response Plan Quarterly Update. July-September 2016. Geneva:; October 2016.

582. Pan-American Heath Organization/World Health Organization. Epidemiological Update. Zika Virus Infection. 16 October 2015.. Washington D.C.: PAHO, WHO; 2015.

583. Heukelbach J, Alencar CH, Kelvin A, Oliveira WKd, Cavalcanti. LPdG. Zika virus outbreak in Brazil. Journal of Infection in Developing Countries. 2016; 10(2): p. 116-120.

584. Avšič Županc T, Petrovec M. Zika: an old virus with a new face. Slovenian Journal of Public Health. Zdrav Var. 2016; 55(4): p. 228-230.

585. Campos G, Bandeira AC, Sardi SI. Zika Virus Outbreak, Bahia, Brazil. Emerging Infectious Diseases. 2015 October; 21(10).

586. Quicke, al e. Zika virus infects human placental macrophages. Cell Host \& Microbe. 2016;(20): p. 83-90. 
587. World Health Organization. WHO's response to Zika virus and its associated complications. Report to donors. Zika Response February to December 2016. Geneva: WHO; 2016.

588. Chang C, Ortiz K, Ansari A, M.E. G. The Zika outbreak of the 21 st century. Journal of Autoimmunity. 2016;(68): p. 1-13.

589. Ai JW, Zhang Y, Zhang W. Zika virus outbreak: 'a perfect storm'. Emerging Microbes and Infections. 2016; 5(e21).

590. World Health Organization. Zika virus infections in humans 1954-2007, confirmed by virus isolation. Table. Geneva: WHO; 2018.

591. Pan-American Health Organization/World Health Organization. Epidemiological Update 2015. Zika virus infection.. Geneva: PAHO/WHO; October 2016.

592. Dictionary M. Macular Rash. [Online].; 2019. Available from: https://medicaldictionary.thefreedictionary.com/macular+rash.

593. Heymann D, Hodgson A, Sall AA, Freedman DO, Staples JE, Althabe F, et al. Zika virus and microcephaly: why is this situation a PHEIC? The Lancet. 2016; 387: p. 719-720.

594. World Health Organization. Zika Strategic Response Plan. July 2016-Dec 2017. Geneva:; 2016. Report No.: WHO/ZIKV/SRF/16.3.

595. Dowd KA, Ko SY, Morabito KM, Yang ES, Pelc RS, DeMaso CR, et al. Rapid Debelopment of a DNA vaccine for Zika virus. Science. 2016 September; 354(6309): p. 237-240.

596. Organization WH. WHO Zika Virus Outbreak Global Response. Interim report May 2016. Geneva: WHO; 2016. Report No.: WHO/ZIKV/SRF/16.2.

597. Lucey RD, Gostin LO. The Emerging Zika Pandemic Enhancing Preparedness. Journal of the American Medical Association. 2016 March; 315(9): p. 865-866.

598. International Monetary Fund. World Economic Outlook Database. [Online].; 2015 [cited 2019 May. Available from: https://www.imf.org/external/pubs/ft/weo/2015/01/weodata/weorept.aspx?pr.x=43\&pr.y=1 $2 \&$ sy $=2013 \&$ ey $=2014 \&$ scsm $=1 \&$ ssd $=1 \&$ sort $=$ country $\& d s=. \& b r=1 \& c=512 \% 2 \mathrm{C} 668 \% 2 \mathrm{C} 91$ 
4\%2C672\%2C612\%2C946\%2C614\%2C137\%2C $311 \% 2 \mathrm{C} 962 \% 2 \mathrm{C} 213 \% 2 \mathrm{C} 674 \% 2 \mathrm{C} 911 \% 2$ C676\%2C193\%2C548\%2C122\%2C $556 \% 2 \mathrm{C} 912 \% 2 \mathrm{C} 6$.

599. Kapiriri L, Ross A. The Politics of Disease Epidemics: a Comparative Analysis of the SARS, Zika, and Ebola Outbreaks. Global Social Welfare. 2018 September.

600. Petersen E, E.Wilson M, Touch S, McCloskey B, Mwaba P, Bates M, et al. Rapid Spread of Zika Virus in The Americas. Implications for Public Health Preparedness for Mass Gatherings at the 2016 Brazil Olympic Games. International Journal of Infectious Diseases. 2016 March;(44): p. 11-15.

601. Attaran A. Off the podium: why public health concerns for global spread of Zika virus means that Rio de Janeiro's 2016 Olympic Games must not proceed. Harvard Public Health Rev. 2016; 10.

602. Codeço C, Villela D, Gomes MF, Bastos L, Cruz O, Struchiner C, et al. Zika is not a reason for missing the Olympic Games in Rio de Janeiro: response to the open letter of Dr Attaran and colleagues to Dr Margaret Chan, Director - General, WHO, on the Zika threat to the Olympic and Paralympic Games. Mem Inst Oswaldo Cruz. 2016 June; 111(6): p. 414-415.

603. Lewnard JA, Gonsalves G, Ko AI. Low Risk of International Zika Virus Spread due to the 2016 Olympics in Brazil. Annals of Internal Medicine. 2016 July; 165(4): p. 286-287.

604. Hayden Ch. E. Spectrum of Ebola Haunts Zika Response. Nature. 2016 March; 531: p. 19.

605. World Health Organization. WHO position statement on integrated vector management. Weekly Epidemiological Record. 2008a; 1(20): p. 177-181.

606. RBM Partnership to End Malaria. Vector Control. [Online].; 2019 [cited 2019 March 15. Available from: https://endmalaria.org/our-work-working-groups/vector-control.

607. World Health Organization. Vector Control. Vector Control Advisory Group. [Online].; 2019 [cited 2018 March 25. Available from: http://www.who.int/neglected_diseases/vector_ecology/VCAG/en/.

608. Kleber de Oliveira W, França GVAd, Carmo EH, Duncan BB, Kuchenbecker RdS, Schmidt aMI. Infection-related microcephaly after the 2015 and 2016 Zika virus outbreaks in Brazil: a surveillance-based analysis. The Lancet. 2017;(390): p. 871-870. 
609. Zanluca CV, Campos Andrade de Melo AL, Pamplona Mosimann GI, Viana dos Santos C, Nunes Duarte dos Santos KL. First report of autochthonous transmission of Zika virus in Brazil. Vol. 110(4), 569. Rio de Janeiro: Mem Inst Oswaldo Cruz; June, 2015.

610. Brasil P, Pereira JP, Moreira ME, R.M , Nogueira R, Damasceno L, et al. Zika Virus Infection in Pregnant Women in Rio de Janeiro. The New England Journal of Medicine. 2016 December; 375(24): p. 2321-2334.

611. Gomez EJ, Aguilar Perez F, Ventura D. What explains the lacklustre respose to Zika in Brazil? Exploring the institutional, economic and health system context. BMJ Global Health. 2018 August; 3(e000862): p. 1-6.

612. Garcia E, Yactayo S, Nishino K, Millot V. Zika virus infection: global update on epidemiology and potentially associated clinical manifestations. Weekly Epidemiological Record. 2016 February; 91(7): p. 73-88.

613. Monteiro M, Shelley-Egan C, Dratwa J. On irresponsibility in times of crisis: learning from the response to Zika virus outbreak. Journal of Responsible Innovation. 2017; 4(1): p. 71 77.

614. Kraunerm F, Riesen M, Reveiz L, Oladapo OT, Martinez-Vega R, Porgo TV, et al. Zika Virus Infection as a Cause of Congenital Brain Abnormalities and Guillain-Barre Syndrome: Systematic Review. PLOS Medicine. 2017 January; 14(1): p. 1-27.

615. Messina J, al e. Mapping global environmental suitability for Zika virus. eLife. 2016; e15272.

616. Pan American Health Organization/ World Health Organization. Number of Reported Cases of Dengue and Severe Dengue (SD) in the Americas, by Country-March 20, 2015 (EW 53). Washington D.C: PAHO/WHO; 2014.

617. Pan American Health Organization/ World Health Organization. Number of Reported Cases of Dengue and Severe Dengue (SD) in the Americas, by Country-January 15, 2016 (EW 52). Washington D.C.: Regional Office for the Americas.; 2016.

618. Pan-American Health Organization/ World Health Organization. Zika Epidemiological Update. Washington, D.C.: PAHO/WHO; August 2017. 
619. World Health Organization. Zika Situation Report. [Online].; 2016 [cited 20180228. Available from: http://apps.who.int/iris/bitstream/10665/204348/1/zikasitrep_5Feb2016_eng.pdf?ua=1.

620. Martinez-Palomo A. Zika Virus: An international emergency? Journal of Public Health Policy. 2016;(37): p. 133-135.

621. World Health Organization. A globla brief on vector-borne diseases. Geneva: WHO, DCO; 2014. Report No.: WHO/DCO/WHD/2014.1.

622. Hough P. The Global Politics of Pesticides. Forging consensus from conflicting interests. 3rd ed. New Yorl: Earthscan from Routledge; 2013.

623. Wiwanitkit V. Concurrent malaria and dengue infection: a brief summary and comment. Asian Pacific journal of tropical biomedicine. 2011; 1(4): p. 326-327.

624. World Health Organization. World Malaria Report 2017. Geneva:, Global Malaria Program; 2017.

625. World Health Organization. Global Strategic Framework for Integrated Vector Management.. Geneva: WHO; 2004.

626. World Health Organization. WHO position statement on integrated vector management. Geneva: WHO; 2008.

627. World Health Organization. A70/26 Rev.1 Add.1 Global Vector Control Response. In WHA 70 Seventieth World Health Assembly; 2017; Geneva. p. 1-3.

628. Rasmussen SA, al e. Zika Virus and Birth Defects - Reviewing the Evidence for Causality. The New England Journal of Medicine. 2016; 374(20): p. 1981-1987.

629. Mlakar J, Korva M, Tul N, Popović M, Poljšak-Prijatelj MJ, Kolenc M, et al. Zika Virus Associated with Microcephaly. The New England Journal of Medicine. 2016 March; 374(10): p. 951-958.

630. Chua A PINCWDMF. Update on Zika Diagnostic Tests and WHO's related activities. PLoS Neglected Tropical Diseases. 2017; 11(2): p. e0005269.

631. The Lancet Infectious DIseases. Zika virus at the games: is it safe? The Lancet Infectious Disesaes. 2016 June; 16: p. 619. 
632. Attaran A. Zika virus and the 2016 Olympic Games. The Lancet Infectious Diseases. 2016 September; 16: p. 1001-1002.

633. McConnell J, de Ambrogi M, Cleghorn S, Sekkedis O. Editor's Reply. The Lancet Infectious Diseases. 2016 September; 16: p. 1003.

634. World Health Organization. Report of the WHO Ad-hoc Advisory Group on aircraft disinsection for controlling the international spread of vector-borne diseases.. Geneva: WHO; 2016. Report No.: WHO/HSE/GCR/2016.12.

635. World Health Organization. Global Consultation of research related to Zika virus infection.. Geneva: WHO; 2016.

636. World Health Organization. Zika Virus Research Agenda. document. Geneva: WHO; October, 2016. Report No.: WHO/ZIKV/PHR/16.1.

637. McNeil DG. How the Response to Zika Failed Millions. The New York Times. 2017 January.

638. Cheng M, Sattar R, Goodman J. CBC. [Online].; February.

639. Pan-American Health Organization. Number of Experts Deployed to Countries. Map. Washington DC: PAHO/WHO; December 2016.

640. J. HC, Kieny MP, Murgue B. The Zika Challenge. The New England Journal of Medicine. 2016; 374(19): p. 1801-1803.

641. Vannice KS, Giersing BK, Kaslow DC, Griffiths E, Meyer H, Barrett A, et al. Meeting Report: WHO consultation on considerations for regulatory expectations of Zika virus vaccines for use during an emergency. Vaccines. 2016 February.

642. Interview Maria Van Kerkhove, head of the outbreak investigation task force at the Centre for Global Health at Institute Pasteur. [Online]. Available from: www.who.int/csr/disease/zika/video-interviews/en/.

643. Morens D, Fauci A. Pandemic Zika: A formidable challenge to medicine and public health. The Journal of Infectious Diseases. 2017.

644. Fauci A, Morens D. Zika Virus in the Americas - Yet Another Arbovirus Threat. N Engl J Med. 2016 February;(374): p. 601-604. 
645. World Health Organization. Zika. WHO Statements Emergency Committee. [Online].; 2016. Available from: http://www.who.int/mediacentre/news/statements/2016/1stemergency-committee-Zika/en/.

646. World Health Organization. Zika: Response funding. [Online].; 2018 [cited 2019 February. Available from: https://www.who.int/emergencies/zika-virus/response/contribution/en/.

647. UN Secretary-General. UN Secretary-General`s Terms of Reference Zika Response MultiPartner Trust Fund. New York: UN, Secretary General; 4 May 2016.

648. World Health Organization. Fifth meeting of the Emergency Committee under the International Health Regulations (2005) regarding microcephaly, other neurological disorders and Zika virus-Statement. [Online].; 2016 [cited 2017. Available from: https://www.who.int/en/news-room/detail/18-11-2016-fifth-meeting-of-the-emergencycommittee-under-the-international-health-regulations-(2005)-regarding-microcephalyother-neurological-disorders-and-zika-virus.

649. Organization of American States. Draft Declaration on Zika Virus: Inter-American Cooperation to meet a Global Health Threat.. Document OEA/Ser. G. ; 6 June 2016. Report No.: CP/CG-2052/16 rev. 2.

650. Gostin L, Hodge JG. Zika virus and global health security. The Lancet. 2016; 16: p. 10991104.

651. Alonso P, Engels D, Reeder J. Renewed push to strengthen vector control globally. The Lancet. 2017; 389: p. 2270-2271.

652. World Health Organization. WHA 70 Main Documents. [Online].; 2017 [cited 2018 November. Available from: http://apps.who.int/gb/e/e_wha70.html.

653. Prada P. Did Brazil, global health agencies fumble Zika response? Reuters. 2016 January.

654. Mccaughey B. The CDC is brushing off the Zika virus. The New York Post. 2016 January.

655. World Health Organization. Emergency preparedness, response. Zika virus infection Brazil and Colombia.. WHO; October 2015. Report No.: Disease Outbreak News 21.

656. Rasanathan JJK, MacCarthy S, Diniz D, Torreele E, Gruskin. aS. Engaging Human Rights in the Response to the Evolving Zika Virus Epidemic. American Journal of Public Health. 2017; 107(4): p. 525-531. 
657. World Health Organization. Zika. [Online].; 2016. Available from:

http://www.who.int/mediacentre/news/statements/2016/emergency-committee-Zikamicrocephaly/en/.

658. World Health Organization. WHO Zika. [Online].; 2016 [cited 2018. Available from: http://www.who.int/emergencies/Zika-virus/en/.

659. Larocca

RA,AP,PJPS,ZPMdAIMJ,BZA,BM,ND,KM,NR,MNB,LZ,MET,BCA,BEN,GPB,JD,N.

Vaccine protection against Zika virus from Brazil. Nature. 2016 August; 536(7617): p. 474478.

660. Haug CJ, Kieny MP, Murgue B. The Zika Challenge. The New England Journal of Medicine. 2016 May; 374(19): p. 1801-1802.

661. Organization WH. WHO global consultation of research related to Zika virus infection. Geneva: WHO; 2016.

662. World Health Organization. Fourth Meeting Emergency Committee on Zika, September 2nd, 2016. [Online].; 2016 [cited 2017. Available from: https://www.who.int/newsroom/detail/02-09-2016-fourth-meeting-of-the-emergency-committee-under-theinternational-health-regulations-(2005)-regarding-microcephaly-other-neurologicaldisorders-and-zika-virus.

663. Kickbusch I, Reddy KS. Global Health Governance-the next political revolution. Public Health. 2015;(129): p. 838-842.

664. Smith A. Political Groups, Leader Change, and the Pattern of International Cooperation. Journal of Conflic Resolution. 2009 December; 53(6): p. 853-877.

665. Kim K. Sources of Variation in International Cooperation: A comparative analysis of USJapan Automobile Trade Negotiations: (1981-81 \& 1993-95). Pacific Focus. 1999 Spring; XIV(1): p. 113-158.

666. Zartman WI, Touval S. International Cooperation. The Extents and Limits of Multilateralism ; 2010.

667. Stein AA1. Why Nations Cooperate. Circumstance and Choice in International Relations. Ithaca, New York: Cornell University Press; 1990. 
668. Bolsen T, Druckman JN, Cook FL. Citizens', scientists' and policy advisors' beliefs about Global Warning. The Annals of the American Academy. 2015 Marcg;(658): p. 271-295.

669. Miller CA, Edwards PN. Changing the Atmosphere Cambridge, MA: MIT Press; 2001.

670. Jasanoff S, Markle GE, Petersen JC, al. e. Handbook of Science and Technology Studies Thousand Oaks, CA: Sage Publications; 1995.

671. Hasenclever Aea. Integrating theories of international regimes. Review of International Studies. 2000; 26: p. 3-33.

672. Gerspacher NaBD. The Nodal Structure of International Police Cooperation: An Exploration of Transnational Security Networks. Global Governance. 2007;(13): p. 347364.

673. Prell C. Social Network Analysis London: SAGE Publications Ltd.; 2012.

674. Kim K, Andrew S, Jung K. Public Health Network Structure and Collaboration Effectiveness during the 2015 MERS Outbreak in South Korea: An Institutional Collective Action Framework. International Journal of Environmental Research and Public Health. 2017; 14(1064): p. 1-15.

675. Burt RS. The Network Structure of Social Capital. Organizational Behaviour. 2000; 22: p. 345-423.

676. Worobey M, Watts TD, McKay RA, Suchard MA, Granade T, Teuwen DE, et al. 1970s and 'Patient 0' HIV-1 genomes illuminate early HIV/AIDS history in North America. Nature. 2016 November; 539(7627): p. 98.

677. Foundation KF. Kaiser Family Foundation. [Online].; 2016. Available from: http;//kff.org/global-health-policy/timeline/global-hivaids-timeline/.

678. Patterson AS. The UN and the Fight Against HIV/AIDS. In Harris P, Siplon P. The Global Politics of AIDS. London: Lynne Rienner Publishers; 2007. p. 203-220.

679. UNAIDS. Global Report. UNAIDS Report on the Global AIDS Epidemic. Geneva: Joint United Nations Programme on HIV/AIDS ; 2013.

680. World Health Organization. Global Programme on AIDS 1978-1995. Final Report. Geneva: WHO, Global Programme on AIDS; 1997. Report No.: WHO/ASD/97.1. 
681. Mann J. Control Startegies. AIDS Action. 1987 November;(1).

682. Vieira MA. The securitization of the HIV/AIDS epidemic as a norm: a contribution to constructivist scholarship on the emergence and diffusion of international norms.. Brazilian Political Science Review. 2007 July/December; 1(2).

683. Maclean SJ. Microbes, Mad Cows and Militaries: Exploring the Links between Health and Security. Security Dialogue. 2008 October; 39(5): p. 475-494.

684. Poku N. The Global AIDS Fund: context and opportunity. In Poku N, Whiteside A. Global Health and Governance HIV/AIDS. New York: Palgrave, Macmillan; 2004. p. 93-101.

685. UN General Assembly. Resolution 55/2 United Nations Millenium Declaration. In ; 2000; New York.

686. UNAIDS. Global AIDS Response Progress Reporting 2012. Geneva: UNAIDS; 2012.

687. Memeli P. Managing the HIV/AIDS Pandemic: Paving a Path into the Future of International Law and Organization. Law \& Policy. 2000 December; 22(2): p. 203-224.

688. Piot P, Coll Seck AM. International response to the HIV/AIDS epidemic: planning for success. Bulletin of the World Health Organization. 2001; 79(12): p. 1106-1112.

689. Wallace Brown G. Multisectoralism, Participation, and Stakeholder Effectiveness: Increasing the Role of Nonestate Actors in the Global Fund to Fight AIDS, Tuberculosis, and Malaria. Global Governance. 2009;(15): p. 169-177.

690. Richey LA, Haakonsson SJ. Access to ARV Treatment: Aid, trade and governance in Uganda. Copenhagen:; 2004.

691. South Centre/ WHO. The Use of Flexibilities in TRIPs by Developing Countries: Can they Promote Access to Medicines Musungu S, Oh C, editors. Geneva: South Centre; 2006.

692. World Trade Organization. Responding to least developed countries' special needs in intellectual property. [Online].; 2013. Available from: https://www.wto.org/english/tratop_e/trips_e/ldc_e.htm.

693. Hankins C, Sidibe M, Fontaine C. Responding effectively to the HIV pandemic. In Beck E, Mays N, Zuniga JM, Whiteside AW, Holland L. The HIV Pandemic. Local and global implications. Oxford: Oxford University Press; 2006. p. 737-754. 
694. UNAIDS. AIDS Scorecards.. Geneva: UNAIDS; 2010.

695. Chan M. Ten years in Public Health 2007-2017. Geneva: World Health Organization; 2017.

696. United Nations Development Program. UNDP Support to the Implementation of the 2030 Agenda for Sustainable Development. New York: UNDP; 2016.

697. Patton C. Globalizing AIDS Minneapolis: University of Minnesota Press; 2002.

698. AIDS Society. AIDS Society. [Online].; 2018. Available from: https://www.iasociety.org/Who-we-are/About-the-IAS/Annual-Report-2018.

699. Nay O. How do policy ideas spread among international administrations? Policy entrepreneurs and bureaucratic influence in the UN response to AIDS.. Journal of Public Policy. 2012 March; 32(1): p. 53-76.

700. Saguier MI. Global Governance and the HIV/AIDS Response: Limitations of Current Approaches and Policies. 2007 May 1..

701. Sachs J, McArthur J. The Millennium Project: a plan for meeting the Millennium Development Goals.. The Lancet. 2005; 365(9456): p. 347-353.

702. Macias AE, De la Torre A, Bourlon M, Leal P, Moreon-Espinosa S, Huertas M, et al. La influenza epidemica en Mexico: el dogma roto y sus lecciones. Revista de Investigacion Clinica. 2009; 61(2): p. 94-97.

703. Lipsitch M, Steven R, Cauchemez S, Ghani A, Ferguson N. Managing and Reducing Uncertainty in an Emerging Influenza Pandemic. The New England Journal of Medicine. 2009 July; 361(2): p. 112-113.

704. Health Security Working Group. North America Plan for Animal and Pandemic Influenza (NAPAPI). Washington D.C.: US Department of Health and Human Services; April 2012.

705. World Health Organization. Mathematical Modellin of the Pandemic H1N1 2009. Weekly Epidemiological Record. 2009 August; 84(34): p. 341-352.

706. World Health Organization. Emergency Committee H1N1 2009. [Online].; 2011 [cited 2014 May 25. Available from: http://www.who.int/csr/disease/swineflu/meetings/en/.

707. Vance MA. Disease mongering and the fear of pandemic influenza. Int.J.Health Serv. $2011 ;(41)$. 
708. Memish JAATRFAAAKDAMSAMA. Middle East respiratory syndrome coronavirus (MERS-CoV): a cluster analysis with implications for global management of suspected cases. Travel Med. Infect. Diseases. 2015; 13: p. 311-314.

709. Eddy GA, Cole FEJ. The Development of a vaccine against African Hemorrhagic Fever. In International Colloquium on Ebola Virus Infection and Other Haemorrhagic Fevers; 1977; Antwerp. p. 162-166.

710. Ullman RH. Redifining Security. International Security. 1983 Summer; 8(1): p. 129-153.

711. Knobler S, Mahmoud A, Lemon S, Mack A, Sivitz L, Oberholtzer K, editors. Learning from SARS: Preparing for the Next Disease Outbreak: Workshop Summary Washington DC: National Academies Press; 2004.

712. World Health Organization. WHO Framework Convention on Tabacco Control. Status of Payements of Voluntary Assessed Contributions as of June 2017. Geneva: Conference of the Parties, Framework Convetion on Tobacco Control; 2017.

713. World Health Organization. 2012 global progress report on implementation of the WHO Framework Convention on Tobacco Control. Geneva: World Health Organization.; 2012. Report No.: 9789241504652.

714. AIDS Society. AIDS Society web site. [Online]. [cited 2015. Available from: https://www.iasociety.org/Default.aspx?pageId=79.

715. Majumder M, Rivers C, Lofgren E, Fisman D. Estimation of MERS-Coronavirus Reproductive Number and Case Fatality Rate for the Spring 2014 Saudi Arabia Outbreak: Insights from Publicly Available Data.. PLOS Currents Outbreaks. 2014 December; 1.

716. ProMed. ProMed International Society for Infectious Diseases. [Online].; 1994-2019 [cited 2019 April. Available from: http://www.promedmail.org/index.php.

717. Bogoch I. OJ, Brady MUG, Kraemer M, German MI, Creatore MA, Kulkarni JS, et al. Anticipating the international spread of Zika virus from Brazil. The Lancet. 2016; 387: p. 335-336.

718. Henao-Restrepo, AM; Camacho, A; Longini ,IM; et al.. Efficacy and effectiveness of an rVSV-vectored vaccine in preventing Ebola virus disease: final results from the Guinea ring vaccination, open-label, cluster-randomised trial (Ebola Ça Suffit!). The Lancet. 2017 February; 389(10068). 
719. Zarnegar Deloffre M. Human Security, Humanitarian Response and Ebola. PS. 2015 January.

720. Cox RW. Structural issues of global governance: issue for Europe. In Cox R, Sinclair T, editors. Approaches to world order. Cambridge: Cambridge University Press; 1996.

721. Murphy CN. Global Governance: poorly done and poorly understood. International Affairs. 2000; 76(4): p. 789-803.

722. Rourke M. Access by Design, Benefits if Convenient: A Closer Look at the Pandemic Influenza Preparedness Framework's Standard Material Transfer Agreements. The Milbank Quarterly. 2019 March; 97(1). 